\title{
Strafwerk : over de arbeidsverhouding tussen gedetineerden en Justitie
}

Citation for published version (APA):

de Jonge, G. (1994). Strafwerk : over de arbeidsverhouding tussen gedetineerden en Justitie. [Doctoral Thesis, Maastricht University]. Papieren Tijger. https://doi.org/10.26481/dis.19950120gj

Document status and date:

Published: 01/01/1994

DOI:

10.26481/dis.19950120gj

Document Version:

Publisher's PDF, also known as Version of record

\section{Please check the document version of this publication:}

- A submitted manuscript is the version of the article upon submission and before peer-review. There can be important differences between the submitted version and the official published version of record.

People interested in the research are advised to contact the author for the final version of the publication, or visit the DOI to the publisher's website.

- The final author version and the galley proof are versions of the publication after peer review.

- The final published version features the final layout of the paper including the volume, issue and page numbers.

Link to publication

\footnotetext{
General rights rights.

- You may freely distribute the URL identifying the publication in the public portal. please follow below link for the End User Agreement:

www.umlib.nl/taverne-license

Take down policy

If you believe that this document breaches copyright please contact us at:

repository@maastrichtuniversity.nl

providing details and we will investigate your claim.
}

Copyright and moral rights for the publications made accessible in the public portal are retained by the authors and/or other copyright owners and it is a condition of accessing publications that users recognise and abide by the legal requirements associated with these

- Users may download and print one copy of any publication from the public portal for the purpose of private study or research.

- You may not further distribute the material or use it for any profit-making activity or commercial gain

If the publication is distributed under the terms of Article $25 \mathrm{fa}$ of the Dutch Copyright Act, indicated by the "Taverne" license above, 


\section{STRAFWERK}

Over de arbeidsverhouding tussen gedetineerden en Justitie

\section{PROEFSCHRIFT}

ter verkrijging van de graad van doctor aan de Rijksuniversiteit Limburg te Maastricht, op gezag van de Rector Magnificus, Prof. dr. H. Philipsen, volgens het besluit van het College van Dekanen, in het openbaar te verdedigen op vrijdag 20 januari 1995 om 14.00 uur

door

Gerard de Jonge

Uitgeverij Papieren Tijger

Breda

1994 
Promotores:

Prof. mr. G.P.M.F. Mols

Prof. mr. A.J.C.M. Geers

Beoordelingscommissie:

Prof. mr. Th.A. de Roos (voorzitter)

Prof. mr. W.J.P.M. Fase

Prof. mr. C. Kelk (Universiteit Utrecht)

Prof. drs. J.J.J. Tulkens (Rijksuniversiteit Groningen) 
The futility of severe punishment and cruel treatment may be proven a thousand times, but so long as society is unable to solve its social problems, repression, the easy way out, will always be accepted.

Georg Rusche and Otto Kirchheimer in 'Punishment and Social Structure'. 


\section{Inhoudsopgave}

Inleiding

Hoofdstuk I

Van strafslavernij tot 'werkzame detentie'

Van ergastulum tot Rasphuis

1.1

Erger dan slavernij

1.2

Een hinderlijke onderklasse

1.3

1.4

Berichten uit Utopia

1.5

Weerklank in 'Boeventucht'

6

Zitten en werken

De teloorgang van Sint Raspinus

Van het Organisatiebesluit van 1821 tot de

2.4 Opkomst, ondergang en reïncarnatie van de rijkswerkinrichting 
$\begin{array}{lll}4.3 & \text { Arbeid moet resocialiseren } & 47 \\ 4.4 & \text { Arbeid als regiemsactiviteit } & 48 \\ 4.5 & \text { Expansie van de arbeidsplicht } & 51\end{array}$

$5 \quad$ Het voorontwerp Penitentiaire Beginselenwet en de nota

'Werkzame Detentie': de rehabilitatie van de arbeid $\quad 52$

Slotopmerkingen

\section{Hoofdstuk II}

De arbeidsrechtelijke positie van de gedetineerde

Werknemers, ambtenaren of slaven van de staat

Het ontstaan van de arbeidsverhouding

\section{Hoofdstuk III}




$\begin{array}{ll}1.4 & \begin{array}{l}\text { De VN Standaard Minimum Regels en } \\ \text { de Europese Gevangenisregels } \\ \text { Andere internationale regels over detentie-omstandigheden }\end{array} \\ 2.5 & \text { Naar een recht op een billijke beloning } \\ 2.1 & \text { Inleiding } \\ 2.2 & \text { Onwil in Nederland } \\ 2.3 & \text { Papieren beloften in Duitsland } \\ 2.4 & \text { Experimenten in Zweden } \\ 2.5 & \text { Aanbevelingen van de Raad van Europa } \\ 2.6 & \text { De pro's en contra's van een normale arbeidsbeloning } \\ 2.7 & \text { Voorwaarden voor normalisering van het loon } \\ 3 & \text { Slotopmerkingen }\end{array}$

\section{Hoofdstuk IV}

\section{Strafrechtelijke arbeidsdwang als sluitstuk van} een sociale zekerheids-strategie

Verbindingen tussen het gevangeniswezen en het stelsel van sociale zekerheid

2.7 Nieuwe parallelle arbeidsmarkten: sociale dienstplicht en kampementen 


\section{Hoofdstuk V}

Naar een Wet op de Penitentiaire Werkvoorziening 205

1 De Wet Sociale Werkvoorziening: voorbeeld voor gevangeniswezen 206

1.1 De personenkring van de WSW 206

$\begin{array}{lll}1.2 & \text { (Ex-)gedetineerden en de WSW } & 207\end{array}$

1.3 De arbeidsverhouding in de WSW 208

1.4 Organisatie, uitvoering en financiering van de WSW 209

$\begin{array}{lll}1.5 & \text { De arbeidsvoorwaarden van de WSW } & 209\end{array}$

1.6 Rechtsmiddelen voor de WSW-er 211

2 Omtrekken van een Wet op de Penitentiaire Werkvoorziening 212

$3 \quad$ Slotopmerkingen

\section{Hoofdstuk VI}

De penitentiaire arbeidsverhouding in abolitionistisch perspectief

1 De gevangenis als geslaagd fiasco

1.1 Het civilisatieproces als emanciperende factor 243

1.2 Hoe minder hoe beter: het reductionisme 245

1.3 Het abolitionisme als leidend beginsel 246

$1.1 \quad$ Lestings normaliserings-concept 250

$1.5 \quad$ Arbeid als object van normalisering 252

1.6 Een veronderstelling 254

$2 \quad$ Loon naar werken: van wens tot wet 255

2.1 Het wetgevingsmodel van d'Anjou 256

2.2 Machtsmiddelen van gedetineerden 258

2.3 Opkomst en ondergang van gedetineerdenvereniging 260

$2.4 \quad$ Zeven jaar procederen tegen arbeid op cel 265

$3 \quad$ Lessen uit het verleden

Samenvatting 



\section{Inleiding}

Als medeplichtige aan de moordaanslag, die in 1881 op tsaar Alexander II werd gepleegd, werd Vaszilij Jaksakov als dwangarbeider naar een loodmijn in zuid-oost Siberië gestuurd, waar hij krepeerde. Zijn illegale aantekeningen zijn door een anonieme bewerker gepubliceerd en geven uit de eerste hand een uniek en aangrijpend beeld van de ellendige omstandigheden waaronder eind vorige eeuw grote groepen veroordeelden in eindeloze dagmarsen van gevangenis naar gevangenis naar hun - vaak letterlijke - eindbestemming werden gemarcheerd. ${ }^{1}$

Dwangarbeid is nog steeds - vooral in totalitaire politieke systemen - een belangrijk middel in de strijd tegen al of niet politiek gemotiveerde criminaliteit. Aleksandr Solzjenitsyin heeft in 'Een dag uit het leven van Ivan Denisovitsj' de wereld onthuld hoe het er in de stalinistische dwangarbeiderskampen ('de Gulagarchipel') toeging. Nu de archieven stilaan worden ontsloten verschijnen de eerste voorzichtige schattingen van de omvang van deze vorm van repressie. De gegevens wijzen uit, dat de bevolking van de kampen het grootst was in de jaren vlak vóór (plm. 1,5 mln.) en vlak na (plm. 2,5 mln.) de Tweede Wereldoorlog. De perestroika heeft nauwelijks iets aan het feit veranderd dat ook in de post-communistische Russische federatie verreweg de meeste veroordeelden hun straf doorbrengen in werkkampen. ${ }^{2}$ Ook al wordt het door de explosieve groei van de werkloosheid in de voormalige Soviet-Unie steeds moeilijker om werk voor gedetineerden te vinden, toch blijft de omvang van het dwangarbeid-systeem indrukwekkend. Penal Reform International meldt het bestaan van 513 arbeids-kolonies (op 1 januari 1993) met een bevolking van ruim 400.000 en een capaciteir van ruim $600.000 .^{3}$

In de Volksrepubliek China is al meer dan 40 jaar een van de belangrijkste doelen van de straf 'heropvoeding door arbeid'. Hongda Harry Wu heeft onlangs voor het eerst beschreven hoe in bijna 1000 werkkampen (laogaidui), waarvan sommigen met het formaat van kleine steden, grote aantallen veroordeelden moeten werken ter verbetering van hun persoonlijke politieke instelling en tot voordeel van 's lands economie. ${ }^{4}$ Ook voor de export wordt geproduceerd, zelfs in die mate, dat in 1991 president Bush van de Verenigde Staten de Chinese leiders met stappen dreigde 'als aan deze valse concurrentie geen einde kwam'. ${ }^{5}$ Het Nederlandse Volvo sloeg eerder - in 1989 - een Chinees aanbod af om voor hun productie gebruik te maken van goedkope gevangenenarbeid. ${ }^{6}$ 
Elke vergelijking van het kleine Nederlandse gevangeniswezen met deze gigantische dwangsystemen lijkt mank te gaan. Gaan wij immers niet voorbeeldig met onze gedetineerden om? Worden binnen onze strafinrichtingen de mensenrechten niet pijnlijk nauwkeurig gerespecteerd? Ook al valt op dat laatste nog wel wat af te dingen, toegegeven moet worden dat de bejegening van 'onze' gedetineerden afgemeten aan die in tal van andere penitentiaire systemen behoorlijk genoemd kan worden. Anderzijds is elke borstklopperij misplaatst want Nederland is met de opening van het Amsterdamse Rasphuis in 1596 een van de eerste landen ter wereld waar gedetineerden systematisch tewerk gesteld zijn. De strafrechtelijke dwangarbeid is hier als het ware uitgevonden. Blijkens de recente nota 'Werkzame dententie' is het thema van de terwerkstelling van gedetineerden onverminderd actueel. ${ }^{7}$ Ook bij ons wordt gemikt op een commerciële exploitatie van hun arbeidskracht. Ook hier wil de overheid gedetineerden heropvoeden, weliswaar niet door middel van stelselmatige politieke indoctrinatie, maar door inplanten van een bij ons sociaal-economisch stelsel passend arbeidsethos. Reclassering wordt aldus in essentie (in ambtelijk jargon) 'toeleiding naar de arbeidsmarkt'.

In dit bock wordt de al vier eeuwen oude praktijk om gedetineerden in de eerste plaats als goedkope arbeidskrachten te beschouwen aan een kritische analyse onderworpen.

In het eerste hoofdstuk wordt gezocht naar het ontstaan van de gedwongen arbeid in strafinrichtingen als onderdeel van de straf-executie. Waarom sloeg in onze streken deze vorm nu juist aan? Waarom zonden wij de gestraften niet naar de galeien, waarom niet naar de koloniën?

Het tweede hoofdstuk wordt besteed aan een analyse van de arbeidsrechtelijke positie van de gedetineerde in het penitentiare recht en in de jurisprudentie van (vooral) de beroepscommissie uit de Centrale Raad voor de Strafrechtstoepassing. De penitentiairrechtelijke rechtspositie van de werkende gedetineerde wordt daarbij op hoofdpunten vergeleken met de civielrechtelijke rechtspositie van de 'vrije' arbeider. Daarna wordt in een derde hoofdstuk gezocht naar de juridische fundering van de thans voor veroordeelde gedetineerden geldende arbeidsplicht en wordt bezien wat de overheid eigenlijk tegenhoudt om gevangeniswerk normaal te belonen.

Georg Rusche heeft in de dertiger jaren van deze eeuw de economische rol van gedetineerden proberen te verklaren aan de hand van de door hem ontwikkelde arbeidsmarkt-hypothese. Zijn veronderstelling is door anderen in een reeks van onderzoeken getoetst. In het eerste deel van het vierde hoofdstuk wordt geprobeerd de waarde van Rusche's model in te schatten voor de huidige strafexecutic. Vervolgens wordt aan de hand van Garlands 'Punishment and welfare' bezien of het zinvol kan zijn het Nederlandse gevangeniswezen te bezien als sluitstuk en bodem van het stelsel van socialc zekerheid. Welke gevolgen een dergelijke positionering voor de juridische vormgeving van de gedetineerdenar- 
beid zou kunnen hebben is het onderwerp van hoofdstuk vijf. Daarin worden de contouren geschetst van een Wet op de Penitentiaire Werkvoorziening, waarmee volgens schrijver dezes de positie van de gedetineerde als arbeider in één keer goed geregeld zou kunnen worden.

Het verhaal dat in dit boek wordt verteld is eigenlijk een uit de hand gelopen pleidooi voor de emancipatie van de gedetineerde. Impliciet is het ook een betoog tegen de vrijheidsstraf als zodanig. Dat wordt echter pas expliciet in het afsluitende hoofdstuk waar de vraag aan de orde komt of de door de schrijver gepropageerde hervorming van de gedetineerdenarbeid niet eerder bijdraagt tot verdere legitimering van het gevangeniswezen dan tot afbouw daarvan.

Bunde/Maastricht juli 1994 


\section{Noten}

1. Anoniem, Aus den Sibirischen Bleibergwerken; unedierte Briefe des zu lebenslănglicher Zwangsarbeit verurtheilten russischen Professors Vaszilij Jaszakov; mit den Zeichnungen und dem Autogramm des Verurtheilten, Berlijn, 1893.

2. A.S. Mikhlin en R.D. King, The Russian prison system: yesterday, today and tomorrow, paper presented at 'Prisons 2000', an international conference on the present state and future of the prison system, Leicester, 810 april 1994.

3. Penal Reform International, Newsletter No. 14, september 1993, bl. 2.

4. Hongda Harry Wu, Laogai; the Chinese Gulag, Boulder/San Francisco/Oxford, 1992. 5. De Volkskrant 17 seprember 1991, 'Chinese gevangenen produceren voor de export'. De Volkskrant 31 juli 1992, 'China stopt verkoop van produkten uit gevangenis aan VS'.

6. NRC-Handelsblad 10 augustus 1989, 'China benadert Volvo met plan gevangenenarbeid'.

7. Werkzame detentie; beleidsnota voor het gevangeniswezen, Tweede Kamer, 19931994, 22 999, nrs. 10-11. 


\section{Hoofdstuk I}

\section{Van strafslavernij tot 'werkzame detentie'}

Fysieke vrijheidsberoving wordt pas een interessante strafsoort wanneer er voldoende vrije personen zijn om die aan te voltrekken, lijf-en doodstraf geen oplossing blijken te bieden en galeistraf of verbanning naar overzeese gebiedsdelen niet mogelijk is. In een door humanistische ideeën daarvoor rijp gemaakt Noordwest Europa begint met de opening van het Amsterdamse Rasphuis aan het eind van de 16e eeuw de zegetocht van de gevangenisstraf. Maar het verzorgen van gedetineerden kost geld. Als vanzelfsprekend worden ze daarom aan het werk gezet. In de Republiek heeft elke stad van enige betekenis al gauw zijn eigen tuchthuis waar zwervers en andere deugnieten onder toezicht van stadsbesturen en regenten hun tijd met noeste arbeid vullen. Fohn Howard inspecteerde eind 18 eeeuw het resultaat van bijna twee eeuwen gevangenispraktijk en was over onze inrichtingen niet ontevreden. Koning Willem I was dat wel toen hij begin $19 e$ eeuw een bont geheel van tijdens de post-revolutionaire tijd verwaarloosde tuchthuizen aantrof. Hij centraliseerde het bestuur over de strafinrichtingen en zorgde voor de eerste algemene regeling van arbeid en beloning. Het gevangeniswezen versteende toen 1850 het cellulaire stelsel werd ingevoerd. Gewerkt werd slechts nog in de eenzame afzondering van de cel. Ondanks de erbarmelijke arbeidsomstandigheden en de eenvoudige aard van de produkten waakten particuliere ondernemers en vrije ambachtslieden angstvallig tegen valse concurrentie door de celarbeid.

Pas na de Tweede Wereldoorlog, waarin dwangarbeid in de concentratiekampen miljoenen gevangenen de dood in joeg, kwam mèt de afschaffing van het cellulaire stelsel en een toenemende belangstelling voor de persoon van de veroordeelde ook diens rol als werkende mens in beeld. Sommigen zagen duizenden gedetineerden in ware gevangenisfabrieken helpen aan de wederopbouw van het land. Toen dat een illusie bleek filosofeerden anderen over de reclasserende waarde van de gevangenisarbeid. De realiteit bleek altijd sterker dan de leer: fustitie had altijd te maken met een grotendeels ongeschoolde, niet zeer gemotiveerde en betrekkelijk kort-gestrafte gedetineerdenpopulatie, voor een werkgever niet bepaald de aantrekkelijkste ondergeschikten. Tot op de dag van vandaag blijft fustitie echter in de opvoedende en economische waarde van gedwongen, nauwelijks betaalde, penitentiaire arbeid geloven. De nota 'Werkzame Detentie' is daar het meest recente voorbeeld van. 


\section{Van ergastulum tot Rasphuis}

\subsection{Erger dan slavernij}

Ook al zijn er in het oude Rome voorbeelden van economische uitbuiting van gestraften aan te wijzen, pas aan het eind van de zestiende eeuw, wanneer in 1596 het Amsterdamse Rasphuis in gebruik wordt genomen, kan er worden gesproken van een systematisch verband tussen gevangenisstraf en verplichte arbeid. Sinds die tijd moeten gevangenen werken, wat niet per se het lot was van hen die in de oudste als zodanig nog aanwijsbare gevangenis, de Carcer Mamertinus te Rome, werden gesmeten: zij wachtten daar gemeenlijk op de voltrekking van hun doodvonnis.'

Vandekerckhove leert ons, dat in het oude Rome de publieke gevangenzetting als straf pas laat is ontstaan. Aanvankelijk was het gevangenhouden van personen daar puur een privé-aangelegenheid van vrije burgers. Als men daar de ruimte voor had kon men zelf in zijn carcer privatus zijn debiteuren en in zijn ergastulum $^{2}$ onwillige slaven opsluiten. Op den duur was daar de instemming van een magistraat voor nodig, althans voor het detineren van debiteuren. In een latere fase werd het gebruik van de private kerker door het intussen steviger gevestigd staatsgezag verboden en vervangen door eigen administratiefrechtelijke lijfsdwang. ${ }^{3}$

Slaven, die door het openbaar gezag waren gestraft, werden aan hun meester teruggegeven als die zelf de straf ten uitvoer kon en wilde leggen. Wilde de meester hen niet meer hebben, dan kon de strafslaaf rekenen op het levenslang, geketend, gebrandmerkt, half kaal geschoren en onder militaire bewaking, verrichten van mijnarbeid, aldus nog steeds Vandekerckhove, die daaraan toevoegt: 'Zulke dwangarbeid hield uiteraard ook de detentie in, waarschijnlijk in de ergastula van de staat. Ergastula waren immers niet alléén private instellingen: ze bestonden niet alleen te lande op de boerderijen, maar ook bij steengroeven, bij molens en waarschijnlijk bij alle arbeidsintensieve werken, privaat òf publiekrechtelijk van karakter. (...) Deze straf (de straf van de mijn) werd eveneens aan vrijen toegekend, maar dan alleen aan mensen van lage afkomst (...), die dan ipso facto hun vrijheid verloren en eveneens strafslaven (servi poenae) werden (...). Vermits de veroordeling tot dwangarbeid uiteraard de detentie impliceerde, gebeurde het dus ook (sedert dat de dwangarbeid als straf bestond, en dat is volgens Mommsen (...) sedert het principaat, waarschijnlijk sedert het jaar 23) dat vrije lieden strafrechtelijk gevangen gezet werden, namelijk wanneer ze tot de een of andere vorm van dwangarbeid veroordeeld waren'."

Dwangarbeid was geen element van een te executeren vrijheidsstraf, maar vrijheidsbeneming was een sequeel van een gedwongen tewerkstelling.

De Romeinse overheersing heeft in onze streken geen sporen of verslagen van een dergelijke vrijheidsbeneming achtergelaten. 


\subsection{Een hinderlijke onderklasse}

Als in de late middeleeuwen verpauperde boeren een werkloze, bedelende, stelende, zwervende, kortom een moeilijk te beheersen onderklasse zijn gaan vormen, ontstaat de behoefte om deze groep door middel van strafsancties in bedwang te houden.

In zijn inleidend essay bij Gemereks' boek 'Het Kaïnsteken' probeert Cataluccio het straatbeeld van een laat-middeleeuwse stad te schilderen: 'De straten, stegen, kerkportalen, markten en pleinen waren vergeven van armen, bedelaars en vagebonden, die door hun massaliteit het stedelijk leven soms compleet ontwrichtten en lam konden leggen. Deze paupers vormden een bonte verzameling van kleuren, afwijkingen, (on)hebbelijkheden, geuren en geluiden. Het geschreeuw en de stank (van echte of gefingeerde wonden) waren soms niet om te harden en door de handtastelijkheden waarmee het bedelen gepaard ging, was er voor de 'gewone burgers' soms geen doorkomen aan. Om de massaliteit van de paupers en de sociale dreiging die van hen uitging te illustreren, zijn de volgende getallen verhelderend: het gemiddelde percentage bedelaars in de steden steeg in deze periode tot $20 \%$; een stad als Parijs telde, naar verluidt, in de $16 \mathrm{e}$ eeuw zo'n 30.000 bedelaars op een totaal van nog geen 100.000 inwoners. $^{.5}$

Een toenemend aantal marginalen (les marginaux: bedelaars en vagebonden) in de steden heeft volgens Spierenburg op zich nog niet geleid tot de introductie van de gevangenis in de Europese maatschappij. Dat nieuwe instituut is volgens hem de resultante van meer factoren. In de eerste plaats heeft dat te maken met een verandering in houding tegenover de marginalen tussen het einde van de vijftiende en het begin van de zeventiende eeuw. Werd volgens diep-christelijke opvattingen armoede aanvankelijk als een soort heilige staat beschouwd, die de schenkers van aalmoezen glans verleende, later concentreerde de aandacht zich op de ontvangers van de charitas. Er kwam een onderscheid tussen valide en invalide bedelaars. Armoe werd nu eerder als een vloek gezien en de bedelaar als een bedreiging voor de stabiliteit van de samenleving. Arm zijn werd een schande en gezonde bedelaars moesten maar werken voor de kost. Spierenburg stelt de definitieve doorbraak van die nieuwe mentaliteit rond 1500. Daarbij waren onze streken in de $16 \mathrm{e}$ eeuw in sterkere mate gepacificeerd geraakt dan voordien, verschenen staten op het Europese schouwtoneel en ontstonden netwerken van steden. Dat maakte dat de stedelijke burgerij het ongewenste geboefte niet langer, zoals tot dan te doen gebruikelijk, al of niet verminkt de poort uit kon jagen en het probleem niet meer op de buren kon afschuiven. De toegenomen integratie van de Hollandse steden maakte dat de zorg voor de openbare orde het plaatselijk niveau oversteeg. Men voelde zich langzamerhand verplicht binnen de eigen muren een oplossing voor het marginalen-probleem te zoeken. Het gevangenzetten van lastige 'gezonde' armen die niet voor de reguliere charitas in aanmerking kwamen was dan ook aanvankelijk een alternatief voor hun verbanning, zo kan men lezen in Spierenburgs magistrale boek over de vroeg-moderne geschiedenis van het West-Europese gevangeniswezen 'The prison experience'. 
Een nieuw probleem was geboren: wat te doen met gedetineerden? Het antwoord was en is: laat ze werken. Het idee kwam uit Engeland en schoot in Holland wortel.

\subsection{Berichten uit Utopia}

Thomas More laat in zijn in 1516 gepubliceerde 'Utopia' de door hem bedachte wereldreiziger Raphael Hythlodaeus de voordelen van dwangarbeid beschrijven. Tijdens een ontmoeting te Antwerpen met Peter Gilles en More vertelt Raphael hun over een gesprek dat hij met de aartsbisschop van Canterbury ('de kardinaal') had over de beste manier om criminaliteit te bestrijden. Nadat hij de kardinaal had uitgelegd waarom hij de doodstraf daar geen goed middel voor vond had Raphael zijn betoog aldus vervolgd: 'En nu over de vraag, die men dan gewoonlijk stelt: welke straf is dan beter? Als mij werd gevraagd, welke slechter zou zijn geweest, zou ik meer moeite met een antwoord hebben gehad. Want, waarom zouden we de waarde in twijfel trekken van een systeem dat de Romeinen, bestuurders bij uitstek, zo lang bruikbaar gevonden hebben? Zoals we weten veroordeelden zij mensen voor de zwaardere delicten tot levenslange strafslavernij in mijnen of steengroeven.

Toch heb ik de beste oplossing gezien toen ik, door Perzië reizend, in het gebied der Polyleritae terecht kwam. (...) (I)n dat land der Polyleritae wordt een dief verplicht het gestolene aan de eigenaar terug te geven en niet, zoals in de meeste landen, aan de Koning die, volgens de Polyleritae, daar ongeveer evenveel recht op heeft als de dief zelf. Als hij de goederen niet meer bezit, dan wordt de waarde ervan aan zijn eigen bezittingen onttrokken; wat overblijft wordt aan zijn vrouw en kinderen ter hand gesteld. Hij zelf wordt tot zware dwangarbeid veroordeeld. Behalve in gevallen van beroving met geweld wordt hij niet in de gevangenis gestopt of geketend, maar bij openbare werken tewerk gesteld. Als hij zijn gereedschap neerlegt of de lijn trekt, dan maken ze hem niet nog inerter door hem in de boeien te slaan, maar sporen zij hem met zweepslagen aan. Als hij hard werkt wordt hij best goed behandeld. Elke avond moet hij aantreden voor het appèl en 's nachts wordt hij ingesloten, maar verder heeft hij, afgezien van een zeer lange werkdag, een aangenaam leven. (...) Hier en daar worden veroordeelden niet bij openbare werken ingezet, maar aan particuliere ondernemers verhuurd. Iedereen die hun diensten kan gebruiken kan ze op de markt per dag huren, tegen een lager loon dan hij een vrije arbeider zou moeten betalen. (...) Zo pakt men dat daar aan en het ziet er bruikbaar en humaan uit. De criminaliteit wordt fel bestreden, maar men spaart de levens van de misdadigers. Die worden gedwongen zich te beteren, oppassende burgers te worden en de rest van hun leven besteden aan het weer goed maken wat ze ooit hebben misdaan.' De kardinaal was wel gecharmeerd van dat dwangarbeid-idee en vond het zeker ook iets voor landlopers, zo vertelde Raphael zijn gesprekspartners die hij aan de voet van de Antwerpse Onze Lieve Vrouw was tegengekomen. ${ }^{7}$ 


\subsection{Weerklank in 'Boeventucht'}

Het zou volgens Gelderblom c.s., die de tekst van de in 1587 gepubliceerde 'Boeventucht' bezorgd hebben, onverantwoord zijn te concluderen dat Coornhert invloed heeft ondergaan van More's denkbeelden over armoede en misdaad: het gesprek met Hythlodaeus is immers een mystificatie, een literaire tekst: 'Beide auteurs hebben wel vergelijkbare kritiek op de wereld waarin zij leven, maar ze verwerken die op totaal uiteenlopende wijze. More voert een pleidooi voor een 'ideale' samenleving waarin privé-eigendom onbekend is (niemand hoeft zich dus te vergrijpen aan andermans bezit); waarin werk naar keuze aanwezig is voor allen die kunnen werken (ledigheid bestaat dus niet); kortom, waarin alleen het beste uit de mensen wordt gehaald. Coornhert daarentegen doet een aantal concrete, praktische voorstellen voor werkverschaffing en voor een efficiënter strafsysteem. De samenleving én de individuele gestrafte zullen daar uiteindelijk beter van worden." ${ }^{8}$

De anglicist Turner, die Utopia vertaald heeft, meent echter dat More's voorstellen op sociaal, economisch en politiek gebied wel degelijk letterlijk genomen moeten worden. Hij gelooft niet, dat het boek alleen maar metaforen bevat. Wat erin staat is gemeend. Het is een serieuze poging een oplossing voor maatschappelijke problemen van die tijd te vinden. ${ }^{9}$

Anders dan de neerlandicus Gelderblom ziet de historicus Spierenburg wèl een nauw verband tussen Boeventucht en de door More in diens Utopia geventileerde crimineel-politieke ideeën. Spierenburg wijst erop, dat de eerste versie van Boeventucht al in 1567 geschreven is, toen Coornhert in de Haagse Voorpoort gevangen zat. Hij meent dat Boeventucht niet bij het werk van Coornherts onmiddelijke tijdgenoten aansluit, maar bij dat van een vorige generatie denkers, waartoe More behoorde. Daarbij stelt hij vast dat More de enige buitenlander was, die dwangarbeid voor delinquenten bepleitte. ${ }^{10}$

Coornherts plannen om de misdaad te bestrijden weken inderdaad niet zoveel af van de praktijken der fictieve Polyleritae. Zijn opvattingen kwamen in het kort op het voigende neer.

Een grote massa 'ledigh gheboefte' $(12 / 13)^{11}$ zorgde voor overlast. Er moesten middelen worden bedacht om aan die situatie een einde te maken. Er was gebrek aan toezicht op armoedzaaiers, die overlast veroorzaakten. Het 'gheboefte' bleef ongestraft rondlopen en was zelfs niet eens bang voor de doodstraf. Lijfstraffen hielpen niet en leken zelfs tot een 'toeneminghe des oncruyts' (159-160) te leiden. De baljuws en schouten arresteerden overigens liever rijken dan armen, van welke laatsten immers geen winst maar verlies kon worden verwacht. Er moesten andere oplossingen komen. Eerst moesten volgens Coomhert de schout en schepenen bij de wijkhoofden nagaan welke wijkbewoners, zonder inkomsten of bezittingen, 'dagelijx ledigh ghaan drincken en de tuysschen (dobbelen), latende wijf ende kind honger lijden of tot last van de ghemeente bedelen' (241-243). En als eenmaal bekend was wie die nietsnutten waren, moesten de meisjes en vrou- 
wen onder toezicht van 'matronen' (317) en werkloze mannen onder 'scherp opsicht' van 'vier eerzame mannen' (345) tewerk gesteld worden. Daarbij had Coornhert alleen het oog op de autochtone bevolking want vreemdelingen moesten zijn inziens worden verwijderd. Om een dergelijk beleid kracht bij te zetten was er volgens Coornhert behoefte aan nieuwe strafsoorten Hij wilde 'alle ghesonde bedelaers, dieven, gheweldighers, knevelaers ende andere quaed doenders niemanden ghedood hebbende, zonder te vergeten wijvesmiters, dagelijxe dronckers, tuyschers, doorbrengers ende kinders hoor ouderen lastigh ofte wederspanigh zijn' (404-408) al naar gelang de ernst van hun delict voor één, zes of honderd jaar galeien (beurtschepen) laten roeien, overigens 'alleen om menschen te voeren' (396). In de tweede plaats wilde hij het 'quade volck' (430) duinen laten afgraven en meren laten dempen om er goed land van te maken. Ten derde wilde hij in elke regio gevangenissen laten bouwen, waarin de gedetineerden produktieve arbeid moesten verrichten: 'DE derde middel is, datmen midts in elck Landschap mocht bouwen een grote stercke ghevangenisse met menichte van hutkens ende een ruyme plaatse int midden, daermen elck een ambacht konnende zoude leveren zijn stof ende ghereetschappe (als een scoemaker leest, elsen, leer naelden) om wat werx te makene, zonder hem brood te gheven, hy en leverde eerst een matelijck daghwerck. Maer die gheen ambachten konnen, mochten leeren nette breyden, speldemaken, spinnen, weven houtsagen ende andere dergelijcke onkonstige, maer nutte ambachten, om metter tijd werck (als voorn) te leveren, ofte vasten.'(445-455). Ook in de steden wilde hij dergelijke gevangenissen, zij het dat de gevangenen van daar uit ook bij diverse openbare werken konden worden ingezet, zoals het fortificeren van steden, het bouwen van muren en dijken, het uitbaggeren van wateren, bij het heien en graven. Zó kon men Nut trecken uyt den onnutten rabbauwen'( 479-480) en hun aantal verminderen.

Wil men Coornherts ideeën in moderne termen vertalen, dan kan men hem scharen onder hen die het strafrecht funktionalistisch, vanuit een crime-control idee, benaderen. In die zin was hij voorstander van politie-registratie van verdachte personen, van een harde lijn tegen illegalen, van verhoging van de pakkans en van commercialisering van gevangenenarbeid. Geen wonder dat Coornhert door sommige moderne criminologen helemaal niet als een hervormer wordt gezien. Zij begrijpen niet, dat de Coornhert-Liga (een in 1971 door een aantal vooruitstrevende strafrecht-juristen en criminologen opgerichte vereniging voor strafrechthervorming) diens naam heeft aangenomen. De historicus Spierenburg heeft daaraan de veertiende stelling bij zijn proefschrift gewijd: 'Indien de Coornhert-Liga werkelijk lotsverbetering van gevangenen nastreeft, kan ze haar naam beter veranderen, daar Coornhert zelf expliciet voorstander was van lotsverzwaring'. Ook Bianchi begrijpt niet hoe Coornhert als strafrechthervormer kan zijn beschouwd. Hij vraagt zich af 'of de eervolle plaats die Coornhert gekregen heeft in het pantheon van de geschiedenis der criminologie, wel verdiend is'. Bij het lezen van Boeventucht bekroop Bianchi namelijk het gevoel dat hij een 'wrede domme Spiessbürger is geweest, die over mensen praat als koopwaar'. Vergeleken 
met 'echte' humanister uit zijn eeuw, zoals Erasmus, More en Vives, valt Coornhert volgens Bianchi echt door de mand. 'Coornhert wil misdadigers straffen en uitbuiten, ongeacht de hoedanigheid van de samenleving en de overheid die voor het ontstaan van het misdadig gedrag een belangrijke faktor vormen. Als het aan Coornhert lag zouden de gevangenissen nu onmiddellijk worden voorzien van b.v. tredmolens waar de Boeven, gevoed met slechts water en brood, door harde arbeid een bijdrage zouden kunnen leveren aan de energievoorziening. Want Boeven moet je voor je laten werken: daar zijn ze voor', fuimineerde deze criminoloog, die daarbij over het hoofd zag dat de door hem genoemde 'echte' humanist als More precies hetzelfde nastreefde als Coornhert: beheersing van her Europese probleem van de zwervende, bedelende en stelende paupers. ${ }^{12}$

Bonger bestreed een dergelijke negatieve visie op Coornhert. Weliswaar - zo betoogde hij- heeft Coornhert Boeventucht geschreven om de maatschappij van zijn dagen zoveel mogelijk te verlossen van beroepsbedelaars en dieven, (niet uit medelijden of barmhartigheid) en zijn de straffen die hij voorstelt 'in vele - nier alle - gevallen in onze ogen zeer wreed', toch betekende dit volgens hem een vooruitgang in vergelijking met hoe daarvóór gestraft werd. Bonger verwijt Bianchi Coornhert af te meten aan een normen- en waardenpatroon van de twintigste eeuw: 'Het komt er op neer, dat schr. Coornhert verwijt, dat hij geen marxistische maatschappijbeschouwing heeft en dat hij de oorzaak van bedelarij en diefstal niet zoekt in de kapitalistische produktieverhoudingen, waarbij delinkwenten slachtoffers van het systeem zijn. Het is waar, Coornhert is geen maatschappelijk hervormer, hij is een moralist. Ik houd vol, dat Coornherts voorstellen, in de Boeventucht vastgelegd, een wezenlijke verbetering waren, in vergelijking met de straffen, die voordien werden opgelegd. En dat geldt zelfs voor zijn - overigens niet gerealiseerde - plan om veroordeelden, op water en brood, als roeiers te gebruiken in het binnenlands verkeer. Voordien werden ze opgehangen (voor kleine diefstallen), verminkt, gegeseld, gebrandmerkt, verdronken, in kooien uitgehongerd en verbannen, nu was er een mogelijkheid tot reclassering', aldus Bonger. ${ }^{13}$ Coornherts' visie op de relatie misdrijf-maatschappij-arbeid was in de ogen van De Vries voor de 16 de eeuw 'ongewoon nieuw en heilzaam: een schrede in de vermenselijking van het strafrecht'. ${ }^{14}$

'Het nieuwe zit in de koppeling van verschillende systemen (armenzorg, strafrecht, overheid) waardoor hij een eenheid in de bestrijding van de criminaliteit heeft ontwikkeld', zei De Beer, die vervolgde: 'Coornhert is mijns inziens te beschouwen als een der eerste voorstanders van een criminele politiek die gebaseerd is op een grondige analyse van de criminaliteitsproblematiek, maatschappelijke achtergronden daarvan en het strafstelsel' ${ }^{15}$

De Coomhert-Liga heeft overigens noch in Spierenburgs, noch in Bianchi's betichtingen aanleiding gezien om haar naam te veranderen. Wellicht orndat Coomhert de eerste Nederlander was, die een rationeel debat over doeleinden van straf entameerde en daarmee een historisch voorbeeld voor het vergelijkbare streven van de oprichters van de Liga was. ${ }^{16}$ Weliswaar was Coomherts benade- 
ring van criminaliteit anders dan die van de leden van de Coornhert-Liga, 'dat neemt niet weg dat hij voor de zestiende eeuw wel degelijk met moderne, we zouden nu zeggen progressieve, voorstellen kwam', aldus Heumekers naar aanleiding van de herdenking van de 400 ste sterfdag van deze ijveraar voor (religieuze) tolerantie. ${ }^{17}$

\subsection{Zitten en werken}

Hoewel Coornhert niet zelf tot de founding fathers van het in 1596 geopende Amsterdamse Rasphuis behoorde ${ }^{18}$, is zijn suggestie om het 'leeglopend gheboefte' gedwongen te werk te stellen door de Amsterdamse schepenen in het kader van dat project wel gerealiseerd. Het bleek een nationaal en internationaal succes. In 1697 werd in Amsterdam voor de vrouwen het Spinhuis operationeel. In de Staten van Holland openden Leiden (1598), Haarlem (1609), Gouda (1610), Alkmaar (1613) en Delft (rond 1620) tuchthuizen naar Amsterdams model. Buiten Holland was Leeuwarden (1598) er vlug bij en volgden ook Groningen (1609), Utrecht (1616) en Middelburg (1642), telkens op initiatief van de stedelijke machtselites. In Noord Duitsland werden in de jaren 1629-1630 te Bremen, Hamburg, Lübeck en Danzig tuchthuizen naar Nederlands model geopend. ${ }^{19}$

Over de doelstellingen van de opsluiting bestond bij de oprichters bepaald geen communis opinio: bij sommigen overheerste een mededogen met de opgepakte armoedzaaiers, bij anderen stond een strikte controle op het gedrag van de opgesloten criminelen voorop. Spierenburg, die dit vaststelt, omschrijft de opkomst en ontwikkeling van de gevangenis als een 'blind proces'. De diverse soorten tuchthuizen, die zich in Europa in de loop van de tijd ontwikkelden zijn volgens hem eerder terug te voeren tot bepaalde maatschappelijke processen, dan tot de individuele inzichten van de oprichters ervan. ${ }^{20}$

Men was het er wel over eens dat de nieuwe strafinrichtingen zich zelf moesten kunnen bedruipen en wel door het benutten van de arbeidskracht van de gedetineerden.

Sellin beschreef de strafgestichten, zoals die intussen overal in Europa waren ontstaan, als staats fabrieken, die dienstbaar waren aan de mercantilistische bedoelingen van de heersende klasse, die meer oog had voor haar handelsbelangen dan voor de verbetering van delinkwenten. Om concurrentie met de vrije ondernemers te vermijden, waren de tuchthuizen vaak aan particulieren verpacht. En die waren alleen maar uit op een winstgevende exploitatie van de werkkracht van de gedetineerden. ${ }^{21}$ De tucht- en spinhuizen waren volgens Hallema vóór alles werkhuizen, fabrieken en magazijnen voor het opslaan van verwerkte produkten: 'De regenten en hun boekhouder waren tevens, ja vooral, fabrikanten en kooplieden'.22

Spierenburg, die aan het werk van de 'amateur onderzoeker' Hallema en de 'criminoloog' Sellin weinig of geen waarde hechtte ${ }^{23}$, kwam op grond van zijn archief-werk tot andere bevindingen. De gevangenissen leken volgens hem helemaal niet op fabrieken, maar eerder op uitvergrote, wat complexere huishoudens, 
waarvan men wel wilde dat ze zichzelf konden bedruipen, maar wat eigenlijk nooit gelukt is. Als fabrieken waren ze niet levensvatbaar; ze moesten niet zelden uit speciale belastingen, bijvoorbeeld op wijn en bier of uit opbrengsten van loterijen, worden gefinancierd. Het 'plan van arbeid' resulteerde altijd in verilies. Er moest voortdurend geld uit andere bron bij, bijvoorbeeld bijdragen van particulieren voor het levensonderhoud van familieleden, die op hun verzoek waren ingesloten en vergoedingen van andere jurisdicties voor het overnemen van gevangenen.

Aan degenen, die menen dat de tucht-annex-werkhuizen ten doel hadden het ongeregelde volk tot een werkwillig arbeidspotentieel te disciplineren werpt Spierenburg tegen dat er daarvoor eenvoudig veel te weinig mensen in dat soort inrichtingen werden opgesloten. In zijn visie waren de tuchthuizen veeleer zichtbare symbolen van onderdrukking, net zoals openbare terechtstellingen dat waren geweest.

In het pre-industriële Europa was de gedwongen arbeid in de eerste plaats een straf. Er werd niet, zoals later in het $19 \mathrm{e}$ eeuwse Amerika het geval zou zijn, primair materieel gewin mee beoogd. De functie van de gevangenen-arbeid was in de door Spierenburg beschreven vroeg-moderne tijd een tweeledige. Ten eerste was het een onderdeel van het op disciplinering gerichte regiem: de arbeidsplicht diende tot bestrafting en correctie van de gedetineerden en ter verzekering van de orde binnen de inrichting. En ten tweede moest de arbeid de kosten van de inrichting binnen aanvaardbare grenzen houden. Het laatstgenoemde streven was meer een uiting van traditionele voorzichtigheid dan van een mercantilistisch beleid. Volgens Spierenburg kunnen gevangenissen-annex-werkhuizen dan ook niet worden gezien als proto-kapitalistische arbeidsgewenningsinrichtingen. ${ }^{24}$

\subsection{De teloorgang van Sint Raspinus}

Wat voor werk deden gevangenen nu eigenlijk? De mannen raspten aanvankelijk vooral tropisch hardhout (brasiliehout of fernambuk) tot rode verfstof voor de laken-industrie. Daarnaast hielden mannen èn vrouwen zich bezig met 'textiele werkvormen' als her spinnen van wol, het weven van grof linnen en canvas, naaien, het slaan van hennep, breien (netten, kleding), herstel van kleding, het spoelen van zijde, het hekeien van vias, het twijnen van touw, het 'vollen' van textiel, en het pluizen van touw tot 'werk' waarmee schepen gebreeuwd konden worden.

Het met lichaamskracht hout-raspen, onverbrekelijk verbonden met de genese van het Nederlanđse gevangeniswezen, moet het op den duur afleggen tegen de voortschrijdende techniek van de molenaars. ${ }^{25}$ Een streven om blijvend dat werk op de ouderwetse manier in de tuchthuizen te laten verrichten mislukte.

In een artikel over de gevangenisarbeid in de tijd van de Republiek beschrijft Hallema de concurrentieslag om de produktie van geraspt braziliehout. Het Amsterdamse tuchthuis had daar sinds 1602 het monopolie op, hetgeen op den duur door particuliere molenaars en andere strafgestichten werd getrotseerd. Ook zij 
wilden graag profiteren van de toenmalige grote vraag naar rode verfstof voor de lakenindustrie.

Doordat de Amsterdammers stug aan hun monopolie vasthielden was Rotterdam pas relatief laat in staat (in 1663) een tuchthuis te openen, dat - het Amsterdamse monopolie ten spijt - toch óók hout voor de verfindustrie begon te raspen.

Het kwam in de tweede helft van de $18 \mathrm{e}$ eeuw zelfs tot slepende processen tussen de regenten van het Amsterdamse tuchthuis en de particuliere molens. De toenemende concurrentie noopte Amsterdam tot het inzetten van meer gedetineerden, het uitbetalen van overwerk en het belonen van de suppoosten naar rato van het aantal afgeleverde zakken geraspt hout ${ }^{26}$ Het mocht allemaal niet baten, de rasperij had zijn belangrijkste tijd gehad en Sint Raspinus, de bedachte schutspatroon van het Amsterdamse tuchthuis ${ }^{27}$, kon definitief tussen de coulissen van de geschiedenis terugtreden.

De arbeidsplicht leidde soms tot verzet. Hallema maakt melding van een geval van werkweigering in het Goudse tuchthuis anno 1619. De zwaarte van de arbeid leidde daar (waar hennep werd 'gebeukt') tot verzet van gedetineerden. De 13-jarige Evert Carelssen antwoordde op de vraag waarom hij niet wilde werken, dat zijn taak hem te zwaar viel. Hij wilde liever leren lezen en schrijven, maar omdat hij te veel moest produceren had hij daar geen tijd voor. Om zijn brutaliteit af te leren werd hij gegeseld en voor acht dagen op water en brood gezet.

Een ander geval van werkstaking deed zich op 10 november 1696 in het Rotterdamse tuchthuis voor. Vier gedetineerden hadden in letterlijke zin het bijltje er bij neergelegd. Waarom vermeldt de historie niet, maar het ligt voor de hand dat de zwaarte van de arbeid er mede debet aan was. Van enig stakingsrecht was geen sprake: toen de desbetreffende personen niet uit hun cellen wilden komen kregen ze gewoon niets meer te eten of te drinken. Enkele dagen later werden ze met geweld uit hun cel gehaald en daarna voor hun vergrijp gegeseld. ${ }^{28}$

\subsection{Howards reisreportages}

Hoe gevangenisarbeid er in de nadagen van de Republiek uitzag komt naar voren uit de ooggetuigeverslagen die de eerste, zij het inofficiële, Europese gevangenisinspecteur John Howard ons heeft nagelaten.

Deze 'Sheriff of Bedford', heeft aan het eind van de $18 \mathrm{e}$ eeuw systematisch nationaal en internationaal - veld-onderzoek gedaan naar de toestand van strafinrichtingen en hun bewoners. In zijn 'The state of the prisons' heeft hij zijn bevindingen opgetekend en een aantal hervormingsvoorstellen geformuleerd. ${ }^{29}$

In de zeventiger en tachtiger jaren van de $18 \mathrm{e}$ eeuw was Howard enkele malen in 'Holland', waar hij de strafinrichtingen te Rotterdam, Amsterdam, Middelburg, Utrecht, Groningen, Leeuwarden en Zwolle bezocht. Hij was tamelijk ingenomen met de staat, waarin hij die gevangenissen aantrof: schoon en ruim, maar dat kon er aan liggen dat in die inrichtingen alleen wanbetalers waren ondergebracht. De echte criminelen zaten in de rasp-en spinhuizen. Howard stelde 
vast dat de Staten niet zoals bijoorbeeld Engeland, veroordeelden naar de koloniën transporteerden, maar dat de mannen in de rasphuizen en de vrouwen in de spinhuizen aan het werk werden gezet, onder het motto: 'Maak ze ijverig en ze worden braaf. Hij constateerde dat het raspen van hout, dat intussen veel goedkoper in molens gebeurde, bijna overal piaats had gemaakt voor arbeid voor de wolindustrie en dat de gevangenen daarmee de kosten van het eigen levensonderhoud konden verdienen en er zelfs wat geld aan over hielden, zodat ze na hun ontslag nog wat hadden. Howard meldde dat sommigen zelfs na afloop van hun straf in het (rasp-)huis wilden blijven werken. Hij had echter wel vernomen dat de produktie van de gedetineerden niet voldoende opleverde om de inrichtingen ermee te kunnen financieren.

Op bezoek in het Rotterdamse rasp- (en spin-)huis zag hij de gedetineerden de volgende soorten werk verrichten: sommige mannen raspten er nog hour, andere kamden wol, sponnen en kaardden, breiden visnetten en sorteerden koffiebonen. De vrouwen sponnen wol en vlas. De opzichter van het Rotterdamse etablissement ontving zijn salaris van de stad en één zevende van de opbrengst van het werk van de gedetineerden, zodat hij er belang bij had, dat het werk goed gedaan werd. Maar, omdat de hoeveelheid te verrichten arbeid door de regenten werd vastgesteld, werd voorkomen dat hij een slavendrijver werd.

In de Middelburgse gevangenis zag Howard de gederineerden laken weven en jute zakken voor de Verenigde Oostindische Compagnie maken. In het Amsterdamse Rasphuis was het raspen van hout nog steeds de meest voorkomende arbeid, maar Howard zag er ook twee man zijde winden. Anderen waren in de magazijnen aan het sorteren en wegen. Weer anderen zorgden voor de aanvoer van het hout. Er werd 's ochtends gewerkt van zes tot twaalf en 's middags van één tot vier. In overuren maakten ze snuisterijen als tabaksdozen die zij aan bezoekers verkochten. Howard zag dat niet àl het hout meer met de hand werd geraspt, maar dat velen bezig waren met het klein hakken ervan voor de twee molens van het rasphuis: het was voor de meeste gevangenen een te grote opgave om de zes tot acht zaagbladen te bedienen. Gevangenisartsen hadden vastgesteld dat dat soort werk de oorzaak was van veel lichamelijke klachten.

In het Amsterdamse Spinhuis hielden de vrouwen zich onledig met spinnen en naaiwerk, dat vaak uit de stad werd toegestuurd. Haar werktijden waren van zes tot twaalf en van één tot acht. Dat Spinhuis was kennelijk niet selfsupporting, want Howard vermeldt dat het werd ondersteund door een kleine jaarlijkse belasting op tabak- en drankverkoop en door een kwart van de opbrengst van openbare tentoonstellingen en vermakelijkheden.

Toen Howard in 1783 voor een tweede keer in Amsterdam kwam waren alle gedetineerden naar een nieuw werkhuis overgebracht. De vrouwen moesten daar wol kaarden, spinnen en opwinden, weven en schoonmaken (huisdienst). De jongens en de mannen waren hoofdzakelijk bezig met het pluizen van touw, waarmee de naden van de schepen van de Admiraliteit en de VOC gebreeuwd werden.

Howard heeft niets genoteerd over de aard en de beloning van de arbeid in de ook door hem bezochte strafinrichtingen te Leeuwarden, Groningen en Utrecht. 
In het 'Tucht-huys' te Zwolle zag hij de vrouwen spinnen en breien. Wat de mannen daar deden vermeldt hij niet.

Het beeld dat Howard geschetst heeft is niet spectaculair. Volgens Howard (die kon vergelijken) was hier alles goed geregeld. 'Ik weet niet wat ik meer moet bewonderen, de orde en reinheid in de: gevangenissen, de jjver en het geregeide leven van de gevangenen. of de menselijkheid en aandacht van de magistraten en regenten'. Hij was ervan overtuigd dat arbeid voor gevangenen heilzaam, ja onontbeerlijk is. In de Engelse Bridewells had hij te veel leegloperij waargenomen. Zijn advies: laat elke gezonde gedetineerde werken, maar dan wel in aparte kamertjes, zodat zij niet in de verleiding komen om te midden van de massa de lijn te: trekken. De direkteur moest de produktiemiddelen beheren en een actief, verstandig man met karakter zijn. Hij moest zijn gevangenen tien uur per dag aan. het werk houden, de eetpazzes daarbij inbegrepen, aldus Howard, die overigens niet dacht, dat strafinrichtingen ooit selfsupporting zouden kunnen zijn. Hij zag wel in, dat er een groot verschil is tussen de opbrengst van onvrijwillige en die van vrij verkozen arbeid. Ook de best bestuurde strafgestichten in Holland steunden nog op belastingbijdragen, zo stelde hij vast. Hij vond het onjuist dat directeuren een deel van de opbrengst van her werk in hun eigen zak staken. Alle verdiensten moesten volgens hem aan de algemene middelen van de inrichting ten goede komen. De opbrengst van overwerk moest volgens hem worden betaald aan degene die het verrichtte. ${ }^{30}$

Howard heeft de nadagen van de Hollandse tuchthuizen beschreven. Kort na zijn dood in 1791 zullen. de gevolgen van de Franse Revolutie het strafrecht, de straffen en de uitvoering daarvan. immers ingrijpend veranderen.

Voordat hier wordt ingegaan op de ontwikkeling van de gedetineerden-arbeid in de $19 \mathrm{e}$ eeuw is het goed erop te wijzen dat het in Noord-West Europa gerecipiëerde Hollandse model van in tuchthuizen werkende gedetineerden maar één van de manieren was om de overlast van de bezitloze onderklasse te beteugelen. In mediterrane streken werd die van oudsher naar de galeien gestuurd en de Engelsen leegden hun overvolle Bridewells door toepassing van de 'transportstraf', waarmee zij een groot deel van hun criminelen naar de koloniën konden verbannen. Daar werden ze als goedkope arbeidskrachten, de facto als slaven, gebruikt.

Het is opmerkelijk dat de Nederlanders, als zeevarend en koloniën bezittend volk, de galei- en transportstraffen, die immers evenzeer als het werk in de tuchthuizen de gedwongen tewerkstelling van het 'ledigh gheboefte' inhielden, nooit hebben ingevoerd.

\subsection{De galeistraf}

Hoewel Coornhert, zoals hierboven is beschreven, het Nederlandse handelsverkeer graag: had ondersteund met de toepassing van de galeistraf, is het in de 
Lage Landen gebleven bij een tweetal mislukte experimenten. Galeien waren meer iets voor mediterrane streken.

Zysberg ziet de galeistraf tussen 1490 en 1500 in Frankrijk op het toneel verschijnen wanneer het koninkrijk ter ondersteuning van zijn politieke aspiraties in Italië een machtige Middellandse Zee-vloot creëert, met galeien als belangrijkste bestanddeel. De nieuwe straf, aanvankelijk bedoeld als aiternatief voor executies en verminkingen, voorzag in de eerste plaats de vloot van roeiers. Repressieve motieven kwamen op de tweede plaats. In de jaren 1550-1560 werd de galeistraf een zelfstandig onderdeel van het sanctie-arsenaal dat de rechter ter beschikking stond. ${ }^{31}$

Aanvankelijk deden naast veroordeelden en slaven uit pure economische noodzaak ook 'vrijwilligers' op de galeien dienst. Sellin stelde vast dat zij verdwenen toen de economie aantrok en er aan wal minder ellendig werk voor ze beschikbaar kwam. Dat had tot gevolg, dat tot aan het moment waarop de Franse galei-vloot in 1748 werd afgeschaft, de galeien tegen het eind van de zestiende eeuw alleen nog maar door slaven en veroordeelden geroeid werden. Gedurende periodes waarin er meer veroordeelden waren dan de galeiën konden bevatten, werden er wel galériens verkocht, bijvoorbeeld aan Malta. In tijden van schaarste aan vlootbemanning werden de rechterlijke instanties onder druk gezet om galeistraffen op te leggen.

Was de galeistraf aanvankelijk bedoeld als alternatief voor de doodstraf, later werden er ook vaak lichtere vergrijpen mee bestraft. Daarbij wilde het nogal eens voorkomen, dat de kapiteins van de galeien 'hun' veroordeelden lang na het einde van hun straftijd aan boord vasthielden.

Veroordeling tot een galeistraf werd in feite als een soort doodstraf beschouwd; de bezittingen van de veroordeelde werden geconfisceerd en het resultaat van dat alles was diens mort civil. De tot galeistraf veroordeelde werd publiekelijk tentoongesteld, gegeseld en tenslotte gebrandmerkt met de letters GAL (van galérien, galeiboef). Van tijd tot tijd werden uit grote steden van Frankrijk de galeiboeven opgehaald. Aan elkaar geketend in groepen van vifftig tot enkele honderden werden zij dan onder grote publieke belangstelling naar havens als Mar seille en Toulon gebracht.

's Winters werden de galeien in de havens opgelegd en werden de roeiers, samen met de daar al verblijvende niet meer voor het roeien geschikte galériens in de werkplaatsen op de vlootbases tewerkgesteld. Sommigen mochten op het haventerrein eigen winkeltjes drijven. Ook werden veel veroordeelden overdag in de stad als huisknecht, of in de handel of industrie aan het werk gezet. 'Omdat de lonen die hun door hun particuliere werkgevers betaald werden maar ongeveer een-vijfde bedroegen van wat de vrije arbeider ontving, keerden de Marseillaanse ondernemers zich tegen elk poging om de galeien uit hun haven weg te halen', aldus nog steeds Sellin. ${ }^{32}$

Als aan het eind van de zeventiende eeuw de galei-vloot aan militaire betekenis inboet komt er een overschot aan tot galeistraf veroordeelde personen. Zij 
worden op het haventerrein en in de stad Marseille tewerk gesteld. En als de koning in september 1748 de ontbinding van de galei-vloot gelast kan dat worden beschouwd als het moment waarop de bagno's worden geboren: grote etablissementen in de oorlogshavens, waar veroordeelden dwangarbeid verrichten. ${ }^{33}$

Er waren meer landen rond de Middellandse Zee, die er galeien op na hielden. Zo stuurde ook Spanje zijn veroordeelden naar de galeien. Ook daar werden die aanvankelijk bemand door slaven en vrijwilligers. Toen er op de reguliere vloot tekorten aan arbeidskrachten ontstonden omdat vrijwilligers steeds moeilijker te vinden waren werd vanaf de eerste helft van de 16 e eeuw omzetting van lijfin galeistraffen mogelijk. In de daaropvolgende eeuw kon de galeistraf in veel gevallen ook direct worden opgeiegd. In Spanje is de galeistraf pas in 1803 afgeschaft.

Het kwam voor dat staten die niet aan zee grensden galei-roeiers leverden, bijvoorbeeld Beieren aan Venetië. Andere jurisdicties gebruikten galeien op hun meren, zoals de Zwitserse kantons Luzern en Bern.

In noordelijke landen als Engeland, de Nederlanden en Scandinavië is wel met galeien geëxperimenteerd, maar zonder veel succes. ${ }^{34}$

Rusche en Kirchheimer troffen in een Antwerpse editie uit 1570 van Joost Damhouders boek 'Praxis rerum criminalium' een beschrijving aan van een op instigatie van Philips de Tweede door Margaretha van Parma uitgevaardigd edict om landlopers naar de Spaanse galeien te sturen. De schrijvers noteren dat het toenemend belang in die periode van de galeistraf als strafsoort blijkt uit het feit dat in eerdere edities van Damhouders boek niets over dat onderwerp vermeld wordt, terwijl daar later een heel hoofdstuk aan besteed wordt. ${ }^{35}$ Dat kan betekenen dat zo nu en dan ook zwervers uit onze contreien als 'export-produkt' met de Spaanse roeibanken kennis hebben gemaakt.

In de Lage Landen liep het met de galeistraf zo'n vaart niet. Hallema meldt ons, dat de galeistraf in de noordelijke Nederlanden (op papier) maar zo'n 10 jaar heeft bestaan: vanaf de 'Ordonnantie aangaende de diensten ende het beleid op de galeien dezer landen' van 8 juli 1598 tot 1609, het jaar waarin de galeien door de Staten-Generaal werden afgedankt en dus ook de galeistraf niet meer werd toegepast. Het enige Nederlandse bagno heeft in Vlaardingen gestaan en had een toepasselijke naam: Slavenburch, gebouwd in 1601, afgebroken in 1793. Dat was het winterverblijf van de roeiers. ${ }^{36}$ De toepassing van de galeistraf is volgens genoemde auteur in ons gebied zeer beperkt gebleven. Voor opzending van gestraften naar de Spaanse galeien was de rechterlijke macht destijds uit politieke overwegingen niet erg te vinden. 'Positief zouden Spanje en zijn vorst met gestadige toevoer van tot galeistraf veroordeelden gebaat zijn, negatief Holland door vermindering van het getal ervaren zeerotten, koopvaarders en handelslui', aldus Hallema. Hij meende overigens, dat de galeien in de Nederlanden vooral zo snel zijn afgeschaft omdat op onze wateren dat scheepstype niet bruikbaar was. ${ }^{37}$ 


\subsection{De transportstraf}

Netzomin als de galeistraf is de 'transportstraf' in ons land tot ontwikkeling gekomen. De transportstraf kwam neer op een rechterlijk bevel de veroordeelde naar een ver overzees gebiedsdeel te deporteren en hem daar onder staatsregie of uitgeleend aan particulieren te laten werken. Vele landen hebben - tot ver in deze eeuw - van dit soort verbanning van hun criminele onderklasse gebruik gemaakt. Sutherland en Cressey ${ }^{38}$ noemen naast de kampioen van de transportstraf Engeland: Portugal (export van gedetineerden naar Brazilië en Angola), Spanje (waarheen dat land zijn gedetineerden stuurde vermelden deze schrijvers niet $\left.{ }^{39}\right)$, Rusland (naar Siberië), Italië (naar eilandjes voor de kust) en Frankrijk (zie hieronder).

Het intensiefst is de transportstraf door Engeland gebruikt, zowel bij de kolonisering van Noord-Amerika als van Australië. Engeland sloeg daarmee volgens Hughes twee vliegen in één klap: de overbevolkte gevangenissen konden worden geleegd en er kon een leger van rechteloze arbeiders naar de koloniën worden gestuurd om daar werk te verrichten waarvoor geen vrije kolonist te vinden was.

De juridische basis voor transport over zee lag in een Engelse wet uit 1597. In 1611 werden de eerste veroordeelden naar de plantages van de Virginia Company gestuurd. Vanaf 1618 werd dat een gestage stroom, richting Nieuwe Wereld. De meesten waren 'gewone criminelen', maar er waren ook krijgsgevangenen bij. $\mathrm{Na} 1717$ nam het aantal transporten toe en konden, op gxond van nieuwe wetgeving, ook minder zware criminelen naar Amerika worden gestuurd. 'Engelse cipiers deden goede zaken door deze ongelukkige kolonisten aan verschepers te verkopen, die hen (of, juridisch juister, de rechten op hun werkkracht voor zeven of veertien jaar) weer doorverkochten aan de eigenaars van plantages in het Caraïbische gebied en Amerika', aldus Hughes.

Zo rakkte Engeland jaarlijks op een makkelijke manier van zo'n 700 veroordeelden af. Tot 1775, toen de Amerikaanse koloniën tegen Engeland in opstand kwamen. Men wilde geen Engelse criminelen meer en men had die trouwens ook niet meer nodig omdat de. Amerikaanse economie al sterk van slavernij afhankelijk was geworden. De handel in zwarte slaven had de arbeid van blanke veroordeelden uit de markt geprijsd, aldus Hughes. Aan de vooravond van de revolutie kwamen er 47.000 Afrikaanse slaven per jaar in Amerika aan, meer dan de Engelse gevangenissen in de halve eeuw die daaraan voorafging over de Atlantische Oceaan had gestuurd.

Engeland kon toen z'n gedetineerden niet meer kwijt en borg ze voorlopig op in hulks, oude oorlogsbodems die in de Thames waren opgelegd. ${ }^{40}$

De Engelse autoriteiten vonden uiteindelijk toch weer een plek om gestraften naar toe te sturen: Australië. Een eerste vloot, met zo'n 700 veroordeelden werd in 1787 naar Botany Bay, aan de oostkust van Australië, gestuurd. Tot. 1868, het jaar waarin het laatste transport plaatsvond, zijn er ongeveer 160.000 Engelse 
veroordeelden naar Australië getransporteerd. Alles op basis van een nieuwe wet, die transport naar andere gebieden dan Amerika mogelijk maakte, de Transportation Act van 1784. Overigens moet worden opgemerkt, dat het transportsysteem, zelfs niet op het hoogtepunt ervan, het gebruik van gevangenisstraf heeft overtroffen, zij het dan, dat laatstgenoemde sanctie bijna nog alleen voor geringe vergrijpen werd opgelegd.

Het transporteren van gedetineerden naar Australië had financieel gezien andere gevolgen voor de Engelse overheid dan de daaraan voorafgaande transporten naar Amerika. De Amerikaanse kolonisten betaalden voor het vervoer van de Engelse veroordeelden. De gedeporteerden behoorden hen in eigendom toe en werden, net zoals slaven, als kapitaal beschouwd. Virginia en Maryland waren geen strafkolonies, maar vrije kolonies waar veroordeelden als slaven werden gebruikt. In het 'lege' Australië waren er nog geen vrije kolonisten gevestigd on de getransporteerden van de staat over te nemen. Daar moesten speciale strafkolonies worden gesticht, die van Engeland een startsubsidie kregen, maar na drie jaar self-supporting moesten zijn.

oen er na verloop van tijd voldoende vrije kolonisten in Australië waren, werden de meeste veroordeelden als goedkope arbeidskrachten volgens het zogenaamde assignment-system aan hen toegewezen. De getransporteerden waren in Australië geen slaven, zoals in Amerika. De overheid bleef formeel voor hen verantwoordelijk. Uiteindelijk werkte misschien nog één op de tien getransporteerden rechtstreeks onder overheidsgezag en wel aan openbare werken, zoals het graven van greppels, tunnels, gevangenissen, rechtbanken, pieren en wegen. Deze government-men konden op die manier hun schuld aan de Engelse maatschappij inlossen. Tewerkstelling door de overheid werd als de ergste straf beschouwd.

De assignment van getransporteerde veroordeelden was gedurende de eerste vijftig jaar waarin Europeanen zich in Australië vestigden de spil waar het koloniale systeem om draaide. Het was een belangrijke, zo niet de belangrijkste, reden waarom emigranten überhaupt daar naartoe wilden gaan. Op het moment waarop de behoefte aan goedkope arbeidskrachten in Australië afnam (toen er goud gevonden werd en de immigranten toestroomden) en de gevangeniscapaciteit in Engeland werd uitgebreid, kwam er een eind aan de transporten naar Australië van Engelands criminele (of gecriminaliseerde) onderklasse. De regering had er in 1851 gevangenissen bijgebouwd. Zo ging bijvoorbeeld de grote, sombere, gevangenis van Dartmoor open, en in Portsmouth was een nieuwe gevangenis gebouwd om de overbevolkte hulks te vervangen. In 1852 was er in Engeland plaats yoor 16.000 gedetineerden: ${ }^{41}$

Er was, zo leest men bij Aschrott, in Australië een beweging tegen de praktijk van de deportarie op gang gekomen, die uiteindelijk leidde tor het staken van de deportaties. In 1853 verving Engeland krachtens de eerste Penal Service Act de deportatie voor straffen onder 14 jaar door een nieuwe straf, de penal servitude. In 1857 werd de transportstraf formeel geheel afgeschaft. Daarmee hielden de transporten naar Van Diemensland (Tasmanië), in die dagen het belangrijkste 'afzetgebied', weliswaar op, maar daarmee was het met de export van veroordeelden 
nog niet helemaal afgelopen. Nog in 1.868 is een scheepslading Engelse veroordeelden in West-Australië, aan land gebracht. ${ }^{42}$

De duur van de penal servitude werd berekend naar het aantal jaren deportatie waarvoor men, gezien de feiten, in aanmerking zou zijn gekomen. Bij latere wetgeving vervalt deze rekensom en wordt de penal servitude een zelfstandige hoofdstraf, die bestond uit een periode eenzame opsluiting, gevolgd door tewerkstelling: bij openbare werken. Bij goed gedrag kon men, voorzien van een verlofpas (ticket of leave), in vrijheid worden gesteld. ${ }^{43}$

Het einde van de transportstraf ${ }^{44}$ en de omstandigheid dat er voor steeds meer strafbare feiten steeds langere straffen werden opgelegd veroorzaakten een enorme expansie van het Britse gevangeniswezen en legden de basis voor het huidige stelsel. $^{45}$

Juist toen de Engelsen ophielden met het verschepen van hun veroordeelden begint Frankrijk de bevolking van zijn overvolle bagno"s te Toulon, Brest en Rochefort naar Algerije, Guyana en Nieuw-Caledonie te sturen. Daar werd zij voornamelijk bij ontginningswerkzaamheden ingezet.

Pierre heeft beschreven hoe de transportation niet alleen op de "gewone" delinkwent werd toegepast, maar tevens hoe de Franse staat die benutte om van een flink aantal politieke tegenstanders af te komen. In de 40-er en 50-er jaren van de 19 e eeuw werden heel wat revolutionairen naar Algerije verbannen. Van 1872 tot 1878 werden duizenden verslagen commumards naar Nieuw-Caledonië verscheept. Het door zijn beroerde leefomstandigheden beruchtste, maar niettemin langst gebruikte verbanningsoord was echter Frans Guyana met zijn Duivelseiland, waar Alfred Dreyfus de bekendste banneling zou worden. In 1938 werd de transportstraf uit de Code Pénal geschrapt, maar verbanning naar de koloniën bleef mogelijk.

Sinds het midden van de negentiende eeuw zijn er 52.000 veroordeelden en 15.600 personen uit anderen hoofde naar Frans Guyana verbannen. Daarbij komen nog 20.000 gestraften en 10.000 bannelingen die naar Nieuw-Caledonië zijn getransporteerd plus nog eens duizenden Indo-Chinezen, die naar het eiland Paolo Condor zijn gezonden. Pas in augustus 1953 werden de laatste bagnards uit Guyana naar Frankrijk gerepatrieerd en verdwenen daar de laatste sporen van de transportstraf. ${ }^{46}$

Nederland heeft de transportstraf nimmer gekend en, op een enkel experiment na, zijn veroordeelden niet naar de koloniën gestuurd. Wel heeft Spierenburg ontdekt dat van 1684-1690 op verzoek van de gouverneur van Suriname het Amsterdamse stadsbestuur met toestemming van de Staten een aantal gedetineerden naar deze westelijke kolonie heeft getransporteerd om daar dwangarbeid te verrichten. De vervoerskosten moesten betaald worden door het gerecht dat het desbetreffende vonnis uitsprak. Sporadisch werden veroordeelden naar Suriname gestuurd, maar in de negentiger jaren van de 17 e eeuw hield men daar: mee op, wellicht omdat de Surinaamse autoriteiten geen behoefte meer aan veroor- 
deelden hadden of omdat het Rasphuis daar te weinig geschikte kandidaten voor telde. ${ }^{47}$

De meest aannemelijke verklaring daarvoor is misschien, dat de Nederlandse gezagsdragers nimmer zijn geconfronteerd met een combinatie van factoren die een transportsysteem aantrekkelijk en noodzakelijk maakte. Er was geen ernstige overbevolking van de tuchthuizen en de belangrijkste kolonie, Oost Indië, telde meer dan voldoende goedkope autochtone arbeidskrachten. Men vergete daarbij niet dat opsluiting in de $17 \mathrm{e}$ en $18 \mathrm{e}$ eeuw niet de enige strafsoort was. Daamaast werd nog 'gewoon' gebruik gemaakt van de doodstraf en verminkende lijfstraffen. ${ }^{48}$

Toen begin $19 \mathrm{e}$ eeuw de vrijheidsstraf de belangrijkste sanctie werd en tegelijkertijd toenemende aantallen armoedzaaiers problemen met de openbare orde begonnen te geven heeft men in het Koninkrijk zijn toevlucht genomen tot een vorm van binnenlandse transportation: tewerkstelling in de Veenkoloniën.

Toch werd in de loop der tijd de mogelijkheid van overzees transport van gedetineerden nog wel eens overwogen. Zo vroeg koning Willem I, op zoek naar mogelijke bezuinigingen op de kosten van het onderhoud van gevangenen in 1817 de departementen van Justitie, Oorlog en van Publiek onderwijs, de Nationale Nijverheid en Kolonien om advies 'ten aanzien van het nut dat van geconfineerde of gedetineerde Militairen zoude kunnen getrokken worden, hetzij voor de Militaire dienst, hetzij voor bepaalde werken in Europa of in de Kolonien. (...)'.49 De adviesaanvrage bleef zonder consequenties.

In de 'Geschiedenis van het Wetboek van Strafrecht' van Smidt valt te lezen, dat de mogelijkheid tot deportatie van veroordeelden herhaaldelijk is geopperd, maar telkens is verworpen. 'Bij de schriftelijke en mondelinge gedachtenwisseling, voorafgegaan aan de vaststelling van het eerste boek van een wetboek van strafregt in 1840 en 1847 , verklaren vele leden der vertegenwoordiging zich herhaaldelijk en met nadruk voor de opneming van de deportatie in ons strafstelsel, zonder dat het hen gelukte de regering daartoe te bewegen. Wat men toen verlangde was echter niet deportatie verbonden aan kolonisatie, op het voorbeeld van Engeland gegeven. Men wilde geen strafkoloniën zoals de Engelschen bezitten' (...) 'Van het tuchthuis in Nederland zouden de zwaarste misdadigers worden vervoerd naar eene strafinrichting in een der koloniën om daar hun verdere straftijd door te brengen (...) een transatlantische gevangenis.'

Bij de beraadslagingen die in 1869/1870 aan de afschaffing van de doodstraf voorafgingen werd ook, maar evenmin met succes, voor invoering van deportatie gepleit.

In de Memorie van Toelichting bij het wetboek van 1886 is het volgende over de transportstraf opgemerkt: 'Zeker is de deportatie geene absoluut verwerpelijke straf. In uitgebreide staten waar het zeer grote aantal misdadigers, ook nadat zij hunne straf hebben ondergaan, eene voortdurende bedreiging is voor de openbare orde en veiligheid en waar het daarenboven zeer groot bezwaar oplevert de noodige gevangenissen te bouwen en naar de strenge eisen van het penitentiaire stelsel in te richten, valt veel te zeggen voor de deportatie op ruime schaal, zoveel 
mogelijk verbonden aan kolonisatie.' Maar, wordt verder opgernerkt, Nedierland heeft geen behoefte aan zo'n straf wanneer de gevangenissen 'naar een vast en goed stelsel worden ingerich.t.' Vervolgens wordt in de Memorie van Toelichting een aantal bezwaren tegen deportatie opgesomd: het was moeilijk te bepalen voor welke misdrijven die sanctie moest gelden; door gebrek aan toezicht kon men de zedelijke verbetering van gedeporteerden wel vergeten en vanuit Nederland was er onvoldoende zicht. op de uitvoering van die straf. Daarbij vreesde men dat Europeanen niet tegen veldarbeid in de tropen bestand zouden zijn, dat er geen plaats voor hen was 'op voldoende afstand van bevolkte steden', dat de ballingsoorden te ver uit de koers van onze koopvaarders zouden liggen en dat de kans bestond dat een en ander veel te duur zou worden als de overzeese ballingsoorden zichzelf niet zouden kunnen bedruipen. 'Gesteld dus zelfs de wenscheliikheid der deportatie stond vast, zoolang hare mogelijkheid niet is bewezen zal men in een strafstelsel waarin zij niet is opgenomen, moeten berusten; onder voorbehoud om, zoo dit bewijs later mogt worden geleverd, bij eene wijzigingswet, de levenslange en langdurige gevangenisstraf waar zij in het wetboek wordt bedreigd, geheel of ten deele te vervangen door wegvoering naar een oord in ballingschap'. ${ }^{50}$

Tot strafrechtelijke deportatie uit Nederland naar Indië is het nooit gekomen. Het omgekeerde was wel mogelijk. Het in 1867 ingevoerde alleen voor Europeanen en daarmee gelijkgestelde personen geldende Wetboek van Strafrecht voor Nederlands Indië kende in artikel 5 de straf van verbanning uit Nederlands Indië. Aan import-dwangarbeiders had men in 'de gordel van smaragd' geen behoefte omdat artikel 5 van het in 1873 ingevoerde wetboek van strafrecht voor Inlanders ruime mogelijkheden tot gedwongen tewerkstelling van de plaatselijke bevolking bood: dwangarbeid in en buiten de ketting en tewerkstelling aan publieke wer$\mathrm{ken}^{51}$. Als inheemse arbeiders hun langjarige 'koelie-contracten' met de planters verbraken leverde dat volgens de zogenaamde Koelie-ordonnantie uit 1880 een strafbaar feit op. Zo werd - met de zegen van de strafrechtsgeleerde Gr.A. van Hamel - met strafrechtelijke dwangarbeid de vaak gewelddadige arbeidsdwang die op de plantages heerste ondersteund. ${ }^{52}$ Vooral de tabaks- en rubberplanters aan de oostkust van Sumatra betoonden zich adepten van deze 'poenale sanctie'. Herhaaldelijk vroegen zij de gouvemeur-generaal om verzwaring van de tenarbeidstelling aan de publieke werken (de zogenaamde krakalstraf) 'opdat zij, behandeld wordende op een wijze waarvoor zelfs het Europeesche werkvolk nog niet rijp is, niet tot excessen komen.' Pas nadat in 1929 Amerika had geweigerd produkten van gedwongen arbeid af te nemen werd een begin gemaakt met de geleidelijke afschaffing van de poenale sanctie. ${ }^{53}$ 


\section{Van het Organisatiebesluit van 1821 tot de Beginselenwet van 1886}

\subsection{De arbeidsregeling}

De Republiek is nooit op eigen kracht tot unificatie van strafrecht en strafexecutie gekomen. Daar was een fenomenale 'aanjager', de Franse revolutie, voor nodig. 'Geen gewest van ons vaderiand had (...) zijne eigene volledige strafwetgeving; iedere stad of dorp werd door verschillende ordonnantiën geregeerd, aan welke de omstandigheden en de behoeften van het oogenblik het aanzijn hadden gegeven, en welke soms zo duister en onbestemd waren, dat nevens het Romeinsche en Canonieke, zelfs het Mozaïsche regt groot gezag op de uitspraken der justitie uitoefenden', schreef Van Deinse in 1860. Een uniform strafprocesrecht kende de Republiek bij lange na niet; elke rechter procedeerde op zijn eigen manier. ${ }^{54}$

Algemene regels met betrekking tot de tenuitvoerlegging van de vrijheidsbeneming waren er al helemaal niet. De werkende gedetineerde was sinds zijn 'uitvinding' in 1596 volstrekt afhankelijk geweest van de regenten, die de diverse stedelijke rasp-, spin- en tuchthuizen bestuurden. ${ }^{55}$

De politieke veranderingen aan het eind van de $18 \mathrm{e}$ eeuw leidden weliswaar tot verandering van staatsvorm en wetgeving, maar nog niet meteen tot modernisering en centralisering van het gevangeniswezen. Tot 1821 bleef daar alles nog zo'n beetje bij het oude, zij het dat de namen van de gestichten en van de functionarissen in de Franse tijd veranderden.

Het Crimineel Wetboek voor het Koninkrijk Holland, dat op 1 februari 1809 werd ingevoerd, introduceerde de verplichting om te werken als element van de gevangenisstraf in de wet. ${ }^{56} \mathrm{Al}$ in 1811 werd dit wetboek echter vervangen door de Code Pénal, die - zij het in hier en daar aangepaste vorm - tot de inwerkingtreding van het Wetboek van Strafrecht in 1886 zou blijven gelden. De Code Pénal kende eeuwige en tijdelijke dwangarbeid (en ook deportatie) als zelfstandige hoofdstraffen, maar reeds op 11 december 1813 werd de dwangarbeid door koning Willem I bij Souverein Besluit afgeschaft. ${ }^{57}$ Artikel 7 van dat Besluit bepaalde: 'De straf van Altoosdurenden Dwangarbeid (travaux forcés à perpétuité) voorafgegaan door eene openlijke Tentoonstelling aan de Kaak, en met Brandmerk, wordt afgeschaft. In plaats dier straf, wordt gesubstitueerd de straf van Geeseling, met den Strop om den hals, aan de Galg vastgemaakt, Brandmerk, en een confinement in een Rasp- of Tuchthuis, voor een termijn, door den Rechter te bepalen, niet te boven gaande een tijd van twintig achtereenvolgende jaren: of wel de straf van het zwaaien met het Zwaard over het hoofd, uittevoeren op een Schavot, met alle dezelfde toebereidselen, welke bij de onthoofding worden in acht genomen, vergezeld van een confinement, in een Rasp-Tucht- of Werkhuis, mede voor eenen tijd door den Regter te bepalen, niet te boven gaande den termijn van twintig achtereenvolgende jaren.'

Het elfde artikel verving de tijdelijke dwangarbeid (travaux forcés à temps) door 
een 'Confinement in een Rasp- of Tucht- of Werkhuis, voor een tijd, door den Regter te bepalen, niet te boven gaande den termijn van vijftien achtereenvolgende jaren $(\ldots)^{\prime} .{ }^{58}$

Al was arbeidsdwang dan geen hoofdstraf, 'Krachtens art. 21 van de Code Pénal werden de veroordeelden tot tuchthuisstraf, zonder onderscheid van geslacht, gebruikt tor arbeid, waarvan de opbrengst deels te hunner bate mocht worden besteed', schrijft Hallema. ${ }^{59}$

Koning Willem $I$ had een failliete boedel geërfd, een ratjetoe van strafinrichtingen, waar sinds het einde van de $18 \mathrm{e}$ eeuw niemand meer naar omgekeken had en waar hoognodig de bestuurlijke bezem doorheen moest. Daarom droeg hij nog in 1813 de President van het Hoog Gerechtshof der Vereenigde Nederlanden op om - samen met de Commissaris-Generaal voor de Binnenlandse Zaken en de Procureurs-generaal - hem te adviseren 'omtrent den tegenwoordigen staat der gevangenissen en de voegzaamste middelen, om onverwijld de onmenschlievende verwaarlozing te doen ophouden, welke, te dezen aanzien, in de laatste drie jaren, plaats gevonden heeft. ${ }^{60}$ Het geld voor de exploitatie van de inrichtingen moest bij voorkeur door de arbeid van veroordeelden worden opgebracht. In 1816 liet minister van Justitie Van Maanen de 'Collegiën van Regenten' van de strafinrichtingen het volgende weten: 'Vervolgens wenschte ik wel, dat men overlegde met hoedanigen arbeid de gevangenen, op de voordeligste wijze, zouden kunnen worden bezig gehouden, en in hoeverre de opbrengst van dien arbeid zoude kunnen strekken om de kosten te bestrijden, na aftrek, in alle geval, van dat gedeelte, hetwelk aan de gevangenen is toegezegd, en in dier voege, dat het rendement van den arbeid, die elke gevangene over een heel jaar zoude kunnen berekend worden te verrigten, afgetrokken zijnde van de som, waarop zijne verpleging over een gelijk tijdvak is begroot, het restant der subsidie zouden aanwijzen, die voor elken gevangene jaarlijks van 's Lands wege zoude moeten worden betaald.' (...) 'Het zal bijna overbodig zijn de anmerking te maken, dat, waar zulks mogelijk is, de kleedingstukken en andere noodwendigheden in de gevangenissen zouden mogen vervaardigd worden, en dat in het bepalen der stoffen dier kleeding en liggingstukken, gelijk mede in de wijze van kleeding als anderzins, zal behooren te worden gelet zoo wel op het minst kostbare als op het meest voordelige voor de gevangenen'. ${ }^{61}$ Van Maanen deed in 1818 een circulaire uitgann, waarin hij enkele ministeries advies vroeg over een aantal bezuinigingsvoorstellen. Zo zouden gedetineerden als regel hun eigen kleding moeten fabriceren. Ook voor militairen en schepelingen zouden ze dat kunnen doen. Verder kunnen ze voor de Marine touw 'plukken'. En tenslotte opperde Van Maanen de mogelijkheid om contingenten gevangenen in te zetten bij het aanleggen van vestingwerken. ${ }^{62}$.

In 1820 stelde Willem I een speciale commissie in, die de toestand van alle strafinrichtingen moest onderzoeken. Daarbij moest die speciale aandacht besteden aan de manier waarop in de gevangenissen werd gewerkt en hoe de arbeid van gevangenen 'zonder werkelijk nadeel voor de fabrieken en andere takken van de Nationale Nijverheid (...) voor henzelve en voor het Rijk van meer uitgestrekt nut en voordeel' kon zijn. ${ }^{63}$ 
Kort daarop kreeg de gedetineerden-arbeid, als onderdeel van de eerste uniforme, landelijke reglementering van het gevangeniswezen, een juridische basis: het 'Koninklijk Besluit van den 4den November 1821, nr. 16, houdende Organisatie der Gevangenissen, benevens vaststelling en invoering van eenen staat, betrekkelijk de voeding, kleeding- en liggingstukken der gevangenen', hier verder het Organisatiebesluit 1821. te noemen. ${ }^{64}$

De arbeidsrechtelijke positie van gedetineerden werd in het Organisatiebesluit. 1821 als volgt beschreven:

\section{Van den arbeid der gevangenen}

29. Alle de tot detentie veroordeelden zullen worden gebruikt, en des noods gedwongen tot den huisdienst van de gebouwen, waarin zij geplaatst zịnn.

30. Daarenboven zullen de veroordeelden, die zich in de hiervorengenoemde huizen van reclusie en tuchtiging bevinden, eenen anderen arbeid moeten verrigten, waarvan het loon gedeeltelijk ten gerijve van 's Rijks schatkist, gedeeltelijk ten voordele dezer gevangenen zelve strekken zal, gelijk zulks hierna nader wordt geregeld.

Ook zal er aan de militairen, die zich in de huizen van militaire detentie bevinden, en aan de veroordeelden, in huizen van correctie, gelegenheid tot zoodanigen arbeid worden gegeven, immers voor zoo veel de omstandigheden het zullen toelaten.

31. Deze arbeid zal ieder jaar, naar een algemeen plan geregeld en over de gemelde gevangenissen verdeeld worden, in dier voege, dat alle deze gestichten zich wederkeerig de hand leenen, als uitmakende gedeelten van één en hezzelve geheel.

32. De werkplaatsen in de gevangenissen zullen in het bijzonder zijn bestemd tot het fabriceren der stoffen en andere voorwerpen, voor het gebruik der gevangenen benoodigd.

De arbeid der gevangenen zal zich over andere voorwerpen van 's Rijks dienst, en over het algemeen, zoveel mogelijk, over verschillende voorwerpen uit strekken, waarbij, alsmede bij het in omloop brengen der in de gevangenissen gefabriceerde waren, ook bijzonder moet gelet worden, dat aan de nijverheid van particulieren binnen het Rijk geen' billijken grond tot klagten wordt gegeven.

33. De gevangenen die een ambacht verstaan, zullen tot de beoefening van hetzelve kunnen worden toegelaten; deze toelating zal zich echter niet uitstrekken tot dat van smid, slotenmaker en timmerman.

Zij die het dekkerswerk verstaan, zullen dat niet voor den dienst van het gesticht mogen verrigten.

34. De groote mechanieken zullen zoo veel mogelijk uit de werkplaatsen in de gevangenhuizen worden geweerd.

35. Het loon van den arbeid zal, zoo veel mogelijk, bij de taak geregeld, en overeenkomstig den gewonen prijs in de commercie bepaald worden. 
36. De bepaling van het loon der gevangenen, tot den dienst van het huis gebruikt, als koks, broodbakkers, sjouwers, waschvrouwen en andere van dit soort; zal bij den dag en op denzelfden voet geschieden.

37. Overeenkomstig het vastgestelde bij artikel 30, zal van het arbeids- en dagloon ten behoeve van de administratie worden afgetrokken als volgt:

$5 / 10$ voor de gevangenen tot correctionele straffen veroordeeld.

$6 / 10$ voor de veroordeelden tot reclusie, en de militairen die zich in huizen van militaire detentie bevinden.

$7 / 10$ voor de veroordeelden tot dwangarbeid, zonder onderscheid tusschen burgerlijke gevangenen, en gewezen militairen.

Moetende evenwel her bepaalde bij dit artikel slechts als voorlopig worden beschouwd, om, na proefnerning van een jaar tijds, te worden gewijzigd of bevestigd naar bevind.

38. Het loon, door de gevangenen verdiend, zal, na den aftrek in het vorige artikel gemeld, in twee deelen worden gesplitst, waarvan het eene hun tot zakgeld zal strekken, en het ander voor ieder hunner een uitgaans-kasse zal vormen, welke bij de loslating van den gevangenen te zijner beschikking zal worden gesteld, of ingeval de gevangene vóór dien tijd komt te overlijden, ter beschikking van zijne erfgenamen of regthebbenden zal worden gehouden.

Het zakgeld zal op 2/10 van het arbeidsloon en dagloon worden bepaald, behalve voor de veroordeelden tot dwang-arbeid, alsmede voor de militairen die niet kunnen worden gerehabiliteerd, welke daarvan slechts 11/2/10 zullen genieten.

39. De gelden, uitmakende de uitgaanskasse der gevangenen, zullen, in afwachting dat dezelve tot de bestemming worden gebruikt, met de noodige waarborg op intrest worden uitgezet, en van deze interessen, alsmede van het kapitaal, zal op zijn tijd, aan die daartoe geregtigd zullen wezen, rekening en verantwoording worden gedaan. (...)

\subsection{Specificatie van werk en loon}

De organisatie van de arbeid vond zijn nadere uirwerking in het 'Reglement. omtrent den arbeid in de gevangenhuizen te verrichten'. De aard en verdeling van de werkzaamheden werden voortaan 'naar algemeen plan' op centraal niveau door de 'Raad van Administratie over de burgerlijke en militaire gevangenhuizen', onder de opperdirectie van de minister van Justitie geregeld. Daarbij werden de gevangenen, die arbeid moesten verrichten 'naar gelang van hunne meerdere. of mindere bedrevenheid in het werk' in drie klassen verdeeld en werd hun loon dienovereenkomstig bepaald. Artikel 17 van het Reglement zegt daarover: 'De hoofdklassen dier verdeeling zullen zijn: a. die van eerste en tweede werklieden; b. die van gewone werklieden; c. die van leerlingen' ${ }^{65}$

Uit de zeer uiteenlopende declaraties, die door de 'gevangenhuizen' bij de centrale gevangenisadministratie werden ingediend, bleek dat ieder gesticht zijn 
eigen loonbeleid voerde. Daaruit vloeiden 'voor de schatkist aanmerkelijke bezwaren' voort. Om aan die verschillen een einde te maken kwam er in 1824 een eerste algemene loonregeling tot stand. ${ }^{66} \mathrm{Het}$ aanhangsel van die loonregeling bevat een opsomming van verschillende werkzaamheden, die door gevangenen konden worden verricht en een specificatie van de betrekkelijke dag- en stuklonen.

Bij elke volgende majeure wijziging van de loonregeling werd een nieuw overzicht van de beschikbare werkzaamheden en corresponderende beloningen gegeven. ${ }^{67}$ Het werk bestond blijkens die opgaven vooral uit het bewerken van vlas, wol, katoen en hennep tot weefsels en confectie van die weefsels tot kledingstukken voor gevangeniswezen, leger en vloot.

Gevangenisfunctionarissen gebruikten gedetineerden ook wel in voor privéaangelegenheden. Dat valt af te leiden uit een ministeriële circulaire uit 1854, waarin de gevangenisbesturen wordt aangemaand een eind aan dergelijke praktijken te maken. ${ }^{68}$

Contant geld kregen gedetineerden niet in handen. Het zakgeld werd aanwankelijk uitgereikt 'in eene fictieve munt van blik, leder of papier, naar mate dit voor ieder gevangenhuis zal worden bepaald', zo meldt een desbetreffend Koninklijk Besluit. De kantinebeheerder wordt daarin met ontslag bedreigd als hij toch 'specien van goud, zilver, koper of biljoen' of enig ander voorwerp van waarde als betaling aanneemt. ${ }^{69}$ In 1861 verdween ook de fictieve munt en werden inkomsten en (kantine)uitgaven geboekt op ten behoeve van de gedetineerden door de gevangenisadministraties aangehouden rekeningen. Eventuele overschorten werden bij wijze van uitgaanskas toegestuurd aan de burgemeester van de plaats waar de ex-gedetineerde ging wonen en konden daar worden afgehaald. ${ }^{70}$

\subsection{De functie van de gevangenisarbeid}

De overheid zag in de beginjaren van het moderne gevangeniswezen de arbeid, waartoe veroordeelden verplicht waren, niet als straf, maar als middel om de orde in de gestichten te handhaven, ter bevordering van de 'verbetering' van de veroordeelden en ter bestrijding van de kosten van hun levensonderhoud. ${ }^{71}$

Een poging om in een in 1838 aan de Tweede Kamer aangeboden ontwerp van het eerste boek van een nieuw wetboek van strafrecht de dwangarbeid als hoofdstraf te introduceren werd door de redactie van het Weekblad van het Regt. uiterst negatief onthaald: 'Het is bekend, dat de dwangarbeid voor ons geheel nieuw is, dat zij hier te lande vroeger niet bestaan heeft, en, in 1813, als niet nationaal, als te Fransch, werd afgeschaft. Het is even bekend, dat er in Frankrijk en in andere landen, waar nog bagnes gevonden worden, over dezelve luide klachten worden aangeheven, en dat men schier overal op de afschaffing bedacht is, en tegelijkertijd wil men bij ons diezelfde straf, als eene nieuwigheid invoeren. Vreemd verschijnsel'.$^{72}$

De beoogde straf - dwangarbeid - sneuvelde mèt het wetsontwerp. En mocht iemand nog aan de bedoelingen van de overheid getwijfeld hebben: in een wet uit 
1854, waarin wijziging werd gebracht in enkele straffen wordt nog eens duidelijk gezegd: 'De dwangarbeid is en blijft vervangen. ${ }^{13}$

Als op 1 oktober 1850 te Amsterdam een cellulaire gevangenis in gebruik wordt gesteld om er met een 'Pennsylvanisch' stelsel van afzondering te experimenteren wordt de arbeid tot de belangrijkste bezigheid van de onder dat regiem dag en nacht afgezonderde gevangene. De veroordeeide mag daar slechts in de eigen cel werken. De dag-produktie en de gereedschappen worden 's avonds uit zijn cel gehaald. Huisdienst of diensten buiten de gevangenis mogen slechts geheel afgezonderd van de andere gevangenen worden verricht. ${ }^{74}$

Het experiment werd in 1851 gelegaliseerd. ${ }^{75}$ De cellulaire opsluiting werd de kern van de gevangenisstraf en is dat - in beginsel - tot vlak na de Tweede Wereldoorlog gebleven. De aard van de gevangenenarbeid werd gedurende die tijd bepaald door het gegeven, dat het werk altijd door één persoon binnen een beperkte ruimte moest kunnen worden verricht. Eenvoudige handarbeid is dan het enige waarmee men de gevangene kon bezig houden. De eenzame opsluiting heeft ongetwijfeld een meer efficiënte exploitatie van de arbeidskracht der veroordeelden, bijvoorbeeld door het creëren van gemeenschappelijke werkplaatsen, zoals in het hier te lande verworpen Auburn-stelsel mogelijk was, in de weg gestaan. De oud-hoofdinspecteur van het gevangeniswezen Alstorphius Grevelink die, toen hij nog in functie was, het nodige tot de bestendiging van het cel-stelsel had bijgedragen ${ }^{76}$, kwam na zijn ontslag - en dus te laat - tot de conclusie, dat het onzin was de gedetineerden in hun cellen te laten verpieteren. 'Het is eene bekende zaak dat na onderwijs, godsdienstig en maatschappelijk, in arbeid en arbeidsonderwijs de magtigste hefboom tot opbeuring is gelegen. Alles derhalven dat arbeid kan benadeelen en dat leidt om een der weldadigste takken daarvan onmogelijk te maken, dient bij het beheer van veroordeelden zorgvuldig te worden vermeden', schreef hij bijna lyrisch. De weldadige tak die Alstorphius Grevelink bedoelde was die der land, veld- en tuinarbeid, waarbij hij wees op de praktijk van de (destijds onder beheer van de minister van Binnenlandse Zaken vallende) rijks-bedelaarsgestichren te Veenhuizen, waar die soorten arbeid de boventoon voerden. ${ }^{77}$

Weliswaar werd het intramurale arbeidspotentieel vergroot, toen in 1860 ook ònveroordeelden als ze dat wilden konden gaan werken ${ }^{78}$, maar de overheid besefte dat door de betrekkelijk korte tijd die deze categorie in de huizen van arrest doorbracht op die plek nauwelijks financieel rendement van hun arbeid te verwachten viel. ${ }^{79}$

Modderman zag, in ander opzicht, wel winstpunten in de verplichte gevangenisarbeid. Die zou in zijn optiek vooral dieven op het rechte pad kunnen brengen. In zijn oratie bij de aanvaarding van het hoogleraarsambt in de rechtsgeleerdheid aan het Athenaeum Illustre te Amsterdam in 1864 formuleerde hij het als volgt: 'Vraagt men: aan welke straf kan in 't algemeen 't vermogen worden toegekend om van diefstal terug te houden, dan is het antwoord: daar de diefstal bijna altoos - minima praetor curare non potest - gepleegd wordt uit zucht om zich zonder ar- 
beid de vruchten van den arbeid te verwerven, zoo moet aan hem die stelen wil, het uitzigt worden geopend om omgekeerd te moeten arbeiden zonder VRIJE beschikking over de vruchten daarvan. Vraagt men verder: welke straf moet op hem die gestolen heeft, worden toegepast om hem voor zoveel mogelijk te verbeteren, dan is het antwoord gereed: eene zoodanige waardoor hij aan geregelden arbeid wordt gewend. ${ }^{80}$

Als in 1886 de arbeid als bestanddeel van de vrijheidsstraf een plaats in het nieuwe wetboek van Straf heeft gekregen en in datzelfde jaar het Organisatiebesluit 1821 wordt vervangen door de Wet tot Vaststelling der Beginselen van het Gevangeniswezen krijgt de arbeidsplicht van veroordeelden een wettelijke basis, het resultaat van bijna een halve eeuw experimenteren door de post-revolutionaire gevangenisregie.

\subsection{Opkomst, ondergang en reïncarnatie van de rijkswerkinrichting}

Evolueerde in de $19 \mathrm{e}$ eeuw de gevangenisarbeid tot een belangrijk element van de vrijheidsstraf, tezelfdertijd ontwikkelde de vrijheidsbeneming zich als middel om bepaalde categorieën werklozen tot een arbeidzaam leven te verheffen.

In 1818 werd onder auspiciën van koning Willem I door Johannes graaf Van den Bosch de Maatschappij yoor Weldadigheid opgericht. Het. was zijn bedoeling om armen die tot werken in staat waren op vrijwillige basis in landbouwkolonies te laten werken zodat zij daardoor in hun eigen onderhoud en dat van hun familie konden voorzien. In 1818 werd daartoe in Drenthe de kolonie 'Frederiksoord' en in 1820 de koloniën Willemsoord en Wilhelmina-oord opgericht. Gebrek aan spontane belangstelling onder de doelgroep zorgde voor de stichting van zogenaamde onvrije koloniën, waar bedelaars en landlopers, hetzij na afloop van hun straf, hetzij op eigen verzoek, bij wijze van politiemaatregel naartoe konden worden gestuurd.

De eerste onvrije kolonie was de Ommerschans, die in 1822 was uitgegroeid tot een gesticht met 1000 tot 1200 bedelaars, die onder toezicht van militairen op omringende boerderijen tewerk werden gesteld. In de periode 1822-1823 kwamen daar te Norg nog 3 grote gestichten bij. Het huidige strafgesticht Esserheem is daar nu nog van over. In 1859 nam de staat de onvrije koloniën van de Maatschappij over. Daarmee was de rijkswerkinrichting (r.w.i.) ontstaan. ${ }^{81}$

Van Duyne heeft vastgesteld, dat gedurende de gehele. 19e eeuw het probleem van de beclelarij en landloperij met een mengeling van filantropie en strafrecht werd benaderd, 'een soort armenzorg in strafrechtelijk gewaad, bestemd voor hen, die zonder vooruitzicht om zich in de maatschappij staande te houden, zich maar in arren moede aangaven', ${ }^{82}$

Pas bij de invoering van het huidige wetboek van strafrecht in 1886 is plaatsing in een r.w.j. een (bijkomende) straf geworden, zoals thans nog vermeld in art. 9, lid I b, onder ten tweede van dat wetboek. Zij kan voor ten hoogste drie jaren worden opgelegd bij veroordeling wegens bedelarij, landloperij of soute- 
neurschap (artt. 432 en 433 jo. 434 Sr.) en voor maximaal een jaar na herhaaldelijke veroordelingen wegens openbare dronkenschap (art. 453 lid $4 \mathrm{Sr}$.). Ook de toch betrekkelijk moderne: Wet op de Economische Delicten kent-in artikel 7 b - als bijkomende straf plaatsing in een r.w.i.

Werden in 18802468 personen tot plaatsing in een r.w.i. veroordeeld, in 1977 werd deze bijkomende straf voor het laatst opgelegd. Het afsterven van deze strafsoort wordt in 'Noyon/Langemeijer' toegeschreven aan 'de betere sociale omstandigheden en de daarmee verweven sociale wetgeving en andere sociaal-hygiënische opvang' ${ }^{83}$

Noyon c.s. moeten hebben gedacht aan hetgeen minister Scholten in 1964 over de zin van deze bijkomende straf heeft gezegd. 'De sterke teruggang in de bevolking van de rijkswerkinrichtingen in de laatste decennia heeft de vraag doen opkomen of deze bijkomende straf in het tegenwoordige strafrechtelijke en penitentiair-rechtelijke bestel nog wel reden van bestaan heeft. Wanneer men de delicten beschouwt, waarvoor die straf kan worden opgelegd, dan blijkt dat deze voor een groot deel uitingen zijn van een zekere vorm van onmaatschappelijkheid, waarvoor in het tegenwoordige stadium van de sociale ontwikkeling in de maatschappij betere en meer positieve vormen van benadering buiten de strafwet bestaan. (...) Nu evenwel in de gevangenis de gemeenschap zijn intrede heeft gedaan, terwijl ook op andere punten het regiem ruimer is geworden en bij de tenuitvoerlegging van deze straf aan de arbeid in gemeenschap een sterke resocialiserende werking is toegedacht, is gaandeweg het verschil tussen beide vormen van vrijheidsbeneming geheel vervaagd, terwijl het in de huidige stand van de penitentiaire ontwikkeling ook niet uitvoerbaar lijkt om weer een verantwoord verschil in de tenuitvoerlegging aan te brengen. Een en ander leidt ertoe, dat de bijkomende straf van plaatsing in een rijkswerkinrichting thans in haar tenuitvoerlegging niet principieel afwijkt van de gevangenisstraf, doch dat de duur van deze bijkomende straf veelal onevenredig lang is, omdat bij de oplegging het oude uitgangspunt, dat zij dient om de delinkwenten te leren werken en te gewennen aan regelmatige arbeid, nog wordt aangehouden'. ${ }^{84}$

In december 1983 is de Tweede Kamer een wetsontwerp ingediend tot afschaffing van het bordeelverbod en, in samenhang daarmee, tot afschaffing van de bijkomende straf van plaatsing in een rijkswerkinrichting. Bijna tien jaar later, in november 1993, is dat wetsvoorstel echter ingetrokken omdat het parlement het in strijd met art. 107 van de Grondwet (het zogenaamde codificatie-artikel) achtte als gemeenten door de voorgestelde wijziging van art. 250bis Sr. de facto konden uitmaken of exploitatie van prostitutie als misdrijf strafbaar is. ${ }^{85}$ Wat nu. met de rijkswerkinrichtingen? De VVD-er Talsma schetste er tijdens de beraadslagingen in de Eerste Kamer een nieuwe toekomst voor. Daarbij wees hij op het steeds grotere probleem van dakloze drugs- en drankverslaafden die zich door niemand willen laten opnemen, op tewerkstelling in het kader van alternatieve straffen en op het streven van de regering om delinquente jongeren in 'kampementen' te detineren. ${ }^{86}$ Naar aanleiding van opmerkingen van de toenmalige mi- 
nister-president Lubbers heeft een door de minister van Justitie Hirsch Ballin en staatssecretaris Kosto ingestelde werkgroep eind 1993 een voorstel gedaan om een experiment te ontwikkelen, waarbij in zogenaamde jeugdwerkinrichtingen (j.w.i.) de maatschappelijke integratie van een geselecteerde groep "jeugdige criminelen' wordt voorbereid door 'een periode van structurering en disciplinering. De werkgroep mikt op jongeren van 18 tot 23 jaar, die 'mede door her gemis van een adequate opvoeding, vorming en opleiding zijn vervallen tot ernstig crimineel gedrag'. Later kunnen ook wellicht jeugdigen van 12 tot 18 jaar aan het experiment deelnemen. In de j.w.i. wordt de jongeren gedurende een programma van 15 maanden met een intra- en een extramurale fase in de eerste plaats (zelf) discipline bijgebracht. Door hard werken moeten ze in de j.w.i. aan regelmatige arbeid wennen. Of er voor de jongeren na ontslag uit het kampement betald werk beschikbaar is, is ook voor de bewindslieden een vraag: 'De praktijk leert dat het irreëel is te verwachten dat de jongeren uit deze doelgroep in deze tijd via de normale kanalen aan een betaalde baan geholpen kunnen worden. Met extra inzet en begeleiding kunnen de kansen op (her)intreding op de arbeidsmarkt echter aanzienlijk worden De bewindslieden achtten 'de beschikbare juridische mogelijkheden' voldoende op het experiment op te baseren. Plaatsing in een j.w.i. kan in de visie van de bewindslieden geschieden in het kader van:

- een schorsing van de voorlopige hechtenis onder de voorwaarde van deelname aan het j.w.i.-traject;

- uitstel van vonniswijzing in afwachting van het vervuld hebben van het experiment en

- veroordeling tot cen gedeeltelijk voorwaardelijke vrijheidsstraf, met als bijzondere voorwaarde de deelname een het experiment. ${ }^{87}$

Slaagt het experiment, dan is de kans groot dat plaatsing in dit soort inrichtingen in het rijtje sancties van art. $9 \mathrm{Sr}$. zal worden opgenomen. De wetgever zal dan dankbaar gebruik kunnen maken van de op papier nog bestaande rijkswerkinrichtingen, want dat zijn die kampementen in feite toch.

\section{Van fin de siècle tot commissie-Fick}

\subsection{Arbeid: een wezenlijk bestanddeel der gevangenisstraf}

Artikel 14 van het wetboek van Strafrecht van 1886 luidde: 'De gevangene is verplicht tot het verrichten van den hem opgedragen arbeid, overeenkomstig de voorschriften ter uitvoering van artikel 22 gegeven'. Deze tekst kwam overeen met die van art. 15 van het zogenaamde Oorspronkelijke Regeeringsontwerp (ORO), dat in 1879 aan de Tweede Kamer was aangeboden. In de Memorie van Toelichting bij het ORO heette het: 'Verpligte arbeid is een wezenlijk bestanddeel der gevangenisstraf. De wet moet dit uitdrukken, maar de verdere regeling der zaak overlaten aan reglementaire voorschriften'. Het genoemde artikel 22 zei dat 
de arbeid 'naar beginselen door de wet te stellen' bij 'algemeenen maatregel van inwendig bestuur' diende te worden geregeld. ${ }^{88}$ Aldus geschiedde in de Wet tot vaststelling der beginselen van het gevangeniswezen van 14 april 1886 (Stb. nr. 62; hier verder Beginselenwet 1886 te noemen) en de Algemeene maatregel van inwendig bestuur, bedoeld in art. 22 van het Wetboek van Strafrecht, van 31 augustus 1886 (Stb. nr. 159; hier verder Gevangenismaatregel 1886 te noemen).

De Beginselenwet 1886 besteedde vijf artikelen aan de arbeid en het arbeidsloon. Deze luidden aldus:

\section{Arbeid en arbeidsloon}

Art. 12

De verplichte arbeid zal zich bij voorkeur uitstrekken tot den huisdienst en over voorwerpen voor's Rijks dienst.

\section{Art. 13}

Het door den gevangene of verpleegde verdiend arbeidsloon is zijn eigendom.

Dit loon wordt in de strafgevangenissen, behalve voor hen die tot levenslange gevangenisstraf veroordeeld zijn, en in Rijkswerkinrichtingen verdeeld in uitgaanskas en zakgeld.

Het laatste blijft onder bewaring van het bestuur van het gesticht, doch is ter beschikking van den gevangene of verpleegde, volgens daaromtrent te stellen regelen.

Art. 14

Moedwillig door den gevangene of verpleegde tijdens zijn straftijd toegebrachte schade kan zoowel op de uitgaanskas als op het zakgeld worden verhaald.

De uitgaanskas is overigens onvervreemdbaar en niet vatbaar voor beslag.

$\mathrm{Zij}$ wordt den gevangene of verpleegde bij of na zijne in vrijheidstelling uitgekeerd.

De uitkeering kan ook in termijnen geschieden.

Art. 15

In de strafgevangenissen geldt als regel, dat de gevangenen elken werkdag gedurende ten minste 10 uur arbeiden.

Art. 16

Aan elken gevangene en verpleegde wordt minstens eén etmaal per week als rustdag gegund.

De wetgever vond het kennelijk nodig om in art. 12 eerst van al de buitenwacht er van te overtuigen, dat de gevangenisarbeid niet nadelig voor het vrije bedrijf zou zijn. In zijn Memorie van Toelichting toonde de minister zich ervan bewust, "dat het in waarheid voor een particulieren fabrikant moeielijk is met den Staat te concurreeren, waar deze optreedt als verkooper van goederen, die hij voor eigen rekening in de gevangenissen liet fabriceren. Dit laatste moet daarom 
ook alleen dàn geschieden als geen andere arbeid kan worden verkregen. En op den voorgrond behoort te blijven staan - even als tot dusverre - dat de Regeering zooveel mogelijk in de gevangenissen die goederen doet fabriceeren die zij zelve bij de verschillende departementen voor den algenneenen dienst kan gebruiken'.

Ter voorkoming van misverstanden legde de minister de kamer uit wat onder het door de gevangene verdiende loon (art. 13) moest worden verstaan. Dat was niet het geld, dat de particuliere opdrachtgever voor de verrichte werkzaamheden aan het gevangenisbestuur betaalde, maar het bedrag dat de gevangene uiteindelijk van de inrichting ontving. 'Het moet den gevangene geheel onverschillig zijn of hij Rijks- dan wel particulieren arbeid verricht, - hij hebbe in beide gevallen alleen met het gevangenisbestuur te maken. Te zijn opzichte zou men alles Rijksarbeid kunnen noemen.' Dat krachtens art. 14 door gedetineerden toegebrachte schade zonder rechterlijke tussenkomst op hun verdiensten kon worden verhaald vond de Tweede Kamer prima: 'Hieraan is het voordeel verbonden, dat de gevangene, die de schade heeft toegebracht, door de inhouding van zijn kantinegeld, op gevoelige wijze de gevolgen van zijn moedwil ondervindt'. Een minimum-werktijd van 10 uur (art. 15) vond de minister niet te hoog: "Men. vergete niet dat de arbeid - om zichzelve - ter voorkoming; van verveling, door nagenoeg alle gevangenen wordt begeerd. Staat men hun nu nog; toe dat zij juist roldoende arbeiden om zich niet te vervelen, maar aan de andere zijde: ook nier meer dan zij aangenaarn vinden, dan ligt het voor de hand dat zoodanige regeling voor een strafgesticht niet deugt!', zo citeerde de bewindsman een oud wetsvoorstel, waarin uitbreiding van het aantal arbeidsuren werd aanbevolen.

De wekelijkse rustdag was in art. 16 expres niet ais Zondag omschreven om Israělitische gevangenen hun Sabbath te kumnen laten vieren. ${ }^{89}$

In de Gevangenismaatregel 1886 worden de wetteliik bepalingen enigszins uitgewerkt. Details, zoals de vaststelling, van de tarieven van een 'gering" arbeidsloon, laat de maatregel aan de minister van Justitie over. De gevangene mag de helft van dat loon als zakgeld besteden, de andere helft gaat naar zijn uitgaanskas. De uitgaanskas wordt 'wanneer grond bestaat voor de overtuiging, dat de ontslagene werkelijk het voornemen, heeft zich ter platse te vestigen, na met het noodige reisgeld verminderd te zijh, in ééns of in termijnen ter uitreiking gezonder aan den burgemeester der gemeente, waarheen de gevangene (...) zich bij ontslag begeeft.' (art. 91). Vanaf 1892 mogen gedetineerden in beginsel over het afzonderlijk geboekte 'eigen geld" beschikken. ${ }^{90}$

De nieuw-geregelde gevangenisarbeid vond een scherpe criticus in een politieke gevangene. Op 19 januari 1887 werd de wegens majesteitsschennis tot een jaar gevangenisstraf veroordeelde Ferdinand Domela Nieuwenhuis ("ús Forlosser') opgesloten in de cellulaire gevangenis te Utrecht. "Tegenstanders zongen: 'Nieuwenhuis moer zakjes plakken, hi, ha,ho!', schrijft De Jong in een biografie over deze 'messias van cie Nederlandse arbeidersklasse:" Dat . Darover rept Dornela echter niet als hij, gekozen in de Tweede Kanner, in 1888 de minister van Justitie 
kapittelt over de gevangenisarbeid. 'Niemand kan, dunkt mij, tegenstander zijn van arbeid in de gevangenis, dat staat als een paal boven water, maar door dat werken in de gevangenis opent men -en dat kan niet anders - concurrentie met den vrijen arbeid in de maatschappij'. Hij vond het geen goed tegen-argument, dat gevangenen vooral voor het Rijk werkten, 'want de arbeid die in de gevangenissen niet verricht zou worden, zou anders in de vrije maatschappij gedaan moeten worden (...)'. Dat het gevangeniswezen onder de marktprijzen produceerde achtte hij tegen het belang van de vrije arbeid indruisen. Domela wees er op dat gevangenen niet uitbetaald kregen waarop zij recht hadden. Dat volgens artikel 13 Beginselenwet 1886 het door gevangenen verdiende loon hun eigendom was kon hij uit eigen ervaring bestrijden. Hij had namelijk vertaalwerk gedaan, waarvoor de uitgever $f 1,60$ per dag betaalde. Hij hield daar uiteindelijk maar een kwartje aan over. Hij wenste de zekerheid te hebben, 'dat de gevangenen niet op hun loon, dat uit den aard der zaak reeds schraal is, bestolen worden in een huis, waar men dieven opsluit'.

Het sofistische antwoord van minister Ruys van Beerenbroek luidde: 'Art. 13 van de wet van 14 april 1886, nr. 62 bepaalt dat het door de gevangenen of verpleegden verdiende loon hun eigendom is; maar dat artikel bepaalt niet de hoegrootheid van het loon. Wanneer nu op andere wijze de hoegrootheid van dat loon rechtens is bepaald, dan kan men niet spreken van onthouden van een deel van het loon, want het gehele loon wordt aan de verpleegden tegoed gedaan voorzover hij daar recht op heeft'. En die 'hoegrootheid' was bij ministeriële beschikking bepaald op een maximum van 25 cents daags. ${ }^{92}$

\subsection{Valse concurrentie}

Een factor die verhinderde dat strafgestichten produktie-eenheden van betekenis werden was de vrees van her vrije bedrijf en van de vrije arbeider voor valse concurrentie door de goedkope gevangenisarbeid. Al in 1827 werden de gevangenisbesturen aangespoord om de gefabriceerde produkten niet te ver boven of onder de marktprijs aan te bieden. ${ }^{93}$ Bijna twintig jaar nadien werden de gevangenisdirecties aangemaand om wat minder opdrachten aan te nemen van leger en vloot. EI waren op het departement van Justitie namelijk klachten ingediend 'tegen het verrigten van een groot gedeelte vari het confectiewerk ten dienste van 's Rijks Zee en Landmacht door gevangenen, tot afbreuk van den vrijen ambachtsman'. ${ }^{94}$

In de nadagen van de XIXe eeuw was de overheid in penologisch opzicht nauwelijks in de gevangenisarbeid geïnteresseerd. De monotone arbeid was deel van een al even monotoon en afstompend gevangenisregiem. Kritiek op het cellulaire stelsel vanuit socialistische hoek en langzamerhand ook van het Nederlands genootschap tot Zedelijke verbetering der Gevangenen bleef voorlopig zonder effect. ${ }^{95}$ De gedetineerdenarbeid was - als deelaspect van het regiem - niet of nauwelijks object van afzonderlijke aandacht. Als de gedetineerden-arbeid al pennen in beweging bracht, waren dat die van lieden die meenden dat hun betrekking of 
nering erdoor in gevaar kwam. In 1892 promoveerde De Bonvoust Beeckman aan de Universiteit van Amsterdam op het onderwerp 'Arbeid van gevangenen en vrije arbeid'. ${ }^{96} \mathrm{Hij}$ meende, dat het niet mogelijk was om elke concurrentie tussen arbeid van gevangenen en "vrije arbeid" uit te sluiten. Met die concurrentie viel het zijns inziens trouwens nogal mee. Ondernemers, die gevangenen als werkkrachten wilden gebruiken, hadden aan hen ongeoefend, onbekwaam en onwillig personeel, dat lang niet zoveel produceerde als de vrije arbeider. Daarbij vereisten gedetineerde arbeiders relatief veel en dus kostbaar toezicht, terwijl allerlei bureaucratische regeltjes efficiënt werken ook al niet bevorderden. Het voordeel van de lage lonen werd daardoor bijna weer teniet gedaan.

Daarbij vond De Bonvoust Beeckman, dat men te gemakkelijk veronderstelde, dat de vrije arbeid door de gevangenen-arbeid werd beconcurreerd.

De promotus wees erop dat er in strafinrichtingen geen extra arbeidsplaatsen werden gecreëerd, maar dat er slechts sprake was van verplaatsing van arbeid naar de strafinrichtingen. Trouwens, als men de geringe produktie van het gevangeniswezen vergeleek met de totale landelijke produktie, kon onmogelijk worden volgehouden dat gevangenisarbeid de lonen van de vrije arbeiders of de prijzen van produkten negatief beïnvloedde.

Om nu toch zoveel mogelijk aan de geuite bezwaren tegemoet te komen zou de gevangenisarbeid vooral moeten worden benut om het gevangeniswezen zelf in stand te houden. Bij voorkeur moesten daarbij goederen worden geproduceerd die nergens anders in het land gemaakt werden. Tot een ander voorbeeld dan speelgoed kwam de schrijver echter niet.

De Bonvoust Beeckman vond dat de werkende gedetineerde meer loon moest krijgen dan het kwartje dat zij destijds ontvingen: 'Verder komt mij het meest aanbevelenswaardig voor, de gevangenen per stuk te betalen en hun dan een loon uir te keren, veel hoger dan nu het geval is, doch iets lager dan het loon dat de vrije arbeider geniet. Deze regeling is het rechtvaardigst en prikkelt tevens de ijver der gevangenen'. ${ }^{97}$ Van dat loon moest dan wel eerst twee-derde worden afgetrokken voor de kosten van zijn levensonderhoud en schadeloosstelling van de slachtoffers, terwijl een-derde voor het onderhoud van zijn vrouw en kinderen bestemd was.

Om een einde te maken aan de steeds terugkerende Kamervragen over de schade die arbeid in gevangenissen de vrije nijverheid zou berokkenen, werd in 1895 een 'Commissie van Onderzoek inzake de afbreuk, door den arbeid in gevangenissen, rijkswerkinrichtingen en rijksopvoedingsgestichten aan den arbeid in de vrije maatschappij gedaan' (de commissie-Kerdijk) ingesteld, die in 1897 de minister van Justitie haar verslag aanbood. ${ }^{98}$

Net als De Bonvoust Beeckman (aan wiens proefschrift de commissie overigens niet refereerde) vond de commissie de vrees voor oneerlijke concurrentie door gevangenisarbeid nogal overdreven. Uit een uitvoerige steekproef was haar gebleken, dat er in de strafgestichten door lang niet alle gevangenen gewerkt werd. De verhouding tussen arbeid voor het Rijk en voor particulieren kon door 
de commissie bij gebrek aan gegevens niet nauwkeurig worden vastgesteld. Op grond van humanitaire, penitentiaire en penologische belangen was gevangenisarbeid volstrekt noodzakelijk en de daaruit voortvioeiende concurrentie diende te worden aanvaard. Daarbij moest worden bedacht dat in gevangenissen en aanverwante gestichten werkkrachten zaten opgesloten die in vrijheid ook zouden (moeten) werken. Nochtans diende men ernaar te streven die concurrentie zo beperkt mogelijk te houden. Dat zou kunnen door gedetineerden goederen te laten vervaardigen voor mensen zonder of met zeer geringe koopkracht en door hen zaken te laten produceren die tot dan toe moesten worden geïmporteerd. Maar vooral werd uitbreiding van de arbeid ten behoeve van het Rijk bepleit. Als interessant, maar vermoedelijk niet haalbaar, somde de commissie de voordelen op van deportatie, verbonden met kolonisatie, ontginning van woeste gronden en uitbreiding van de 'huisdienst'.

Decennia later kreeg het punt van de concurrentie weer aandacht van de overheid als de minister van Justitie een 'Commissie van onderzoek naar den gevangenisarbeid' instelt. In het verslag, dat deze commissie in 1931 aan de minister aanbood, werd een daling van het aandeel van de arbeid voor particulieren vastgesteld. Was dat in 1914 nog $20 \%$ van de totaal verrichte arbeid, in 1928 was dat nog geen $8 \%$.

In tegenstelling tot de commissie-Kerdijk, die zich niet over de beloningskwestie uitliet, deed deze commissie wel aanbevelingen over het voor gevangenisarbeid te betalen loon: 'de eenige manier om tot een beter arbeidstempo te komen, is den gevangene een rechtstreeks belang bij de productie te verzekeren, d.w.z. ook bij den gestichtsarbeid het te verdienen loon - waar dit mogelijk is - afhankelijk te stellen van de hoeveelheid afgeleverd product'. ${ }^{99}$

$\mathrm{Na}$ publicatie van het laatstgenoemde verslag is het onderwerp van de valse mededinging uit de discussie verdwenen.

\subsection{Reclassering door arbeid}

In 1900 heeft de voorman van de Nieuwe Richting in het strafrecht, Franz von Liszt, een lezing over de zin van gevangenisarbeid gegeven. Na zijn gehoor te hebben meegedeeld dat hij geen tijd had gehad een verhaal over een interessanter onderwerp voor te bereiden, gebruikte hij het thema om zich te keren tegen de manier waarop de vrijheidsstraf in het Duits rijk ten uitvoer werd gelegd en zich uit te spreken voor een 'progressief' systeem. Hij stelde vast dat arbeidsdwang al zolang de vrijheidsstraf bestond, de kern daarvan was. Hij verzette zich tegen de vraag hoe je de arbeidskracht van gedetineerden moest benutten: ten bate van particuliere ondememers, ten gunste van de overheid of ter wille van de 'innere Kolonisation', zoals hij de Pruisische praktijk noemde, waarbij gevangenen werden ingezet om woeste gronden te ontginnen. De enig juiste vraag was volgens hem: wat beoogt men met de vrijheidsstraf bij de individuele gedetineerde bereiken? Von Liszt meende dat de arbeidsplicht alleen zin had voor gevangenen die nog voor verbetering vatbaar waren. Die categorie diende volgens een progressief 
stelsel naar de vrije maatschappij te worden teruggesluisd. Eerst diende deze groep - om murw te worden gemaakt - zo'n 6 à 9 maanden cellulair te worden opgesloten, vervolgens diende ze een tijd gemeenschappelijke arbeid te verrichten om daama onder stringente voorwaarden in vrijheid te worden gesteld. Daarmee pleitte hij voor een instrumenteel gebruik van de arbeid, die hij als middel tot verandering, tot reclassering beschouwde en verzette hij zich tegen willekeurig gebruik van gedecineerden-arbeid ten behoeve van puur economische doeleinden. ${ }^{100}$

In de oratie 'De arbeid als element van de vrijheidsstraf, waarmee de strafrecht-geleerde Simon van der Aa op 20 oktober 1906 het hoogleraarsambt aan de Rijksuniversiteit te Groningen aanvaardde, werd op de voordracht van Von Liszt voortgeborduurd. Van der Aa loofde de reclasserende mogelijkheden van de gedetineerden-arbeid. Als aanhanger van de 'Nieuwe Richting' in de strafrechtswetenschap wilde hij zich vooral bezig houden met het onderzoek naar de oorzaken van de misdaad en naar middelen om die te bestrijden. Wat dat laatste betreft speelde naar zijn mening de arbeid als element van de vrijheidsstraf een belangrijke: rol. Hij had op international niveau een toenemende belangstelling voor de rol van de arbeid bij de strafexecutie bespeurd, zonder dat zulks overigens tor nieuwe initiatieven had geleid. Wat de ontwikkelingen tegenhield was volgens hem de opvatting dat straf' in de eerste plaats moest vergelden. 'Onder de heerschappij van het vergeldingsbegrip is de arbeid een deel van het leed, dat den gevangene wordt toegebracht, en hiertoe kan met allerlei soorten en regeiingen worden volstaan, die aan hoogere penologische eisen niet voldoen', aldus Van der Aa. Hij bestreed de visie, waarin de arbeid als nuttig mididel voor de handhaving van discipline wordit beschouwd. Hij steide daar het volgende tegenover: 'De straf, een der maatregelen tot bestrijding van de misdaad, de uiterste, strekt tot de beveiliging van de maatschappij, waartoe het meest dienstig is eene aan de persoonlijke en zakelijke omstandigheden zich aanpassende behandeling van den misdadiger, welke zoo mogelijk er op gericht moet zijn hem te handhaven als of te maken tot medewerker en deelhebber aan haren bouw en haar leven. Hiertoe is arbeid het eerst aangewezen middel. Immers de arbeid is de sociale verrichting bij uitnemendheid. Hij is de grondslag voor alle leven en samenleven."

Van der Aa, die meende dat veel werkkracht en produktievermogen in de strafgestichten teloor ging, pleitte voor een organisatie van de gescichtsarbeid die gericht was op instructie en het bijbrengen van vakkennis. De arbeid moest produktief zijn en beloond worden, waarbij hij aantekende dat de loonregeling voor nadere uitwerking vatbaar was. Werd de gevangenisarbeid in die zin ge(re)organiseerd, dan kon die volgens hern 'uit het oogpunt van socialiseering en reclasseering niet te hoog worden aangeslagen' Op den duur zou het volgens Van der Aa zó worden dat niet de arbeid ten dienste zou staan van de vrijheidsberoving, maar deze straf er zou zijn 'ter wille van de arbeid'. ${ }^{101}$

Van der Aa's denkbeelden werden in 1916 door de inspecteur van het gevangeniswezen voor de arbeid, Verschoor, uitgewerkt. Zich afzettend tegen een rapport uit: 1907, waarin her Nederlands Genootschap tot zedelijke verbetering van 
gevangenen stelselmatig vakonderwijs aan gevangenen bepleitte, meende hij dat herintreding in de reguliere arbeidsmarkt vooral kon worden bevorderd door gedetineerden onder directe leiding van werkmeesters werkervaring en vakkennis te laten opdoen. Om de overgang van gevangenisarbeid naar werk in de vrije maatschappij soepei te laten verlopen dienden er volgens hem aanpassingsinstituten te komen, waar de uit detentie ontslagene, in afwachting van een echte baan, onmiddellijk in opgenomen kon worden en waarin hij aan het. werk zou kunnen op het niveau waarop hij dat binnen de muren gewend was. ${ }^{102}$

Van der Aa's belangstelling voor de gevangenisarbeid was geen toevalige. Als hoofdinspecteur van de gevangenissen had hij bijgedragen tot een betere organisatie en uitbreiding van de rijks-arbeid in de strafgestichten, vertelde de directeur van het Rotterdamse huis van bewaring Beyerink zijn gehoor, toen hij te Amsterdam op 20 januari 1939 'voor hoogere gevangenisambtenaren' een voordracht over het ontstaan en de ontwikkeling van de arbeid in de Nederlandse strafgestichten hield. Hij wees op de grote verschuiving die er sinds het einde van de 19e eeuw had plaatsgevonden van arbeid voor particuliere opdrachtgevers naar arbeid voor het Rijk en wees met. kennelijke trots op cijfers van het Centraal Bureau voor de Statistiek, waaruit bleek, dat in 1936 slechts $2,4 \%$ van het totaal aantal ingeslotenen niet werkte.

Geheel in de lijn van Von Liszt en Van der Aa brak hij een lans voor aanpassing van de arbeid aan de individuele gedetineerde. Als praktijk-man toonde hij zich echter bewust van de problemen die het bereiken van dat ideaal in de weg stonden: 'Zeker wordt door de consciëntieuze directie het uiterste gedaan om zooveel mogelijk passend werk te verschaffen, maar zoowel voor den intellectueel als voor den dommen, licht zwakzinnigen los werkman, is een werkelijk nuttige arbeid van eenig belang voor later in vele gevallen met den besten. wil niet te verkrijgen.' De vraag of de overheid het recht had gevangenen tot het verrichten van werk te dwingen beantwoordde hij bevestigend: 'Het welbegrepen eigenbelang van den veroordeelde makt het niet alleen gewenscht, maar zelfs noodzakelijk dat arbeid een integrerend deel van de straf uitmaakt. Het gewend blijven aan arbeid of het weer geregeld kunnen arbeiden, na een periode, waarin deze gelegenheid ontbrak, is van niet te onderschatten belang voor zijn toekomst, daar gebrek aan arbeid leidt tot verslapping en dus de gevangene in een mindere conditie in de maatschappij zou terugbrengen. Bovendien is het handhaven van orde en tucht, waar ledigheid des duivels oorkussen is, vooral in een strafgesticht, niet wel mogelijk, indien men de opgeslotenen zonder werk laat.

Zonder arbeid zou trouwens het leven in een cel tot een ondragelijke kwelling worden en een sterke strafverzwaring beteekenen, terwijl het ongetwijfeld bij hen, die daartoe toch al meer of minder gepraedisponeerd zijn, zou leiden tot ernstige zenuwoverspanning of zelfs krankzinnigheid ${ }^{.03}$

Intussen was de arbeidsproduktie echter niet meer alleen-zaligmakend. Niet het minst dank zij de inzet van het Nederlands Genootschap tot Zedelijke Verbetering der Gevangenen ging, sinds de aanvang van de 20ste eeuw, het vakonder- 
richt een steeds belangrijker plaats in het gevangenisregiem innemen. De tegenstelling tussen economisch belang van de arbeid en die van de opleiding van de gedetineerde werkers was in Beyerinks tijd nog niet opgelost. Wèl had de nieuwe benadering van de gevangenisarbeid zijn weerslag gekregen in de artikelen 48 tot en met 59 van de nieuwe Gevangenismatregel van 1932 (S. 194). De arbeid moest voortaan dienstbaar zijn aan de lichamelijke, zedelijke en geestelijke ontwikkeling van de gevangenen.

Verder werd bepaald, dat vakarbeid met vakonderwijs kon worden verenigd. De arbeid moest bij voorkeur (en volgens een jaarlijks op te stellen plan voor de arbeid) voor's rijks dienst worden verricht. Voor particulieren mocht ook gewerkt worden, maar wel tegen tarieven die in het vrije bedrijfsleven gangbaar waren. De tot arbeid verplichte gevangenen moesten ten minste 10 uur per dag werken en ontvingen daarvoor 'een gering arbeidsloon, door Onzen Minister vast te stellen'. Het loon was voor de helft zakgeld (dat bijvoorbeeld aan kantine-artikelen kon worden besteed) en voor de helft uitgaanskas, die óf aan de ex-gedetineerde kon worden meegegeven óf aan een ander kon worden overgemaakt, die deze dan weer aan de vrijgelatene kon uitkeren. Tenslotte werd bepaald dat moedwillig door de gevangene toegebrachte schade zonder meer van zijn zakgeld of uitgaanskas kon worden afgehouden.

De arbeid moest een reclasserende functie gaan vervullen, maar de economische crisis van de dertiger jaren maakte zo'n verheven bedoeling volstrekt illusoir. De opdrachten liepen terug. 'Eerst in de loop van 1947 zou de arbeid weer geheel in de pas komen', schreef Eggink. ${ }^{104}$

\subsection{Vermichtung durch Arbeit}

Himmler en zijn medewerkers hebben de arbeidskracht van gedetineerden op grote schaal gebruikt om de Duitse oorlogsmăchine draaiende te houden. In deel 8 van zijn 'Het Koninkrijk der Nederlanden in de Tweede Wereldoorlog' heeft De Jong beschreven hoe die gevangenen ten behoeve van SS-bedrijven en particuliere ondernemingen in en vanuit concentratiekampen en in het 'vrije' bedrijf werden uitgebuit. Steeds meer ging de behoefte aan dwangarbeiders het aantal mensen bepalen dat de kampen werd binnengevoerd van ' 40 tot en met eind ' 42 zur Vernichtung durch Arbeit. Toen de vervulling van economische taken door een al te rigoureuze doorvoering van dat moorddadige principe in gevaar kwam, werd eind ' 42 verordonneerd, dat de dwangarbeiders minder streng behandeld moesten worden.

erd in '39 geput uit een 'reservoir' van ongeveer 20.000 gevangenen, geschat wordt dat in de jaren '43-'44 in de ca. 150 SS-bedrijven gemiddeld vijftigduizend gevangenen tewerkgesteld waren, terwijl in de particuliere Duitse industrie ca. 450.000 gevangenen werkten. Er was vrijwel geen grote onderneming (zoals bijvoorbeeld IG Farben, Krupp, BMW en Agfa) die niet met gevangenen werkte.

Vanuit de concentratiekampen werden bijvoorbeeld voor de door de SS 
geëxploiteerde Deutsche Erd- und Steinwerke GmbH uit graniet- en kleigroeven. bouwmaterialen gewonnen. Daarmee moesten onder meer de gigantische bouwsels die Albert Speer voor Hitler had ontworpen worden opgericht. De meeste daarvan zijn echter nooit gerealiseerd en volgens De Jong moet men wel aannemen, dat van de door gevangenen in de eerste jaren uitgehouwen granietblokken veel is gebruikt bij de aanleg van de Duitse Autobahnen.

De dwangarbeiders ontvingen geen loon, bij extra-inspanning soms wel premies. De SS- en particuliere bedrijven moesten per dwangarbeider per dag wel een bedrag aan het SS-Wirtschafts- und Verwaltungshauptamt betalen.

Het dwangarbeiders-systeem kwam volgens De Jong neer op een gigantische verspilling van arbeidskracht omdat de meeste dwangarbeiders door de slechte voeding fysiek niet in staat waren tot arbeid in een normaal tempo of daartoe niet bereid waren. Van elke drie gevangenen zijn volgens De Jongs' berekeningen er twee gestorven. ${ }^{105}$

Ook in Nederland hebben de Duitsers gevangenen voor de particuliere industrie laten werken. Concentratiekamp Vught, dat - zoals De Jong schrijf - rechtstreeks onder het SS-Wirtschafts- und Verwaltungshauptamt ressorteerde en volgens Rauter als 'Musterbetrieb der SS' fungeerde, kende een zogenaamd 'PhilipsKommando'. Een ploeg van circa twaalfhonderd gevangenen heeft vanaf februari '43 twintig maanden lang in de 'Philips Speciale Werkplaats Vught' administratief en produktiewerk voor Philips NV verricht, waarvoor dat bedrijf de gebruikelijke bedragen aan de Kampkommandantur afdroeg. Dekkers heeft dit een van de meest omstreden handelingen van de NV Philips tijdens de bezetting genoemd $^{106}$, maar De Jong benadrukte, dat Philips door aan de bezetter bepaalde eisen te stellen, in staat is geweest om de leden van het 'Philips-Kommando' een zekere bescherming te bieden tegen doorzending naar de Duitse vernietigingskampen. ${ }^{107}$ Teulings heeft uitlatingen van Frits Philips, dat die eisen een zegening zijn geweest voor de (in totaal) meer dan 3000 gevangenen uit dat Kommando, betwist. Dit verhaal bevat meer 'Dichtung' dan 'Wahrheit'. Het concentratiekamp Vught werd gebouwd vanwege de nabijheid van Philips als een van de weinige werkverschaffers die aan de gestelde SS-eisen voldeden (tenminste vow 500 man werk, van het type eenvoudige montage-arbeid). Er werden door Philips geen extra eisen gesteld. De genoemde 'eisen' waren algemene voorwaarden die diezelfde Duitse SS-Verwaltung aan de participerende ondernemingen stelde. Het is niet in te zien hoe deze SS-voorwaarden een zegening konden berekenen voor de meer dan 3000 gevangenen uit het Philips-commando'. 108

\subsection{Vae victis}

Na de Tweede Wereldoorlog waren de rollen omgekeerd. Als gevolg van wat Romijn 'een ware arrestatiewoede' heeft genoemd hebben tussen de 120.000 en 150.000 'foute' Nederlanders kortere of langere tijd in bewaringskampen doorgebracht. Een half jaar na de bevrijding stonden 96.044 personen als politieke ge- 
vangenen geregistreerd. Op 1 juni 1946 zaten er nog 70.740 mensen gevangen in 98 kampen, op 1 oktober nog 49.266 in 92 kampen en op 1 januari 194.735 .294 in 68 kampen. $\mathrm{Zij}$, die door een bijzonder gerechtshof waren veroordeeld, moesten hun straf uitzitten in inrichtingen waarin de Beginselenwet gevangeniswezen. van 1886 van toepassing was. Vele anderen ondergingen de door de Tribunalen opgelegde 'tuchtrechtelijke' maatregel van internering. ${ }^{109}$

De regiems in de kampen werden geregeld in de 'Interneeringsregeling 1946' (S. G 310, 1946). De geïnterneerden dienden volgens het eerste lid van artikel 10 dier regeling 'arbeid te verrichten ten behoeve van de gemeenschap, bij voorkeur ten behoeve van het Rijk of van andere publiekrechtelijke lichamen.' Arbeid ten behoeve van anderen was overigens ook toegestaan, mits tegen tarieven die in het vrije bedrijf golden (art. 11). Het werk moest zoveel mogelijk in overeenstemming zijn met ieders opleiding, aanleg en persoonlijkheid (art. 12) en men moest er na ontslag uit internering nog iets aan hebben (art. 12 lid 2). Er mocht maximaal acht en een half uur per dag en 48 uur per week gewerkt worden (art. 13 lid 1) en de geïnterneerden ontvingen voor hun arbeid een door de Directeur-Generaal voor Bijzondere Rechtspleging nader te bepalen 'matig loon', in de vorm van een uitgaanskas en zakgeld.

Vanuit de kampen werden de geïnterneerden tewerkgesteld, onder meer bij projecten van de Heide Mij, de Dienst Uitvoering Werken (DUW) en in de kolenmijnen. ${ }^{110}$ 'Op geen enkel gebied is de verbetering, die de commissie sedert haar vorige bezoeken kon constateren, zo groot als op het gebied der terwerkstelling. Moest zij verleden jaar de ervaring opdoen dat in tal van kampen een deel en zelfs een groot deel van de gedetineerden in het geheel niet werkte, thans is daarvan bijna nergens meer sprake', aldus het Verslag van de vaste Commissie voor Privaat- en Strafrecht omtrent bezoeken aan kampen voor politieke delinquenten en strafgestichten. ${ }^{111}$ In een eerder verslag had de commissie tot haar leedwezen moeten constateren, dat er aan de tewerkstelling van de politieke delinquenten nog zeer veel ontbrak. 'Een groot deel van hen werkt in het geheel niet. Hoe ongunstig deze ledigheid de stemming onder de gevangenen beïnvloedt, behoeft wel niet betoogd te worden. Indien er één middel is om hen geschikt te maken weer als normale burgers in de maatschappij terug te keren - hetgeen toch, op de zeer weinigen na, op wie de doodstraf zal worden toegepast, of die tot levenslange gevangenisstraf worden veroordeeld, na korter of langer tijd het geval zal moeten zijn, dan is dit toch wel het doen werken en liefst flink doen werken. Bovendien kunnen alleen op deze wijze de ontstellend hooge kosten der interneering gedrukt worden'.112

Ontvingen de gedetineerden aanvankelijk geen enkel arbeidsloon, na de invoering van de Interneringsregeling $1946 \mathrm{kwam}$ in de karnpen van het Directoraat-Generaal Bijzondere Rechtspleging (DGBR) $20 \%$ van de verdiensten aan de gedetineerden ten goede: $10 \%$ voor het gezin, $7 \%$ voor de uitgaanskas en $3 \%$ voor zakgeld (kantine). Daarmee werd er in de kampen meer verdiend dan in de reguliere gevangenissen, waar arbeid en beloning onder de vigueur van de Beginselenwet 1886 c.a. vielen. Veel politieke delinquenten wilden in de mijnen wer- 
ken, omdat daar - na aftrek van een vast bedrag voor kost en inwoning en voor onderhoud van werkkleding - het gehele, relatief hoge, loon aan het gezin kon worden gezonden. Toen de commissie Zuid-Limburg bezocht waren daar ruim 2500 gedetineerden en geînterneerden in de mijnen werkzaam. De positie van deze 'vrijwilligers' leek sterk op die van vrije arbeiders maar ze mochten geen eisen stellen. Dat blijkt uit de reactie van de vaste commissie op een staking die in kamp Valkenburg was uitgebroken met het doel een vrijwel algehele gelijkstelling met vrije arbeiders af te dwingen. Het sprak volgens de commissie vanzelf dat het DGBR zulke eisen niet kon inwilligen. 'Het stellen van eisen, welker inwilliging men met behulp van een staking tracht af te dwingen, kan bij personen, die rechtens van hun vrijheid zijn beroofd, onder geen enkele omstandigheid worden toegelaten'. ${ }^{113}$

Zo konden tienduizenden 'foute' Nederlanders hun morele schuld enigszins delgen door met hun werkkracht bij te dragen aan de wederopbouw van Nederland. Een nobeler doel heeft gedetineerden-arbeid wel nooit kunnen hebben. Sommigen koppelden deze vorm van 'Wiedergutmachung' aan het avontuur en meldden zich voor uitzending naar Nieuw Guinea, waar zij tegen een relatief hoge beloning nog bruikbare goederen uit legerdumps moesten selecteren. ${ }^{114}$

\section{De Beginselenwet Gevangeniswezen 1951}

\subsection{Arbeid moet renderen}

Nog nooit hadden zoveel mensen persoonlijk met de gevangenis kennis gemaakt. Tijdens de oorlog de 'goeden' en daarna de 'fouten'. Daardoor bestond er brede belangstelling voor het werk van de op I maart 1946 door de toenmalige minister van justitie Mr. H.A.M.T. Kolfschoten ingestelde commissie 'voor verdere uitbouw van het gevangeniswezen', naar haar voorzitter de commissie-Fick genoemd. Het rapport, dat deze commissie op 1 september 1947 heeft uitgebracht werd de grondslag voor de Beginselenwet Gevangeniswezen van 1951 (Stb. 596) die, samen met een nieuwe Gevangenismaatregel, op 1 juni 1953 in werking trad. ${ }^{1.5}$ Het rapport getuigt van een na-oorlogs optimisme: met zijn allen aan de slag voor de wederopbouw, niets is onmogelijk.

Juist in die tijd werden politieke gevangenen op grote schaal aan particuliere bedrijven toegewezen om mee te helpen bij de reconstructie van de vaderlandse economie. Maar dat was voor de commissie-Fick geen interessant gegeven. Zij wijdde bewust geen afzonderlijke beschouwingen aan de problemen van de gedetineerde politieke delinkwenten omdat dat vraagstuk toch binnen afzienbare tijd opgelost zou zijn, terwijl de commune delinkwenten een blijvend element in de samenleving vormden. ${ }^{116}$ De commissie vond het arbeidstempo van gedetineerden onbevredigend en vestigde haar hoop op de toepassing van 'moderne methoden tot verhoging van de arbeidsproduktiviteit'. De gevangenisarbeid moest vol- 
gens de commissie zoveel mogelijk overeenkomen met de arbeid in de vrije maatschappij. Er moest haars inziens dan ook met kracht naar gestreefd worden om de verplichte gevangenisarbeid zo veel mogelijk te organiseren volgens methoden van de moderne onderneming.

De commissie drong aan op een grotere efficiency in de gevangenisarbeid en achtte de voorwaarden daarvoor aanwezig omdat haars inziens de arbeidsgemeenschap in het toekomstige gevangenisbestel een veel grotere plaats zou gaan innemen dan voordien het geval was. De arbeid moest, meer dan voorheen, beheerst worden door het 'economisch motief'. Zowel de produktie als de winst dienden te worden vergroot en wel door verhoging van het arbeidsloon, verbetering van de outillage van de werkplaatsen en verhoging van het peil der gevangenissen. Een hogere beloning zou de gevangene niet alleen meer arbeidsvreugde geven ('een reclasseringsfactor van belang!') maar hij zou daarmee ook zijn gezin kunnen ondersteunen, zij het niet volledig, want het sprak volgens Fick c.s. vanzelf dat een gevangene niet integraal het loon van het vrije bedrijf behoorde te ontvangen. Hij kreeg zakgeld en het Rijk zou zo nodig - door middel van een kostwinnersvergoeding - voor de gezinnen zorgen. Om het arbeidstempo te verhogen wees de commissie invoering van het stukloon af en vond zij het beter te werken met bepaalde toeslagen op het loon. Wat de sociale verzekering betreft, vond de commissie het aanbeveling verdienen om voor gedetineerden een regeling te treffen gelijk aan de toen bestaande Ongevallen-en Invaliditeitswet. Zij be-pleitte voorts uitbetaling van loon tijdens ziekte, hetgeen tot dan niet gebeurde. De commissie realiseerde zich dat loonsverhoging voor gedetineerden de kostprijs van hun produkten (die voor $95 \%$ door de Rijksdiensten werden afgenomen) zou verhogen, maar zag daarin geen onoverkomelijk bezwaar. Ten opzichte van de $5 \%$ particuliere opdrachtgevers maakte een loonsverhoging niets uit, aan hen werden toch al de prijzen van het vrije bedrijfsleven in rekening gebracht 'om te vermijden dat het particuliere bedrijf zich bij de Regering beklaagt over oneerlijke concurrentie".

De commissie-Fick wilde dat er te Veenhuizen een modern geoutilleerde gevangenisfabriek zou worden gesticht. Daar zouden voldoende werkkrachten voor zijn want de commissic ging ervan uit dat de gevangenisbevolking niet binnen afzienbare tijd beneden de 6.000 à 7.000 man zou dalen, genoeg om een fabriek van redelijke omvang mee draaiende te kunnen houden. De afzet leek gegarandeerd: "immers de vraag naar de produkten van de gevangenisarbeid is zo groot dat de gezamenlijke gestichten niet aan deze vraag kunnen voldoen'. In de overige strafgestichten was volgens de commissie moeilijk plaatsruimte voor gemeenschapsarbeid te vinden. Dat probleem zou echter kunnen worden opgelost zodra het gevangeniswezen de beschikking zou krijgen over de kampen waarin de politieke delinkwenten waren gehuisvest.

Voor het welslagen van de gevangenisarbeid was het volgens de commissieFick nodig om het salaris van het arbeidspersoneel te verhogen om hen voor de gestichtsarbeid te behouden. Bij de gevangenisarbeid diende de nadruk te liggen 
op arbeidsintensieve produkten. De commsissie pleitte niet voor een vakopleiding als grondslag voor de bezigheid der gevangenen: niet veel gevangenen waren daar geschikt voor en de duur van hun straftijd was vaak te kort om het vak meester te worden. Alleen voor jeugdigen met voldoende geschiktheid en strafduur werd een vakopleiding aanbevolen.

De commissie-Fick zag een tak voor de reclassering om de beste man op de beste arbeidsplaats te krijgen. In de voorlichtingsrapporten diende aan dit punt apart aandacht besteed te worden. In tewerkstelling buiten de gevangenis zag de commissie een fraaie overgang voor de terugkeer naar de maatschappij. Wat de arbeidsduur betrof vond de commissie de toen verplichte 10 uur per werkdag. (art. 54 Gevangenismaatregel, oud) te veel: een werkweek van 48 uur leek haar voldoende. ${ }^{117}$

\subsection{De winsten blijven uit}

De meeste voorstellen van de commissie-Fick werden overgenomen in de nu nog geldende Beginselenwet gevangeniswezen van 21 december 1951 (S. 596). Met deze wet werd definitief ${ }^{118}$ met het cellulaire stelsel gebroken, waardoor de inrichting van gemeenschappelijke arbeidszalen mogelijk werd. In de Memorie van Toelichting bij het ontwerp van de Beginselenwet had de minister daarover gezegd: 'De arbeid, die in eenzaamheid kan worden verricht, mist de prikkel tot inspanning door vergelijking met prestaties van anderen terwijl arbeid in gemeenschap bovendien grotere mogelijkheden biedt tor werk dat meer vakbekwaamheid vereist. en bevordert. ${ }^{319}$

De voorgestelde regeling van de arbeid en het arbeidsloon in de artikelen 32 tot en met 38 werd zonder veel parlementaire discussie aanvaard. Voor minister en parlement was de verplichting tot het verrichten van arbeid uberhaupt geen punt: van discussie. Wel was er enig debat over de categorieën gedetineerden waarvoor die plicht moest gelden. Via een door de geachte afgevaardigde Donker verdedigd amendement werd in artikel $32 \mathrm{BWG}$ opgenomen dat de arbeidsplicht ook voor tot hechtenis veroordeelden gold.

Artikel 33 van de wet moest de aloude bij ondernemers en arbeiders levende vrees voor concurrentievervalsende effecten van de arbeid wegnemen door te bepalen dat er voomamelijk voor het Rijk gewerkt zou worden en dat, waar er toch ten behoeve van particuliere opdrachtgevers zou worden geproduceerd, dit tegen de in het vrije bedrijf geldende loontarieven zou gebeuren. In zijn Memorie van Antwoord wees de minister (intussen was dat Struycken) er daarbij op dat het aantal produktieve gedetineerden slechts $0,23 \%$ van de hand- en industriearbeiders in de vrije maatschappij uitmaakte. ${ }^{120}$

In de Memorie van Toelichting op de bepalingen over het loon werd stilgestaan bij de vraag in hoeverre een verhoging daarvan mogelijk was en of een deei van zo'n verhoogd loon aan de gezinnen van de gedetineerden kon worden overgemaakt. Ervaringen met zo'n stelsel in bewarings- en interneringskampen had- 
den uitgewezen, dat wat er aan loon aan de gezinnen werd overgemaakt toch weer van de daaraan verleende steun werd afgetrokken, waardoor de 'prikkel, gelegen in lotsverbetering voor het gezin door de arbeid van de gedetineerde' verloren ging. Omdat dit gevolg slechts te vermijden viel als gedetineerden meer dan de steun-norm zouden verdienen, maar dit niet haalbaar was, zag de bewindsman van loonsverhoging af.

De arbeidstijd werd aangepast aan die, welke in het vrije bedriif gold: 48 uur per week, behoudens noodzakelijk overwerk. De gevangenisarbeid moest een sociaal effect sorteren, hetgeen kon worden bereikt door het onderhouden, vergroten of aanleren van vakbekwaamheid, een streven waarvoor art. 38 Beginselenwet de ruimte moest bieden. ${ }^{121}$

Uit een verslag van Gevangeniswezen over de periode 1945 tot en met 1953 komt naar voren dat het economisch optimisme van de commissie-Fick intussen was gesmoord in de realiteit van de strafexecutie: 'In het begin van de verslagperiode was de arbeidssituatie in de gestichten niet gunstig. De gestichten waren sterk overbezet, zodat de cellen werden bewoond door meer dan één gedetineerde. Werd voordien de arbeid in de meeste gestichten cellulair verricht, het bleek nu wenselijk de arbeid zoveel mogelijk in gemeenschap te doen plaatsvinden. De hiervoor benodigde werkruimte en outillage was echter slechts in zeer beperkte mate aanwezig. Er bestond een nijpend gebrek aan grondstoffen en het contact met de afnemers was verbroken. De gedetineerden konden dan ook slechts met veel moeite aan het werk worden gehouden.' Toch werd geconstateerd dat aan het eind van de verslagperiode de werkvoorziening in de gestichten bevredigend was. Van het rendementsdenken van de commissie-Fick bleef in het verslag niets over. De gevangenisarbeid had niet tot doel winsten te maken. In het geheel van de penitentiaire bedrijvigheid had de arbeid "een dienende doch geen verdienende' functie. ${ }^{122}$

Enkele jaren later velde de commissie-'s Jacob, na bestudering van de gebouwen van het gevangeniswezen, een vernietigend oordeel over de arbeidsmogelijkheden. 'De arbeidsruimten zijn over het algemeen zeer slecht te noemen. Slechts in een enkel gesticht zijn één of meer aanvaardbare werkplaatsen aanwezig. Een verantwoorde organisatie en economische bedrijfsvoering is in de huidige situatie onbestaanbaar'. De commissie, voorstandster van een zekere regionale concentratie van strafgestichten, meende dat zulks ook bevorderlijk was voor een goede organisatie en economische bedrijfsvoering van de gevangenisarbeid. 'Bij een regionale structuur zullen ruim 1500 gedetineerden verdeeld worden over 3 centra, elk centrum zal dus beschikken over ruim 500 gedetineerden. Van deze 500 gedetineerden zullen ongeveer 100 in open gestichten kunnen verblijven. Indien mogelijk zullen deze bij het vrije bedrijf in de omgeving van het centrum tewerkgesteld dienen te worden. De gevangenisarbeid van het centrum zou dus regelmatig de beschikking hebben over ruim 350 gedetineerden, indien althans (...) een percentage van ongeveer $10 \%$ wordt gereserveerd voor huis- en terreindienst. 
Deskundigen menen op grond hiervan te mogen stellen dat men, bij een normaal gedifferentieerd produktieprogramma, ook bij regionale concentratie zal kunnen beschikken over een zodanig aantal arbeidskrachten, dat het alleszins mogelijk is produktie-processen op gezonde organisatorische basis op te zetten'. ${ }^{123}$

\subsection{Arbeid moet resocialiseren}

De kwestie van arbeid en beloning kwam weer op de politieke agenda toen minister van Justitie Scholten in 1964 de Tweede Kamer een nota aanbood met materiaal voor een parlementaire discussie over de verdere ontwikkeling van het $\mathrm{Ne}$ derlandse gevangeniswezen. ${ }^{124}$ De minister had niet de bedoeling het werk van de commissie-Fick nog eens over te doen. Fundarnentele vernieuwingen beoogde hij niet. Uitgaande van het reëel bestaande strafrecht werd het beleid ter discussie gesteld. Het kernthema daarbij was 'resocialisering'.

Scholten wilde de tenuitvoerlegging van de vrijheidsstraf, conform het bepaalde in artikel 26 van de Beginselenwet, dienstbaar maken aan de wederaanpassing van de gedetineerden aan de eisen van het maatschappelijk leven. Bij die doelstelling paste 's ministers streven de gedetineerde zoveel mogelijk in de gelegenheid te stellen zinrijke en bij zijn aanleg en opleiding passende arbeid te laten verrichten. Daartoe moest de organisatie van de arbeid worden verbeterd en diende er een bevredigende oplossing van het probleem van de beloning te komen, zo stelde de bewindsman. De gestichtsarbeid moest de gedetineerden resocialiseren en zowel de orde en discipline in de gestichten als de vakbekwaamheid van de gestraften bevorderen.

Legde de commissie-Fick nog de nadruk op het economisch belang van de gedetineerden-arbeid, minister Scholten nam afstand van het idee dat gestichtsarbeid winstgevend moest worden. Ook hij vond: 'De functie daarvan is niet een verdienende, maar een dienende'. Er werd wel gestreefd naar een economisch verantwoorde en efficiënte werkwijze, maar dat was niet het leidende beginsel. De 48-urige werkweek waar de commissie-Fick nog aan hing werd een 421/2-urige, mèt een vrije zaterdag. Dat laatste met enige tegenzin want het 'op verantwoorde wijze bezig houden van de gedetineerden in het week-end, wanneer in het algemeen moet worden gewerkt met de helft van de normale personeelsbezerting, vormt in de strafgestichten toch altijd een probleem', zoals de minister opmerkte. De outillage van de werkplaatsen - een van de aandachtspunten van de commissie-Fick - kon nog slechts worden gekenschetst als een begin van die welke volgens de moderne inzichten zou moeten bestaan.

Daar deugde dus nog niet zo veel van, hetgeen niet bevorderlijk was voor het tempo, de werklust en de arbeidsgewenning bij de gederineerden. Dat laatste gold, volgens de nota ook voor het door de gedetineerden verrichte huishoudelijke werk, dat 'ook niet over de hele lijn efficient' georganiseerd was. In de huizen van bewaring kon slechts 'eenvoudig, sorns eentonig' werk worden verstrekt. In de gevangenissen was het beleid erop gericht 'die arbeid te doen verrichten die zich leent voor het toepassen van moderne arbeidsmethodieken.' Er werd ge- 
tracht zo veel mogelijk langlopende orders te krijgen waarbij in beginsel de voorkeur uitging naar orders van overheidsdiensten en bedrijven, omdat deze minder door eventuele schommelingen in de conjunctuur werden beïnloed. In verband met moeilijkheden bij het verkrijgen van overheidsorders had de ministerraad in 1959 besloten dat het gevangeniswezen aanspraak kon doen gelden op passende langlopende overheidsorders. De produktiviteit in de gestichtsbedrijven werd ongunstig beinvloed door de voortdurende wisseling van arbeidskrachten, de onmogelijkheid voor gedetineerden om werk te kiezen dat hun het beste lag of dat zij het liefste declen, door inschakeling, van gedetineerden die in het geheel niet gewend waren te werken, door wijzigingen in de bestemming van gestichten en door onderbrekingen van de arbeid, bijvoorbeeld 'voor beweging in de open lucht of om deel te nemen aan lichamelijke oefeningen, dan wel voor een gesprek met zijn adwocaat, met een reclasserings- of sociaal ambrenaar of geestelijke verzorger.' (...) 'Tenslotte - het gaat hier nu eenmaal om een tewerkstelling onder dwang - moet ondanks betere werkomstandigheden, aangenamer werk en het gericht zijn van de gestichtsarbeid op de wederaanpassing, bij een groot gedeelte van de gedetineerden de neiging worden overwonnen om met een minimum aan inspanning te volstaan'.

Waar de commissie-Fick nog had gepleit voor een redelijke beloning voor de gestichtsarbeid, nam minister Scholten gas terug: 'Het loon dat krachtens de geldende loonregeling gedetineerden voor de arbeid wordt toegekend is (...) geen loon in eigenlijke zin, en is ook niet als zodanig bedoeld', zei hij. Het was meer bedoeld als spaarpotje bij ontslag uit detentie en voor de aankoop van kantine-artikelen.

Wat wilde Scholten dan wel? In de huizen van bewaring wilde hij uitbreiding van de arbeid. Hij wilde dat daar ongeveer de helft van de bevolking in arbeidszalen aan de arbeid deel zou kunnen nemen. De huishoudelijke werkzaamheden moesten geleidelijk bedrijfsmatig worden georganiseerd. De mogelijkheden voor vakopleiding van jeugdige gedetineerden zouden worden onderzocht. Scholten dacht aan een centralisatic van de arbeid in een industricel complex, een echo van de eerder door de commissie-Fick geuite wens om te komen tot een modern geourilleerde gevangenisfabriek.

Voor vrouwelijke gederineerden wilde de minister meer arbeidsmogelijkheden scheppen, met name in de huishoudelijke sector. ${ }^{125}$

\subsection{Arbeid als regiemsactiviteit}

Het eerstvolgende departementale stuk van enige importantie dat over het gevangeniswezen verscheen was de 'Nota Beleidsvraagstukken gevangeniswezen', die staatssecretaris Zeevalking op 21 september 1976 aan de Tweede Kamer aanbood. Er was volgens deze bewindsman sinds de nota van 1964 weliswaar veel tot stand gebracht, maar voor het probleem van de arbeid en de arbeidsbeloning was nog geen oplossing gevonden. Het was moeilijk gebleken de arbeid af te stemmen op de overige regiems-activiteiten, zoals gesprekken met stafleden of advocaten, 
familiebezoek, sport, etcetera. De gemiddelde detentieduur was te kort voor opleiding en instructie van gedetineerden, die meestal nauwelijks ervaring hadden met geregelde en geschoolde arbeid. Daardoor kon niet goed aan gestelde levertijden en produktie-eisen worden voldaan. Zeevalking zei te zoeken naar alternatieve arbeidsvormen om toch mede via de arbeid te komen tot het ankweken van goede vaardigheden. Zijn streven was om waar mogelijk buiten-arbeid te stimuleren 'hetzij door gedetineerden individueel (in open inrichtingen) dan wel in groepsverband (in half-open inrichtingen)'.

De beloningskwestie werd ook in deze nota niet uitgewerkt: 'Voorlopig gaan de gedachten uit naar een uitbouw van het bestaande stelsel van het geven van zakgeld. Het zakgeld is thans te gering dan dat daarvan een prikkel zou kunnen uitgaan om zich voor de arbeidsprestatie te kunnen inzetten', aldus de staatssecretaris, die de problematiek voor nadere bestudering naar een werkgroep verwees. De invoering van het minimumloon voor gedetineerden zou volgens de berekeningen van Zeevalking op een jaarlijks bedrag van 24 miljoen gulden extra neerkomen.

De beloning van de arbeid zou, wat Zeevalking betreft, niet direct aan de economische waarde ervan gekoppeld behoeven te worden: 'Men kan de arbeid zien als een onmisbaar onderdeel van een pakket van penitentiaire activiteiten, waarvan ook recreatie en maatschappelijk werk deel uitmaken. Het is daarom verdedigbaar dat in inrichtingen, waar het dagprogramma in verband met zekere vormingsactiviteiten niet in een volledige werkdag voorziet, of waar de arbeidsweek korter is dan de gebruikelijke 40 uur, een beloning wordt toegekend die overeenkomt met hetgeen in andere inrichtingen bij een volledige werkweek van 40 uur wordt verdiend'.

De arbeid was in deze visie niet langer de spil waar het gevangenisleven om draaide, maar een onderdeel van een scala van regiems-activiteiten. ${ }^{126}$ Deze opvatting vond weerklank in een rapport dat de Commissie doelstelling en functie huis van bewaring (naar haar voorzitter de commissie-Van Hattum genoemd) in 1977 uitbracht. Deze commissie besteedde speciale aandacht aan de arbeid, weliswaar primair van belang voor de situatie in de huizen van bewaring, maar qua strekking evenzeer van belang voor die in de andere inrichtingen van het gevangeniswezen. Allereerst bepleitte de commissie de afschaffing van de arbeidsplicht voor veroordeelden die zich $(\mathrm{nog})$ in een huis van bewaring bevinden, zodat die net zoals de onveroordeelden - een recht krijgen om aan de arbeid deel te nemen. Van Hattum en de zijnen maakten bezwaar tegen de extreem lage beloning, het geringe niveau van de geboden werkzaamheden en her gebrek aan continuitteit daarin.

De commissie was van mening dat in beginsel aan de gedetineerde een volwaardig loon (ten minste het minimumloon) moest worden toegekend waardoor hij zijn status als kostwinner zou kunnen behouden: 'Mogelijkheden ziet de commissie in een verschuiving in de algemene middelen van bijstandsuitkering naar loon, waardoor dit de overheid niet per se extra geld behoeft te kosten'. Op korte termijn diende wat haar betreft al een zodanige beloning te worden toegekend dat het wat aantrekkelijker werd om te gaan werken. 
De commissie achtte de verhoging van de kwaliteit van de arbeid in de huizen van bewaring niet eenvoudig realiseerbaar, 'mede gezien de vlottende bevolking en het uiteenlopen van vaardigheden en scholing van de ingeslotenen'. De belangen van de gedetineerden dienden echter hoger te worden aangeslagen dan het rendement van hun arbeid. De commissie betoonde zich voorstander van een systeem van één dagdeel arbeid en één dagdeel bestemd voor overige activiteiten. Halvering van de arbeidstijd diende overigens niet tot halvering van de beloning te leiden omdat de gedetineerde zijn kostwinnersfunctie binnen de inrichting moest kunnen behouden. Het rapport pleitte voor een vorm van arbeidskeuze voor gedetineerden en keerde zich tegen een systeem waarin de beste baantjes als beloning voor goed gedrag werden vergeven. De commissie-Van Hattum deed de volgende aanbevelingen met betrekking tot de arbeid in de huizen van bewaring:

- De arbeid dient één van de activiteiten te zijn waaraan gedetineerden - op basis van vrijwilligheid - kunnen deelnemen.

- Art. 32 Beginselenwet dient in die zin te worden gewijzigd dat ook de veroordeelden in de huizen van bewaring op basis van vrijwilligheid aan de arbeid kunnen deelnemen.

- Arbeidsprojecten moeten zoveel mogelijk zijn afgestemd op de capaciteiten, ervaring en interesse van de gedetineerden; zo mogelijk dient de eigen arbeid te kunnen worden voortgezet.

- De arbeid moet worden teruggebracht tot maximaal één dagdeel (ochtend of middag) om ruimte te verkrijgen voor deelname aan andere bezigheden. ${ }^{127}$

Ruim 3 jaar na het uitkomen van het rapport van de commissie-Van Hattum bood de toenmalige staatssecretaris Haars haar eindoordeel erover aan de Tweede Kamer aan. Zij achtte een vrijblijvende deelname aan de arbeid en de andere activiteiten niet te rijmen met het doel dat door middel van deze activiteiten werd nagestreefd: 'Naarmate de variatic in arbeid en andere bezigheden toeneemt, zal het beleid nadrukkelijker worden gebaseerd op het uitgangspunt dat gedetineerden aan activiteiten kunnen deelnemen, mits ze zichzelf verplichten tot regelmatige deelname'. Haars wees het optrekken van de beloning tot ten minste het peil van het minimumloon af, met de volgende motivering: 'Om aan deze voorwaarden te kunnen voldoen, zou de arbeid in de detentiesituatie een geheel andere plaats moeten gaan innemen. Verder zou dit loon dan grotendeels moeten gaan naar diegenen voor wie de gedetineerde kostwinner of onderhoudsplichtige is. Dit is in het Nederlandse penitentiaire bestel niet realistisch'. ${ }^{128}$

Merkwaardigerwijze wordt kort daarop, in het kader van een heroverweging van de collectieve uitgaven, van regeringswege het denkbeeld geopperd om één of meer gevangenissen zodanig in te richten dat daar door geselecteerde gevangenen, met het vrije bedrijf vergelijkbare, professionele arbeid kon worden verricht. Door een geringere behoefte aan bewakend personeel en een aanzienlijke toename van de opbrengst van de arbeid zou het Rijk per jaar miljoenen kunnen besparen, zelfs als aan gedetineerden het minimumloon zou worden uitbetaald. ${ }^{129}$ 
Het volgende beleidsdocument van het gevangeniswezen, waarin het probleem van arbeid en arbeidsbeloning serieus wordt besproken is de op 2 septernber 1982 door staatssecretaris Scheltema aan de Tweede Kamer aangeboden nota 'Taak en toekomst van het Nederlandse gevangeniswezen'. Dit op verzoek van de Tweede Kamer geschreven stuk sluit aan op de Nota beleidsvraagstukken uit 1976. Ook Scheltema kwam er niet uit. Hij herhaalde in eerdere nota's genoemde factoren die aan een zinvolle, produktieve en reclasserende gedetineerden-arbeid in de weg zouden staan en legde zich in feite bij deze neer. Slechts een deel van de arbeid kon dienen tot scholing en opleiding van gedetineerden; 'voor een aanzienlijk deel beperkt de functie van de arbeid er zich toe de gedetineerden in samenwerkingsverband zo nuttig mogelijk bezig te houden; overigens is alle arbeid, ook de celarbeid, bedoeld als noodzakelijke tijdsbesteding', aldus Scheltema. Hij zei verder dat in verband met de economische teruggang, die investeringen in de gevangenisarbeid belemmerde en méér nog vanwege het in het maat-schappelijk leven toegenomen belang van de niet-arbeidstijd, de aandacht tijdens de detentie meer en meer uitging naar andere inrichtingsactiviteiten.

Scheltema wees pleidooien voor minimumloon voor gedetineerden echter niet zo categorisch af als staatssecretaris Haars dat in 1980 had gedaan. Hij had er alleen geen geld voor 'in deze tijd van een sterk neerwaarts gaande conjunctuur, waarin ook de overheid aanzienlijk moet bezuinigen'. Invoering van het wettelijk minimumloon zou volgens zijn berekening tot een extra uitgave van ca. f. 35 miljoen leiden. Wel was er eind 1977 verbetering in de arbeidsbeloning voor langge-straften en de in Amsterdam gedetineerde vrouwen gekomen. De arbeidscluur was in een aantal gesloten inrichtingen al tot een blok van 4 uur per dag teruggebracht. 'De arbeid en de overige activiteiten worden hierdoor meer als gelijkwaardige activiteiten erkend', aldus de nota 'Taak en Toekomst' dat zich daarmee aansloot bij de aanbevelingen van de commissie-Van Hattum. De arbeid was daarmee niet langer de spil waarom het gevangenisleven draaide, maar ging op in een 'regiemsactiviteitenprogramma'. ${ }^{130}$

Gevangeniswezen raakte steeds meer gepreoccupeerd met (zo niet geobsedeerd door) plaatsgebrek voor de toenemende aantallen preventief gehechten en gestraften die een veranderd handhavingsklimaat voortbracht. De vraag hoe er ondanks allerlei bezuinigingsoperaties toch geld voor meer cellen kon worden ge-vonden drukte de discussie over andere problemen, zoals die rond arbeid en beloning, in de marge. De gedwongen tewerkstelling boette daarmee echter niet aan betekenis in. In een nieuwe, extramurale, verschijningsvorm veroverde zij terrein.

\subsection{Expansie van de arbeidsplicht}

In de tachtiger jaren breidt de arbeidsplich $t$ zich buiten de gevangenismuren uit. Aanvankelijk bij wijze van experiment, en sinds 1989 als hoofdstraf, kunnen daders van strafbare feiten worden gestraft met het verrichten van maximaal 240 uur onbetaalde arbeid 'ten algemenen nutte' in die gevallen waarin de rechter overweegt een onvoorwaardelijke straf van niet meer dan zes maanden op te leg- 
gen. De wet bepaalt, dat de verdachte zelf moet aanbieden zulk werk te willen verrichten. Feitelijk heeft hij echter geen vrije keus: het altematief is namelijk 'zitten'. Daarom moet er bij dienstverlening - ondanks de juridische fictie van vrijwilligheid - de facto worden gesproken van gedwongen strafrechtelijke tewerkstelling. Wordt de dienstverlening naar de mening van het Openbaar Ministerie niet naar behoren verricht, dan kan het de rechter vragen om de tenuitvoerlegging van de voorgenomen vrijheidsstraf te gelasten en wordt de zogenaamde vrijwillige arbeid omgezet in de arbeidsplicht die voor gevangenen geldt. Die arbeidsplicht wordt niet langer door de gevangenismuren ingeperkt. Zij is strafrechtelijk vaker en gemakkelijker op te leggen dan ooit tevoren. En als de plannen, zoals door de Commissie Alternatieve Sancties zijn ontwikkeld voor een nieuwe straf van 'vrijheidsbeperking', werkelijkheid zullen worden, zal gedwongen arbeid (in de een of andere vorm en onder welke benaming dan ook) daar een integrerend bestanddeel van gaan uitmaken. Noch binnen, noch buiten de muren is de reële productie daarbij van doorslaggevende betekenis.

Minister Mulderije gaf in 1951 al precies aan waar het Justitie om gaat: om de symbolische beschikking over de persoon en werkkracht van de veroordeelde. ${ }^{131}$

\section{Het voorontwerp Penitentiaire Beginselenwet en de nota 'Werkzame Detentie': de rehabilitatie van de arbeid}

In juli 1993 heeft het ministerie van Justitie een voorontwerp voor een Penitentiaire Beginselenwer (PBW) gepubliceerd. ${ }^{132}$ Daarin wordt nog maar één bepaling aan de arbeid gewijd en wel artikel 46 , dat luidt:

1. De gedetineerde heeft het recht op deelname aan de in de inrichting beschikbare arbeid.

2. De directeur draagt zorg voor de beschikbaarheid van arbeid voor gedetineerden.

3. Gedetineerden die tot een vrijheidsstraf zijn veroordeeld zijn verplicht de aan hen door de directeur opgedragen arbeid zowel binnen als buiten de inrichting of afdeling, te verrichten.

4. De arbeidstijd wordt in de huisregels vastgesteld binnen de grenzen van hetgeen buiten de inrichting of afdeling gebruikelijk is.

5. Onze minister stelt regels omtrent de samenstelling en de hoogte van het arbeidsloon. De directeur is belast met de vaststelling en uitbetaling van het arbeidsioon.

De ontwerp-Memorie van Toelichting: ${ }^{33}$ meldt dat in dit nieuwe artikel 46 de artikelen $32 \mathrm{t} / \mathrm{m} 38$ van de Beginselenwet en de artikelen $49 \mathrm{t} / \mathrm{m}$ 62a van de Gevangenismaatregel zijn samengevoegd.

De bepalingen over de uitgaanskas keren niet terug omdat die in de praktijk al is afgeschaft. De arbeid hoeft ook niet langer bij voorkeur ten behoeve van 's rijksdienst te worden verricht, zoals nu nog in artikel 33 lid 1 BWG staat vermeld. 
Dat is volgens de ontwerpers niet meer nodig omdat er op dit moment op grote schaal voor particuliere opdrachrgevers wordt gewerkt.

De arbeidsplicht voor veroordeelden wordt gehandhaafd. Deze beperking in de handelingsvrijheid van gedetineerden wordt wezenlijk geacht voor het doel van de vrijheidsbeneming: de voorbereiding op de terugkeer in de vrije maatschappij. Artikel 46 PBW maakt het mogelijk om de huidige praktijk waarin veroordeelden, die (nog) in een huis van bewaring verblijven, geen arbeidsplicht wordt opgelegd (hun wordt daar geen arbeid 'opgedragen') te handhaven. Overigens wordt in de Memorie van Toelichting wel vastgesteld dat het Europees verdrag tot bescherming van de rechten van de mens (EVRM) toestaat om ook in het huis van bewaring een arbeidsplicht door te voeren.

Over de hoogte van het arbeidsloon zwijgt de PBW. Uit een oogpunt van rechtsgelijkheid wordt het wenselijk geacht dat de hoogte en de wijze van samenstelling van het arbeidsloon centraal worden vastgesteld. De arbeidstijd kan naar het oordeel van de ontwerpers beter op inrichtingsniveau worden geregeld. In de Memorie van Toelichting wordt niet gerefereerd aan discussies die in het verleden zijn gevoerd over het invoeren van een normaal loon. Het enige dat daarover wordt gezegd is: 'Een referentiekader hierbij vormen de in de vrije maatschappij geldende normen. Hiermee in overeenstemming is een stelsel waarbij loon naar prestatie wordt toegekend'.

Opvallend is dat er - naast de arbeidsplicht voor veroordeelden - voor alle categorieën een recht op arbeid wordt gecreëerd en dat de directeuren verplicht: worden voor voldoende werk te zorgen. Gedetineerden zullen in die zin vooruit lopen op de vrije burger, aan wie artikel 19 van de Grondwet slechts een vrije arbeidskeus garandeert en dat de overheid slechts opdraagt te bevorderen dat er voldoende werkgelegenheid is.

Zo indifferent als de gevangenisarbeid in het voorontwerp voor een P.B.W. wordt behandeld, zo prominent is de rol ervan in de nota-Kosto 'Werkzame Detentie. ${ }^{134} \mathrm{Al}$ voor de publicatie ervan had de staatssecretaris laten weten dat het afgelopen moest zijn met het gelanterfant achter de tralies. Gedetineerden moesten de handen weer uit de mouwen steken, zo sprak hij tijdens een door hemzelf georganiseerde studiedag over het gevangeniswezen. De arbeid moest: wat hem betreft weer een centrale functie gaan vervullen tijdens de: detentie. ${ }^{135}$

In een nieuw in te voeren 'standaardregime' zal 'maximale arbeid' centraal staan. Gedetineerden, die niet aan de arbeid deelnemen moeten op hun cel blijven en mogen daar alleen uit vanwege de wettelijke gegarandeerde bezoek-, lucht-, recreatie- en sporttijden. De huidige bloktijden-regeling waarbij van maandag tot en met vrijdag telkens één dagdeel voor de arbeid en één dagdeel voor andere activiteiten is bestemd en in het kader waarvan hooguit 20 uur per week gewerkt wordt verdwijnt. De voor de arbeid beschikbare tijd wordt verhoogd tot ten minste 26 uur per week en wordt gegoten in een regime van vier dagen arbeid en drie dagen met een 'verkort dagprogramma'. De capaciteit van de arbeidsruimten zal worden uitgebreid, de acquisitie van opdrachten voor de 
gedetineerdenarbeid zal moeten worden versterkt en de inrichtingsarbeid zal op een meer cornmerciële leest worden geschoeid. Omdat de staatssecretaris en zijn ambtenaren ook niet meteen weten hoe zoiets moet zal met behulp van externe expertise worden onderzocht hoe die inrichtingsarbeid meer bedrijfsmatig kan worden verricht en welke produkten er 'gelet op de marktsituatie' het beste kunnen worden vervaardigd. De bewindsman voorziet geen grote winsten, hij zal al tevreden zijn als met deze operatie zal worden bereikt dat de arbeidsvoorzieningen meer dan thans het geval is kostendekkend kunnen functioneren.

In het standaardregime beginnen gedetineerden met eenvoudige arbeid waarvoor geen speciale vaardigheden zijn vereist. Op basis van getoonde inzet en kwaliteiten kan vervolgens hoger gekwalificeerde arbeid worden 'verdiend'. Is de inzet onvoldoende dan volgt verbliff in de cel tijdens de arbeidsuren en wordt individuele arbeid verricht of geen arbeid. De gedetineerden wordt loon naar werken in het vooruitzicht gesteld. Die zal worden gekoppeld aan het kwantitatieve en kwalitatieve niveau van de arbeid, maar bedragen worden in deze nota niet genoemd.

Het standaardregime kent twee pijlers: arbeid en structuur. Verveling en ledigheid zullen plaats maken voor zinvolle tijdsbesteding. 'Het dagelijks verrichten van werk om in het levensonderhoud te voorzien kan een gunstig effect hebben op de verdere levensloop. Het wennen aan de strucrurering van de dag rond de arbeid en het bijbrengen van arbeidsdiscipline zijn daartoe voorwaarden waaraan met de invoering van het standaardregime wordt voldaan'.

$\mathrm{Na}$ de invoering van het standaardregime zal de gedetineerde, als men de voor de nachtrust bestemde tijd in de berekeningen betrekt, bijna $70 \%$ van zijn detentie-tijd op zijn cel doorbrengen ${ }^{136}$. Als hij niet hard of goed genoeg werkt kan dat percentage nog oplopen.

Hoewel Justitie schat dat 70 à $80 \%$ van de gedetineerden de verlangde arbeid ook zal willen verrichten wordt wel rekening gehouden met weerstand van de gedetineerden tegen de gevolgen van het strakkere regime, bijvoorbeeld tegen het korten op de voor recreatie beschikbare tijd. "Het overwinnen van weerstanden die dit naar verwachting zal oproepen is een van de obstakels, die de komende jaren zullen moeten worden overwonnen'. Als ander - en gezien het nieuwe primaat van de arbeid bepaald geen onbelangrijk - obstakel wordt gezien het gebrek aan arbeidsplaatsen in de bestaande inrichtingen en de bouwkundige belemmeringen om de arbeidscapaciteit substantieel uit te breiden. De over-all indruk van de nota is, dat in de gevangenis-arbeid als een essenticel een middel wordt gezien om de in tal en last groeiende gestichtsbevolking in het gareel te houden. Als de arbeid de kern van de tenuitvoerlegging van de gevangenisstraf is en - zoals in de nota wordt gesteld - de gevangenisstraf primair ten dienste van de vergelding als strafdoel staat dan moet worden vastgesteld dat de tewerkstelling van gedetineerden een strafkarakter draagt. Werk als strafwerk, passend in dit tijdperk van neovergelding. ${ }^{137}$ 


\section{Slotopmerkingen}

De in het voorafgaande uitgevoerde verkenningen in de historie van de (Westeuropese) penitentiaire dwangarbeid maken duidelijk dat, sinds de uitvinding van de detentie als strafsoort, van gevangenen altijd is gevergd dat ze werkten. In de beste gevallen betrof het eenvoudig handwerk waarvoor een bescheiden vergoeding werd betaald. In de slechtste gevallen - de bagno's en in de Duitse concentratickampen - moest er gewerkt worden tot de dood er op volgde. Geen enkele straffende overheid heeft zich ooit verplicht gevoeld de voor gedetineerden geldende arbeidsdwang op bijzondere rechtsgronden te baseren. $\mathrm{Zij} \mathrm{had} \mathrm{en} \mathrm{heeft}$ een axiomatisch karakter. Aan de gedetineerden-arbeid werden, afhankelijk van tijd, plaats en overheersende penologische theorie afwisselend punitieve, economische en reclasserende functies toegedacht, soms tegelijkertijd. Stilzwijgend achtte men dwangarbeid inherent aan de tenuitvoerlegging van de vrijheidsstraf en dat is, althans in Nederland, nog steeds het geval.

In de volgende hoofdstukken zal worden getracht die vanzelfsprekendheid te doorbreken. Daartoe worden nu allereerst de voornaamste verschillen tussen de rechtspositie van de gedetineerde/arbeider en die van de vrije werknemer in kaart gebracht. 


\section{Noten}

1. L. Vandekerckhove, Over het ontstaan van de gevangenisstraf; cen kijk op het oude Rome, Leuven/Amersfoort 1989, bl. 11 en 29.

2. Het ergastulum was volgens Vandekerckhove (a.w., bl. 34) cen economische en geen penitentiaire instelling. Het was een (ondergrondse) verbliffplaats die diende voor de gewone behuizing van slaven, en waarin ook de gestrafte slaven (geketend) in ondergebracht werden.

3. L. Vandekerckhove, a.w., bl. 19, 20 en 55.

4. L. Vandekerckhove, a.w., bl. 37.

5. B. Geremek, Het Kainsteken; het beeld van de armen en vagebonden in de Europese literatuur van de 15 e tot de 170 eeuv, (Warschau 1980), Baarn 1992, bl. 18 en 19. Het genoemde essay van $M$. Cataluccio werd bewerkt door Romke Visser.

6. P. Spierenburg, The prison experience; disciplinary institutions and their inmates in early modern Europe, New Brunswick en Londen 1991, bl. 17-38.

7. Thomas More, Utopia (1516), translated with an introduction by Paul Turner, Harmondsworth 1965, bl. 51-54.

8. D.V. Coornhert, Boeventucht, naar de druk van 1587 uitgegeven en van commentaar voorzien door A-J Gelderblom, M. Meijer Drees en een werkgroep van Utrechtse neerlandici, (Utrecht 1980) Muiderberg 1985, bl. 31 en 32.

9. Thomas More, $a, w$, bl. 11 en 12. 10. P. Spierenburg, 'Boeventucht en vrijheidsstraffen. Coornherts betekenis voor her ontstaan en de ontwikkeling, van het gevangeniswezen in Nederland', in de bundel Scherp toezicht; van 'Boeventucht' tot 'Samenleving en Criminaliteit', onder redactic van C. Fijnaut en P. Spierenburg, Arnhem 1990, bl. 11-30. 11. D.V. Coornhert, in de aangehaalde uitgave van Boeventucht door A-J. Gelderblom c.a. De getallen tussen haakj̣es verwị̄zen naar de in die uitgave gebruikte regelnummering van Boeventucht.

12. H. Bianchi, (boekbespreking) D.V. Coornhert, 'Boeventucht', uitgegegeven en toegelicht door een werkgroep van Utrechtse neerlandici. Instituuut De Vooys, Utrecht 1980, De Nieuwe Taalgids 1981, bl. 452-457. 13. H. Bonger, 'Coornhert en Bianchi', De Nieuwe Taalgids 1982, bl. 230-233.

14. Th(eun) de Vries, 'Dirck Volkertszoon Coornhert; Wellevenskunstenaar', Vitrine 1990, nr. 3, bl. 20.

15. P. de Beer, 'De eigenwijsheid van Coornhert', Tïdschrift voor Criminologie 1988, nr. 3, bl. 232 .

16. Rationaliteit wordt in de eerste 'Alternatieve justitiebegroting' van de CoornhertLiga (Deventer 1971, bl. 5) een fundamentele voorwaarde voor een behoorlijk strafrechtelijk beleid genoernd.

17. A. Heumekers, 'Een granieten voorvechter van tolerantie en gewetensvrijheid', de Volkskrant (Folio) 23 december 1989.

18. Coornhert zou hooguit via contacten met de Amsterdamse dichter Hendrick Laurensz. Spiegel diens broer Jan Laurensz.

Spiegel, die in het Amsterdamse stadsbestuur zat, kunnen hebben beïnvloed. Zie: A-J. Gelderblom e.a., a.w., bl. 36-39.

19. P. Spierenburg, The Prison Experience, a.w., bl 51, 55 en 56. Over de navolging van het Hollandse voorbeeld in de Duitse staten in de $17 \mathrm{e}$ ceuw: E. Schmidr, Zuchthäuser und Gefängnisse, Göttingen 1960, bl. 7. In zuidelijk Europa kwam de gevangenisstraf ongeveer een ecuw later in zwang. Zic hierover: $A$. Laingui, 'Aspects historique de la procédure pénale', Revue Internationale de droit pénal', 61 e jrg., 3e/4e kwartaal 1990, bl. 378-379. 20. P. Spierenburg, The prison experience, a.w., bl. 48 en 49 .

21. J.Th. Sellin, Slavery and the penal system, New York/Oxford/Amsterdam 1976, bl. 81 en 82 .

22. A. Hallema, Geschiedenis van het gevangeniswezen, hoofdzakelijk, in Nederland', 's-Gravenhage 1958, bl. 146.

23. P. Spierenburg, The Prison Experience, a. wo., bl. 7: 'Hallema's investigations of Dutch prisons are highly unreliable and historians should disregard them'.

24. P. Spierenburg, The prison experience, a.w., bl. 105-134. 
25. P. Spicrenburg, The prison experience, a.w., bl. 125-129.

26. A. Hallema, "De gevangenisarbeid in concurrentie met het particuliere bedrijfsleven en de strijd om het Amsterdamse ruchthuismonopolie ten tijde van de Republiek', Economisch Historisch Jaarboek, deel 19, 1935, bl. 114-201.

27. P. Spierenburg, The prison experience, a.w., bl. 92-98.

28. A. Hallema, Geschiedenis van het gevangeniswezen, a.w., bl. 150 en 158.

29. J. Howard, The state of the prisons, waarvan in 1777 de eerste en in 1780 en 1784 de tweede en derde druk verschenen, telkens bijgewerkt met de resultaten van zijn jongste reizen. Hier is gebruik gemaakt van een heruitgave door Everyman's Library, Londen/New York 1929, bl. 46-61.

30. J. Howard, The state of the prisons, a.w., bl. 38,39 en $46-61$.

31. A. Zysberg, 'Les galères de France de 1660 à 1748: une institution pénitentiaire sous l'Ancien Régime', in J.G. Petit La prison, le bagne et l'histoire, Genève 1984, bl. 70 en 71. Zie ook: A. Zysberg, 'Le temps de galères (1481-1748)', in J.G. Petit e.a., Histoire des galères, bagnes et prisons; XIIIe-XXe siècles, Toulouse 1991, bl. 79-106.

32. J.Th. Sellin, Slavery and the penal system, a.w., bl. 46 en 48. en 52-54.

33. A. Zysberg, a.v., bl. 74-76.

34. J.Th. Sellin, a.w., bl. 52-54.

35. G. Rusche en O. Kirchheimer, Punishmene and social sinucture, New York 1968, bl. 53 en 54 (cerste editie, New York 1939).

36. A. Hallerna, 'Vlaardingen en Dordrecht als oudste Nederlandse galeiendepôts', Tijdschrift voor Geschiedenis 1953 , nr. 66, bl. 7591.

37. A. Hallema, 'Toepassing van de galeistraf in de Nederlanden gedurende de $15 \mathrm{e}$ en 16e eeuw', Tijdschrift voor Strafrecht (LX) 1951 , bl. 129 en 138.

38. E.H. Sutherland en D.R. Cressey, Principles of criminology, 6e druk, Chicago/PhiladelphiarNew York 1960, bl. 269.

39. Volgens Pike werden Spaanse veroordeelden wel naar strafinrichtingen in NoordAfrika overgebracht, maar heeft de transportstraf in Spanje nooit zo'n grote rol gespeeld als in Engeland en Frankrijk; R. Pike, Penal servitude in early modern Spain, Wisconsin 1983, bl. $47,48,141$ en 142.

40. R. Hughes, The fatal shore; the epic of Ausiralia's founding, New York 1987, bl. 4044. Zie ook J. Howard, The state of the prisons, a.w., bl. 252 e.v. Hulks on the Thames.

41. R. Hughes, a. w., bl. 57-71, 269-284 en 569-580.

42. R. Hughes, a.w., bl. 572 en 578 .

43. P.F. Aschrott, Strafensystem und

Gefängniswesen in England, Berlïn en Leipzig, 1887, facsinile-druk, Frankfurt/M. 1978, bl. 46.

44. D. Smith, The demise of transportation: mid-Victorian penal policy, Criminal fustice History 1982, Vol. III, bl. 46.

45. M. Ignatieff, $A$ just measure of pain; the penitentiary in the industrial revolution, 17501850, Londen en Basingstoke 1978, bl. 200 en 201.

46. M. Pierre, 'La transportation (18481938)', in J.G. Petit e.a., a.w., bl. 231-259. 47. P. Spierenburg, Fudicial violence in the Dutch Republic, Ansterdam 1978, b]. 186.

48. R. Rijksen, Achter slot en grendel, 2e herziene druk, Alphen aan den Rijn 1972, bl. 16.

49. Koninklijk Besluit van den. 26sten Mei $1818, \mathrm{nr} .7$, 'houdende grondslagen door den Minister van Justirie in acht te nemen, bij eene nadere en bepaalde voordracht tot het invoeren van een meer eenparig stelsel voor de dienst der gevangenissen, zoowel ten opzichie der verpleging als van den arbeid der gevangenen, art. 6 , in J.J. De Jongh, Verzameling van wetten, decreten, besluiten, reglementen, instructiën en bepalingen, betrekkelijk het gevangeniswezen in de Nederlanden, deel I (1791-1844), Lceuwarden 1846, nr. 62 bis. De Jonghs 'Verzarneling' is voortgezet, in deel II (1845-1859), Leeuwarder 1860, deel III (1860-1874) en deel IV (1875-1889) (geen plaats en jaar van uitgave vermeld).

Deze bron wordt verder geciteerd als: De Jongh, a. w., deel (..), nr. (...).

50. H.J. Smidr, Geschiedenis van het Wetboek van Strafrecht, tweede druk, Haarlem, eerste deel, Haarlem 1891, bl. 161-164. In een anonieme brochure getiteld Nieuwe berigten ontrent het Pennsylvanische gevangenis- 
stelsel en gedachten over lïfstraffen, deportatie en gevangenisstraffen, die in 1844 te Groningen is uitgegeven, wordt op de bl. 40 en 41 aan deportatie een generaal-preventief effect toegeschreven: 'De verwijdering der meest volleerde en ergste boosdoeners van hen, die niet meer in de maatschappij willen of kunnen terug keeren, zal het aankweeken van nieuwe leerlingen in het vak nog beter keeren, dan de maatschappij tot zedelijke verbetering'.

51. A.M.C. Bruinink-Darlang, Het penitentiair stelsel in Nederlands-Indie van 1905 tot 1940, Alblasserdam 1986, bl. 22 en 23 . Over de rewerkstelling in de tịd vóór de wet van 1873، zie R.J. Brunner, 'Het Gevangeniswezen te Batavia tijdens de Oost-Indische Compagnie', Tijdschrift voor Strafrecht (XLII) 1932, vooral bl. 47-52 en 70-77.

52. J. Bireman, Koelies, planters en koloniale politiek, Dordrech//Providence 1987, bl. 22-

33. Zie ook zijn artikel in de Volkskrant van

28 februari 1987: 'De verborgen terreur in de Buitengewesten'.

Van Hamel is vooral bekend als een der grondleggers van de zgn. Nieuwe Richting in de Nederlandse strafrechtswetenschap. Fijnaut citeert van hem o.m. de volgende uitspraak: 'Zij (de klassiek-juridische richting; gdj) blijft de kampioen der individuele vrijheid tegenover misbruik van overheidsgezag al heet het justitie', in C. Fijnaut, Verleden, heden en toekomst van de geintegreerde strafrechtswetenschap, Arnhem/Antwerpen 1986, bl. $14 \mathrm{en} 15$.

53. A.M.C. Bruinink-Darlang, a.w., bl. 76, 78,87 en 101.

54. A.J. van Deinse, De algemene beginselen van strafregt, ontwikkeld en in verband beschouwd met de algemeene, bepalingen der Nederlardsche strafwetgeving, tweede druk, Middelburg 1860, bl. 43 en 51 .

55. Volgens Spierenburg beschikte het Amsterdamse Rasphuis van meet af aan over een aantal tuchtrechtelijke bepalingen, in 1595 door Sebastiaan Egberts ontworpen, in $\mathrm{P}$. Spierenburg, The prison experience, a.w., bl. 49 en 50.

56. A. Hallema, Geschiedenis van het gevangeniswezen, hoofdzakelijk in Nederland, a.w., bl. 190.

57. W.C. van Binsbergen, Poenaal panora- ma, Zwolle 1986, bl 130 en 131. Zie ook: H.A. Diederiks, S. Faber en A.H. Huussen jr., Strafrecht en criminaliteit (Cahiers voor lokale en regionale geschiedenis), Zutphen 1988, bi. 25 .

58. Besluit van den souvereinen vorst van den IIden. December 1813, nr. I, waarbij de Galei-straf wordt opgeheven, en houdende bepalingen ten aanzien der lijfstraffelijke Regtsoefening, in de Verenigde Nederlanden, in De Jongh, $a . w$, deel $\mathrm{I}, \mathrm{nr} .20$.

59. A. Hallema, Geschiedenis van het gevangeniswezen, $\alpha$.w., bl. 209 .

60. Extract van het besluit van Zijne Koninklijke Hoogheid van (datum ontbreekt) December 1813, bepalingen bevattende zoo wegens voordragten het Justitiewezen betreffende; als ten aanzien van het doen eener Propositie omtrent de Gevangenissen. De Jongh, deel I, nr. 19. Zie ook A. Hallema, 'Het gevangeniswezen in het verenigd Koninkrijk der Nederlanden tijdens de regering van Koning Willem I', Tïdschrift voor Strafrecht (XL) 1930, bl. 260.

61. Circulaire van de minister van Justitie van den 30sten Januarij 1816, nr. 325, houdende opgave van enige punten, welke aan de overweging der Collegiën van Regenten onderworpen worden, om, betrekkelijk het gevangeniswezen, een vast en doelmatig stelsel te kunnen aannemen, in De Jongh, a. w., deel I, nr. 50 .

62. Circulaire van den minister van justitie van den 25 sten Julij 1818, nr. 401, mededelende eenige door Z.M. aangewezene punten van bezuiniging in het Gevangenisstelsel, in De Jongh, $a . w$, deel I, nr. 63.

63. Koninklijk besluit van den 12 den December $1820, \mathrm{nr}$. 97. houdende benoeming eener Commissie van inspectic voor de Tuchthuizen des Rijks en voorsehriften omtrent derzelver verrigtingen, in De Jongh, a. w., deel I, nr. 77.

64. Koninklijk besluit van den 4 deri. November 1821, nr. 16, houdende Organisatie der Gevangenissen, benevens vaststelling en invoering van eenen staat, betrekkelijk de voeding, kleeding-en liggingstukken der gevangenen (...), in De Jongh, a.w., deel $\mathrm{I}, \mathrm{nr}$. 84. 
65. Koninklijk besluit van den 21 sten. October 1822, nr. 46, arresterende het Reglement omtrent den arbeid, in de gevangenhuizen te verrichten, in De Jongh, $a . w$, deel $\mathrm{I}$, nr. 89.

66. Missive van den staatsraad, administrateur voor het armwezen en de gevangenissen, van de 22 sten. December 1824 , nr. 49 , houdende voorschriften omtrent de keuze en de regeling van het loon der tot de huisdienst en den overigen arbeid gebezigd wordende gevangenen, in De Jongh, $a, w$, deel I, nr. 166. 67. In 1826, 1828, 1842 en 1849. Zie De Jongh, a.w., deel I, nr. 251, 325, 443 en deel II, nr. 553.

68. Circulaire van den minister van Justitie, van den 10den. Junij 1854, nr. 83/34b, houdende verbod tot het vergen door beambten in de Gevangenissen van persoonlijke diensten van gevangenen, in De Jongh, $a$.w., deel II, nr. 661 .

69. Koninklijk besluit van den 11 den. Februarij 1823, nr. 101, houdende voorloopige goedkeuring van het Reglement voor de dienst der Kantines, welke bij art. 46 van het Besluit van den 4 den. November $1821, \mathrm{nr}$. 16 , zijn ingesteld, in De Jongh, a.w., deel I, nr. 101.

70. Koninklijk Besluit van den 23sten. Mei 1861, nr. 47, in De Jongh, $a . w$. , Deel III, nr. 50.

71. Missive van den administrateur voor het armwezen, voorlopig belast met De administratic der gevangenissen, van den 25 sten. Junij 1828, nr. 12, houdende verschillende beschouwingen tot het in stand houden der pistoles of vrije kamers in de Gevangenissen, in De Jongh, $a$. w. , deel $\mathrm{I}, \mathrm{nr} .309$.

72. Weekblad van het Regt 1 November 1839 , nr. 53 en 16 December 1839 , nr. 61. 73. Wet van den 29 sten. Junij 1854, houdende eenige veranderingen in de straffen op misdrijven gesteld, in De Jongh, a.w., Deel I, nr. 664 .

74. Weekblad van het Regt 11 November 1850 , nr. 1172 , bl. 1 en 2.

75. Wet van den 28 sten. Junij 1851, tot invoering van het stelsel van eenzame opsluiting, ten aanzien van enkele op te leggen straflen, in De Jongh, a.w., deel II, nr. 585.
76. Zie H. Franke, Twee eeuwen gevangen: misdaad en straf in Nederland, Utrecht 1990, bl. 232 .

77. P.W. Alstorphius Grevelink, Bedenkingen tegen het ontwerp van wet ter vernicuwde. uitbreidùng der celstraf, 's-Gravenhage 1874, bl. 8-11.

78. 'Voorschriften nopens den arbeid in een huis van arrest', 27 Julij 1860, nr. 117, in De Jongh, a.w., deel III, nr. 21 .

79. Circulaire van 12 November 1839 , nr. 148 , omtrent het verschaffen van arbeid aan de gevangenen in huizen van Burgerlijke en Militaire Verzekering en van Arrest, in De Jongh, a.w., deel I, nr. 417.

80. A.E.J. Modderman, Straf-geen kwaad, Arnsterdam 1864, bl. 41-42.

81. R. Berends, A.H. Huussen jr., R. Mens en $\mathrm{R}$. de Windt, Arbeid ter disciplinering en bestraffing; Veenhuizen als onurije kolonie van de Maatschappij van Weldadigheid 1823-1859, Zutphen 1984, wooral de bijdragen van De Windt en Mens.

82. P.C. van Duyne, 'Landlopers in het nicuwe Wetboek van Strafrecht', Tijdschrifi voor Criminologie 1987, nummer 4, bl. 80 en 90.

83. T.J. Noyon, G.E. Langemeijer en J. Remmelink, Het wetboek van strafrecht, losbladig, 7e druk, commentaar op art. $32 \mathrm{Sr}$, suppl. 64 , onder punt 8 .

84. Het Nederlandse gevangeniswezen; nota over het Nederlandse gevangeniswezen aangeboden door de minister van Justitie aan de Tweede Kamer der Staten-Generaal, (verder naar de veranıwoordelijke minister, Y. Scholten, de nota-Scholten te noemen), Tweede Kamer, 1963-1964, 7709, nr. 2, bl. 23.

85. Afschaffing van de bijkomende straf ran plaatsing in een rijkswerkinrichting $\mathrm{en}$ in verband daarmee vervallenverklaring van enige bepalingen in het Wetboek van Strafrecht benevens wijziging van artikel $250 \mathrm{bis}$ van het Wetbock van Straffecht, Brief van de minister van Justitie houdende intrekking van het wetsvourstel aan de Voorzitter van de Eerste Kamer der Staten-Generaal van 16 november 1993, Eerste Kamer, 1993-1994, 18202 , nr. 127.

86. Eerste Kaner, 12 okrober 1993, 3-155 en 3-156. 
87. Circulaire van de minister en de staatssecretaris van Justitie van 15 november 1993, 40256 i/93 DJ - experiment met een jeugdwerkinrichting.

88. H.J. Smidt, Geschiedenis van het Wetboek van Strafrecht, tweede druk, eerste deel, a. w., bl. 262, 314 en 315 .

89. H.J. Smidt en E.A. Smidt, Geschiedenis van het Wetboek van Strafrecht, vierde deel, Haarlem 1900, bl. 407-422.

90. Missive: van de minister van Justitie van 24 december 1892, in De Jongh, a. w., deel $\mathrm{V}, \mathrm{nr} .775$.

91. A. de Jong, Domela Nieuwenhuis, Den Haag 1972, bl. 18-22 en flaptekst.

92. Tweede Kamer, 1888-1889, Handelingen I-183, Vaststelling der Staatsbegroting voor het dienstjaar 1889. (Algemeene beraadslaging over hoofdstuk IV), bl. $536 \mathrm{en}$ 552. In de Handelingen wordt de naam van de minister als Ruys van Beerenbroek gespeld. De verfransing 'Ruys de Beerenbrouck' is echter bekender.

93. Missive van 7 december 1827 , nr. 26, betrekkelijk de fabrieksprijzen, in De Jongh, a.w., Deel I, nr. 284.

94. Missive van 7 april 1846, nr. 73, houdende kennisgeving, dat het Departement van Marine heeft bewilligd, om bij invoering van katoenen stoffen, ter vervanging van wit gebleekt linnen, de nog bij dat Departement in gebruik blijvende linnensoorten aan de Administratie over den Arbeid der Gevangenissen op te dragen, in De Jongh, a.w., deel II, nr. 488.

95. M. Adang, Gevangenisbouw in Nederland, de zin van de straf en de hoogte, van de

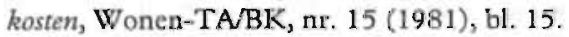
96. M.H. de Bonvoust Beeckman, Arbeid van gevangenen en vrije arbeid, Amsterdam $1892,70 \mathrm{bl}$.

97. M.H. de Bonvoust Beeckman, a.w., bl. 48.

98. Verslag van de commissie van onderzoek inzake de afbreuk, door den arbeid in gevangenissen, rijkswerkinrichtingen en rijksopvoedingsgestichten aan den arbeid in de vrije maatschappij gedaan, Den Haag 1897, $281 \mathrm{bl}$.

Voorzitter van de commissie was kamerlid A. Kerdijk; secretaris was de latere hoogleraar strafrecht Simon van der Aa.
99. Verslag van de commissie van onderzoek naar den gevangenisarbeid, 's-Gravenhage 1931, bl. 64 .

100. F. von Liszt, Die Gefüngnisarbeit; Vortrag, gehalten am 26. Juli 1900, Berlijn 1900, $20 \mathrm{bl}$.

101. J.S. van $\operatorname{der} A a$, De arbeid als element van de vrijheidsstraf, Groningen 1906, 36 bl. Zie met name bl. 14 en 28.

102. E.C. Verschoor, 'Over gevangenisarbeid en reclassering', Tijdschrift voor Strafrecht (XXVI) I 1916, bl. 274-275.

103. J.F. Beyerink, Ontstaan en ontwikkeling van den arbeid in Nederl. Strafgestichten (zonder plaats, zonder jaartal maar vermoedelijk 1939), $35 \mathrm{bl}$.

104. J.W. Eggink, De geschiedenis van het $\mathrm{Ne}$ derlandse gevangeniswezen, Assen, bl. 215.

105. L. de Jong, Het Koninkrijk der Nederlanden in de Tweede Wereldoorlog, deel 8, 'Gevangenen en gedeporteerden', eerste helft, 'sGravenhage 1978, bl. 83-121.

106. F. Dekkers, Eindhoven 1933-1945. Kroniek van Nederlands Lichtstad in de schaduw van het Derde Rijk, Haarlem 1982, bl. 214. 107. L. de Jong, a.w., bl. 637-643 en bl. 668-671.

108. A. Teulings, Philips; geschiedenis en praktijk van een wereldconcern, Amsterdam 1977 , bl. 114.

109. P. Romijn, Snel, streng en rechtvaardig; politiek beleid inzake de bestraffing en reclassering van 'foute' Nederlanders, 1945-1955, (uitgever De Haan, geen plaats vermeld) 1989, bl. 164,212 en 214.

110. J.W. Eggink, a.w. , bl. 215.

111. Tweede Kamer, 1947-1948, nr. 631, bl. 9 .

112. Tweede Kamer, 1945-1946, nr. 212, bl. 6-7.

113. Tweede Kamer, 1947-1948, nr. 631, bl. 9 en 10.

114. H. Strabbing, 'En de peukjes worden alweer weggegooid', in de Volkskrant 23 januari 1988, Het Vervolg, bl. 3. Het betrof een groep van 119 politieke delinquenten, die op 29 mei 1947 scheep ging, een jaar later door twee kleinere groepen gevolgd.

115. Rapport van de commissie voor de verdere uitbouw van het gevangeniswezen (commissie-Fick) 's-Gravenhage 1947. 
116. Rapport van de commissie-Fick, a.w., bl. 7 .

117. Rapport van de commissic-Fick, a.v., bl. 71-79.

118. De Eerste Wereldoorlog had in Nederland een zodanige stijging van het aantal gedetineerden tot gevolg gehad, dat in de praktijk niet aan het cellulaire stelsel viel vast te houden. Dit leidde tot een 'noodwet', de 'Wet, tot vaststelling in de tegenwoordige buitengewone omstandigheden van bepalingen ter verkrijging van meer plaatsruimte. voor de tenuitvoerlegging van gevangenisstraf, militaire gevangenisstraf daaronder begrepen, van hechtenis, van militaire detentie en vañ voorlopige hechtenis' van 22 november $1918_{3}$, S nr. 607 . Art. 1 van die wet luidde: 'Iedere gevangenisstraf, militaire gevangenisstraf daaronder begrepen, kan in gemeenschap worden ondergaan'.

119. Tweede Kamer, 1948-1949, 1189 , Vaststelling van cen nieuwe Beginselenwet gevangeniswezen en daarmede verband houdende wijzigingen van het Wetboek van Strafrecht en het Werboek van Strafvordering, Memoric van Toelichting, nr. 3, bl. 2. 120. Tweede Kanner, Bijl. Hand. II 1950 1951,1189 , bl. 26.

121. Tweede Kamer, Bijl. Hand II, 1948$1949,1189, \mathrm{MvT}$, nr. 3, bl. 12 en 13.

122. Het Nederlandse gevangeniswezen in de jaren 1945 tot en mer 1953, 's-Gravenhage 1954, bl. $80-87$.

123. De Nederlandse gevangenissen en haar noodzakelijke verbeteringen; een rapport van de commissie bouwkundige voorzieningen van het gevangeniswezen (naar haar voorzitter de commissic-'s Jacob genoemd; gdj), 'sGravenhage 1958, bl. 25, 62 en 63 .

124. Nota-Scholten, a.rw. .

125: Nota-Scholten, a.w., bl. 7-9 en 36-38.

126. Nota beleidsvraagstukken gevangeniswezen, Tweede kamer, 1976-1977, 14 102, nrs. 1-2, bl. 6, 43 en 44 .

127. Rapport commissie doelstelling en functie huis van bewaring, 's-Gravenhage 197'7, b!. 60-63 en 126.

128. Tweede Kamer, 1980-1981, 16556 , nr. 1, Doelstelling en functic huis van bewaring; brief van de staatssecretaris van Justitie van 19 december 1980 , bl. 15 .

129. Heroverweging collectieve uitgaven
(Rijksbegroting) Deelrapport 38; heroverweging strafrechttoepassing, Tweede Kamer, 1981-1982, 16.625 , nr. 47 bi. 39 en 40 . 130. Taak en Toekomst van het Nederlandse gevangeniswezen, nota op 2 september 1982 door de staatssecretaris van Justitie aangeboden aan de Tweede Kamer der Staten-Generaal, Tweede Kamer, 1981-1982, 17 539, nrs. 1-2, bl. 37-4i. De grote invloed van deze nota op het penitentaire debat blijkt o.m. uit het feit dat Tulkens haar in 1991 nog gebruikt als basis voor een opstel over de toekomst van het gevangeniswezen. Zie J.J.J. Tulkens, Vanuit het oogpunt van de gevangene, in: Th.W. van Veen en G. van Essen, Sanctietoepassing - een nieuwe ordening; opstellen aangeboden aan Dr. G.H. Veringa, Arnhem 1991, bl. 81-100.

131. Handelingen Tweede Kamer, 19501951, bl. 2149.

132. Voorontwerp Penitentiaire Beginselenwet. Voorontwerp van wet tot vaststelling van een Penitentiaire Beginselenwer en daarmee verband houdende intrekking van de Beginselenwer gevangeniswezen en wijziging van het Wetboek van Strafrecht en het Wetboek van Strafvordering. Wettekst en Memorie van Toelichting, Den Haag juli 1993.

133. Voorontwerp Penitentiaire Beginselenwet, a.w., Memorie van Toelichting bl. $72 \mathrm{cn}$ 73.

134. Werkzame detentie; beleidsnota voor het gevangeniswezen, Tweede Kamer, 19931994, 22 999, nrs. 10-11. De belangrijkste elementen van deze beleidsnota zijn terug te vinden in de (vertrouwelijke) gespreksnotitie Sturen op Kwaliteit van de departementele ambtenaren L. Filting en A. Rook, 's-Gravenhage januari 1993.

135. J. Wanders, 'Arbeid adelt straks ook voor gedetineerden', de Volkskrant $10 \mathrm{sep}$ tember 1993. Zie ook W. Baardemans, 'Veel allochtonen moeten na detentie toch het land verlaten'; openbaar debat gevangeniswezen, in Vrijspraak oktober 1993, 7e jrg., bl. 10-12. 136. De nota splitst het tijdsbeslag van de diverse activiteiten uit over een dag van. 07.30 tot 21.00 uur, waardoor er in termen van de nota zelf relatief minder uren op cel tijken te moeten worden doorgebracht.

137. C. Kelk, 'Hoe werkzaam is de nota 'Werkzame detentie'?', Trema, 1994, no. 8, bl. 304. 


\section{Hoofdstuk II}

\section{De arbeidsrechtelijke positie van de gedetineerde}

Als gevolg van het toenemen van de gemiddelde strafduur en de daarmee gepaard gaande uitbreiding van de gevangeniscapaciteit zal het ministerie van fustitie tegen het einde van dit millennium permanent over zo'n 12.000 goedkope, onmondige en ongeorganiseerde arbeidskrachten kunnen beschikken. Van dit aantal is bijna de helft wettelijke verplicht te werken en zal de rest daartoe besluiten om niet de hele dag 'achter de deur' te moeten doorbrengen.

Voor ondernemers die overwegen hun productie naar een van de lage-lonen landen over te hevelen wordt uitbesteding van arbeid aan een zich commercialiserend gevangeniswezen een serieus alternatief. Tenminste, zolang het strafrechtelijke klimaat blijft zoals het is en de rechtspositie en de beloning van de werkende gedetineerde blijven zoals ze nu zijn: verre inferieur aan die van de vrije arbeider.

In dit hoofdstuk wordt nagegaan wat de belangrijkste elementen zijn van de arbeidsverhouding tussen de gedetineerde en zijn werkgever, het ministerie van fustitie. Daarbij wordt onderzocht in hoeverre zijn positie overeenkomt met of-wat eerder te verwachten is - verschilt met die van werknemers die onder het regime van het burgerlijk arbeidsrecht vallen. Fuist een vergelijking met het burgerlijk recht is van belang omdat de bepalingen van de Beginselenwet Gevangeniswezen en van de Gevangenismaatregel 'het vrije bedrijf' als referentiekader gebruiken.

De conclusie is dat er weliswaar sprake is van een primitief soort penitentiair arbeidsrecht maar dat de inhoud daarvan volledig wordt gedicteerd door de monopolistische werkgever: de minister van fustitie. Vooralsnog valt deze bedrijfstak buiten het gezichtsveld van de vakbonden, maar als de gevangenisindustrie serieus doorzet kan worden verwacht dat de werknemers-organisaties zich met deze kwestie zullen gaan bemoeien. 
De: penitentiaire rechter doet regelmatig uitspraken in arbeidsrechtelijke geschillen tussen directies van strafinrichtingen en gedetineerden. Daarbij laat hij zich niet veel gelegen liggen aan de beginselen van het burgerlijk arbeidsrecht. Hij weigert namelijk categorisch om gedetineerden als werknemers te beschouwen. Dat blijkt uit een tweetal beslissingen over beroepen van veroordeelden die hadden geklaagd over disciplinaire straffen die ze hadden opgelopen omdat zij aan een stakingsactie hadden meegedaan. Bij die gelegenheid heeft de Beroepscommissie van de sectie gevangeniswezen van de Centrale Raad voor Strafrechtstoepassing uitgemaakt dat zij het stakingsrecht ontberen. ${ }^{1}$ Dat vloeit volgens de Beroepscommissie eensdeels voort uit artikel 32 lid 1 Beginselenwet Gevangeniswezen, op grond waarvan veroordeelden verplicht zijn de hun opgedragen arbeid te verrichten en anderdeels uit artikel 28 Gevangenismaatregel dat zegt dat de gedetineerden te allen tijde verplicht zijn de bevelen op te volgen 'hun door of namens de directeur gegeven'. Daarom kan volgens de Beroepscommissie tussen die partijen niet gesproken worden van een werkgever-werknemer verhouding. Slechts in dié verhouding wordt volgens de Beroepscommissie in artikel 6, deel II van het Europees Sociaal Handvest het recht op collectief optreden, waaronder het stakingsrecht, aan de betrokkenen toegekend.

Het noet er op grond van de in beide uitspraken opgenomen formulering ' $\mathrm{Nu}$ derhalve aan gedetineerden het stakingsrecht niet toekomt (...)' voor worden gehouden dat de Beroepscommissie niet alleen veroordeelden het werknemerschap in de zin van het Europees Sociaal Handvest ontzegt, maar dat dit voor alle categoriee̊n gedetineerden geldt. Volgens de definitie van artikel 1 Beginselenwet Gevangeniswezen zijn dat: 'de personen, ingesloten in de huizen van bewaring, gevangenissen, rijkswerkinrichtingen en justitiële inrichtingen voor verpleging van ter beschikking gestelden'.

In een noot bij de eerste van beide zojuist genoemde uitspraken geeft Kelk de Beroepscommissie toe dat er binnen de muren geen sprake is van een zuivere, door het burgerlijk recht geregeerde, rechtsverhouding. Er is volgens hem echter evenmin sprake van 'pur sang dwangarbeid' maar van een vorm van dwangarbeid die bepaalde aspecten gemeen heeft met de arbeidssituatie in de vrije samenleving, zoals vaste, normale werktijden, arbeidsloon, vrije dagen etcetera. Verder meent Kelk dat bezwaarlijk kan worden beweerd dat gedetineerden ambtenaren zijn, hoewel zij met dezen gemeen hebben dat zij zich in een bijzondere gezagsverhouding tot de overheid bevinden.

Kelks veronderstelling vindt steun in een uitspraak van de Hoge Raad in een procedure tegen een verdachte die tijdens de Tweede Wereldoorlog als gevangene van de Duitsers als Kapo ${ }^{2}$ of Oberkapo had gewerkt. Hem was ten laste gelegd dat hij 'als ambtenaar' in de zin van artikel 21 Besluit Buitengewoon Strafrecht, namelijk als 'kapo en/of later oberkapo', een aantal strafbare feiten had begaan. De Bijzondere Strafkamer van de rechtbank te 's-Gravenhage had de verdachte vrijgesproken, overwegende dat hij geen aanstelling in staats- of publiekrechtelij- 
ke dienst had gehad. Wel kon, voigens de rechtbank, worden gezegd dat hij zekere diensten verrichr had, maar het in staats- of publieke dienst zijn bij de vijand veronderstelde naar het oordeel van de rechtbank een zekere mate van vrijwilligheid en vrije keuze. De Hoge Raad liet deze overweging en de vrijspraak intact. ${ }^{3}$ In zijn noot bij het desbetreffende arrest zei Van Veen dat het niet aannemelijk was dat bij het formuleren van het begrip 'in krijgs-, staats- of publieke dienst van de vijand' in het Besluit Buitengewoon Strafrecht gedacht was aan de gevangene die in een gevangenis tot werkzaamheden wordt verleid of geprest, maar gevangene blijft.

Hoewel de gedetineerde, wat de inrichtingsarbeid betreft noch de hoedanigheid van werknemer noch die van ambtenaar bezit mag hij volgens Kelk, in diens zoeven genoemde annotatie, echter evenmin als 'slaaf van de staat' worden gezien. Deze term heeft Kelk waarschijnlijk ontleend aan een in de Amerikaanse penitentiair-rechtelijke litteratuur nogal eens geciteerde uitspraak uit 1871 van een rechtbank in Virginia waarin onomwonden werd vastgesteld dat een gedetineerde een slaaf van de staat was: als gevolg van het door hem begane delikt had hij niet alleen zijn vrijheid verspeeld, maar ook al zijn subjectieve rechten. ${ }^{4}$

In Nederland worden gedetineerden door het enkele feit van hun vrijheidsbeneming niet automatisch van al hun burgerlijke rechten en vrijheden beroofd. $\mathrm{Zij}$ blijven in tal van opzichten autonome rechtssubjecten. Behalve waar het gaat om hun arbeidsrechtelijke positie: op dat terrein zijn zij, zeker als veroordeelden, volslagen afhankelijk van Justitie en kunnen zij in zoverre wel degelijk als 'slaven van de staat' beschouwd worden.

Men kan het probleem van de juridische benoeming van de arbeidsrechtelijke rechtspositie van gedetineerden gemakkelijk oplossen door - zoals Ohle - de rechtsbetrekking tussen hen en Justitie als een sui generis verhouding te definiëren. ${ }^{5}$

Een andere mogelijke benadering is om net als Depenbrock ${ }^{6}$ de arbeidsverhouding tussen gedetineerden en de staat niet als een zelfstandige juridische relatie op te vatten maar die slechts als bestanddeel van de strafexecutie als 'allesomvattende rechtsverhouding' te beschouwen. Het heeft volgens laatstgenoemde auteur geen zin om onderscheid te maken tussen privaat- en publiekrechtelijke elementen in die arbeidsverhouding. Zou men dat wel proberen, dan raakt men volgens hem verstrikt in tal van onoplosbare conflicten tussen particulier en openbaar belang, bijvoorbeeld bij het vaststellen van arbeidstijden, het toedelen van werkruimte en dergelijke.

Het is echter de vraag of de arbeidsverhouding tussen gedetineerden toch niet anders te omschrijven valt dan als een sui generis-rechtsbetrekking of als een juridisch niet nader te definiëren onderdeel van de strafexecutie. Daartoe wordt in het onderstaande een poging ondernomen. Het is daarbij noodzakelijk om een onderscheid te maken tussen onveroordeelde en veroordeelde gedetineerden omdat alleen ten aanzien van de laatste categorie een arbeidsplicht geldt en dàt verschil werkt door in tal van onderdelen van de arbeidsrelatie van gedetineerden met Justitie. 


\subsection{Onveroordeelden en veroordeelden}

Omdat onveroordeelden volgens artikel 32 lid 2, eerste voizin, van de Beginselenwet Gevangeniswezen (BWG), niet tot arbeid verplicht zijn, zijn zij formeel vrij om al of niet een arbeidsverhouding met de directie van de inrichting aan te gaan. Hun keus is op zijn zachtst gezegd beperkt. Niet werken betekent dat zij in de voor de arbeid bestemde tijd op cel moeten verblijven en niets verdienen, zodat zij bijwoorbeeld geen kantine-artikelen kunnen kopen. Als zij wèl willen werken is er (hoewel het niet verboden is om voor eigen rekening of voor derden te werken) de facto toch maar één werkgever: de directeur van de inrichting.

Men kan stellen dat àls onveroordeelen zich voor de gestichtsarbeid opgeven en hun dat wordt verschaft er naar civielrechtelijke maatstaven een arbeidsovereenkomst ontstaat. Er is immers sprake van een tweezijdige rechtshandeling, er wordt werk verricht en er wordt een loon (hoe laag ook) betaald. Men kan daaraan tegenwerpen dat de onveroordeelde weliswaar vrij is om zich al of niet voor de arbeid aan te bieden, maar dat de directeur niet de bevoegdheid heeft zo'n aanbod af te slaan. Artikel 32 lid 2, tweede volzin BWG lijkt de directeur de verplichting op te leggen werkwillige onveroordeelden arbeid te verschaffen: 'Indien zij verklaard hebben aan de verplichte arbeid te willen deelnemen, worden zij te dien aanzien op gelijke voet als de veroordeelden behandeld'. Zo'n 'recht op tewerkstelling' wordt herhaald in artikel 2 lid 1 van hoofdstuk III van het (standaard) Huishoudelijk Reglement Huizen van Bewaring (HHR-HvB) dat luidt: 'Onveroordeelden zijn niet tot arbeid verplicht. Zij kunnen echter aan de arbeid deelnemen, wanneer zij de wens daartoe te kennen geven'. Als de directeur verplicht zou zijn om iedere onveroordeelde die om werk vraagt aan te nemen zou aan een essentiële voorwaarde voor de civielrechtelijke arbeidsovereenkomst, de contractsvrijheid aan beide kanten, niet zijn voldaan. In werkelijkheid heeft de directeur wel enige vrijheid om een aanbod van een onveroordeelde af te slaan. Zo hoeft hij aanvragen van onveroordeelden aan wie het werk eerder om disciplinaire redenen of wegens wanprestatie was ontnomen niet meteen weer werk te verschaffen. Ook kan hij onveroordeelden die zich voor de arbeid aanbieden op een wachtlijst plaatsen als er geen (geschikt) werk voor hen is.

Het overeenkomst-karakter van de arbeidsverhouding tussen directies en onveroordeelden wordt benadrukt door de vorm waarin die wordt gegoten. Zo werd in het Amsterdamse huis van bewaring 'Het Schouw' gebruik gemaakt van het volgende schriftelijke (standaard)arbeidscontract, dat door de gedetineerde diende te worden ondertekend: ${ }^{7}$

\section{Arbeidscontract Huis van Bewaring Het Schouw}

Naam:

Reg.nr.: pav.: cel:

Datum inkomst:

Datum plaatsing: afgehandeld door:

Ondergetekende:

Geeft door ondertekening van dit contract te kennen, dat hij aan de gemeenschappelijke arbeid wil deelnemen, waarbij de volgende regels gelden: 
$01 \mathrm{Hij}$ is op de hoogte van het arbeidsreglement.

02 De duur van het contract is voor 14 dagen geldig.

03 Het contract wordt met medeweten van de gedetineerde verlengd.

04 De plaatsing in een andere werksituatie zal betrokken gedetineerde meegedeeld worden.

05 De gedetineerde kan zijn wensen voor eventuele plaatsing in een andere werksituatie kenbaar maken aan zijn werkmeester. Aan de direktie is het voorbehouden om deze wensen in te willigen of niet. In ieder geval zal het contract (periode van 14 dagen) tot het einde toe nagekomen moeten worden.

06 Bij een disciplinaire straf of maatregel van 5 dagen, gehele of gedeeltelijke afzondering of langer, wordt de arbeidsplaats van de betrokken gedetineerde niet opengehouden.

07 Ongeoorloofd afwezig zijn op de arbeid is tijdens de duur van het contract niet: toegestaan. Van het ongeoorloofd afwezig zijn wordt een rapport opgemaakt. Ongeoorloofd afwezig zijn wordt beschouwd als werkweigering.

$08 \mathrm{Bij}$ ziekmelding beslist de med. dienst of betrokken ged. arbeidsongeschikt is of niet. Mocht blijken dat gedetineerde wel arbeidsgeschikt was, dan treedt artikel 7 van dit contract in werking.

09 Tijdens ziekte (arbeidsongeschikt periode), zal de arbeidsplaats van betrokken gedetineerde open blijven.

10 Ten aanzien van alle situaties waarin het arbeidsreglement en het arbeidscontract niet voorzien, zal de directie beslissen.

Datum

Handtekening

Hoewel de voorwaarden in een dergelijk arbeidscontract eenzijdig worden vastgesteld staat het de onveroordeelde vrij om géén contract met de directie te sluiten. Voorts verbiedt de wet hem niet om een arbeidsovereenkomst aan te gaan met een werkgever buiten de inrichting. Er is zeker werk van 'buiten' te bedenken dat in de beperkte ruimte van de eigen cel uit te voeren is. In hoeverre een directeur gehouden is gedetineerden faciliteiten voor het uitvoeren van opdrachten van derden of voor het verrichten van werk voor eigen rekening te verschaffen is overigens niet duidelijk. Als een en ander geen of weinig extra kosten en moeite voor de inrichting met zich mee brengt en dergelijke werkzaamheden niet onverenigbaar zijn met de 'goede orde en tucht' in de inrichting moet het in beginsel mogelijk zijn dat onveroordeelden werkzaamheden verrichten voor eigen rekening of voor opdrachtgevers van buiten de inrichting. Een dergelijk opvatting vindr steun in artikel 3 van Hoofdstuk III van het HHR-HvB, dat luidt: 'Onveroordeelden hebben recht op het verrichten van eigen arbeid of werkzaamheden waarnaar hun voorkeur uitgaat in hun cel, voorzover deze activiteiten naar het redelijk oordeel van de directeur verenigbaar zijn met de goede gang van zaken in de inrichting?. 
Nóg een reden om de arbeidsrechtelijke positie van onveroordeelden te vergelijken met die van vrije arbeiders in het bedrijfsleven is het feit dat het penitentiaire recht in tal van artikelen het 'vrije bedrijf' voor het regiem ais maatstaf neemt. Zo wordt op grond van de artikelen 33 lid 2 BWG en 55 lid 2 Gevangenismaatregel (GM) door Justitie aan opdrachtgevers van buiten de inrichting het voor soortgelijke arbeid in het vrije bedrijf gebruikelijke loon in rekening gebracht, dient de arbeidsduur in de inrichtingen krachtens artikel 37 BWG zoveel mogelijk te worden aangepast aan die welke geldt in het vrije bedrijf en moet er op grond van artikel 50 GM naar worden gestreefd de arbeidsprestaties der gedetineerden gelijk te doen zijn aan die in het vrije bedrijf.

Over de arbeidsrechtelijke status van die gedetineerden die onherroepelijk tot een vrijheidsstraf veroordeeld zijn lijkt nauwelijks misverstand mogelijk. De artikelen 14, 20 jo. 22 van het Wetboek van Strafrecht verplichten hen om tijdens hun detentie te werken en de betrekkelijke internationale regelingen laten dat ook toe. Overigens wordt daar ten onrechte door de Beroepscommissie de conclusie aan verbonden dat de door veroordeelden te verrichten arbeid niet als dwangarbeid moet worden opgevat. ${ }^{8}$ Het betreft echter wel degelijk dwangarbeid, ook in de definitie van de anti-dwangarbeidverdragen van de International Labour Organisation (ILO). Het is een van de weinige in het internationale recht toegesiane vormen van dwangarbeid. Deze uitzondering op het verbod van dwangarbeid berust op de (impliciete) aanname dat arbeid inherent aan de vrijheidsstraf is. Daarbij wordt als tweede axioma aanvaard dat gevangenisarbeid niet of nauwelijks beloond hoeft te worden. Tegen deze 'dubbele inherentieleer' is, zoals uit het navolgende nog zal blijken, een aantal argumenten aan te voeren. Zo kan worden betoogd dat de arbeidsdwang niet zozeer als een natuurlijk sequeel van de vrijheidsstraf, maar als een straf op zich kan worden beschouwd en wel als een vermogensstraf, omdat de staat daarmee - immers op geld waardeerbare - arbeidskracht van de gedetineerde afneemt. Aangezien straffen in ons rechtsbestel uitdrukkelijk op voorafgaande wetsbepalingen moeten zijn gebaseerd en arbeid in geen enkele strafbepaling figureert moet de in artikelen 14,20 jo. $22 \mathrm{Sr}$. neergelegde arbeidsplicht als in strijd met het nulla poena-beginsel worden geacht. Alleen als vrijheidsstraf-vervangende straf is (onbetaalde) arbeid uitdrukkelijk als zodanig in ons sanctie-arsenaal opgenomen ( 9 lid 1 ten $3 \mathrm{e}$ jo. artikel $22 \mathrm{~b}$ e.v. Sr.). Daarbij heeft de wetgever eventuele strijdigheid van deze nieuwe straf met anti-dwangarbeidsbepalingen willen voorkomen door in artikel $22 \mathrm{c} \mathrm{Sr}$. te bepalen dat dienstverlening slechts kan worden opgelegd 'na een daartoe strekkend aanbod van de verdachte'.

\subsection{Het ontstaan van de arbeidsverhouding}

Met enig recht kan worden beweerd dat er door een tweezijdige rechtshandeling tussen onveroordeelden en Justitie (de directeur van de strafinrichting) een arbeidsverhouding ontstaat op de zelfde manier waarop dat in het burgerlijk recht geschiedt. Artikel 7A:1637a BW, luidt: 'De arbeidsovereenkomst is de overeen- 
komst, waarbij eene partij, de arbeider, zich verbindt, in dienst van de andere partij, den werkgever, tegen loon gedurende zekeren tijd arbeid te verrichten'.

Over het eerste bestanddeel van deze definitie, de overeenkomst, is hierboven al gesproken. Een tweede, voor een arbeidsovereenkomst bepalend element is de zinsnede: 'in dienst van de andere partij.' Het gaat hier om het onzelfstandigheidscriterium, dat inhoudt dat de arbeider onder het gezag van zijn wederpartij staat. Daarvan is sprake wanneer die wederpartij krachtens de overeenkomst gerechtigd is aanwijzingen te geven omtrent het verrichten van de arbeid, alsmede ter bevordering van de goede orde in de onderneming (artikel 7A:1639b BW), aldus Bakels."

Het hoeft nauwelijks betoog dat aan het gezagscriterium in de penitentiaire inrichtingen in ruime mate wordt voldaan. Het beheerst álle betrekkingen tussen personeel en gedetineerden en zeker ook de arbeidsrechtelijke.

Een fraaie illustratie van die gezagsverhouding komt uit de pen van Van Zijl. Hij noteerde het volgende gesprek tussen cen gedetineerde die wegens onvoldoende werkprestatie een straf-rapport had opgelopen en de direkteur:

- Je hebt je werk niet af. Hoe komt dat?

- Nee meneer de directeur. Ik...

- Je weet toch dat je hier verplicht bent te werken?

- Ja meneer de directeur, maar...

- Voor morgen dan maar dubbele produktie?

- Ik accepteer het, maar ben het er niet mee ...

- Goed, spreken we dat af. ${ }^{10}$

De gezagsverhouding die de werknemer-werkgever verhouding kenmerkt vinden we in het penitentiaire recht in zijn algemeenheid verwoord in artikel $28 \mathrm{GM}$ : 'De gedetineerden zijn te allen tijde verplicht de bevelen op te volgen hun door of namens de directeur gegeven'. Onder deze absolute bevelsmacht valt ook arbeid die de gedetineerde verricht. Meer specifiek zeggen de artikelen 32 lid I BWG, 49 lid 1 GM en 2 lid 2 HHR-HvB, dat de arbeid 'naar behoren' moet worden verricht, een behoren dat eenzijdig door of vanwege de directie wordt genormeerd.

De onzelfstandigheid van de gedetineerde/arbeider ligt voorts besloten in artikel 6 van het Arbeidsreglement dat luidt: 'De gedetineerde is gehouden de opgedragen arbeid overeenkomstig de hem door of namens het hoofd van de afdeling arbeid gegeven aanwijzingen, waarbij met name acht wordt geslagen op de veiligheidsvoorschriften, naar behoren te verrichten"."

of er loon wordt betaald is een andere factor, die bepalend is voor het antwoord op de vraag of er sprake is van een arbeidsovereenkomst. Ook gedetineerden ontvangen een loon, hoe gering dat ook moge zijn. De artikelen 34 lid 1 BWG en 56 lid 1 GM zeggen immers: 'Door Onze Minister wordt het aan de gedetineerden toe te kennen arbeidsloon vastgesteld'.

Tenslotte is daar dan nog de eis dat de arbeid 'gedurende zekeren tijd' verricht moet worden. Die tijd vangt bij gedetineerden aan op het moment dat zij als on- 
veroordeelde arbeid aanvaarden en als veroordeelde arbeidsplichtig worden en wordt vanzelfsprekend begrensd door het moment waarop zij in vrijheid worden gesteld.

Op grond van het voorgaande kan worden betoogd dat in ieder geval de arbeidsverhouding tussen ónveroordeelden en Justitie: dezelfde bestanddelen bevat die bij civielrechtelijke arbeidsovereenkomsten tor de wezenlijke kenmerken gerekend worden. Op grond daarvan kan men stellen dat deze categorie gecletineerden arbeidsrechtelijk gelijk zou moeten worden gesteld met vrije arbeiders. De directeuren van de strafinrichtingen waar werkende onveroordeelden verblijven kunnen in die optiek als werkgevers in civielrechtelijke zin worden beschouwd. Het penitentiaire recht bepaalt echter anders. Daaraan is vooral de bepaling van artikel 32 lid 2, tweede lid BWG debet, die werkende onveroordeelden gelijk stelt aan veroordeelden, aan wier arbeidsverhouding met de staat géén tweezijdige rechtshandeling ten grondslag ligt en op wie het burgerlijke arbeidsovereenkomstenrecht alleen al om die reden niet van toepassing kan worden geacht.

Gebruikt men bij het beschrijven van de arbeidsrechtelijke relatie tussen Justitie en geïnstitutionaliseerden de termen 'werknemer' in plaats van het puur civielrechtelijke 'arbeider' en het begrip 'arbeidsverhouding' in plaats van 'dienstbetrekking', dan valt de vergelijking tussen gedetineerdenarbeid en de 'vrije arbeid' wat gemakkelijker te maken. In tal van wetten en besluiten wordt het begrip 'werknemer' gebruikt en dat is ruimer dan het begrip 'arbeider' in het BW. Het begrip 'arbeidsverhouding' is ruimer dan 'dienstbetrekking'. Het begrip 'arbeidsverhouding' omvat volgens Bakels ${ }^{12}$, 'tevens een aantal rechtsrelaties krachtens welke arbeid wordt verricht die niet uit een arbeidsovereenkomst voortvloeien, maar die maatschappelijk gezien met een dienstbetrekking te vergelijken zijn'.

Het kan voor de ontwikkeling van zijn rechtspositie van wezenlijk belang zijn of een werkende gedetineerde als arbeider of als werknemer, in de zin van de diverse arbeidsrechtelijke regelingen, kan worden gedefinieerd.

De arbeidsverhouding tussen veroordeelden en Justitie laat zich nog het best kenschetsen als een arbeidsverhouding op grond van de wet. Het is een rechtsverhouding die alle kenmerken heeft van de arbeidsovereenkomst, behalve de contractsvrijheid: noch de veroordeelde, noch de staat heeft de keus. Zij móéten met elkaar een arbeidsverhouding aangaan. Ook met deze beperking kan er niettemin gesproken worden van een werknemer/werkgever verhouding, termen die bij de navolgende bespreking van rechten en plichten van beide partijen $z 0$ veel mogelijk zullen worden aangehouden.

Bovenstaande opmerkingen over het ontstaan van een arbeidsverhouding tussen al of niet veroordeelde gedetineerden en de staat betreffen strafrechtelijk meerderjarigen. Uit artikel $77 \mathrm{~b}$ lid $1 \mathrm{Sr}$. vloeit voort dat op personen, die volgens de bijzondere bepalingen voor jeugdige tot vrijheidsbenemende sancties, worden veroordecld de in de artikelen 14 en $20 \mathrm{Sr}$. neergelegde arbeidsplicht niet van toe- 
passing is. Wel kan krachtens artikel 77c W.v.Sr. het materiële volwassenen-strafrecht op 16- en 17-jarigen worden toegepast en dan vallen de desbetreffende personen, voorzover ze tot vrijheidsstraffen zijn veroordeeld, onder het arbeidsregiem van de Beginselenwet Gevangeniswezen. Het penitentiaire recht kent niet, zoals het burgerlijk recht in artikel 7A:1637g BW, het vereiste dat een minderjarige alleen met een schriftelijke of mondelinge machtiging van zijn wettelijke vertegenwoordiger een arbeidsverhouding mag aangaan. Daarmee is aan die wettelijke vertegenwoordiger de kans onthouden om in die machtiging bepaalde voorwaarden te stellen, zoals dat in het burgerlijk recht wel mogelijk is. ${ }^{13}$ De staat neemt kennelijk de rol van wettelijke vertegenwoordiger over.

\subsection{Het arbeidsreglement}

De inhoud van de arbeidsverhouding tussen staat en gedetineerden wordt op het laagste niveau van regelgeving bepaald door het in artikel 49 lid 3 GM bedoelde, bij circulaire vastgestelde, arbeidsreglement dat in de werkplaatsen, voor de gedetineerden duidelijk zichtbaar, moet zijn opgehangen. Dit arbeidsreglement is in meer dan één opzicht van belang.

In de eerste plaats ontheft dit reglement veroordeelden formeel van de arbeidsplicht zolang zij zich in huizen van bewaring bevinden. ${ }^{14}$ Deze ontheffing vloeit voort uit een in 1981 ten departemente genomen besluit om 'In het kader van de uniformering van enige regiemsaspecten van de gedetineerden in de huizen van bewaring $(\ldots)$ de arbeidsplicht voor veroordeelde gedetineerden in de huizen van bewaring af te schaffen' ${ }^{15}$ Artikel 1 van het arbeidsreglement verwoordt dit als volgt: 'De gedetineerden, die in een huis van bewaring verblijven, zijn niet tot arbeid verplicht. Indien zij verklaren aan de inrichtingsarbeid te willen deelnemen, worden zij te dien aanzien op gelijke voet behandeld als gedetineerden in een gevangenis'. Een directeur die een veroordeelde totaalweigeraar, die zich als 'passant' in een huis van bewaring bevond, onder verwijzing naar art. $32 \mathrm{BWG}$ toch wilde laten werken, werd door de Beroepscommissie $(\mathrm{BrC})$ op zijn vingers getikt: ${ }^{16}$ Veroordeelden zullen zeker geen bezwaar tegen deze regeling hebben, maar staatsrechtelijk valt moeilijk in te zien hoe bij eenvoudige circulaire de artikelen 14 en $20 \mathrm{Sr}$. jo. 32 lid $1 \mathrm{BWG}$ voor wat betreft de veroordeelden in de huizen van bewaring buiten werking kan worden gesteld. ${ }^{17}$ Daarbij is het overigens wel zo dat deze 'vrijstelling' weer met één ministeriële pennestreek teniet kan worden gedaan, hetgeen de arbeidsrechtelijke positie van veroordeelden in de huizen aan departementale willekeur overlevert.

Het arbeidsreglement bevat verder een aantal voor de arbeidsverhouding wezenlijke bepalingen, zoals met betrekking tot een wachtlijst-systeem, de arbeidstijd, de onderbreking van de arbeid, de aansprakelijkheid voor tijdens het werk veroorzaakte schade en (tijdelijke) uitsluiting van de arbeid.

Bij circulaire wordt op zo'n manier een aantal bijzonder belangrijke aspecten van de arbeidsverhouding vastgesteld zonder dat de wet - zoals bijvoorbeeld wel het geval is in het burgerlijk recht (artikelen 7A:1637j t/m 7A:1637m BW) ${ }^{18}$ enige eisen stelt omtrent de verbindendheid van dat reglement. 


\subsection{De aard en de hoogte van het arbeidsloon}

Tot de essentialia van de civielrechtelijke arbeidsovereenkomst behoort de verplichting van de werkgever om loon te betalen (artikel 7A:1637a BW). 'Ontbreekt zij, dan is er geen sprake van een arbeidsovereenkomst', aldus Bakels. Waar een loon betaald wordt is echter niet zonder meer sprake van een arbeidsovereenkomst. Dat geldt met name voor gedetineerden aan wie krachtens artikel 34 lid 1 BWG door 'Onze Minister' een arbeidsloon voor verrichte werkzaamheden moet worden uitbetaald. ${ }^{19}$ Hoewel het woord anders doet vermoeden, verstaat de minister onder arbeidsloon namelijk heel iets anders dan een 'verschuldigde vergoeding voor bedongen arbeid'. ${ }^{20}$ Dat blijkt uit een brief van de bewindsman aan stakende gedetineerden in het Groningse huis van bewaring die een hoger loon eisten. Hij schreef hun: 'Tijdens de detentie wordt u van rijkswege geheel verzorgd. Deze verzorging voorziet in een basispakket voorzieningen dat toereikend is om aan de normale behoeften te voldoen. Het loon, dat u voor arbeid ontvangt, moet $\mathrm{u}$ zien als een zakgeld waarvoor u kantine-artikelen kunt aanschaffen, (waarvan $\mathrm{u}$; gdj) telefoonkosten kunt voldoen en voorzover $\mathrm{u}$ in bepaalde gevallen in aanmerking zou komen voor verlof, de eigen bijdrage in de (reis)kosten kunt bekostigen'. ${ }^{2 !}$

De hoogte van dit loon, alias zakgeld, wordt op basis van de Loonregeling gedetineerden 1948 periodiek bij circulaire nader vastgesteld. ${ }^{22}$ De loonhoogte is niet gekoppeld aan de aard of de omvang van de werkzaamheden, noch aan persoonlijke hoedanigheden van de desbetreffende gedetineerde, maar is in 1977 door middel van een 'experimentele loonregeling' gedifferentieerd naar de aard van de strafinrichtingen. In inrichtingen voor langgestraften ${ }^{23}$ gelden sindsdien hogere tarieven dan in andere. ${ }^{24}$ Het basisloon in de inrichtingen voor niet-langgestraften ontwikkelde zich sinds 1980 als volgt: per 1 januari $1980 f 3,65$ per dag; per 1 januari $1981 f 3,80$ per dag en per 1 maart $1986 f 4$,- per dag.

Laatstgenoemd bedrag is als basisloon sindsdien niet gewijzigd. Het geldt ook bij weekenddiensten en kan worden verhoogd met een prestatietoeslag van $f 0,70$ tot $f 1,45$ per dag.

Her basisloon in inrichtingen voor langgestraften bedroeg laatstelijk $f 4,20$ per dag. ${ }^{2 s}$ Laatstgenoemd bedrag kan worden aangevuld met een toeslag, die per dag maximaal $f 6,40$ bedraagt. De toeslag wordt toegekend door de werkmeester die daartoe een punten-systeem hanteert. Per dag kunnen 16 punten à $f 0,40$ worden toegekend voor produktie, inzet, houding en kwaliteit. De produktienorm wordt eenzijdig door de directie vastgesteld. ${ }^{26}$ In inrichtingen voor langgestraften ontvangen gedetineerden voor weekendwerk de normale dagvergoeding plus een weekendtoeslag. Onder dag-vergoeding moet, óók in het weekend, worden begrepen: het basisloon, vermeerderd met de prestatietoeslag, die men gemiddeld op werkdagen heeft gekregen. ${ }^{27}$ Als iemand in een dergelijke inrichting 7 dagen in de week werkt, moet volgens de Beroepscommissie het loon op de volgende manier worden berekend: 
- basisloon over zeven dagen $=7 \times f 4,20=f 29,40$;

- prestatietoeslag over zeven dagen $=16$ punten $\times 7 \times f 0,40$ per dag $=f 44,80$;

- extra toeslag voor onregelmatigheid weekenddienst over twee dagen $=9$ punten $\times 2 \times f 0,60$ per $\operatorname{dag}=f 10,80$.

Aldus kan een gedetineerde in een inrichting voor langgestraften maximaal $f 85$,- per week verdienen. ${ }^{28}$

Het punten- en toeslagensysteem wordt niet in alle straf inrichtingen op dezelfde manier gehanteerd bij het berekenen van het zieken- of werkloosheidsgeld $^{29}$, hetgeen dan ook een bron van klachten van gedetineerden vormt.

De ongelijkheid tussen de beloning van gedetineerden in inrichtingen voor langgestraften en die in andere strafinrichtingen heeft tot een aantal procedures geleid.

Een langgestrafte, die in een huis van bewaring verbleef, werd niet ontvankelijk verklaard in zijn beklag over het niet op hem van toepassing verklaren van de zogenaamde experimentele loonregeling omdat niet de directeur van de inrichting maar de minister van Justitie de loonhoogte vaststelt. Daarbij werd door de Beklagcommissie vastgesteld dat de desbetreffende circulaire niet van toepassing is op gedetineerden die in een huis van bewaring verblijven. De beroepscommissie, die deze opvatting ondersteunde, overwoog wel dat dit anders zou liggen 'indien door bepaalde handelingen van directie-zijde de selectieprocedure ernstig zou zijn vertraagd'. ${ }^{30}$

De loonregelingen 'kleven' dus niet aan de persoon van de gedetineerde maar aan de inrichtingen, waarvan een aantal bij circulaire als inrichting voor langgestraften is aangewezen. Dit kreeg ook de Gedetineerdenvereniging 'Nederheide' te horen van de President van de Arnhemse rechtbank, toen zij de Staat der Nederlanden had gedagvaard met als eis om aan de in de PVI (Penitentiaire Vormings Inrichting) te Doetinchem ${ }^{31}$ verblijvende langgestraften het hogere loon van de 'experimentele' loonregeling uit te betalen. Door dat na te laten zou de minister in strijd handelen met het gelijkheidsbeginsel. Voorts zou hij de gedetineerden in de PVI onvoldoende voor de door hen verrichte arbeid belonen en aldus afbreuk doen aan het in artikel $26 \mathrm{BWG}$ neergelegde resocialisatiebeginsel, aldus de vereniging. De President overwoog: 'dat het gelijkheidsbeginsel inhoudt, dat gelijke gevallen gelijk dienen te worden behandeld. Dat i.c. sprake is van gelijke gevallen wordt vooralsnog niet aannemelijk geacht. Vast staat, dat een dergelijke loonregeling in 1977 is ingevoerd ten behoeve van gedetineerden, die verblijven in gevangenissen voor langgestraften. De PVI is niet zo'n gevangenis'. Hij weigerde dan ook de gevraagde voorziening. Over de volgens de gedetineerden te lage betaling zei hij in zijn vonnis: 'Overigens wordt overwogen, dat, gelet op het over en weer aangevoerde, wel aannemelijk is geworden, dat een arbeidsloon van $f 26,25$ per week voor de in de PVI verblijvende gedetineerden te laag is om de kosten, die zij tijdens hun detentie noodzakelijkerwijs moeten maken te bestrij- 
den, doch niet zoveel te laag dat moet worden aangenomen, dat de Staat onrechtmatig handelt door de weigering van de minister van Justitie om de beloning van de in de PVI verblijvende gedetineerden te verhogen tot het loon dat kan worden verdiend in gevangenissen voor langgestraften'. ${ }^{32}$

Dat loonrechten niets met de status van de persoon van de gedetineerde te: maken hebben maar alles met die van gebouwen, werd nog eens duidelijk gemakt in het kader van een klachtprocedure van een gedetineerde die van de gevangenis te 's-Gravenhage tijdelijk was overgebracht naar het belendende Penitentiair Selectie Centrum (PSC) dat de status van huis van bewaring heeft. In de gevangenis verdiende hij $f 52$,- en in het PSC plotseling nog maar $f 26,25$ per week. Hoewel deze klager (overigens tot verbazing van annotator Balkema) ontvankelijk werd verklaard ${ }^{33}$, 'nu appellant er recht op heeft dat verzoeken door hem gedaan door het hoofd (van het PSC; gdj) zorgvuldig worden behandeld', werd het beroep op gelijke behandeling afgewezen. 'De zogenaamde experimentele loonregeling voor penitentiaire inrichtingen voor langgestraften, waarop appellant zich beroept, is immers slechts van toepassing in de inrichtingen die expliciet voor opneming van langgestrafte gedetineerden zijn aangewezen; de werking van deze loonregeling strekt zich niet uit tot langgestrafte gedetineerden die (tijdelijk) in het Penitentiair Selectiecentrum, dat de status van huis van bewaring heeft, verblijven', aldus de Beroepscommissie. ${ }^{34}$

Door het ontbreken van gevangenissen voor langgestrafte vrouwen (zij werden vooral in de Penitentiaire Inrichting voor Vrouwen (PIV) 'De Singel' te Amsterdam ondergebracht) kwam tot 1 mei 1979 geen enkele langgestrafte vrouw voor de 'experimentele' loonregeling in aanmerking. Op genoemde datum stelde de Staatssecretaris van Justitie echter bij circulaire vast dat die regeling ook op 'De Singel' van toepassing was. ${ }^{35}$ Een langgestrafte vrouw, die in de afdeling voor vrouwen van de Gevangenis en het Huis van Bewaring te Maastricht gedetineerd was en tweemaal zonder succes overplaatsing naar 'De Singel' had gevraagd, wilde in aanmerking komen voor de experimentele loonregeling zoals die intussen in de PIV gold. In kort geding stelde zij dat de Staat onrechtmatig had gehandeld door de loonregeling voor langgestraften wel van toepassing te verklaren op 'De Singel' en niet op de vrouwenafdeling van de strafinrichting te Maastricht. De President van de Haagse rechtbank stelde allereerst vast dat de bedoelde regeling voor gevangenissen was en nier voor gedetineerden. Hij meende dat er in dat geval geen sprake was van willekeur aan de kant van de staat, omdat aannemelijk was geworden dat het aantal langgestrafte vrouwen in Maastricht beduidend lager was dan in 'De Singel'. Deze uitspraak werd in appèl bevestigd. ${ }^{36}$

Zeker in vergelijking met de minimumloon-regelingen in het civiele arbeidsrecht heeft het 'arbeidsloon' dat werkende gedetineerden ontvangen eerder het karakter van een fooi dan van een redelijke geldelijke waardering voor de door hen verrichte werkzaamheden. 
Invoering van een normaal loon voor gedetineerden is herhaaldelijk punt van aandacht geweest.

In 1964 legde de toenmalige minister van Justitie Scholten het probleem van de arbeidslonen 'in volle omvang' voor aan de Centrale Raad van Advies voor het Gevangeniswezen, de Psychopatenzorg en de Reclassering, nu Centrale Raad voor Strafrechtstoepassing geheten. Een commissie uit die Raad stelde over deze materie een rapport op dat in januari 1966 door de Raad werd gefiatteerd. Daarmee stelde de Raad zich achter de mening van de commissie dat in principe een volwaardig loonsysteem het juiste was en dat daarmee in de prakrijk moest worden geëxperimenteerd. ${ }^{37}$ Men adviseerde om in een destijds te Gouda nieuw te bouwen (maar uiteindelijk nooit gebouwde) gevangenis van meet af aan een volwaardig loonsysteem in te voeren. De Raad amendeerde de voorstellen van de commissie maar op één punt: zij stelde voor niet met een proefneming te wachten totdat de nieuw te bouwen gevangenis te Gouda in gebruik zou zijn genomen, 'doch reeds eerder in een ander gesticht een eerste experiment met het volwaardige loonsysteem te houden'. ${ }^{38}$ Het lid van de Raad Cohen Stuart gaf daarbij als zijn mening te kennen: 'Om tegenover de gedetineerden goed te laten uitkomen, hoe de arbeid gezien moet worden, zou zelfs een $\mathrm{CAO}$ voor gedetineerden denkbaar zijn'. ${ }^{39}$ Daartoe werd de minister echter allerminst geïnspireerd, want over 's Raads advies werd van hem nooit meer iets vernomen. Alleen Versloot, lid van de Centrale Raad, zei in 1970 nog dat het hem was opgevallen dat de aanbevelingen van de Commissie Arbeidsbeloning niet door enig onderzoek waren gevolgd. ${ }^{40}$ Hoewel Versloot zijn ideeën omtrent de arbeid in een nota beloofde neer te leggen, heeft dat niet meer mogen gebeuren. In 1974 verliet hij de Raad, die daarmee ook zijn belangstelling voor deze problematiek verloor. ${ }^{41}$

In de diverse gevangenisnota's, die door het departement na de Tweede Wereldoorlog zijn gepubliceerd ${ }^{42}$ is regelmatig aandacht aan het probleem van de te lage beloning geschonken, maar invoering van een normale beloning is telkens op grond van praktische en financiële bezwaren afgewezen. Wellicht omdat dit onderwerp weinig kiezers in positieve zin aanspreekt heeft geen enkele grote politieke partij ooit gepleit voor normalisering van het loon voor gedetineerden. Opvallend is overigens wel, dat de bewindslieden op Justitie zich nooit principieel tegen toekenning van het minimumloon aan gedetineerden hebben verzet. Staatssecretaris Haars had er in 1978 alleen om praktische redenen moeite mee toe te zeggen dat in gevangenissen een minimumloon zou worden uitbetaald. ${ }^{43}$

Intussen wert er in de zeventiger, begin tachtiger jaren op buitenparlementair niveau door de Bond van Wetsovertreders (BWO) en de Coornhert-Liga (vereniging voor strafrechthervorming) voortdurend voor de invoering van het minimumloon binnen de muren gepleit. ${ }^{44}$ Ook de gedetineerden zèlf roerden zich door met een zekere regelmaat voor meer loon te staken. Het ontbreken van de politieke wil om iets aan de - het wordt hier herhaald - nimmer principieel onredelijk gevonden looneisen tegemoet te komen blijkt uit de omslachtige redenering waarmee de staatssecretaris van Justitie in 1985 gedetineerden in het Groningse 
huis van bewaring probeerde uit te leggen waarom zij hun niet méér wilde betalen. Zij schreef hun: 'De gedachte om aan gedetineerden het wettelijk minimumloon uit te keren is niet nieuw' en dan komen de 'maren': 'Het gelijkschakelen van de beloning in de inrichtingen met de wettelijke minima welke gelden in de vrije maatschappij, brengt met zich mee dat er gesproken moet worden van een gelijkwaardige arbeidsproduktiviteit, arbeidsorganisatie en arbeidstijd. (...) Voorwaarde is verder dat het loon, na aftrek van kosten wegens voeding e.d., grotendeels gaat naar degenen voor wie de gedecineerde kostwinner of onderhoudsplichtige is. (...) Voorts is gewenst dat grote verschillen in inkomen tussen de gedetineerden onderling worden vermeden'. Dat zou volgens de staatssecretaris moeten inhouden dat er gekort zou worden op de lonen van gedetineerden die geen verplichtingen jegens derden hebben. Verder voorzag zij problemen in gevallen waarin gedetineerden niet wilden werken of niet aan hun onderhoudsplicht zouden willen voldoen. ${ }^{45}$

Kortom, door het voor te stellen alsof invoering van het minimumloon een bijzonder gecompliceerde zaak is werd de boot wederom afgehouden.

\subsection{Vorm en wijze van uitbetaling van het loon}

Hoewel de BWG noch de GM uitsluitsel geven over de vraag uit welke bestanddelen het loon bestaat, moet uit de Loonregeling 1948 worden afgeleid dat het uit geld bestaat. Gezien de hierboven weergegeven opvattingen van de staatssecretaris van Justitie over aftrekposten op het eventueel aan gedetineerden uit te betalen minimumloon, gaat Justitie er impliciet van uit dat er in de vorm van voeding, huisvesting en verdere verzorging thans ook een deel van het loon in natura' wordt uitbetaald. Dat is ook de reden dat gedetineerden, die vanuit een penitentiaire open inrichting (POI) bij een particuliere werkgever geplaatst zijn, slechts $40 \%$ van het volle loon, dat die werkgever aan de staat moet betalen in handen krijgen.

In het civiele arbeidsrecht is loonbetaling in natura niet uitgesloten en van speciale betekenis voor bij de werkgever inwonende arbeiders (artikel 7A:1637 p $\mathrm{BW})$.

Een - in Nederland onbekende - vorm van loon 'in natura' voor gedetineerden ligt besloten in een systeem dat in de Verenigde Staten van Amerika good lime heet. In plaats van geld kunnen gedetineerden tijd verdienen die van hun straftijd wordt afgetrokken. Ook Griekenland en Spanje kennen dat systeem. ${ }^{46} \mathrm{Op}$ de Nederlandse Antillen is om de overbevolking van cellen tegen te gaan bij wijze van tijdelijke maatregel 5\% strafkorting toegekend aan gedetineerden die aan het eind van hun straftijd zware lichamelijke arbeid buiten de gevangenismuren hadden verricht. ${ }^{47}$

De manier waarop het loon aan gedetineerden wordt uitbetaald is door wekelijkse overschrijving ervan op de door de inrichtingsadministratie voor elke gedetineerde bijgehouden 'zakgeld'-rekening (artikelen 73 en 75 Hfdst. III HHRHvB). De plaats van uitbetaling is de inrichting waar de gedetineerde verblijft. 
Storting op andere rekeningen is niet verboden, maar komt in de praktijk niet voor. Op niet-tijdige betaling staat geen sanctie. Men kan er op basis van artikel 51. BWG over klagen, maar civielrechtelijke sancties als het moeten betalen van vertragingsrente en verhoging wegens vertraagde betaling zoals geregeld in artikel 7A:1638 q BW, kent het penitentiaire recht niet.

\subsection{De besteding van het loon}

Het door de gedetineerden verdiende loon is hun eigendom (artikelen 35 BWG en 56 lid 2 GM). Contant geld is in de strafinrichtingen niet, althans niet legaal, in omloop. Het geld dat een gedetineerde bij binnenkomst bij zich heeft wordt hem afgenomen en bijgeschreven op zijn rekening 'eigen geld', een tweede rekening die voor elke gedetineerde door de gevangenis-administratie wordt bijgehouden en waarop van 'buiten' geld kan worden gestort. Het saldo van de rekening 'eigen geld' is binnen de inrichting niet vrij besteedbaar. Dat is wel het geval met het saldo van de 'zakgeld'-rekening waarop - zoals gezegd - het arbeidsloon wordt gestort. Op die zakgeld-rekening mag periodiek een bedrag van de 'eigen-geld'- rekening worden bijgeschreven. Alle gedetineerden mogen per week $f 60$,- van de 'eigen geld'- naar de 'zakgeld'-rekening overmaken. ${ }^{48}$ Voorstellen om de rekening 'eigen geld' en de rekening 'zakgeld' tot één rekening samen te voegen om de gedetineerden geen onnodige beperkingen op te leggen in hun bestedingspatroon zijn door de staatssecretaris afgewezen met de volgende motivering: ' $(\ldots)$ een dergelijke maatregel zal leiden tot een grote mate van ongelijkheid aangezien de ene gedetineerde over aanzienlijk meer geldmiddelen zal kunnen beschikken dan de andere. Ik acht dat uit een oogpunt van een goed beheer van de inrichting geen goede zaak'.49

Het verdiende loon is binnen de inrichting niet helemaal vrij besteedbaar omdat het alleen kan worden uitgegeven aan artikelen die daar te koop of te huur zijn (artikel 59 lid 1 GM). In de praktijk komt dat neer op artikelen die in de kantine te koop zijn, op huur van audio-visuele apparatuur en videobanden en het betalen van telefoonkosten. Vanuit de inrichting kunnen wel allerlei goederen of diensten (cursussen) worden besteld. 'Invoer' ervan is echter afhankelijk van toestemming van de directeur die trouwens besteding van het zakgeld, als hij wil, helemaal kan controleren. Artikel 59 lid 2 GM legt de bevoegdheid daartoe aldus vast: 'De directeur kan verbieden dat het arbeidsloon en de periodieke overschrijving, beide bedoeld in het eerste lid, voor een bepaald doel worden besteed, indien dit wordt vereist in het belang van de orde in het gesticht of indien dit zou leiden tot een onevenredige vermeerdering van de werkzaamheden van de bij het gesticht aangestelde ambtenaren, dan wel in het belang van de voorkoming of opsporing van strafbare feiten of tot het tegengaan van gevaar voor vlucht en de directeur redelijkerwijs tot dit oordeel heeft kunnen komen.'

De directeur kan geld aan de rekening 'zakgeld' onttrekken ter hoogte van de schade die een gedetineerde 'moedwillig of door achteloosheid' tijdens zijn deten- 
tie aan 'het Rijk' heeft toegebracht. De directeur heeft daar geen executoriale titel voor nodig. Hij kan dat doen bij wijze van 'parate executie' (artikelen 35 lid 2 BWG en $61 \mathrm{GM}$ ). Het schade-verhaal is overigens beperkt tot het arbeidsloon dat op die rekening staat. Dat blijkt uit een uitspraak van de Beroepscommissie in een geval waarbij de directeur van het Maastrichtse huis van bewaring beslag had gelegd op de rekening 'zakgeld' van een gedetineerde die zijn cel-inventaris had vernield. De Beklagcommissie had eerder beslist dat, ondanks het feit dat her op deze rekening gestorte bedrag in casu niet door arbeid was verdiend, de directeur daartoe in redelijkheid had kunnen beslissen. Tijdens de behandeling van het beroep zei de directeur dat het feit dat op appellants rekening 'zakgeld' geen door arbeid verdiend geld stond 'gezien de omvang van de toegebrachte schade' niet van belang was. Dir ging de Beroepscommissie te ver. Zij verklaarde het beroep van de gedetineerde op dit punt gegrond, zeggende: 'Nu krachtens (...) art. 61 (GM; gdj) de aan het Rijk toegebrachte schade alleen op het arbeidsloon kon worden verhaald en op appellants rekening "zakgeld" geen uit arbeid verdiende inkomsten stonden geboekt, kon de directeur $(\ldots)$ geen beslag leggen op appellants rekening "zakgeld" en de door hem toegebrachte schade hierop verhalen $(\ldots)^{3} \cdot{ }^{50}$

De bevoegdheid wan de directeur tot schade-verhaal is verder beperkt door een uitspraak van de Beroepscommissie uit 1990, waarin zij vaststelde 'dat artikel 35 lid 2 Beginselenwet gevangeniswezen, nader uitgewerkt in artikel 61 Gevangenismaatregel, ten aanzien van een gedetineerde door wiens opzet of schuld het Rijk schade is toegebracht, het verhaalsobject voor die schade beperkt tot het door die gedetineerde in detentie verdiende arbeidsloon, zulks in afwijking van het principe van artikel 1177 Burgerlijk Wetboek dat iemand met zijn gehele vermogen voor zijn schulden aansprakelijk is. Aldus kan de directeur van een inrichting of een ambtenaar namens hem aan die artikelen geenszins de bevoegdheid ontlenen om eenzijdig de omvang van de verplichting van een gedetineerde om het Rijk schadeloos te stellen te bepalen, voorzover uit het burgerlijk recht voortvloeiend. In zoverre moet het daarom in strijd met bedoelde artikelen worden geoordeeld dat in het onderhavige geval aan klager een bedrag van $f 2000$,- ter zake van vergoeding van in zijn cel ontstane brandschade in rekening is gebracht'. ${ }^{51}$ Daarnee maakte de Beroepscommissie een eind aan de tot dan toe gebruikelijke 'parate executie', een inbreuk op het eigendomsrecht, waarbij de bewijslast was omgedraaid: de gedetineerde kon via een klachtprocedure ex artikel 51 BW/ proberen aan te tonen dat zijn loon ten onrechte was aangetast. De Beroepscommissie gaf echter een merkwaardige draai aan haar uitspraak door de volgende redenering: 'Aan die artikelen ( 35 lid 2 BWG jo. 61 GM; gdj) kan een directeur van. een inrichting - of een ambtenaar namens hem - de bevoegdheid ontlenen om bij wijze van tuchtrechtelijke maatregel te bepalen dat door een gedetineerde opzettelijk of door schuld aan het Rijk veroorzaakte schade zal worden vergoed. Daarbij dient echter naar analogie van het in artikel 44 onder 3 Beginselenwet Gevangeniswezen voor tuchtrechtelijke boetes voorgeschrevene het op het arbeidsloon te verhalen schadebedrag te worden beperikt tot een bedrag van ten hoogste twee weken arbeidsloon'. 
Hier overschreed de Beroepscommissie de grenzen van de extensieve wetsinterpretatie en schiep zij in feite een nieuwe tuchtrechtelijke bepaling en wel één, die haaks staat op het beleid van de staatssecretaris. Die heeft namelijk bewust zuinig met de sanctie van geldboete willen omspringen en heeft bij circulaire bepaald dat die alleen in speciaal daartoe aangewezen inrichtingen mag worden toegepast. $^{52}$

\subsection{Geen arbeid geen loon}

Een van de kempunten van het individuele civiele arbeidsrecht is dat een werkgever in beginsel geen loon verschuldigd is over de tijd waarin de werknemer de bedongen arbeid niet heeft verricht. In de penitentiaire praktijk speelt dit beginsel een rol wanneer er geen of onvoldoende arbeid beschikbaar is voor werkwillige of werkplichtige gedetineerden en in gevallen van arbeidsongeschiktheid. Verder komt de kwestie 'geen arbeid geen loon' aan de orde wanneer gedetineerden de voor de arbeid bestemde tijd willen gebruiken om te studeren. Ook wanneer een veroordeelde, die in een gevangenis verblijft, weigert de hem opgedragen arbeid te verrichten zal het beginsel een rol spelen. Over deze gevallen volgen hier enkele opmerkingen. De vraag hoe in het penitentiaire recht op werkweigering wordt gereageercl wordt behandeld in een aparte paragraaf over de beëindiging van de arbeidsverhouding tussen gedetineerden en staat.

\subsection{Werkloosheid}

Gedetineerden. die in een huis van bewaring verblijven en te kennen geven dat zij willen werken worden op een wachtlijst gezet zolang alle beschikbare arbeidsplaatsen bezet zijn. Artikel 1 lid 2 van het: (model)Arbeidsreglement zegt daarover: 'De tewerkstelling van de gedetineerden geschiedt naar de volgorde van hun binnenkomst in de inrichting. Is bij de binnenkomst in de inrichting geen arbeid beschikbaar dan wordt de betrokken gedetineerde in afwachting van de toewijzing van arbeid op een wachtlijst geplaatst'. ${ }^{53}$ Dit (model)reglement gaat, blijkens de toelichting erop in de desbetreffende circulaire, op voor die penitentiaire inrichtingen waar gemeenschappelijke arbeid wordt verricht. Over de periode tussen de aanmelding en de aanvang van de werkzaamheden wordt geen loon, ook niet in de vorm van een 'werkloosheidsuitkering', betaald. Artikel 75 lid 3 van het. derde hoofdstuk van her (model)huishoudelijk reglement huizen van bewaring bepaalt echter: "Voorschotten op het arbeidsloon worden niet verstrekt. Bij binnenkomst kan evenwel aan de gedetineerde die niet over geld beschikt en bereid is te arbeiden, een voorschot worden verstrekt'.

Als er helemaal geen werk voorhanden is wordt volgens artikel 15 lid 3 van de Loonregeling Gedetineerden ${ }^{54}$ 'het normale loon' toegekend. Dat is het zogenaamde grondloon zonder toeslagen. De Beroepscommissie heeft deze bepaling in 1986 enigszins genuanceerd door vast te stellen dat deze bepaling niet van toepassing is als er in beginsel wel arbeid beschikbaar is, maar die door het ontbreken van voldoende leidinggevend of toezichthoudend personeel niet kan worden. 
verricht. İn zo'n geval maakt de arbeidswillige, maar zijns ondanks werkloze, gedetineerde ook aanspraak op de toeslagen die hij placht te verdienen. ${ }^{55}$ In 1994 heeft de Beroepscommissie vastgesteld dat onder het 'normale loon' moet worden verstaan: het loon dat de desbetreffende gedetineerde onder normale omstandigheden placht te verdienen. Ontving men vóór de aanvang van de onvrijwillige werkloosheid gewoonlijk het grondloon èn toeslag, dan moet datzelfde bedrag, zijnde het normale loon worden doorbetaald. ${ }^{56}$ De Beroepscommissie acht onvoldoende continuiteit in het aanbod van werk een hoogst onwenselijke situatie: 'Een van de uitgangspunten van het Nederlandse gevangeniswezen, waarbij uitvoering wordt gegeven aan artikel 26 van de Beginselenwet gevangeniswezen, is immers het verrichten van arbeid'. 57

\subsection{Arbeidsongeschiktheid door ziekte}

Net als in het civiele arbeidsrecht moet de staat de gedetineerde arbeider tijdens zijn ziekte loon doorbetalen. De vrije arbeider krijgt gewoonlijk per saldo zijn volle loon uitbetaald ${ }^{58}$ Het penitentiaire recht is hier heel wat zuiniger: een gedetineerde die tijdelijk niet kan werken tengevolge van ziekte of ongeval wordt een 'ziekengeld' toegekend ter grootte van ' 80 pct. van het wegens verrichte arbeid laatstelijk toegekende zakgeld', waaruit begrepen moet worden, dat die $80 \%$ ook over de in dat 'zakgeld' begrepen toeslagen moet worden berekend. Gedetineerden die in de ene inrichting al ziek waren en ziekengeld kregen, krijgen diezelfde uitkering in de inrichting waarnaar ze worden overgeplaatst. Gedetineerden die in de 'vrije maatschappij' ziek waren en dat in de penitentiaire inrichting waarin ze zijn geplaatst nog zijn, ontvangen $80 \%$ van het arbeidsloon zonder toeslagen. Onveroordeelden die tijdens detentie ziek geworden zijn maar gedurende de laatste vijf werkdagen vóór hun ziekmelding een of meer dagen geen arbeid hebben willen verrichten ontvangen geen ziekengeld. ${ }^{59}$ In inrichtingen waar de zogenaamde experimentele loonregeling voor langgestraften geldt is een slechtere regeling van kracht. Daar wordt bij ziekte niet $80 \%$ van het laatstverdiende zakgeld (d.w.z. het arbeidsloon plus toeslagen) maar een uitkering gelijk aan het dagloon zonder toeslagen uitbetaald. ${ }^{60}$

Tijdens zwangerschapsveriof wordt in inrichtingen voor langgestrafte vrouwen blijkens een recente uitspraak van de Beroepscommissie echter $80 \%$ van het grondloon mèt eventueel ontvangen toeslagen uitgekeerd. ${ }^{61}$

De penitentiaire regels geven geen beperking aan de termijn gedurende welke 'ziekengeld' moet worden betaald.

De Ziektewet, de WAO en de AAW zijn - afgezien van de zeldzame gevallen waarin een gedetineerde een beroep kan doen op de 'nawerking' van deze wetten -niet van toepassing op gedetineerden die tijdens hun detentie arbeidsongeschikr worden. ${ }^{62}$

Personen die al in de vrije maatschappij een Ziektewet-uitkering ontvingen kunnen daar ook 'binnen' rechten op doen gelden, zij het dat de bedrijfsvereniging haar aan derden kan verstrekken of pas na afloop van de detentie kan uitkeren. ${ }^{63}$ 
Het begrip 'arbeidsongeschiktheid' heeft in het penitentiaire recht niet dezelfde inhoud als daarbuiten. Dat blijkt uit een uitspraak van de Beroepscommissie over de disciplinaire bestrafting wegens werkweigering van een veroordeelde die een uitkering, krachtens de AAW genoot omdat hij naar het oordeel van het Gemeenschappelijk Administratie Kantoor (GAK) voor 80 tot $100 \%$ arbeidsongeschikt was. De Beklagcommissie had in die zaak het volgende overwogen: 'De toekenning van een uitkering krachtens de AAW betekent, dat klager door de Gemeenschappelijke Medische Dienst niet in staat is verklaard met arbeid, die voor zijn krachten en bekwaamheden is berekend en die met het oog op zijn opleiding en vroegere beroep hem in billijkheid kan worden opgedragen, te verdienen wat lichamelijk en geestelijk gezonde personen van dezelfde opleiding met arbeid op dezelfde plaats gewoonlijk verdienen. De arbeid in de gestichten dient zich uit te strekken tot het verrichten van huisdienst en het vervaardigen van voorwerpen. Op grond van de AAW staat aan klager niets in de weg om huisdienst te verrichten; het gaat in de AAW om het verdienen van loon op gelijke voet met gezonde anderen voor arbeid in de vrije maatschappij. Daar valt huishoudelijk werk niet onder, tenzij het bij een schoonmaakbedrijf zou zijn. Dat blijkt niet het geval te zijn geweest met klager. Hlet vervaardigen van voorwerpen was, toen klager nog werkte, het indraaien van schroeven. Dat gebeurt in de vrije maatschappij niet meer in handwerk, doch door machines. Nu bovendien gebleken is, dat klager door de gestichtsarts tot arbeid, als in de Beginselenwet bedoeld, in staat is geacht, is de werkweigering onvoldoende gegrond'. ${ }^{64}$

Dat arbeidsongeschiktheid in de vrije maatschappij niet automatisch ook ongeschiktheid voor de gestichtsarbeid met zich mee brengt, bevestigde de Beroepscommissie nog eens in een uitspraak over een klacht van een gedetineerde die vóór zijn detentie arbeidsongeschikt bevonden was voor zijn werk als magazijnbediende. De gestichtsarts had in zijn op artikel 45 lid 1 GM gebaseerde rol van keuringsarts klager niet ongeschikt geacht voor gestichtsarbeid. Dat klager vóór zijn detentie in de vrije maatschappij een uitkering op grond van de Ziektewet genoot achtte de Beroepscommissie 'ten deze irrelevant'. ${ }^{65}$

Aan het oordeel van de gestichtsarts wordt op die manier een bijzonder gewicht toegekend. In dit geval bleek uit niets dat een keuringsarts van de uitkerende instantie was geconsulteerd. De gestichtsarts heeft blijkbaar een dubbele functie: die van behandelend huisarts en die van keuringsarts. De Rotterdamse gestichtsarts Kamermans zei over het probleem van de arbeidsongeschiktheid van gedetineerden: 'Hoewel de financiële belangen veel kleiner zijn dan buiten (maximaal zijn enkele tientallen guldens per week te verdienen) is er toch vaak onduidelijkheid (...). Allereerst het misverstand dat een AAW- of WAO-uitkering recht geeft op ziekengeld tijdens de detentie. Het soort en de hoeveelheid werk dat tijdens de detentie angeboden wordt is over het algemeen ook voor volledig afgekeurden zonder meer te doen en wel vergelijkbaar met wat in psychiatrische klinieken als "arbeidstherapie" wordt aangemerkt. Ten tweede het misverstand dat behandeling en controle niet zouden samengaan. In Nederland (en dan ook alléén daar!) is deze scheiding aangebracht, uitgaande van de veronderstelling dat 
de behandel-relatic zou lijden onder de controle-relatie. In de detentiesituatie blijkt dat dit alleen het geval is wanneer de directie onzorgvuldig met de verstrekte informatie over arbeids(on)geschiktheid omgaat. Als regel komen maar zeer weinig conflicten over "ziekengeld" voor". ${ }^{66}$

Dat hier toch problemen kunnen rijzen is door de staatssecretaris onderkend. Die komt het gewenst voor dat overleg tussen gestichtsarts en verzekeringsgeneeskundige, dan wel de Gemeenschappelijke Medische Dienst, plaatsvindt, voordat aan een arbeidsongeschikte gedetineerde, die al in de vrije maatschappij arbeidsongeschikt was, gestichtsarbeid wordt opgedragen. ${ }^{67}$

Bij conflicten over de vraag of een gedetineerde geschikt is om gestichtsarbeid te verrichten zal in eerste instantie de Beklagcommissie (veelal naar aanleiding van een klacht over het niet krijgen van ziekengeld of over een disciplinaire sanctie wegens werkweigering) over de vraag 'ziek/niet ziek' moeten oordelen. Daarmee worden de beklag- en beroepsrechrer belast met rechtspraak over kwesties die naar hun aard (loonconflict) bij de Kantonrechter en in een latere fase eventueel bij de sector bestuursrecht van de rechtbank lijken thuis te horen ${ }^{68}$

Een ziekmelding, die door de directie niet serieus genomen wordt, mag, niet zonder meer als een voor disciplinaire bestraffing in aanmerking komende werkweigering worden opgevat. De Beroepscommissie heeft uitgemaakt, dat 'indien een gedetineerde opgeeft niet te kunnen werken (...) niet tot strafoplegging mag worden overgegaan alvorens door een arts is bevonden dat (diens) klachten ongegrond of niet ernstig genoeg zijn om een werkweigering te rechtvaardigen $(\ldots)^{\prime}$. Daarbij bepaalde de Beroepscommissie aanvankelijk dat die 'keuring' per se door een arts moet geschieden en dat een verpleegkundige daartoe niet gekwalificeerd moet worden geacht. In latere jurisprudentie werd die eis verzacht en achtte de Beroepscommissie het oordeel van een verpleegkundige 'optredende namens de arts' wel toelaatbaar ${ }^{69}$ Ziek in bed blijven zonder zich via de gestichtsarts ziek te melden kan verwijdering van de arbeidszaal voor de duur van veertien dagen opleveren. Men heeft dan 'zonder opgaaf van redenen' werk geweigerd en de $\mathrm{BrC}$ is niet genegen om achteraf vast te doen stellen of men werkelijk ziek was of niet. ${ }^{70}$

Vindt de arts de gedetineerde die zich heeft zick gemeld toch arbeidsgeschikt, dan wordt hem niet alleen ziekengeld onthouden maar kan de directeur hem ook op de dag van de ziekmelding uitsluiten van de gemeenschappelijke arbeid (artikel 27a Hfdst. III HHR-HvB), zodat hij zich niet alsnog van een dagloon kan voorzien. $\mathrm{De} \mathrm{BrC}$ heeft het zelfs toelaatbaar gevonden dat een - volgens de gestichtsarts - onterechte ziekmelding met 6 dagen uitsluiting van de arbeid werd bestraft. ${ }^{\text {x }}$ Op die manier wordt er een boete gesteld op onterecht bevonden ziekmeldingen. Als bijkomende sanctie kan per geval worden bepaald dat ook deelname aan andere gemeenschappelijke activiteiten, zoals de avondrecreatie, wordt verboden. ${ }^{72}$ Laatstgenoemde maatregel moet dan wel in verband met de orde in de inrichting 'volstrekt noodzakelijk' zijn en mag niet als een voor iedere gedetineerde in dit soort gevallen geldende algemene regel worden gehanteerd. De Beroepscommissie heeft hierover herhaaldelijk gezegd dat het in zijn algemeenheid gewenst is dat subversief gedrag van gedetineerden, zoals het veinzen ziek te zijn, 
wordt voorkomen, maar dat de gedetineerde die zich ziek meldt niet zonder meer tevens van de avondrecreatie uitgesloten kon worden. Een dergelijke maatregel kon volgens de Beroepscommissie slechts getroffen worden indien dit ten aanzien van de gedetineerde volstrekt noodzakelijk was. Die noodzaak kon niet gelegen zijn in het ziek zijn alleen: ook andere feiten en omstandigheden moesten deel uitmaken van het individuele afwegingsproces. ${ }^{73}$ Dat standpunt verdroot de staatssecretaris van Justitie dermate, dat hij bij circulaire bepaalde dat het avondprogramma geacht moest worden deel uit te maken van het dagprogramma, zodat ziekgemelde gedetineerden dus ook niet aan de avond-recreatie mochten deelnemen. ${ }^{74}$

Weigering het werk te hervatten na arbeidsgeschikt-verklaring door de inrichtingsarts komt veroordeelden, die in gevangenissen verblijven, op een disciplinaire straf te staan. Uitsluiting van de arbeid is daar, gezien de arbeidsplicht die voor deze categorie onverkort geldt, formeel niet mogelijk.

Conflicten over de arbeidsgeschiktheid zijn vrijwel onoplosbaar omdat de directeur blindelings op het oordeel van de gestichtsarts afgaat. Het medisch oordeel van die arts is niet vatbaar voor beklag ex art. $51 \mathrm{BWG}$, zodat dit in het kader van bekiagzaken over disciplinaire straffen die wegens werkweigering zijn opgelegd buiten discussie blijft. De BrC heeft het overigens in een geval juist gevonden, dat een veroordeelde, die een diepgaand conflict over zijn arbeidsgeschiktheid had met de gevangenisarts, na 3 maal een straf van 14 dagen afzondering op eigen cel te hebben uitgezeten daarna 'slechts' tijdens de voor de arbeid bestemde uren in zijn gevangenis-cel moest verblijven. ${ }^{75}$

\subsection{Studeren in plaats van werken}

Gedetineerden kunnen in de tijd die gewoonlijk voor het verrichten van arbeid. bestemd is studeren. Onveroordeelden hoeven daarvoor geen toestemming te vragen omdat zij nu eenmaal niet tot het verrichten van arbeid verplicht zijn. ${ }^{76} \mathrm{Zij}$ zullen die toestemming echter wel moeten hebben als zij tijdens hun studie toch van een zeker inkomen verzekerd willen zijn. Daartoe moeten zij zich eerst voor de arbeid aanmelden. Als vervolgens toestemming wordt verkregen de gewenste studie te volgen wordt het arbeidsloon doorbetaald. Als een onveroordeelde onderwijs wil volgen dat door de inrichting zeif wordt georganiseerd en tijdens de gemeenschappelijke arbeid groepsgewijs wordt gegeven, is hij trouwens sowieso verplicht zich voor die arbeid op te geven.

Op deze wijze is verwezenlijking van het grondrecht op onderwijs afhankelijk gemaakt van deelname aan de arbeid. Voor studieuze onveroordeelden betekent. dat een verkapte invoering van de arbeidsplicht ${ }^{77}$, iets dat zich slecht lijkt te verdragen met de anti-dwangarbeidsconventies nrs. 29 en 105 van de Internationale Arbeidsorganisatie.

Onderwijs dient volgens artikel 78 van de Europese Gevangenisregels te worden beschouwd als een regiemsactiviteit die geiijkwaardig is aan de arbeid en die 
net zoals de arbeid betaald moet worden voorzover er wordt gestudeerd op tijden waarop gewoonlijk gewerkt wordt. De Europese Gevangenisregels maken daarbij geen onderscheid tussen preventieven en veroordeelden. De Memorie van Toelichting bij deze Regels stelt uitdrukkelijk vast dat deelname van gedetineerden an scholingsprogramma's van evenveel belang is als hun inschakeling bij de arbeid. $^{78}$

Veroordeelden - voorzover zij in in huizen van bewaring verbiijven - dienen op grond van artikel $52 \mathrm{Hfdst}$ III HHR-HvB als arbeidsplichtigen altijd toestemming van de directeur te hebben on te mogen studeren en toch een vergoeding te kunnen blijven ontvangen.

De tweede volzin van artikel 76 lid 2 GM maakt toekenning van een 'studieloon' mogelijk: 'Voor de tijdens de arbeidsuren plaatsvindende studie kan aan gedetineerden een beloning worden toegekend volgens door Onze. Minister nader vast te stellen regelen'. Deze regels waren aanvankelijk vastgelegd in een circulaire van $1978^{79} \mathrm{die}$, naast vergoeding van studie- en examenkosten, toekenning van een beloning ter hoogte van het grondloon mogelijk maakte. Dan moest wel aan een aantal voorwaarden zijn voldaan. Zo moesten de studieresultaten kwantitatief en kwalitatief voldoende zijn en moest de beschikbaar gestelde tijd ook daadwerkelijk voor studie benut worden. Verder moest de studie een reële bijdrage leveren aan de herinpassing van de gedetineerde in het arbeidsproces in het bijzonder en aan zijn maatschappelijk functioneren in het algemeen. In 1988 is er over deze materie een nieuwe circulaire gekomen, betreffende de voorwaarden waaronder op 's Rijks kosten aan schriftelijke cursussen en examens kan worden deelgenomen. ${ }^{80} \mathrm{Bij}$ laatstgenoem de circulaire werd die van 1978 ingetrokken, waardoor de in artikel 76 lid 2 GM 'nader vast te stellen regelen' zijn vervallen.

\subsection{Vakantie}

In het civiele arbeidsrecht is op grond van art. 7A:1638bb BW de werkgever verplicht aan de arbeider over elk jaar, dat de dienstbetrekking heeft geduurd, vakantie te verlenen gedurende tenminste viermaal de bedongen arbeidsdagen per week, of, als de bedongen arbeidstijd in uren per jaar is uitdrukt, gedurende tenminste een overeenkomstig aantal dagen.

Ook binnen de muren is er een soort vakantie-regeling gekomen, ook al was eerder een proef-procedure over een beweerd recht op vakantie mislukt.

In 1979 had een langgestrafte gedetineerde namelijk een aantal - in de inrichting op te nemen - vakantie en/of snipperdagen van in totaal 3 weken per jaar geclaimd. De Beroepscommissie was echter van mening dat 'onvoldoende gebleken (was) van een in de inrichting geldende zorgvuldigheidsnorm, welke de directie bij toepassing van artikel 49 , 1e lid van de Gevangenismaatregel zou verplichten vakantie en/of snipperdagen aan gederineerden toe te staan'. Hieraan deed volgens de Beroepscommissie niet af dat de directie wel bleek. te voelen voor een aan de vrije maatschappij aangepast systeem, waarbij gedetineerden ook binnen de inrichting meer 'vrije' dagen konden verkrijgen en daartoe zelfs een voorstel bij het Departement had ingediend. ${ }^{81}$ 
Niet lang daarna kregen werkende gevangenen recht op vakantie met behoud van loon. Onder vakantie moet hier vrijstelling van de arbeid worden verstaan, niét het verlaten van het gesticht, want daar zijn speciale verlofregelingen voor.

Op grond van de 'Regeling arbeidsvrije dagen' van $1980^{82}$ kunnen langgestrafte gedetineerden verzoeken om gedurende één dag, of een gedeelte daarvan, per twee maanden te worden vrijgesteld van de verplichting tor deelneming aan de inrichtingsarbeid. Als zo'n verzoek wordt ingewilligd ontvangt de gedetineerde het zogenaamde grondloon over de uren waarop hij niet deelneemt aan de inrichtingsarbeid. Deze 'snipperdagen' mogen niet worden opgespaard om ze aaneengesloten te kunnen opnemen.

Op bij circulaire vastgestelde feest- en gedenkdagen hoeven de gedetineerden niet te werken en ontvangen zij toch arbeidsloon, inclusief toeslagen. ${ }^{83}$ Overigens wordt alleen op christelijke feestdagen loon doorbetaald. Gederineerden die een ander geloof aanhangen hoeven op hun godsdienstige feest- of gedenkdagen (mits als zodanig door het gevangeniswezen erkend) weliswaar niet te werken, maar ze krijgen geen loon doorbetaald. Waarom niet? Omdat, zo zei de Beroepscommissie, de desbetreffende circulaire daarin niet voorziet. ${ }^{84}$

Uit het in 1984 gewezen Suikerfeest-arrest ${ }^{85}$ blijkt dat ook in het burgerlijk arbeidsrecht onderscheid wordt gemaakt tussen algemeen erkende christelijke feestdagen en volgens andere godsdiensten geldende feestdagen. De Hoge Raad meende dat werknemers die naar de desbetreffende godsdienst leven voor de viering van hun feestdagen in beginsel snipperdagen mochten opnemen.

\subsection{De beëindiging van de arbeidsverhouding}

In het burgerlijk arbeidsrecht kunnen arbeidsovereenkomsten op verschillende manieren eindigen. ${ }^{86}$ Ten eerste kunnen werkgever en werknemer met inachtneming van de algemene beginselen van het contractenrecht met elkaar afspreken dat de arbeidsverhouding eindigt. Een tweede mogelijkheid is het opzeggen van de arbeidsovereenkomst in de vorm van een eenzijdige rechtshandeling. Wil zo'n opzegging rechtsgeldig zijn dan moeten daarbij de normen van artikel 7A:1639 o e.v. van het BW en die van het Buitengewoon Besluit Arbeidsverhoudngen 1945 (BBA) in acht genomen zijn.

Een derde mogelijkheid die het civjele recht biedt is ontbinding van de arbeidsovereenkomst door de Kantonrechter 'wegens gewichtige redenen' (artikelen $1639 \mathrm{BW}$ en $429 \mathrm{a}-429 \mathrm{r} \mathrm{RV}$.). Verder eindigt de arbeidsovereenkomst bij overlijden van de arbeider en bij ommekomst van de arbeidsovereenkomst voor bepaalde tijd (7A:1639 l BW).

De beëindiging van de arbeidsverhouding tussen gedetineerden en de staat wordt door andere regels beheerst.

Voor werkende gedetineerden in huizen van bewaring, waar geen arbeidsplicht geldt, zijn de mogelijkheden om een eenmaal aangegane arbeidsverhouding te beëindigen beperkt. Immers, hoewel onveroordeelden niet hoeven te werken, dienen ze op grond van artikel 32 lid 2 BWG, na aanvaarding van arbeid, behan- 
deld te worden als waren zij arbeidsplichtige veroordeelden aan wie het recht tot eenzijdige beëindiging van de arbeidsverhouding niet toekomt. Door de directeur van een huis van bewaring is dat in het kader van een beroepszaak een keer zó geformuleerd: 'dat ten aanzien van het verrichten van de opgedragen arbeid nietveroordeelden indien zij -onverplicht - hebben gekozen voor het verrichten van arbeid, zij ook verplicht zijn de opgedragen arbeid uit te voeren en zich bij gebreke daarvan blootstellen aan het opleggen van straf of maatregelen als waren zij tot arbeid verplichte veroordeelden'. De Beroepscommissie relativeerde dat standpunt door vast te stellen dat van een onveroordeelde in redelijkheid niet gevergd kan worden dat hij gedurende zijn gehele detentieperiode aan zijn keuze voor arbeid wordt gehouden. Wel werd het recht van de onveroordeelde om zijn baantje eenzijdig op te zeggen aan een aantal, vrij vage, normen gebonden. De Beroepscommissie was weliswaar van oordeel dat een niet-veroordeelde, die vrijwillig heeft verkozen aan de arbeid deel te nemen en die zich bereid heeft verklaard een bepaald soort arbeid te verrichten, die arbeid ook dient te verrichten nadat hem die is opgedragen. Maar, zei de Beroepscommissie: 'In redelijkheid valt echter niet van een onveroordeelde te vergen, dat hij gedurende zijn gehele detentieperiode als onveroordeelde aan de keuze gebonden wordt gehouden. Indien hij daartoe de wens te kennen geeft moet hij ook weer van zijn arbeidsplicht (nadruk gdj) bevrijd kunnen worden, bij voorkeur in onderling overleg tussen onveroordeelde en directie, c.q. de werkmeester namens deze'. De Beroepscommissie stelde 'dat van de onveroordeelde mag worden verwacht, dat hij niet zonder meer zijn arbeid staakt maar deze afmaakt tot, al naar gelang de omstandigheden, einde werktijd, einde van de periode waarvoor de arbeidsafspraak (nadruk gdj) is gemaakt, c.q. tot het moment waarop het voorwerp dat in bewerking is genomen, gereed is gemaakt'. ${ }^{87}$ De Beroepscommissie sprak zich niet ten gronde uit over de rechrmatigheid van het toepassen van straffen of maatregelen op onveroordeelden die hun werkzaamheden onregelmatig, althans in strijd met de voorwaarden, die in deze uitspraak werden gesteld, beëindigen.

Hoewel deze uitspraak een onveroordeelde betrof, moet worden aangenomen dat hij ook geldig is voor veroordeelden die in huizen van bewaring gedetineerd zijn en daar de facto van de arbeidsplicht zijn ontheven.

Genoemde uitspraak houdt in dat niet alleen de gedetineerde maar ook diens 'werkgever', de directeur van het huis van bewaring, de arbeidsverhouding rechtmatig kan opzeggen. De jurisprudentie van de Beroepscommissie levert ons een voorbeeld van zo'n opzegging.

In het huis van bewaring 'Het Schouw' te Amsterdam verloor een gedetineerde zijn arbeidsplaats omdat hij - om redenen die overigens niets met de arbeid van doen hadden - een disciplinaire straf van zes dagen afzondering had opgelopen. Volgens het arbeidscontract, dat destijds in dat huis van bewaring werd gebruikt en dat door klager was ondertekend, zou de arbeidsplaats vervallen bij een afwezigheid van vijf dagen of meer. De Beroepscommissie was van oordeel dat appellant, mede doordat hij het arbeidscontract had ondertekend waarin stond vermeld wanneer de arbeidsplaats verviel, de consequenties van het oplopen van 
een disciplinaire straf had kunnen voorzien. De annotator van deze uitspraak, Van den Berg, achtte de door de Beroepscommissie veronderstelde wilsvrijheid van gedetineerden een fictie: 'Onder het mom van contractsvrijheid is zo een extra sanctie ingebouwd'. Hij vond deze handelwijze van de directeur naar misbruik van omstandigheden neigen en: 'Mocht de arbeidsovereenkomst niet reeds op grond hiervan nietig zijn, dan kan voorts aangevoerd worden dat de werkgever bij tenuirvoerlegging van de overeenkomst niet te goeder trouw heeft gehandeld. Immers de werkgever is dezelfde als de directeur die de disciplinaire straf oplegt en het de werknemer daarmee onmogelijk maakt op de werkzaal te verschijnen. Dit nu acht ik een onbillijke handelwijze van de werkgever/directeur'. ${ }^{88}$

De directie van een huis van bewaring kan een gedetineerde dus 'ontslaan' en hem zodoende noodzaken opnieuw te 'solliciteren', dat wil zeggen op de wachtlijst te gaan staan. ${ }^{89}$ Een veel gebruikelijker middel is echter het tijdelijk uitsluiten van de arbeid of het bestraffen van gedetineerden die zich in de ogen van de directie niet als goed werknemer gedragen.

Door een dergelijke uitsluiting wordt de gedetineerde als gevolg van het beginsel 'geen arbeid geen loon' direct in zijn portemonnaie getroffen. Het is in feite een vermogenssanctie en wel één die artikel $44 \mathrm{BWG}$ niet kent. De Beroepscommissie heeft niets tegen de uitsluiting op zichzelf. Wel toetst zij de redelijkheid van de duur ervan aan 'de emst van de gepleegde feiten' en 'alle belangen en omstandigheden van het geval'. Zo achtte zij een uitsluiting van de gemeenschappelijke arbeid voor de duur van 14 dagen in een geval waarin een gedetineerde een werkmeester van vriendjespolitiek had beschuldigd onredelijk en achtte zij een uitsluiting voor de duur van 7 dagen meer in overeenstemming met de ernst van de zich voorgedaan hebbende feiten. ${ }^{90}$

Uitsluiting van deelname aan de arbeid voor de duur van 14 dagen in een geval waarin een preventief gedetineerde zich te ziek voelde om te werken, maar een verpleegkundige hem wèl arbeidsgeschikt achtte, werd door de Beroepscommissie niet redelijk geacht. Daarbij nam die commissie in aanmerking dat in dat geval zowel de directeur als de inrichtingswerkers op de hoogte waren van de langdurige medische klachten van klager die overigens in die inrichting niet eerder werk had geweigerd of andere problemen had opgeleverd. De Beroepscommissie bekortte de uitsluiting tot vijf dagen. Van belang is de overweging van de Beroepscommissie in deze uitspraak dat uitsluiting van deelname aan de arbeid geen straf is, maar een maatregel opgelegd krachtens artikel $76 \mathrm{Hfdst}$. III van het HHR-HvB. ${ }^{11}$

Dat de directeur overigens vrij is in zijn keuze tussen een echte straf ex artikel $44 \mathrm{BWG}$ en genoemde maatregel blijkt uit een uitspraak van de Beroepscommissie wararin deze de uitspraak van de Beklagcommissie bij het huis van bewaring te Groningen bevestigde. Laatstgenoemde commissie had beslist dat het weigeren van een op zichzelf redelijke opdracht van een werkmeester in strijd is met de goede orde en tucht binnen de inrichting en dat de directeur daarop 'met enige disciplinaire straf of maatregel' kan reageren. ${ }^{92}$ 
Veroordeelden en directeuren van gevangenissen zitten als werknemer en werkgever door de wettelijke arbeidsplicht arbeidsrechtelijk aan elkaar vastgeketend. Een soort opzeggings- of ontslagrecht als in huizen van bewaring valt te ontwaren is daar niet denkbaar. De maatregel van 'uitsluiting van de arbeid' is in gevangenissen wettelijk onmogelijk. Werkweigering, of wat de directie daarvoor houdt, kan slechts worden gesanctioneerd door de disciplinaire bestraffing ex artikel 44 BWG of door de maatregel van afzondering als bedoeld in artikel 24 lid 1 sub c GM. Laatstgenoemde maatregel kan echter niet naar believen worden opgelegd. Dat bilikt uir een uitspraak van de Beroepscommissie (daterend uit de tijd waarin veroordeelden die in huizen van bewaring verbleven nog onverkort aan de arbeidsplicht gehouden werden) in de zaak van een veroordeelde die geen wasknijpers wilde maken. Deze gedetineerde was voor dat feit al gedurende drie achtereenvolgende weken disciplinair gestraft met steeds één week afzondering op eigen cel, met als conditie dat de straf zou worden opgeheven als hij zich bereid zou verklaren wasknijpers te maken. Toen hij het na afloop van de derde straftijd nóg weigerde was hij met toepassing van artikelen 24 lid sub c onder 2 GM en 19 lid 1 sub c Hfdst. III HHR-HvB in afzondering geplaatst. De Beroepscommissie wees de toepassing van deze maatregel tegen werkweigering niet principieel af, maar vond deze in casu ten onrechte opgelegd omdat niet was aangevoerd of gebleken dat de directeur bij het opleggen van deze maatregel een onderzock had verricht of laten verrichten naar appellants persoonlijkheid. Immers, artikel 19 lid 1 sub c Hfdst. III HHR-HvB bepaalt dat afzondering alleen kan worden toegepast op gedetineerden die, gelet op hun persoonlijkheid, naar het redelijk oordeel van de directeur niet voor plaatsing in algehele of beperkte gemeenschap in aanmerking komen. ${ }^{93}$

Met wie in een gevangenis om principiële redenen werk weigert worden korte metten gemaakt. Een gevangene, die de mening verkondigde dat arbeid geen element is van de vrijheidsstraf en overigens niets bijdraagt tot het vergroten of het verwerven van vakbekwaamheid, kreeg voor herhaalde werkweigering telkens een disciplinaire straf van 7 dagen afzondering in eigen cel opgelegd. 'Het is niet onbillijk of onredelijk om op de weigering de nommale arbeid te verichten met de disciplinaire straf van afzondering; in een cel niet zijnde een strafcel te reageren, zo bilijkte de Beroepscommissie deze handelwijze: van de directeur. $\mathrm{Zij}$ ging echter niet accoord met her opleggen van aaneensluitende periades van zeven dagen ondat daardoor een periode vañ afzondering ontstaat die de maximale termijn van veertien dagen, genoemd in artikel 44 lid 2 BWG, te boven kan gaan. ${ }^{94}$

Totaalweigeraars, die ook niet ais uitvloeisel van de hun opgelegde vrijheidsstraf voor de staat willen werken, krijgen aldus telkens een disciplinaire straf van vijf dagen afzondering opgelegd, op werkdagen ten uitvoer te leggen. De Beroepscommissie ging niet accoord met de oplegging van telkens 14 dagen afzondering zoals bedoeid in artikel 44 lid 2 BWG. Het blijven weigeren van arbeid nadat een daarvoor opgelegde straf is geèindigd wordt telkens als een nieuw feit. gezien waarvoor opnieuw straf kan worden opgelegd. ${ }^{95}$ 
Veroordeelden die vanuit een penitentiaire open inrichting (POI) bij een particuliere werkgever arbeid verrichten kunnen door laatstgenoemde worden ontslagen. Een dergelijk ontslag resulteert gemeenlijk in een terugplaatsing naar een gesloten gevangenis waar de betrokken gedetineerde weer onder het regiem van verplichte arbeid valt. $\mathrm{De} \mathrm{BrC}$ vindt, dat de directeur van een $\mathrm{POI}$ in het algemeen moet kunnen uitgaan van de juistheid van de beslissing van de particuliere werkgever maar gaat in bijzondere gevallen de schuldvraag toch ook weer niet uit de weg. ${ }^{96}$

Concluderend kan worden gezegd dat gedetineerden, die in een huis van bewaring verblijven en daar arbeid verrichten, niet voor de hele duur van hun verblijf aldaar aan die keuze zijn gehouden. Onder bepaalde voorwaarden kunnen zij de arbeidsverhouding eenzijdig beëindigen. Ook de directie van een huis van bewaring kan eenzijdig een einde aan de arbeidsverhouding maken, bijvoorbeeld als een gedetineerde één van de in het 'arbeidscontract' gestelde voorwaarden schendt en aldus wanprestatie levert. Naast die ontslagmogelijkheid beschikt de directeur over de sanctie van uitsluiting van de arbeid, waarbij de arbeidsverhouding weliswaar intact blijft maar de gedetineerde gedurende een zekere periode niet aan het werk wordt gezet en daardoor inkomen derft.

Naast het toepassen van deze arbeidsrechtelijke sancties kan in een huis van bewaring op onregelmatigheden in het arbeidsgedrag met disciplinaire straffen of met maatregelen worden gereageerd.

In gevangenissen maakt de daar onverkort gehandhaafde arbeidsplicht 'ontslag' of uitsluiting onmogelijk. Op wanprestatie door de gevangene/arbeider kan slechts disciplinair worden gereageerd, hergeen vooral voor totaalweigeraars tot langdurige eenzame opsluiting heeft geleid. Zo leeft de 'poenale sanctie' die de koelies in Nederlands Indië trof als zij hun arbeidscontract niet nakwamen nog heden ten dage voort in de Nederlandse penitentiaire inrichtingen. ${ }^{97}$

Vanzelfsprekend wordt de arbeidsverhouding tussen gedetineerde en staat van rechtswege beëindigd bij de invrijheidstelling van de gedetineerde..$^{98}$

\section{Enkele bijzondere onderwerpen}

\subsection{De werkstaking}

Aan het begin van dit hoofdstuk werd het al gesignaleerd: werkstaking door gedetineerden wordt door gevangeniswezen beschouwd en behandeld als werkweigering. Stakingen plegen, aldus Kelk, repressief tegemoet te worden getreden en minstens te resulteren in disciplinaire bestraffing. ${ }^{99}$ Het organiseren van werkstakingen wordt als subversiviteit opgevat en is ooit zelfs als indicatie beschouwd voor plaatsing in een Extra Beveiligde Inrichting (EBI). ${ }^{100} \mathrm{Het}$ stakingsrecht komt zoals aan het begin van dit hoofdstuk duidelijk werd, de gedetineerden niet toe. 
Niettemin vinden regelmatig stakingen plaats. Op 17 januari 1983 hebben ongeveer 45 gederineerden van de gevangenis 'Schutterswei' te Alkmaar door middel van een werkstaking actie gevoerd tegen door de staatssecretaris aangekondigde bezuinigingen in het gevangeniswezen. ${ }^{101}$ Een aantal stakers, dat op grond van werkweigering en ordeverstoring een disciplinaire straf van 3 dagen afzondering opgelegd had gekregen, had daarover geklaagd. De Beklagcommissie wees de klachten af. Daarbij overwoog zij 'dat hoewel het doel van de actie op zichzelf redelijk en begrijpelijk was, appellanten door de wijze waarop zij dit hebben gemeend te moeten verwezenlijken - nl. door een stakingsactie waarbij alle bevelen van de directie werden genegeerd - de veiligheid en de orde binnen de inrichting ernstig hebben verstoord en daartoe het toelaatbare in belangrijke mate hebben overschreden'. In beroep hadden de stakers aangevoerd dat hun actie had voldaan 'aan de meest strikt geformuleerde voorwaarden ter rechtvaardiging van een staking in de vrije maatschappij, die van het Nederlandse Christelijke Werkgeversverbond'. De Beroepscommissie passeerde dit argument en vond dat de straffen terecht waren uitgedeeld: 'In de detentiesituatie hebben tot gevangenisstraf veroordeelden krachtens artikel 32 lid 1 Beginselenwet Gevangeniswezen de plicht de hun opgedragen arbeid te verrichten en voorts zijn zij op grond van artikel 28 Gevangenismaatregel verplicht alle door of namens de directeur gegeven bevelen op te volgen. Niet kan worden gesproken van een werkgever-werknemerverhouding (nadruk gdj). Slechts in die verhouding wordt in artikel 6, deel II van het Europees Sociaal Handvest aan werkgevers en werknemers in geval van belangengeschillen het recht op collectief optreden, waaronder het stakingsrecht, toegekend. Nu derhalve aan gedetineerden het stakingsrecht niet toekomt en voorts de situatie in een penitentiaire inrichting geen ruimte laat voor massale acties gepaard gaand met het neerleggen van werk en het niet opvolgen van gegeven bevelen, waardoor immers op zich al de orde in de inrichting wordt verstoord, kon de directeur in redelijkheid besluiten tot het nemen van disciplinaire maatrege$\operatorname{len}^{2} \cdot{ }^{102}$

De Beroepscommissie achtte een boete op staking toelaatbaar, in die zin dat, nu de loonregelingen uitgaan van betaling per gehele dag, de gedetineerde die zijn arbeid door middel van een staking onderbreekt het loon voor een slechts gedee!telijk gewerkte dag kan worden onthouden. ${ }^{103}$

Kelk heeft naar aanleiding van deze jurisprudentie voor meer ruimte voor de werkstaking gepleit. Aan een korte 'politieke' protest-staking zou volgens hem enige erkenning kunnen toekomen. ${ }^{104} \mathrm{Hij}$ gaf als zijn mening te kennen dat de gedetineerde wat de inrichtingsarbeid betreft weliswaar noch de hoedanigheid van werknemer noch die van ambtenaar bezit maar dat hij evenmin als 'slaaf van de staat' mocht worden gezien. Verder vond hij dat het penitentiaire grondrecht op een humane, maatschappij-gerichte, bejegening vergde dat legitieme acties tot behoud van de humaniteit enige consideratie verdienen. Hij kwam tot de slotsom, dat collectieve werkstakingen van gedetineerclen zeker niet onder alle omstandigheden zouden mogen worden afgewezen. Hij achtte het echter ondoenlijk 
daarvoor voor de penitentiaire situatie wettelijke regels te ontwerpen. Kelk (die en passant vaststelde, dat de strafbaarheid van werkstakingen in veel Westeuropese landen reeds, gedurende de vorige eeuw is afgeschaft) noemde het een zeer zwak punt dat het de directie is, die hier als werkgever-contractant en tevens ais strafrechter optreedt. ${ }^{105}$

Op de opvatting van de Beroepscommissie dat gedetineerden geen stakingsrecht bezirten valt wel het een en ander af te dingen. Zonder aan werkende gedetineerden de status van ambtenaar of arbeidscontractant te willen of te kunnen toekennen, kan worden vastgesteld, dat gedetineerden werkzaam zijn in de publieke sector. Hun werkgevers zijn de directeuren van de strafinrichtingen en hun arbeid richt zich overwegend op produktie voor 's-Rijks dienst (art. 33 lid 1 BWG). Wil men gedetineerden zien als werknemers in de publieke sector, dan rijst de vraag in hoeverre het hun in die kwaliteit rechtens is geoorloofd om te staken. Men kan stellen dat zij dan in dezelfde positie verkeren als andere werknemers van de overheid (ambtenaren en arbeidscontractanten) ten aanzien van welke groepen de overheid in 1980 een voorbehoud maakte bij de goedkeuring van art. 6 vierde lid van het Europees Sociaal Handvest. ${ }^{106}$ Dat zou betekenen dat ook als gedetineerden als werknemers in de publicke sector zouden worden beschouwd hun geen recht op collectieve actie toe zou komen.

Omdat genoemd voorbehoud echter niet gevolgd werd door een wettelijke regeling met betrekking tot het recht op collectieve actie voor (bepaaide categorieën van) overheidspersoneel, heeft het gaandeweg aan kracht verloren en is de rechter ook aan het overheidspersoneel stakingsrecht gaan toekennen, ook al kumnen zij zich niet beroepen op artikel $6 \mathrm{ESH}$. Rood heeft het aldus geformuleerd: 'Intussen is door de rechtspraak algemeen aanvaard dat ook aan overheidspersoneel het hier besproken recht toekomt. Het verschil in rechtspositie tussen dat personeel en de collega's in de private sector komt vooral tot uiting in de fundering van dat recht. Zal in de private sector doorgaans gewezen worden op art. 6 Handvest, in de publieke sector zal eerder een beroep op algemene rechtsbeginselen voor die fundering moeten zorgen'. ${ }^{107}$

In deze optiek hebben gedetineerden art. 6 ESH helemaal nier nodig om hun recht op collectieve actie op te baseren en kunnen stakingen alleen rechtens ontoelaatbaar worden geacht als er sprake is van een ernstige verstoring van de orde en veiligheid in de inrichting. De tolerantiegrenzen zullen daarbij moeten warden getrokken door de beklag- en de beroepsrechter. In deze benadering zou her oproepen tot het organiseren van en het meedoen aan stakingsacties op zich niet meer mogen leiden tot tuchtrechtelijke sancties of regimaire maatregelen, maar zou slechts het voortzetten van stakingen tegen een verbod van de directie tot genoemcle sancties kunnen leiden. Het is dan de taak van de beklag- en de beroepsrechter om per geval uit te maken of een dergelijk verbod bij afweging van alle in aanmerking komende belangen en omstandigheden redelijk en billijk geacht kan worden. 
Het is niet zo dat het gevangeniswezen alleen maar punitief op stakingen reageert. $\mathrm{Er}$ is in het nabije verleden daarnaast ook wel inhoudelijk op de eisen ingegaan.

De aankondiging, dat er per 1 oktober 1977 in de gevangenis Schutterswei te Alkmaar (die toen voor langgestraiten bestemdi was) bij wijze van experiment een hoger loon verdiend kon worden, veroorzaakte een stakingsgolf onder gedetineerden in andere inrichtingen. Een stakingsoproep, gedaan door gedetineerden in het Groningse huis van bewaring, had zo'n overweldigend effect dat het loonexperiment subiet tot alle inrichtingen voor langgestraften werd uitgebreid. ${ }^{108}$

De minister van Justitie schreef op 13 oktober 1977 aan de directeuren van de penitentiaire inrichtingen het volgende: 'De door de gedetineerden gehouden werkstakingen hebben mij tot dusverre geen aanleiding gegeven tot ingrijpen; mede omdat in de inrichtingen geen ordeverstoringen platstsonden'. Hij kondigde een uitbreiding van de experimentele loonregeling aan per 14 november 1977. Zij zou dan voor alle inrichtingen voor langgestraften gaan gelden. De minister in nog steeds dezelfde brief: "Van de gederineerden verwacht ik dat zij, voorzover nog niet is gebeurd, onmiddellijk de normale werkzaamheden hervatten. Ik acht voortduren van de werkstakingen niet aanvaardbaar'. ${ }^{109}$

Een tweede geva! waarin een landelijke werkstaking van gedetineerden - naast punitief ingrijpen overigens - een inhoudelijke reactie van de departementsleiding teweeg bracht deed zich begin 1985 voor. Op initiatief van gedetineerden in het Groningse huis van bewaring werd vanaf februari van dat jaar in diverse strafinrichtingen gestaakt voor de invoering van het minimumloon voor werkende gedetineerden. ${ }^{110}$ De staatssecretaris richtte zich daarop per brief direct tot de gedetineerdencommissie van het huis van bewaring te Groningen en legde daarin tamelijk uitvoerig uit waarom er van de invoering van een minimumloon geen sprake kon zijn. Uit het epistel viel overigens niet op te maken of werkstakingen door gedetineerden door het departement ongecorloofd werden geacht. ${ }^{111} \mathrm{De}$ directies blijven in ieder geval op stakingen reageren met straf. Zo werd een werkstaking uit protest tegen vermeende discriminatie van Surinaamse gedetineerden bestraft met 3 dagen afzondering op eigen cel omdat er voldoende andere mogelijkheden zouden zijn geweest deze klacht onder de aandacht van de leiding te brengen. ${ }^{12}$

\subsection{Medezeggenschap}

In veel gevallen kan de werkstaking van gedetineerden worden gezien als een uiterste middel om met de gestichtsleiding in gesprek te komen over door de autoriteiten onderdrukte of genegeerde problemen in de inrichting. Tot nu toe ontbreekt er een reële overlegstructuur waarbinnen gedetineerden op geregelde tijden over essentiële zaken met de directies kunnen overleggen. Ondernemingsraden, waarin gedetineerden zitting hebben, kent het penitentiaire recht niet. In een aantal inrichtingen functioneren weliswaar zogenaamde gedetineerden(overleg)commissies, waarin door de directie 'goedgekeurde' en dus niet al te kritische ge- 
detineerden zitting hebben, maar die commissies zijn schoolvoorbeelden van repressieve tolerantie. Over huishoudelijke kwesties mag van alles worden gezegd. Over onderwerpen die het directiebeleid werkelijk kunnen raken moet worden gezwegen. ${ }^{113}$ De overlegcommissies bestaan bij de gratie van de directies. Elke wettelijke basis ontbreekt eraan. In geen enkele circulaire wordt hun (voort)bestaan gegarandeerd.

Weliswaar luidt artikel 16 GM: 'De directeur bevordert het overleg en de onderlinge gedachtenwisseling in het gesticht', maar deze regel is slechts uitgewerkt voor de aan de inrichtingen verbonden ambtenaren. Paragraaf 7 van Hfdst. II HHR-HvB is gewijd aan de overlegstructuur binnen de inrichting. Daarin speelt de grootste groep anwezigen, de gedetineerden, geen enkele rol. $\mathrm{Zij}$ moeten het voorlopig hebben van eigen initiatief. Als zij willen mogen zij belangenverenigingen oprichten voor onderling overleg over zaken die hun inrichtingsleven betreffen. De directies moeten daar enige ruimte voor verschaffen maar zijn niet verplicht om met (besturen van) dergelijke verenigingen te overleggen. Over deze kwestie is een aantal keren geprocedeerd.

In 1980 eiste de Vereniging van Gedetineerden van het huis van bewaring te Rotterdam in Kort Geding onder meer dat de President de directeur van die inrichting zou gebieden om overleg met haar bestuur te voeren, zo vaak de vereniging daarom vroeg. ${ }^{114}$ Hoewel het in die procedure niet tot een vonnis is gekomen, omdat de directie met de vereniging op een aantal andere punten tot een vergelijk kwam, is die eis door een aantal andere gedetineerdenverenigingen overgenomen en uitgeprocedeerd. Zo eiste de Vereniging van Gedetineerden in het huis van bewaring II te Haarlem in Kort Geding dat de directie rechtstreeks en op gezette tijden met het bestuur van de vereniging overleg voerde. In eerste aanleg werd (onder meer) deze vordering door de President van de Haarlemse rechtbank toegewezen. Het Amsterdamse Hof wees deze eis in appel echter af omdat een recht op een dergelijk overleg niet uit het recht van vereniging en vergadering voortvloeide. In cassatie is door de Vereniging niet tegen dat oordeel van het Hof opgekomen, zodat de Hoge Raad zich over dat punt niet heeft behoeven uit te laten. ${ }^{115}$

Hoewel een directeur dus rechtens niet gehouden is om met aldus georganiseerde gedetineerden te overleggen gebeurt dat in de praktijk wel, zij het niet rechtstreeks maar via vertegenwoordigers van de directie. Hoe wankel dergelijke constructies zijn blijkt uit een uitspraak van de Amsterdamse rechtbankpresident in een Kort Geding, dat door de gedetineerdencommissie (Gedeco) van het huis van bewaring 'De Havenstraat' te Amsterdam tegen de staat werd gevoerd om een besluit van de directeur, waarin deze eerder toegekende overleg-faciliteiten had gehalveerd, ongedaan te maken. De President vond deze beslissing - marginaal getoetst - niet onredelijk. ${ }^{116}$

Bij het ontbreken van een gestructureerd overleg tussen gedetineerden en directie lijkt de ontwikkeling van een medezeggenschapsrecht voor deze groepering een illusie. Ondenkbaar is een ontwikkeling in die richting allerminst. In een 
onder auspiciën van de Raad van Europa in 1986 gepubliceerde studie met de naam 'Les régimes des institutions pénitentiaires" wordt vrij uitvoerig ingegaan op de vraag hoe gedetineerden meer dan tot nu toe kunnen participeren in het gevangenisregiem. ${ }^{117}$

Het rapport wijst erop dat 'participatie' in het bedrijfsleven hèt middel is om een evenwicht tot stand te brengen tussen werknemers en bedrijfsleiding. Ook al is het gevangeniswezen niet zonder meer met het bedrijfsleven te vergelijken, toch kan introductie van het begrip participatie in het beheer van penitentiaire inrichtingen een belangrijk middel zijn bij de bestrijding van de schadelijke psycho-sociale gevolgen van gevangenschap. Natuurlijk stelt, aldus nog steeds dit rapport, het penitentaire kader grenzen aan de medezeggenschap van gedetineerden, maar in een aantal opzichten zou deze toch kunnen worden gerealiseerd. Men kan verwachten dat het verantwoordelijkheidsgevoel van gedetineerden kan worden gestimuleerd als van hen wordt gevraagd de gang van zaken in de inrichting tot op zekere hoogte mede te bepalen. Volgens het rapport zouden gedetineerden inspraak moeten hebben als het gaat om zaken als onderwijs en vorming, sport en de ontwikkeling van technische en creatieve vaardigheden. In inrichtingen, waar de sfeer daarnaar is, zouden gekozen gedetineerden-vertegenwoordigers met de directie moeten kunnen vergaderen om detentie-perikelen te bespreken en potentile conflicten de wereld uit te helpen. Het gevangeniswezen zou kunnen profiteren van tal van medezeggenschapsmodellen die in het bedrijfsleven zijn ontwikkeld.

Het rapport van de Raad van Europa heeft tot nu toe geen merkbare invloed gehad op de Nederlandse penitentiaire praktijk. Daar wordt alleen met gedetineerden als groep overlegd als het niet anders kan. Van hen wordt vooral verwacht dat ze luisteren naar wat hen opgedragen wordt. Als men het met bepaalde zaken niet eens is, dan is men noodgedwongen op het klachtrecht gemodelleerde, dus op een conflictmodel, aangewezen en wordt een forum betreden dat ten enenmale niet geschikt is om problemen tussen bewaakten en bewakers op te lossen.

Men kan zich afvragen of de ten behoeve van het Nederlandse bedrijfsleven ontwikkelde participatie- en inspraak-constructies model kunnen staan bij het uitwerken van een medezeggenschapsrecht voor gedetineerden. De eventuele introductie van een daarmee vergelijkbare vorm van participatie kan echter moeilijk beperkt blijven tot de arbeidsrechtelijke aspecten van de detentiesituatie. Daarvoor vloeien de belangrijkste kanten van het leven in een 'totale inrichting' ${ }^{319}$, het wonen, werken en recreëren, teveel in elkaar over. Medezeggenschap van gedetineerden tot een van deze aspecten, de arbeid, te beperken zou al snel frustrerend werken.

De neiging van directies van strafinrichtingen om zich steeds meer als managers van bedrijven te beschouwen ${ }^{119}$ brengt met zich mee dat participatie van de 'inwonende' arbeiders in volle omvang op de agenda van gevangeniswezen moet komen. 
Het ligt voor de hand om te kijken of er naar analogie van de Wet op de Ondernemingsraden (WOR) penitentiaire medezeggenschapsregelingen te construeren zijn. ${ }^{120}$

De ondernemingsraad, zoals in de WOR bedoeld, kan worden gezien als een personeelsvertegenwoordiging die (het bestuur van) de onderneming adviseert over economische aangelegenheden en medebeslissingrecht heeft in sociale aangelegenheden. Een van de belangrijkste xechten van een ondernemingsraad is, dat zij door de ondernemer (tijdig) wordt geïnformeerd over de kwesties waarover geadviseerd en medebeslist kan worden.

In de detentiesituatie zou aan medezeggenschap vorm gegeven kunnen worden door het creëren van een gedetineerdenraad met recht van advies betreffende de aard en uitvoering van het regime en medebeslissingsrecht over sociale aangelegenheden. De arbeid zou dan onder de term 'sociale aangelegenheden' moeten vallen.

Een complicatie binnen de 'gevangenisbedrijven' is dat de directie daar met twee antagonistische categorieèn werknemers te maken heeft: de gedetineerden en het inrichtingspersoneel. De belangen van de overheidsdienaren lopen uiteraard allerminst parailel met die van de gedetineerden. Het inrichtingspersoneel zal dan ook via eigen ambtelijke medezeggenschapsconstructies als dienstcommissies hun inspraak moeten blijven reguleren. Het is hooguit denkbaar vertegenwoordigers van alle groeperingen -directie, personeel en gedetineerden - in een gestichtsraad bijeen te brengen.

Er is bij het ontwerpen van de Wet op de Ondernemingsraden niet aan gedacht dat penitentiaire inrichtingen - gezien de centrale functie van de arbeid daarin - tevens als ondernemingen en dat gedetineerden tevens als werknemers kunnen worden gezien. Een rechtstreeks beroep door gedetineerden op die wet, met de bedoeling om ondernemingsraden van de grond te krijgen ligt daarom niet voor de hand. Deelnemers aan een conferentie over 'Die Gewerkschaften und die ökonomische und soziale Situation der Gefangenen und Entlassenen', die in april 1975 te Bielefeld gehouden is, hielden het creëren van een dergelijke medezeggenschapsvorm binnen strafinrichtingen voor absoluut theoretisch. ${ }^{121}$ Toch js het niet volstrekt ondenkbaar dat onveroordeelden die in huizen van bewaring vrijwillig aan de arbeid deelnemen medezeggenschap claimen op basis van de WOR. Gaat men er van uit dat de arbeidsverhouding tussen preventieven en directie alle trekken van een arbeidsovereenkomst heeft, dan kan het huis van bewaring worden beschouwd als een onderneming in de zin van artikel 1 van de WOR, nl. als een 'in de maatschappij als zelfstandige eenheid optredend organisatorisch verband waarin krachtens arbeidsovereenkomst arbeid wordt verricht'. De staat is dan ondernemer in de zin van datzelfde artikel, nl. als 'de publiekrechtelijke rechtspersoon die een onderneming in stand houdt waarin uitsluitend of nagenoeg uitsluitend krachtens arbeidsovereenkomst arbeid wordt verricht'. De directie is dan de 'bestuurder', die in artikel 1 WOR wordt gedefinieerd als 'hij die 
alleen dan wel tezamen met anderen in een onderneming rechtstreeks de hoogste zeggenschap uitoefent bij de leiding van de arbeid'. Een proefprocedure op basis van art. 36 WOR over de vraag of die - als ondernemer - ondernemingsraden in zijn huizen van bewaring in moet stellen lijkt interessant, al was het maar om te vernemen met welke argumentatie zo'n eis zou worden afgewezen.

Het valt echter nauwelijks te verwachten dat gedetineerden een aanvaardbare medezeggenschapsregeling zullen krijgen zolang dat nog niet voor het inrichtingspersoneel het geval is: ' $(.$.$) juist aan medezeggenschap lijken gevangenisdi-$ recreuren geen behoefte te hebben. Ze lossen hun zaakjes liever binnenskamers op zonder inmenging van "derden", aldus De Clerck in een artikel in het vakbondsblad van de AbvaKabo ${ }^{122}$, waarin de moeilijkheden worden beschreven die de dienstcommissies van het gestichtspersoneel ondervinden bij pogingen om hun medezeggenschapsrecht te realiseren.

Ook al zou men. de WOR niet op werkende onveroordcelden van toepassing achten, dan moet toch worden vastgesteld dat het volstrekt ontbreken van enige medezeggenschapsregeling in strijd is met artikel 19 lid 2 van de Grondwet dat luidt: 'De wet stelt regels omtrent de rechtspositie van hen die arbeid verrichten en omtrent hun bescherming daarbij alsmede omtrent medezeggenschap'.

\section{3" Gedetineerden en vakbonden}

Het behoeft nauwelijks betoog dat het opkomen voor de rechten van de werkende gedetineerde geen prioriteit bij de gevestigde vakbonden geniet. Het punt komt in hun programma's niet voor. Áls een bond zich al met gevangeniswezen bemoeit is dat alleen maar om daar de belangen van het bewarend personeel te behartigen. ${ }^{123}$

Zich van deze realiteit maar al te sterk bewust heeft de eigen organisatie van (ex-) gedetineerden bij tijd en wijle gepoogd zichzelf als vakbond te profileren. De in 1972 opgerichte Belangengroepering Wetsovertreders (BWO) beschreef zichzelf in 1975 als 'een soort vakbond dus, net zoals het gevangenispersoneel een vakbond heeft', toen zij pleitte voor een CAO voor alle gedetineerden die werkzaamheden verrichten. ${ }^{124}$ Een jaar later meldde diezelfde groepering: 'Het ligt in de bedoeling de organisatie van de BWO zó in te richten dat ze als een soort vakbond kan werken. En dan niet als een "gewone" vakbond, maar meer in de geest van bijv. de VVDM en de Bond voor minderjarigen'. ${ }^{125}$

In 1981 werd de roep in eigen gelederen om de organisatie tot een vakbond om te smeden luider ${ }^{126}$ en op 27 mei 1982 presenteerde de BWO zich inderdaad als een vakbond, met als een van de eisen het recht op minimumloon. In de staturen werd met zoveel woorden de werkstaking genoemd als 'dwangmiddel' om binnen de inrichtingen actie te voeren om de eisen ingewilligd te krijgen. ${ }^{127}$ Het streven van de BWO om als echte vakbond te gaan functioneren leidde van meet af aan bij hen die daardoor de activistische inslag van die bond in het gedrang zagen komen tot kritiek: 'Als we op dezelfde manier gaan werken als de andere 
groepen, die het leven in de bajes proberen te verbeteren of het hele strafrechtssysteem bekritiseren, dan kunnen we beter de BWO opheffen en opgaan in die reeds bestaande organisaties', aidus "Theo" (Metz; gdj) in die dagen bestuurlid van de BWO. ${ }^{128}$ In een in 1984 tijdens zijn voorzitterschap gepubliceerde beleidsnota werd het karakter van de BWO zó geschetst: 'De BWO is vooral een actiegroep en die benaming hangt samen met de wijze waarop de BWO functioneert. Dat betekent dat het niet lang en slepend overleg is waarlangs de BWO haar doel wil bereiken, maar dat het gaat om het vormen van een macht aan de hand van heel concrete bezwaren tegen her gevangenissysteem'. ${ }^{129}$ Die angst voor een 'reformistisch' verwateren van de BWO is niet bewaarheid. Een echte vakbond is die club nooit geworden, vooral door niet op te lossen continuilteitsproblemen in de leiding waardoor beleidsvoornemens nooit echt tot uitvoering konden kornen. Een ontwikkeling zoals bij de VVDM heeft plaatsgevonden, van actiegroep, via belangenvereniging tot bij het FNV aangesloten vakbond, heeft er voor de BWO tot nog toe niet in gezeten. ${ }^{130}$

Het heeft er één moment op geleken dat het initiatief van de andere kant zou komen. In 1977 kopte het reclasseringsblad blad KRI: 'Vakbeweging ontdekt gedetineerden'. Naar aanleiding van een staking van gedetineerden dat jaar had staflid Madlener aangekondigd dat de vakbeweging zich meer met het lot van de gedetineerden zou gaan bemoeien. Tegenover KRI concludeerde deze functionaris dat de controle op de werkomstandigheden in de justitiële inrichtingen te kort schoot en dat de rechtspositie van gedetineerden in sociaal-economisch opzicht nog steeds slecht genoemd moest worden. Gebrek aan mankracht en middelen maakten het de FNV niet gemakkelijk adequaat op de problemen van gedetineerden te reageren, aldus Madlener, die overigens vaststelde dat er historisch een gespannen verhouding tussen vakbeweging en gevangenenarbeid bestond. ${ }^{131}$ Bij deze goede voomemens is het echter gebleven. Contacten tussen de gevestigde vakbonden en gedetineerden zijn tot nu toe op de vingers van één hand te tellen.

Op 19 november 1982 schreef de AbvaKabo, aan de vooravond van acties van het gestichtspersoneel, de volgende brief aan de gedetineerden van de Bijlmerbajes (Penitentiair Connplex 'Overamstel' te Amsterdam):

Het personeel, werkzaam bij het Gevangeniswezen in Nederland zal zijn ongenoegen en ontevredenheid ten opzichte van dit Kabinet en de minister van Justitie in het bijzonder uiten op maandag 22 november a.s. door het voeren van een stiptheidsactie in het Penitentiaire Complex Overamstel.

Wij gevoelen de behoefte $u$ hiervan in kennis te stellen, te meer omdat mogelijke effecten van deze actie u tijdens uw detentie zullen treffen.

Wij willen u op deze wijze hiervoor om begrip vragen, hoewel wij beseffen dat een appèl als deze (lees: 'dit'; gdị) voor u moeilijk zal zijn.

Echter, wij vertrouwen erop dat, indien onze eisen, die wij aan het Kabinet en de minister van Justitie hebben kenbaar gemaakt, worden ingewilligd, een wissel- 
werking zullen hebben, die ook in de situatie, waarin gedetineerden zich tijdens detentie bevinden, verbetering zal betekenen.

Wij zeggen u nu reeds dank voor uw solidaire opstelling.

Met vriendelijke groeten, namens de Bond van Personeel in Straf- en aanverwante Gestichten en AbvaKabo,

(W. van Keulen)

Bestuurder

Het antwoord, dat twee gedetincerden de bond stuurden ${ }^{132}$ geeft een idee van de breedte van de kloof tussen beider leefwerelden en belangensferen:

Amsterdam, 21 november 1982

Beste mevrouw/ meneer Van Keulen,

Vandaag ontvingen wij een brief die u ons op 19 november jl. stuurde namens de beide vakbonden Abvakabo en Bond van Personeel in Straf- en aanverwante Gestichren. Daarin stelde u ons in kennis van de maandag 22 november a.s. uit te voeren stiptheidsacties.

Het is jammer dat $u$ in zulk moeilijk Nederlands schreef, dat wij ons afvroegen hoeveel gedetineerden u werkelijk bereikt hebt.

$\mathrm{U}$ vroeg ons in die brief om begrip voor uw actie, onder andere omdat wij daardoor mogelijkerwijs getroffen zouden kunnen worden. Hoewel u beseft dat dar voor ons wel eens moeilijk zou kunnen zijn, besluit u met een voorbarige dankzegging voor onze 'solidaire' opstelling.

Zo'n eenzijdige 'bejegening' van gedetineerden door bewakend personeel is tekenend voor de omgang met het gestichtspersoneel, zoals wij die dagelijks ervaren. Er wordt voor ons gedacht, $u$ stelt ons voor een voldongen feit. De solidariteit, waar $\mathrm{u}$ in uw brief gemakshalve maar van uitgaat, is op die wijze afgedwongen solidariteit.

Van veel waarde voor uw actie kan dat niet zijn.

Hoe kunt $U$ ware solidariteit van ons verwachten? $U$ hebt uw eisen niet aan ons bekend gemaakt en hebt ons niet uitgelegd hoe eventuele inwilliging daarvan voor onze situatie een verbetering kan betekenen, zoals u schrijft. Hoe kunt u die solidariteit verwachten als $u$ ons niet bij de voorbereiding van de actie betrokken hebt?

We zijn diep teleurgesteld over de manier waarop u ons hebt geconfronteerd met uw actie en hebt nagelaten ons tijdig bij de voorbereidingen van uw actie te betrekken.

Het materiele beleid van regering en minister van justitie schiet inderdaad ernstig tekort. Veel daarvan komt doordat (...) de justitiedoelstellingen humanisering, 
bejegening en resocialisering steeds het onderspit delven tegen. het primitieve doel ons vooral op te sluiter..

Ons lekker makkelijk weg te stoppen, zich niet bekommerend om het feit dat niemand van ons daar beter van wordt en de samenleving dus ook niet.

Integendeel. Bezuiniging doet inderdaad vrezen dat dat allemaal nog erger zal worden en wij nog minder mogelijkheden krijgerı om ons zinvol op een terugkeer naar de samenleving voor te bereiden.

Wij hopen dat u hiertegen. maandag zult strijden. In dat geval wensen wij u sterkte en succes.

Toch lijkt de manier waarop u ons over deze: (actie) hebt ingelicht een bewijs dat de verbetering van onze detentiesituatie evenzeer een mentaliteitsverbetering van het gevangenispersoneel behoeft.

Zodat gedetineerden misschien eens als volwassenen behandeld worden en niet voortdurend als kinderen met allerlei eenzijdige beslissingen worden geconfronteerd.

Wiị zịn benieuwd naar uw antwoord.

$\begin{array}{ll}\text { Robert Burghout } & \text { HVB Het Schouw, pav. } 3 \\ \text { Paul Vertegaal } & \text { Wenckebachweg 48, } \\ & \text { 1096 AN A.'dam }\end{array}$

De contactarmoede tussen de organisaties van de 'vrije' arbeiders en hun gedetineerde broeders en zusters werd nog eens gedemonstreerd toen in 1984 vrouwelijke gedetineerden, die staakten tegen door justitie aangekondigde bezuinigingsmaatregelen, bij de bonden om steun ankiopten. Weigerde de afdeling Amsterdam elke verbale of financiële steun, het hoofdbestuur van de AbvaKabo keurde de staking zelfs af. De FNV gaf het verzoek om steun door aan het vrouwensecretariaat dat de stakende vrouwen tenminste nog een briefje stuurde. ${ }^{133}$

Tussen de bonden en gedetineerden is het nooit wat geworden. Maar waarom zouden de bonden zich ook voor de gedetineerden interesseren? In hoeverre zoli de manier waarop de vrijheidsstraf ten uitvoer wordt gelegd. in de ogen van de leden überhaupt iets met de kernthema's van de officiële vakbondspolitiek te maken kunnen hebben?

Schumann ${ }^{134}$ onderscheidt drie redenen waarom de bonden zich wèl voor de strafexecutie zoudien moeten interesseren. Ten eerste zijn de meeste (ex-)gedetineerden arbeider; ten tweede houden gevangenissen onmenselijke arbeidsvoorwaarden in stand en ten derde zijn de belangen van het bewarend personeel objectief beschouwd het beste gediend met een executie-beleid dat zich de normalisering van de levensomstandigheden van de gedetineerden ten doel stelt. Schumann moet echter vaststellen dat de houding van de (Duitse) bonden ten aanzien van de strafexecutie zich in niets onderscheidr van die van de rest van de bevolking. Het is, zegt deze schrijver, de vraag of vakbondsleden niet zelfs nega- 
tief zouden reageren als de. Deutscher Gewerkschaftsbund (DGB) of bepaalde individuele bonden zich met de strafexecutie zouden gaan bemoeien. Scholing van de (ondernemingsraads-)leden zou volgens hem een voorwaarde zijn voor een vakbondsengagement op dit terrein. Een duidelijke stellingname van de bond voor de invoering van sociale zekerheidsrechten en normaal loon voor gedetineerden zou een sterke signaalwerking hebben, zo zegt Schumann. Hij acht het echter onwaarschijnlijk dat de bond zich voor deze kwestie sterk zal willen maken.

Als belangrijkste oorzaak van het feit, dat de bonden geen invloed hebben binnen de strafinrichtingen noemde Schumann de omstandigheid dat algemeen wordt aanvaard dat gevangenen geen werknemers zijn en ook niet over een daarmee gelijk te stellen rechtspositie beschikken en daarom ook geen vakbondsvrijheid bezitten. Dat is echter een onjuiste veronderstelling omdat op grond van een uitspraak van het Bundesverfassungsgericht van 14 maart 1972 de grondrechten van gedetineerden alleen bij wet kunnen worden beperkt. Lidmaatschap van een vakbond is dus mogelijk, aldus Schumann, ook al is de arbeidsverhouding in publiekrechtelijke en niet in civielrechtelijke regels neergelegd.

Deze auteur vindt dat er met ledenwerving binnen de inrichtingen moet worden begonnen. Ook al stelt de detentie grenzen aan de uitoefening van het lidmaatschap, iets is er toch wel mogelijk. Het zou volgens hem goed zijn als vakbondsleden zich kandidaat stelden voor de commissies van toezicht om zo contact te kunnen hebben met de (georganiseerde) gedetineerden. Dat zou vooral de arbeidsomstandigheden binnen de muren ten goede kunnen komen. Er zijn echter geen tekenen die er op wijzen dat de Duitse bonden zich zouden willen inzetten voor de gedetineerde arbeiders.

Het gebrek aan interesse bij de vakbonden is door Leder verklaard uit het feit dat hun leden precies dezelfde vooroordelen koesteren als de rest van de samenleving. Hij wijst op een geval waarin het districtsbestuur van de vakbond voor overheidspersoneel (ÖTV) te Bad Homburg Friedberg een aanvraag voor het lidmaatschap van twee gedetineerden afwees met het argument dat er bij hen geen sprake was van een vrijwillig dienstverband in de zin van de vakbondsstatuten. ${ }^{135}$

Van een dergelijke negatieve ballotage door Nederlandse vakbonden zijn geen gevallen bekend, maar misschien hebben gedetineerden ook nooit gevraagd om in hun hoedanigheid van gedetineerde/arbeider als lid te mogen worden ingeschreven. Als een aanmerkelijke groep gedetineerden inschrijving zou vragen zou dat de bonden vermoedelijk in een lastig parket kunnen brengen, omdat belangenbehartiging van inrichtingspersoneel en gedetineerden tegelijk onvermijdelijk tot conflicten met de achterban zal leiden. De bonden zullen nooit belangen van de opgeslotenen laten prevaleren boven die van de ambtenaren, die hen opgesloten houden. Daarvoor behoren de bonden waarschijnlijk teveel tot de gevestigde orde en hebben zij te veel belang bij het voortbestaan van het huidige penitentiair systeem. Revolutionair elan van die kant te verwachten is een illusie. De Franse gedetineerde Livrozet heeft dat scherp tot uitdrukking gebracht in zijn kritiek op 
het gebrek aan solidariteit van de CGT (Conféderation Générale du Travail) en PCF (Parti Communiste Français) met het lot van de gedetineerden als deel van het proletariaat. Hij hield het ervoor dat deze clubs collaboreerden met het onderdrukkingsapparaat van de bourgeoisie. Naar zijn smaak mochten bewaarders niet met gewone werknemers over één kam geschoren worden. Dat de ene arbeider de andere opsloot omdat de laatstgenoemde zijn baas bestolen heeft kon volgens hem niet door de beugel. Men kan volgens Livrozet nu eenmaal niet voor Justitie werken en solidair zijn met het proletariaat. ${ }^{136}$

\subsection{Arbeidsomstandigheden - arbeidstijden}

Hoewel tot nog toe niemand de werkende gedetineerden als arbeider in civielrechtelijke zin wil zien lijkt, via de omweg van het arbeidsomstandighedenrecht, enige kentering bespeurbaar. Bij de vernieuwing van enkele onderdelen van dat specifieke rechtsgebied blijkt de gedetineerde wel degelijk als 'werknemer' te worden erkend.

Zo is de Arbeidsomstandighedenwet 1980 (Arbo-wet), ondanks aanvankelijke principiële en praktische bezwaren van de ministers van Sociale Zaken en Werkgelegenheid en Justitie ${ }^{137}$ daartegen, óok van toepassing op justitiële inrichtingen. Wel kan de wet geclausuleerd worden. Artikel 2 lid 4 Arbo-wet luidt namelijk: 'Bij of krachtens algemene maatregel van bestuur kunnen, met inachtneming van het belang van de beveiliging van gestichten als bedoeld in de Beginselenwet gevangeniswezen (Stb. 1951, 596) en de rijksinrichtingen voor kinderbescheming, met betrekking tot arbeid in bovenbedoelde gestichten en inrichtingen regelen worden gesteld welke afwijken van het bij of krachtens deze wet bepaalde of strekken ter aanvulling daarvan (...)'.

Over een concept van zo'n algemene matregel van bestuur (a.m.v.b.) is eind 1988 door de Arbo-raad aan de staatssecretaris van Sociale zaken en Werkgelegenheid advies uitgebracht. ${ }^{138}$

In de bij het concept-a.m.v.b. behorende Nota van toelichting was de vraag in hoeverre ten aanzien van gedetineerden sprake is van arbeid in de zin van de Arbo-wet aldus beantwoord: 'In het algemeen kan worden gesteld, dat de wet van toepassing is indien de geinstitutionaliseerden werkzaamheden verrichten in de in de inrichting aanwezige werkplaatsen of als zij in het kader van arbeid op cel, therapie, opleiding, recreatie of vorming, in de inrichtingen gebruik maken van gereedschappen, machines of andere hulpmiddelen die gevaar kunnen opleveren voor hun veiligheid, gezondheid of welzijn'. In het licht van artikel 1 Arbowet zou er, aldus de Arboraad, voor de duidelijkheid in die Nota van Toelichting op kunnen worden gewezen dat het gaat om georganiseerde activiteiten, die volgens het regiem onder enigerlei vorm van direct toezicht plaatsvinden.

Invoering van de a.m.v.b. zou volgens artikel 10 ervan onder meer tot gevolg hebben dat directeuren van strafinrichtingen 'zoveell mogelijk' samen dienen te werken in het behartigen van de zorg voor de veiligheid, de gezondheid en het 
welzijn binnen de inrichting. Hierin week het concept-a.m.v.b. weliswaar af van artikel 13 van de Arbowet, die zo'n samenwerking verplicht stelt, maar toch gaf het gedetineerden in beginsel een 'recht' op overleg met de directie over arbeidsomstandighedenkwesties. 'Nu kan', zegt Geers, 'het belang van deze bepaling wel gerelativeerd worden. Immers, zo geformuleerd, is zij louter een expressie van een vooral normatief bepaald uitgangspunt, dat de werkgever en werknemers in het algemeen zouden moeten samenwerken. De opdracht krijgt eerst praktische betekenis door de rechten, bevoegdheden, faciliteiten, overige verplichtingen en organisatorische voorzieningen die de tot samenwerking verplichte partners krijgen'. Hiermee hangt volgens Geers samen dat het woord 'werknemers' in de tekst niet betekent, dat de werkgever moet overleggen en samenwerken met iedere werknemer afzonderlijk, maar met de werknemers als collectiviteit, met name de ondernemingsraad. ${ }^{139}$

Zo noopt een betrekkelijk vreemde eend in de penitentiair-rechtelijke bijt als de Arbo-regelgeving het gevangeniswezen ertoe om de gedetineerden als groep als gesprekspartner te erkennen.

Een andere consequentie van de Arbeidsomstandighedenwet is dat de Arbeidsinspectie (thans: I-SZW) de bevoegdheid krijgt om naar believen de penitentiaire inrichtingen te bezoeken ter controle op de naleving van die wet. $\mathrm{Zij}$ is bevoegd desnoods het werk stil te doen leggen en kan zodoende op dit terrein de absolute zeggenschap van de directies te doorbreken. De werknemers/gedetineerden krijgen het recht om (met behoud van loon) het werk te onderbreken als dat ernstig gevaar voor personen oplevert. Deze mogelijke inbreuken op de autonomie van de gestichtsdirecties joegen de Centrale Raad voor Strafrechtstoepassing (CRS) de schrik op het lijf. Dit advies-orgaan schreef aan de staatssecretaris van Justitie het aanvechtbaar te vinden dat arbeid in gevangenissen en huizen van bewaring wordt beschouwd als arbeid in de zin van de Arbo-wet: 'Het arbeid verrichten in een inrichting makt deel uit van het regiem. Dat is niet hetzelfde als het verrichten van arbeid in de samenleving'. De CRS meende dat toepassing van de Arbowet op de arbeid van gedetineerden zelfs 'regelrecht regiemsondermijnend' kon uitwerken. Vooral de op artikel 38 Arbowet gebaseerde bevoegdheid van de gedetineerde werknemer om het werk te onderbreken en de onderbreking voort te zetten, indien en zolang naar zijn redelijk oordeel gevaar voor personen aanwezig is en de Arbeidsinspectie niet tijdig op kan treden, leidde de CRS tot het idee "dat hiermee de gedetineerde een handvat wordt gegeven via de arbeidssituatie in het penitentiaire regiem storend te kunnen manoeuvreren'. De in artikel 10 van het concept-a.m.v.b. neergelegde opdracht aan de directeur om zoveel mogelijk met de gedetineerden samen te werken, achtte de CRS een voorbeeld van onvoldoende rekening houden met de positie van het ministerie en met die van de directeuren. Dat door invoering van het ontwerp niet aan de inrichting verbonden ambtenaren van de arbeidsinspectie vrije toegang zouden krijgen en zouden kunnen interveniëren in het regiem betekende volgens de CRS dat de volledige verantwoordelijkheid van de minister voor het regiem wordt aangetast. 
Vooral om deze redenen meende de voorzitter van de sectie gevangeniswezen van de CRS, Van Veen, de staatssecretaris van Justitie te moeten adviseren zich nog eens over dit ontwerp-a.m.v.b. te beraden. ${ }^{140}$

Het op 1 september 1990 in werking getreden Arbeidsomstandighedenbesiuit Justitiële Rijksinrichtingen ${ }^{14 i}$ kwam ten dele aan de genoemde bezwaren tegemoet. Wat uit het concept gehandhaafd bleef was de inspanningsverplichting voor de directeur om zoveel mogelijk met de gedetineerden samen te werken. De huidige redactie van artikel 10 van het besluit luidt aldus:

'In afwijking van het bepaalde in artikel 13 van de Arbeidsomstandighedenwet werken de directeur van de inrichting en de gedetineerden of jeugdigen zoveel mogelijk samen in het behartigen van de zorg voor veiligheid, de gezondheid en het welzijn in verband met de arbeid van gedetineerden en jeugdigen binnen de inrichting.'

Volgens De Waal sloot deze formulering aan bij de praktijk waarin in veel inrichtingen reeds een vorm van overleg was ontwikkeld tussen gedetineerden en directie. Zijns inziens zou de samenwerking over arbeidsomstandigheden hierbij kunnen aansluiten. ${ }^{142}$ Intussen blijkt echter uit niets dat er een vorm van overleg over arbeidsomstandigheden tussen gedetineerden en directies is ontwikkeld.

Ondanks de bezwaren van de CRS mag de Arbeidsinspectie aanwijzingen geven, eisen stellen en het werk desnoods stilleggen en mogen gedetineerden het werk desnoods onderbreken, dit alles echter alleen: "voorzover geen inbreuk wordt gemaakt op de orde, de veiligheid of de goede gang van zaken in de inrichting of op het ongestoorde verloop van de tenuitvoerlegging van de vrijheidsbeneming of andere beperkingen die krachtens de wet door de daartoe bevoegde autoriteiten zijn opgelegd', aldus art. 12 van het Arbeidsomstandighedenbesluit Justitiële Rijksinrichten.

Het belang van het Arbeidsomstandighedenbeshuit Justitiële Rijksinrichtingen had kunnen blijken in het geval waarin een gedetineerde uit zijn baantje als schilder in de huisdienst werd gezet ondat hij niet zo maar op 5 meter hoogte schilderwerk wilde verrichten. Helaas beriep klager zich niet op Arbo-wet en dacht de $\mathrm{BrC}$ er niet aan deze regelgeving in haar overwegingsgen te betrekken. De $\mathrm{BrC}$ meende uit eigen hoofde te kunnen vaststellen dat het uitvoeren van schilderwerk op die hoogte, vanaf een ladder zonder bijzondere veiligheidsvoorzieningen, "naar objectieve maatstaven beschouwd' niet zodanig gevaarlijk of anderszins onverantwoord geacht kon worden dat in het algemeen van een gedetineerde niet in redelijkheid verlangd kon worden dergelijke werkzaamheden uit te voeren. ${ }^{143}$ In een latere uitspraak werden het Arbeidsomstandighedenbesluit Justitiële Rijksinrichtingen, de Arbeidsomstandighedenwet en het Veiligheidsbesluit voor Fabrieken of Werkplaatsen 1938 voor het eerst uitdrukkelijk als rechtsbronnen gebruikt bij de beoordeling van een klacht van een gedetineerde over het moeten werken met een zijns inziens onveilige snijmachine waardoor hij een vingertopje was kwijtge- 
raakt. Zijn klacht werd echter afgewezen omdat hij niet aannemelijk had kunnen maken dat het personeel van de werkzaal nalatig was geweest betreffende de controle van de desbetreffende machine. ${ }^{14}$

Angst voor inmenging door de Arbeidsinspectie in de "binnenlandse aangelegenheden' van het gevangeniswezen en vrees voor manipulatie van het regiem door gedetineerden wordt niet door de feiten gerechtvaardigd. Bij een behoorlijke bedrijfsvoering in de justitie-inrichtingen hoeft geen der partijen te vrezen dat een beroep op de Arbeidsomstandighedenwet zal leiden tot de verstoring van de orde en rust.

Daarbij dient de overheid zich te richten naar het vierde grondbeginsel van de Europese Gevangenisregels dat luidt: 'Strafinrichtingen en -instellingen dienen regelmatig te worden bezocht door ervaren, hiertoe opgeleide en door een bevoegde autoriteit benoemde inspecteurs. Zij moeten in het bijzonder nagaan of en in hoeverre deze inrichtingen worden bestuurd overeenkomstig de bestaande wetten en voorschriften, de doelstellingen van het gevangeniswezen en de in deze regels vervatte vereisten'. In de Memorie van Toelichting op dit vierde beginsel heet het: 'Het belang van cen regelmatige inspectie wordt onderstreept door het feit, dat dit vereiste tot grondbeginsel is verheven. Alle gevangenisdirecties moeten crop toezien dat de gehanteerde criteria in overeenstemming zijn met de regels. De inspectieprocedure zal van land tot land verschillen. De doelmatigheid en de geloofwaardigheid van de inspectiediensten nemen toe naarmate zij onafhankelijker van de gevangenisdirecties kunnen optreden en indien de resultaten van hun werk worden gepubliceerd'. ${ }^{145}$

Hoewel dit beginsel niet speciaal voor de Nederlandse arbeidsinspectie geschreven zal zijn, is het duidelijk dat de Raad van Europa controle door deskundige en onafhankelijke derden toejuicht.

Een andere regeling, die een bijdrage kan leveren tot partiële gelijkschakeling van werkende gedetineerden met hun in vrijheid verkerende collega's, is de beoogde nieuwe Arbeidstijdenwet, waarvan het ontwerp op 16 maart 1994 aan de Tweede Kamer is aangeboden. ${ }^{146}$

Blijkens een interne notitie van het Directoraat-Generaal van de Arbeid zouden er geen inhoudelijke gronden zijn voor de onderbrenging van de groep geïnstitutionaliseerden in justitiële rijksinrichtingen onder de nieuwe Arbeidstijdenwet. Justitie vreesde dat als geïnstitutionaliseerden de bevoegdheid kregen naleving van de wettelijke bepalingen af te dwingen zulks in strijd zou kunnen komen met een ongestoorde tenuitvoerlegging van de vrijheidsbeneming. Verder bleven, aldus deze notitie, de bestaande regelingen met betrekking tot de arbeidstijden van geïnstitutionaliseerden binnen het voorgestelde regime van de Arbeidstijdenwet. Voorts zouden de geldende arbeidstijden 'zowel op papier als in de praktijk' geen bedreiging vormen voor de veiligheid of gezondheid van degene die de werkzaamheden verricht. Daarbij zou uitbreiding van de werkingssfeer van de Arbeidstijdenwer tot geïnstitutionaliseerden ook geen wijziging van de arbeidstijden van die groep met zich mee brengen. ${ }^{147}$ 
In zijn advies over de herziening van de Arbeidswet 1919 noemde de Sociaal Economische Raad (SER) de departementale notitie 'weinig overtuigend'. ${ }^{148} \mathrm{Het}$ was de raad bekend, dat in sommige huizen van bewaring, anders dan in gevangenissen, arbeidsovereenkomsten met gedetineerden op basis van vrijwilligheid werden afgesloten. De raad achtte het dan ook onjuist dat op deze arbeidsovereenkomsten de beoogde Arbeidstijdenwet niet van toepassing zou zijn. Voorts wees de raad op artikel 37 BWG dat zegt: 'De arbeidsduur wordt zoveel mogelijk aangepast aan die welke geldt in het vrije bedrijf. Ook werd artikel 75 van de Europese Gevangenisregels aangehaald, dat luidt:

1. Het maximale aantal werkuren van de gedetineerden per dag en per week dient te worden vastgesteld in overeenstemming met plaatselijke regels of gewoonten met betrekking tot de tewerkstelling van vrije werknemers.

2. Gedetineerden dienen ten minste één rustdag per week te hebben en moeten voldoende tijd beschikbaar hebben voor onderwijs en andere activiteiten, die nodig zijn met het oog op hun heraanpassing in de maatschappij'.

Een en ander in aanmerking nemend achtte de raad het ongewenst arbeid in justitiële inrichtingen, verricht door genstitutionaliseerden, van de werkingssfeer van de wet uit te zonderen. De wetgever heeft blijkens het wetsontwerp voor de Arbeidstijdenwet het advies van de raad op dat punt gevolgd.

\section{Slotopmerkingen}

De arbeidsrechtelijke positie van gedetineerden is een schijnrechtspositie. Een andere conclusie kan uit het voorgaande niet worden getrokken. Zeker, vrijwel alle aspecten van de gedetineerdenarbeid zijn op papier keurig geregeld in Beginselenwet, Gevangenismaatregel, huishoudelijke reglementen en tal van circulaires. Voorzover deze normen nog lacunes vertonen worden ze angevuld met arbeidsrechtelijke jurisprudentie van de Beroepscommissie uit de Centrale Raad voor Strafrechtstoepassing. Dat alles kan toch niet verhullen dat gedetineerden voor een minder dan symbolisch loon in alle opzichten moeten dansen naar het pijpen van hun monopolistische werkgever: Justitie. Wie zich verzet tegen dit dictaat wacht een sanctie, varirend van onthouding van loon tot en met plaatsing in een strafcel.

Gedetineerden worden door Justitie in een dubbelzinnige positie gebracht. Formeel wordt van hen verwacht dat zij zich na hun detentie zullen proberen te gedragen als werknemers die verantwoordelijkheid aan kunnen. Materieel worden zij gedurende de vrijheidsbeneming als arbeider niet serieus genomen, hebben zij hoegenaamd geen stem bij de totstandkoming van hun arbeidsvoorwaarden en in de manier waarop de arbeid moet worden verricht. De (recente) geschiedenis laat zien, dat pogingen van gedetineerden/arbeiders om door Justitie als sociale partner te worden aanvaard altijd schipbreuk hebben geleden. Justitie kan toenaderingspogingen gemakkelijk afhouden omdat elke maatschappelijke of politieke stimulans om tot betere arbeidsverhoudingen met de gedetineerden te 
komen ontbreekt. Daarbij weet Justitie zich in de rug gedekt door het gegeven dat gedetineerden grondrechtelijk in een zeer zwakke positie verkeren: geen enkel verdrag verbiedt hun gedwongen terwerkstelling. Dwangarbeid en straf lijken axiomatisch met elkaar verweven te zijn. 
1. BrC 15 juli $1983,82 / 83$, PI 1984, nr.

7, m.n. C. Kelk en BrC 1 december 1983, A 130/83, PI 1984, nr. 25.

2. 'Kapo' is afgeleid van het Italiaanse 'Capo', dat 'chef' of 'opzichter' betekent. In de Duitse karnpen werden alle gevangenen die met een. zeker gezag over andere gevange-nen waren bekleed zo ge- noemd. Zie hierover: L. de Jong, Het Koninkrijk der Nederlanden in de Tweede Wereldoorlog, deel 8, eerste: helff, 's-Gravenhage: 1978, bl. 504-518.

3. HR 2 mei 1989, Ngt 1989, 669, m.n. Th.W.V.V.

4. Ruffin v. Commonwealth, 62 Va. (21 Gratt.) 790, 796 (1871), geciteerd in M.G. Hermann en M.G. Haft, Prisoners' rights sourcebook; theory - litigation - practice, New York 1973, bl. 520 en S. Kranzz, The law of corrections and prisoners' rights cases and materials, St. Paul, Minn. 1986, bl. 292.

5. C.D. Ohle, Arbeitsbelohnung und Arbeitsentlohnung in Gefangenenarbeitswesen, Hamburg 1972, bl. 168.

6. J. Depenbrock, Erwachsenen-Strafvollzug; die rechtlichten: Grundlagen des Erwachsenen-Strafvollzuges und ihre Auswirkungen auf die Arbeit, das Wahlrecht und den Rechtsschutz des Strafgefangenen, Bonn 1960, bl. 132-133.

7. Van zo'n contract wordt melding gemakkt in $\mathrm{BrC} 7$ april 1987, A 17/87, PI 1987, nr. 74.

8. BrC 28 augustus $1980, \mathrm{~A} 60 \mathrm{t} / \mathrm{m} 63 / 80$, PI 1980, nr. 84. Ook: Pres. Rb. 's-Gravenhage, I oktober 1980, PI 1980, nr. 85. Zie voorts: BrC (geen datum, geen kenmerk), $P I$ 1981, nr. 24.

9. H.L. Bakels, Schets van het Nederlandse arbeidsrecht, Deventer 1992, bl. 16. Bij de behandeling van het individuele arbeidsrecht van gedetineerden wordt hier de indeling gevolgd, die Bakels in deze elfde editie zijn boek aanhoudt.

10. F. van Zijl, 'Gezellig dat het was ... De bajes is de bajes niet meer', de Volkskrant van 24 juni 1989, Het Vervolg, bl. 1 en 5.

11. Circulaire van 29 november 1984, nr. 1076/384, PI 1985, nr. 2 .

12. Bakels, a.w., bl. 17.
13. Zie de artikelen $7 \mathrm{~A}: 1637 \mathrm{~g}$ lid $4 \mathrm{en}$ 7A: $1638 f$ lid 2 BW.

14. Circulaire van 27 juni $1985, \mathrm{nr}$. 432/385, PI 1985, nr. 65.

15. Circulaire van 18 november $1982, \mathrm{nr}$. 1278/382, PI 1983, nr. 7.

16. BrC 18 juni 1991, A 7/91, Rechtshulp 1991, nr. 12, bl. 36-37. In die uitspraak vermeldde de $\mathrm{BrC}$ het interne departementale document waarbij de arbeidsplicht. voor veroordeelden in de huizen van bewaring werd afgeschaft: een nota d.d. 10 juli 1981, nr. $122 / 81 / \mathrm{MR} / \mathrm{NR}$.

17. Deze exceptie is niet contra legern door een creatieve uitleg van de in genoemde wersartikelen gebezigde term 'de hem opgedragen arbeid'. Immers, waar geen arbeid wordt opgedragen, hoeft ook niet gewerkt te: worden.

18. De Hoge Raad zal een reglement dat niet (geheel) aan de wettelijke eisen voldoet echt niet snel onverbindend achten: HR 7 oktober 1988, NJ 1989, 335 m.nt. P.A.S. en HR 22 mei 1992, NJ 1992, 607.

19. In penitentiaire open irrichtingen ontvangen de gedetineerden $40 \%$ van het met de externe werkgever overeengekomen loon, en in ieder geval $40 \%$ van het bruto-minimumloon. Zie de 'Interimregeling weekgeld gedetineerden in POI's' (circulaire van 11 april 1991, nr. 124825, 91 DJ), Sancties 1991, nr. 4 , bl. 238. Verpleegde ter beschikking gestelden ontvangen een aan het niveau van de bijstandsuitkeringen gerelateerd zak- kleedgeld, voor zover zij niet in aanmerking komen voor een AAW/WAO-uitkering en geen of onvoldoende ander inkomen genieten (circulaire van de minister van justitie d.d. 31 januari 1994, kenmerk 42 1805/94/DJ). Op verpleegde ter beschikking gestelden rust geen atbeidsplicht, aldus het Openbaar Rapport van de Nationale ombudsman van 6 maart 1990, nr. $90 / \mathrm{R} 125$.

20. Bakels, a.sv, bl. 62 .

21. Circulaire van 14 februari $1985, \mathrm{nr}$. 148/385, PI 1985, nr. 35. 
22. Besluit van de minister van Justitie van 23 februari 1948, nr. 1506, zoals sindsdien gewijzigd, $P I$ 1983, nr. 87.

23. 'In de Beginselenwet wordt de grens tussen kort- en langgestraften gelegd bij een werkelijke straftijd van 6 maanden (onder het begrip werkelijke straftijd wordt al enige tijd verstaan: de periode vanaf het onherroepelijk worden van het vonnis c.q. arrest tot de datum van vervroegde invrijheidstelling c.q. ontslag)', aldus staatssecretaris Kosto in een brief aan de Tweede Kamer, getiteld Herzicning differcntiatiestelsel gevangeniswezen (Tweede Kamer, 1989-1990, 21 634, nr. 1, bl. 8. In dat zelfde schrijven zegt deze bewindsman zich voor te stellen de grens tussen kort- en langgestraften te leggen bij een werkelijke straftijd van 12 maanden. In de Memorie van Toelichting bij het Voorontwerp Penitentiaire Beginselenwet ('s-Gravenhage: juli 1993, bl. 34) wordt het voornemen geuit om in een nog te concipiëren Penitentiaire Maatregel een driedeling te realiseren van straffen naar hun lengte.

24. Zie de circulaires van 19 september 1977, nr. 1083/377, PI 1980, nr. 2 en de circulaire van 8 november 1977, nr 1207/377, PI 1980, nr. 3.

Langgestraften zijn personen met een werkelijke straftijd van 6 maanden. Voor jeugdige langgestraften, dat wil zeggen personen jonger dan 23 jaar, is die termijn 5 maanden. Langgestraften komen lang niet altijd in een gevangenis, die speciaal voor langgestraften is aangewezen, terecht, bijvoorbeeld omdat hun strafrestant na aftrek van de voorlopige hechtenis te kort is om nog voor overplaatsing naar zo'n inrichting in aanmerking te komen. 25. Zie de circulaires van 13 februari 1986 , nr. $145 / 386$, PI 1986, nr. 30 en van 17 februari 1989,092 DJ 89, PI 1989, nr. 37.

26. BrC 25 september 1991, A 201/91, Rechishulp 1992, nr. 5, bl. 30 .

27. BrC 16 juli 1992, A 89/92, Rechtshulp 1993, nr. 4, bl. 16.

28. BrC 28 juni 1993, A 130/93, Rechtshulp 1994, nr. 1, bl. 28.

29. Dit bleck uit een telefonische enquête van de schrijver d.d. 1 juli 1993 onder de strafinrichtingen, 'De Grittenborg' te Hoogeveen, 'De Kantelberg' te Den Haag, 'De
Marwei' te Leeuwarden, 'De Geerhorst' te Sittard, 'Esserheem' te Norgerhaven en 'Overmaze' re Maastricht. De ziekengeld-uitkeringen voor langgestraften bleken te variçren tussen het basisloon zonder toeslagen ( $f$ 4,20 ) en $80 \%$ van het laatst verdiende loon (inclusief toeslagen).

30. BrC 18 februari 1980, A $68 / 70, P I$ 1980, nr. 52.

31. Dat was toen een inrichting voor kortgestraften van 23 jaar en ouder.

32. Arrondissementsrechtbank Arnhem, (kort geding), 3 mei 1985, N7 1986, 148.

33. Klachten over regelingen van algemene strekking worden gewoonlijk niet-ontvankelijk verklaard.

34. $\mathrm{BrC} 28$ augustus 1985, A 109/85, PI 1985, nr. 82.

35. Circulaire van 6 april $1979, \mathrm{nr}$. $312 / 379$.

36. Hof 's-Gravenhage, 31 okrober 1985, PI 1986, nr. 46.

37. Centrale Raad van Advies voor het Gevangeniswezen, de Psychopatenzorg en de Reclassering (C.R.v.A.), Rapport van de Commissie Arbeidsbeloning van Gedetineerden, 's-Giravenhage januari 1966, bl. 25-27. 38. C.R.v.A., Plenaire vergadering van 14 mei 1966, 3e vervalgbiad.

39. C.R.v.A., concept verslag van de $21 \mathrm{e}$ plenaire vergadering, gehouden op $14 \mathrm{mei}$ 1966 te 's-Gravenhage, bl. 6.

40. C.R.v.A., concept verslag van de le vergadering van de Commissie Arbeid en Arbeidsbeloning op 6 november 1970 te Dordrecht.

41. C.R.v.A., Jaarverslag 1970 , bi. 11.

42. Zie het eerste hoofstuk.

43. Vaste Commissie voor Justitie, Openbare Commissievergadering van 10 april 1978, bl, 356. Zie ook Handelingen Tweede Kamer, 1978-1979, 18 oktober 1978, bl. 602 en 6003 .

44. Zie bijvoorbeeld de daor de CoornhertLiga geschreven Notities over het Gevangeniswezen, Utrecht 1978, bl. 23-33. Ook: G. de Jonge, Hans van de Velde en Rino Verpalen, BWO-Bajesboek, Rotterdam 1982, bl. 20.

45. Circulaire van 14 februari 1985 , $\mathrm{nr}$. 148/385, PI I985, nr. 35. 
46. B. Knight and S.T. Early Jr., Prisoners' rights in America, Chicago 1986, bl. 166-167. A. Pitsela, 'Greece', in A.M. van Kalmthout en P.J.P.' Tak, Sanction-systems in the memberstates of the Council of Europe, Part I, Deventer/Arnhem 1988, bl. 169-170. F. BuenoArus, 'Espagne', Revue internationale de droit pénal', 61e année-nouvelle série, 3e et 4e trimestres 1990. bl. 510.

47. Brief van de minister van Justitie van de Nederlandse Antillen d.d. 15 februari 1993; aan het, Bureau voor Rechtshulp te Haarlem. 48. Circulaire van 18 februari 1986, nr. 131/386, PI 1986, nr. 29.

49. Circulaire van 21 juni $1984, \mathrm{nr}$. $491 / 384$, PI 1984, nr. 61.

50. BrC 15 juni 1983, A $76 \mathrm{~d} / \mathrm{m} \mathrm{79/83,} \mathrm{PI}$ 1983, nr. 95.

51. BrC 8 januari 1990 , A $183 / 89$, Rechtshulp 1990, nr. 6/7, bl. 32-34, m.n. G. de Jonge. In gelijke zin: $\mathrm{BrC} 13$ november 1990, A 223/90, Rechrshulp 1991, nr. 5, b. 35.

52. C. Kelk, Kart begrip van het detentierecht, Nijmegen 1988, bl. 180.

53. Circulaire van 29 november 1984, nr. $1076 / 384$.

54. Besluit van de minister van Justitie van 23 februari $1948 \mathrm{nr}$. 1506, zoals sindsdien gewijzigd, PI 1983, nr. 87.

55. BrC 10 juni 1986, A 54/86, PI 1986, nr. 84 .

56. BrC 25 februari 1994, A 403/93.

57. BrC 27 mei 1993, A 47/93, Rechtshulp 1994, nr. i, bl. 28.

58. Krachtens art. 7A:1638c BW behoudt de zieke werknemer gedurende renminste zes weken aanspraak op het (minimum)loon. Het penitentiaire recht kent geen regeling voor de manier waarop de berrokken bedrijfsvereniging op basis van artr. 39-39d van de Ziektewet (zoals gewjizigd bij wet van 22 december 1993, Stb. 1993, 750) de beweerde ongeschiktheid tot het verrichten van arbeid kan controleren in het (zeldzame) geval dat de gedetineerde arbeid verricht voor een particuliere werkgever. Voorzover de cel van de verzekerde als diens eigen waning kan worden beschouwd is de gedetineerde nier zelfstandig bevoegd de vertegenwoordiger van de bedrijfsvereniging daarin binnen te: laten. Omgekeerd houdt niets een directeur van een penitentiaire inrichting tegen om zo'n controleur toegang tot de cel van de betrokken gedetineerde te verlenen, zelfs tegen de wil van laatstgenoemde. In voorkomende gevallen zal een oplossing gevonden kunnen worden door in overleg met de gestichtsarts en/of medische dienst een gesprek tussen de verzekerde gedetineerde en de controleur te: arrangeren. De directeur zal dan telkens wel bijzondere toestemming, voor een dergelijk bezoek moeten geven. Weigering van een dergelijke toestemming kan onrechtmatig zijn jegens de bedrijîtsvereniging en/of de werkgever. 59. Circulaire van 26 februari $1974, \mathrm{nr}$. $318 / 373$, PI 1983, nr. 88. Zie ook BrC 20 augustus 1982, A 32/82 II, PI 1982, nr. 90. 60. BrC 13 maart 1985, A 192/84, PI $1985, \mathrm{nr} .44$.

61. BrC 24 juni 1994, A 94/122.

62. Circulaire van 7 januari 1981 , nr. $845 / 380$, PI 1981 , nr. 15 en

Circulaire van 2 maart $1982, \mathrm{nr} .87 / 382, P I$ 1982 , nr. 41.

63. Art, 42 Ziektewet.

64. BrC 26 februari 1980, A 100/79, PI 1980, nr. 49. In gelijke zin: $\mathrm{BrC} 28$ mei 1991, A 41/91, Rechtshulp 1991, nr. 12, bl. 37.

65. $\mathrm{BrC} 20$ augustus $1982, \mathrm{~A} 32 / 82$, PI 1982, nr. 90.

66. C. Kamermans, 'Gezondheidszorg en de gedetincerde', in B.A.J. Cohen en H.J. Leliefeld (red.), Inleiding tot de forensische geneeskunde, 2e druk, Zeist 1990, bl. 506. 67. Circulaire van 7 januari 1981, nr. 8.45/380, PI 1981, nr. 15.

68. Hoe kritiekloos de BrC afgat op het oordeel van de gestichtsarts blijkt bijvoorbeeld uit: BrC 2 okrober 1990, A 204/90 en BrC 15 oktober 1990, A 191/90, Rechtshulp 1991 , nr. 5, bl. 34-35.

69. BrC 7 december 1977, A 21/77, PI 1980, nr. 61,

BrC 1 december 1983, A 130/83, PI $1984, \mathrm{nr} .25 \mathrm{en}$

BrC 15 oktober 1987, A 81/87, PI 1988 , nr. 26.

70. BrC 1 augustus 1991, A 154/91, Rechtshulp 1992, nr. 5, bl. 29.

71. BrC 29 januari 1991, A 287/90, Rechtshulp 1991, nr. 8/9, bl. 38 . 
72. Circulaire van 25 juli $1985, \mathrm{nr}$. 436/385, PI 1985, nr. 67.

73. BrC 6 februari 1986, A $228 / 85, P I$ $1986, \mathrm{nr} .56$ en

BrC 15 oktober 1987, A 81/87, PI $1988 \mathrm{nr}$.

26.

74. Circulaire van 25 mei $1992,204624 / 92$

DJ, wijziging huishoudelijke reglementen

m.b.t. het avondprogramma.

75. BrC 15 november 1993, A 339/93.

76. BrC 3 november 1980, A $66 / 80$ en $85 / 80$, PI 1981, nr. 7 .

77. BrC 11 mei 1989, A 238/88 met noot

G. de Jonge, Rechtshulp 1989, nr, 11, bl. 11-

12.

78. Council of Europe, European Prison

Rules, Recommendation nr. R. (87) 3,

Straatsburg 1987, Explanatory memorandum, bl. 73 .

79. Circulaire van 2 augustus 1978, $\mathrm{nr}$. 1594/377, PI 1980, nr. 26.

80. Circulaire van 20 juni 1988 , nr. 361/388, PI 1988, nr. 77.

81. BrC 1 november 1979, A $36 / 79, P I$ $1980, \mathrm{nr}$. 33. Hoewel de beslissing van $\mathrm{BrC}$ daar niets over zegt, mag worden aangenomen dat de gedetineerde zijn eis op het toenmalige BW had gebaseerd.

82. Circulaire van 21 februari 1980 , nr. 102/380, PI 1980, nr. 43.

83. Circulaire van 17 september $1981, \mathrm{nr}$. 882/381, PI 1981, nr. 57.

84. BrC 24 maart 1981, A $7 / 81$, PI 1982, nr. 54 en

BrC 19 december 1983, A 141/83, PI 1984, nr. 26.

85. HR 30 maart 1984, $N f 1985,350$

m.nt. E.A.A. Het Suikerfeest markeert het einde van de Ramadan.

86. Bakels, a. $w_{4}$, hoofdstuk 3.6, bl. 84-139.

87. BrC 5 maart 1982, A 105/81, PI 1982, nr. 66.

88. BrC 7 april 1987, A 17/87, PI 1987, nr. 74.

89. BrC 16 april 1991, A 3/91, Rechtshulp 1991 , nr. 12, bl. 37.

90. BrC 5 december 1986, A 166/86, $P I$ 1987, nr. 22.

91. BrC 15 oktober 1987, A 81/87, PI 1988 , nr. 26.
92. BkC HvB Groningen (klaagschrift nr. 28/89), 11 augustus 1989. Bevestigd door BrC 7 december 1989, A 182/89.

93. BrC 7 mei 1980, A $79 / 79$, PI $1980, \mathrm{nr}$. 73.

Eerder in gelijke zin $\mathrm{BrC} 26$ februari 1980, A 100/79, PI 1980, nr. 49.

94. BrC 7 juli 1980, A $11 / 80$, PI 1980 , nr. 86.

95. BrC (geen datum, geen kenmerk), $P I$ $1981, \mathrm{nr} .24$. In gelijke zin: $\mathrm{BrC} 21$ januari 1985, A 157/84, PI 1985, nr. 21.

96. BrC 29 augustus 1991, A $146 / 91 \mathrm{cn}$ BrC 31 oktober 1991, A 263/91. Beide uitspraken in Rechtshulp 1992, nr. 5, bl. 30. Zie ook BrC 5 maart 1992, A 399/91, Rechtshulp 1993, nr. 1, bl. 25.

97. Hierbij moet worden opgemerkt, dat in het Nederlandse civiele arbeidsrecht kort na de Tweede Wereldoorlog een "poenale sanctie' heeft gestaan op het beëindigen van een arbeidsverhouding zonder toestemming van de directeur van het arbeidsbureau (art. 6 BBA). Zic HR 29 april 1947, nr. 449. 98. De wet zwijgt over de vraag of de arbeidsplicht eindigt als de gedetineerde de pensioengerechtigde leefuijd bereikt. In art. 45 van het Duitse Strafvollzuggesetz staat tuitdrukkelijk dat de arbeidsplicht niet geldt voor gedetineerden die de 65 -jarige leeftijd hebben bereikt.

99. C. Kelk, Recht voor gedetineerden, Alphen aan den Rijn 1978, bl. 314.

100. Toen in EBI's niet alleen vluchtgevaarlijk geachte, maar ook nog 'beheersgevaarlijk' geachte gedetineerden werden ondergebracht; circulaire van 12 januari 1990, nr. 1267, DJ 90, Sancties 1990, afl. 1, nr. 5. 101. In die januari-maand werd om dezelfde reden gestaakt in het h.v.b en de vrouwengevangenis te Groningen, het h.v.b. te Rotterdam en het h.v.b. Het Schouw (Bijlnerbajes) te Amsterdam, aldus het BWO-Nieuws, 6e jrg., nu. 1, januariffebruari 1983, bl. 7 en 1618.

Kort nadien hebben zowel in het h.v.b. als in de gevangenis (de Koepel) te Breda gedetineerden een werkstaking georganiseerd om vitging te geven aan hun angst: voor verslechteringen, aldus $B W O$-Nieuws, 6e jrg., nr. 2, maart/mei 1983, bl. 10. 
102. BrC 15 juli 1983, A $82 / 83$, PI 1984 , nr. 7, m.n. C. Kelk; in gelijke zin: $\mathrm{BrC} 1$ december 1983, A 130/83, PI 1984, nr. 25.

103. BrC 8 augustus $1984, \mathrm{~A} 83 / 84$, PI 1984, nr. 77.

104. Door het ontbreken van goede inspraakmogelijkheden hebben werkstakingen van gedetineerden vaak het karakter van protest-stakingen. Bijvoorbeeld een massale ziekmelding met het karakter van een werkstaking van 50 gedetineerden in het huis van bewaring te Leeuwarden uit protest tegen de kwaliteit van het eten (de Volkskrant 19 juli 1991), werkweigering van veertig gedetineerden in PI Overmaze te Maastricht tegen inperking van de bezoekregeling (de Volkskrant 28 maart 1992) en een werkstaking van vijftig gedetineerden in de Utrechtse vrouwengevangenis tegen het verminderen van het aantal recreatie-uren (NRC-HB 7 oktober 1993). 105. C. Kelk in diens uitvoerige annotatie van $\mathrm{BrC} 15$ juli 1983, A 82/83, PI 1984, nr. 7.

106. M.G. Rood, Staken in Nederland, Schoonhoven 1991, bl. 96.

107. M.G. Rood, a.w., bl. 98 .

108. Voor een overzicht van deze stakingsacties zie de Bajeskrant, nr. 19, september/oktober 1977, de Bajeskrant, nr. 21 (datum?) en het BWO-Nieuws, 1ste jrg., nr. 3, 28 januari 1978 en KRI, 7e jrg., nr. 8, november 1977. 109. Deze brief is facsimile afgedrukt in het BWO-Nieuws, 1ste jrg., nr. 3, 28 januari 1978. bl. 9.

110. Voor een overzicht van die stakingsacties zie BWO-Nieuws, 8ste jrg., nr. 1 januari/februari 1985.

111. Deze brief is gepubliceerd bij circulaire van 14 februari 1985, nr. 148/385, PI 1985, nr. 35.

112. BrC 13 november 1992, A 269, 1992, Rechtshuls 1993, nr. 4, bl, 16.

113. Dit probleem wordt duidelijk verwoord in een bijdrage van gedetineerde $\mathrm{H}$. Cybulkiewicz aan BWO-Nieuws, 13e jrg., 1990, nr. 3, bl. 15-18.

114. De dagvaarding, waarin die eis vervat is bevindt zich in het archief van de auteur. 115. HR 25 juni 1982, Ny 1983, 295.

116. Pres. Rb. Amsterdam 23 november 1989, rolnr. KG 89/2250 V.
117. Conseil de l'Europe, Comité Européen pour les problèmes criminels, Les régimes des institutions pénitentiaires, Strasbourg 1986, bl. 7-25.

118. Terma van E. Goffman, Asylums; Essays on the Social Situation of mental patients and other inmates, Chicago 1962.

119. Council of Europe, Prison management, Straatsburg 1983.

120. In verband met de relatief korte gemiddelde verblijfsduur van de gestichtsbevolking zou ook kunnen worden gekeken naar de bijzondere medezeggenschapsregeling in het onderwijs met betrekking tot vaste krachten. en de leerlingen en hun ouders. Zie hierover bijw.: W.J.J. Beurskens, 'Medezeggenschap in het onderwijs', in P.F. van der Heijden (red.), Schets van het medezeggenschapsrecht, Deventer 1992, bl. 141-195.

121. K.F. Schumann, 'Was geht die Gewerkschaften ein Strafvollzug an?' Ein Tagungsbericht, Kriminologisches foumal 1975/3, b!. 237.

122. D. de Clerck, 'Deconcentratiebeleid is vallen en opstaan; gebrekkig overleg in gevangenissen;' in Aanén 18 december 1989 , bl. 8-10.

123. Dat is ook de optiek van waaruit een nota als 'Om de kwaliteit van het criminaliteitsbeleid" (AbvaKabo-CFO),

Zoetermeer/Den Haag 1985, is geschreven.

124. Bajeskrant, nr. 5, mei/juni 1975, bl. 15.

125. Bajeskrant, maart/april 1976 , bl. 18 .

126. BWO-Nieuws, 4e jirg., nr. 6, 1981, bl.

8-9.

127. BWO-Nieurvs, 5e jrg., nr. 3/4, augustus/september 1982 , bl. 35 .

128. BWO-Nieuws, 4e jrg., nr. 6, 1981, bl. 9.

129. BWO-Nieuws, 7e jrg., nr. 1, jarıuari/fe-bruari 1984

130. De Volkskrant 14 juni 1989, 'Dienstplichtigenbond zoekt aansluiting bij vakcentrale FNV?

131. KRI, 7e jrg., nr. 9/10, december 1977, b. 24 .

132. Beide brieven zijn afgedrukt in $B W O$ Nieuws, 5e jrg., nr. 5, november/december 1982. 
133. BWO-Nieuws, 7e jrg., januari/februari 1984, bl. 23-24, 'Vrouwenstaking Bijlmerbajes'.

134. K.F. Schumann, a.w., bl. 227-239. 135. C. Leder, Arbeitsentgelt im Strafvollzug der Bundesrepublik Deutschland. Paradigma für fehlende soziologische Problemsicht. Rheinstetten-Neu, W-Germany 1978, bl. 41, 49.

136. S. Livrozer, De la prison à la révolte, (geen plaats vermeld) 1975, bil. 207-208. 137. A.J.C.M. Geers e.a. (red.), Arbeidsomstandigheden; recht en praktijk, (losbladig), Deventer, [nr. 30.1], Suppl. 86, bl. 42. 138. Arboraad, Advies over het ontwerp-arbeidsomstandighedenbesluit jeugdbescherming en delinkwentenzorg, Zoetermeer 1988.

139. A.J.C.M. Geers, Recht en humanisering van de arbeid, Deventer 1988, bl. 133.

140. Brief van de Centrale Raad yoor Strafrechtstoepassing aan de Staatssecretaris van justitie d.d. 15 april 1988, nr. SG 78/88 (bij de CRS als openbaar advies verkrijgbaar). Zie ook: Jaarverslag 1988 van de CRS, 'sGravenhage juli 1989, bl. 12-14.

141. Besluit van 26 juli 1990 , Stb. 453 (zoals gewijzigd bij besluiten van 20 september 1990, Stb. 491 en van 22 oktober 1990, Stb. $54 \mathrm{l})$. Tot de justitiële rijksinrichtingen behoren gevangenissen, huizen van bewaring, justitïle rijksinrichtingen voor verpleging voor ter beschikking gestelden en rijksintichtingen voor justitięle kinderbescherming.

142. R. de Waal, 'Arbeidsomstandighedenbesluit Justitiele Rijksinrichtingen', PS, 21, 19 september 1990, bl. 1386.

143. BrC 22 november 1991, A 279/91, Rechtshulp 1992, nr. 5, bl. 30.

144. BrC 11 mei 1993, A 488/92, Rechtshulp 1994, nr. 1, bl. 28-29.

145. Council of Europe, European Prison Rules, Explanatory Memorandum, Straatsburg 1987, bl. 35 .

146. Bepalingen inzake de arbeids- en rusttijden (Arbeidstijdenwet), Tweede Kamer, 1993-1994, 23 646. Over dit voorstel:

A.J.C.M. Geers en G.J.J. Heerma van Voss, 'De overheid treedt terug: de nieuwe Arbeidstijdenwet', Sociaal Recht, 1994 - 5, bl. 136-144.
147. Directoraat-Generaal van de Arbeid; directie sociaal arbeidsbeleid (Commissie Arbeidswetgeving; Werkgroep Herziening Arbeidswet); (WAT/20; 4 september 1989). 148. Sociaal Economische Raad, Advies herziening Arbeidswet 1919, 992/05, Den Haag 1992, bl. 26-27. 


\section{Hoofdstuk III}

\section{De arbeidsplicht en de loonkwestie}

Ook al mag volgens de mensenrechten-catalogus niemand in slavernij of dienstbaarheid worden gehouden en is dwangarbeid uit den boze, voor gedetineerden geldt dat laatste niet onverkort. Artikel 2 van de tegen dwangarbeid gerichte Arbeidsconventie nr. 29, artikel 8 van het Internationaal Verdrag inzake Burgerrechten en Politieke Rechten en artikel 4 van het Europees Verdrag tot Bescherming van de Rechten van de Mens en de Fundamentele Vrïheden laten toe dat overheden de arbeidskracht van gedetineerden naar eigen inzicht kunnen gebruiken.

Wie naar de ratio en naar de juridische legitimering van die uitzondering zoekt moet vaststellen dat die nagenoeg ontbreekt. Arbeidsplicht wordt kennelijk inherent geacht aan detentie.

In de eerste paragraaf van dit hoofdstuk wordt geprobeerd de vanzelfsprekendheid van de penitentiaire arbeidsplicht te problematiseren. Dat geschiedt door een evaluatie van de betrekkelijke internationale rechtsregels.

Daar waar overheden een arbeidsplicht voor gedetineerden juridisch on-problematisch vinden, menen zij over het algemeen ook dat voor zulke verplichte arbeid niet of nauwelijks betaald behoeft te worden: een arbeidsplicht is inherent aan detentie en onderbetaling is inherent aan arbeidsplicht.

Ook deze schijnbare vanzelfsprekendheid wordt in dit hoofdstuk tegen het licht gehouden. De belangrijkste feitelijke en juridische argumenten voor en tegen het betalen van een loon, dat vergelijkbaar is met dat dat wan vrije werknemers, passeren in een tweede paragraaf de revue.

Geconcludeerd wordt dat er geen goede argumenten zijn om de penitentiaire arbeidsplicht en de daaraan gekoppelde onderbetaling te laten voortbestaan. 
In het vorige hoofdstuk is vastgesteld dat de arbeidsplicht, zoals die thans de iure voor veroordeelden en de facto voor onveroordeelden geldt, in 1886 als iets vanzelfsprekends in het Wetboek van Strafrecht is opgenomen en vervolgens zonder veel plichtplegingen in het penitentiaire recht is overgenomen.

Was dwangarbeid in haar diverse verschijningsvormen eind vorige eeuw zeker in de koloniën van diverse Westeuropese staten - niets ongewoons, in de twintigste eeuw komt het probleem van de forced labour op de internationale politieke agenda. De Internationale Arbeids Organisatie brengt in de dertiger en vijftiger jaren een tweetal verdragen tot stand, die zich tegen dwangarbeid richten. Daarmee is bescherming tegen gedwongen arbeid een mensenrecht geworden, hetgeen wordt bevestigd in overeenkomstige bepalingen van jongere verdragen als het Internationaal Verdrag inzake Burgerrechten, het Europees Verdrag tot bescherming van de Rechten van de Mens en in de intussen tot stand gekomen minimumregels voor de bejegening van personen die rechtens van hun vrijheid beroofd zijn.

Merkwaardigerwijs maken alle genoemde internationale regelingen een uitzondering op het verbod op dwangarbeid waar het om gedetineerden gaat. Zij behoren tot de weinige categorieën over wier arbeidskracht overheden, zij het binnen bepaalde grenzen, kunnen beschikken. Zo heeft de penitentiaire arbeidsplicht zoals die in ons land sinds 1596 geldt in de twintigste eeuw een internationaalrechtelijke legitimering gekregen.

Het is echter de vraag of de verdragsrechtelijke uitzonderingen op het dwangarbeid-verbod wat betreft de categorie gedetineerden gehandhaafd moeten blijven. Voordat daarover conclusies worden getrokken passeren hieronder eerst de diverse internationale regelingen de revue.

\subsection{De Arbeidsconventies nr. 29 en nr. 105}

De in 1919 ontstane en in 1946 als gespecialiseerde instelling aan de Verenigde Naties gekoppelde International Labour Organisation (ILO), in het Nederlands: Internationale Arbeidsorganisatie (IAO) ${ }^{1}$, heeft een tweetal verdragen tot stand gebracht die zich keren tegen verplichte of gedwongen arbeid.

Het eerste is het Verdrag betreffende de gedwongen of verplichte arbeid van 1930, ook wel Arbeidsverdrag of Arbeidsconventie nr. 29 genoemd. Het tweede is het in 1957 door de Algemene Vergadering van de IAO aanvaarde Verdrag betreffende de afschaffing van gedwongen arbeid, ook wel Arbeidsverdrag of Arbeidsconventie $\mathrm{nr}$. 105 genoemd.

Hoewel, zoals hieronder zal blijken, beide verdragen verschillende verschijnselen willen bestrijden, hebben zij elk mede betrekking op gedetineerden-arbeid. 
Het Verdrag betreffende de gedwongen of verplichte arbeid van 1930 is er. vooral gekomen om slavernij en daarmee vergelijkbare praktijken in koloniale gebieden te bestrijden. ${ }^{2}$ Hoewel Nederland deze conventie in 1933 toch heeft goedgekeurd $^{3}$, bestond daar aanvankelijk weinig animo voor. Toen destijds aan ons land werd gevraagd of een dergelijk verdrag er überhaupt moest komen kreeg een door de IAO uitgezonden 'verkenningscommissie' te horen dat Nederland de tijd nog niet rijp achtte de dwangarbeid af te schaffen. ${ }^{4}$ Volgens Sternheim vonden velen in Nederland de bemoeienissen van de IAO met 'den gedwongen arbeid voor inboorlingen' niet aangenaam omdat ons land belang had bij het voortbestaan van een stelsel van 'heerendiensten' en 'koeliekontrakten' in NederlandsIndië. In het kader van zulke herendiensten voerde de inheemse bevolking openbare werken uit zonder daar ook maar een cent voor te ontvangen. Daarnaast werkten vele honderdduizenden Javanen en Chinezen onder zogenaamde koeliekontrakten op de tabaks-, koffie-, thee- en rubberplantages. Degene die zo'n kontrakt - gewoonlijk voor 3 jaar - sloot was onvrij. Door verbreking of niet-nakoming van zo'n kontrakt riskeerde men een geldboete, een gevangenisstraf of beide. ${ }^{5}$ Deze poenale sancties deden volgens Middendorps interpretatie van de criminele statistiek alleen al in 1926 meer dan 30.000 arbeiders in de gevangenis belanden en dat voor feiten die vrijwel nergens ter wereld meer strafbaar waren. ${ }^{6}$

De meerderheid van de geraadpleegde regeringen vond het - desgevraagd echter wèl tijd dat er op internationaal niveau iets tegen het verschijnsel dwangarbeid werd ondernomen, waarop het Bureau van de IAO de tekst van een toepasselijk verdrag ontwierp: Arbeidsconventie nr. 29.

Het tweede artikel van de uiteindelijke tekst maakt duidelijk dat gedetineerdenarbeid onder bepaalde voorwaarden niet onder het in het verdrag geformuleerde begrip van dwangarbeid valt:

Art. 2

1. Voor de toepassing van dit verdrag duidt de uitdrukking 'gedwongen of verplichte arbeid' aan: elken arbeid of dienst, welke van een persoon wordt gevorderd onder bedreiging met een of andere straf en waarvoor bedoelde persoon zich niet, vrijwillig heeft aangeboden.

2. De uitdrukking 'gedwongen of verplichte arbeid' zal echter voor toepassing van dit verdrag niet omvatten: (...)

c. elken arbeid of dienst van een persoon, gevorderd als gevolg van een veroordeeling, uitgesproken bij een rechterlijke beslissing, op voorwaarde, dat die arbeid of dienst ten uitvoer gelegd wordt onder opzicht en toezicht van de openbare machten, en dat de bedoelde persoon niet afgestaan wordt aan of ter beschikking gesteld wordt van particulieren, maatschappijen of private rechtsperșonen. ${ }^{7}$ 
Her valt op dat bij de voorbereiding van Arbeidsconventie $\mathrm{nr}$. 29 geen der daarbij betrokken partijen de vraag heeft gesteld op welke rechtsgrond een arbeidsplicht voor tot vrijheidsstraf veroordeelde personen kon worden gebaseerd. Het werd de gewoonste zaak van de wereld gevonden, iets dat nu eenmaal bij de vrijheidsstraf hoorde, er inherent aan was.

De Britse regeringsvertegenwoordiger Vernon, sprekende over de soorten werk die volgens de ontwerp-tekst niet onder de definitie van dwangarbeid zouden moeten vallen zei over het punt van de gedetineerden-arbeid simpelweg "dat veroordeelde gedetineerden, die gedurende hun straf werken, niet het soort dwangarbeid verrichten dat dit verdrag voor ogen staat en dat daarom voor het werk dat hún wordt opgedragen een uitzondering moet worden gemaakt'. ${ }^{8}$ Vertegenwoordigers van sommige landen vonden zelfs dat het, in tegenstelling tot de bedoeling van de ontwerp-tekst, mogelijk moest zijn gedetineerden ten behoeve van particulieren te laten werken. De regeringsvertegenwoordiger van Zuid-Afrika probeerde - zij het tevergeefs - de bepaling, dat gedetineerden niet aan particulieren ter beschikking mochten worden gesteld, uit de concept-tekst verwijderd te krijgen. ${ }^{9}$ De Belgen stelden voor - eveneens zonder resultaat - om het verbod om gedetineerden voor particulieren te laten werken niet te laten gelden als het ging om aannemers van openbare werken en als zulke arbeid onder toezicht van de openbare macht stond. ${ }^{10}$ De vertegenwoordiger van de Britsindische overheid Latifi wilde de ontwerp-conventie in dit opzicht nóg verdergaand amenderen. $\mathrm{Hij}$ stelde voor het verbod om gedetineerden voor particulieren te laten werken geheel uit de tekst te verwijderen om op die manier voorwaardelijk invrijheidgestelden bij 'reclasserings-minded' particulieren en dito organisaties te kunnen laten werken, hetgeen hun herinpassing in de maatschappij zeer ten goede zou komen. Volgens de Britsindische werknemersvertegenwoordiger Shiva Rao had Latifi daarbij allerminst de reclassering van ex-gedetineerden voor ogen, maar wilde de Indiase regering de gevangenisbevolking kunnen inzetten om stakingen te breken, wat volgens hem al eerder gebeurd was. Hij riep de vergadering dan ook op om te voorkomen dat op deze manier 'een nieuw wapen werd gesmeed tegen de vrije Indiase arbeiders', die toch al zoveel weerstand ontmoetten in hun strijd voor de elementairste rechten. Latifi's voorstel werd, ondanks de steun vanı de Zuidafrikaanse regeringsvertegenwoordiger Herbst, verworpen.

Maar Latifi had nòg een pijl op zijn boog. In een ander amendement stelde hij voor om die stammen, klassen of groepen, die zich systematisch aan zware delicten schuldig maakten, van het verbod op dwangarbeid uit te zonderen. Weer opponeerde Shiva Rao die de vergadering op het hart drukte te voorkomen dat gecriminaliseerde bevolkingsgroepen op dezelfde manier zouden kunnen worden uitgebuit als eerder door Latifi was voorgesteld met betrekking tot gedetineerden. Ook dit wijzigingswoorstel werd verworpen. ${ }^{11}$

De discussie in de boezem van de IAO draaide aldus uitsluitend om de vraag of en in hoeverre particulieren van de werkkracht van gevangenen mochten profiteren. De legitimiteit van de op hen uitgeoefende arbeidsdwang stond op zichzeif niet ter discussie. 
De positie van gedetineerden was in de debatten over het ontwerp van Arbeidsconventie $\mathrm{nr} .29$ maar bijzaak. Het verdrag draaide in de eerste plaats om het uitbannen van exploitatie van de 'inheemsen' in de koloniën.

De positie van de gederineerde in zijn rol van arbeider kwam in IAO-verband, na de aanvaarding van verdrag $\mathrm{nr} .29$ en vóór de inwerkingtreding ervan op $1 \mathrm{mei}$ 1932, diepgaander aan de orde in een tweetal publicaties van het Internationaal Arbeidsbureau (IAB). ${ }^{12}$ De gedachtenvorming over het karakter van de gedetineerden-arbeid binnen dat IAB was geen nevenprodukt van het werk aan Arbeidsconventie $\mathrm{nr}$. 29. Zij was op gang gebracht door een adviesaanvraag van de Volkenbond over de tekst van de 'Standard Minimum Rules for the Treatment of Prisoners' die in 1929 door de Internationale Gevangeniscommissie - de zogenaamde Berner commissie - geconcipieerd waren. In de geschriften van het IAB werd de arbeidsdwang voor veroordeelden niet afgewezen. Integendeel, de verplichte arbeid werd gezien als het belangrijkste bestanddeel van de vrijheidsstraf. Wel maakte het IAB zich zorgen over de gevaren die op de loer lagen als mensen in onderworpenheid moesten werken. Die gevaren dreigden niet alleen voor gedetineerden maar ook voor de vrije arbeiders, wier rechtspositie door oneigenlijke concurrentie van de gedetineerden-arbeid zou kunnen afzakken tot het niveau van die der gevangenen. ${ }^{13}$

Het IAB ging na welk systeem van gedetineerden-arbeid het grootste risico van uitbuiting door particulieren inhield: de contractarbeid, het stukloonsysteem of de arbeid onder staatsdirectie of staatsregie.

Onder contractarbeid verstond het IAB een stelsel waarbij gedetineerden aan particuliere ondernemers konden worden uitgeleend. Daarbij werd onderscheiden tussen:

- een lease-systeem, gebaseerd op een overeenkomst tussen de staat en een derde aan wie gedetineerden worden 'verhuurd'. Die derde, de lessee, heeft de contractuele verplichting om die gedetineerden te voeden, te kleden en te bewaken. Hij moet de staat per persoon een bepaald bedrag betalen waarvoor hij zich het recht verwerft om de 'geleasde' gedetineerden voor de duur van de overeenkomst voor zich te laten werken;

- een 'totaal-contract', waarbij de gedetineerden voor een eenmalig bedrag als groep aan een derde worden verhuurd, maar waarbij - in tegenstelling tot bij het lease-systeem - de staat voor de bewaking en huisvesting van de gedetineerden verantwoordelijk blijft. De particuliere contractant zorgt voor de voeding van de gedetineerden en voorziet ze van grondstoffen en gereedschap;

- bijzondere contracten, waarbij de staat het beheer van de gevangenis in eigen houdt en zèlf de gedetineerden selecteert die aan de particuliere contractant ter beschikking worden gesteld. Die particuliere ondernemer zorgt voor de grondstoffen en het gereedschap en diens eigen werknemers geven binnen de strafinrichting leiding aan de arbeid. De ondernemer betaalt dag- of stuklonen. De gehele produktie wordt zijn eigendom. 
Onder het stukloon-systeem verstond het IAB een stelsel waarin de staat opdrachten van particuliere ondernemers vitvoert. De ondernemer zorgt voor de grondstoffen en soms voor het gereedschap en hij betaalt de staat per geproduceerd artikel. $\mathrm{Bij}$ dit systeem is er geen contact tussen personeel van het particuliere bedrijf en de gederineerden.

Tenslotte onderscheidde het IAB nog een systeem van staats-regie waarbij de overheid voor de grondstoffen en het gereedschap zorgt en de produktie zelf afneemt of op de vrije markt verkoopt.

Van deze stelsels was destijds het lease-systeem het populairst omdat het de gevangenisautoriteiten de grootste financiële voordelen bood. Of en in welke mate de genoemde produktiestelsels zich verdroegen met het verbod van verplichte arbeid ten behoeve van particulieren was volgens het IAB nimmer uit te maken zonder diepgaand onderzoek van het desbetreffende geval. Het Bureau deed de aanbeveling om bij het opstellen van internationale regels voor de bejegening van gedetineerden goed rekening te houden met het verdrag betreffende de gedwongen of verplichte arbeid. ${ }^{14}$

$\mathrm{Na}$ de Tweede Wereldoorlog is de gedetineerden-arbeid in wat bredere zin onderwerp van studie van de Verenigde Naties (VN) geworden. In 1949 had een commissie, deskundig op het terrein van criminaliteitspreventie en bejegening van delinquenten, het onderwerp op de agenda staan. Vanaf die tijd ging de discussie niet primair over het gevaar van particuliere exploitatie van de gedetineerdenarbeid maar vooral over de invloed van de arbeid op de vorming van de gedetineerde, op de bedrijfsvoering van de inrichting en op de nationale economie. Daarbij werd ook gekeken naar het belang van die arbeid voor de personen die economisch van gedetineerden afhankelijk waren. In 1955 verscheen onder de titel 'Prison labour' over deze problematiek een uitvoerige beschouwing van de afdeling economische en sociale zaken van de $\mathrm{VN} .{ }^{15}$ In dat rapport werd - onder meer - vastgesteld dat in vrijwel alle landen tot vrijheidsstraf veroordeelde personen verplicht waren om te werken. Ook in dit rapport werd niet naar de legitimiteit van dit axioma gevraagd. Nieuw was dat tegenover deze arbeidsplicht een recht van gedetineerden op arbeid werd gesteld, iets dat in die tijd slechts in Denemarken, Noorwegen en Zweden werd erkend.

Dit VN-rapport onderscheidde, naast de systemen die in 1932 al door het IAB waren opgesomd, nóg twee manieren waarop gedetineerden-arbeid werd geëxploiteerd: bij de uitvoering van openbare werken en - voorafgaande aan de invrijheidstelling - door tewerkstelling bij particulieren. ${ }^{16}$ De populariteit van het lease-systeem, van de 'totaal'-contracten met particuliere ondernemingen en van het stukloonsysteem was intussen afgenomen. In de meeste landen gold een stelsel van staatsregie, en dan vooral voor die variant waarbij volledig in staatsbeheer vervaardigde goederen door de overheid zelf werden afgenomen en niet op de vrije markt werden verkocht. Als modernste en meest veelbelovende ontwikkeling werd in dit VN-rapport uit 1955 het werken vanuit de strafinrichting in het vrije bedrijf als voorbereiding op de invrijheidstelling gezien. ${ }^{17}$ 
De VN beschouwde het lease- en het contract-systeem, waarbij gedetineerden ter beschikking van particulieren worden gesteld, als in strijd met Arbeidsconventie nr. 29. Ook al léék extramurale tewerkstelling van gedetineerden bij particuliere ondernemers in strijd met artikel 2, lid 2 onder c van genoemd verdrag, toch viel dat systeem volgens de $\mathrm{VN}$ niet onder het soorten gedetineerden-arbeid dat die conventie verbood. Daarbij werd er op gewezen dat ook systemen van staatsregie allerminst een garantie tegen uitbuiting boden of een vrijwaring voor barre arbeidsomstandigheden betekenden. In het $\mathrm{VN}$-rapport werd de hoop uitgesproken dat de IAO, als de verantwoordelijke organisatie, aandacht wilde geven aan de herziening van de definitie van dwangarbeid in artikel 2 van Arbeidsconventie nr. 29. Dat artikel moest volgens dit VN-rapport zó worden geformuleerd dat het ook kon worden geratificeerd door staten, die weliswaar de beginselen van de conventie onderschreven, maar ook onveroordeelden tewerk wilden stellen zodat die hun zelfrespect behielden en hun familie konden ondersteunen. Verder moest het ook mogelijk worden om veroordeelden voor particulieren te laten werken, maar wel onder voorwaarden die een afdoende bescherming tegen uitbuiting boden en op een wijze die zowel voor de samenleving als voor de veroordeelde profijtelijk was. ${ }^{18}$

\section{Arbeidsverdrag nr. 105}

IAO-verdrag nr. 29 bleck ontoereikend om een bijzondere variant van arbeidsdwang te kunnen bestrijden: het groorschalig en vooral om politieke redenen bijeendrijven van mensen in dwangarbeiderskampen. ${ }^{19}$ Op grond van klachten van diverse staten, verenigd in de Economische en Sociale Raad (Ecosoc) van de VN, heeft een Ad Hoc Commissie van de VN en de IAO in 1953 over de aard en omvang van dit verschijnsel gerapporteerd. ${ }^{20}$ Van de ongeveer 100 beschuldigingen die tegen 24 staten waren geuit had bijna een-derde betrekking op arbeidsomstandigheden in de USA en het Verenigd Koninkrijk en ongeveer tweederde op clie in de toenmalige USSR en zijn 'satellieten'. De USSR had echter geweigerd mee te werken aan de enquête die de Ad Hoc Commissie onder de leden van de VN dienaangaande had verspreid. De desbetreffende post werd ongeopend geretoumeerd omdat die lasterlijke verzinsels over de Sovjetunie zou bevatten. ${ }^{21}$ De Koude Oorlog woedde op zijn hevigst. Tijdens het debat over het ontwerp van IAO-verdrag nr. 105 zei de regeringsafgevaardigde van de Sovjetunie Arutiunian daar later nog over, dat de Ad Hoc Commissie destijds met maar één doel voor ogen was opgericht, namelijk om animositeit jegens de Sovjetunie te kweken. ${ }^{22}$

De Sovjetunie werd - onder meer - het volgende verweten:

- dat het een systeem van dwangarbeid kende dat vooral een gewelddadige onderdrukking van oppositie tegen het regime beoogde;

- dat een van de pijlers van dat systeem de strafrechtspleging was, die zo was in- 
gericht dat tallozen, en in het bijzonder zij die zich tegen het regime uitspraken, tot dwangarbeid veroordeeld werden zonder dat zij zich daar behoorlijk tegen hadden kunnen verdedigen;

- dat het systeem van dwangarbeid uiterst belangrijk was voor de nationale economie omdat het grote hoeveelheden goedkope arbeidskrachten opleverde voor werk in de onontgonnen en ongezonde landstreken;

- dat het aantal tot dwangarbeid veroordeelden in de miljoenen iiep en dat die mensen in kampen, verspreid over de hele Sovjetunie, waren opgesloten; dat de omstandigheden in die kampen slecht waren en de mortaliteit er hoog was;

- dat in de Sovjetunie het verschil tussen de positie van de vrije arbeider en de dwangarbeider kleiner werd als gevolg van de vele beperkingen waaraan de wet de vrije arbeidskeus bond. ${ }^{23}$

De beschuldigingen - vooral afkomstig van de USSR - aan het adres van de USA logen er overigens ook niet om. Grote aantallen arbeiders zouden er niet onder de sociale verzekeringswetgeving vallen. Vrouwelijke arbeiders zouden er geen bescherming genieten. Op het terrein van arbeid en beloning zouden zwarten zodanig worden gediscrimineerd dat zulks in feite op dwangarbeid neerkwam. De geëiste loyaliteitsverklaringen kwamen neer op politieke discriminatie van de arbeiders. Patiënten in psychiatrische inrichtingen zouden worden geëxploiteerd. Zwarten zouden worden gedetineerd om ze aan het werk te zetten. Mexicanen en andere gastarbeiders zouden dwangarbeid verrichten. Gedurende de oorlog hadden de VS buitenlanders en gewetensbezwaarden tot arbeid verplicht. In de VS zouden gedetineerden onbeloond dwangarbeid verrichten.

De Ad Hoc Commissie vond de aantigingen tegen de USA of niet relevant ò ongegrond, op één na: de wetgeving in de staat Arkansas maakte het mogelijk dat gedetineerden voor particulieren werkten. ${ }^{24}$ De verwijten jegens de Sovjetunie werden wèl terecht geacht. De strafwetten van de USSR maakten volgens de Ad Hoc Commissie veroordeling tot 'opvoedende' arbeid mogelijk en creëerden een systeern van dwangarbeid als middel tot politieke onderdrukking. Hoeveel werkkampen er waren en hoeveel personen zich daarin bevonden viel uit de voorhanden gegevens niet goed op te maken. Wel hadden de getuigenissen van tal van voormalige gevangenen de Ad Hoc Commissie een beeld gegeven van de onmenselijke omstandigheden in die kampen. ${ }^{25}$

In vier andere landen achter het toenmalige 'ijzeren gordijn', Bulgarije, Tsjecho-Slowakije, Roemenië en Polen, werd eveneens het bestaan van systematische dwangarbeid vastgesteld. Voorts stelde de Commissie vast dat een indirecte variant van dwangarbeid voorkwam in de Unie van Zuid-Afrika en in ZuidwestAfrika. Voor een aantal landen, wier wetgeving dwangarbeid niet uitsloor, viel de concrete aanwezigheid ervan niet te bewijzen.

De Ad Hoc Commissie achrte de door haar vastgestelde feiten zo ernstig dat: zij het ontwerpen van nieuwe verdragen of het aanpassen van bestaande aanbeval $^{26}$ : de aangetroffen dwangarbeid-systemen vormden een ernstige bedreiging van de mensenrechten en de rechtspositie van de arbeider, zoals neergelegd in het Handvest van de Verenigde Naties. ${ }^{27}$ 
Aan de scherpe toon van de debatten die de Algemene Vergadering van de IAO over het spoedig hierna opgestelde ontwerp-verdrag betreffende de afschaffing van de gedwongen arbeid in 1957 voerde, zal de gewapende interventie van de Russen bij de Hongaarse opstand in het jaar daarvóór niet vreemd zijn geweest.

De Amerikaanse werkgeversvertegenwoordiger Parker onthield zich van stemming over het ontwerp-verdrag vanwege de 'cynische' steun die het van de Sovjetunie en haar satellieten kreeg. 'Iedereen weet, hun eigen afgevaardigden incluis, waar dwangarbeid op het ogenblik voorkomt: achter de IJzeren- en Bamboegordijnen', aldus Parker. ${ }^{28}$

De Russische regeringsvertegenwoordiger Arutiunian sloeg onmiddellijk terug door de Amerikaanse werkgeversvertegenwoordigers te verwijten bewust allerlei overblijfselen van de slavernij in stand te houden, zoals rassendiscriminatie, schuldslavernij ${ }^{29}$ en het uitbuiten van Mexicanen en Portoricanen als dwangarbeiders. Zijn landgenoot Surguchev, die optrad als Russische werkgeversvertegenwoordiger, wuifde de beschuldigingen, dat Siberië door dwangarbeiders ontgonnen werd, weg door te zeggen dat het Russische pioniers en hun nakomelingen waren die dat gebied in cultuur brachten. Niet door middel van dwangarbeid, 'maar uit puur enthousiasme om nieuwe, onbetreden, maagdelijke grond in akkers te veranderen en dát werk te verrichten waar het land behoefte aan heeft'. ${ }^{30}$

Op 25 juni 1957 werd de tekst van Arbeidsconventie nr. 105, het Verdrag betreffende de afschaffing van gedwongen arbeid, door de Algemene vergadering van de IAO aanvaard. Het trad in 1959 in werking en werd nog datzelfde jaar door Nederland bekrachtigd. Het verdrag verplicht elk IAO-lid dat het bekrachtigd heeft om doeltreffende maatregelen te nemen teneinde de onmiddellijke en algehele afschaffing te bewerkstelligen van gedwongen of verplichte arbeid: a) als middel tot politieke dwang of opvoeding of als een straf voor het koesteren of uiten van politieke opvattingen of van opvattingen welke ideologisch in strijd zijn met de gevestigde politieke, sociale of economische orde; b) als een methode voor het op de been brengen en gebruiken van arbeidskrachten voor economische ontwikkeling; c) als een middel tot arbeidsdiscipline; d) als een straf voor deelneming aan stakingen en e) als een middel tot rassen-, sociale, nationale of godsdienstige discriminatie. ${ }^{31}$

\subsection{De implementatie van Arbeidsverdragen nr. 29 en nr. 105}

De Internationale Arbeidsorganisatie heeft regelmatig onderzocht hoe het stond met de toepassing van de Arbeidsverdragen nr. 29 en nr. 105 en besteedde daarbij afzonderlijk aandacht aan de positie van de gedetineerde als arbeidskracht.

In een eerste, in 1962 opgemaakt, rapport ${ }^{32}$ wordt vastgesteld dat Arbeidsverdrag nr. 29 twee voorwaarden stelt waaraan voldaan moet zijn, wil gedetineer- 
denarbeid toelaatbaar zijn. Ten eerste wordt in artikel 2 , lid 2 onder $c$ van dat verdrag geëist dat het alleen personen mag betreffen die bij rechterlijk vonnis zijn veroordeeld. Het verdrag stelt, aldus het rapport, impliciet de eis dat zo'n vonnis tot stand gekomen is met inachtneming van de algemene rechtsbeginselen, zoals die in 'beschaafde" landen worden erkend. Daarbij moet worden gedacht aan de presumptio innocentiae, de gelijkheid van eenieder voor de wet, een eerlijke en onpartijdige procesvoering en de onafhankelijkheid en onpartijdigheid van de rechters, het recht op rechtsbijstand, duidelijkheid van strafbepalingen en het verbod van strafbaarheid met terugwerkende kracht. Het rapport verwees daarbij naar de rechtswaarborgen die zijn opgenomen in de artikelen $7 \mathrm{t} / \mathrm{m} 11$ van de Universele Verklaring van de Rechten van de Mens en de artikelen 14 en 15 van het in die tijd nog in staiu nascendi verkerende Verdrag inzake Burgerlijke en Politieke Rechten.

De onderzoekscommissie beschikte niet over voldoende informatie om er gerust op te kunnen zijn dat in álle landen die zich aan Arbeidsverdrag nr. 29 hadden gebonden aan deze eisen werd voldaan. In een aantal landen bleken, in strijd met dit verdrag, ook onveroordeelden tot werken verplicht te zijn. Tegen dat laatste had de commissie alleen dán geen bezwaar als die gedetineerden dat op vrijwillige basis deden en als dat gebeurde in overeenstemming met de Standaard Minimum Regels voor de behandeling van gedetineerden. ${ }^{33}$

De onderzoekscommissie stelde vast dat de arbeidsstelsels in de penitentiaire inrichtingen van de meeste landen voldeden aan de tweede eis die Arbeidsverdrag nr. 29 aan gedetineerden-arbeid stelt, namelijk dat die niet direct ten behoeve van particulieren verricht mag worden. Dat gold zeker voor die landen waar het particuliere belang geen enkele rol speelde omdat uitsluitend voor de overheid gewerkt. Het zelfde gold voor stelsels waarbij particuliere ondernemers weliswaar de grondstoffen leverden en de produkten verkochten, maar waarbij het werk in de gevangenissen onder leiding van de gevangenisdirectie werd verricht. Wat niet met het verdrag strookte, was het in een aantal landen waaronder Zuid-Afrika, toegepaste lease-systeem waarbij gedetineerden buiten de inrichting ten behoeve van particulieren werkten. Daarbij moesten die particulieren zorgen voor het levensonderhoud van die 'geleasde' gedetineerden en hen ook bewaken, terwijl zij vrijelijk over hun arbeidskracht mochten beschikken. In de ogen van de rapporteurs was zo'n lease-systeem alleen geoorloofd als de arbeid aan een aantal voorwaarden voldeed. De beloning moest gelijk zijn aan het elders gebruikelijke, de vakbonden moesten ermee accoord gaan en zulke arbeid mocht alleen op vrijwillige basis verricht worden. Gelijksoortige eisen golden voor stelsels, zoals bijvoorbeeld in Nederland, waarbij bepaalde speciaal daarvoor geselecteerde personen op basis van vrijwilligheid in de periode voorafgaande aan hun invrijheidstelling voor particuliere werkgevers buiten de inrichting werkten. ${ }^{34}$

Over de betekenis van Arbeidsconventie nr. 105 merkte de onderzoekscommissie op dat dit verdrag op zich zelf geen algemeen verbod op gedwongen of verplichte arbeid inhoudt en al helemaal niet voor gedetineerden, behalve als die ar- 
beid wordt gebruikt als middel tot politieke onderdrukking, ten behoeve van de economische ontwikkeling, voor het bijbrengen van arbeidsdiscipline, als straf voor deeiname aan stakingen of als vorm van discriminatie. Zo verbiedt deze conventie arbeidsdwang als middel tot politieke heropvoeding ${ }^{35}$, maar niet als middel tot reclassering in de zin dat ex-gedetineerden daardoor hun plaats in de maatschappij weer kunnen innemen zonder dat de omstandigheden hen tot nieuwe delicten nopen. De diverse voorzieningen die er bestaan voor maatschappelijke wederinpassing dienen, aldus de commissie scherp te worden onderscheiden van methoden van politieke heropvoeding.

In een aantal landen konden alleen 'gewone' delinquenten tot gevangenisarbeid worden verplicht; personen die wegens 'politieke' delicten tot gevangenisstraf waren veroordeeld genoten een geprivilegieerde status die vooral bleek uit het ontbreken van de arbeidsplicht. De onderzoekscommissie moest echter vaststellen dat uit de beschikbare informatie niet altijd viel op te maken volgens welke criteria zo'n politieke status toegekend werd, welke autoriteiten daartoe bevoegd waren en of gevangenisarbeid in sommige gevallen niet tóch als politiek dwangmiddel werd gebruikt. Daarbij kwam dat in een groot aantal landen het politieke karakter van een delict niets uitmaakte voor de manier waarop de vrijheidsstraf tenuitvoer werd gelegd. ${ }^{36}$

In 1968 verscheen er een tweede rapport van de $\mathrm{IAO}$ over de mate waarin de anti-dwangarbeid verdragen werden gerespecteerd. ${ }^{37}$ Dit rapport was extra interessant in het perspectief van het intussen in 1966 door de VN aanvaarde Verdrag inzake Burgerrechten en Politieke Rechten en het in datzelfde jaar aangenomen Verdrag inzake Economische, Sociale en Culturele Rechten, die bijzondere bepalingen tegen gedwongen of verplichte arbeid bevatten en een recht op vrije arbeidskeuze. ${ }^{38}$

Moest de onderzoekscommissie in 1962 haar conclusies met betrekking tot de handhaving van de Arbeidsconventies nr. 29 en 105 ten aanzien van gedetineerden nog vrijwel uitsluitend baseren op interpretatie van de regelgeving van de diverse landen, nu kon men beschikken over meer feitelijke informatie over de praktijk. Die wees erop dat in de meeste landen de gedetineerden-arbeid met Arbeidsconventie nr. 29 in overeenstemming was. In een aantal landen konden toch ook nog preventief gehechten tot arbeid worden verplicht. Ook liet in een aantal landen, waaronder de Bondsrepubliek Duitsland en Canada, de wetgeving toe dat gedetineerden ter beschikking van particulieren werden gesteld. ${ }^{39}$

Een derde onderzoeksrapport over de naleving van de genoemde conventies verscheen in 1979. Het bleek nog immer voor te komen dat preventief gedetineerden verplicht waren te werken, ook in landen die Arbeidsconventie nr. 29 geratificeerd hadden. ${ }^{40}$ De commissie wees in dat verband op Indonesië waar grote aantallen personen, zonder dat zij waren berecht, gedurende meer dan tien jaar in heropvoedingskampen gedetineerd zaten en dat zij daarbij tot het verrichten van bepaalde werkzaamheden, zoals het bedrijven van landbouw, waren verplicht. ${ }^{41}$

De onderzoekscommissie onderstreepte dat artikel 2, lid 2 onder c van Arbeidsconventie nr. 29 een rechterlijk vonnis als basis voor verplichte arbeid door 
gedetineerden eiste. Daaruit vloeit, aldus de commissie, voort dat als door andere organen een arbeidsplicht wordt opgelegd, dat niet strookt met de bepalingen van deze conventie. Men stelde namelijk vast dat in een aantal landen bestuursorganen wettelijk bevoegd waren om naar aanleiding van diverse overtredingen zoals landloperij, ledigheid en anti-sociaal gedrag de desbetreffende personen een arbeidsplicht op te leggen.

Ook dit rapport benadrukte dat Arbeidsverdrag nr. 105 niet speciaal op gedetineerden-arbeid betrekking heeft. ${ }^{42}$

\subsection{Dwangarbeid in het IVBPR en het EVRM}

Het verbod op verplichte of gedwongen arbeid, dat in Arbeidsconventie nr. 29 is neergelegd, ziet men terugkeren in de later tot stand gekomen artikelen 8 van het Internationaal Verdrag inzake Burgerrechten en Politieke Rechten (IVBPR) en 4 van het Europees Verdrag tot bescherming van de Rechten van de Mens (EVRM). Ook de laatstgenoemde verdragen laten gedwongen tewerkstelling van gedetineerden echter toe. Een andere overeenkomst tussen deze drie internationale regelingen is dat ze met geen woord reppen over een eventuele beloning van gedetineerden-arbeid. Klachten over het ontbreken of over de geringe hoogte van zo'n loon zijn volgens vaste jurisprudentie van de Europese Commissie voor de Rechten van de Mens niet ontvankelijk en wel om de eenvoudige reden dat het EVRM geen enkele bepaling omtrent beloning van werkende gedetineerden bevat. ${ }^{43}$

Uit een inventarisatie van Smaers van de jurisprudentie van ECRM en EHRM met betrekking tot artikel 4 van het Mensenrechtenverdrag blijkt dat gedetineerden geen recht op (aangepaste) arbeid hebben, niets te vertellen hebben over de organisatie van de werkzaamheden en aan het verdrag geen recht op loon of sociale zekerheidsuitkeringen kunnen ontlenen. Het Hof acht de arbeidspliche rechtmatig mits de vrijheidsberoving zèlf rechtmatig is en het opgedragen werk binnen de grenzen van het gebruikelijke biijft, de reclassering dient en de arbeidsplicht in de (nationale) wet verankerd ligt. ${ }^{44}$

In een aantal opzichten wijken de bepalingen van het EVBPR en het EVRM af van het genoemde ILO-verdrag, waardoor bij het beoordelen van beweerde schendingen het probleem kan ontstaan welke bepaling de voorrang geniet. Het is aan de nationale rechter om in het concrete geval uit te maken welke verdragsverplichting het zwaarst moet wegen, aldus Heringa en Zwart. ${ }^{45}$

Arbeidsconventie nr. 29 acht het alleen toelaatbaar dat veroordeelden tot arbeid worden gedwongen ('Any work or service exacted from any person as a consequence of a conviction of a court of law' heet het in artikel 2 lid 2 onder $c$ ). Nòch het IVBPR, nòch het EVRM hebben die beperking tot veroordeelden overgenomen. Naar de letter van laatstgenoemde verdragen kan aan alle categorieën gedetineerden een arbeidsplicht worden opgelegd. De enige voorwaarde die daarbij wordt gesteld is dat de detentie zelf rechtmatig moet zijn (artikelen 8 lid 3.a en c 
sub i IVBPR, en 4 lid 3 onder a EVRM). Bij het aanvaarden van de Europese gevangenisregels hebben de lid-staten van de Raad van Europa zich echter gebonden aan artikel 71 lid 2 van de Europese Gevangenisregels (EGR), die luidt: 'Van veroordeelde (nadruk gdj) gedetineerden mag worden verlangd dat zij werken $(\ldots)^{46}$, waarmee is aangegeven, dat zulks van onveroordeelden niet gevergd mag worden.

In de tweede plaats verschillen IVBPR en EVRM in zoverre van Arbeidsconventie nr. 29 dat laatstgenoemd verdrag in artikel 2 lid 2 onder c een clausule bevat die verbiedt dat arbeidsplichtige veroordeelden aan particuliere ondernemers ter beschikking worden gesteld terwijl EVRM en IVBPR niet zo'n verbod bevatten.

De vraag of arbeid ten behoeve van particuliere werkgevers zich verdraagt met artikel 4 lid 3 onder a van het EVRM is in 1967 door een aantal Westduitse gedetineerden aan de Europese Commissie voor de Rechten van de Mens voorgelegd. De uitspraak van de Commissie is niet alleen van belang in verband met de vraag naar de toelaatbaarheid van het beschikbaar stellen van de arbeidskracht van gedetineerden aan particuliere ondernemers, maar vooral ook omdat daarin is weergegeven hoe de Arbeidsconventies 29 en 105 door de Commissie zijn gebruikt bij de interpretatie van artikel 4 EVRM. ${ }^{47}$

Eenentwintig Westduitse gedetineerden hadden bij de Commissie geklaagd over het feit dat zij voor particuliere bedrijven moesten werken zonder dat zij daarvoor een normaal loon ontvingen. Dat beschouwden zij als een vorm van dwangarbeid die zich niet met artikel 4 EVRM verdroeg. Op grond van de zojuist. genoemde juisprudentie strandde de klacht voorzover die het ontbreken van een normale beloning betrof. Het klacht-onderdeel dat zich richtte tegen de verplichting on voor particuliere ondememers te werken noopte de Commissie tot een uityoerige interpretatie van de zinsnede uit artikel 4 lid 3 onder a EVRM : "werk. hetwelk gewoonlijk wordt verlangd'.

De Commissie stelde vast dat deze zinsnede niets bevat dat een staat belet om overeenkomsten, als waarover werd geklaagd, met particuliere werkgevers te sluiten of dat die zó zou moeten worden uitgelegd dat gedetineerder uitsluitend voor: de overheid zouden mogen werken.

De Commissie meende uit de geschiedenis van de totstandkoming van artikel 4 lid 3 onder a EVRM's te mogen afleiden dat de woorden 'werk hetwelk gewoonlijk: wordt verlangd" niet bedoelden arbeid ten behoeve van particulieren uit te sluiten. Integendeel, de Commissie nam aan ${ }^{49}$ dat de restrictie die Arbeidsconventie $\mathrm{nr} .29$ datiomtrent bevat, in de latere verdragen bewust is weggelaten omdat, toen IVBPR en EVRM geconcipieerd werden, het alom gebruikelijk was gedetimerden ook ten behoeve van particuliere ondememers te werk te stellen. Qok wat sit betreft: werden de klagers niet ontvankelijk verklaard.

Door deze uitspraak is duidelijk geworden dat Arbeidsconventie nr. 29 geen sluitende bescherming geeft tegen uitbuiting van gedetineerden door particuliere werkgevers. Het is vooral de taak van de nationale wetgevers om op dit terrein nadere regels te geven. Onze BWG doet dat in artikel 33 aldus: 1) De arbeid zal 
zich behalve tot het verrichten van huisdienst bij voorkeur uitstrekken tot het vervaardigen van voorwerpen voor 's Rijks dienst en tot objecten van algemeen nut'. Het tweede lid van dat artikel maakt echter duidelijk dat arbeid ten bate van derden eveneens wettig is: "Tewerkstelling ten behoeve van andere openbare lichamen dan het Rijk of van particulieren vindt slechts plaats tegen betaling aan het Rijk van het voor soortgelijke arbeid in het vrije bedrijf gebruikelijke loon'. De enige restrictie waaraan Arbeidsconventie nr. 29 de arbeid ten behoeve van particulieren de verdragspartijen lijkt te binden is dat arbeid voor particulieren onder toezicht en controle van ambtenaren van het gevangeniswezen moet staan. Dat toezicht is er in Nederland automatisch wanneer er in de inrichtingen voor particuliere opdrachtgevers wordt gewerkt. Dat ligt echter anders waar gedetineerden vanuit een penitentiaire open inrichting bij particuliere ondernemers werken. Beginselenwet noch Gevangenismaatregel bevatten instructies aan de directies met betrekking tot de eisen waaraan die externe arbeidsplaatsen moeten voldoen of over de wijze waarop de kwaliteit daarvan wordt gecontroleerd.

De anti-dwangarbeidbepalingen in IVBPR en EVRM lijken thans voor Nederland van niet meer dan symbolische betekenis. Toch vormden ze in het begin van de zeventiger jaren belangrijke referentiepunten in het dan op gang komende juridische debat over de dienstverlening als alternatief voor de vrijheidsstraf. De aanzet daartoe werd gegeven door de Arnhemse Politierechter, toen hij in 1971 als bijzondere voorwaarde bij een gedeeltelijk voorwaardelijke veroordeling bepaalde, dat de veroordeelde gedurende de daarbij bepaalde proeftijd drie maanden weekend-werk moest verrichten in een sociaal pedagogisch centrum. Hoewel de veroordeelde dik tevreden was met deze dienstverlening avant la lettre was de officier van justitie dat niet. Het Arnhemse Hof sprak er in appèl zijn veto over uit omdat de Politierechter naar de mening van dat Hof met het opleggen van deze bijzondere voorwaarde een nieuwe strafsanctie zou hebben gecreëerd. Het Hof sneed zich echter in de vingers door in dezelfde uitspraak vast te stellen dat de bedoelde bijzondere voorwaarde op zich niet in strijd was met artikel $14 \mathrm{c} \mathrm{Sr}$ omdat deze voorwaarde ondanks alles zou strekken tot de bevordering van een 'goed levensgedrag'. De Hoge Raad casseerde in het eerste arrest van een reeks die onder de naam van de 'Amhernse IJzervlechters' arresten zou voortleven 's Hofs uitspraak wegens innerlijke tegenstrijdigheid..$^{50}$ Daardoor hoefde Nederlands hoogste rechtscollege zich niet inhoudelijk uit te laten over de namens requirant opgeworpen rechtsvraag, die inhield of de omstreden bijzondere voorwaarde zich wel verdroeg met artikel 2 van Arbeidsconventie nr. 29 en artikel 4 van het EVRM. Volgens de toelichting op het middel was er geen sprake van een introductie van een nieuwe - bij genoemde verdragen verboden - strafsoort nu in dit geval de verdachte zelf om het stellen van die voorwaarde had verzocht. Ook al kon de Hoge Raad hierover het zwijgen toedoen, Procureur-Generaal Langemeijer was in zijn conclusie wel degelijk op deze kwestie ingegaan. Hij meende (daarin bijgevallen door annotator Van Veen) dat de bewuste voorwaarde wèl toelaatbaar was en niet in strijd kwam met genoemde verdragen. Bij een bereidverklaring van de ver- 
dachte kon zijns inziens van meet af aan al geen sprake zijn van 'forced' of van 'compulsary labor'. Zelfs zonder een dergelijke bereidverklaring zou een dergelijke bijzondere voorwaarde volgens Langemeijer niet met het Verdrag van Rome in strijd komen. Dat verdrag maakte het volgens hem mogelijk om veroordeelden in het kader van een conditional release tewerk te stellen en de term conditional release was volgens Langemeijer wel zo ruim dat een voorwaardelijke veroordeling daaronder kon worden begrepen. Wèl achtte hij de bijzondere voorwaarde - als er geen sprake van een bereidverklaring was - in strijd met artikel $2 \mathrm{c}$ van Arbeidsconventie nr. 29 , dat het verbood om veroordeelden te werk te stellen bij particuliere instellingen zoals in dat geval het bewuste sociaal pedagogisch centrum.

$\mathrm{Na}$ (herhaalde) terugverwijzing door de Hoge Raad gaf het Arnhemse Hof, in strijd met de visie van Langemeijer, als zijn mening te kennen dat de omstandigheid dat de verdachte had aangeboden de in de bijzondere voorwaarde bedoelde werkzaamheden te verrichten aan de werkzaamheden het gedwongen karakter niet ontnam omdat het desbetreffende besluit was genomen onder de druk van een mogelijke vrijheidsbeneming. Maar - ook al kwam de bewuste voorwaarde volgens het Hof wel degelijk neer op een vorm van forced of compulsory labor, daarmee (en daarin volgde het Hof Langemeijer wel) was die voorwaarde nog niet in strijd met artikel 4 EVRM. Ook het Hof meende dat een bijzondere voorwaarde als deze kon worden beschouwd als een conditional release from detention als in dat artikel bedoeld. Maar, wederom gelijk Langemeijer, achtte het Hof het in strijd met artikel $2 \mathrm{c}$ van Arbeidsconventie nr. 29 dat in dit geval de veroordeelde arbeid moest verrichten bij een particuliere instelling als het sociaal pedagogisch centrum was: een civielrechtelijke stichting. ${ }^{51}$

Hoewel ook tegen dit arrest beroep in cassatie werd ingesteld, slaagde de Hoge Raad er wederom in om een beslissing te geven zonder inhoudelijk op de toelaatbaarheid van de Arnhemse voorwaarde te hoeven ingaan, mogelijk om geen blokkades te leggen voor verdere experimenten met 'dienstverlening'. ${ }^{52} \mathrm{Pas}$ vele jaren later gaf de Hoge Raad aan dat de bereidverklaring van de verdachte om een dienstverlening te verrichten daaraan wel degelijk het karakter van forced of compulsory labor ontnam, daarmee Langemeijer aan een verlaat gelijk helpend. Waar zo'n bereidverklaring ontbreekt kon een bijzondere voorwaarde waarbij een dienstverlening werd opgelegd volgens de Hoge Raad in strijd zijn met het recht en wel in het bijzonder nnet het bepaalde in art. 4 tweede lid EVRM en artikel 8 derde lid van het dan intussen ook door Nederland geratificeerde IVBPR omdat zulks zou neerkomen op de verplichting tot het verrichten van onvrijwillige arbeid. Daarmee nam de Hoge Raad aisnog afstand van het door het Amhemse Hof ingenomen standpunt dat een aanbod tot het verrichten van dienstverlening het gedwongen karakter daarvan niet opheft. Met deze stellingname maakte de HR het mogelijk, dat arbeid ten algemenen nutte voor particuliere instellingen kan worden verricht zonder dat daardoor artikel 2 lid $c$ van Arbeidsconventie nr. 29 wordt geschonden. Deze fictie van vrijwilligheid, neergelegd in de artikelen 22 c en $22 \mathrm{~d}$ lid $4 \mathrm{Sr}$ is de basis geworden waarop de eind $1989 \mathrm{in}$ artikel $9 \mathrm{Sr}$ geintroduceerde hoofdstraf van het verrichten van arbeid ten algemenen nutte steunt. 
Het gaat daarbij om de initiële bereidheid van de verdachte. Is die eenmaal vastgesteld dan heeft de rechter een grote mate van vrijheid om zelfstandig zwaarte en duur van de te verrichten arbeid te bepalen..$^{53}$

De rechtmatigheid van arbeidsplicht die op veroordeelden rust is door de Hoge Raad nimmer aan verdragsrechtelijke bepalingen getoetst: dat is, zoals we in het vorige hoofdstuk zagen slechts sporadisch en zeer summier door de Beroepscommissie uit de Centrale Raad. voor Strafrechtstoepassing gedaan.

\subsection{De VN' Standaard Minimum Regels en de Europese Gevangenisregels}

Een andere - hierboven al even genoemde - internationale standaard waaraan de rechtspositie van werkende gedetineerden kan worden afgemeten ligt besloten in de artikelen $71 \mathrm{t} / \mathrm{m} 75$ van de uit 1987 daterende Europese Gevangenisregels (EGR). Deze regels vinden hun oorsprong in de Standaard Minimum Regels (SMR) voor de bejegening van gedetineerden, zoals die door het eerste $\mathrm{VN}$-congres over criminaliteitspreventie en de behandeling van daders in 1955 zijn opgesteld, in 1957 door de Sociaal-Economische Raad van de VN (Ecosoc) zịn aanvaard, en zoals die laatstelijk in 1977 zijn geamendeerd.

In 1977 aanvaardde het Comité van Ministers van de Raad van Europa een Europese variant van de Minimumregels (ESMR). Deze ESMR vormden de basis voor de huidige EGR.

Evenals de SMR hebben de EGR juridisch slechts de status van aanbevelingen. ${ }^{54}$ Volgens de Memorie van Toelichting bij de EGR vormen zij een leidraad voor het gevangeniswezen van de lid-staten. De leden van de Raad van Europa die deze regels hebben aanvaard zijn er moreel en politiek aan gebonden. ${ }^{55}$

Vergelijkt men de genoemde internationale aanbevelingen met elkaar, dan valt op dat de SMR, voorzover ze het over de aard van de arbeid hebben (artt. 71$76)^{56}$, uitdrukkelijk stellen dat gevangenisarbeid niet 'kwellend' mag zijn. Dat is in artikel 71 lid 1 SMR zo geformuleerd: 'Prison labour must not be of an afflictive nature'. In de ESMR werd dat een nuance anders geformuleerd. Artikel 72 lid 1 van die regels luidt: 'Prison labour must not be of a punitive nature' en: 'Prisoners shall not be asked to do any especially dangerous or unhealthy work'.

In de EGR wordit deze kwestie compleet anders benaderd en wordt in artikel 71 lid 1 gedetineerden-arbeid als volgt gedefinieerd: 'Prison work should be seen as a positive element in treatment, training and institutional management':

De verplichting om te werken is in de successieve regelingen telkens anders geformuleerd. In de SMR (artikel 71 lid 2) zó: 'All prisoners under sentence shall be required to work (...). Maar zowel ESMR (in artikel 72 lid 2) als EGR (in artikel 71 lid 2) stellen slechts: 'Prisoners under sentence may be required to work'. Daarbij valt op dat 'shall' is vervangen door 'may be' en dat het in alle gevallen on veroordeelden gaat.

Zowel SMR, ESMR als EGR laten het belang van de gedetineerden prevaleren boven een eventueel winststreven van het gevangeniswezen. Overigens stellen de EGR (in artikel 72 lid 2) wel vast dat arbeid zinvoller kan worden en aan kwaliteit kan winnen als er naar winst gestreefd wordt. 
Een andere verschuiving in de genoemde regelingen heeft plaatsgevonden in de benadering van de rol van de particuliere bedrijven bij de gedetineerden-arbeid. Volgens de SMR dienden die bedrijven bij voorkeur niet te worden betrokken bij het beheer van gevangeniswerkplaatsen en gevangenisboerderijen. Waar dat toch gebeurde diende dat dan onder toezicht van inrichtingspersoneel te geschieden.

De ESMR zeggen dat gedetineerden ò in gevangeniswerkplaatsen of gevangenisboerderijen moeten werken ò bij particuliere bedrijven 'where practicable' maar dan wel onder toezicht van de gevangenis-autoriteiten.

De EGR maken (in artikel 73 lid 1 en onder b) het uitdrukkelijk mogelijk om zowel binnen als buiten de inrichting met particuliere ondernemers samen te werken. De eis van toezicht daarop vanuit de inrichting wordt niet expliciet gesteld.

Alle drie genoemde regelingen stellen de eis dat, als gedetineerden voor particulieren werken, die laatsten aan de gevangenisautoriteiten het loon moeten betalen dat ze anders aan een vrije arbeider kwijt geweest zouden zijn, een en ander afhankelijk van de produktie van de gedetineerden. De desbetreffende regelingen bevatten geen verplichting om (een deel van) dat loon aan de desbetreffende gedetineerden door te geven. Wel stellen die regels in zijn algemeenheid dat er voor de gedetineerden een stelsel van billijke beloning moet zijn. In de Memorie van Toelichting bij het desbetreffende artikel in de EGR staat dat deze regels het belang en de waarde van een stelsel van passende en rechtvaardige beloning in het kader van de bejegening erkennen. Volgens diezelfde Memorie van Toelichting was de tijd echter nog niet rijp om in de EGR een anbeveling tot de ontwikkeling van een loonstelsel, vergelijkbaar met het in de vrije maatschappij geldende, op te nemen. Maar, zo vervolgt die Memorie, in een aantal landen is in dit opzicht al heel wat vooruitgang geboekt en dat moet worden aangemoedigd: elk loonstelsel, hoe dat er ook uit moge zien, kan helpen om gedetineerden te leren met geld om te gaan. ${ }^{57}$

Het is de vraag of de EGR van veel belang zijn voor een progressieve ontwikkeling van de rechten van gederineerden. Erg gedetailleerd zijn ze niet, zodat een overheid al vrij snel kan menen eraan te voldoen. Kelk heeft erop gewezen dat zo'n houding -ook voor Nederland - onterecht zou zijn. Volgens hem is de paradoxale situatie zich gaan voordoen "dat inmiddels enkele elementen van de $\mathrm{Ne}$ derlandse detentiesituatie, als gevolg van bezuinigingen en ontwikkelingen in de sfeer van bureaucratisering, voor de gedetineerden in feite ongunstiger zijn geworden en zelfs niet altijd helemaal beantwoorden aan de desbetreffende regels, hoe algemeen deze ook plegen te zijn gesteld'. Verder merkte Kelk op: '(E)en land dat pleegt zichzelf op de borst te kloppen vanwege de hoge kwaliteit van zijn strafrechtspleging en speciaal z'n straftenuitvoerlegging, kan zich niet permitteren op een minimalistische wijze te voldoen aan internationale minimumregels, doch zal deze veeleer op een royale wijze in de praktiik dienen te brengen'. ${ }^{58}$ 
Een manco van de EGR is dat ze 'geen tanden hebben', ze juridisch niet rechrstreeks afdwingbaar zijn. Daardoor zit er een 'gat' tussen de rechtsbescherming die het nationale penitentiare klachtrecht de gedetineerden biedt en die welke aan EVRM en eventueel IVBPR kan worden ontleend. Alleen zeer ernstige wan-bejegening van gederineerden kan, blijkens de desbetreffende jurisprudentie, schending van bepalingen van laatstgenoemde verdragen opleveren. ${ }^{59}$ Voor het op internationaal niveau normeren van de detentie-omstandigheden hebben deze verdragen tot nu toe niet veel betekenis gehad. Er zijn onvoldoende aanwijzingen dat de EGR genoeg moreel gezag hebben. Kelk heeft daarover eens met veel gevoel voor understatement gezegd: 'Ik heb (...) niet de indruk dat deze regels sterk in het dagelijks bewustzijn van functionarissen van het gevangeniswezen leven'. ${ }^{60}$

Weliswaar kunnen de Europese Commissie en het Hof voor de Rechten van de Mens in hun uitspraken over klachten van gedetineerden rekening met de EGR houden. ${ }^{61}$ Alleen wanneer gedetineerden zeer grof worden bejegend wordt schending van artikel 3 EVRM aangenomen, zo concludeert Duffy, die al in 1983 voorstelde dit te ondervangen door het concipiëren van een aantal additionele artikelen bij het EVRM met betrekking tot de behandeling van gedetineerden. $\mathrm{Hij}$ zou het echter nog beter vinden als de Standard Minimum Rules of een aantal daarvan rechtstreeks in het EVRM werden geïncorporeerd. ${ }^{62}$

Spielmann heeft als rechter in het Europese Hof voor de Rechten van de Mens eens gezegd het spijtig te vinden dat de 'vaders' van het EVRM in dat verdrag geen artikelen hebben opgenomen die in het bijzonder de bejegening van gedetineerden betreffen, zoals bijvoorbeeld wel is gebeurd in artikel 10 IVBPR. Ook hij heeft voorgesteld het EVRM in dit opzicht met een protocol aan te vullen. ${ }^{63}$ En dat zal waarschijnlijk ook gaan gebeuren. In april 1993 heeft het "Committee of Experts for the Development of Human Rights' een aan het EVRM toe te vocgen 'Draft Protocol securing certain additional rights to persons deprived of their liberty' aangenomen. Dat ontwerp-protocol biedt personen die rechtens van hun vrijheid zijn beroofd iets meer garanties dan het EVRM in zijn huidige vorm, maar biedt in de voorgestelde formulering de verdragspartijen alle ruimte om de betrokkenen in de uitoefing van die additionele rechten te beperken. ${ }^{64}$ Over arbeid en beloning bevat het ontwerp overigens geen woord.

On een effectieve rechtsbescherming voor de Europese gedetineerde te scheppen lijkt veel meer nodig. Daartoe is behoefte aan een zo concreet mogelijk geformuleerd stelsel van internationale penitentiaire normen watarop gedetineerden rechtstreeks een berocp kunnen doen. De implementatie van die normen zou dienen te worden gecontroleerd door een internationale inspectic. Een internationale penitentiaire rechter zou klachten over normschendingen snel moeten kunnen afhandelen.

Wat die internationale normen betrefr: die zijn er in de vorm van de EGR. Om die werkelijk gelding te geven zou artikel 3 EVRM met de volgende clausule kunnen worden aangevuld 'Everyone who is deprived of his liberty by arrest or detention shall be treated in conformity with the Furopean Prison Rulcs'is. 


\subsection{Andere internationale regels over detentie-omstandigheden}

Een betrekkelijk nieuwe ster aan het penitentiair-rechtelijk firmament is het 'Body of Principles for the protection of all persons under any form of detention or inprisonment', dat op 9 december 1988 door de Algemene vergadering van de Verenigde Naties is aanvaard. ${ }^{66}$ Hoewel deze Beginselen een aantal fundamentele bepalingen over detentie-omstandigheden bevat, ontbreekt merkwaardigerwijs elke referentie aan gedetineerden-arbeid. Dit 'Body of Principles' lijkt overigens niet zozeer van praktische betekenis voor individuele gedetineerden te zijn, maar is vooral een signaal aan de leden van de $\mathrm{VN}$ om te waken tegen het ontstaan van een voedingsbodem waarop martelpraktijken kunnen gedijen. Het benadrukt het grote belang dat in alle gevallen door derden kan worden gecontroleerd of gedetineerden niet aan de willekeur van politie en justitie zijn overgeleverd. ${ }^{67}$

Een andere internationale regeling die in beginsel vooral tegen uitwassen als martelpraktijken lijkt te zijn gericht kan niettemin ook een rol spelen op het gebied van de gedetineerden-arbeid. Het gaat hier om het Europese verdrag ter voorkoming van marteling en onmenselijke of vernederende behandeling en bestraffing van 1987 dat voor Nederland in 1989 in werking is getreden. Her Comité dat het verdrag uitvoert heeft vèrgaande bevoegdheden waarmee het alle detentieomstandigheden op het grondgebied van de verdragsluitende partijen kan inspecteren en beoordelen, inclusief de arbeidsvoorwaarden en arbeidsomstandigheden.

Hoewel het Europese anti-folterverdrag gedetineerden geen individueel klachtrecht toekent heeft het Comité een open oor voor signalen van individuen en (all of) niet-gouvernementele organisaties en is het bereid gebleken om telkenmale onderzoek te plegen naar beweerde misstanden tijdens zijn reguliere of ad hoc bezoeken aan de desbetreffende landen. Het Comité formuleert wanneer het dat nodig acht aanbevelingen voor verbetering van detentie-omstandigheden. het bijzondere is dat het Comité bij zijn beoordeling van de geïnspecteerde inrichtingen weliswaar de bestaande internationale regelgeving als referentiepunt hanteert, maar dat het zich uitdrukkelijk vrij acht zonodig zelf nieuwe maatstaven voor de bejegening van gedetineerden te ontwikkelen. ${ }^{68}$ Over de arbeidsdwang en de onderbetaling heeft het Comité zich nog niet uitgelaten maar het is goed denkbaar dat als het probleem op een adequate manier ter kennis van het Comité wordt gebracht het de kwestie ten grond zal onderzoeken en zonodig met aanbevelingen terzake zal komen.

Tenslotte wordt hier nog gewezen op artikel 8 van de Basic Principles for the Treatment of Prisoners, aangenomen door de Algemene Vergadering van de VN op 14 december 1990, welke artikel luidt: 'Conditions shall be created enabling prisoners to undertake meaningful remunerated employment which will facilitate their reintegration into the country's labour market and permit them to contribute to their own financial support and that of their families.' 
Met enige goede wil kan hierin een recht op zinvolle arbeid en op een adequate beloning worden gezien. De formulering is -ongetwijfeld om politieke redenen - echter dermate ruim dat de betekenis ervan voor de (Nederlandse) rechtspraktijk minimaal moet worden geacht.

\section{Naar een recht op een billijke beloning}

\subsection{Inleiding}

Zoals we in het vorige hoofdstuk zagen ontvangen werkende gedetineerden maar een schijntje voor hun arbeid. Hoewel dat in de ogen van velen de normaalste zaak van de wereld lijkt ('Ze zitten tenslotte niet voor zweetvoeten' luidt de volkse vertaling van het less eligibility-beginsel) is het juridisch allerminst vanzelfsprekend dat gedetineerden slechts een grijpstuiver met hun arbeid verdienen. Hetzelfde ILO-verdrag nr. 29 uit 1930, dat dwangarbeid door gedetineerden toelaatbaar acht, zegt in zijn 14e artikel: '(...) forced or compulsory labour of all kinds shall be remunerated in cash at rates not less than those prevailing for similar kinds of work either in the district in which the labour is employed or in the district from which the labour is recruited, whichever may be the higher'. Hoewel deze bepaling primair geschreven lijkt te zijn ter beteugeling van de gratis herendiensten die door de machthebbers in de koloniën en overige derde wereld landen tot ver na het begin van deze eeuw van hun onderdanen werden verlangd, zijn gedetineerden niet van toepassing van deze regel uitgezonderd.

Het veel jongere Europees Sociaal Handvest (Turijn 1961) verbindt de verdragspartijen in artikel 4 ertoe om het recht van werknemers op een billijke beloning te erkennen. Beschouwt men gedetineerden niet als werknemers, dan zouden ze aan dit Handvest wat dit betreft geen recht op een billijk loon kunnen ontlenen. Een dergelijk standpunt heeft echter geen gevolgen voor de toepasselijkheid van het internationale verdrag inzake economische, sociale en culturele rechten (New-York, 1966), dat in ariikel 7 de staten, die partii bij dat verdirag zijn, verplicht het recht van een ieder op billijke en gunstige arbeidsvoorwaarden te erkennen.

Hoewel gederineerden met gebruikmaking van artikel 15 lid 4 Grondwet in. beginsel óbk van een grondrecht op een billijke beloning kunnen worden 'beroofd' kan zulks - gezien de formulering van dat Grondwetsartikel - alleen als het vitbetalen van een normaal loon voor gevangenisarbeid zich niet met de vrijheidsontneming zou verdragen.

In het gedraai rond de hete brij van de beloningskwestie hebben in ons land internationale rechtsregels overigens nauwelijks een rol gespeeld. Wel moralisme, politieke onwil en zuinigheid.

Hierna volgt een beschrijving van het debat zoals dat sinds de Tweede Wereldoorlog in Nederland is gevoerd en dat voor de gedetineerden nog steeds niet: 
tot tastbare resultaten heeft geleid. Vervolgens wordt de discussie beschreven die voorafging aan de invoering van de loonregeling zoals die uiteindelijk werd opgenomen in het Duitse Strafvollzugsgesetz (StVollzG). Tenslotte wordt een Zweeds experiment met normale beloning voor gevangenisarbeid gesignaleerd. Ook in andere landen zal met bijzondere loonsystemen wordt gewerkt. Het is echter niet de bedoeling hier zoveel mogelijk stelsels in kaart te brengen. Het is slechts de bedoeling om de belangrijkste argumenten voor en tegen een normaal gedetineerden-loon te inventariseren en daartoe lijkt een blik op het Duitse, Zweedse en Nederlandse stelsel te volstaan. Deze argumenten worden vervolgens op hun juridische en praktische waarde geschat voor de Nederlandse situatie.

\subsection{Onwil in Nederland}

De commissie-Fick, die vanuit de wederopbouw-gedachte in 1947 voor een forse verhoging van de produktiviteit van de gevangenisarbeid had gepleit, had wel ingezien dat zoiets niet zonder verhoging van het arbeidsloon te realiseren zou zijn. Naast zakgeld diende de gedetineerde een kostwinnersvergoeding te krijgen die aan zijn gezin (iedereen werd toen kennelijk verondersteld een gezin te hebben) werd uitgekeerd. De commissie-Fick was haar tijd ver vooruit met haar aanbeveling de werkende gedetineerde volledig onder de werking van de toenmalige sociale zekerheidswetgeving te laten vallen. ${ }^{69}$

Met dit voorstel is destijds niets gedaan maar daarmee was de problematiek natuurlijk niet uit de wereld. Die bleek zelfs van zodanig gewicht, dat de leidsman van de Utrechtse school, Pompe, die - zoals Fijnaut het omschreven heeft meende dat de doeltreffendheid van het strafrecht het beste werd gediend door haar medemenselijkheid en rechtvaardigheid ten opzichte van misdadigers ${ }^{70}$, er tamelijk uitgewerkte gedachten over op papier heeft gezet.

Tijdens het twaalfde 'International Penal and Penitentiary Congress' dat in 1950 in Den Haag werd gehouden stelde Pompe voorop dat er tussen de Staat en de gedetineerde geen civielrechtelijke verplichting tot het betalen van loon kon ontstaan. Het enkele feit van de gevangenschap verplichtte hem tot werken. De Staat hoefde slechts in het levensonderhoud van de gedetineerde te voorzien. Maar, zei Pompe daar meteen achteraan, uit doelmatigheidsoverwegingen diende de Staat tegenover de arbeidsprestaties van gedetineerden een vergoeding te stellen. Hij schetste twee loonsystemen, die daarbij konden worden toegepast. Een eerste mogelijkheid was dat er een penitentiair minimum-loon werd vastgesteld waarvan de gedetineerde kantine-artikelen kon kopen en waaraan hij een spaarcentje ${ }^{71}$ kon overhouden. Zo'n penitentiair minimumloon kon door een stelsel van toeslagen, afhankelijk van aard en zwaarte van het werk, worden verhoogd.

Een andere mogelijkheid was volgens Pompe de gedetineerde hetzelfde salaris te betalen dat in de vrije maatschappij voor vergelijkbaar werk werd uitbetaald. Van zo'n salaris konden de kosten worden afgetrokken die de Staat makkte voor 
bewaking, bewassing, kleding en overig levensonderhoud van de gedetineerde. Eventueel kon daarvan ook een deel worden afgehouden ter ondersteuning van het gezin van de gedetineerde en voor schadevergoeding aan de slachtoffers van het door de gedetineerde begane delict. Wat er na de inhoudingen overbleef kon dan volgens Pompe aan de gedetineerde ter beschikking worden gesteld voor aankopen in de kantine of om te sparen. Het laatstgenoemde systeem had Pompes voorkeur omdat volgens hem daarin de opvoedende waarde en het sociaal-economisch nut van de gedetineerden-arbeid het best tot uitdrukking kwam. ${ }^{\mathrm{T2}}$ De overheid deed echter niets met Pompes aanbevelingen. Aan het eind van de vijftiger jaren werd de discussie over de beloning door Veringa heropend. In een drietal artikelen in het Maandschrift voor het Gevangeniswezen schetste hij de voorwaarden waaraan zijns inziens een loonsysteem diende te voldoen. Daarbij ging hij ervan uit dat het doel van de gevangenisarbeid was: handhaving van orde en discipline in het gesticht, betere en snellere wederaanpassing aan de vrije maatschappij en het onderhouden c.q. vergroten van de vakbekwaamheid. Tegen die achtergrond kende hij aan het loon een tweetal functies toe: het leverde geld op om in de kantine te besteden en het was bestemd voor een spaarcentje dat werd uitgekeerd bij het verlaten van de inrichting.

Veringa bepleitte de invoering van een algemeen basis-loon dat - afhankelijk van door de opzichter, meesterknecht of werkmeester toe te kennen punten - telkens lager of hoger uit kon vallen, afhankelijk van de factoren 'ijver', 'houding' en 'kwaliteit'. Over de wenselijke hoogte van zo'n basis-loon liet de schrijver zich echter niet uit. ${ }^{73}$ Over het niveau van het gevangenisloon wordt pas weer gesproken als in 1964 minister van Justitie Scholten in zijn nota 'Het Nederlandse gevangeniswezen' vaststelt dat, ondanks een verhoging van de in 1948 bij de 'Loonregeling gedetineerden' vastgestelde bedragen, daarmee de principiële vraag over de juistheid van het bestaande systeem nog niet was opgelost. 'Daarover zijn verschillende opvattingen mogelijk', zo zei hij, 'zowel wat betreft de omvang en aard van het loon (een volledig loon of een vergoeding) als wat betreft de bestemming (onderhoud van het gezin, gehele of gedeeltelijke betaling van kosten van levensonderhoud van de gedetineerde zelf, kantine- en uitgaanskas, eventuele schadevergoeding aan het slachtoffer, etc.) alsook wat betreft de voor de toekenning te stellen normen: aard van het werk, omvang van de produktie, ijver en goede wil, enz.'. De minister verzocht de Centrale Raad van Advies voor het Gevangeniswezen, de Psychopatenzorg en de Reclassering (CRvA) ${ }^{74}$ dit onderwerp in studie te nemen en hem daarover te adviseren. ${ }^{75}$

Een commissie uit de CRvA (de Commissie Arbeidsbeloning van Gedetineerden) stelde een rapport over deze kwestie op. ${ }^{76}$ Inhoud en strekking daarvan werden in 1966 door de Raad overgenomen: een volwaardig loonsysteem was in principe het juiste en er moest snel mee worden geẻxperimenteerd. De Raad vond het niet nodig om - zoals de commissie had anbevolen - pas daarmee te beginnen in een in Gouda nieuw te bouwen gevangenis. De minister kon wat de CRvA betreft alvast in een bestaand gesticht met zo'n volwaardig loonsysteem starten. ${ }^{77}$

Tijdens de debatten over het rapport van de commissie ging Cohen Stuart, lid 
van de Raad, het verst met voorstellen tot wijziging van 'het statuut' van de werkende gedetineerde: 'Om tegenover de gedetineerden goed te iaten uitkomen, hoe de arbeid gezien moet worden, zou zelfs een $\mathrm{CAO}$ voor gedetineerden denkbaar zijn'.78

Op het advies van de Raad is blijkbaar ambtelijke euthanasie gepleegd want de minister heeft er nooit iets mee gedaan. In 1970 zei het lid van de CRvA Versloor dat het hem was opgevallen dat de aanbevelingen van de Commissie Arbeidsbeloning niet door enig onderzoek waren gevolgd. ${ }^{79} \mathrm{Hij}$ beloofde nog zijn ideeën over de arbeid in een nota neer te leggen ${ }^{80}$, maar was daar, toen hij de Centrale Raad in 1974 verliet, niet meer aan toegekomen. De Raad heeft sindsdien dat thema niet meer opgepakt.

Het rapport van de Commissie Arbeidsbeloning van Gedetineerden (hier verder de Commissie te noemen) heeft echter nauwelijks aan actualiteit ingeboet en zou zó weer als basis voor een debat over het gedetineerdenloon kunnen dienen. Daarom wordt er hier nader naar gekeken.

De Commissie had haar advies met de volgende argumenten onderbouwd. Alleen wanneer het 'binnen' betaalde loon dezelfde economische, sociale en psychologische functies had als het arbeidsloon in het gewone maatschappelijk leven kon het bijdragen tot de resocialisatie van de gedetineerde. Het gedetineerdenloon was echter dusdanig láág dat men daarmee allerminst in zijn levensonderhoud kon voorzien, laat staan er een zekere levensstandaard mee kon bereiken. De uirbetaalde bedragen droegen er niet toe bij dat men zich als arbeider gewaardeerd voelde en vormden geen prikkel om werk te verrichten. Het had volgens de Commissie echter geen zin om een volwaardig loon te betalen voor economisch niet waardevolle arbeid. Zij achtte het maatschappelijk niet juist en ook voor de gedetineerden onbegrijpelijk als zij relatief veel zouden verdienen met werk dat in de vrije maatschappij niet veel opbracht. Dat betekende volgens de Commissie dat gestreefd moest worden naar een produktie op commerciële basis: in de strafgestichten moest in principe economisch waardevolle arbeid worden verricht en de beloning daarvan diende navenant te zijn.

Niet alleen het soort werk was volgens de Commissie bepalend voor de hoogte van het loon, minstens even belangrijk was in haar ogen de manier waarop dat loon werd besteed: "omdat het loon van een arbeider pas zin heeft en dus het loon van een gedetineerde pas een resocialiserend effect heeft, als het op een door het individu en door de samenleving betekenisvolle en gewaardeerde wijze kan worden aangewend' ${ }^{81}$ Hoewel de Commissie vond dat er nog sociaal-wetenschappelijk onderzoek nodig was naar de vraag wat dan wel een zinvolle besteding van het. loon was, weerhield dat haar er niet van te adviseren over te gaan tot spoedige invoering van een volwaardig loonsysteem, hetgeen echter niet gebeurde. Het zou overdreven zijn te zeggen dat daarna het debat verflauwde: er was eenvoudig geen sprake van enig debat.

Pas jaren later, in 1972, rakelden Buitelaar en Sierksma de loonkwestie weer op in hun marxistische analyse van het Nederlandse gevangeniswezen. Zij concludeerden uit litteratuuronderzoek dat gevangenisarbeid weliswaar door het ge- 
vangeniswezen als een resocialiserende bezigheid werd beschouwd, maar dat er onder de gevangenen geen sprake was van een ideologie die de arbeid tot iets prijzenswaardigs maakte. De arbeid werd door hen zelfs negatief gewaardeerd, vooral vanwege de onderbetaling die sterk als uitbuiting werd ervaren, aldus deze schrijvers. Zij trokken de volgende vergelijking tussen de situatie waarin vrije arbeiders verkeerden en die van gedetineerden: 'Hoewel er in Nederland niet van een arbeidsplicht sprake is, wordt er speciaal in perioden van hoogconjunctuur nadruk gelegd op de noodzaak van regelmatige arbeid. Hoewel men niet meer bewust slogans zoals "arbeid adelt" bezigt, ligt in ons economisch systeem en de erbij behorende ideologie deze gedachte wel degelijk opgesloten. Er moet hard gewerkt worden en men moet gehoorzamen aan de "baas" of het ritme van de lopende band. Tegelijk is het werk vaak volstrekt zinloos voor de arbeider en zijn loon is exploitatief van aard. In de gevangenis vinden we al deze kenmerken in extreme vorm terug: volstrekt zinloos werk meestal, met arbeidsplicht en een onbeschoft lage beloning'.

Plannen als van de commissie-Fick en de Commissie Arbeidsbeloning van Gedetineerden om de gevangenisarbeid te industrialiseren en economisch rendabel te maken zouden ook in de visie van Buitelaar en Sierksma betekenen dat de lonen van gevangenen gelijk zouden moeten worden getrokken met die van arbeiders in de fabrieken buiten de muren. De auteurs merkten daarbij wel op dat door industrialisering de gevangenis haar ideologische rol (bevestiging van de bestaande economische orde) nog effectiever zou kunnen spelen dan voorheen: 'De arbeidsplicht blijft bestaan, terwijl her arbeidsregiem strikter zal worden tengevolge van de toenemende concurrentiedruk van andere bedrijven'. Zij keerden zich echter niet tegen hervormende maatregelen die de situatie voor de gevangene draaglijker konden maken. In dat perspectief moet dan ook hun volgende stellingname worden gezien: 'Fundamenteel lijkt ons het verdienen van een arbeidsloon, tenminste op landelijk minimumniveau, waarmee hij zijn eventuele gezin, vriend of vriendin kan onderhouden, hetgeen bepaalde relaties op peil kan houden en zijn "achterban" een gang naar "de steun" bespaart'. ${ }^{82}$

Politiek kwam de loonkwestie sinds de nota-Scholten uit 1964 pas weer aan de orde toen D'66-staatssecretaris Zeevalking in 1976 de nota 'Beleidsvraagstukken Gevangeniswezen' aan de Tweede Kamer aanbood. Daarin werden allereerst plannen ontvouwd om de gevangenisarbeid aantrekkelijker en gevarieerder te maken. Deze staatssecretaris zag in dat de motivatie tot het verrichten van arbeid niet alleen ontleend wordt aan de aantrekkelijkheid van het werk maar ook aan de beloning. 'Het laatste is een oud probleem dat reeds vele malen is bestudeerd, zonder dat een bevredigende oplossing is gevonden', aldus Zeevalking, die verder ging: 'Dit hangt voor een belangrijk deel samen met het gekozen uitgangspunt, te weten: een loon dat min of meer in overeenstemming is met dat in de vrije maat- 
schappij. Voorwaarde voor een "normaal" loon is echter een gelijkwaardige arbeidsproduktiviteit. Voorwaarde is ook dat de inrichtingsarbeid even efficiënt wordt georganiseerd als in de vrije maatschappij. Voorwaarde is verder, dat dit loon grotendeels gaat naar degenen voor wie de gedetineerde kostwinner of onderhoudsplichtige is. Tenslotte is het gewenst dat grote verschillen in inkomen worden vermeden. Voorlopig gaan de gedachten uit naar een uitbouw van het bestaande stelsel van het geven van zakgeld. Het zakgeld is thans te gering dan dat daarvan een prikkel zou kunnen uitgaan om zich voor de arbeidsprestatie in te zetten'. De staatssecretaris beloofde een werkgroep in te stellen om deze problematiek te bestuderen en waarschuwde alvast voor de kosten van een en ander: 'Zo kost $f 1,-$ verhoging van het zakgeld per gedetineerde per dag bij een landelijk aantal van plm. 3000 gedetineerden $f 750.000$,- per jaar. De invoering van het minimumloon voor gedetineerden zou neerkomen op een jaarlijks bedrag van 24 mln. extra op de begroting van her gevangeniswezen'.

Het jaar daarop startte op basis van een advies van de projectgroep 'arbeid en arbeidsbeloning van gedetineerden' in gevangenissen voor langgestraften een (formeel nog steeds lopend) experiment waarbij in gevangenissen voor langgestraften ongeveer twee maal zoveel voor verrichte arbeid wordt betaald als in andere strafinrichtingen. ${ }^{83}$

Interessant is, dat Zeevalking in zijn nota opmerkte dat de arbeid in de inrichtingen niet alleen beloond diende te worden wanneer die economische waarde had of winst opleverde: 'De arbeid kan nog om een andere reden "lonend" zijn, zodat een beloning op haar plaats is. Men kan de arbeid zien als een onmisbaar onderdeel van een pakket van penitentiaire activiteiten, waarvan ook recreatie en maatschappelijk werk deel uitmaken. Het is daarom verdedigbaar, dat in inrichtingen waar het dagprogramma in verband met zekere vormingsactiviteiten niet in een volledige werkdag voorziet, of waar de arbeidsweek korter is dan de gebruikelijke 40 uur, een beloning wordt toegekend die overeenkomt met hetgeen in andere inrichtingen bij een volledige werkweek van 40 uur wordt verdiend'. ${ }^{84}$

De naar hervormingen strevende Coornhert-Liga reageerde nog in 1976 op Zeevalkings voornemens met een Tegen-Nota Beleidsvraagstukken Gevangeniswezen. Daarin schreef Kneepkens over het ontbreken van concrete stappen aan het loonfront dat het meer dan treurig was dat het probleem van arbeid en beloning nog steeds niet op menswaardige wijze was geregeld. Onderbetaling van arbeid tot ver beneden het officiële minimumloon mocht zijns inziens in een beschaafde Westeuropese staat niet voor te komen. 'Continuering van het non-beleid van 1964' was volgens hem een van de ergste omissies in de nota Zeevalking. ${ }^{85}$

De parlementaire bespreking van de nota Beleidsvraagstukken liet lang op zich wachten. Vlak voordat er in 1978 in de Tweede Kamer eindelijk een openbare commissie-vergadering aan werd gewijd, publiceerde de Coornhert-Liga bij wijze van aanvulling op haar Tegen-nota een aantal 'Notities over het gevangeniswezen'. Deze 'Notities' omvatten ideeën over arbeid en beloning in de gevan- 
genis en kritiek op het geldende arbeids- en beloningssyreem, zoals die waren naar voren gebracht door de werkgroep 'Arbeid en beloning' van de Regio Noord van de Liga en de niet-gedetineerde leden van de afdeling Groningen van de Belangengroepering Wetsovertreders (BWO). Deze organisaties stelden voorop dat de arbeid in de gevangenis in principe geen juridische verplichting diende te zijn. Het geboden werk moest zoveel mogelijk aansluiten op de belangstelling en mogelijkheden van de gedetineerden en diende van zodanige aard zijn dat zij hun vakbekwaamheid konden vergroten. Er moesten geen orders worden aangenomen voor produkten die door een paar eenvoudige handelingen in elkaar gezet konden worden, zoals wasknijpers en fietswielen.

Verder moesten de gedetineerden een volwaardig loon verdienen, tenminste het minimumloon. Dat zou, aldus de Liga, hen in staat stellen de financiele verplichtingen die zij vóór hun detentie waren aangegaan te blijven nakomen. Verder moesten er secundaire arbeidsvoorwaarden komen, zoals een geïnstitutionaliscerd werkoverleg tussen gedetineerden en werkmeesters waarin het beleid met betrekking tot de arbeidsomstandigheden en de inhoud van de arbeid kon worden vastgesteld. Verder moesten de gedetineerden volgens de Liga aanspraak kunnen maken op dezelfde sociale voorzieningen als mensen buiten de gevangenis dat konden. Vakbonden, waarbij gedetineerden zich aansloten, moesten binnen de gevangenis dezelfde faciliteiten hebben als daarbuiten. De Arbeidsinspectie moest binnen de gevangenis dezelfde werkzaamheden kunnen verrichten als op de arbeidsplaatsen in de vrije maatschappij. ${ }^{86}$ De eis tot normalisering van het loon maakte aldus deel uit van een heel pakket verlangens met betrekking tot de arbeidsrechtelijke positie van de gedetineerden.

Tijdens de openbare commissie-vergadering over de Nota Beleidsvraagstukken noemde staatssecretaris Haars de loonkwestie een 'heet hangijzer'. Zij stel$\mathrm{de}^{87}$ : 'Allereerst en heel duidelijk: gedetineerden ontvangen geen minimumloon. Hun arbeidsbeloning is ook niet onderhevig aan sociale lasten of loonbelasting. De arbeidsbeloning die thans in een aantal inrichtingen voor langgestraften wordt verstrekt moet los worden gezien van de sociale voorzieningen. Ik heb er ook moeite mee, toe te zeggen, dat (...) in de gevangenissen een minimumloon zal worden uitbetaald, want in wezen houdt dat een andere waardering in voor de arbeid in de gevangenissen dan in feite plaatsvindt. Een gedetineerde werkt niet louter voor de produktie. Bij zijn arbeid zijn er ook mogelijkheden tot vakopleiding en scholing, zodat de arbeid van de gedetineerde niet kan en mag worden vergeleken met arbeid in het vrije bedrijf. ${ }^{8 s}$ (...) Het geven van een minimumloon vergt een andere benadering dan de betcre vergoeding die de laatste tijd aan een aantal gedetineerden is gegeven. (...) Als wij al een mininumloon zouden geven, zouden naar mijn visie ook de bijstandsuitkeringen aan de familieleden vervallen. Ik weet niet of de familieleden daarmee zo verschrikkelijk gelukkig zouden zijn, want nu krijgen zij de volledige bijstand. De gedetineerde krijgt bepaalde vergoedingen, die hij zelf kan gebruiken. Ik meen dat op dit punt niet positief kan worden gereageerd'. Zij zegde echter op aandringen van mevrouw Haas-Berger 
(PvdA) toe de kosten van een experiment eens op een rijtie te zullen zetten en dat heeft ze ook gedaan, namelijk ter gelegenheid van de bespreking van de nota Beleidsvraagstukken eind 1978 in de Tweede Kamer. Haars: 'Wat betreft het geven van minimumloon aan gedetineerden wijst een zeer voorzichtige berekening uit, dat dat de staat $f 37 \mathrm{mln}$. zou kosten. Hierop kunnen de bijstandsgelden die zouden moeten worden uitgekeerd in mindering worden gebracht. Dit bedrag is ongeveer geschat op $f 14 \mathrm{mln}$., hetgeen betekent, dat $f 23 \mathrm{mln}$. ten laste van de justitiebegroting zou komen indien gedetineerden het minimumloon zou worden betaald.

Ik vraag mij trouwens af of de gedetineerden er bij verlening van het minimumloon qua besteding en resocialisatie niet op achteruit zouden gaan. Betaling van het minimumloon houdt in dat een volledige arbeidsdag moer worden gevraagd. Op dit moment werken de gedetineerden een halve dag en doen zij de andere helft alle mogelijke andere dingen.

Ik zou het jammer vinden indien het laatste kwam te vervallen, aangezien informatieverstrekking, studie en sport daardoor deels onmogelijk zouden worden. Bovendien betwijfel ik of de echtgenoten het prettig zouden vinden niet meer van de zekere bijstandsuitkering maar van het onzekere minimumloon van hun echtgenoot te moeten leven. Dit is overigens een punt op zich zelf. ${ }^{89}$

Intussen was in juni 1977 het rapport van de commissie 'Doelstelling en Functie Huis van Bewaring' (naar haar voorzitter het Rapport van de commissieVan Hatrum te noemen) verschenen. Daarin werd gereageerd op de mededeling in de Nota Beleidsvraagstukken Gevangeniswezen uit 1976 dat voorshands geen oplossing voor het probleem van de zeer geringe beloning van de arbeid te verwachten was. De commissie-Van Hattum was echter van mening dat in beginsel aan de gedetineerde een volwaardig loon (dat wil zeggen tenminste het minimumloon) moest worden betaald: 'Alleen hierdoor zal hij zijn status als kostwinner kunnen behouden. Het ministerie van justitie dient hiertoe in overleg met andere departementen (zoals die van sociale zaken en financiën) naar wegen te zoeken om dit te realiseren'. De commissie-Van Hattum zag mogelijkheden om dit te realiseren in een verschuiving in de algemene middelen vari bijstandsuitkering naar loon, wardoor dit de overheid niet per se extra geld behoefde te kosten. Een forse: optrekking van het loon achtte de commissie op korte termijn echter niet realiseerbaar. Daarom pleitte zij 'voorshands' voor toekenning van een zodanige beloning dat het wat aantrekkelijker werd om te gaan werken. Over concrete bedragen liet de commissie zich niet uit. ${ }^{90}$ In haar (meer dan drie jaar na het verschijnen ervan geopenbaarde) eindoordeel over het rapport van de commissieVan Hattum liet staatssecretaris Haars zich weer uit over de beloningskwestie. Deze keer was zij, onder verwijzing naar haar opmerkingen tijdens de openbare commissie-vergadering van 10 april 1978 en haar opmerkingen in de Tweede Kamer in oktober 1978, peremptoir: een minimumloon voor gedetineerden kwam er niet. Ze formuleerde het zo: 'Reeds eerder is dezerzijds in principe het optrekken van de beloning tot het peil van het minimumloon in de vrije maatschappij af- 
gewezen. Voorwaarde zou immers moeten zijn een gelijkwaardige arbeidstijd, arbeidsproduktiviteit en -organisatie. Om aan deze voorwaarden te kunnen voldoen, zou de arbeid in de detentiesituatie een geheel andere plaats moeten gaan innemen. Verder zou dit loon dan grotendeels moeten gaan natar diegenen voor wie de gedetineerde dan kostwinner of onderhoudsplichtige is. Dit is in het Nederlandse penitentiaire bestel niet realistisch'. ${ }^{91}$

Dat een nieuwe staatssecretaris niet per se een nieuw geluid betekent bleek uit de manier waarop Scheltema in zijn op 2 september 1982 aan de Tweede Kamer gepresenteerde nota 'Taak en toekomst van het Nederlandse gevangeniswezen' het loon-thema behandelde. Het pleidooi dat herhaaldelijk en van verschillende kanten was gehouden voor toekenning van het minimumloon aan gedetineerden kwam hem 'vooralsnog' niet realistisch voor. Het belangrijkste argument tegen invoering van zo'n minimumloon ontleende hij aan de veronderstelde benadeling van diegenen, die financieel van gedetineerden afhankelijk zijn. 'De bijstandsuitkeringen aan die personen zouden dan komen te vervallen. Dit brengt hen echter in een zeer afhankelijke situatie ten opzichte van de gedetineerde. Tegen weigerachtigheid van de gedetineerde om zijn verplichtingen na te komen, is niet eenvoudig op te treden, zeker niet door her gevangeniswezen. Bovendien dient er geen ongerechtvaardigde ongelijkheid te ontstaan tussen gedetineerden zonder verplichtingen jegens derden en hen die, al of niet gedetineerd, van het minimumloon voor zichzelf en eventueel anderen moeten rondkomen. Dat zou betekenen', aldus nog steeds de bewindsman, 'dat inhoudingen op het minimumloon moeten kunnen plaatsvinden. Hiermee stuit men op een uiterst ingewikkeld vraagstuk, waar het gehele sociale verzekeringsstelsel mee gemoeid is. Het korten van uitkeringen waarop men recht heeft, is cen kwestie van veel algemener belang dan dat ze voor wat gedetineerden betreft afzonderlijk kan worden opgelost. Als daarbij bedacht moet worden dat die kortingen eerder regel dan uitzondering kunnen worden om bovengenoemde redenen, lijkt het met voorrang ter hand nemen van dit onderwerp niet voor de hand te liggen'.

Daarnaast zei de staatssecretaris er eenvoudig niet de extra financiële middelen voor te hebben om een minimumloon in te voeren "(i)n deze tijd van een sterk neerwaarts gaande conjunctuur, waarin ook de overheid aanzienlijk moet bezuinigen'. Hij becijferde de invoering van een minimumloon op een extra uitgave van $f 35 \mathrm{mln}$. per jaar. 'Indien kortingen moeten worden toegepast, zullen daarvoor personele en organisatorische voorzieningen moeten worden getroffen. Onder deze omstandig-heden is tockenning van het minimumbon een volstrekte onmogelijkheid'. ${ }^{92}$

Het parlement heeft geen moeite gedaan om de staatssecretaris op andere gedachten te brengen. De basis voor het gedetineerdenloon was en bleef de Loonregeling 1948, aangevuld met de hier al eerder genoemde experimentele loonregeling voor hen die in inrichtingen voor langgestraften verblijven.

Een staking voor een hoger loon, geïnitieerd door gedetineerden in het Groningse huis van bewaring, noopte staatssecretaris Korte-van Hemel in $1985 \mathrm{nog}$ 
eens op een rijtje te zetten waarom er geen minimumloon kon worden betaald. Het is eentonig, maar dient hier toch gedocumenteerd te worden, al was het maar om de 'verstening' van de oude negatieve argumenten vast te leggen en het insluipen van nieuwe te signaleren. De opeenvolgende bewindslieden maakten het zichzelf langzamerhand steeds moeilijker om echt iets aan het loon te doen door steeds meer - vooral praktische - problemen te construeren. Korte-van Hemel schreef de Groningers: 'Tijdens de detentie wordt u van rijkswege geheel verzorgd. Deze verzorging voorziet in een basisvoorzieningenpakket dat toereikend is om aan de normale behoeften te voldoen. Het loon, dat $u$ voor arbeid ontvangt moet $u$ zien als een zakgeld waarvoor $u$ kantine-artikelen kunt aanschaffen, telefoonkosten kunt voldoen en voor zover $u$ in bepaalde gevallen in aanmerking zou komen voor verlof, de eigen bijdrage in de (reis)kosten kunt bekostigen.

De gedachte om aan de gedetineerden het wettelijk minimumloon uit te keren is niet nieuw.

Het gelijkschakelen van de beloning in de inrichtingen met de wettelijke minima welke gelden in de vrije maatschappij, brengt met zich mee dat er gesproken moet worden van een gelijkwaardige arbeidsproduktiviteit, arbeidsorganisatie en arbeidstijd.

Voorwaarde is verder dat het loon, na aftrek van kosten wegens voeding e.d., grotendeels gaat naar degenen voor wie de gedetineerde kostwinner of onderhoudsplichtige is. Dit betekent dat degenen die van het inkomen van de gedetineerde afhankelijk zijn geen recht meer kunnen doen gelden op b.v. bijstandsuitkeringen. Voorts is het gewenst dat grote verschillen in inkomen tussen de gedetineerden onderling worden vermeden.Een dergelijke situatie van ongelijkheid, welke onvermijdelijk tot ongewenste spanningen in de inrichtingen zal leiden, zal ontstaan bij invoering van het wettelijk minimumloon. Slechts in geval van kortingen op de uitkeringen van degenen die geen verplichtingen hebben jegens derden, zou deze ongelijkheid kunnen worden weggenomen.

Problemen waarvoor geen praktische oplossing voor de hand ligt, zullen daarnaast optreden wanneer een gedetineerde niet bereid is de hem opgedragen werkzaamheden te verrichten of wanneer hij wcigert zijn financiële verplichtingen jegens degenen die van hem afhankelijk zijn na te komen' ${ }^{3.93}$

Alle strafinrichtingen ontvingen een kopie van de brief van Korte-van Hemel. De reactie van de voorzitter van de gedetineerdencommissie 'De Boschpoort' te Breda was: 'Het is een standaardbrief die ze aan alle inrichtingen heeft gestuurd. Er wordt ingegaan op eisen die wij helemaal niet hebben gesteld.' Hij concludeerde dat de acties niets hadden uitgehaald en dacht dat met de afwijzing van de staatssecretaris de zaak voorlopig van de baan was. ${ }^{94}$ En zo was het.

\subsection{Papieren beloften in Duitsland}

In het Duitse equivalent van de Nederlandse Beginselenwet Gevangeniswezen, het op 1 januari 1977 in werking getreden Strafvollzugsgesetz (StVollzG), is 
het recht op loon voor arbeid vastgelegd in artikel 43. De hoogte van het loon is op grond van artikel 200 StVollzG gekoppeld aan de jaarlijks in de vrije maatschappij gemiddeld ontvangen sociale uitkeringen. Dat normbedrag wordt (aan de hand van de in het voorgaande kalenderjaar uitgekeerde bedragen) jaarlijks door de Bundesminister voor arbeid en sociale zaken bekend gemaakt. Aan werkende gedetineerden komt $5 \%$ van die norm toe waarbij het dagelijkse grondloon het 250 ste deel van die $5 \%$ is. Het grondloon kan lager of hoger uitvallen, afhankelijk van inschaling in een van de vijf loon-categorieën die het Duitse systeem telt. ${ }^{95}$ Het grondloon kan (per categorie) door toeslagen met maximaal 30\% worden verhoogd. In 1989 bedroeg her dagelijkse grondloon DM 7,55 (in Nederland $f$ 4,20 grondloon, te verhogen met maximaal $f$ 6,40 aan toeslagen). De Duitse werkende gedetineerde 'verdient' uiteindelijk ongeveer hetzelfde als de Nederlandse (lang)gestrafte: een habbekrats.

Een opvallend element van het Duitse loonstelsel is de koppeling van de loonhoogte aan het gemiddelde niveau van de sociale uitkeringen. Sterk contrasterend met het overheidsdenken in Nederland is het uitgangspunt waarmee de Duitse wetgever de loonkwestie te lijf is gegaan. Die had er - in ieder geval aanvankelijk - wel oren naar om de beloning gelijkwaardig te laten zijn aan de geleverde arbeidsprestatie. In de loop van het wetgevingsproces werd daar echter stap voor stap afstand van genomen. Enerzijds bestond meningsverschil over de vraag of de loonhoogte moest worden bepaald door de geleverde arbeidsprestatie, het plaatselijk gebruikelijke loon of van het gemiddeld door uitkeringsgerechtigden genoten inkomen. Aan de andere kant werd -onder verwijzing naar de hoge kosten die een en ander met zich mee zou brengen- de berekeningsgrondslag van het gedetineerdenloon steeds verder teruggeschroefd: anvankelijk zou die $75 \%$ van het plaatselijk gebruikelijke loon moeten bedragen. Men kwam tenslotte uit op bovengenoemde $5 \%$ van de gemiddeld ontvangen uitkeringen. De aanvankelijk goede bedoelingen zijn slechts nog symbolisch te vinden in het tweede lid van artikel $200 \mathrm{StVollzG}$ waarin staat dat uiterlijk op 31 december 1980 een besluit wordt genomen over een verhoging van de grondslag van het gedetineerdenloon. Die datum is niet gehaald. De beoogde aanpassing naar boven van het arbeidsloon is voorlopig mislukt. De verhoging die in 1980 zou plaatsvinden is voortdurend uitgesteld. Zeer tor ongenoegen van de Duitse gedetineerden, die massaal bij de ECRM hebben geklaagd over de Duitse overheid die de wettelijke beloften om hun loon te normaliseren niet nakomt. Hun voorman, Dieter Hammers, zei: 'Hier gevangen zitten is het twintigste-eeuwse equivalent van slavernij'. ${ }^{96}$

Het merkwaardige is dat de, in ieder geval verbaal op opwaardering van het loon mikkende, Duitse wetgeving tot stand is gekomen na een discussie waarin nauwelijks andere praktische en politieke argumenten een rol speelden dan die de Nederlandse overheid juist deden besluiten tot het afwijzen van normalisering van de penitentiaire salariëring. In één opzicht was er wel verschil: een aantal Duitstalige auteurs had meer oog voor de rechtsgrondslagen van de loonaanspraken van gedetineerden dan de Nederlandse debattanten. Hieronder een samenvarting van hun meningen zoals zij die ventileerden voordat op 1 januari 1977 het Strafvollzugsgesetz van kracht werd. 
In zijn in 1968 gepubliceerde studie van het probleem van de honorering van gedetineerden-arbeid stelde Heising dat, als de overheid een burger dwingt om onbeloonde arbeid te verrichten, die overheid daarmee een inbreuk op diens rechtssfeer maakt. Voor zo'n inbreuk is dus een wettelijke basis nodig, niet alleen wat het opleggen van een arbeidsplicht betreft maar ook ter legitimering van het niet vergoeden van de verrichte arbeid. Heising stelde (anno 1968) vast dat het Duitse recht zweeg over de vraag of door gedetineerden verrichte arbeid vergoed moest worden. Zijn stelling was dat het ontbreken van een wettelijke loonaanspraak niet zonder meer voortvloeide uit de aard van de vrijheidsstraf. Die bestond immers 'slechts' uit inperking van de bewegingsvrijheid. Geen enkel strafdoel rechtvaardigde in zijn visie de onteigening van de economische waarde van de arbeid van gedetineerden en daaraan ontbrak trouwens elke wettelijke basis. Men kon volgens Heising niet volhouden dat er geen loon betaald hoeft te worden omdat er geen sprake is van een arbeidsovereenkomst: ook zonder zo'n overeenkomst kunnen loonaanspraken bestaan.

Zij die vrezen dat mèt de uitbetaling van een nomaal loon aan gedetineerden de tenuitvoerlegging van de straf zal worden verstoord door arbeidsrechtelijke conflicten, die bijvoorbeeld de vorm van stakingen zouden kunnen aannemen, miskennen volgens de schrijver dat die arbeidsplicht door voor de arbeid te betalen niet wordt aangetast.

Volgens hem is het ook niet zo dat door het qualitatief minderwaardige karakter van de verrichte arbeid de aanspraak op loon zou wegvallen. De arbeid van de gedetineerde mag niet zo maar met die van de vrije arbeider worcien vergeleken. Heisings stelling is dat de vergoeding van de tijdens de tenuitvoerlegging van de vrijheidsbeneming verrichte arbeid bij het ontbreken van een werknemer-werkgever verhouding moet worden beschouwd als compensatie voor de economische waarde van de arbeidskracht.

Dan zijn er diegenen die vinden dat uitbetaling van een normaal loon in strijd. is met het beginsel dat het levenspeil van de gedetineerden niet te hoog mag zijn omdat anders het afschrikwekkende effect van de straf verdwijnt en de gevangenis voor werklozen een aantrekkelijke optie wordt. Volgens Heising is over deze vooronderstelling; geen rationeel debat mogelijk. Dit probleem ligt volgens hem op het terrein van de massa-psychologie.

Het argument dat door het uitbetalen van normale lonen de kosten van de tenuitvoerlegging van de vrijheidsstraf te hoog worden wijst Heising af door te stellen dat dát niets af doet aan de rechtsaanspraken op uitbetaling van een dergelijk loon.

Heising pleitte voor het ontwikkelen van een systeem waarmee de economische waarde van de arbeidskracht van de individuele gedetineerde kan worden berekend. Tegelijkertijd diende er volgens hem een methode te worden gevonden om de kosten van levensonderhoud van gedetineerden te berekenen, zodar die weer van het uit te keren loon konden worden afgehouden. ${ }^{97}$

De stelling dat de gedetineerde recht heeft op vergoeding van de economische waarde van zijn arbeidskracht kreeg bijval van Heierli die dat de juridisch meest 
correcte benadering noemde. Financieel zou dat naar zijn mening de gedetineerde, vergeleken bij de status quo ante, geen grote voordelen brengen (denk aan de te introduceren aftrekposten; gdj), maar er zat zijns inziens het grote pedagogische voordeel aan vast dat voor de gedetineerde de relatie tussen arbeid en beloning zichtbaar werd. Hij achtte daarom de manier waarop het loon werd berekend van groot belang. Hij betoonde zich voorstander van een loondervingsregeling met het karakter van een sociale zekerheids-uitkering. Zo'n regeling zou moeten voorzien in een basisloon dat van inrichtingswege door middel van (prestatie)toeslagen kon worden verhoogd.

Heierli vond het wel raadzaam dat de besteding van het loon aan bepaalde regels werd gebonden. Over het loon moesten allereerst belastingen en premies betaald worden. Dan was er een deel bestemd voor in de inrichting te besteden zakgeld en voor een uitgaanskas. Er was wat hem betreft geen reden om er iets van af te houden voor de kosten van de detentie. Daaraan droeg de gedetineerde immers al bij door het betalen van belasting. Wel moest eventueel geld voor ondersteuning van het gezin op het loon worden ingehouden. Tenslotre diende een deel van het loon te worden besteed aan het vergoeden van schade aan eventuele slachtoffers van het delict waarvoor de vrijheidsstraf was opgelegd.

Volgens. Heierli schiep de detentie zèlf de rechtsplicht tot het betalen van een basisloon. Lag de rechtsgrond voor het uitbetalen van het basisloon in de vrijheidsbeneming zelf, uitbetaling van prestatietoeslagen was echter afhankelijk van de arbeidsprestatie van de individuele gedetineerde. Heierli stelde uitdrukkelijk dat het basisloon ook betaald moest worden aan gedetineerden die onvrijwillig werkloos waren. Bij arbeidsongeschiktheid moesten loon en toeslagen worden berekend op de manier zoals dat ook in de vrije maatschappij gebeurde. ${ }^{98}$

Gedetineerden hebben volgens Fahsei - precies zoals vrije burgers - recht op arbeid. Dat vloeit voort uit het recht op een vrije beroepskeuze en een vrije keuze van de plek waar de arbeid verricht wordt. Noch de letter, noch de geest van de wet ontnemen de gedetineerde het recht op arbeid of perken dat in. In zijn visie komt de gevangene het recht om te werken in volle omvang toe. Omdat er in de strafgestichten nu eenmaal geen vrije arbeidsmarkt bestaat rust op de overheid de verplichting om in die inrichtingen voor werk te zorgen. De plicht van de overheid om voor dat werk te betalen is geen andere dan die op de normale werkgever rust. Verder vervallen loonaanspraken geenszins door het bestaan van een arbeidsplicht.

Deze schrijver wijst erop dat voor het bestaan van een arbeidsverhouding niet bepalend is of er de facto werk verricht wordt maar of de werkgever kan bepalen wat voor werk er gedaan moet worden en hoe en waar dat gebeurt. Er bestaat geen beginsel dat binnen een arbeidsverhouding alleen loon betaald behoeft te worden als er ook feitelijk werk is verricht. Fahsel stelt vast dat er in de strafgestichten sprake is van een feitelijke arbeidsverhouding. Loonaanspraken van gedetineerden komen geenszins te vervallen omdat de aard van de vrijheidsstraf zulks met zich mee zou brengen. 
De hoogte van het loon moet worden vastgesteld zoals dat ook in de vrije maatschappij gebeurt. Daarbij dient volgens deze schrijver wel te worden gedifferentieerd naar loon tijdens opleiding en scholing, loon voor onproduktief en ongeschoold werk en loon voor produktieve arbeid. Verder vindt hij dat van het loon een deel voor kost en inwoning aan de staat moet worden betaald. Evenals Heierli vindt hij het niet nodig dat de gedetineerde apart moet meebetalen voor de instandhouding van de strafinrichtingen: dat moet uit de algemene middelen worden bekostigd. Verder zijn volgens hem inhoudingen noodzakelijk voor belastingen en premies, onderhoudsbijdrage voor gezin, zakgeld, uitgaanskas, schadevergoeding aan benadeelden en ter afbetaling van eventuele schulden. ${ }^{99}$

Dan waren er auteurs als Koch, Lichtenberger en Ohle die de stelling dat aan gedetineerden loon naar werken moest worden betaald niet zozeer juridisch motiveerden maar de grondslag daarvoor zagen in de beoogde resocialiserende en speciaal preventieve werking van de vrijheidsstraf.

Als arbeid een belangrijke factor is in het socialiseringsproces van het vrije individu, dan is die arbeid voor de gederineerde een belangrijke factor in het resocialiseringsproces, aldus Koch. Hij achtte de betaling van een vergoeding voor het gedane werk vooral vanuit een opvoedkundig standpunt wenselijk. Om 'executiepedagogische' redenen diende volgens hem in de toekomst aan de arbeidsplicht voor gevangenen te worden vastgehouden. De kwestie van de arbeidsbeloning moest volgens Koch niet zozeer rechtstheoretisch worden bekeken als wel in het kader van de resocialisering. Men diende zich daarbij voortdurend af te vragen in hoeverre veranderingen binnen het vigerende stelsel het herintreden van de gevangene in de vrije maatschappij positief konden beïnvloeden. Koch betoonde zich geen voorstander van een normale vergoeding van gedetineerden-arbeid omdat de hoogte van het loon door de grote verschillen in vaardigheden van de gedetineerden, in soort werk en in arbeidsprestaties nauwelijks te berekenen viel. Wel pleitte hij voor een verhoging van de destijds bestaande vergoeding. Anders dan anderen vond hij dat de besteding van het verdiende inkomen volstrekt vrij moest worden gelaten en niet bestemd moest worden voor zaken als detentie- en proceskosten, alimentatie of schadevergoeding. ${ }^{100}$

Lichtenberger meende dat het systeem van arbeidsbeloning anno 1971 het uiteindelijke doel van de vrijheidsstraf, de resocialisatie, tegenwerkte en daarom door een resocialisatie-bevorderend systeem moest worden vervangen. Hij pleitte ervoor om alleen dan loon te betalen als de besteding daarvan tot de resocialisatie van de gedetineerde kon bijdragen. Daarom stelde hij voorwaarden aan de manier waarop het geld mocht worden uitgegeven. Het was niet goed als gedetineerden het hele bedrag in handen kregen. Belastingen en premies moesten er zijns inziens in ieder geval van worden afgehouden. Ook 'detentiekosten' zouden wat hem betreft in beginsel kunnen worden ingehouden maar daar moest dan wel eerst een wettelijke basis voor komen. Verder moest een deel van het geld als uitgaanskas bewaard blijven. Geld voor kosten van levensonderhoud van gezin en 
familie en bedragen voor schadeloosstelling van slachtoffers van het delict waarvoor men 'zat', mocht echter niet van het loon worden afgehouden. Dergelijke aanspraken dienden primair door de schuldeisers zelf te worden waargemaakt.

Evenals Heising ging Lichtenberger na waaruit de belangrijkste bezwaren tegen het betalen van een normaal loon aan gedetineerden bestonden. Volgens sommigen zou het betalen van een normaal loon aan gedetineerden slecht op het publiek overkomen. Men zou daaruit opmaken dat gedetineerden in de warten werden gelegd. Op zo'n manier was de straf immers geen leed meer. Zo'n opvatting berustte volgens Lichtenberger echter op verkeerde ideeën over de zin van hard strafrechtelijk optreden en zou door een goede voorlichting kunnen worden beïnvloed. Men moest leren inzien dat vrijheidsbeneming op zichzelf al leedtoevoeging genoeg was.

Een ander argument tegen de invoering van een normaal loon, namelijk dat de produktiviteit van de gedetineerde arbeider niet te vergelijken is met die van de vrije arbeider, gaat volgens de schrijver niet op omdat die vergelijking helemaal niet gemaakt mag worden. Het gaat erom dat arbeid wordt verricht en die moet betaald worden.

De tegenwerping, dat uitbetaling van een volwaardig loon onrust onder de gedetineerden teweeg zou brengen bij onderlinge verschillen in verdiensten, ging volgens Lichtenberger niet op. Immers, met het geldende systeem van arbeidsbeloning waren toen àlle gedetineerden ontevreden.

Het belangrijkste argument tegen de invoering van een normaal gedetineerdenloon was, volgens Lichtenberger, dat dat eenvoudigweg te duur was. Het kosten-argument verloor volgens deze schrijver echter zijn kracht, waar vaststond dat het geldende loonsysteem het tegendeel van resocialisatie bewerkstelligde. ${ }^{101}$

Ohle bezag het loon-probleem vanuit het strafdoel van de speciale preventie. Dat kon volgens hem alleen worden bereikt door gedetineerden te laten werken. Immers, de gevangenisarbeid kon de gedetineerde weer geschikt maken voor de 'vrije arbeid'. De arbeidsbeloning diende zijns inziens te worden gezien als een zelfstandig resocialiseringsmiddel. Zonder een adequate beloning verwordt gevangenis-arbeid echter tot een bijkomende straf. Volgens Ohle meet de gedetineerde aan zijn beloning af of de maatschappij hem werkelijk wil resocialiseren of niet. Het zou naar de mening van Ohle echter met elk resocialisatiestreven botsen om gedetineerden geld in handen te geven waarover zij ook in de vrije maatschappij niet vrij zouden kunnen beschikken. Daarom vond hij dat het loon diende te worden gebruikt om ermee de kosten van de detentie te bestrijden, de belastingen en premies te betalen, eventuele alimentatieverplichtingen te voldoen, benadeelden schadeloos te stellen en schulden te betalen ${ }^{102}$.

De nog niet van kracht geworden artikelen 49 en 50 StVollzG bevatten regelingen met betrekking tot alimentatieverplichtingen van gedetineerden en een bijdrage in de kosten van de detentie. Pas wanneer in de (verre?) toekomst het 
detentieloon voldoende niveau heeft kunnen deze aftrekposten van kracht worden. Tot dan toe geidt alieen dat van gedetineerden met voldoende eigen inkomsten een bijdrage in de detentiekosten kan worden verlangd, zij het dat daaronder niet de kosten van huisvesting en personeel begrepen zijn. ${ }^{103}$

\subsection{Experimenten in Zweden}

In Zweden heeft men zich niet tot debatten en papieren wetten beperkt maar is men in de praktijk met het betalen van een normaal loon aan gedetineerden gaan experimenteren. Het Zweedse equivalent van onze Beginselenwet Gevangeniswezen bepaalt dat gedetineerden voor verrichte werkzaamheden betaald moeten worden. Net als bij ons wordt de hoogte van het loon door de minister vastgesteld. Ook die gedetineerden die deelnemen aan vormingsactiviteiten, beroepskeuze-onderzoek, studie of andere georganiseerde activiteiten of behandelingen ontvangen een loon. In het begrotingsjaar $1988 / 89$ bedroegen de gemiddelde verdiensten 9,5 Zweedse kronen (ongeveer $f 3,-)$ per uur. Al sinds jaren worden -op experimentele basis- in de open inrichting Tillberga en de gesloten inrichting Skogome (beide inrichtingen met een landelijke bestemming) en de regionale open inrichting te Vångdalen lonen op marktniveau betaald. Men wil daarmee de gedetineerden vlak voor hun invrijheidstelling sociaal-economisch weer op het buiten de muren gangbare niveau brengen. ${ }^{104}$

Het experiment met een volwaardig loon loopt in Tillberga al vanaf 1972, dat in Skogome vanaf 1975. In Tillberga wordt een normaal loon betaald aan gedetineerden die daar ingezet zijn bij de produktie van pre-fab houten huizen en aan hen die daar in een constructie-werkplaats werken. Het loon wordt niet belast maar het uit te betalen bedrag is gelijk aan het netto-loon van houtbewerkers en arbeiders in de metaalindustrie. Voor elke gedetineerde wordt apart een bestedingsplan opgesteld. Hij moet bereid zijn een aanzienlijk deel van zijn inkomsten te besteden aan het afbetalen van eventuele schulden en ondersteuning van zijn gezin. Een deel van het loon moet voor de verloven worden gereserveerd en voor de eerste tijd na het ontslag. Verder moeten de gedetineerden voor de kosten van hun levensonderhoud betalen. Ongeveer $30 \%$ van het verdiende loon is vrij besteedbaar. Het experiment in Skogome lijkt op dat te Tillberga, alleen is het werk er anders: er is een wasserij en een kleermakerij.

In 1979 achtte de Zweedse minister van Justitie Romanns de tijd rijp om te bezien of het experiment met lonen op vrije markt-niveau kon worden uitgebreid. Hij stelde een parlementaire commissie in om hem daarover te adviseren. ${ }^{105}$ Deze zogenaamde MAIK-commissie rapporteerde in 1984 dat de experimenten met een normaal loon, die sinds 1972 in Tillberga en sinds 1975 te Skogome liepen, grote voordelen voor de gedetineerden bleken te hebben. Er was echter nog een aantal vraagstukken met betrekking tot belastingheffing en sociale verzekeringen niet opgelost.

De commissie had intussen in 1982 een experiment met normaal loon in de regionale open inrichting Vangdålen geëntameerd. Als richtiijn voor de loonbere- 
keningen wordt daar de CAO voor beschermde werkplaatsen aangehouden. De inrichting houdt de verschuldigde belasting in en men bouwt er pensioenrechten op. Het inkomen van iedere gedetineerde wordt daar gebudgetteerd. In tegenstelling tot de landelijke inrichtingen Tillberga en Skogome behoeft men voor Vangdålen met zijn regionale bestemming niet speciaal geselecteerd te worden. ${ }^{106}$

De commissie had onderzocht hoeveel extra zo'n systeem van normale beloning nu kost. Ze had berekend dat in het kader van het experiment te Vangdălen $72 \%$ van het bruto-loon in de schatkist terug vloeide in de vorm van belastingen of besparingen voor lokale overheden. $8 \%$ werd gereserveerd voor schadevergoedingen, huurschulden en levensonderhoud. De resterende $20 \%$ ontvingen de gedetineerden contant.

Op grond van wat zij het 'normaliseringsbeginsel' noemde stelde de MAIKcommissie voor om gedetineerden precies dezelfde rechten te geven op het gebied van de sociale zekerheid als andere burgers hadden. De commissie zag wel een aantal 'natuurlijke' grenzen aan haar normaliseringswoorstellen. Een gedetineerde zat nu eenmaal niet vrijwillig in de gevangenis en was verplicht de hem opgedragen arbeid te verrichten. Die arbeidsplicht achtte de MAIK-commissie van grote betekenis bij het streven naar normalisering van het beloningssysteem. Tengevolge van die verplichting is er namelijk geen sprake van een op het arbeidsrecht gebaseerde contractuele verhouding tussen het gevangeniswezen en de gedetineerde.

Die is daarom geen werknemer in de civielrechtelijke betekenis van het woord. Dat heeft gevolgen voor de toepasselijkheid van de sociale zekerheids- en arbeidswetgeving.

De MAIK-commissie meende dat de arbeidsplicht moest worden gehandhaafd, niet alleen om passiviteit te bestrijden maar vooral om de gedetineerde vast te laten wennen aan het leven buiten de gevangenis. De commissie vond het niet zinvol om binnen een dwangsysteem, dat een gevangenis nu eenmaal is, over contractuele verhoudingen te spreken. Daarom diende haars inziens het recht op loon vastgelegd te blijven in de penitentiaire wetgeving. Om de arbeidsvoorwaarden van gedetineerden gelijk te maken aan die van andere burgers wilde de commissie uitdrukkelijk in de wet vastgelegd zien in welke opzichten de inrichtingsarbeid gelijk moet worden gesteld aan bedriifsmatige arbeid. De MAIK-commissie meende dat gedetineerden cloor middel van een inspraakprocedure invloed moesten kunnen hebben op zaken als bijvoorbeeld de beloning.

Al deze overwegingen leidden haar tot (onder meer) de volgende aanbevelingen:

- De beginselen die ten grondslag liggen aan het stelsel van de sociale werkvoorziening kunnen leidraad zijn voor de organisatie van de arbeid in strafinrichtingen. De lonen zouden moeten worden vastgesteld zoals dat in de sociale werkvoorziening gebeurt.

- Het genormaliseerde loon wordt besteed met behulp van een verplichte budgetplanning die wordt gemaakt door de gedetineerde samen met de inrich- 
tingsstaf of de reclassering. Omdat niet alle gedetineerden behoefte aan een gedetailleerde budgetplanning zullen hebben moet daarbij de meeste aandacht uitgaan naar de mensen die dat het meest nodig hebben. Geen enkele gedetineerde dient echter meer dan 20 à $30 \%$ van zijn bruto-inkomen tot zijn vrije beschikking te krijgen. Wat er - buiten dat percentage - overblijft na aftrek van belastingen en bijdrage aan de kosten van levensonderhoud moet voor hem worden gereserveerd.

- Verdient een gedetineerde eenmaal een normaal loon dan moet hij voor zijn levensonderhoud betalen.

- Gedetineerden dienen zoveel mogelijk op dezelfde voet als gewone werknemers in aanmerking te komen voor ziektewet-, arbeidsongeschiktheids- en werkloosheidsuitkeringen.

- Gevangeniswezen dient net als voor haar eigen werknemers het werkgeversaandeel in de sociale lasten voor zijn rekening te nemen.

- Over de genormaliseerde lonen dient net als over elk inkomen uit arbeid belasting te worden geheven.

- Het genormaliseerde loon mag niet voor beslag vatbaar zijn: uit reclasseringsoverwegingen lijkt hier de budgetplanning het aangewezen instrument.

Het verdiende volgens de commissie aanbeveling om stapsgewijs het door haar gepropageerde volwaardig loonsysteem uit te breiden tot alle inrichtingen. Zij benadrukte dat de hogere uitgaven voor $3 / 4$ zouden worden gedekt door evenredig hogere inkomsten voor de staat en besparingen bij het centrale en regionale bestuur. Een verdere besparing kon plaatsvinden door het aantal gedetineerden terug te dringen. Die kant moest het volgens de MAIK-commissie op: naar minder gedetineerden en een zinniger inhoud van de vrijheidsstraf. ${ }^{107}$

\subsection{Aanbevelingen van de Raad van Europa}

In Resolutie (75) 25 over gedetineerden-arbeid heeft het Comité van Ministers van de Raad van Europa onder meer aanbevolen om de beloning van de arbeid in de strafgestichten in overeenstemming te brengen met het loon dat in de vrije maatschappij betaald wordt. ${ }^{108}$ Deze resolutie vormt een van de bijlagen van het rapport 'Work in Penal Institutions' dat Neale voor de Raad van Europa heeft opgesteld. In dat rapport wordt verbazingwekkend weinig inhoud aan deze aanbeveling gegeven. Neale kwam niet verder dan het debiteren van algemeenheden over een wenselijk gedetineerdenloon. Hij stelde vast dat het beloningsniveau in veel Europese landen net hoog genoeg is om de directe levensbehoeften van de gedetineerden te dekken. Wel constateerde hij een (bijna) algemene overeenstemming over de therapeutische waarde die het verdienen van een eigen inkomen kan hebben: dat is goed voor het besef van eigenwaarde en voor het verantwoordelijkheidsgevoel bij de gedetineerden. Neale vond dat het streven naar een hoger loon moest worden gesteund omdat dat kon bijdragen tot het normaliseren van het leven in de strafinrichtingen en een prikkel was tot een juiste houding ten 
aanzien van arbeid. Hij zei er echter niet bij hoe een hoger loonniveau zou kunnen worden bereikt en hoe de juridische en sociaal/politieke barrières die zulks in de weg staan geslecht zouden kunnen worden. ${ }^{109}$

Het in 1983 uitgekomen rapport van de Raad van Europa 'Prison Management' bouwt voort op Neales rapport van 1976 en Resolutie (75)25. De arbeid wordt een uiterst belangrijke factor genoemd bij het 'managen' van strafinrichtingen. De Europese penitentiaire systemen zouden prioriteit moeten geven aan arbeid. Die moest overigens wel op een hoger technologisch niveau worden gebracht, reëel worden beloond en op de arbeidsmarkt zijn georinteerd. De produktie zou marktgericht moeten zijn, aan kwaliteitseisen moeten voldoen en ten volle gebruik moeten maken van de aanwezige arbeidskracht. Dat alles in het kader van goed geleide, moderne en commerciële ondernemingen die produktieen winstgericht draaien. De rapporteurs wezen daarbij op het voorbeeld van de loon-experimenten in Zweden en op een gevangenisfabriek in het Engelse Coldingley. ${ }^{110}$ Het oude probleem werd met een modernistisch management-sausje overgoten, maar daarmee kwam de oplossing ervan geen stap dichterbij.

Het Europese document met de meeste status is thans Recommendation (87) 3 van de Raad van Europa met betrekking tot de Europese Gevangenisregels (EGR). Artikel 76 lid 1 EGR luidt: 'Er moet een stelsel van billijke beloning van het werk van gedetineerden zijn'. Wie het bij deze regel behorende gedeelte van de Memorie van Toelichting leest wordt echter niets wijzer over de inhoud die hier aan het begrip 'billijk' moet worden gegeven. Daar wordt alleen gezegd: 'Deze regel erkent het belang en de waarde van een stelsel van adequate en billijke beloning. Omdat zulks in deze fase van ontwikkeling als prematuur moet worden beschouwd, bevat deze regel géén bepaling die de ontwikkeling aanbeveelt van beloningssystemen, die gangbaar zijn voor vergelijkbaar werk in de vrije maatschappij. Er is in dat opzicht in een aantal landen behoorlijk wat vooruitgang geboekt en die moet worden aangemoedigd. Welke ook de aard van een beloningssysteem is en welke voorwaarden er ook aan de besteding van het uitgekeerde bedrag worden gesteld, het draagt bij tot de ontwikkeling van de financiele verantwoordelijkheid van de gedetineerden'.

Men kan niet zeggen dat de Europese Gevangenis Regels op die manier sterke impulsen tot het verbeteren van het loon van werkende gedetineerden uitzenden. Daartoe hadden tenminste suggesties voor een stapsgewijze ontwikkeling van een systeem van rechtvaardige en adequate beloning moeten zijn gegeven."

\subsection{De pro's en contra's van een normale arbeidsbeloning}

De hierboven beschreven pot-pourrivan argumenten tegen normalisering van het gedetineerdenloon kan in een aantal hoofdbestanddelen worden uitgesplitst en wel in crimineel-politieke, technische en financiële. Per categorie worden zij in het onderstaande op hun feitelijke en juridische houdbaarheid getoetst. 


\section{Als gedetineerden evenveel of zelfs meer verdienen dan niet-gedetineerden verliest de vrijheidsstraf haar afschrikwekkende effect.}

Als een dergelijke veronderstelling waar zou zijn dan zou het, na de invoering van een normaal loon, voor een aantal mensen financieel interessant zijn om te gaan 'zitten' en dat kan de bedoeling van de vrijheidsstraf niet zijn. Zij, die er een dergelijke opinie op na houden, gaan uit van een 'calculerende' wetsovertreder die de beslissing om een delict al dan niet te plegen van een rationele kostenbaten analyse laat afhangen. Dat zal in bijzondere gevallen waar kunnen zijn, enig bewijs voor algemene geldigheid van een dergelijke stelling is niet te vinden. Wel zijn er aanwijzingen dat er van de generaal- en speciaal-preventieve werking van de vrijheidsstraf zoals die thans ten uitvoer wordt gelegd, dus inclusief het te verwaarlozen loonniveau, betrekkelijk weinig verwacht moet worden. Men leze de nimmer weersproken conclusies van het in 1975 door het WODC gepubliceerde onderzock 'Effectiviteit van sancties'. ${ }^{12}$ Uit dit litteratuuronderzoek bleek onder meer dat vrijheidsstraf niet effectiever is dan geldboete, de kans op recidive stijgt naarmate de detentie langer duurt en dat de aard van het regiem de recidive nauwelijks beïnvloedt.

Hiermee lijkt de (eerder op emoties dan op feiten gebaseerde) de hierboven geponeerde stelling voldoende betwist. Toch kan haar in het openbaar debat over de vraag hoe gevangenen behandeld moeten worden een zeker politiek en demagogische effect niet worden ontzegd. En dát soort effecten valt echter nauwelijks met rationele argumenten te bestrijden.

Een moeilijker te weerleggen argument tegen het op peil brengen van het gedetineerden-loon is dat normalisering daarvan niet resocialiserend werkt. Deze redenering gaat zo:

2. Er kan pas een normaal loon worden betaald als er nomale werktijden worden aangehouden, maar dat gaat ien koste van resocialiseringsinspanningen.

In Nederlandse penitentiaire termen vertaald zou dat betekenen dat de huidige bloktijdenregeling, in het kader waarvan gedurende één dagdeel wordt gewerkt en één dagdeel aan andere regiemsactiviteiten wordt besteed, zou komen te vervallen. Omdat in het blok waarin niet gewerkt wordt alle reclasserende activiteiten zijn ondergebracht zou normalisering van het loon derhalve anti-resocialiserend werken. De gedetineerden zouden zo uiteindelijk zelf de dupe van hun looneisen worden.

Of deze veronderstelling houdbaar is kan pas worden geverifieerd als vast zou komen te staan dat de arbeidsvrije blokken inderdaad een essentiële bijdrage aan de terugkeer in de maatschappij leveren. Dergelijke bewijzen zijn niet voorhanden. De bloktijdenregeling lijken eerder een gevolg van een tekort aan voldoende inrichtingsarbeid en van de bureaucratische wens om allerlei onoverzichtelijk 'ge- 
loop' in de inrichtingen (bezoek, contacten met hulpverleners etc.) te bundelen.

Een volle arbeidstijd hoeft overigens reclasserende activiteiten niet in de weg te staan. Hoeveel - al dan niet collectieve - arbeidsovereenkomsten kennen niet bijzondere bepalingen voor opleiding en vorming tijdens het werk met behoud van loon? Trouwens, door de beleidsmakers is herhaaldelijk gezegd dat vorming en ontwikkeling van gedetineerden zo belangrijk zijn, dat actieve deelname daaraan op de zelfde manier als arbeid dient te worden beloond. In de Nota Beleidsvraagstukken van 1976 is al gezegd dat het niet juist zou zijn de arbeid in de inrichtingen alleen te belonen als die economische waarde heeft of winst oplevert. De arbeid kon om nog een andere reden 'lonend' zijn. Men kan de arbeid namelijk zien als een onmisbaar onderdeel van een pakket van penitentiaire activiteiten waarvan ook recreatie en maatschappelijk werk deel uitmaken. De Nota noemde het daarom verdedigbaar dat in inrichtingen waar het dagprogramma in verband met vormingsactiviteiten niet in een volledige werkdag voorzag, of waar de arbeidsweek korter was dan de gebruikelijke 40 uur, een beloning werd toegekend die overeenkwam met hetgeen in andere inrichtingen bij een volledige werkweek van 40 uur wordt verdiend. ${ }^{113}$

Vijftien jaar later werd door Justitie van de gedetineerde verwacht, zelfs geëist, dat die deelnam aan vormende activiteiten die hem kunnen voorbereiden op zijn terugkeer in de maatschappij. In zijn nota 'Herziening differentiatiestelsel gevangeniswezen' van 1990 betoogde staatssecretaris Kosto dat het karakter van de straf niet louter in de beneming van de vrijheid als zodanig gezocht moest worden, 'maar ook in de eisen die aan de gedetineerden worden gesteld om te participeren in velerlei regiemsactiviteiten'. Het dragen van de bijbehorende verantwoordelijkheid en het opbrengen van de bijbehorende zelfdiscipline noemde hij daarbij 'elementen die aan de tenuitvoerlegging van de vrijheidsstraf nieuw perspectief kunnen geven'. 114

Zo is de gestichtsarbeid geëvolueerd van essentieel element van de vrijheidsbeneming tot onderdeel van wat. Kosto een 'regiemsactiviteitenprogramma' noemt. Men wordt niet langer voor het verzette wérk beloond maar voor volledige participatie aan alle facetten van het regiem, voor (braaf) méédoen. De arbeidsverhouding wordt onderdeel van een veel meer omvattende inspanningsverplichting. De gedetineerden mag zich niet afzijdig te houden. Hem wordt een zeer bepaalde levensstijl opgelegd. Hij dient zijn volle medewerking te geven aan een standaardregime. Hij zál meewerken aan zijn ombouw tot een law abiding citizen, zo niet, dan moet hij het doen met een minimum aan faciliteiten. ${ }^{115}$

Als gedetineerden om deze redenen slechts aan part-time werk kunnen worden geholpen lijkt het redelijk ${ }^{116}$ als de financiële risico's van zo'n beleid voor rekening van de overheid komen: de volle prijs zal dienen te worden betaald voor de door de gedetineerde aan de staat beschikbaar gestelde arbeidstijd, óók als die voor andere zaken dan produktieve arbeid wordt gebruikt.

Een laatste crimineel-politiek argument tegen het betalen van een normaal loon is: 
Een dergelijke veronderstelling miskent echter dat ook thans, bij de huidige lage beloning, er niettemin tussen gedetineerden grote verschillen in inkomen en vermogen bestaan. Men denke aan de relatief bevoorrechte positie van gedetineerden die een AAW, WAO, AOW of AWW uitkering hebben. Die lopen tijdens detentie gewoon door. "Terwijl bij de ene gedetineerde iedere maand het "geldschip" binnenkomt, moet de andere zijn vrouw met bijstandsuitkering geld vragen voor de huur van een televisie', schrijft Platschorre. ${ }^{117}$

Het huidige loonstelsel accentueert de grote verschillen tussen arm en rijk in het gevang, verschillen die de onderlinge verhoudingen van gedetineerden sterk bepalen. Grapendaal heeft dat beschreven in zijn onderzoek naar de gedetineerdensubcultuur in drie Nederlandse gevangenissen.

'Alles draait om geld', vertelde een gedetineerde hem. 'Geld blijft, ongeacht of men nu in de gevangenis of daarbuiten vertoeft, het algemene betaalmiddel. Degenen die relatief rijk zijn, staan voor de keus door middel van hun welstand een leider te worden of zich afzijdig te houden en - voorzover mogelijk - alleen te genieten van de voordelen die een zekere welvaart met zich meebrengt. Indien de keuze in het voordeel van de laatste overweging uitvalt, is de rust die men daarvan ondervindt slechts schijn. Met name wanneer er zeer begeerde goederen in de inrichting aanwezig zijn (harddrugs), is het geen zeldzaamheid dat het rond de cel van een dergelijke "rijke" gedetineerde zoemt van activiteit van andere gedetineerden die geen geld hebben, maar het willen lenen of er door middel van andere zaken aan willen komen. Deze transacties kennen verschillende vormen: ofwel men biedt goederen aan in ruil (soms veranderen hele celinventarissen op deze manier van eigenaar), ofwel men biedt diensten aan en plaatst daarmee de persoon in kwestie voor een moeilijk dilemma, want hij had besloten zijn detentie in afzijdigheid door te brengen, ofwel hij leent domweg geld op grond van zijn inkomsten uit de arbeid die hij verricht. Dit laatste heeft tot gevolg dat allerlei aankopen die hij in de (buiten)kantine kan doen, op een laag pitje komen te staan. Voorts is er ook een levendige handel in bar-bonnen; het aan plaats gebonden equivalent van geld. Deze activiteit rond de cel van een (mogelijk) vermogende gedetineerde, brengt soms de betreffende persoon in verlegenheid. Het komt voor dat hij niets met de drugsscene te maken wil hebben en ook anderszins niet in de kijker wil lopen. Het aankloppen van vele gedetineerden om geld vestigt de aandacht van de bewaarders op hem'. ${ }^{11}$

Kortom, de veronderstelling dat verschillen in beloning bij betaling van een normaal loon een bedreiging van de rust en orde in de inrichting zouden opleveren gaat voorbij aan de binnen de muren al bestaande welstandsverschillen. Men kan hier gemakkelijk tegenoverstellen dat betaling van een normaal loon (ook al is dat eventueel naar vakbekwaamheid, ervaring en werksoort gedifferentieerd) in de strafinrichtingen juist zal kunnen leiden tot vermindering van de financiële verschillen tussen de 'inzittenden'. De armen zullen minder bij de rijken hoeven bedelen. De rijken hebben minder kans de armen in de schulden te steken of tot 
het verlenen van bepaalde diensten te dwingen. Het kan de vorming van 'cliëntsystemen' terugdringen.

\section{Technische bezwaren}

Een tweede hoofdbezwaar tegen normalisering van het gedetineerdenloon is dat het zo buitengewoon ingewikkeld zou zijn om voor deze categorie arbeiders een loonstelsel te ontwerpen. Vooral de interferentie met het belastingstelsel en de sociale zekerheidswetgeving zou daarbij schier onoplosbare problemen veroorzaken. ${ }^{119}$ Ook het ontwikkelen van loonschalen zou zeer moeilijk zijn, onder meer door de grote verschillen in vakbekwaamheid, opleiding en inzet van de gedetineerden en het gevarieerde werkaanbod.

Bezwaren van deze aard lijken voor de situatie in Nederland niet erg steekhoudend. De sociale zekerheidswetgeving is in een aantal opzichten afgestemd op de situatie waarin een (potentiële) uitkeringsgerechtigde rechtens van zijn vrijheid beroofd is, ook al pakt die afstemming meestal negatief uit omdat de meeste uitkeringen door of tijdens detentie worden gestaakt of geschorst. ${ }^{120}$ Uitkeringen die tijdens detentie wèl doorlopen kunnen van de gedetineerde worden afgenomen zoals bij ter beschikking gestelden met een arbeidsongeschiktheidsuitkering. $\mathrm{Op}$ zulke uitkeringen wordt - voorzover zij in een zogenaande AWBZ-inrichting worden verpleegd -een eigen bijdrage ingehouden. ${ }^{121}$

Een voorbeeld van toepassing van een sociaal zekerheidsrecht op gedetineerden, maar dan een toepassing waarbij ze baat hebben, levert de uitvoering van de zogenaamde dagdetentie. In het kader van die executiemodaliteit zijn gedetineerden de laatste zes weken van hun vrijheidsstraf overdag in de inrichting aanwezig en mogen ze 's avonds, 's nachts en in het weekend thuis bivakkeren. Die laatste zes weken komen zij in aanmerking voor een uitkering ingevolge de Algemene Bijstandswet. De staatssecretaris van Sociale Zaken en Werkgelegenheid motiveerde dit als volgt: 'In geval van dagdetentie wordt de gedetineerde voorbereid op een volledige deelname aan de maatschappij. Dagdetentie is dus gericht op het bereiken c.q. herstel van de zelfstandige voorziening in het bestaan. Daartoe is voor deze groep gedetineerden de mogelijkheid geopend een beroep te doen op de Algemene Bijstandswet (ABW). Gemeentea kunnen in genoemde situatie bijstand verlenen op grond van de individualiseringsbepaling van de $A B W .^{122}$ Niet iedereen vindt dat overigens een correct gebruik van deze sociale zekerheidsvoorziening. Volgens De Bruijn, die meent dat de kosten van gevangenisstraf, inclusief de kosten van dagdetentie, ex artikel 35 eerste lid Sr. ten laste van het ministerie van Justitie komen, wentelt Justitie op deze manier ten onrechte de financiële gevolgen van dit dagdetentiebeleid op de $\mathrm{ABW}$ af. ${ }^{123}$

Op haar beurt verwijst de penitentiaire regelgeving in een aantal gevallen naar de sociale zekerheidsregelingen zoals die voor niet-gedetineerden gelden, naar wat hier verder het reguliere stelsel van sociale zekerheid zal worden genoemd. Zo zegt artikel 48a Gevangenismaatregel dat de kosten van geneeskundige verzorging van gedetineerden alleen ten laste van de Staat komen als die niet door de 
AWBZ of de Ziekenfondswet worden gedekt. Een ander voorbeeld van verwijzing naar het reguliere stelsel van sociale zekerheid is dat minder- of invalide gedetineerden via plaatsing in een Penitentiaire Open Inrichting (POI) van daaruit in het kader van de Wet Sociale Werkvoorziening (WSW) tewerkgesteld kunnen worden. ${ }^{124}$

Het feit dat de reguliere sociale zekerheidswetgeving gedurende de vrijheidsbeneming in de meeste gevallen niet toepasselijk is betekent overigens niet dat gedetineerden niet voor de financiële gevolgen van ziekte, ongeval of blijvende arbeidsongeschiktheid 'verzekerd' zijn. Dat zagen wij in het vorige hoofdstuk waarin - onder meer - de penitentiaire regelingen en jurisprudentie met betrekking tor arbeidsongeschiktheid en werkloosheid van de gedetineerde/arbeider zijn beschreven.

Er blijkt een bijzonder penitentiair sociaal zekerheidsstelsel te zijn gegroeid, een schaduw-stelsel. De binnen dat schaduwstelsel uitgekeerde bedragen zijn door hun koppeling aan de Loonregeling gedetineerden van 1948 vanzelfsprekend zeer gering. ${ }^{125}$ Dat schaduwstelsel heeft intussen door zijn oriëntatie op het reguliere stelsel heel wat begrippen uit dat laatste overgenomen. Een groot probleem daarbij is dat Justitie in haar circulaires en de Beklag- en Beroepscommissies in hun jurisprudentie die 'geleende' begrippen een heel eigen, penitentiaire, inhoud hebben gegeven, hetgeen bij gedetineerden (en hun raadgevers) nogaì eens voor verwarring en onbegrip zorgt. Als voorbeeld kan de penitentiair-rechtelijke hantering van de aan het reguliere stelsel ontleende term 'arbeidsongeschiktheid' dienen. Personen die 'buiten' in het kader van de ZW, AAW of WAO arbeidsongeschikt worden geacht zijn daardoor niet per se ongeschikt voor de gestichtsarbeid, omdat die door de $\mathrm{BrC}$ in het algemeen veel lichter en eenvoudiger van aard wordt geacht dan het werk dat gewoonlijk in de vrije maatschappij wordt verricht. Gedetineerden en hun bewakers hebben niet zelden moeite met dit soort discrepanties. In een poging om het schaduw- en het reguliere stelsel wat dit betreft op elkaar af te stemmen heeft de staatssecretaris van Justitie de (geneesheerdirecteuren van de strafinrichtingen per circulaire het volgende laten weten: 'Gedetineerden, die uitkeringsgerechtigd zijn ingevolge de Ziektewer kunnen (nog) ongeschikt zijn in de zin van de ZW, maar wel (weer) in staat worden geacht om gestichtsarbeid te verrichten'. 'Er kan', aldus de staatssecretaris, 'derhalve een discrepantie bestaan tussen de geschiktheid tot het verrichten van arbeid in de zin van de ZW en de geschiktheid tor het verrichten van gestichtsarbeid'. Hij wees er daarbij op dat de bedrijfsvereniging die na afloop van detentie aan de gerechtigde zelf of tijdens diens detentie aan diens gezin tot uitkering van ziekengeld overgaat $^{126}$, de inkomsten uit gestichtsarbeid op die uitkering in mindering kan brengen.

Gevangenen die geheel of gedeeltelijk arbeidsongeschikt zijn in de zin van de WAO of AAW (veel hard-drugs verslaafden genieten dergelijke uitkeringen) ontkomen daardoor niet aan de arbeidsplicht. Volgens de staatssecretaris kan er bij 
(gedeeltelijke) arbeidsongeschiktheid toch sprake zijn van geschiktheid voor gestichtsarbeid. ${ }^{127}$ Overigens kunnen inkomsten uit gestichtsarbeid door de bedrijfsverenigingen op de uitkering in mindering worden gebracht.

De staatssecretaris noemde het wèl gewenst dat in dit soort gevallen overleg plaatsvindt tussen gestichtsarts en verzekeringsgeneeskundige dan wel de Gemeenschappelijke Medische Dienst. ${ }^{128}$ Er is echter geen zicht op of dat ook werkelijk gebeurt. Uit jurisprudentie van de $\mathrm{BrC}$ blijkt eerder dat in conflicten over arbeidsongeschiktheid van gedetineerden de gestichtsarts niet. de minste neiging heeft derden om hun deskundige mening te vragen. ${ }^{129}$

De $\mathrm{BrC}$ bevestigde in 1982 de bijzondere uitleg die de staatssecretaris aan het begrip arbeidsongeschiktheid wenste te geven in de volgende overweging: 'Arbeidsongeschiktheid in de zin van buiten de inrichting geldende sociale wetgeving brengt niet automatisch ongeschiktheid mee voor het verrichten van de gestichtsarbeid, die - veel lichter van aard - niet te vergelijken is met arbeid in de vrije maatschappij en een geheel ander doel heeft dan die arbeid'. ${ }^{130}$

Aan de andere kant betekent het feit dat een veroordeelde in strafrechtelijke termen 'ziek' wordt geacht nog niet dat hij arbeidsongeschikt wordt bevonden in de zin van de reguliere sociale zekerheidswetgeving. Bijvoorbeeld: iemand die ter beschikking van de regering is gesteld omdat hij ten tijde van het plegen van het hem ten laste gelegde misdrijf lijdende was aan een gebrekkige ontwikkeling en mogeiijk ziekelijke storing van zijn geestvermogens is daardoor nog niet arbeidsongeschikt in de zin van de AAW. ${ }^{131}$

Men kan vaststellen dat de wederzijdse beïnvloeding van penitentiair en sociaal zekerheidsrecht vele en vaak moeilijke afstemmingsproblemen met zich meebrengt. Platschorre zegt eufemistisch dat de regeling van de gevolgen van detentie in het sociale zekerheidsrecht vrij ongestructureerd tot stand is gekomen en daardoor voor de betrokkenen nogal ontoegankelijk is: 'Degene die wil weten wat er gebeurt in de uitkerings-sfeer in geval van detentie krijgt niet alleen te maken met wetgeving en jurisprudentie, maar ook met circulaires, reglementen en beleid'. Zij pleit voor hemieuwde aandacht voor deze problematiek en vindt dat daarbij het uitgangspunt zou moeten zijn dat gedetineerden hun rechten op sociale uitkeringen zoveel mogelijk zouden moeten behouden. ${ }^{132}$

Met zo veel ervaring op het terrein van het reguliere en het penitentiaire schaduwstelsel van sociale zekerheid kan Justitie niet goed volhouden dat het ontwikkelen van een volwaardig loonstelsel voor gedetineerden afstuit op technische problemen bij de inpassing daarvan in de sociale zekerheid. Misschien zal het zelfs mogelijk blijken dat de arbeidsverhouding tussen Justitie en gedetineerden zo wordt herzien dat het sociale zekerheidsstelsel daar vrijwel zonder ingrijpende regelgeving op aansluit.

Tenslotte is er nog de bedenking dat het vrijwel ondoenlijk zou zijn om - gezien de grote onderlinge verschillen qua kennis, ervaring en gezien het gevarieerde werkaanbod - goede loonschalen voor werkende gedetineerden te ontwikke- 
len. Ook dat bezwaar snijdt geen hout. Voor ambtenaren en voor werknemers in het vrije bedrijf zijn in de loop der tijd zoveel verschillende looncategorieën gecreëerd dat het wel heel wonderlijk zou zijn als dat nu juist voor gedetineerden niet zou iukken.

\section{Financiële bezwaren}

Herhaaldelijk zijn door de bewindslieden op Justitie financiële bezwaren geuit tegen elk voornemen om iets fundamenteels aan de gedetineerdenlonen te doen. In 1976 schatte Zeevalking de meerkosten op 24 miljoen jaarlijks en Haars kwam in 1978 op 37 miljoen, zoals boven is beschreven. Met deze bedragen liet de (toch al niet erg aandringende) Tweede Kamer zich telkens gemakkelijk afbluffen. Té gemakkelijk, want geen van de 'geachte afgevaardigden' vroeg door over de gevolgde berekeningsmethode. Men liet zich met wat ambtelijk natte-vinger werk de mond snoeren.

Op het 'geen geld'-standpunt valt juridisch en feitelijk nogal wat af te dingen. Juridisch door te stellen dat het onthouden van een normaal loon aan gedetineerden niet inherent is aan de vrijheidsstraf, zoals die is bedoeld in artikel 9 Sr. en dus kan worden beschouwd als een illegale vermogensstraf. Weliswaar levert het niet betalen van een (behoorlijk) salaris aan gedetineerden geen schending van het EVRM op. Het Straatsburgse Hof stelde in 1968 simpelweg vast dat een recht op billijke beloning voor gedetineerden-arbeid niet in het EVRM wordt gegarandeerd en dus ook niet een recht is dat kan worden geschonden. ${ }^{133}$ Niemand kan sinds de Golder-case ${ }^{134}$ echter volhouden dat een fooi voor bajeswerk nu eenmaal bij het gevangenisbestaan hoort, daaraan inherent is. De leer van de inherente beperkingen, die inhoudt dat iemand in de uitoefening van zijn grondrechten kan worden beperkt louter op grond van zijn status van gedetineerde, is in die zaak door het EHRM verworpen.

Het EVRM mag dan niet - zoals andere verdragen dat wel doen - een recht op een billiike beloning garanderen, het bevat wel een verbod op dwangarbeid (artikel 4 lid 2). Gedetineerden zijn krachtens artikel 4 lid 3, aanhef en onder a, van dat verbod uitgezonderd. Naast door het verdrag zèlf toegestane beperkingen op de uitoefening van grondrechten mag een staat die partij bij het verdrag is geen aanvullende beperkingen aan gedetineerden opleggen. Het niet aan gedetineerden uitbetalen van een normaal (billijk) loon voor geleverd werk kan heel goed als zo'n verboden aanvullende beperking worden beschouwd. Voor deze opvatting kan steun gevonden worden in artikel 18 EVRM, dat luidt: 'De beperkingen welke, volgens dit Verdrag, op bovengenoemde rechten en vrijheden zijn toegestaan, mogen slechts worden toegepast met het doel waarvoor de bevoegdheid is gegeven'. Volgens Van Dijk en Van Hoof bepaalt dit artikel, 'dat de krachtens de Conventie toegestane beperkingen niet voor een ander doel gebruikt mogen worden dan waarvoor ze zijn voorgeschreven. Uit de formulering van dat artikel volgt, dat alleen die beperkingen zijn toegestaan, die uitdrukkelijk voor een be- 
paald doel zijn voorgeschreven; nu er geen impliciete doeleinden voor beperkingen toelaatbaar zijn, moeten ook inherente beperkingen worden geacht niet te zijn toegestaan'. ${ }^{135} \mathrm{Nu}$ uit niets (in het bijzonder niet uit de travaux préparatoires die ten grondslag liggen aan de anti-dwangarbeidsverdragen van de ILO) valt op te maken dat het doel van de in art. 4 EVRM ten aanzien van gedetineerden toegestane beperking op het verbod van dwangarbeid óók is het hun onthouden van een billijke beloning, kan met recht en reden worden betoogd dat in Nederland artikel 18 EVRM geschonden wordt doordat het gevangeniswezen de hand op de knip houdt. Bovendien wordt het hoog in ons strafrechtelijke vaandel geschreven legaliteitsbeginsel geweld aangedaan omclat deze verkapte vermogenssanctie niet op enige wettelijke regeling berust.

Ook feiteiijk kan het financiële non possumus onder vuur genomen worden door te vragen naar de berekeningsmethode die tot de genoemde schattingen van de meerkosten heeft geleid. Betaling van een normaal loon zal namelijk niet alleen kostenverhogend werken, maar ook hogere besparingen opleveren dan waar thans rekening mee wordt gehouden. Uit de binnen het gevangeniswezen gehanteerde 'Handleiding opstellen bedrijfsplan arbeid' ${ }^{136}$ blijkt bijvoorbeeld dat arbeid van gedetineerden, waarvoor niet door derden wordt betaald als besparing wordt beschouwd. Het gaat dan om arbeid in de huisdienst zoals reiniging, het bedienen van wasserettes, tuinonderhoud, onderhoud van de gebouwen en werk in de keuken. De hieruit voor de inrichting voortvloeiende besparingen werden in 1991 gewaardeerd op een normatief bedrag van. $f 2,50$ per uur. Verder zal uitdrukkelijk rekening moeten worden gehouden met mogelijke besparingen bij het ministerie van Justitie en andere afnemers in de overheidssector doordat. sommige produkten goedkoper worden verkregen dan wanneer zij op de vrije markt zouden. moeten worden gekocht. Er wordt namelijk vooral voor de overheid zelf geproduceerd. ${ }^{137}$ Daarbij is overigens wel een probleem hoe de kostprijs van een tijdens detentie voortgebracht produkt moet worden berekend. Daarbij pleegt Justitie niet de kosten van de hele materiële en personele infra-structuur van gevangeniswezen mee te laten wegen. Zou dat wel gebeuren dan zou elk produkt wellicht. veel duurder uitvallen dan een vergelijkbaar produkt op de vrije markt. Het aitgangspunt bij de thans gehanteerde methode van kostprijsberekening is de volgende: 'In principe moeten alle kosten, die worden gemaakt on tot een produkt te komen gedekt worden door opname hiervan in de calculatie, die voọrafgaạt aạn het uitbrengen van een offerte (...).

Voor de penitentiaire inrichtingen gaat dit systeem maar zeer ten dele op hetgeen leidt tot een aangepaste vorm van calculeren. Soort en grootte van machines worden bijwoorbeeld niet alleen op bedrijiseconomische gronden aangeschaft. Steeds is getracht dié machines en apparatuur aan te schaffen waarmee enerzijds de aansluiting met "de markt" kan worden behouden terwijl daarbij tevens recht wordt gedaan aan de doelstellingen van de gedetineerden-arbeid. Bovendien zijn gedetineerden geen modale werknemers.

Al deze redenen hebben gezorgd voor de angepaste vorm van calculeren $(\ldots)^{2}$. 
Het bij de klanten in rekening gebrachte arbeidsloon dient volgens artikel 55 lid 2 Gevangenismaatregel op hetzelfde niveau te liggen ais in het vrije bedrijf. Uitgaande van het minimumloon, inciusief het aandeel van de werkgever in de sociale lasten, dient $f 35$,- in rekening te worden gebracht. Daarbij komt een opslag van $f 5$,- per uur in verband met overhead zodat $f 40$,- aan loonkosten aan de klant in rekening dient te worden gebracht. Justitie houdt zich niet aan dit voorschrift door op dit bedrag een correctie voor lage produktiviteit toe te passen. In de sectoren 'grafisch', hout, metaal en beton is de produktiviteit $20 \%$ en voor de overige vakgebieden $12,5 \%$ van die in het bedrijfsleven, waardoor geen uurlonen van $f 40,-$, maar van $f$ 8,-, resp. $f 5$,- worden doorberekend. Geen wonder dat de minister erkent dat toetsing van de bedrijfsvoering door middel van vergelijking met: particuliere bedrijven onmogelijk is. ${ }^{138}$ De opbrengsten van de arbeid, zoals die elk jaar in de justitiebegroting worden vermeld, zeggen dus niets over het werkelijke rendement van gestichtsarbeid maar geven slechts de ontvangsten weer uit de als regiemsactiviteit verrichte arbeid zoals die in alle rijksinrichtingen plaatsvindt. In de Justitiebegroting voor 1992 wordt vastgesteld dat de opbrengsten van de arbeid reeds geruime tijd achterblijven bij de ramingen. ${ }^{139}$

De verhouding tussen de aan de gedetineerden uitbetaalde lonen en de zojuist genoemde ontvangsten is sinds 1980 als volgt:

\begin{tabular}{|c|c|c|c|}
\hline Jaar & Verdiende lonen & waarvan in POI & $\begin{array}{c}\text { Opbrengsten } \\
\text { arbeid }\end{array}$ \\
\hline 1980 & 4.006 .100 & 613.000 & 14.261 .700 \\
\hline 1981 & 4.735 .000 & 544.700 & 12.496 .700 \\
\hline 1982 & 4.903 .500 & 578.700 & 13.131 .300 \\
\hline 1983 & 5.455 .800 & 490.000 & 13.862 .900 \\
\hline 1984 & 6.077 .400 & 648.100 & 12.570 .870 \\
\hline 1985 & 5.995 .300 & 564.800 & 11.579 .111 \\
\hline 1986 & 6.725 .400 & 740.600 & 14.957 .274 \\
\hline 1987 & 7.399 .100 & 789.000 & 14.200 .000 \\
\hline 1988 & 8.472 .900 & 813.800 & 14.116 .000 \\
\hline 1989 & 8.363 .100 & 1.021 .400 & 15.110 .000 \\
\hline 1990 & 9.282 .500 & 1.150 .400 & 15.836 .000 \\
\hline 1991 & 11.107 .400 & 1.276 .900 & 15.451 .000 \\
\hline 1992 & 11.746 .900 & 1.239 .700 & 17.213 .000 \\
\hline
\end{tabular}

Bronnen: zie noot ${ }^{140}$ 
Besparingen in ruimere zin zullen plaatsvinden als van een normaal loon de loonbelasting en sociale verzekeringspremies naar de fiscus en de desbetreffende verzekeringsfondsen zullen terugvloeien. Voorts zal de invoering van een normaal loon tot gevolg hebben dat bijstandsuitkeringen aan personen voor wie de gedetineerde onderhoudsplichtig is komen te vervallen.

Bij de schatting van te verwachten meer-kosten zal dienen te worden bezien hoeveel gedetineerden een eigen inkomen hebben en dus niet speciaal voor het verwerven van een inkomen aan het (bajes)werk behoeven te worden gezet. Recent onderzoek van het ministerie van Justitie heeft uitgewezen dat $46 \%$ van de gedetineerden bij de aanvang van hun detentie een uitkering genoot. Deze uitkeringen waren als onder te verdelen: $4 \%$ Ziektewet, $4 \%$ Werkloosheidswet, 5\% 'anders', $23 \% \mathrm{WAO} / \mathrm{AWW}, 26 \% \mathrm{ABW} /$ bijstand en 38\% WWV/RWW. ${ }^{141}$ Voorzover deze personen - met instemming van de uitkerende instantie - met behoud van uitkering in de strafinrichting arbeid tegen een normaal loon verrichten zal dat loon òf worden verrekend met die uitkering, of via de inkomstenbelasting voor een deel naar het desbetreffende fonds of de fiscus terugvloeien. Als de loonkwestie zo wordt bezien dan kan het met de te verwachten extra-kosten voor de overheid nog wel eens meevallen. Nader onderzoek op dit punt lijkt dan ook zinvol.

Bij een debat over de inkomenskwestie zou het aanbeveling verdienen om eens na te denken over het laten doorlopen tijdens detentie van uitkeringen die thans worden gestaakt wanneer men door Justitie van zijn vrijheid wordt beroofd. Daarbij dient dan met name aan de werkloosheidsuitkeringen te worden gedacht.

De redenen waarom dat soort uitkeringen thans wordt beëindigd als men gedetineerd raakt is a) dat men door eigen toedoen werkloos en b) niet voor de (reguliere) arbeidsmarkt beschikbaar is. Om met het eerste punt te beginnen: zeker voor preventief gedetineerden geldt, uitgaande van de presumptio innocentiae, dat dat 'door eigen toedoen' juridisch nog niet vaststaat. Pas als er bij een onherroepelijke strafrechtelijke uitspraak is vastgesteld dat men strafrechtelijk aansprakelijk is staat het 'door eigen toedoen' juridisch vast. Daarbij past nog de aantekening dat voorzover er volgens de rechter sprake is van verminderde toerekenbaarheid er ook geen 'eigen toedoen' in volle omvang aanwezig moet worden geacht als het gaat om de vraag of men onvrijwillig werkloos is of niet.

Wat betreft het argument dat men tijdens detentie niet beschikbaar is voor de (reguliere) arbeidsmarkt, moet worden opgemerkt dar men weliswaar niet voor de arbeidsmarkt in de traditionele betekenis van dat woord beschikbaar is, maar wel degelijk voor de arbeidsmarkt die het gevangeniswezen als monopolistisch werkgever in stand houdt. In die zin zou wel degelijk WW of RWW kunnen worden uitgekeerd tot het moment waarop binnen de muren passende arbeid voor de uitkeringsgerechtigde beschikbaar komt. Door de normen op beide genoemde punten aan te passen aan de situatie waarin de gedetineerde verkeert zou - in ieder geval ten aanzien van preventief gedetineerden - het inkomen grotendeels door het sociale zekerheidsstelsel kunnen worden gefinancierd. Dat zou dan (zie 
de zoëven aangehaalde opmerking van. De Bruijn over Bijstand tijdens dagdetentie) door sommigen kunnen worden opgevat als een afwenteling van detentiekosten op derden. Dezen dienen dan wel te beseffen dat dit al in vrij aanzienlijke mate het geval is, namelijk bij de financiering van inrichtingen waar de terbeschikkingstelling van de regering ten uitvoer wordt gelegd. De Justitiebegroting voor 1992 wijst uit, dat op basis van de Algemene Wet Bijzondere Ziektekosten in 1991 ruim 88 miljoen gulden is terugontvangen (1990: 94,5 miljoen).

Een voorlopige conclusie betreffende het realiteitsgehalte van de herhaaldelijk door de bewindslieden op Justitie geuite vrees voor onoverzienbare meerkosten is dan ook dat die vrees vooralsnog niet door feitelijke berekeningen is gestaafd. Maar zelfs al zouden er - alle kosten en besparingen tegen elkaar afwegend - aanzieniijke meerkosten zijn, dan nog blijft de juridische optie overeind die inhoudt dat het niet betalen van een normaal loon voor werk contra legem is.

Overigens kan men het Zweedse MAIK-comité nazeggen dat de overheid. de loonkosten kan beheersen door een volumebeleid te voeren, dat wil zeggen het aantal detentie-plaatsen aan een maximum te binden.

\subsection{Voorwaarden voor normalisering van het loon}

\section{Commercieel produceren}

Er zijn, zoals uit de hierboven aangehaalde litteratuur is gebleken, nogal wat schrijvers die een eventuele normalisering van het gedetineerdenloon willen koppelen aan een aantal stringente voorwaarden. Die voorwaarden betreffen vooral de produktie en de manier waarop het loon besteed wordt.

Sommigen vinden het betalen van een loon op marktniveau alleen aanvaardbaar als er op strikt commerciële basis wordt geproduceerd: gedetineerden-arbeid moet winst opleveren voor Justitie, anders kan er geen normaal loon worden betaald. Een van de veronderstellingen daarbij is dat er 'binnen' even lang en hard wordt gewerkt als 'buiten'.

$\mathrm{Zij}$ die deze voorwaarden stellen weten eigenlijk bij voarbaat dat die nooit kunnen worden vervuld. In de eerste plaats is de gevangenispopulatie qua vooropleiding en persoonlijkheid heel divers. ${ }^{142}$ Gevangeniswezen is in geen van zijn onderdelen gericht op het maken van winst. Hooguit kan men spreken van zekere stimulansen om de kosten per inrichting te drukken. Directeuren hebben daar enig belang bij gekregen nu ze tot op zekere hoogte zelf de bestemming van hun budgetten kunnen bepalen. Dat is volgens Klinkhamer (in haar verslag van een onderzoek naar de functie van de door gedetineerden verrichte arbeid) het gevolg van het deconcentratie-beleid bij Gevangeniswezen: "Wat betreft de verwerving van de arbeid voor de inrichtingen bestaat een tendens tor deconcentratie. Dit heeft tot gevolg dat de inrichtingen wat betreft de arbeid steeds zelfstandiger worden. Door de deconcentratie zijn de acquisitietaken en alles wat daarmee samenhangt zoals bijv. de prijsafspraken, overgedragen aan de hoofden van arbeid in de 
inrichtingen (...). Zij verwerven tegenwoordig dus zelf de arbeid voor hun inrichting. Door deze deconcentratie moeten de inrichtingen ook voor de kosten opdraaien zodat de betaling voor de arbeid door opdrachtgevers belangrijker is geworden dan vroeger. Toen was het belangrijk dat de inrichtingen voorzien werden van werk en stond de betaling op de tweede plaats.

Tegenwoordig wordt getracht om niet alleen in het loon voor gedetineerden te voorzien maar ook het onderhoud aan machines e.d. van de betaling te realiseren. De inrichtingen kunnen echter niet teveel voor de arbeid vragen omdat zij dan het risico kunnen lopen dat de opdrachtgevers dan naar de sociale werkplaatsen gaan'. ${ }^{143}$

Ook al door de opvatting dat arbeid deel is van een regiemsactiviteitenprogramma is het handhaven van deze voorwaarden in de Nederlandse situatie een garantie voor het niet invoeren van een normaal loon. Het stellen van genoemde voorwaarden is echter op zich onjuist. Immers, de gedetineerde heeft geen enkele invloed op het soort werk dat hij in de inrichting zal doen. Over de organisatie van de arbeid heeft hij al evenmin iets te vertellen. De dagelijkse produktie-norm wordt geheel zelfstandig door de werkmeester bepaald.

Het enige correcte standpunt in deze lijkt te zijn dat het verdienen van een normaal loon niet afhankelijk wordt gesteld van de reële arbeidsproduktiviteit, maar van het enkele feit dat de gedetineerde zijn arbeidskracht gedurende een bepaalde tijd ter beschikking van zijn werkgever, Justitie, stelt. Dàt is voldoende rechtsgrond om betaling van het volle loon te kunnen verlangen. In hoeverre de werkgever de hem ter beschikking staande produktiekracht profijtelijk kan aanwenden is zijn zaak. Verlies op hem terbeschikking staande arbeidskracht behoort tot diens risico-sfeer. Ook bij 'leegloop' dient de werkgever door te betalen. Het enige verschil tussen de particuliere werkgever en Justitie is dat de eerste voor 'overcomplete' arbeidskrachten een ontslagvergunning kan aanvragen en de laatste niet. Daarbij heeft Justitie het voordeel dat zij niet failliet kan gaan bij blijvende verliezen.

\section{Zinvolle besteding van het loon}

Een andere voorwaarde die velen aan het invoeren van een systeem van normale beloning stellen is dat dat loon zinvol besteed wordt en dat het gevangeniswezen kan bepalen hóé dat gebeurt. Auteurs die deze eis stellen gaan er impliciet van uit dat gedetineerden per definitie niet met geld om kunnen gaan en dat het 'zonde' is om dat door de overheid betaalde loon op te zien gaan aan zaken (drugs, gokken) die buiten het normale bestedingspatroon van de oppassende burger vallen.

Hun eerste eis is dat van het gedetineerden-loon belasting en premies worden afgehouden. Welnu, dat is een taak die volgens de wet op iedere werkgever rust, dus daartegen kan weinig worden ingebracht. Dat ligt echter anders als wordt gesteld dat Justitie op dat loon de eventueel door de gedetineerde te betalen alimentatie en andere bijdragen voor levensonderhoud moet inhouden en dient over 
te maken aan degenen die recht op die gelden hebben. Die eis is gebaseerd op de veronderstelling dat gedetineerden wel niet aan zulke verplichtingen zulien voldoen. Dat wijst op een aprioristisch wantrouwen jegens deze groep als zodanig. Het valt namelijk niet in te zien a) waarom nu juist gedletineerden niet diegenen zouden onderhouden die van hun inkomsten afhankelijk zijn en b) waarom per-sonen die eventueel van alimentatie of onderhoudsbijdrage verstoken blijven niet - zoals alle andere burgers - hun rechten via de daarvoor bestaande procedures met inbegrip van eventueel loonbeslag onder de werkgever (Justitie) zouden kunnen realiseren.

Volgens sommigen dient een deel van het loon te worden gereserveerd voor schadeloosstelling van personen die door het delict van de gedetineerde zijn benadeeld.

Ook hier geldt weer dat zo'n verplichte reservering uitgaat van de onmondigheid van partijen. Ten onrechte, want de benadeelde moet zeer wel in staat worden geacht om met de bestaande rechtshulpvoorzieningen het zijne te verkrijgen.

De voorwaarde van verplichte budgettering is misschien door heel honorabele motieven ingegeven, invoering ervan zal de gedetineerde echter nog verder infantiliseren dan tijdens detentie toch al gebeurt. Van onder curatele stelling en bevoogding leert men niet zoveel. Van zèlf doen, ook al gaat dat met vallen en opstaan, met gerechtelijke procedures en loonbeslagen, kan men veel meer van de maatschappelijke en juridische werkelijkheid leren. Vanzelfsprekend is het allerminst verwerpelijk om zich ais gedetineerde bij financiële problemen te laten adviseren, bijvoorbeeld door het Bureau Sociale Dienstverlening (BSD), de reclassering, bureau voor rechtshulp of eigen advocaat.

Een moeilijker te beantwoorden vraag is of gederineerden financieel dienen bij te dragen aan de kosten van hun detentie. Die kosten kan men ruwweg onderscheiden in de kosten van het in stand houden van de hele penitentiaire infrastructuur (personeel, gebouwen, beklag-beroepsinstanties e.d) ${ }^{144}$ en de kosten van de voorziening in de directe levensonderhoud van de gedetineerden (voeding, kleding, medische zorg e.d.).

Van Zeijst heeft er op gewezen dat heffing van zo'n bijdrage cen inbreuk zou betekenen op het in de artikelen 35 lid 1 en 37 e Sr. neergelegde beginsel dat de kosten van de tenuitvoerlegging van de vrijheidsstraf en de terbeschikkingstelling ten laste van de Staat komen. ${ }^{145}$ Hij had de voorbereidingen on tot een eigen bijdrage-regeling te komen ontwaard in de nota 'Heroverweging Collectieve Uitgaven', die onder meer de volgende tekst bevat: 'Hoewel de kosten van de detentie - en derhalve van de verzorging van de gedetineerde - ingevolge de wet ten laste van het Rijk komen lijkt het in beginsel redelijk dat een tijdens detentie doorlopende uitkering op grond van de sociale verzekeringswetten om hem in staat te stellen daarmee in de kosten van het levensonderhoud te voorzien in een aantal gevallen wordt gereduceerd als compensatie voor de van Rijkswege genoten verzorging. Vooraleer een regeling ter zake zou kunnen worden overwogen, waartoe 
wijziging van. het Wetboek van Strafrecht en/of de betrokken sociale verzekeringswetten is aangewezen, is een nader onderzoek naar aard en omvang van tijdens detentie ontvangen uitkeringen wenselijk. Onderkend moet ook worden dat aan een eventuele regeling tal van uitvoeringsproblemen kleven. Voorgesteld wordt om deze problematiek in interdepartementaal verband nader in studie te nemen'. ${ }^{146}$ Of deze: studie ooit is verricht blijkt nergens uit.

Van Zeijst noemde het opmerkelijk dat in de Nota alleen gesproken werd over inhoudingen op sociale uitkeringen: 'Uit een oogpunt van rechtsgelijkheid lijkt het mij geboden ook op inkomen uit anderen hoofde (loon, winst, huur, rente, dividend, etc.) een eigen bijdrage, zo men daar voorstander van is, toe te passen'. Deze auteur wees er op dat de eigen bijdrage in de kosten van detentie al bestaan in de open gevangenissen: 'De tijd lijkt niet meer veraf dat niet alleen tbr-gestelden, maar ook gedetineerden met een inkomen, dat doorloopt tijdens de detentie, moeten bijdragen in de kosten van hun verzorging'. ${ }^{47}$

In het voorjaar van 1993 heeft minister Hirsch Ballin tijdens een redevoering in Heeze gepleit voor het aan veroordeelden opleggen van een eigen bijdrage voor de kosten van hun verblijf in de cel. Als uitgangspunt voor de hoogte van het bedrag nam hij het bedrag van de bijstandsuitkering voor alleenstaanden. De minister dacht op die manier 60 miljoen gulden vrij te kunnen maken voor de exploitatie van 1000 extra cellen. ${ }^{148}$ Vooralsnog zijn er geen stappen ondernomen om dit denkbeeld in wetgeving om te zerten.

De vraag, of gedetineerden een gedeelte van hun inkomen moeten afdragen ter bestrijding van de kosten van de infra-structuur moet ontkennend worden beantwoord. Het gevangeniswezen wordt immers - evenals vele andere overheidsvoorzieningen -uit de algemene middelen gefinancierd. Zodra hij normaal loon ontvangt, waarover belasting en premies worden betaald, draagt ook de gedetineerde bij aan de algemene middelen waaruit zijn tralies worden betaald.

Moeilijker is vol te houden dat een over een normaal loon (of een uitkering) beschikkende gedetineerde helemaal niets aan de kosten van zijn levensonderhoud zou moeten meebetalen. Men kan weliswaar stellen dat men tegen zijn wil wordt vastgehouden en dat de bewakers dus maar voor het levensonderhoud moeten betalen, maar kijkt men bijvoorbeeid naar dienstplichtige militairen en personen op wie civielrechtelijke lijfsdwang wordt toegepast (zie de artikelen 592, 596 Rv.) dan zien we dat die - hoewel ook zij tegen hun wil op een bepaalde plek vastgehouden - wel degelijk een eigen bijdrage moeten leveren aan de kosten van hun directe levensonderhoud. Wel is er een argument om preventief gehechten van elke eigen-bijdrage regeling te vrijwaren. ${ }^{149}$ Dat argument ligt besloten in de presumptio innocentiae die ten aanzien van deze categorie geldt.

Tegen het verlangen van een eigen bijdrage voor het levensonderhoud van veroordeelden die in gevangenissen verblijven valt niet veel in te brengen voorzover zij over een normaal inkomen beschikken. Het introduceren van een dergelijke heffing lijkt echter niet juist zolang niet alle veroordeelden over een reëel inkomen beschikken. Daartegenover staat dat als ooit een eigen bijdragen voor de 
kosten van het directe levensonderhoud zal worden verlangd het niet meer dan redelijk is om in dat geval de betrokken gedetineerden medezeggenschap te geven over de besteding daarvan.

Bij dit alles moet worden bedacht dat er op kleine schaal al zoiets als een eigen. bijdrage-regeling bestaat. Op vrijwillige basis worden van het zakgeld bedragen gestort voor extra-voorzieningen; niet alleen in de recreatieve sfeer (huur TV's) maar ook voor het gewone levensonderhoud, zoals het wassen van eigen kleding.

\section{Slotopmerkingen}

Het ontbreken van een adequate feitelijk en juridische legitimering voor de bij ons geldende penitentiaire arbeidsplicht zou moeten leiden tor de afschaffing van. de artikelen 14 en 20 en navenante aanpassing van artikel 22 van het Wetboek van Strafrecht, waarin deze plicht thans zijn wettelijke basis vindt. Ook uit de Beginselenwet Gevangeniswezen en de Gevangenismaatregel dient de arbeidsplicht: dan te worden geschrapt. Het zou vervolgens in de rede liggen om in de toepasselijke internationale gremia aan te dringen op het schrappen van de uitzonderingsclausules op het verbod op dwangarbeid met betrekking tot gedetineerden in Arbeidsconventie nr. 29, het IVBPR en het EVRM. Het is duidelijk dat Nederland geenszins op wijziging van deze intemationale regelingen hoeft te wacht: zij verplichten immers niet tot gedwongen tewerkstelling van gedetineerden, ze verbieden het enkel niet.

Afschaffing van de arbeidsplicht in het Nederlandse penitentiaire stelsel zou ais gunstig nevengevolg hebben dat de thans bestaande ongelijkheid waarbij veroordeelden die in huizen van bewaring verblijven van de arbeidspiicht zijn ontheven en waarbij veroordeelden die zich in gevangenissen bevinden daaraan onverkort zijn onderworpen.

Met het bepleiten van de afschaffing van de arbeidsplicht wordt geenszins beoogd om de arbeid in de inrichtingen maar helemaal af te schaffen. Integendeel, omdat de overheid als bijkomend gevolg van de vrijheidsbenemeing gedetineerden de toegang tot de reguliere, externe, arbeidsmarkt verspert rust er op diezelfde overheid een plicht om zelf een bijzondere, interne arbeidsmarkt in stand te houden of te scheppen, waarop onder voorwaarden die zoveel mogelijk met die in de vrije maatschappij vergelijk baar zijn, arbeidsovereenkomsten kunnen worden gesloten.

Een belangrijke voorwaarde daarbij is, dat voor het aangeboden werk een normaal loon wordt betaald, dat wil zeggen een loon dat vergelijkbaar is met dat wat er in de vrije maatschappij wordt betaald.

Als in 1995 de dan bestaande 12.0000 cellen het hele jaar door bezet zouden zijn met gedetineerden aan wie voor hun werk het minimumloon betaald moest worden, zou dat de staat ruw geschat $12.000 \times f 50.000,-=600$ miljoen gulden 's jaars kosten. 
Zo'n rekensom is echter veel te simpel zoals in de tweede paragraaf van dit hoofdstuk is betoogd. De financiering van het gerechtvaardigde verlangen van gedetineerden naar een normaal loon zal namelijk niet alleen uit de portemonnaie van Justitie hoeven te komen, indien de kosten ervan voor een deel kunnen worden uitgesmeerd over de bestaande sociale verzekeringen en - voorzieningen, waarvan bijna de helft van de gedetineerden bij aanvang van de detentie blijkt te genieten. Voor een ander deel zullen de hogere loonkosten gedekt kunnen worden door een hoger rendement dat een gevolg zal zijn van een grotere gemotiveerdheid om te werken voor een normaal leven. Verder dient bij de berekening van de totale loonkosten uitdrukkelijk rekening te worden gehouden met de besparingen die worden gerealiseerd doordat een aanzienlijk deel van de gedetineerden 'huisdiensten' verricht, waarvoor anders regulier personeel had moeten worden aangetrokken.

In het volgende hoofdstuk zal de stelling worden betrokken dat het ontbreken van een inkomensregeling voor gedetineerden moet worden opgevat als een hiaat in het stelsel van sociale zekerheid en dat vele, zo niet alle, problemen die de arbeidsverhouding tussen gedetineerden en staat kenmerken kunnen worden opgelost door het invoeren van een Wet op de Penitentiaire Werkvoorziening, een WPW. 
1. L. Betten, Intemational labour law; selected issues, Deventer-Boston 1993, bl. 11.

2. Bureau International du Travail; Conférence Internationale du Travail, XIIe Session, Genève 1929, Commission de Travail Forcé, Proces-Verbaux, Compte rendu provisoire nr. 20, 15 juni 1929, bl. XXVI.

Zie ook: United Nations, Department of economic and social affairs, Prison Labour, New York 1955, 97, bl. 27. Voorts: A. Alcock, History of the International Labour Organisation, Londen en Basingstoke 1971, bl. 81-98. 3. Stb. 1933, nr. 26.

4. Internationale Arbeitskonferenz, Vierzehnte Tagung, Genc̀ve 1930; Zwangsarbeit, bl. 19.

5. A. Sternheim, Geneve, 'Gedwongen arbeid en Nederlands Indié, uit De Vakbeweging, januari 1929 , bl. 5,6 .

6. W. Middendorp, Twee achterlijke arbeidssystemen woor inboorlingen in Nederlandsch Oost-Indie (heerendiensten en poenale sanc(ie), Haarlem, zonder jaartal, bl. 37. Op bl. 53 schrijft hij: '(...) de voor her oliekapitaal in de Volksraad zittende Prof. Mr. Oppenheim vergeleek in 1927 de excessen van de poenale sanctie slechts bij die van den groentijd der studenten. Hij besefte niet het verschil tussen studentengrappen en bloedige arbeidsernst'.

7. Nederlandse vertaling, zoals opgenomen in Stb. 236 van 27 april 1933. Ter vergelijking volgt hier de Engelse versie:

art. 2.1. For the purposes of this Convention the term 'forced or compulsory labour' shall mean all work or service which is exacted from any person under the menace of any penalry and for which the said person has not offered himself voluntarily.

2. Nevertheless, for the purposes of this Convention, the term 'lurced or compulsory labour' shall not include:

c. any work or service exacted from any person as a consequence of a conviction in a court of law, provided that the said work or service is carried out under the supervision and control of a public authority and that the said person is not hired to or placed at the disposal of private individuals, companies or associations.
8. League of Nations, International Labour Conference; Fourteenth Session, Geneva 1930, bl. 269.

9. Bureau International du Travail, XIVe Session, Geneve 1930, Commission du Travail Forcé, proces-verbaux: Provisional Record, nrs. 13-24 juni 1930, bl. VII.

10. League of Nations, a. $2 \%$, bl. 710-711.

11. League of Nations, a.w. bl. 302-305.

12. International Labour Office, Prison Labour: I, International Labour Review maan 1932, Vol. XXV, nr. 3, bl. 311-331 en Prison Labour: II, zelfde tijdschrift april 1932, Vol. XXV, nr. 4, bl. 499-524. Hier verder ILO Prison Labour I of II te noemen.

13. ILO Prison Labour: I, bl. 312-313.

14. ILO Prison Labour: I, bl. 312-313 en 318-324.

15. United Nations, Department of economic and secial affairs, Prison Labour, New York, 1955, bl. vi. Hier verder te citeren als: UN Prison Labour.

16. UN Prison Labour, bl. 12.

17. UN Prison Labour, bl. 29.

18. UN Prison Labour, bl. 28-29.

19. A. Alcock, a. w., bl, 270-283.

20. United Nations - International Labour Office, Report of the Ad Hoc Cammittee on Forced Labour, Geneva 1953, verder aan te halen als: Ad Hoc Committee on Forced Lahour.

21. Ad Hoc Committee on Forced Labour, Appendix III, bl. 519.

22. International Labour Conference 1957 Record of proceeding $X I$; Twenty-second sitting, vrijdag 21 juni 1957, bl. 351.

23. Ad Hoc Committee on Forced Labour, bl. 82.

24. Ad Hoc Commitlee on Forced Labour, bl. 116-121.

25. Ad Hoc Committee on Firced Labour, b]. 91-94.

26. M. Smith, "The extent of forced labor in the world; an official 2-year survey', Monthly Labor Review september 1953, bl. 948-951. Volgens Sinith was de Ad Hoc Commissie niet in staat om over de Volksrepubliek China te rapporteren omdat daar geen documenratie over te verkrijgen was. 
27. Ad Hoc Committee on Forced Labour, bl. 127 en 561.

28. International Labour Conference 1957, a.w., bl. 347.

29. De origincle tekst spreekt over 'debt bondage', ook wel te vertalen als pandelingschap, een in onbruik geraakte term, die men aantreft in de Nederlandse vertaling van de aanhef van Arbeidsverdrag nr. 105. Van Dales Groot Woordenboek der Nederlandse Taal ('s-Gravenhage 1976) geeft er de volgende betekenis aan: pandeling, $m$. (-en), persoon die door een ander voor een schuld in pand genomen is, schuldslaaf, en dic voor de schuldeiser moet arbeiden, totdat de schuld door zijn arbeid is afgedaan; -schap, o., toestand van een pandeling: wettelijk werd het pandelingschap voor geheel Ned.Indie verboden in 1872 .

30. International Labour Conference 1957, a.vo., bl. 350,351 en 357 .

31. 'Artikelen 1 en 2', Tractatenblad 1957, 210 , bl. 8 en 9 .

32. International Labour Conference, Forty-Sixth Session, Geneva 1962. Report III (Part IV), Report of the Committee of Experts on the application of conventions and recommendations, Part Three, Forced Labour. Verder te citeren als $R C E, 1962$.

33. Deze in 1929 geconcipicerde Minimumregels zijn uiteindelijk in 1957 in een resolutie van de Economische en Sociale Raad van de $\mathrm{VN}$ vastgelegd. Ze zijn echter nimmer door de Algemene Vergadering van de VN geratificeerd en hebben uitsluitend morele waarde. Zie C. Kelk, Kort begrip van het detentierecht, Nijmegen, 1993, bl. 63 en N. Rodley, The treatment of prisomers under international law, Oxford 1987, bl. 221-223.

34. RCE, 1962, $\$ 47-56$.

35. Vgl. de 'heropvoeding door arbeid', als leidend beginsel van het penitentiaire stelsel in de Volksrepubliek China, een beginsel dat al vóór 1949 werd toegepast in de door het Rode Leger gecontroleerde gebieden. Zie $\mathrm{H}$ Isaỉa, La fustice en Chine, Parijs 1978 bl. 91. 36. RCE, 1962, of 57 en 160-165.

37. International Labour Conference, Fifty-Second Session, Geneva 1968, Report III (Part 4). Report of the Commirtee of Experts on the application of conventions and recommen- dations, Part Three, Forced Labour. Verder aan te halen als RCE 1968.

38. Art. 8 lid 3 van het Verdrag inzake Burgerrechten en Politieke Rechten bevat een verbod op dwang- of verplichte arbeid, overigens met: een uitzondering voor gedetineerden en voorwaardelijk invrijheidgestelden. De tekst is niet geheel congruent met die van Arbeidsconventie nr. 29.

Art. 6 van het Verdrag inzake Economische, Sociale en Culturele Rechten bevat het recht op vrij gekozen arbeid.

39. RCE $1968, \widehat{y} 1,3,10$ en $98-100$.

40. International Labour Conference, Sixty-Fifth Session, Geneva 1979, Abolition of Forced Labour, General Survey by the Comittee of Experts on the application of conventions and recommendations. Verder te citeren als RCE, 1979. Ook in 1991 en 1992 rapportecrde het Committee of Experts over praktijken die niet met de anti-dwangarbeidverdragen strookten. Zie L. Betten, a.w., bl. 147.

41. Het ging hier om personen die van betrokkenheid bij de Indonesische Communistische Partij werden verdacht. Vele duizenden van hen zijn naar het Molukse eiland Buru overgebracht, waar zij door de overheid bij ontginningsprojekten en in de landbouw te werk zijn gesteld. Het militaire bestuur eigende zich een deel van hun produktie toe, aldus Amnesty International, Indonesien; cin Bericht von Amnesty International, BadenBaden 1977, bl. 113-126.

42. RCE, 1979, \$\$ 89-109.

43. Dec. Adm. Com. Ap. 9449/81, 3 mei 1982, vermeld in Council of Europe, Digest of Strasbourg Gase-Law relating to the European. Convention on Human Rights; Update to Volume 1 (Articles 1-5), Keulen (erc.), 1988, 4.3.1. Zie ook: H.G. Ganter, Die Spruchpraxis der Europäischen Kommission für Menschenrechte auf dem Gebiet des Strafvolleuges, Bonn 1974, bl. 129.

44. G. Smaers, Gedetineerden en mensenrechten; de toepassing van het EVRM in detentiesituaties door de Europese jurisdicties en haar gevolgen voor de rechtspositie van gedetineerden in Belgiè;, proefschrift, Leuven 1993, bl. 353360. Van dezelfde auteur: 'De toepassing van het EVRM op de strafuitvoeringsfase; 
een analyse van de Europese en Belgische rechtspraak m.b.t. de grondrechten van verocrdeelde gedetineerden', Panopticon 1991, bl. 45.

45. A.W. Heringa en T. Zwart, De Nederlandse Grondwet, Zwolle 1991, bl. 210. Met de inwerkingtreding in 1980 van het Verdrag van Wenen inzake het Verdragenrecht zijn er (in art. 30 van dat verdrag) internationale richtlijnen gekomen voor de toepassing van achtereenvolgende verdragen die op eenzelfde onderwerp betrekking hebben. Zie over de problematiek van onverenigbare verdragsbepalingen: I. Sinclair, The Vienna Convention on the Law of Treaties, Manchester 1984, bl. 94-98.

46. Council of Europe, European Prison Rules, Recommendation nr. R (87) 3 adopted by the Committee of Ministers of the Council of Europe on 12 fcbruari 1987 and Explanatory Memorandum, Straatsburg 1987, verder te citeren als: Council of Europe, European Prison Rules.

De Nederlandse vertaling van de 'Rules' is opgenomen in het Bajesboek, R. Verpalen en G. de Jonge (red.), Breda, 1992 bl. 213-233. 47. 'Twenty-one detained persons against the Federal Republic of Germany, decision of 6th. April 1968', Yearbook XI (1968), bl. 528-562.

48. Met name uit de 'travaux préparatoires' voor art. 8 lid 3 onder $c$ IVBPR, die naar de bevinding van de Comtnissie waren gebruikt bij het ontwerpen van art. 4 EVRM.

49. Ook al was daarover in de travaux préparatoires niets terug te vinden, zoals de Commissie zelf vaststelde.

50. HR 31 oktober $1972, \mathrm{NJ} 1973,44$.

51. Hof 's Hertogenbosch, 16 januari 1974, NV 1974, 229.

52. HR 22 oktober $1974, N 71975,39$.

53. HR. 25 april 1989, $\mathrm{Ng} 1990,80$; HR 22 oktober 1991, NF 1992, 464 en HR 20 oktober 1992, $N^{\gamma}$ 1993, 154.

54. N. Rodley, The treatment of prisoners under international law, Parijs/Oxford 1987, bl. 222 .

55. Council of Europe, European Prison Rules, Explanatory Memorandum, Straatsburg 1987, bl. 29-30.

56. Kelk noemde de SMR in de eerste druk van zijn Recht voor gedetineerden (Alphen aan den Rijn. 1978, bl. 185) op het gebied van arbeid en arbeidsloon 'zeer vooruitstrevend'. 57. Council of Europe, European Prison Rules, Explanatory Memorandum, Straatsburg 1987 , bl. 62 .

58. C. Kelk, 'Nieuwe Europese Gevangenisregels', NgCM-Bulletin 14-1, Jan/Feb. 1989 , bl. 34

59. Zie bijv. J. Fawcett, 'Application of the European Convention on Human Rights', in M. Maguire e.a. (eds.), Accountability and prisons; opening up a closed world, Londen en New York 1985, bl. 68-73.

Voorts: A de Zayas, J. Th. Moller en T. Opsahl, 'Toepassing van het Internationale verdrag inzake burgerlijke en politieke rechten door her Cornité voor de rechten van de mens op grond van het Facultatief Protocol', in P. van Dijk (e.a.), Het internationale verdrag inzake burgerlijke rechten en zijn betekenis voor Nederland, Nijmegen 1987, bl. 61-62. 60. C. Kelk, 'De beperkte betekenis van grondrechten in de strafexecutie', Delikt en Delinkwent 6/1989, bl. 585 .

61. Zoals in de zgn. 'Greek-case', 12 Yearbock of the European Convention on Human Rights - The Greek Case (1969), waarbij de Commissie bij de interpretatie van art. 3 EVRM uitdrukkelijk refereerde aan de Standard Minimum Rules.

62. P.J. Duffy, 'Article 3 of the European Convention on Human Rights', in The International and Comparative Law Quarterty 1983, Vol. 32, bl. 345-346.

63. A. Spielmann, 'La protection des droits de l'homme. Quid des droirs des détenus?' In Protecting Human Rights: The European Dimension, Studies in honour of Gérard J. Wiarda, edited by F. Matscher en H. Pezzold, Keulen (enz.) 1988, bl. 589-594.

64. F. Verschueren, 'Ontwerp-Protocol bij het E.V.R.M. dat bijkomende rechten waarborgt voor personen die van hun vrijheid beroofd zij,n'. In de Nieuwsbrief van de Liga voor Mensenirechten, jrg. 12, nrs. 9-10, 1993, bl. 10-12.

65. G. de Jonge, 'Harmonisatie van gedetineerdenrecht', in de onder redactie van G.P.M.F. Mols uitgegeven bundel Dissonanten bij het akkoord van Schengen, Deventer 1990, bl. 154-155. 
66. United Nations, Deparment of Public Information, New York, Press Release GAA/7814, 16 Januari 1989, no. 43/173.

67. Zie over ontstaan en betekenis van het Body of principles: N. Rodley, a.w., bl. 276.

68. Council of Europe, European Committee for the prevention of torture and inhuman or degrading treatment or punishment (CPT), 1st General Report on the CPT's activities, covering the period November 1989 to December 1990, Straatsburg 20 februari 1991, bl. 28.

69. Rapport van de Commissie voor de verdere uitbouw van het gevangeniswezen (Voorzitter: W.A.J.M. Fick), 's-Gravenhage 1947.

70. C. Fijnaut, Verleden, heden en toekomst van de geintegreerde strafrechiswetenschap, Arnhem/Antwerpen 1986, bl. 24 en 26.

71. In de Franse tekst van het congresverslag wordt hier het woord pécule gebruikt. Dat woord is afkomstig van het Latijnse pectlium, dat de betekenis heeft van: 'het bijzondere vermogen der huisvrouw, van het kind en den slaaf en de spaarpenning, spaarpot van den huisslaaf (door bijzonderen arbeid verdiend en meestal opzij gelegd om zich vrij te kopen). Engelbregt, Latïnsch Woordenboek (vierde, veel vermeerderde druk) 1882.

72. W.P.J. Pompe, 'Comment faut-il organiser le travail pénitentiaire pour en obtenir à la fois un bénéfice moralisateur et un rendement économique et social utile?' In de Proceedings (of the) Twelfih International and Penitentiary Congress (The Hague 14-19 August 1950), Volume IV, General and national reports of section II, bl. 359-365, gepubliceerd door de International and Penitentiary Commission, Bern 1951.

73. H.H. Veringa, 'Beloning van gedetineerden', Maandschrift voor het gevangeniswezen, 9 e jrg. 1957-1958, bl. 13-17, 35-43 en 59-67.

74. Thans Centrale Raad voor Strafrechtstoepassing geheten.

75. Het Nederlandse gevangeniswezen. Nota over het Nederlandse gevangeniswezen aangeboden door de minister van Justitie aan de tweede Kamer der Staten-Generaal (NotaScholten), 's-Gravenhage 1964, bl. 38-39.

76. Centrale Raad van Advies voor het Gevangeniswezen, de Psychopatenzorg en de
Reclassering (CRvA), Rapport van de: Commissie Arbeidsbeloning van Gedetineerden, ('sGravenhage) januari 1966, bl. 25-27.

77. CRvA, verslag 21e plenaire vergadering, ('s-Gravenhage) 14 mei 1966, 3e vervolgblad.

78. CRvA, concepe-verslag plenaire vergadering, ('s-Gravenhage) 14t mei 1966, bl. 6 .

79. CRvA, concept-verslag van de le vergadering van de (blijkbaar gercanimeerde) Commissie Arbeid en Arbeidsbeloning op 6 november 1970 te Dordrecht.

80. CRvA, Jaarverslag 1970, bl. 11 .

81. Rapport van de Commissic Arbeidsbeloning van Gedetineerden $a . w .$, bl. 14.

82. W.L. Buitelaar en R.J. Sierksma, Gevangen in de gevangenis, Meppel 1972, bl. 9193, 99, 106-107 en 110.

83. Experimentele loonregeling voor penitentiaire inrichtingen voor langgestrafte gedetineerden. Circulaire van 19 september 1977, Directic Gevangeniswezen nr. 1083/377, PI 1980, nr. 2.

84. Nota Beleidsvraagstuleken Gevangeniswezen (21 september 1976), Tweede Kamer, 1976-1977, 14 102, nrs. 1-2, bl. 43-44.

85. M. Kneepkens, Tegen-Nota Beleidsvraagstukken Gevangeniswezen van de Coomhert-Liga $a_{31}$ trecht 1976, bl. 16.

86. Coornhert-Liga, Notities over het gevangeniswezen; een aanvulling op de Tegen-Nota Beleidsvraagstukken Gevangeniswezen, Utrecht 4 april 1978, bl. 23-32.

87. Openbare commissievergadering van de Vaste Commissic voor Justitie uit de Tweede Kamer over de Nota Beleidsvraagstukken $G e$ vangeniswezen van 10 april 1978, bl. 356 .

88. Op 29 oktober 1982 (NJ 1983,230)

oordeelde de: Hoge Raad dat in het kader van een zogenaamde stage-overeenkomst, waarbij, het vooral gaat om de uitbreiding van de kerinis en ervaring van de stageaire, geen minimumloon betaald behoeft te worden. In een dergelijk geval kan volgens de HR nl. niet van een arbeidsovereenkomst in de zin van art.

7A:1637a BW worden gesproken.

89. Handelingen Tweede Kamer, 1978-1979, bl. 602 .

90. Rappore Commissie Doelstelling en Functie Huis van Bewaring (Cie.-Van Hatrum), 'sGravenhage juni 1977, bl. 61 . 
91. Brief van de staatssecretaris van Justitic van 19 december 1980, Doelstelling en functie huis van bewaring, Tweede Kamer, 19801981, 16556 , nr. 1, bl. 16.

92. Taak en toekomst van het Nederlandse gevangeniswezen. Brief van de staatssecretaris van Justitie (Scheltema) aan de Tweede Kamer van 2 september 1982, Tweede kamer, 1981-1982, 17 539, nrs. 1-2, bl. 38.

93. Werkstaking, circulaire van 14 februari 1985, nr. 148/385, PI 1985, nr. 35.

94. De Stem 7 maart 1985: staatssecretaris Korte-van Hemel: 'werkvergoeding gedetineerclen niet verdubbeld'.

95. De berekening van het arbeidsloon in conctreto geschiedt op grond van de Strafvollzugsvergütungsordnung ( $\mathrm{StVollzVergO}$.) van 11 januari 1977.

96. R. Prowse, H-M. Weber en Ch. Wilson, Rights \& Prisons in Germany: blueprint for Britain?, Paper presented to the British Criminology Society, Annual Conference at the University of York, 24-27 juli 1991.

97. M. Heising, Die Entlohnung der Gefangenenarbeit, Basel und Stuttgart 1968, bl. 69115.

98. U. Heierli, Gefangenenarbeit, Entlohnung und Sozialisation; Fakten und Möglichkeiten, Zürich 1973, bl. 188, 197, 198-199 en 204. 99. J. Fahsel, Das Recht des Gefangenen auf Arbeit und Entlohnung, Saarbrücken 1971, bl. 42-139 en 155-189.

100. P. Koch, Gefangenenarbeit und Resozialisienung, Stuttgart 1969, bl. 2, 100 en. 128133.

101. G. Lichtenberger, Die Arbeitsentlohnung in: Strafvollzug als Mittel der Resozialisation, München 1971, bl, 50-143.

102. C.D. Ohle, Arbeitsbelohmung und Arbeitsentlohnung im Gefangenenarbeitswesen, Hamburg 1972, bl. 28-51.

103. De nog niet van kracht geworden ardkelen 49 en 50 StVollz:G bevatten regelingen met betrekking tot alimentatieverplichtingen van gedetineerden en een bijdrage in de kosten van detentie. Pas wanneer in de toekomst het Duitse detentieloon voldoende niveau heeft kunnen deze aftrekposten van kracht worden. Tot dan toe geldt alleen dat van gedetineerden met voldoende inkomsten een eigen bijdrage in de detentiekosten wordt verlangd, zij het dat daaronder niet de kosten van huisvesting en personeel begrepen zijn.

Zie hierover: J. Feest, a.w. bl. 314-317.

104. Deze informatie is ontleend aan het Engelstalige informatiebulletin Corrections in Sweden, een uitgave van het Kriminalvårdsstyrelsen, Norrköping mei 1990.

105. Decision at Cabinet Meeting on August 30, 1979.

106. Zie - vooral over Vảngdalen - F. Pieters, 'Zweden: strafstelsel en penitentiair systeem', Panopticon (1990), bl. 236.

107. Market adjusted wages to prison inmates; summary of the report from the MAIK-committee, Stockholm 1985, bl. 19-28.

108. Resolution (75) 25 on prison labour (adopted by the Committee of Ministers on 18 September 1975 at the 248 th meeting of the Ministers' Deputies). Bijlage bij het rapport 'Work in Penal Institutions', vermeld in de volgende noot.

109. Council of Europe, Work in Penal Institutions. Report prepared at the request of the European Commitree on Crime Problems by K.J. Neale, Straatsburg 1976, bl. 39-41.

110. Council of Europe, Prison management. Study presented by a co-ordinated criminological research fellowship team composed of H.H. Brydensholt (director of the study), B. van den Goorbergh, M.R. Almeida en P.

Shapland, Straatsburg 1983, bl. 50-51 en 64. 111. Council of Europe, European Prison Rules. Recommendation nr. R(87)3, adopted by the Cornmittee of Ministers of the Council of Europe, 12 februari 1987 and Explanatory Memorandum, Straatsburg 1987, bl. 23 en 62.

112. L.J.M. d'Anjou, G. de Jonge en J.J. van der Kaaden, 'Effectiviteit van sancties', Den Haag, november 1975 , bl. 20. Dit rapport is later opgenomen in de bundel Tegen de regels; een inleiding in de criminologie, onder redactie van J. Fiselier e.a., Utrecht 1977, bl. 441465.

113. Nota Beleidsvraagstukken Gevangeniswezen; 21 seprember 1976, Tweede Kamer, 1976-1977, nr. 14 102, nrs. 1-2, bl. 43.

114. Herziening differentiatiestelsel gevangeniswezen. Brief van de staatssecretaris van Justitie, "s-Gravenhage 4 juli 1990, Tweede Kamer, 1989 - 1990, 21 634, nr. 1, bl. 1-2. 
115. Werkzame detentie; beleidsnota voor het gevangeniswezen, 4 februari 1994, Tweede Kamer, 1993-1994, 22 999, nrs. 10-11, bl. 14.

116. Omdat de gedetineerde zijn volledige arbeidskracht niet op de reguliere arbeidsmarkt kan aanbieden. Deze beknotting van zijn verdien-capaciteit ligt in de risico-sfeer van Justitic (vgl. art. 7A:1638d BW), die immer als monopolistisch werkgever opereert. Een en ander sluit nict uit dat op basis van vrijwilligheid tussen gedetineerden en Justitic part-time overeenkomsten zouden kunnen worden gesloten met een eventedig loon.

117. J. Platschorre, "De gevolgen van detentie in sociale zekerheidsregelingen'. In de bundel Buiten de muren; relaties van gedetineerden, o.r.v. M. Moerings en G. ter Haar, Arnhem 1990, bl. 221.

118. M. Grapendaal, In dynamisch evenwicht; een verkennend onderzoek naar de gedetineerdensubcultuur in drie Nederlandse gevangenissen, 's-Gravenhage 1987, bl. 44-45. 119. E.P. von Brucken Fock, e.a., De rechtspositie van de gederineerde in Nederland on Belgie, Zwolle 1975, bl. 20.

120. Bijv.: art. 24 lid 2 Werkloosheidswet, art. 28 lid 2 Wet op de Sociale Werkvoorziening, art. 42 lid 1 Ziektewer en art. 1 Algemene Bijstandswet (de staat voorziet tijdens detentic in de noodzakelijke kosten van het bestaan. Zie ook de circulaire Toepassing sociale verzekeringswetten op gedetineerden van 2 maart 1982, nr. 87/382, PI 1982, nr. 41. Voorts nog: C. Bakker, 'Detentie en sociale zekerheid', Froces (69) 1990, 3, bl. 63-69. 121. Raad van Beroep Utrecht, 7 augustus 1981, AWBZ 1980/2019, PI 1982, nr. 57. Centrale Raad van Beroep 28 maart 1983, AWBZ 1981/33, PI 1984, nr. 46. Deze eigen bijdrage blijft ook tijdens ontvluchting verschuldigd: Raad van Beroep Zwolle, 29 november $1982, P I 1983, \mathrm{nr} .70$.

122. Circulaire van de staatssecretaris van Sociale Zaken en Werkgelegenheid van 25 juni 1991 aan de gemeentebesturen, kenmerk SZZ/BV/UKB/WBV/91/7425

123. W. de Bruijn, 'Bijstand en dagdetentie; een per abuis verzonden circulaire?' In Sociaal Bestek, nr. 10-1991, bl. 9-10.
124. Toepassing Wet Sociale Werkvoorzicning, circulaire van 26 april $1979, \mathrm{nr}$. 280/379, PI 1980, nr. 58.

125. Zie bijvoorbeeld de bijzondere penitentiaire arbeidsongeschiktheidsregeling, zoals vervat in de circulaire van 21 mei 1982, nr. 306/382, PI 1982, nr. 62.

126. Die op art, 42 lid $1 \mathrm{ZW}$ berustende bevoegdheid is overigens niet aan landelijke normering onderhevig, zodat elke bedrijfsvereniging zịnn eigen beleid kan voeren.

127. Dit spoort met de civielrechtelijke jurisprudentie, die van de werkgever verlangt dat. hij de betrokken arbeidsongeschikte andere: arbeid, waartoe deze wèl in staat is, aanbiedt. Vgl. HR 8 november 1985, NJ 1986, 309 m.n. P.A.S. (Cehave-artest).

128. Circulaire van 7 januari $1981, \mathrm{nr}$. $845 / 380$, PI 1981 , nr. 15.

129. Zie BrC 15.10.1990-A $191 / 90$

(Recheshulp 1991, no. 5, bl. 35) en BrC 20.2.1991 - A 315/90 (Rechtshulp 1991, no. $8 / 9$, bl. 38 .

130. BrC 20 augustus 1982, A $32 / 82$ II, PI 1982, nr. 90.

131. Centrale Raad van Beroep 23 augustus 1982, PI 1984, nr. 84.

132. J. Platschorre, a.w. 132. 22, bl. 234235.

133. Twenty-one detained prisoners against the Federal Republic of Germany, decision of 6th April 1968, Yearbook XI (1968), bl. 528-562.

134. Golder tegen Groot-Brittannię, Europees Hof voor de Rechten van de Mens, 2.1 februari 1975, (CEDH série A 1975 Vol. 17) Nf 1975, 462, met noot E.A. A(lkema). 135. P. van Dijk en G.J.H. van Hoof, De Europese Conventie in theorie en prakrijk, derde druk, Nijmegen 1990, bl. 635.

136. Handleiding opstellen bedrijsplan arbeid, Circulaire van 30 augustus 1991 1, 149435/91 DJ, Ministerie van Justitie, Directie Delinquentenzorg en Jeugdinrichtingen, Afdeling Arbeid, september 1991. Uit dezelfde bron en van dezelfde datum: Uurtarieven arbeidsbedrijven.

137. Artikel 33 lid 1 Beginselenwer Gevangeniswezen spoort daartoe aan door te zeggen: 'De arbeid zal zich behalve tot het verrichten van de huisdienst bij voorkeur uit- 
strekken tot het vervaardigen van voorwerpen bestemd voor 's Rijks dienst en tot objecten van algemeen nut'.

138. Handleiding opstellen bedrijfsplan arbeid, $a . w .$, bl. 1 en 2 en 'Uurtarieven arbeidsbedrijven', bl. 7-8.

139. Rijksbegroting 1992, Hoofdstuk VI, Justitic, Tweede Kamer, 1991-1992, 22 300, hoofdstuk VI, nr. 2, bl. $133 \mathrm{en} \mathrm{nr.} \mathrm{3,} \mathrm{bl.} 3$. 140. CBS Gevangenisstatistick en de Rijksbegrotingen Justitie; de cijfers betreffen de arbeid in strafinrichtingen en rijksinrichtingen voor ter beschikking van de regering gestelden.

141. Werkzame detentie; beleidsnota voor het gevangeniswezen, a. $v$., bijlage 2 .

142. Een groot deel is gedetineerd voor criminaliteit die met drugs te maken heeft. Naar schatting $60 \%$ is verslaafd aan drugs en/of alcohol. Het werkverleden is zeer onregelmatig en de verdere maatschappelijke omstandigheden zijn vaak evenmin rooskleurig. Aldus $M$. Moerings in een toespraak getiteld 'Gevangen en Werk: een problematische combinatie', weergegeven in het BWO-Nieuws, 1991, 14e jaargang, nr. 5, bl. 4.

143. L. Klinkhamer, Arbeid in penitentiaire inrichtingen; onderzoek naar de functie van door gederineerden verrichte arbeid, Utrecht 1991 , bl. 19.

144. Gevangenisdirecteuren blijken daar geen enkele moeite mee te hebben. Directeur van PI De Geerhorst te Sittard, J. Gorissen, in De Limburger van 8 februari 1994: 'Her gevangeniswezen $k a n(.$.$) minder lasten opleve-$ ren voor de overheid als het werk van gederineerden geld in het laatje brengt. Geld dat weer in een verdere opheffing van het cellenrekorr geĭnvesteerd kan worden en in de bouw van extra beveiligde gevangenissen'. Directeur B. Molenkamp van PI De Boschpoort te Breda in NRC-HB van 14 februari 1994: 'Rijk zullen de gevangenissen er niet van worden, maar een aanzienlijk deel van de kosten kan worden terugverdiend'.

145. J. van Zeijst in zijn noot onder een uitspraak van de Raad van Beroep te Zwolle, 29 november 1982, PI 1983, nr. 70 over een inhouding op cen AAW-uitkering i.v.m. een eigen bijdrage ingevolge de AWBZ.
146. Nota Heroverweging collectieve uitgaven, Tweede Kamer, 1981-1982, 16 625, nr. 47, bl. 42-43.

147. J. van Zeijst, t.a.p.

148. NRC-HB, 27 april 1993.

149. Om 'scheve ogen' te vermijden zou dat moeten gelden voor allen die in huizen van bewaring verblijven. 


\section{Hoofdstuk IV}

\section{Strafrechtelijke arbeidsdwang als sluitstuk van een sociale zekerheids-strategie}

In de zomer van 1993 dreigde het Kabinet als reactie op een inzakkende economie een loonmaatregel uit te vaardigen. Het kondigde in één adem een aanscherping van de criteria voor de WTW en een ingreep in de Bijstand aan. Vice-premier Kok maakte tegelijkertijd de nieuwbouw van tweeduizend extra gevangeniscellen bekend. ${ }^{I}$

Gaan recessies in ons economisch stelsel onvermijdelijk gepaard met vollere gevangenissen of betrof het hier een illustratie van het feit dat het gelijktijdig voorkomen van gebeurtenissen nog niet wil zeggen dat daar causaal verband tussen bestaat? In dit hoofdstuk wordt allereerst beschreven wat onderzoek naar een eventuele relatie tussen conjunctuur en het gebruik van de vrijheidsstraf heeft opgeleverd. Daarbij wordt begonnen met een beschrijving van de door de marxist Georg Rusche geformuleerde arbeidsmarkt-hypothese die voor alle onderzoeken naar 'de economische factor' het startpunt is geweest. Na te hebben vastgesteld dat deze onderzoeken niets hebben opgeleverd waarmee de huidige arbeidsrechtelijke positie van gedetineerden kan worden verbeterd en na vastgesteld te hebben dat historiciffilosofen als Foucault, Melossi en Spierenburg daar ook geen materiaal voor aanleveren, wordt te rade gegaan bij David Garland.

Deze socioloog beschrijft het gevangeniswezen als onderdeel van een strategie die gericht is op het handhaven van de sociale vrede. In zijn visie kan het gevangeniswezen worden beschouwd als het sluitstuk van een stelsel van sociale zekerheid dat is ontstaan als reactie op de 'sociale kwestie' die eind vorige, begin deze eeuw de stabiliteit van de samenleving leek te bedreigen. Met Garlands analyse als uitgangspunt kan ook het Nederlandse gevangeniswezen worden gezien als sluitstuk van het stelsel van sociale zekerheid. Aanvaarding van een dergelijke optiek kan vèrgaande gevolgen hebben voor een herbezinning op de plaats van de arbeid binnen de strafgestichten en de wijze waarop die wordt beloond. 


\section{Vrijheidsstraf en werkloosheid}

Het zal niemand verbazen dat vooral marxisten hebben geprobeerd te verklaren waarom gevangenen gewoonlijk gedwongen worden om te werken.

Zij stuitten daarbij echter op het probleem dat Marx noch Engels zich erg uitvoerig over criminaliteit, strafrecht en strafrechtstoepassing heeft uitgelaten. Die beschouwden misdaad als een onvermijdelijk bij-produkt van het kapitalisme en zagen in de strafrechtspleging een instrument waanmee de machthebbers de bestaande orde konden handhaven. ${ }^{2}$ De criminaliteit zou volgens hen en vele van hun tijdgenoten pas verdwijnen zodra er voor iedereen menswaardige levensomstandigheden zouden zijn gecreëerd. ${ }^{3}$

Een van de zeldzame gelegenheden waarbij Marx zijn gedachten over de zin van de straf heeft geopenbaard was in een artikel in de New-York Daily Tribune van 18 februari 1853, waarin hij over de toepassing van de doodstraf in Engeland schreef. Hij betoogde daar dat uit historische gegevens was gebleken dat de strafrechtspleging de mensheid 'sinds de tijden van Kaïn' niet in het gareel had kunnen houden. In hetzelfde artikel keerde hij zich tegen de Kantiaans/Hegeliaanse leer waarin bestraffing als een 'recht' van de misdadiger wordt beschouwd. Aan dat soort metafysica zei hij geen boodschap te hebben. Naar zijn mening kwam het er op neer dat de burgerlijke maatschappij met behulp van de strafrechtspleging probeerde te voorkomen dat de (overigens door haar zèlf voortgebrachte) criminaliteit haar voortbestaan in gevaar zou brengen. Daarom stelde Marx - filosoferend over de zin van de doodstraf - de retorische vraag of het niet zinvoller was om over verandering van het maatschappelijk bestel na te denken in plaats van 'de beul te verheerlijken, die een stelletje misdadigers om zeep helpt, wier plaats alleen maar weer door nieuwe wordt ingenomen'. "

In zijn 'Kritiek op het program van Gotha' uit 1875, dat naast het Communistisch Manifest wel een van zijn belangrijkste programmatische werken wordt genoemd ${ }^{5}$, heeft Marx zich expliciet over de gevangenisarbeid uitgelaten.

De Socialistische Arbeiderspartij van Duitsland had in haar ontwerp-programma de regulering van de gevangenisarbeid geêist en wel 'ter bescherming van de arbeidersklasse tegen de macht van het kapitaal in de huidige maatschappij'.

Marx vond dat maar een slappe eis in zo'n allesonvattend arbeidersprogramma. Men had daarin volgens hem op zijn minst duidelijk moeten stellen dat die eis niet gebaseerd was op vrees voor oneerlijke concurrentie door de goedkope gevangenen-arbeid, maar dat men tegen een onmenselijke bejegening van gevangenen was en dat men die zeker niet wilde beroven van het enige middel waarmee die hun lot nog enigszins konden verbeteren: het verrichten van produktieve arbeid. 'Dat was toch het minste dat men van socialisten mocht verwachten', aldus Marx. ${ }^{6}$

Van Karl Liebknecht bestaat een (in 1918) in de gevangenis geschreven korte schets met de titel "Tegen de vrijheidsstraf' waarin hij over de behandeling van gevangenen zegt: 'Men dwingt hen tot arbeid, maar op een wijze, die den arbeid van een lust tot een last moet maken $(\ldots)^{2}{ }^{2}$ ? 
Het ontbreken van een kant en klare marxistische leer over misdaad en straf heeft Georg Rusche niet verhinderd om de gevangenisstraf aan de historisch-materialistische onderzoeksmethode te onderwerpen en daarmee de basis voor een nieuwe criminologische onderzoeksrichting te leggen.

\subsection{De arbeidsmarkt-hypothese van Georg Rusche}

De invloed van economische factoren op het ontstaan van criminaliteit was al decen-nia voorwerp van criminologisch onderzoek voordat die benadering een rol ging spelen in de leer van de straffen, de penologie. Immers, al in 1905 had Bonger in zijn magnum opus 'Criminalité et Conditions Économiques' de opvatting verdedigd, dat economische omstandigheden de belangrijkste voedingsbodem voor criminaliteit vormen. ${ }^{8}$ Pas in 1933 werd de economische factor door een medewerker van het Frankfortse instituut voor matschappij-onderzoek, Georg Rusche, ook in de leer van de straf geïntroduceerd. Hij heeft als eerste geprobeerd de ontwikkeling van de vrijheidsstraf te verklaren door deze te relateren aan de historische ontwikkeling van de (Westeuropese) economie.

In het artikel 'Arbeitsmarkt und Strafvollzug's formuleerde Rusche de grondslagen van de 'arbeidsmarkt-hypothese', die zijns inziens een bijdrage kon leveren tot de verklaring van de naar tijd en plaats verschillende bejegening van gedetineerden.

Volgens Rusche had de vrijheidsstraf volgens het zogenaamde less eligibilitybeginsel alleen dan een afschrikwekkend effect als gedetineerden er nog beroerder aan toe waren dan de onderste lagen van de samenleving. Als de positie van de laagste maatschappelijke categorie bepalend was voor de aard van het gevangenisregime, was het volgens Rusche zaak om er achter te komen welke factor de positie van die klasse bepaalde. Omdat de leden daarvan gemeen hadden dat zij niets dan hun eigen arbeidskracht bezaten, was volgens hem de economische factor bepalend voor de aard van de vrijheidsstraf en van die economische factor wel in het bijzonder de werking van de arbeidsmarkt. Hij formuleerde de veronderstelling dat de stand van de arbeidsmarkt bepalend was voor de omvang van gevangenispopulaties en de aard van gevangenisregimes.

Bij massale werkloosheid kon aileen een wrede strafexecutie mensen van het plegen van delicten afhouden. Daar waar arbeid schaars was kon het gevangeniswezen volstaan met het tewerkstellen van delinquenten en hen leren tevreden te zijn met de opbrengst van het werk hunner handen. Bij een lage werkloosheid was het ook profijtelijk om gevangenen te laten werken voor de kost en was dwangarbeid het belangrijkste element van de vrijheidsstraf.

Rusche meende dat historisch onderzoek naar de relatie tussen economische stelsels en criminaliteit gegevens opleverde die zijn hypothese ondersteunden.

In de historische ontwikkeling van de straf in Noordwesteuropa onclerscheidde hij drie periodes: de vroege middeleeuwen, waarin de geldboete de voornaamste sanctie was; de late middeleeuwen, waarin lijfstraffen en de doodstraf de bo- 
ventoon gingen voeren en de $17 \mathrm{e}$ eeuw, waarin de vrijheidsbeneming de belangrijkste sanctie werd. De veranderingen in strafsoort verklaarde Rusche vanuit ontwikkelingen op economisch gebied. Het vroeg-middeleeuwse geldboete-stelsel was een weerspiegeling van de maatschappelijke verhoudingen binnen de toenmalige, getaismatig niet erg omvangrijke, boeren-samenleving. Vermogensdelicten werden er betrekkelijk weinig gepleegd omdat er land genoeg voor iedereen was. Als er delicten werden gepleegd waren dat vooral emotioneel gemotiveerde geweldsdelicten. De daders daarvan hadden de wraak van het slachtoffer of diens familie te vrezen. Om moorddadige vetes te voorkomen had de samenleving belang bij een sanctie die verzoening tussen partijen kon bewerkstelligen: een geldboetestelsel.

Toen in de late middeleeuwen door groei van de bevolking de grond schaars werd ontstond er een kloof tussen arm en rijk. Voor het eerst in de geschiedenis ontstond er een soort kapitalistische produktiewijze en hielden de bezitloze arbeiders door onderlinge concurrentie elkaars lonen laag. De criminaliteit veranderde sterk van karakter: vermogensdelicten kregen de overhand. Bedelaars, rovers en dieven vormden een ware plaag voor de stedelijke bevolking en omdat er bij hen geen geld te halen viel werden zij gegeseld, verminkt of gedood. Het werkloze proletariaat viel aldus aan vernietiging ten prooi.

Met de opkomst van het Mercantilisme veranderde rond 1600 de arbeidsmarkt volledig, aldus Rusche. Door expansie van de wereldmarkt en door een afname van de bevolking als gevolg van oorlogen en epidemieën nam het aanbod van arbeidskrachten af, waardoor de lonen stegen en de levensomstandigheden van de laagste klassen enigszins verbeterden. In die situatie had het geen zin meer om misdadigers te verminken of te vernietigen en begon de vrijheidsstraf steeds meer de plaats van lijf-en doodstraf in te nemen.

Aan het einde van de $18 \mathrm{e}$ eeuw veranderde de situatie, toen machines de arbeid gingen verdringen en er een reservoir van industrie-arbeiders ontstond. De laagste klassen boden zich voor een grijpstuiver op de arbeidsmarkt aan. De dwangarbeid in de tuchthuizen rendeerde niet langer en had geen enkele afschrikwekkende werking op de werkloze onderklasse. Toch greep de overheid niet terug op de wrede middeleeuwse straffen. Dat was volgens Rusche niet alleen te danken aan humanitaire verworvenheden, maar ook aan het besef bij de toenmalige politici dat het in de revolutionaire situatie van die tijd nier verstandig zou zijn de onderklasse te provoceren. Daarom bleef men wijselijk aan de vrijheidsstraf vasthouden, zij het dat die wel een andere functie kreeg. Strafinrichtingen, waar eerder zinvol werk verricht was, veranderden in oorden van kwelling, bedoeld om de meest verloederden nog angst aan te jagen. De invoering van het cellulaire stelsel, dat als een hervorming gepresenteerd werd, betekende in werkelijkheid een marteling voor hen die eraan werden onderworpen, aldus nog immer Georg Rusche.

De bepalende rol van het economische stelsel en de conjunctuur illustreerde Rusche met een excursie naar de Nieuwe Wereld.

In de Verenigde Staten van Amerika had de vrijheidsstraf zich namelijk op een 
andere manier ontwikkeld dan in West-Europa. In de VS bestond in de 19 e seuw juist een grote vraag naar arbeidskrachten. Grote oppervlakten in cultuur te brengen land en cen beginnende industriële ontwikkeling zorgden voor zón schaarste op de arbeidsmarkt dat immigratie die zelfs niet kon verhelpen. Er was dan ook betrekkelijk weinig criminaliteit. De gevangenissen dié er waren ontwikkelden zich tot goed renderende productiecentra, met als belanisijkste opdracht misdadigers te veranderen in nuttige leden van de samenleving. ' $Z$ o'n klimaat was bevorderlijk voor een fundamentele hervorming van het Amerikaanse gevangeniswezen. In Europa werd gevangenishervorming pas mogelijk toen de conjunctuur daar een tijdelijke opgang beleefde, de druk op de arbeidsmarkt langzaam verminderde en er ten behoeve van werklozen een sociaal beleid werd ontwikkeld. De aanwezigheid van werkloosheidsvoorzieningen voorkwam in een aantal Europese landen een totale ineenstorting van de arbeidsmarkt toen na de Eerste Wereldoorlog de werkloosheid weer chronisch werd. I.onen en levensstandaard zonken niet zo diep als bij een vrij spel van economische krachten verwacht had kunnen worden. Omdat de criminaliteit niet boven vooroorlogs niveau stecg kon hervorming van het gevangeniswezen doorgaan. Dit in tegenstelling tot wat er tijdens de recessie in de Verenigde Staten gebeurde, waar de werkloosheid niet door een sociaal beleid werd gecompenseerd. Dat resulteerde daar in een enorme stijging van de criminaliteit, een brute repressie daarvan en het terugdraaien van de gevangenishervormingen.

Rusche werkte, naar verluidt, zelf zijn arbeidsmarkt-hypothese uit, maar zijn manuscript werd door zijn collega Otto Kirchheimer, die in verband met de Tweede Wereldoorlog met een aantal andere medewerkers van het Frankfortse Instituut naar de Columbia-universiteit te New York was uitgeweken, herzien en geactualiseerd. ${ }^{10}$

Het resultaat was het - pas na zijn her-uitgave in 1968 onder criminologen fameus geworden - boek 'Punishment and Social Structure', dat veel bekender is geworden dan Rusches artikel uit 1933, hoewel daarin toch alle elementen van de arbeidsmarkt-theorie al aanwezig waren. ${ }^{1 !}$

\subsection{Conjunctuur, criminaliteit en vrijheidsbeneming}

De herpublicatic van 'Punishment and Social Structure' leidde tot een recks onderzoeken waarin de arbeidsmarkt-theorie getoetst en uitgewerkt werd. Als zij valide zou blijken te zijn had men immers een instrument waarmee, op basis van historische analyses, prognoses over de ontwikkeling van de vrijheidsstraf konden worden gedaan.

De eerste die de veronderstellingen van Rusche en Kirchheimer op hun waarde heeft onderzocht was Jankovic. ${ }^{12} \mathrm{Hij}$ meende - en die kritiek zou nog vaak worden herhaald - dat zij geen bevredigend antwoord hadden kunnen vinden op de vraag waarom de vrijheidsstraf in Westeuropa was blijven bestaan toen er eind 
$18 \mathrm{e}$, begin $19 \mathrm{e}$ eeuw door de voortschrijdende mechanisering van de arbeid een overschot aan arbeidskrachten ontstond en gevangenisarbeid economisch gezien on-interessant werd. Weliswaar had Rusche gesteld dat om humanitaire en politicke redenen terugkeer naar lijf- en doodstraf uitgesloten was, maar daarmee was volgens Jankovic het voortbestaan van de vrijheidsstraf in laat-kapitalistische samenlevingen onvoldoende verklaard.

Jankovic meende deze vraag te kunnen beantwoorden door te veronderstellen dat onder 'post-industriële economische omstandigheden' de vraag of de arbeidskracht van gedetineerden zou kunnen worden benut niet meer bepalend was voor de aard van de vrijheidsbeneming. Onder zulke economische condities kon men putten uit een groot reservoir goedkope arbeidskrachten en was de gevangenisarbeid van geen enkele economische betekenis. Jankovic sloot de mogelijkheid niet uit, dat de vrijheidsstraf onder dergelijke economische omstandigheden wel een rol speelde bij het reguleren van de omvang van het arbeids-surplus. Hij beredeneerde dat als volgt: De groep 'overtolligen' is economisch direct van staatssteun afhankelijk. De sociale vrede binnen dat reserve-leger van arbeidskrachten wordt bewaard met behulp van cen netwerk van voorzieningen en diensten die door de staat als 'maatschappelijke kosten' worden afgeboekt. De overheid ondersteunt en controleert deze surplus-bevolking met twee instrumenten: het sociale zekerheidsstelsel en het strafrechtelijk systeem. Gegeven het blijvende karakter en de omvang van de surplus-bevolking in de moderne kapitalistische staten zal het volgens Jankovic mogelijk zijn dat men door toepassing van de vrijheidsstraf een klein gedeelte van dat 'surplus' in toom kan houden en dat men op die manier de omvang van de gehele groep 'overtolligen' kan beïnvloeden.

Jankovic heeft voorts de geldigheid onderzocht van de veronderstelling dat er een directe samenhang bestaat tussen de mate waarin de vrijheidsstraf wordt toegepast en de omvang van de werkloosheid. Daarmee onderzocht hij de geldigheid van de door Rusche en Kirchheimer geformuleerde 'strengheidshypothese', die inhoudt dat er strenger wordt gestraft naarmate de economische conjunctuur verslechtert. Met andere woorden: in samenlevingen waar de vrijheidsstraf de zwaarste strafsoort is zouden in tijden van recessie meer en langduriger vrijheidsstraffen worden opgelegd.

De tweede veronderstelling die hij heeft getoetst is de "instrumentaliteitshypothese' van Rusche en Kirchheimer. Die houdt in dat door toepassing van de vrijheidsstraf een deel van de arbeidsreserve uit de markt wordt genomen of, anders gezegd, dat een vergroting van de gevangenispopularie de werkloosheid doet verminderen.

Op grond van onderzoek van (generale) statistische gegevens betreffende de toepassing van de vrijheidsstraf en de economische conjunctuur in de Verenigde Staten van 1926 tot 1974 kwam Jankovic tot de conclusie dat de strengheidshypothese verifieerbaar was. 
De relatie tussen werkloosheid en de toepassing van de vrijheidsstraf was volgens zijn berekeningen positief en statistisch significant en bleek niet afhankelijk van variaties in de aantallen bekend geworden strafbare feiten. Een zelfde geluid kwam van Yaeger die ook kwantitatief onderzoek had gedaan naar een verband tussen werkloosheidscijfers en gevangenispolulaties in de Verenigde Staten. Deze schreef aan de factor werkloosheid zelfs een sterke voorspellende waarde toe met betrekking tot de omvang van de gevangenisbevolking. In zijn visie werd de vrijheidsstraf gebruikt om de werklozen als groep in bedwang te houden. ${ }^{13}$

De door Jancovic onderzochte data boden echter geen steun aan de instrumentaliteitshypothese: hij had geen significant effect kunnen vinden van de toepassing van de vrijheidsstraf op de werkloosheidscijfers. Jankovic achtte het echter niet uitgesloten dat ook daar een relatie aanwezig zou blijken te zijn als men niet (zoals hij gedaan had) alleen naar de aantallen veroordeelden zou kijken, maar alle categorieën gedetineerden bij zo'n onderzoek zou betrekken.

Hale wees later de veronderstelling dat vrijheidsbeneming een bespeurbare invloed zou hebben op de werkloosheidsciffers van de hand omdat het aantal werklozen in de meeste samenlevingen nu eenmaal vele malen hoger is dan het aantal gedetineerden. ${ }^{14}$ Sindsdien is ook niet meer geprobeerd aan te tonen dat de detentiequote invloed heeft op de werkloosheidscijfers. Wat daar ook van zij, Jankovic was op zich al tevreden met zijn bevinding dat het mogelijk bleck om empirisch onderzoek te doen naar eventuele relaties tussen werkloosheid en de toepassing van vrijheidsstraf.

Adamson beweerde, minder bescheiden, dat Rusche en Kirchheimer de weg hadden geplaveid voor een geheel marxistische penologie. Zijn eigen bijdrage daartoe bestond uit onderzoek naar de manier waarop de strafrechtspleging en het financieel/industriële complex elkaar beïnvloeden. Hij veronderstelde dat het arbeidsaanbod en de economische conjunctuur bepalend zijn voor de wijze waarop het strafrechtelijk systeem zijn 'cliëntèle' percipieert: òf als een bedreiging voor de bestaande kapitalistische produktiewijze of als cen exploiteerbaar produktiemiddel.

Veranderingen in straftoemeting en gevangenisregime konden volgens hem worden verklaard vanuit fluctuaties in het arbeidsaanbod en in de conjunctuur en de daarmee gepaard gaande veranderingen in bejegening van de gevangenispopulatie. Op basis van een analyse van een aantal periodes in de $19 \mathrm{c}$-eeuwse Verenigde Staten meende Adamson te kunnen vaststellen, dat schommelingen in arbeidsaanbod en conjunctuur samenvielen met specifieke fasen in de ontwikkelingen van de strafexecutie. Telkens wanneer een economische recessie tot een overschot aan arbeidskrachten leidde begon men zich af te vragen of het tot dan toe gevoerde straftoemetingsbeleid wel afschrikwekkend genoeg was geweest.

In al die gevallen kwam het tot een heroverweging van de rol van de gèvangenisarbeid en werd gekeken naar het effect daarvan op de vrije ondernemingsgewijze produktie en op de vrije arbeid.

Hoewel Adamson de eerste was om te erkennen dat er geen sprake was van een simpel causaal verband, meende hij wel aangetoond te hebben dat conjunc- 
tuur en arbeidsmarkt van invloed waren op de perceptie van gedetineerden: als bedreiging of als produktiemiddel. ${ }^{15}$ Daarmee was echter nog lang geen marxistische penologie gegrondvest. Hooguit kon worden geconstateerd dat de arbeidsmarkt-hypothese, sinds die door Jankovic onder het stof te voorschijn was gehaald, een niet onbelangrijk onderzoeksthema was geworden.

Ook Box heeft gezocht naar een antwoord op de vraag of economische recessie al of niet leidt tot groei van de gevangenispopulatie.

Het hem beschikbare empirisch onderzoek gaf steun aan de veronderstelling dat werkloosheid van verdachten beslissingen van opsporings- en vervolgingsorganen, straftoemetingsadviezen van de reclassering de aard en zwaarte van strafvonnissen negatief benvloedde. Box wees er echter op dat zulks niet betekende dat alleen werkloosheid, los van andere factoren als de aard van het delict en recidive, de beslissingen van de strafrechtelijke diensten zou beïnvloeden. Wel kon op macro-niveau van een verband tussen één van de gevolgen van een economische recessie, werkloosheid, en één bijzondere sociale controle-maatregel, de vrijheidsbeneming, worden gesproken. Van een mechanistische relatie tussen die twee factoren kon zijns inziens echter niet worden gesproken. Zo kon naar zijn mening een dergelijke relatie bijvoorbeeld sterk door specifiek overheidsbeleid worden beïnvloed. ${ }^{16}$

De Nederlandse criminoloog De Haan heeft onderzocht of de bevindingen van Box ook opgingen voor Nederland, waar sinds het midden van de 70-er jaren zowel de werkloosheid als de gedetineerdenpopulatie was toegenomen. Hij konanders dan Box - op macro-niveau echter geen significant verband tussen beide factoren vinden. Hij constateerde dat het aantal opgelegde gevangenisstraffen min of meer stabiel was gebleven en in verhouding tot het totaal aantal opgelegde sancties zelfs was afgenomen. De onmiskenbare toename van het aantal gevangenen gedurende de laatste decennia schreef hij toe aan de toename van de gemiddelde duur van de opgelegde vrijheidsstraffen, een factor die, zo moest hij constateren, Box niet in zijn onderzoek had betrokken. ${ }^{17}$

\subsection{Werkloosheid en straftoemeting}

Volgens de zoëven geciteerde De Haan heeft onderzoek van een aantal Groningse criminologen op micro-niveau wel een significante relatie tussen werkloosheid en het opleggen van vrijheidsstraffen aangetoond.

Het Criminologisch Instituut te Groningen heeft de invloed van werkloosheid op de Nederlandse straftoemeting onderzocht. In het kader daarvan is door Jongman en zijn medewerkers een statistisch verband tussen werkloosheid ('baanloosheid') en geregistreerde criminaliteit aangetoond..$^{18}$

Door Kannegieter is verder vastgesteld dat de arbeidspositie van verdachten een belangrijke afwegingsfactor bij het bepalen van de strafsoort is: werklozen blijken vaker een onvoorwaardelijke gevangenisstraf te krijgen dan werkenden. ${ }^{19}$ Kannegieter heeft zich overigens beperkt tot de vaststelling dàt werkloosheid bij individuele straftoemetingsbeslissingen een rol speelde, maar waagde zich niet 
aan een verklaring voor het aangetroffen statistisch verband.

Iemand die dat -overigens los van het Groningse onderzoek- wèl heeft geprobeerd is Sabol. Volgens deze onderzoeker worden sinds de Tweede Wereldoorlog in Engeland en Wales fluctuaties in de toepassing van de vrijheidsstraf veroorzaakt door anticiperend gedrag van de strafrechter. De mate waarin die vrijheidsstraffen oplegt varieert met de werkloosheidscijfers. Bij onverwachte schommelingen in de werkloosheid is volgens Sabol dat verband her duidelijkst merkbaar ${ }^{20}$. Bevindingen van Chiricos en Bales, die in Florida (VS) vergelijkbaar onderzoek hebben verricht, wijzen in dezelfde richting. $\mathrm{Zij}$ menen dat het sterke verband dat zij vonden tussen werkloosheid en straftoemeting op individueel niveau de conclusie rechtvaardigt dat gevangenissen tot meer dienen dan alleen het bestraffen van delinquenten: 'Het lijkt erop dat daar overtollige arbeidskracht en maatschappelijke springstof worden opgeslagen'. De maatschappelijke verhoudingen worden volgens Chiricos en Bales heel duidelijk bij de berechting van werkloze verdachten. $^{21}$

\subsection{Beperkingen van de arbeidsmarkthypothese}

Hoewel in de ogen van 'Ruschianen' uit onderzoek met behulp van steeds betere statistische methoden een onmiskenbare samenhang tussen schommelingen in de conjunctuur en omvang van de gevangenispopulatie naar voren kwam, ${ }^{22}$ werd een puur economische benadering van de vrijheidsstraf door velen toch te 'kaal' gevonden. Men werd zich ervan bewust dat, óok als het economische stelsel de strafrechtspleging zou beïnvloeden, ook andere krachten daarbij een rol zouden kunnen spelen en dat die ook in de analyse betrokken dienden te worden. Dat komt bijvoorbeeld naar voren uit het onderzoek dat in Frankrijk door Laffargue en Godefroy naar de relatie tussen conjunctuurschommelingen en straftoemeting is verricht. $\mathrm{Zij}$ veronderstelden dat stijging van de werkloosheid en het afglijden van een deel van de werkende klasse naar het sub-proletariaat gedurende economische recessies leidt tot een stijging van de gevangenisbevolking, onafhankelijk van fluctuaties in de bekend geworden criminaliteit. Hun statistische analyse gaf aan dat de arbeidsmarkt gedurende de periode 1920-1939 van invloed kan zijn geweest op de hoeveelheid gevangenen. Over de periode 1952-1985 werd een sterke relatie gevonden. Daarmee achtten zij hun hypothese, dat er een verband bestaat tussen arbeidsmarkt en gevangenisbevolking, bevestigd: een toename van het aantal economisch zwakke individuen op de arbeidsmarkt resulteert in een toename van het aantal gevangenen, althans voor de bestudeerde (heel verschillende) periodes.

Een poging van deze onderzoekers om ook over de periode 1870-1914 zo'n verband te vinden slaagde echter niet. Zij konden geen direct causaal verband aantonen tussen het ontstaan van een nieuwe arbeidersklasse en veranderingen in het discours over strafrechtelijke repressie.

Tot zover opereerden zij 'klassiek' Ruschiaans. Zij gingen echter een stap verder door te veronderstellen dat dergelijke processen kunnen worden versterkt 
door zaken als een gerichte criminele politiek en veranderingen in onveiligheidsgevoelens bij het publiek. Daamaast onderscheidden zij nog een aantal factoren die de relatie tussen werkloosheid en de toepassing van de vrijheidsstraf kan beinvloeden, zoals demografische factoren, het sociaal zekerheidsbeleid, de openbare mening, de opvattingen van binnen het strafrechtelijk apparaat zelf, het vigerende straftoemetingsbeleid, wetgevende matregelen en de beschikbare openbare middelen. ${ }^{23}$

Ook Zimring en Hawkins verweten Rusche en Kirchheimer geen oog te hebben gehad voor andere dan economische factoren. Zo zouden ook ideologische factoren bepalend kunnen zijn geweest voor de ontwikkeling van de vrijheidsstraf. Als voorbeeld wezen zij op het feit dat in de VS onder dezelfde economische condities gelijktijdig twee sterk van elkaar verschillende gevangenisregimes bestaan hebben: het Aubum-stelsel, gekenmerkt door het feit dat er in werkzalen gemeenschappelijk arbeid werd verricht die op maximale efficiency was gericht en het Pennsylvania-stelsel, in het kader waarvan gedetineerden eenzaam, zonder werk maar mèt de Bijbel werden opgesloten. ${ }^{24}$

Inverarity en Grattet verbreedden de discussie over de arbeidsmarkt-hypothese door te onderzoeken of conjunctureel bepaalde werkloosheid naast een eventuele invloed op de gedetineerdenpopulatie ook gevolgen had voor andere vormen van overheidsinterventie. Het zou volgens hen namelijk best eens zo kunnen zijn dat de invloed van werkloosheid op de omvang van de gevangenisbevolking mede afhankelijk is van de mate waarin in tijden van recessie werklozen naar het leger, de bijstand of naar psychiatrische inrichtingen worden gesluisd. Zij zochten daartoe naar effecten van werkloosheid op de recrutering van militairen, de aantallen bijstandsgerechtigden en de omvang van de bevolking van psychiatrische inrichtingen in de Verenigde Staten van Amerika tussen 1948 en 1985 . Hun statistische analyses leverden echter geen duidelijke conclusie op met betrekking tot de invloed van werkloosheid op opnames in psychiatrische inrichtingen. Evenmin werden er aanwijzingen gevonden voor invloed van werkloosheid op de omvang van de strijdkrachten. De invloed van werkloosheid op het aantal ontvangers van bijstand was wel duidelijk. Variaties in aantallen bijstandgerechtigden konden echter niet in verband worden gebracht met variaties in de gedetineerdenpopulatie. Een significante wisselwerking tussen de toepassing van de vrijheidsstraf en andere methoden van sociale controle werd aldus niet gevonden. ${ }^{25}$

Melossi, evenmin tevreden met uitsluitend economische verklaringen voor het fenomeen gevangenisstraf, stelde de arbeidsmarkt-benadering als exogeen model tegenover een endogeen model, waarin de eigen invloed van de diverse onderdelen van het strafrechtelijk systeem op het gebruik van strafsoorten wordt geanalyseerd. Het 'ideale' model zou volgens deze auteur wellicht uit een combinauie van beide benaderingen kunnen bestaan. Zo ziet hij als manco van een puur economische benadering dat daarin geen rekening wordt gehouden met de symbolische rol die de gevangenis in de samenleving vervult. Dat neemt niet weg dat hij verder onderzoek naar de invloed van de - moeilijk grijpbare - economische 
factor van groot belang achtte. Het zou echter wel eens kunnen zijn, zo zegt Melossi, dat bij de analyse van het straftoemetingsbeleid in contemporaine 'moderne' samenlevingen niet slechts moet worden gekeken naar de algemene werkloosheidscijfers, maar in het bijzonder naar die van groepen die nauwelijks of geen toegang tot de arbeidsmarkt hebben, zoals jongeren en etnische minderheden, groepen die meestal oververtegenwoordigd zijn in de gedetineerdenpopulatie. ${ }^{26}$

Eerder had Melossi de rol van de taal in het debat over de waarde van de arbeidsmarkt-hypothese ter sprake gebracht. In tijden van economische recessie zouden politici en andere 'moral entepreneurs' het debat over misdaad en straf in sterk punitieve termen gaan voeren, waardoor er een strafrechtelijk klimaat ontstaat waarin vaker dan voorheen gevangenisstraffen worden opgelegd. ${ }^{27}$

Dan waren er nog degenen die de stand en beweging van de gevangenispopulatie geheel lós van economische factoren wilden verklaren. Zo negeerden Blumstein en Cohen in hun benadering de economische factor volledig. Volgens hen kende elke 'gezonde' maatschappij een betrekkelijk constant volume strafsancties. Maatgevend daarvoor achtten zij het aantal gedetineerden per 100.000 inwoners. $\mathrm{Zij}$ bouwden daarbij voort op de stelling van Durkheim dat elke min of meer stabiele samenleving een constante hoeveelheid criminaliteit genereert en dat de bestraffing van die criminaliteit goed is voor de handhaving van het normbesef in die maatschappij.

Omdat het buitengewoon moeilijk is om een goede definitie van 'criminaliteit' te vinden en het daarom lastig is om Durkheims stabiliteits-hypothese aan de criminaliteitscijfers te toetsen, meenden Blumstein en Cohen dat zij daarbij beter uit konden gaan van hoeveelheid opgelegde strafsancties en meer in het bijzonder van de in hun ogen belangrijkste sanctie, de vrijheidsstraf. Zowel voor de Verenigde Staten van Amerika als voor Noorwegen meenden zij statistische aanwijzingen te hebben dat in beide samenlevingen (zij het op verschillend niveau) het volume aan strafsancties in de loop van vele decennia stabiel was gebleven. ${ }^{28} \mathrm{Hun}$ stability of pumishment-hypothese werd volgens de Nijmeegse criminoloog Fiselier echter niet gesteund door hun onderzoeksresultaten. Hij herhaalde het onderzoek voor Nederland maar vond geen steun voor de leer van het stabiele straf-volume. Voor de arbeidsmarkt-hypothese heeft Fiselier evenin steun kunnen vinden. Hij had geen verband kunnen vaststellen tussen veranderingen in na-oorlogse werkloosheidscijfers en veranderingen in de omvang van de gestichtsbevolking. ${ }^{29}$

\subsection{Gevangenisarbeid als disciplinering}

Naast degenen die de arbeidsmarkt-hypothese wilden 'aankleden' door andere factoren bij de analyse van aard en inhoud van de vrijheidsstraf te betrekken, waren er critici die de waarde van het historische onderzoek waarop die hypothese stoelde -en daarmee in feite de validiteit van de hypothese zelf - in twijfel trokken. Zoals Steinert en Treiber. Zij vonden de economische theorie van Rusche en Kirchheimer veel te schematisch omdat daarin de uiterst gecompliceerde relatie 
tussen economie en politiek geen rol speelde. Daarenboven meenden ze dat in 'Punishment and Social Structure' te gemakkelijk voor wáár was aangenomen dat in de late middeleeuwen op grote schaal lijf- en doodstraffen waren gehanteerd om een schadelijk geachte onderklasse uit te roeien. Zij vonden het door Rusche en Kirchheimer daarover gepresenteerde cijfermateriaal onbetrouwbaar omdat hun eigen onderzoek bronnen had opgeleverd waaruit bleek dat verminkende en kapitale sancties in die tijd helemaal niet zo frequent ten uitvoer waren gelegd. De economische verklaring van de toepassing van de gevangenisstraf werd door Steinert en Treibert sterk gerelativeerd. Zij meenden dat economische effecten van strafrechtstoepassing als regel uiterst zwak zijn. Volgens hen zou de arbeidsmarkthypothese alleen onder heel bijzondere economische omstandigheden kunnen opgaan, namelijk wanneer de strafrechtspleging direct gebruikt wordt om arbeidskrachten te recruteren, bijvoorbeeld om galeien te bemannen of koloniën van goedkope werkkrachten te voorzien.

Steinert en Treiber achtten vruchtbaarder onderzoek naar ontstaan en gebruik van strafsancties mogelijk als de strafrechtspleging werd gezien als deel van een alles omvattend proces, in het kader waarvan de overheid de samenleving trachtte te 'disciplineren'. ${ }^{30}$

Later gaf Steinert overigens te kennen dat, ondanks alle kritiek, een economische benadering van het verschijnsel vrijheidsstraf misschien tòch vruchtbaar kon zijn als men de relatie tussen het economische stelsel en het strafrechtelijk handhavingssysteem zou analyseren met behulp van het begrip arbeidsethos. In die visie is het strafrechtelijk systeem vooral een ideologisch apparaat dat op zich niet bijdraagt tot de vorming van een bepaalde arbeidsmoraal, maar waarin die wel tot uitdrukking komt. Het strafrecht is een politiek handhavingssysteem, zonder directe eigen economische belangen. Het is in de visie van Steinert veeleer een van de middelen waarmee de geldende arbeidsmoraal zichtbaar kan worden gemaakt. Daarvoor doet het er niet toe dat het strafrecht, gemeten aan zijn officiële doelstellingen (preventie, afschrikking), een faliekante mislukking is. Het gaat om het symbolische van de strafrechtspleging, om het uitdragen van de heersende moraal. In de strafsancties wordt de heersende arbeidsmoraal, die bepaalt wie, waarom en onder welke voorwaarden moet werken, nauwkeurig weerspiegeld. Met het opleggen van gevangenisstraf wordt gemikt op de puur uiterlijke disciplinering. Bij de op resocialisering gerichte sancties gaat het om de psychische voorbereiding van de dader op zijn rol van arbeider en consument. Geldstraffen, die de consumptiemogelijkheden beperken, prikkelen tot harder werken om het geleden verlies te compenseren. De straffen sluiten aldus aan op de beoogde maatschappelijke aanpassing van de veroordeelde en kunnen worden beschouwd als gedramatiseerde uitingen van de heersende arbeidsmoraal. $\mathrm{Zij}$ dragen bij tot de bestendiging dáárvan en hebben nauwelijks invloed op de criminaliteit. ${ }^{31}$

De kritiek op de stellingen van Rusche en Kirchheimer is in 1981 door Schumann geëvalueerd. Hij stelde vast dat er in de eerste plaats twijfel was ontstaan aan de validiteit van de historische analyse waarop zij hun stellingen met betrek- 
king tot de samenhang tussen arbeidsmarkt en de toepassing van de gevangenisstraf hadden gebaseerd. Hij meende echter dat zulke kritiek geen stand hield als men de relatie tussen arbeidsmarkt en gevangenisstraf niet zozeer kwantitatief, maar eerder kwalitatief bezag. In het laatste geval moet worden bezien hoe de arbeidskracht van gedetineerden wordt gewaardeerd: of zij gedurende de gevangenschap wordt benut of van geen belang wordt geacht. De arbeidsmarkt-theorie kon volgens Schumann dan als volgt worden geherformuleerd: wanneer er sprake is van een arbeidssurplus wordt dat overschot niet door het gevangeniswezen geabsorbeerd maar bij krapte op de arbeidsmarkt zal de in de strafinrichtingen beschikbare arbeidsreserve echter wel economisch worden benut.

De economische benadering van Rusche en Kirchheimer leek alleen een verklaring op te leveren voor het gebruik van de vrijheidsstraf tijdens het Mercantilisme maar bood geen antwoord op de vraag waarom tijdens de industriële revolutie, toen er arbeidskrachten in overvloed waren, tóch aan de gevangenisstraf werd vastgehouden. De arbeidsmarkt-theorie heeft verder weinig verklarende kracht voor de penologische ontwikkelingen in de 20ste eeuw. De relatie tussen kapitalistische economieën en de gevangenisstraf bleek complexer te zijn en daarom werd er gezocht naar andere dan puur economische verklaringen voor het verschijnsel 'gevangenisstraf'. In het debat duiken dan begrippen als 'disciplinering' en 'arbeidsethos' op.

Schumann, die kennelijk ook voor de disciplineringstheorie was gewonnen, meende zelf dat het strafrechtelijk systeem moest worden gezien als behorende tot het complex van mechanismen die erop zijn gericht een mens te produceren die geschikt is voor de kapitalistische produktiewijze. Hij kende aan de gevangenisstraf zelf echter geen disciplinerend effect toe. De gevangenis diende er volgens hem slechts toe bepaalde personen tijdelijk onschadelijk te maken, er werden zoals sommigen beweerden geen 'model-arbeiders' voor de maatschappij klaargestoomd. De gevangenis was volgens hem de harde kern van een scala van controle-technieken. In noodgevallen, als niets meer helpt, wordt incidenteel naar dit uiterste controle-middel gegrepen. De enige funcrie die Schumann de vrijheidsstraf toedacht is het vermogen bepaalde groepen (vooral jeugdigen) aan de onderste regionen van de arbeidsmarkt te binden. ${ }^{32}$

Het standpunt van Schumann verschilt hemelsbreed van de analyses die Foucault en Melossi van de gevangenis en de gevangenisarbeid hebben gemaakt, Foucault met behulp van zijn eigen filosofie van de macht en Melossi als adept van Rusche en Kirchheimer.

\subsection{De vaststelling van cen machtsverhouding}

In zijn 'Surveiller et Punir' schreef Foucault aan de gevangenisarbeid vóór alles een disciplinerende functie toe. ${ }^{33}$ Economisch achtte hij die arbeid door haar geringe omvang en haar lage rendement niet van belang. De werkelijke betekenis 
ervan lag volgens hem niet in haar produktieve vermogen maar in haar invloed op het menselijk functioneren. Het gaat vooral om de onderwerping aan hèt grote gebod van het menselijk bestaan: te moeten werken. ${ }^{34} \mathrm{Bij}$ de gevangenisarbeid draait alles om het beginsel van orde en regelmaat. Door de gedetineerde bezig te houden leer je hem wennen aan orde en regelmaat. Als gevangenisarbeid enig effect heeft, dan is dat daarin gelegen dat zij individuen aflevert die afgestemd zijn op de normen van een industriële samenleving. Door het belonen van gevangenisarbeid leert de gedetineerde beseffen dat het in het leven draait om het verdienen van een salaris, om het verwerven van bezit, dat men moet sparen en aan zijn toekomst moet denken. Het arbeidsloon vertegenwoordigt in de gevangenis niet de tegenwaarde van een bepaalde prestatie, maar functioneert als prikkel tot verandering van de gedetineerde. Het arbeidsloon is een juridische fictie, want het is geen vergoeding voor vrijwillig aangeboden arbeidskracht maar een beloning voor in correctioneel opzicht nuttig geachte activiteiten. Het nut van de gevangenisarbeid ligt dan ook beslist niet in de opbrengst ervan en ook niet in de mogelijkheid dat gedetineerden daar bepaalde vaardigheden mee verwerven. In de lege economische huls van de gevangenisarbeid gaat het in de visic van Foucault om de vaststelling van een machtsverhouding, om de systematische onderwerping van het individu en om diens aanpassing aan het produktieapparaat.

\subsection{De reproduktie van proletariërs}

Zag Foucault de discplinering van individuen als een verschijnsel dat zich in alle levenssferen voordoet en beschreef hij de gevangenis als één van de theaters waarin het disciplinerings-spel wordt opgevoerd, in de ogen van Melossi was deze analyse te vrijblijvend. Hoewel de conclusies van Foucault er toch niet om logen zocht hij naar een puur marxistische verklaring van wat er in de gevangenissen gebeurde.

Volgens hem was 'disciplinering' een concept van de bourgeoisie die met behulp daarvan het arbeidsproces op een kapitalistische wijze kon organiseren en sturen. ${ }^{35}$ Melossi en Pavarini hebben als een tweede Rusche en Kirchheimer gezocht naar een relatie tussen de opkomst van de kapitalistische produktiewijze en het ontstaan van de gevangenis. Op grond van een historische analyse van het ontstaan van de gevangenis in Engeland en Europa (in het bijzonder in Italie) en een studie van de ontwikkeling van het gevangeniswezen in de eerste helft van de 19e eeuw in de Verenigde Staten van Amerika kwamen ze tot de volgende conclusies.

De geschiedenis van het gevangeniswezen wijst volgens deze auteurs uit dat een gevangenis in economische zin nimmer rendabel is geweest. Daarom is het onjuist om een gevangenis letterlijk als een fabriek te beschouwen. Men kan hooguit zeggen dat de eerste gevangenissen, wat hun interne organisatie betreft, waren ontworpen naar het voorbeeld van de fabriek. Het ging daarbij niet zozeer om de produktie van goederen, maar om de produktie van een bepaald type 
mens, de proletariër. Het ging om de produktie van onderdanen voor een geïndustrialiseerde staat, door gevangenen een training in fabrieks-discipline te geven. Zo ontstond er een nauwe relatie tussen de 'logica van de vrije markt' en de 'logica van de inrichting'. Wanneer het aanbod van arbeidskracht op de vrije markt de vraag overtreft veranderen de gevangenissen in plaatsen waar arbeidskracht vernietigd wordt. Daarentegen fungeert de gevangenis, bij een krap arbeidsaanbod als een plaats waar de arbeidskrachten worden benut om vervolgens, na een proces van herkwalificatie, weer op de vrije markt te worden gebracht. Melossi en Pavarini stellen dat de penitentiaire praktijk zich beweegt tussen enerzijds een 'negatieve imperatief' van destructie en afschrikking en anderzijds de 'positieve imperatief' van produktie en her-opvoeding.

De gevangenis is te vergelijken met een fabriek die proletariërs voortbrengt in plaats van goederen. De werkelijke functie van de gevangenis is de voortdurende reproduktie van de maatschappelijke orde van de bourgeoisie. De gevangenis wordt als institutie het symbool van de macht van de bourgeoisie. De gevangenis staat model voor de ideale maatschappij, waarin de bezitloze crimineel wordt (her-)opgevoed tot een maatschappelijk ongevaarlijke proletariër.

De economische bepaaldheid van het karakter van de gevangenisstraf wordt door Melossi en Pavarini op deze manier niet in kwantitatieve maar - net als door Schumann - in kwalitatieve zin uitgelegd. Het gaat niet om de produktie maar om de produktiewijze; niet om het uitbuiten van arbeidskracht alleen, maar om het omvormen van de 'crimineel' tot arbeider in de klassiek-kapitalistische betekenis. ${ }^{36}$ Op die manier poogden deze auteurs de arbeidsmarkt-hypothese met de disciplineringstheorie te verbinden.

Werd de arbeider aanvankelijk door zijn eigen werkgever gedisciplineerd, met het toenemen van de aantallen werklozen werd die taak steeds vaker door Justitie overgenomen.

Ignatieff heeft beschreven hoe in het Engeland van het begin van de $19 \mathrm{e}$ eeuw de werkgevers zeer goed bleken te beseffen dat een hervorming van de maatschappij in kapitalistische zin de stabiliteit van de samenleving in gevaar zou kunnen brengen. De machthebbers waren zich ervan bewust dat in een vrije markteconomie de staat de rol moest overnemen van de vroegere paternalistische werkgevers. Sindsdien is de disciplinering van de arbeiders meer en meer aan de strafrechter overgelaten. ${ }^{37}$

\subsection{De reproduktie van het gezin}

Ook de historicus Spierenburg uitte zijn scepsis ten aanzien van een puur economische benadering van de vrijheidsstraf. In geen enkel van de door hem geraadpleegde archieven had Spierenburg een bevestiging gevonden van Rusches veronderstelling dat de tucht- annex werkhuizen ooit winstgevend zijn geweest. Zijn conclusie is dat bij de autoriteiten poenale motieven altijd sterker aanwezig 
zijn geweest dan economische. De tuchthuizen hadden niet zozeer het karakter van fabrieken maar waren veeleer naar het ideale huisgezin gemodelleerd. 'De hechte, maar hiërarchische eenheid van vader, moeder, kinderen en bedienden werd door de overheden als een microkosmos beschouwd, waarin de relatie weerspiegeld werd, die zij het liefst met hun eigen onderdanen zouden hebben'. Criminelen en marginalen - welke laatsten steeds vaker ook als delinquenten werden beschouwd - werden gezien als lieden die de paternalistische orde verstoorden. Zij werden niet zo zeer in een economische optiek als een reservoir van bruikbare arbeidskracht beschouwd als wel, moreel bezien, als personen die de disciplinerende familieband hadden verbroken. De arbeid hielp de rust en orde in de inrichtingen te bewaren en droeg tegelijk bij tot de bestrijding van de kosten van levensonderhoud. Men beschouwde dwangarbeid voor deze outsiders meer als een oefening in discipline dan als een middel hen aan het ritme van de fabriek te laten wennen. ${ }^{38}$

\subsection{Over de bruikbaarheid van de onderzoeksresultaten}

Echt overtuigende bewijzen van de geldigheid van de arbeidsmarkt-hypothese heeft 'Ruschiaans' onderzoek voorlopig niet opgeleverd. Daarvoor was het telkens te zeer naar tijd en plaats beperkt.

Dat een (betrekkelijk gering) aantal onderzoekers zegt op macro-niveau een significant verband tussen werkloosheid en de toepassing van de vrijheidsstraf te hebben gevonden kan niet worden beschouwd als een ondubbelzinnige bevestiging van de arbeidsmarkt-hypothese. De waarde van die theorie lijkt vooral de aansporing die ervan uitgaat om ook economische factoren in criminologisch/penologisch onderzoek te betrekken ${ }^{39}{ }^{39} \mathrm{Zij}$ heeft tot nu toe echter geen 'rekenmodel' opgeleverd waarmee conjuncturele bewegingen kunnen worden omgezet in prognoses omtrent gedetineerdenpopulaties.

Omdat de op de arbeidsmarkt-hypothese gebaseerde onderzoeken zich vooral op de macro-relatie tussen werkloosheid en de omvang van de gevangenisbevolking hebben geconcentreerd, beschikken we al helemaal niet over een bruikbare theorie over de eventuele invloed van de conjunctuur op de aard van penitentiaire regimes en op de mate waarin de arbeidskracht van gedetineerden wordt benut.

Voorzover uit - evenzeer op de noties van Rusche en Kirchheimer stoelend onderzoek naar voren komt dat er in het kader van individuele straftoemetingsbeslissingen, op micro-niveau, wèl een relatie is tussen werkloosheid en de mate waarin vrijheidsstraf wordt opgelegd, dan nog zegt dat niets over de manier waarop het gevangeniswezen met de arbeidskracht van deze werklozen omgaat.

Ook onderzoek naar de veronderstelde disciplinerende rol van de gevangenis heeft niet zo veel opgeleverd, dat daarmee kan worden gewerkt aan de (verdere) emancipatie van de gedetineerde/arbeider. Melossi kan niet overtuigen met wat hij in het gevangeniswezen heeft willen zien: een fabrick, die arbeiders produceert. Spierenburgs veronderstelling dat het (arbeids)regime in de tucht/werkhui- 
zen was gemodelleerd naar de discipline van het toenmalige gezin geeft geen verklaring voor de huidige functic van de arbeidsdwang nu de rol van het gezin wezenlijk anders is dan in de tijd waarop zijn historische beschouwingen betrekking hebben. Foucault heeft het verschijnsel van de gevangenisarbeid vooral gebruikt om er mee de waarde van zijn disciplineringstheorie te demonstreren. Zo kan wat in de werkzalen van Justitie gebeurt wellicht als metafoor van machtsuitoefening gelden, omgekeerd levert zijn disciplineringstheoric niet direct iers op waarmee de ondergeschoven positic van de gevangene/arbeider veranderd kan worden.

De marxistische en foucauldiaanse benaderingen mogen dan intrigerende beschouwingen over de gedetineerde/arbeider als object van overheidsbemoeienis hebben opgeleverd, zij hebben tot nu toe niet kunnen leiden tot veranderingen in de praktijk van de vrijheidsbeneming, noch hebben zij naspeurbare invloed gehad op degenen, die het beleid van het gevangeniswezen voor de nabije toekomst formuleren. Mogelijk ligt dat aan het feit, dat men - op cnkele uitzonderingen zoals Inverarity en Grattet na - het verschijnsel van de gevangenisstraf te veel als een op zichzelf staand fenomeen heeft bestudeerd. Het toepassen van grote economische en disciplinerings-theorieën op het relatief kleine veld van het gevangeniswezen heeft de onderzoekers niet gebracht wat zij hoopren re bewijzen. Ze konden, voorzover ze dat al wilden, de (Westeuropese en Noordamerikaanse) strafinrichtingen niet ontmaskeren als puur kapitalistische uitbuitings- dan wel vernietigingsmachines en ook niet als mallen, waaruit gedisciplineerde model-arbeiders te voorschijn kwamen.

Overheid, gevangeniswezen en gedetineerden blijken een complexere relatie met elkaar te hebben.

Een nieuwe en mogelijk meer belovende benadering lijkt die van David Garland. Overigens zonder de marxistische en foucauldianse paradigma's over boord te zetten probeert hij het gebruik van de vrijheidsstraf een plaats te geven in het hele gamma van instituties dat gedurende de laatste eeuw is gecreëerd om de immer anwezige 'sociale kwestie' onder eruptie-niveau te houden. Hij ziet het gevangeniswezen als onderdeel van een al-omvattende strategie die gericht is op handhaving van de sociale rust. Met de term strategie wordt overigens niet gedoeld op een complot van machtselites tegen een potentieel opstandige minderheid van de bevolking maar aan een reeks samenhangende wetgevende en bestuurlijke maatregelen die alle in meer of mindere mate de pacificatie van de sociaal-economisch zwakke lagen van de bevolking ten doel hebben.

In de volgende paragraaf wordt bezien of situering van het gevangeniswezen binnen het stelsel van sociale zekerheid consequenties kan hebben voor de positie van de gedetineerde als loon-afhankelijke arbeider. 


\section{Het strafstelsel en de sociale zekerheid}

\subsection{Het beheer van de arbeidsreserve}

In zijn boek 'Punishment and welfare; a history of penal strategies' heeft Garland ${ }^{40}$ onderzocht welke de rol de strafrechtspleging speelt in de (Engelse) verzorgingsstaat. Het moderne Britse strafstelsel is zijns inziens ontstaan tussen 1895 en 1914, toen het Victoriaanse vrije-markt kapitalisme plaats maakte voor monopolie-kapitaal, produktieplanning en marktkontrole. In die tijd kwam ook het socialisme op, verwierf de arbeidersklasse stemrecht en kwam het vakbondswezen tot bloei. De 'sociale kwestie' ontstond en deze leidde tot een roep om staatsinterventie in de sociale sfeer en op de arbeidsmarkt. Het oude, nog op het laissez faire-systeem stoelende controle-apparaat verloor zijn basis. Daarmee was een orde-probleem ontstaan dat hèt onderwerp werd van het criminologische debat van rond de eeuwwisseling. Een van de belangrijkste resultaten daarvan was de conclusie dat de gevangenis als disciplinair instituut ernstig in gebreke was gebleven.

Aan het einde van de $19 \mathrm{e}$ eeuw was er volgens Garland in tweeërlei opzicht sprake van een crisissituatie. Ten eerste met betrekking tot de rol en functie van de staat ten aanzien van de sociaal/economische sector en ten tweede omtrent de positie en regulering van de lagere klassen. De oplossing van deze problemen werd gezocht in het creëren van een stelsel van sociale zekerheid en een daarop afgestemde strafrechtspleging. De staatsmacht werd niet langer als een negatieve maar als een produktieve maatschappelijke factor gezien. Een nieuw geformuleerd sociaal beleid was uit op een betere integratie van 'probleem-groepen' in de maatschappij. Daartoe werd een aantal nieuwe instrumenten gecreëerd: het instituut 'arbeidsbureau', een onder overheids-regie staand stelsel van sociale zekerheid en een reeks staats-werkinrichtingen. Er ontstond een stelsel dat enerzijds respectabele, gedisclipineerde en oppassende arbeiders bestaanszekerheid bood en anderzijds onwillige deugnieten daarvan uitsloot.

Daarmee was de politieke angel uit de sociale kwestie gehaald en was zij teruggebracht tor een praktisch probleem: hoe kon in individuele probleemgevallen ingegrepen worden, eventueel met behulp van het strafrecht?

De vraag met welke middelen de maatschappelijke vrede bewaard kon worden is als zodanig nimmer onderwerp van het openbare debat geweest, maar kwam telkens aan de orde in tal van programma's, officiële rapporten, debatten tussen deskundigen en in bestuursgremia. Over belangrijke punten van criminele politiek werd nimmer in termen van klasse-tegenstellingen gedebatteerd: zij werden in de kleine kring der machthebbers afgehandeld.

Daarbij werd niet zozeer moeite gedaan om voorstellen met betrekking tot effectievere strafrechtspleging theoretisch te onderbouwen als wel ze zó in te kleden dat ze politiek en ideologisch 'te verkopen' waren.

Het sociale zekerheidsstelsel vervulde een sleutelrol bij het creëren van rust en solidariteit onder de mensen. Alle burgers kregen op die manier belang bij de in- 
standhouding van het bestaande maatschappelijk stelsel, dat werd gekenmerkt door vrij ondernemerschap, individualisering en ongelijkheid. Dit stelsel werd mede in stand gehouden door een repressie-apparaat dat verzet daartegen in de kiem moest smoren. Het strafrechtelijk systeem ondersteunde de instituties van het sociale zekerheidsstelsel. Het nam de 'mislukkingen' van de sociale sector over en onderwierp die aan een reeks normaliserende, corrigerende, orthopedagogische en isolerende maatregelen die het 'mislukte' individu ofwel terug deden keren in de maatschappij of hem daar voorgoed uit verwijderden. Er ontstond een uitwisseling van clinten (en wat er over hen in dossiers vastgelegd was) tussen de diensten van het sociale zekerheidsstelsel en het strafrechtelijk apparaat. Het strafrechtelijk systeem ging fungeren als eindstation van de sociale zekerheid met de gevangenis als eindpunt binnen het strafrechtelijk systeem.

Garland stelt vast dat her strafrecht nooit in staat is gebleken om misdaad te voorkomen of veroordeelden te resocialiseren. Daar gaat het volgens hem ook niet in de eerste plaats om. Het strafrechtelijk systeem heeft vooral een andere functie: het beheert delinquentie, maar draagt niet aan de oplossing van de onderliggende problemen bij.

\subsection{Dwang als element van sociale zekerheid}

Men kan zeggen dat het streven van politici en werkgevers sinds het ontstaan van de 'sociale kwestie' er vóór alles op gericht is geweest om de bestaande arbeidsreserve op een zo goedkoop mogelijke wijze rustig te houden. Primair door middel van een stelsel van sociale verzekeringen en voorzieningen en subsidiair door het strafrechtelijk complex. Beide stelsels kenmerken zich door drang of dwang op de 'cliëntèle'. Bij het strafrecht is dat evident, bij het sociale zekerheidsstelsel wordt dat meer en meer het geval. Daarin wordt steeds minder volstaan met het louter garanderen van een materieel bestaansminimum door het verstrekken van uitkeringen. Er wordt steeds meer naar gestreefd om beslag te leggen op de tijd van uitkeringsontvangers. Dat tijdsbeslag wordt bereikt door hen onbetaalde arbeid te laten verrichten of hen (hoe voorspelbaar vruchteloos valk ook) te verplichten naar betaalde arbeid te solliciteren of zich daarvoor te laten om- of bijscholen. In Engelse termen kan men zeggen, dat er een omslag plaats heeft van 'welfare' naar 'workfare': de uitkering moet als het ware worden terugbetaald in de enige valuta waarover de werkloze nog beschikt: zijn tijd. Daarvan moet hij, wil hij zijn uitkering behouden, een belangrijk deel aan de gemeenschap ter beschikking stellen. In kringen van welzijns-bestuurderen viel dat streven in goede aarde.

De Harmonisatieraad Welzijnsbeleid beschouwde het leveren van een tegenprestatie als een maatschappelijke plicht van uitkeringsgerechtigden: 'Men toont zich als het ware bereid voor het verkregen recht tevens een prestatie te leveren, die verder gaat dan alleen de administratieve verplichting belasting te betalen'. ${ }^{41}$

Ook waar betaald werk niet voorhanden is, wordt ledigheid dus niet langer ge- 
duld. Wat dat betreft is er weinig verschil tussen de houding van voorstanders van de vrije markt-economie en die van de geleide-economie van de voormalige USSR, waar sinds 1922 het zich onttrekken aan maatschappelijk nuttige arbeid onverenigbaar werd geacht met de principes van een socialistische maatschappij. Tot 1970 stond daar op het leiden van een 'parasitaire levenswijze' zelfs de straf van verbanning. ${ }^{42}$

Het succes van wat Garland een penal/welfare-strategie noemt moet niet worden gezocht in het reclasseren van wetsovertreders of in de preventie van criminaliteit. Het ligt in haar vermogen om de criminaliteit op een in de ogen van het publiek acceptabele manier te 'managen'. Dat gaat volgens een standaardprocédé: in officiële beleidsstukken wordt de meest wenselijke aanpak van de problematiek geschetst. Als daar vervolgens in de praktijk weer eens niets van terecht blijkt te zijn gekomen, wordt dat telkens goed gepraat met standaard-argumenten als 'geldgebrek', 'gebrek aan voldoende goed opgeleid personeel', 'te korte straffen', 'te veel veroordeelden', etc. En dat blijkt tot nog toe te werken.

Een van de interessante gevolgen van de analyse van Garland is dat het gevangeniswezen daarin zijn positie als corpus alienum onder de maatschappelijke instituties verliest. Beschouwt men, net als Garland, het gevangeniswezen in abstracto als element van een alomvattende strategie die gericht is op beheersing van dat deel van de bevolking dat voor zijn bestaan op het verrichten van arbeid in loondienst is aangewezen en de facto als onderdeel van het hele stelsel van sociale zekerheid dat tot dat doel is gecreëerd, dan kan dat leiden tot een nieuwe manier van denken over de rol van het gevangeniswezen en meer in het bijzonder over de rol van de arbeid en de beloning daarvan binnen het gevangenisregime.

\subsection{Verbindingen tussen het gevangeniswezen en het stelsel van sociale zekerheid}

Er is een aantal argumenten dat ervoor pleit het gevangeniswezen, in regelgeving en beleid, in beginsel als een van de vele instituties op het gebied van de sociale zekerheid te behandelen. Een eerste argument daarvoor is dat het 'gevangenisbedrijf kan worden beschouwd als cen bijzondere arbeidsmarkt die wordt gekenmerkt door de aanwezigheid van slechts één potentiële werkgever, Justitie, en een door diezelfde Justitie gecreeerd arbeidsaanbod van personen die om allerlei redenen (tijdelijk) geen toegang hebben tot andere arbeidsmarkten. De justitiële arbeidsmarkt kan niet los gezien worden van de meer of minder reguliere arbeidsmarkten. Connecties tussen een sociale en een punitieve strategie jegens kansarme (en dus potentieel oproerige) groepen kunnen voor een deel door een analyse van het grensverkeer de justitiële en de niet-justitiële arbeidsmarkten worden waargenomen.

De onderlinge verbondenheid van de strafrechtspleging en het systeem van sociale zekerheid komt tevens tot uitdrukking in de uitwisselingsmomenten, die het in principe geheel door Justitie gesubsidieerde gevangeniswezen met het stelsel van sociale uitkeringen heeft. 


\subsection{Connecties op arbeidsmarktniveau}

Om.zoveel mogelijk mensen, die niet op de reguliere (of 'eerste') arbeidsmarkt terecht kunnen tóch aan de slag te houden is er in de loop der tijd door de overheid een aantal 'parallelle' arbeidsmarkten gecreëerd.

In navolging van Hanesch ${ }^{43}$ kan men naast de hiervoor al genoemde 'eerste' arbeidsmarkt, waarop onder de in een vrije marktekonomie geldende condities arbeid tegen loon wordt geruild, een aantal andere arbeidsmarkten onderscheiden.

Voor hen die - al of niet tijdelijk - niet op de 'eerste' arbeidsmarkt terecht kunnen is er een nieuwe vorm van werkgelegenheid gecreëerd op een 'tweede' (surrogaat) arbeidsmarkt. Daarop worden met behulp van loonkosten-subsidies tijdelijke banen aan langdurig werklozen aangeboden met het doel hen op een later tijdstip zo mogelijk weer onder normale voorwaarden de 'eerste' arbeidsmarkt in te laten stromen. Die 'tweede' arbeidsmarkt lijkt in zoverre op de 'eerste', dat daarop tussen werknemer en werkgever normale, privaatrechtelijke, arbeidsovereenkomsten worden afgesloten. Dan kan er, wat men zou kunnen noemen, een twee-en-een-halfde arbeidsmarkt worden onderscheiden, die in Nederland belichaamd wordt in de gemeentelijke 'banenpools'. Banenpools bieden betaalde arbeid op boventallige plaatsen in de collectieve sector aan langdurig werklozen, die moeilijk plaatsbaar zijn op de reguliere (eerste) arbeidsmarkt. Banenpoolers sluiten weliswaar een arbeidsovereenkomst ex art. 7A:1637a BW af met een (gemeentelijke) stichting, maar niet met een particuliere werkgever. Werk via een banenpool wordt niet zelden uit vrees voor een sanctie van de uitkerende instantie aanvaard, ook al weten alle betrokken partijen op voorhand dat de kans op doorstroming naar reguliere arbeid uitermate klein is. ${ }^{44}$

Vervolgens kan een 'derde' arbeidsmarkt worden onderscheiden waarop het privaatrechtelijke arbeidsrecht in het geheel geen rol meer speelt. Op deze arbeidsmarkt gaat het om maatschappelijk nuttig geachte arbeid die met behoud van uitkering, of hooguit tegen een vergoeding voor extra werkzaamheden, door uitkeringsgerechtigden wordt verricht. Deze personen blijven in een publiekrechtelijke relatie tot de uitkerende instantie staan en genieten bij het verrichten van dat maatschappelijk nuttige werk niet de bescherming van het reguliere arbeidsrecht. Dit soort werk wordt soms afgedwongen onder dreiging van verlies van uitkering. In die gevallen is er de facto sprake van een arbeidsplicht.

Voorts kan men, nog immer in navolging van Hanesch, spreken van een 'vierde' arbeidsmarkt. Die richt zich op de zogenaamde arbeid die in het kader van de sociale werkvoorziening in zogenaamde 'beschutte werkplaatsen' wordt verricht. Daarbij is sprake van een publiekrechtelijke rechtsverhouding tussen werknemer en werkgever.

Het gevangeniswezen kan - tenslotte - worden beschouwd als een vijfde arbeidsmarkt, uitsluitend bestemd voor personen die rechtens van hun vrijheid zijn beroofd en met slechts één werkgever: Justitie. De toegang tot de markt en de daarop heersende voorwaarden worden bij uitsluiting door Justitie bepaald. 


\subsection{Werkloze jongeren op de derde arbeidsmarkt}

Het bestaan van een sociaal/poenale strategie ter preventie van sociale onrust kan bij ons wellicht het beste worden geilllustreerd door de arbeidsmarkt, die met de inwerkingtreding van de Jeugdwerkgarantiewet (JWG) in het leven is geroepen.

In het kader van de Jeugdwerkgarantiewet (JWG), die op 1 januari 1992 landelijk is ingevoerd, wordt aan alle werkloze jongeren onder de 21 jaar en alle werkloze schoolverlaters tot 27 jaar, zodra zij langer dan een. half jaar werkloos zijn, een baan in de publieke sector aangeboden. Voor een minimumloon doen zij in tijdelijk dienstverband werk-ervaring op. Het afslaan van zo'n aanbod kan korting op of stopzetting van de (RWW-)uitkering betekenen. Het dreigen met de sanctie van intrekking van de uitkering was voor de leden van de PvdA-fractie van de Vaste Commissie voor Sociale Zaken en Werkgelegenheid aanvankelijk moeilijk te verteren. Zij wilden van de minister weten waarop de volledige uitsluiting uit de sociale zekerheidswetgeving van weigerachtige JWG-ers was gebaseerd omdat tot dan toe een $100 \%$-korting een onbekend verschijnsel was. ${ }^{45}$ Het antwoord luidde kortweg: 'De consequentie van het aanbieden van een werkgarantie behoort naar ons oordeel te zijn dat bij een weigering van een inkomenszekerheid door middel van passende JWG-arbeid niet alsnog een beroep op de inkomenszekerheid door middel van een uitkering in verband met werkloosheid kan worden gedaan'. ${ }^{46}$ Volgens Penterman, medewerker bij de Jongerenbeweging FNV, was de term 'werkgarantie' onjuist. Zijns inziens ging het bij dit plan zonder meer om dwangarbeid. ${ }^{47}$

De sociale beheersings-gedachte die aan de Jeugdwerkgarantiewet ten grondslag ligt komt naar voren in uitlatingen van diverse leidende politici. Zo zei De Kam (PvdA): 'Zelfs bij een aanzienlijke verlichting van de arbeidskosten van lager betaalden zal het werkloosheidsprobleem niet vóór het midden van de jaren negentig zijn opgelost. Wil er geen complete generatie werklozen blijvend buiten spel komen te staan, dan is het de dure plicht van de overheid een vangnet onder de arbeidsmarkt te spannen. Dat kan eenvoudig door de werkingssfeer van het Jeugd Werk Garantie Plan (...) uit te breiden tot alle langdurig werklozen. Workfare dus, werken voor je uitkering.' De Kam wenste overigens zijn stellingname niet uitgelegd te zien als een pleidooi voor een arbeidsplicht. Volgens hem was niemand verplicht om aan 'workfare' mee te doen, maar een dergelijke weigerachtigheid diende zijns inziens niet met een soort basisinkomen beloond worden: 'Wie meeëet uit de ruif die grotendeels wordt gevuld met sociale premies en belastinggeld van de werkenden moet zich maar laten onderhouden door een ander of kiest voor een leven van de hand in de tand'. ${ }^{48}$

Lubbers (CDA) hechtte aan scholing van werklozen en tijdelijke inzet van hen in de niet-commerciële dienstverlening. Dit om te: voorkomen dat zij 'blijvend deel gaan uitmaken van de collectieve dienstverlening'. Daarbij overwoog hij invoering van "dwingende elementen" om inschakeling van langdurig werklozen in het arbeidsproces te bevorderen. ${ }^{49}$ Voorhoeve (VVD) bleek zeer gecharmeerd van 
een ontwikkeling in Zweden waar sinds 1986 aan alle mensen, die werkloos zijn of dreigen te worden een soort arbeidsmarkt-training wordt gegeven. Alleen werklozen die daaraan meedoen hebben recht op een uitkering. Na afloop ervan moeten ze passend werk aanvaarden en daarvoor desnoods verhuizen. Voorhoeve: 'Soms leidt enige aandrang tot een sociaal betere houding. (...) Je moet mensen prikkelen weer aan het werk te gaan'. ${ }^{50}$

Doorstroming vanuit de JWG-arbeidsmarkt naar de 'eerste' arbeidsmarkt is problematisch omdat introductie van JWG-ers in de marktsector tot verdringing van mensen met een normaal arbeidscontract kan leiden. De vakcentrale FNV heeft haar aanvankelijk verzet tegen uitbreiding van de werking van de JWG naar de marktsector echter opgegeven, onder de voorwaarde dat het JWG daar geen werk mag verdringen dat anders door gewone werknemers zou worden gedaan. Ook het Verbond van Nederlandse Ondernemingen heeft een aanvankelijk weigering om jongeren uit het Jeugdwerkgarantieplan toe te laten in het bedrijfsleven laten varen, zodat deze 'derde' arbeidsmarkt lijkt op te gaan schuiven naar de 'tweede'. ${ }^{51}$

Dat de JWG-arbeidsmarkt in de gehele strategie tot beheersing van de werklozen nauw grenst aan die van Justitie bleek uit een onderzoek van de Haagse Sociale Dienst naar de vraag hoe werkloze jongeren die een JWG-plaats weigeren aan hun geld komen. Het onderzoek richtte zich op 1132 schoolverlaters onder de 21 jaar met een RWW-uitkering die de sociale dienst eind 1990 in haar bestand had. ${ }^{52}$ Een jaar later was een deel van de groep regulier aan het werk, een deel via de JWG terwijl 125 jongeren een aangeboden JWG-plaats uitdrukkelijk hadden geweigerd. Het onderzoek wees uit dat een derde van deze uitvallers delicten beging, waarvan 14 pas ná het stopzetten van de uitkering. Het onderzoek leidde tot nogal alarmistische berichtgeving in de pers. ${ }^{53}$

\subsection{De strafrechtelijke vijfde arbeidsmarkt}

De werknemers die partij zijn op de justitiële of 'vijfde' arbeidsmarkt vallen in drie categorieën uiteen. De eerste categorie bestaat uit strafrechtelijk minderjarigen die ter voorkoming van strafvervolging in het kader van een van de HALTprojecten maatschappelijk nuttig werk moeten doen ${ }^{54}$. De tweede bestaat uit diegenen die tor het verrichten van onbetaalde arbeid ten algemenen nutte (arr. 9 lid la onder ten derde Sr.) zijn veroordeeld: de 'dienstverleners'. De derde categorie bestaat uit gedetineerden, waarvan de ónveroordeelden zich ex art. 32 lid 2 Beginselenwet Gevangeniswezen formeel vrijwillig op die arbeidsmarkt begeven en veroordeelden ex art. $14 \mathrm{Sr}$. daartoe wettelijk zijn verplicht.

Deelnemers aan HALT-projecten en dienstverleners bewegen zich op vrijwel hetzelfde arbeidsterrein als personen die in het kader van de JWG te werk worden gesteld. $Z \mathrm{ij}$ werken in de publieke sector en voor 'non-profit' instellingen. Hun rechtspositie verschilt daarin met die van JWG-ers, dat zij niet tot dienstverlening worden verplicht om een uitkering te kunnen behouden. $\mathrm{Zij}$ worden daartoe ge- 
noopt om te voorkomen dat zij worden vervolgd of een vrijheidsstraf moeten ondergaan. Dienstverlening geschiedt 'om niet'. Mislukt een dienstverlening, dan kan aan de dienstverlener op vordering van het Openbaar Ministerie alsnog een vrijheidsstraf worden opgelegd. Dan wordt hij van rechtswege arbeidsplichtig en opereert hij, zoals alle veroordeelden, op een arbeidsmarkt waarop zowel voor de overheid als voor het particuliere bedrijfsleven moet worden gewerkt, zij het zonder contract en slechts tegen een symbolische vergoeding.

De vijfde - strafrechtelijke - arbeidsmarkt valt dáár samen met de eerste waar veroordeelden de laatste maanden van hun straf vanuit een open inrichting voor particuliere werkgevers werken. Daarbij zijn de veroordeelden echter niet zelf contractpartij maar wordt de overeenkomst tussen Justitie en de particuliere werkgever gesloten en wordt het loon voor hun arbeid niet aan de gedetineerde zelf maar aan de overheid uitbetaald, die dat ten dele aan de gedetineerde doorbetaalt.

\subsection{Nieuwe parallele arbeidsmarkten: sociale dienstplicht en kampementen}

Van der Louw had er al in 1982 voor gepleit en Brinkman bracht het idee in het najaar van 1992 tijdens de algemene beschouwingen te berde. De laatste werd door Lubbers teruggefloten, maar kwam er begin 1993 weer op terug. Er moest een sociale dienstplicht komen. ${ }^{55}$ Jongens en meisjes moesten zich, desnoods onder lichte dwang, gedurende enkele maanden tot een jaar aan maatschappelijk nuttig werk wijden. De sociale dienstplicht werd gezien als een moreel appèl, als een middel om solidariteit mee te genereren en om de integratie van allochtone jongeren te bevorderen.

De discussie over sociale dienstplicht is gestimuleerd door de (naar haar voorzitter genoemde) commissie-Meijer die de minister van Defensie moest adviseren over de vraag of de militaire dienstplicht moest worden afgeschaft. Hoewel de minister (Ter Beek) daar in zijn instellingsbesluit helemaal niet naar gevraagd had, meende de door hem ingestelde Commissie Dienstplicht de regering in overweging te moeten geven om een nader onderzoek in te stellen naar de mogelijkheden voor een systeem van burgerdienst. ${ }^{56}$ De commissie-Meijer motiveerde haar ongevraagde advies door te stellen dat de burgerdienst in de samenleving regelmatig wordt aangedragen als oplossing voor de onrechtvaardige verdeling van de militaire dienstplichtlast en dat het vraagstuk tot dan toe niet systematisch was behandeld. Daarom had deze commissie het Sociaal Cultureel Planbureau (SCP) gevraagd een verkenning te maken en die als bijlage met haar rapport meegestuurd. ${ }^{57}$

Het SCP constateerde, in wat het 'Een beschouwing over maatschappelijke dienstplicht en vrijwillige dienstverlening' noemde ${ }^{58}$, dat burgerdienstplicht in de publieke opinie tamelijk populair was. Bij een enquête had maar liefst $64 \%$ van de ondervraagden zich er vóór uitgesproken, jongeren en ouderen overigens in gelijke mate.

Als belangrijk argument vóór invoering van burgerdienstplicht noemde het Planbureau dat door vergrijzing van de bevolking er alleen al in de zorgsector 
'over een jaar of tien' tenminste 40.000 arbeidsplatitsen zouden kunnen worden aangewezen die zich lenen voor vervulling door sociaal dienstplichtigen en waarvan de vervulling door geldgebrek vermoedelijk onzeker is. Het SCP gaf nóg een aantal argumenten pro burgerdienstplicht: 'Burgerdienstplicht als oplossing voor de problemen van de publieke sector speelt in op waarden als "solidariteit", "verantwoordclijkheid" of "burgerplicht". Een ander moticf voor de instelling van cen burgerdienstplicht voor jongeren is de veronderstelde vormende werking'.

Het idee bleek koren op de molen van de Raad voor her Jeugdbeleid dic in juni 1993 met het voorstel kwam om jongeren na hun schooltijd éen jaar de kans te geven op vrijwillige basis maatschappelijk nuttig werk te verrichten. Daarbij werd gedacht aan werkzaamheden in de sfeer van zorg en welzijn, het milieu, openbare orde, cultuur, media, infrastructuur en ... defensie. Het 'rondkijk-' of 'snuffeljaar' zou niet vrijblijvend moeten zijn: de jongeren zouden een contract en een vergoeding net onder het minimumloon moeten krijgen. Er diende gedurende maximaal een jaar 32 uur per week gewerkt te worden. De organisatie van deze maatschappclijke orintatie moest, net als bij het Jeugdwerkgarantieplan, in handen komen van een stichting.

Als het yoorstel van de Raad voor het Jeugdbeleid wordt gerealiseerd worden jongeren daar een goed deel van hun uijd mee bezig gchouden. De maatschappelijke oriëntatie moet volgens de Raad namelijk bij voorkeur op 12-jarige lceftijd, als vast onderdeel van de lessen op school beginnen. Jongeren die na school meteen willen studeren mogen dat echter gaan doen. Jongeren die aan de 'maatschappelijke oriëntatie" meedoen krijgen na alloop cen intensicve arbeidsbemiddeling cadeau. De voorstellen van de Raad zouden geen consequenties voor de JWG hebben. ${ }^{59}$

Voor bepaalde groepen werkloze jongeren die delicten begaan zijn andere 'beheersmaatregelen' opgestart. Justitie heeft daarbij vooral het oog op bepaalde groepen (allochtone) jongeren, wier strafbare gedragingen decls worden toegeschreven aan verzet tegen de normen en waarden van hun ouders en voor een ander deel aan hun kansloze positie op de reguliere arbeidsmarkt. ${ }^{60}$ Voormalig premier Lubbers suggereerde deze jongeren in 'kampementen' onder te brengen, waar zij een straffe arbeidstraining zouden dienen te ondergaan.Lubbers sloot daarbij niet uit, dat omgeschoolde militairen en JWG-jongeren als bewakers bij die kampementen werden ingezet. En staatssecretaris Kosto, die door de détente overtollig geworden beroepsmilitairen werft als gevangenenbewaarder, wil deze 'jonge criminelen' de kans geven na hun invrijheidstelling (...) beroepsmilitair te worden. ${ }^{61}$ Een duidelijker voorbeeld van een geïntegreerde beheersingsstrategie is nauwelijks denkbaar. Nadat de aanvankelijke kritiek op Lubbers idee was verstomd kondigden minister Hirsch Ballin en staatssecretaris Kosto eind 1993 een experiment met een jeugdwerkinrichting (jwi) aan. Jongeren van 18 tot 23 jaar kunnen vanaf 1 januari 1994 in het kader van een schorsing van de voorlopige hechtenis, van uitstel van vonniswijzing of van een bijzondere voorwaarde bij een (gedeeltelijk) voorwaardelijke vrijheidsstraf door deelname aan een 15 maanden durend programma aan een regulier werknemersbestaan worden gewend. Een 
belangrijk element van het programma vormt namelijk de 'arbeidstoeleiding' (de term, is van Justitie), die bestaat uit arbeidsgewenning door middel van werken, scholing en 'arbeidsinpassing door werkervaringsplaatsen en bemiddeling naar reguliere banen'. Jongeren die zich niet aan de regels van het programma houden kunnen naar een 'gesloten setting' worden teruggeplaatst. De bewindslieden achten het overigens 'irreëel' te verwachten, dat deze jongeren in deze tijd via de normale kanalen aan een betaalde baan geholpen kunnen worden. ${ }^{62}$

De verwachting is dan ook gerechtvaardigd, dat in het kader van het jwi-experiment een Jeugdwerkgarantieplaats de eerste stap zal zijn richting reguliere arbeidsmarkt. Connexiteit tussen het strafrechtelijk en het sociaal zekerheidsstelsel is hier op voorhand duidelijk bespeurbaar.

\subsection{Connecties via het uitkeringsstelsel}

Waar Fase vaststelde dat in het civiele arbeidsrecht de aansluiting met het sociale verzekeringsrecht moeizaam of slecht is, geldt dit a fortiori voor het penitentiaire arbeidsrecht. ${ }^{63}$

De meeste sociale voorzieningen en verzekeringen zijn in zoverre afgestemd op het strafirechtelijk systeem dat de uitkering wordt gestopt zodra de uitkeringsgerechtigde gedetineerd raakt. Het openbaar ministerie meldt daartoe beide uitkerende instanties de gevangehouding van verdachten die een werkloosheidsuitkering, een ziektewetuitkering of een uitkering krachtens de Algemene Bijstandswet genieten. ${ }^{64}$ Een en ander is gebaseerd op de wetenschap dat het gevangeniswezen de (totale) zorg voor de cliënt overneemt. Zodra de gedetineerde weer op vrije voeten komt is hij in beginsel weer uitkeringsgerechtigd, zij het dat het gamma beschikbare uitkeringen door het feit van de detentie kan zijn beperkt. Zo kan de weg naar de werkloosheidsuitkering zijn afgesloten omdat hij niet over een relevant arbeidsverleden beschikt.

Sommige voorzieningen en verzekeringen blijven ook tijdens detentie 'doorlopen' en kunnen Justitie besparingen opleveren. Daarmee wordt bijvoorbeeld uitdrukkelijk rekening gehouden in art. 48a van de Gevangenismaatregel die luidt: 'Onverminderd het bepaalde bij of krachtens de Algemene Wet Bijzondere Ziektekosten (Stb. 1979, 709) komen ten laste van de Staat de kosten van geneeskundige verzorging van de gedetineerde die in een inrichting van het gevangeniswezen gevangenisstraf of hechtenis ondergaat, voorzover de gedetineerde niet als verplicht verzekerde aanspraak geldend kan maken op verstrekkingen krachtens de bepalingen van de Ziekenfondswet'. Een vergelijkbare tekst bevat art. 46 van het Reglement tenuitvoerlegging, terbeschikkingstelling. Bij het AWBZ-fonds (fonds uit hoofde van de Algemene wet bijzondere ziektekosten) worden voor een belangrijk gedeelte de verpleegkosten gedeclareerd van daarvoor in aanmerking komende tbs-gestelden en overige ten laste van Justitie komende verpleegden. ${ }^{65}$

Dat er een aantal 'uitwisselingsmomenten' tussen het stelsel van de sociale zekerheid en het strafrechtelijk systeem bestaat blijkt onder meer uit de praktijk van 
de Algemene Bijstandswet en de daarop gebaseerde bijzondere regelingen. Zo worden bijstandsgerechtigden betrekkelijk gemakkelijk gecriminaliseerd door moeilijk op hun feitelijk gehalte controleerbare uitlatingen in de media over oneigenlijk gebruik of misbruik van deze sociale voorziening. Uitkeringsgerechtigden zijn herhaaldelijk voorwerp van onderzoek naar fraude en worden zo voortdurend in het verdachtenbankje gezet. De presumptio innocentiae is niet van toepassing op uitkeringsgerechtigden. Zij dienen periodiek schriftelijk te bevestigen dat zij niet frauderen. De gemeentelijke: sociale diensten zijn uitgerust met een eigen opsporingsapparaat dat met behulp van 'sociaal rechercheurs' het waarheidsgehalte van de eigen opgaven van de uitkeringsonvangers natrekt. Wanneer fraude ontdekt wordt treedt een administratief sanctie-systeem in werking, dat afhankelijk van de ernst van het feit en de persoon van de dader, volstaat met maatregelen binnen het kader van de desbetreffende sociale wetgeving en wel door de uitkering te stopppen, daarop eventueel een strafkorting toe te passen en terugbetaling van de ten onrechte genoten bedragen te vorderen. Tot voor kort strad bij emstige fraude naast het administratieve ook het strafrechtelijke sanctiestelsel in werking en vond er vervolging van de vermoedelijke fraudeurs plaats. Sinds april 1993 zijn de administratiefrechtelijke en strafrechtelijke handhaving zodanig op elkaar afgestemd dat cumulatie van administratieve en strafrechtelijke sancties wordt vermeden. ${ }^{66}$

Een ander voorbeeld van connexiteit tussen Bijstand en Gevangeniswezen is het gegeven dat bijstandsgerechtigden gedurende een korte periode na aanvang van de voorlopige hechtenis hun huur nog vergoed kunnen kriggen.

Aan het einde van de detentie-periode worden de contacten tussen her strafrechtelijk systeem en het sociale zekerheidsstelsel gereactiveerd door uitkeringsgerechtigden tijdig bij de uitkerende instanties te melden, zodat het einde van de detentie op een nieuwe uitkeringsperiode kan aansluiten. De organisatie van Justitie is daar speciaal voor toegerust. Enerzijds beschikken de inrichtingen over Bureaus Sociale Dienstverlening ${ }^{67}$ en anderzijds kunnen gedetineerden de reguliere reclasseringsorganisatie als intermediair tussen de strafrechtspleging en het sociale zekerheidsstelsel inschakelen.

In de zogenaamde 'dagdetentie-centra' is de wisselwerking tussen beide stelsels helemaal sterk, nu, zoals in het vorige hoofdstuk is beschreven, de in een dergelijk centrum geplaatste gedetineerden in aanmerking komen voor een gewone bijstandsuitkering.

\section{Slotopmerkingen}

Met dit alles is nog niet 'wettig en overtuigend' bewezen dat gevangeniswezen een integrerend onderdeel van ons sociale zekerheidssteisel is of moet worden. Wel is door het signaleren van een aantal verbindingslijnen tussen het sociale en het poenale stelsel de waarde van Garlands visie op de rol van het gevangeniswezen in de 'sociale kwestie' belicht. 
Binnen afzienbare tijd zal het Parlement zich moeten uitlaten over een nieuwe Penitentiaire Beginselenwet. Dat zou een goede gelegenheid zijn om de positie van het gevangeniswezen in ons hele sociale bestel te heroverwegen. Als de ministers van Justitie, van WVC en van Sociale Zaken en Werkgelegenheid het gevangeniswezen willen zien als onderdeel van het sociale zekerheidsstelsel zouden daaruit consequenties getrokken kunnen worden met betrekking tot de regeling van arbeid en beloning van gedetineerden. Als wordt erkend dat een strafinrichring naast een instrument van justitiële repressie ook een sociale voorziening is, dan kan de regulering van de penitentiaire arbeid en beloning worden afgestemd op de manier waarop dat bij andere sociale voorzieningen gebeurt. Ziet men de gevangenis als een 'beschutte plaats' dan zou de Wet Sociale Werkvoorziening ten voorbeeld kunnen staan aan een vergelijkbare regeling voor het gevangeniswezen. In het volgende hoofdstuk wordt dat idee nader uitgewerkt. 
1. De Volkskrant 19 juli 1993, 'Kabiner wil volgend jaar toch loonstop'.

2. P. Phillips, Marx and Engels on law and laws, Oxford 1980, bl. 153 en 165.

3. M. Cain en A. Hunt, Marx and Engels on law, Londen/New York/San Francisco 1979 , bl. 149 en 150.

4. Marx-Engels Werke, Berlijn 1969, Band 8, bl. 506-509.

5. K. Marx, Kritiek op het Program van Gotha (1875), Amsterdam 1975, bl. 5.

6. K. Marx, Kritick op het Program van Gotha, a.w., bl. 29. Zie ook: Marx-Engels, Ausgewähle Schriften, Kritik des Gothaer Programs, Berlijn 1983, Band II, bl. 27 en K. Marx, Critique of the Gotha Programme, Moskou 1976, bl. 30.

7. K. Liebknecht, "Tegen de vrijheidsstraf, 1918, opgenomen in Karl Liebknecht en Rosa Luxembourg over misdaad en straf, uirgegeven op verzock van het 'Comité van actie tegen de bestaande opvattingen omtrent misdaad en straf', Amsterdam 1922 (met een inleiding van Clara Meijer Wichmann).

\section{W.A. Bonger, Criminalité et conditions} Economiques, Amsterdam 1905, bl. 724.

9. G. Rusche, 'Arbeitsmarkt und Strafvollzug. Gedanken zur Soziologie der Strafjustiz', Zeitschrift fïr Sozialforschung, Parijs 1933, bl. 63-78.

10. D. Melossi, 'Punishment and social Structure', in T. Platt en P. Tagaki (red.), Punishment and penal Discipline; essays on the prison and the prisoners' movement, San Francisco (1980) 1982, bl. 17 en 18.

Volgens Melossi was Rusche niet verrukt van het werk van Kirchheimer, met wie hij de in * houd wan het boek waarschijnlijk zelfs nooit heeft besproken.

11. G. Rusche and O. Kirchheimer, $P_{u}$ nishment and social Structure, New York (1939) 1968.

12. I. Jankovic, 'Labor Market and Imprisonment', in T. Platt and P. Tagaki, a. $w_{4}$, bl. 93-112.

13. M.G. Yacger, 'Unemployment and imprisonment; research note', The Gournal of
Criminal Law Er Criminology 1979, Vol. 70, nr. 4 , bl. 586-588.

14. Chr. Hale, 'Unemployment, Imprisonment, and the Stability of Punishment Hypothesis: some results using cointegration and error correction models', Youmal of Quantitative Criminology 1989, Vol. 5, nt. 2, bl. 169186.

15. Chr. Adamson, "Towards a Marxian Penology: Captive criminal Populations as economic Threats and Resources", Social Problems April 1984, Vol. 31, nr. 4, bl. 435-458. In de achter het artikel opgenomen lijst. van gebruikte bronnen zal men vergeefs zoeken naar Rusches 'oer'-artikel en naar Jankovic' bijdrage aan het R\&K-debat.

16. S. Box, Recession, Crime and Punishment, Basingstoke 1987 , bl. 86-97 en 190-193.

17. W. de IIaan, The Politics of Redress. Crime Punishment and penal Abolition, Londen 1990, hoofdstuk 3: Explaining Expansion; The Politics of Punishment, bl. 36-63. 18. R.(W.) Jongman, F. Weerman en L Kroes, 'Maatschappelijke tweedeling en criminaliteit', in R.W. Jongman (red.), De armen van Vrouwe fustitia; sociale positie, criminaliteic en justitielle reacties, Nijmegen 1993 , bl. 129-140.

19. G. Kannegieter, 'Een passende straf: over verschillen in straftoemeting aan werkende en werkloze verdachten', in R.W. Jongman, a.w., bl. 41-61.

20. W.J. Sabol " The Dynamics of Unemployment and Imprisonment in England and Wales, 1946-1985', Joumal of Quantitative Criminology 1989, Vol. 5, nr. 2, bl. 147-168. 21. Th. G. Chiricos en W. D. Bales, 'Unemployment and Punishment: An empirical Assessinent', Criminology 1991, Vol. 29, nr. 4, bl. 701-724.

22. Zie bijvoorbeeld D.F. Greenberg, 'Imprisonment and Unemployment: A Comment', Journal of Quantitative Criminology 1989, Vol. 5, nr. 2, bl. 189.

23. B. Laffargue en Th. Godefroy, 'Economic Cycles and Punishment: Unemployment 
and limprisonment; A Time-series Study: France, 1920-1985', Contemporary Crises December 1989, Vol. 13, nr. 4, bl. $371-404$ en van dezelfde auteurs: 'La prison républicaine et son environment économique; population en prison et marché du travail', $D e-$ viance et Sociêté 1990, Vol. 14, nr. 1, bl. 3958.

24. F.E. Zimring en G. Hawkins, The Scale of Imprisonment, Chicago en Londen 1991, bl. 10-14.

25. J. Inverarity, en R. Grattet, 'Institutional Responses to Unemployment: A Comparison of U.S. Trends, 1948-1985', Contemporary Crises, 13 (1989), bl. 351-370.

26. D. Melossi, "An Introduction: fifty Years later, Punishment and Social Structure in comparative Analysis', Contemporary Crises, 13. (1989), bl. 311-326.

27. D. Melossi, Punishment and social Ac-tion: changing Vocabularies of punitive Motive within a political Business Cycle', Current Perspectives in social Theory 1985, Vol. 6, bl. 169-197. Melossi heeft dit thema uitgewerkt in zijn artikel 'Gazette of Morality and Social Whip: Punishment, Hegemony and the Case of the USA, 1970-92', Social E Legal Studies, London etc., Vol. 2. (1993), bl. 259-279.

28. A. Blumstein en J. Cohen, 'A Theory of the Stability of Punishment, The Foumal of Criminal Law and Criminology 1973, Vol. 64, nr. 2, bi. 198-207.

29. J.P.S. Fiselier, 'De hypothese van het stabiele strafniveau', in G.J.M. Corstens (red.), Straffen in gerechrigheid, Arnhem 1987, bl. 353-370. Het onderzoek naar cen eventuele relatic tussen werkloosheid en gestichtsbevolking vermeldt de auteur terloops in noot 24 bij dit opstel.

30. H. Steinert en H. Treiber, 'Versuch, die These von der strafrechtlichen Ausrottungspolitik im Spätmittelalter 'auszurotren'. Eine Kritik an Rusche/Kirchheimer und dem Okonomismus in der Theorie der Strafrechtsentwicklung', Kriminologisches foumal. 1978, 10. Jg., bl, 81-106.

31. H. Steinert, 'Die Geschichte der sozialen Kontrolle als Geschichte von Kapitalstrategien, Arbeitsmoral und moralische Emporung', Kriminologisches fournal 1986, 1. Beiheft, bl. 77-96.
32. K.F. Schumann, 'Produktionsverhalltnisse und staatliches Strafen. Zur aktuelien Diskussion über Rusche/Kirchheimer', Kritische Justiz 1981, 14. Jg., bl. 64-77.

33. M. Foucault, Surveiller et punir; naissance de la prison, Parijs 1975, bl. 245-247.

34. M. Foucault in zijn 'Geschiedenis van de waanzin', zoals geciteerd door H.C.M.

Michielse, Welzijn E' discipline; van tuchthuis tot psychotherapie, Meppel/Amsterdam 1989, bl. 54 .

35. D. Melossi, 'Punishment and social Structure', in T. Platt en P. Tagaki, a.w., bl. 17-27.

36. D. Melossi en M. Pavarini, The Prison and the Factory; Origins of the penitentiary System (oorspronkelijk gepubliceerd als Carcere e Fabrica, Bologna 1977), Londen en Basingstoke 1981.

37. M. Ignatieff, $A$ just Measure of Pain; The Penitentiary in the Industrial Revolution, 17501850, New York 1978, bl. 183-184.

38. P. Spierenburg, The Prison Experience; disciplinary Institutions and their Inmates in early modern Europe, New Brunswick en Londen 1991, bl. 116-120, 134 en 280-281.

39. Zo onderzocht G.T. Lessan de invloed van de factor inflatic op de omvang van de gevangenisbevolking: 'Macro-economic determinants of penal policy: Estimating the unemployment and inflation influences on imprisonment rate changes in the United States, 1948-1985', Crime, Law and Social Change 1991 nr. 16, bl. 177-198.

40. D. Garland, Punishment and Welfare; $A$ History of Penal Strategies, Aldershot 1985.

41. Marmonisatieraad Welzijnsbeleid, Advies nr. 49: Op eigen kracht; een bodempakket als bestaanszekerheidsvoorziening, 'sGravenhage 1987, bl. 30 en 34-37. 42. G.P. van den Berg, 'Arbeidsovereenkomstenrecht van de Soviet Unie', Sociaal Maandblad Arbeid 1982, nr.11, bl. 703 en HCh. Hoppensack en G. Wenzel, 'Hilfe zur Arbeit und Arbeitszwang; Sozialhilfe und administrative "Normalisierung" yon Lohnarbeit', in S. Leibfried, und F. Tennstedt (red.), Politik der Armut und die Spaltung des Sozialstaats, Frankfurt am Main 1985, bl. 249. 
43. W. Hanesch, 'Armutspolitik und neue Beschăftigungsformen; Perspektiven jenseits des Arbeitszwangs', in S. Leibfrid und F. Tennstedt (red.), a.w., bl. 269 en 270.

44. A.J.C.M. Geers, 'Op de grenzen van het arbeidsmarktbeleid, grondrechten arbeidsrecht en het sociale zekerheidsrecht: de banenpool.' In: W.H.C.M. Bouwens (c.a.), Sociaal recht: de grenzen verkend, Zwolle 1994, bl. 71-85.

45. Jeugdwerkgarantieplan, Tweede Kamer, 1987-1988, 20 278, nr. 4, bl. 4.

46. Jeugdwerkgarantieplan, t.a.p., nr. 5, bl. 7.

47. M. Penterman, 'Jeugdwerkplan lijkt erg op dwangarbeid', de Volkskrant van 18 september 1986. De jongerensecretaris van de AbvaKabo over dit plan: 'Jongeren worden gewoon tijdelijk weggestopt', in Aanéén 11 april 1988 , bl. 11.

In mei hebben jongeren van het 'Haags Axie Komitee' een aantal dagen het kantoor van de stichting, die in Den Haag de JWG uitvoert bezet om zo te protesteren tegen de dwang en sancties in deze werkgelegenheidsmaatregel; bron de Volkskrant van $25 \mathrm{mei}$ 1993.

48. F. de Kam, 'Het einde van de werkloosheid?', Intermediair 2 oktober 1987, 23e jrg., nr. 40, bl. 13.

49. Y. Zonderop, 'Lubbers wil ook oudere werklozen klussen geven; idee premier voor advies naar ambtenaren', bericht in de Volkskrant van 25 februari 1987.

50. Y. Zonderop, 'Voorhoeve zict wel iets in arbeidsdwang', bericht in de Volkskrant van 28 februari 1987.

51. T. Meens, 'Dat het JWG niet werkt, is niemands schuld', de Volkskrant, 29 maart 1993. T. Meens, 'Jeugdwerkplan mag van FNV ook gelden voor marktsector', de Volkskrant, 5 mei 1993. De Volkskrant van 10 mei 1993: 'Jeugdwerkplan mag van VNO gelden in bedrijfsleven.'

52. J. van der Werft, 'Jeugdwerkgaranticplan; uitvallers verdwijnen vaak in crimineel circuit', Aanéén 19 december 1992, bl. 7. 53. B. Pols, 'Afvallers banenplannen gaan "scoren"", NRC-HB, 31 maart 1992.

54. Zie: M. Kruissink en C. Verwers, Halt: een alternatieve aanpak van vandalisme; Eind- rapport van een evaluatie-onderzoek naar HALT-projecten, Arnhem 1989, bl. 42-44. 55. R. Sikkes, 'Politiek neemt terug wat ze eerder gaf; hun eigen schaarste kunnen gebruiken als wapen', de Volkskrant 1 mei 1993. Kees Versteegh, 'Brinkman: sociale dienstplicht', in NRC-HB van 2 oktober 1992. NRC-HB 15 oktober 1992, 'Lubbers en Kamer voelen niets voor instellen sociale dienstplicht'. Voorts: NRC-HB 3 februari 1993, 'Brinkman houdt vast aan sociale dienstplicht jongeren'.

56. Advies commissie dienstplicht, Naar dienstplicht nieuwe stijl, Den Haag 1993, bl. 132.

57. Advies commissie dienstplicht, a.w., bl. 46.

58. Advies commissie dienstplicht, a.w., biịlage 4 .

59. H, van Gelder in NRC-HB van 12 juni 1993, Jongeren moeten na school jaar vrijwilligerswerk kunnen doen'.

60. De Volkskrant 19 april 1993, 'Jeugdcriminelen gaan op proef in werkinrichting' en de Volkskrant 22 april 1993, "Justitie begint proef met "harde" jeugdinrichtingen'.

S. van Rijn, 'Antillen zijn greep op jeugd kwijt', de Volkskrant 12 juli 1993. Zie ook: H. van Hulst en J. Bos, Pan i rèspèt; criminaliteit van geïmmigrcerde Curaçaose jongeren, Utrecht 1993.

61. De Volkskrant van 17 maart 1993, 'Uitspraken Lubbers over strafkampen zijn nutteloos' en E. van Venetie en C. Welgraven, 'De premier wil na een eindsprint het zaakje netjes afleveren', de Volkskrant 28 april 1993. De Volkskrant 15 april 1993, 'Kosto wil jonge crimineel een baan geven'.

62. Circulaire yan 1 december 1993, nr. 408563/93 DJ (experiment met een jeugdwerkinrichting).

63. W.J.P.M. Fase, Wederzijds begrip; over de aansluiting tussen het arbeids- en sociale verzekeringsrecht, Deventer 1993, bl. 43.

64. Richtlijn informatieverstrekking door het openbaar ministerie aan organen en instanties, belast met de uitvocring van de sociale zekerheidswetten, inzake detentie van uitkeringsgerechtigden d.d. 28.10.1992, in werking getreden op 1.1.1993, Stcrt. 1992, 240. 
65. Justitie verwachtte over 1993 ruim 87 miljoen gulden uit dat fonds te ontvangen, Rijksbegroting 1994, Hoofdstuk VI, Justitie, Tweede Kamer, 1993-1994, 23400 hoofdstuk VI, nr. 2, bl. 152. Zie ook R. Verpalen en $\mathrm{G}$. de Jonge, Bajesboek, handboek voor gedetineerden en ter beschikking gestelden, Breda 1992, bl. 154 en 155.

66. Richtlijn voor het doen van aangifte of het opmaken van proces-verbaal terzake van fraude met sociale uitkeringen d.d.

27.1.1993, in werking getreden op 1.4.1993, Strert. 1993, 31.

67. Al in 1954 pleitte Van Bemmelen ervoor om meer sociale ambtenaren voor dat doel in te schakelen. Zie: J. M. van Bemmelen, Gedenkt der gevangenen, 's-Gravenhage, 1954, bl. 52-53. 


\section{Hoofdstuk V}

\section{Naar een Wet op de Penitentiaire Werkvoorziening}

Nil volentibus arduum. Voor hen die ècht willen is niets onoverkomelijk. Dat geldt ook voor een radicale herziening van het statuut van de werkende gedetineerde. Die radicaliteit ligt niet alleen besloten in de hierboven bepleite afschaffing van de arbeidsplicht en de normalisering van het loon, maar ook in de aard van een hier voor te stellen nieuwe regeling.

Kritiek op (onderdelen van) het gevangeniswezen wordt vaak gepareerd met de vraag: 'Wat is dan Uw alternatief?' Welnu, in dit geval is daar een heel concreet antwoord op te geven. Voor zo'n alternatief kan namelijk de Wet Sociale Werkvoorziening (WSW) model staan. De WSW blijkt goed beschouwd bijna als een handschoen op de arbeidsverhouding tussen gedetineerden en de minister van fustitie te passen. Bijna, want de in allerlei opzichten beperkte vrijheid van gedetineerden en de bijzondere machtsstructuur binnen de strafinrichtingen vereisen zodanige aanpassing dat er beter een nieuwe wet kan worden ontworpen: een Wet op de Penitentiaire Werkvoorziening (WPW).

In het onderstaande wordt geprobeerd aan te geven hoe zo'n WPW er uit zou kunnen zien. Daartoe zoorden de belangrijkste bepalingen van de WSW telkens getransformeerd in een WPW-equivalent. Tevens zal worden aangegeven in welke opzichten het wetboek van Strafrecht, de Beginselenwet Gevangeniswezen en de Gevangenismaatregel zouden moeten worden aangepast bij een eventuele introductie van een WPW. 


\section{De Wet Sociale Werkvoorziening: voorbeeld voor het gevangeniswezen}

Om te kunnen beoordelen of en, zo ja, in hoeverre de WSW een bruikbaar mociell biedt voor een bijzondere wettelijke regeling van de arbeidsverhouding tussen gedetineerden en de overheid worden hier eerst de belangrijkste kenmerken van de WSW beschreven. Daarna worden op basis van de kern-artikelen van de WSW equivalenten voor een Wet op de P'enitentiaire Werkvoorziening gemodelleerd.

\subsection{De personenkring van de WSW}

Het doel van de op 1 januari 1969 in werking getreden ${ }^{1}$ WSW is blijkens haar considerans 'de voorziening in aangepaste werkgelegenheid, welke zoveel mogelijk gericht is op het behoud, het herstel of op de bevordering van de arbeidsgeschiktheid ten behoeve van personen, die tot het verrichten van arbeid in staat zijn, doch voor wie, in belangrijke mate ten gevolge van bij hen gelegen factoren, gelegenheid om onder normale omstandigheden werk te verrichten niet of voorshands niet aanwezig is'. Deze doelgroep van de WSW ofwel in de terminologie van de sociale zekerheid 'de personenkring' staat vervolgens nog eens met zoveel woorden vermeld in art. 7 van deze wet.

Voor hen bij wie de afkorting WSW een beeld opwekt van nijver fröbelende geestelijk gehandicapten is het goed om even op de oorsprong van deze regeling te wijzen. De Wet op de Sociale Werkvoorziening is de resultante van een tweetal na de Tweede Wereldoorlog tot stand gekomen regelingen die aanvankelijk vooral bedoeld waren om langdurig werklozen (zonder een bepaalde handicap) aan een betrekking te helpen. In 1950 ontstond er een gemeentelijke sociale werkwoorziening voor handarbeiders, destijds bekend als de gsw-regeling. In 1953 kwam daar een sociale werkvoorziening voor hoofdarbeiders bij, de swh-regeling. In 1952 werd de gsw-regeling ook van toepassing op lichamelijk en in 1955 tevens op geestelijk gehandicapten. Beide regelingen zijn door de WSW geabsorbeerd ${ }^{2}$

In de loop van de tijd is de categorie gehandicapten wel een steeds grotere plaats onder de WSW-werknemers gaan innemen. Volgens een door het ministerie van Sociale Zaken en Werkgelegenheid gemaakte uitsplitsing bestonden in 1982 de toen in dienst zijnde 77.500 WSW-werknemers voor $40 \%$ uit lichamelijk en zintuiglijk gehandicapten, voor 30\% uit verstandelijk gehandicapten en voor plm. $17 \%$ uit (ex-) psychiatrische patiěnten. Ongeveer $12 \%$ van de werknemers bestond toen uit personen zonder een medisch constateerbare handicap. ${ }^{3}$

Volgens Cazemier-Kleij mogen thans weliswaar personen van wie de werkloosheid voornamelijk door economische factoren wordt veroorzaakt niet meer in de sociale werkvoorziening worden opgenomen, toch lijkt het in hoge mate aannemelijk dat de WSW (evenals de WAO en de AAW overigens) een werkloosheidscomponent bevat: 'Alhoewel de WSW blijkens de toelichting op de wet al- 
leen bedoeld was voor gehandicapten, blijkt in de praktijk altijd een bepaald percentage economisch werklozen in deze voorziening aanwezig geweest te zijn'. ${ }^{4}$

Er bestaat voor mensen die in beginsel tot de personenkring van de WSW kunnen worden gerekend geen sollicitatie- of arbeidsplicht. De gemeentebesturen (aan wie de uitvoering van de WSW is overgedragen) dienen wel te bevorderen dat de daarvoor in aanmerking komende personen wordt gewezen op de mogelijkheden die de WSW hun biedt. De gemeenten zijn daarbij overigens gebonden aan een volume-beleid, zodat WSW-dienstbetrekkingen niet ad libitum worden kunnen worden aangeboden. ${ }^{5}$

\section{2 (Ex-) gedetineerden en de WSW}

Nu men gevoeglijk kan aannemen dat gedetineerden 'in belangrijke mate ten gevolge van bij hen gelegen factoren', namelijk door hun detentie, niet of voorshands niet in de gelegenheid zijn om onder normale omstandigheden werk te verrichten en men kennelijk niet per se gehandicapt hoeft de zijn om in de WSW terecht te kunnen komen, rijst de vraag of zij wellicht en bloc tot de personenkring van de WSW gerekend kunnen worden. Daarmee zouden alle vraagstukken rond arbeid en beloning in één klap zijn opgelost: elke justitiële inrichting wordt dan eenvoudigweg als WSW-werkverband beschouwd.

Zo simpel is het helaas niet. De sociale werkvoorziening is, alleen al gezien haar ontstaansgeschiedenis, immers niet in het leven geroepen om de arbeid en de arbeidsbeloning binnen de inrichtingen van het gevangeniswezen te reguleren. Detentie is niet de doorslaggevende factor die iemand tot de personenkring van de WSW doet behoren. Wel is het mogelijk dat men -nog tijdens zijn detentie- in een WSW-werkverband te werk wordt gesteld. Ook is (bij herhaling) uitgemaakt dat 'gezeten hebben' kan worden beschouwd als één van de factoren die iemand tot de personenkring van de WSW kunnen doen behoren.

In 1979 heeft de staatssecretaris van Justitie na overleg met zijn ambtgenoot van Sociale Zaken de (geneesheer-)directeuren van de penitentiaire inrichtingen en diensten het volgende laten weten: 'Indien een gedetineerde die in een open inrichting wordt geplaatst door bij hem gelegen factoren niet in staat is arbeid te verrichten onder normale omstandigheden, is het niet uitgesloten dat hij kan worden gerekend tot de personenkring als bedoeld in artikel 7 WSW. Dit houdt in dat plaatsing van de betrokken gedetineerde in een werkverband der sociale werkvoorziening in overweging zou kunnen worden genomen'. In die gevallen ontstaat er echter geen dienstverband tussen de tewerkgestelde en het desbetreffende gemeentebestuur maar gaat krachtens art. 13 van het Besluit Organisatie Sociale Werkvoorziening de werkgever de overeenkomst aan met de directeur van de open inrichting. ${ }^{6}$

Hoewel dat denkbeeld tot nu toe niet is geopperd, is het niet moeilijk zich voor te stellen dat de in het vorige hoofdstuk genoemde dag-detentiecentra, wier bewoners worden klaargestoomd voor een terugkeer op de vrije arbeidsmarkt en die anspraak op een bijstandsuitkering kunnen doen gelden, onder de werkingssfeer van de WSW zouden komen. 
Uit de door Riegen en Toet vermelde jurisprudentie ${ }^{7}$ van de Afdeling Rechtspraak van de Raad van State blijkt dat een detentie-verleden een factor is die iemand tot de personenkring van de WSW kan doen behoren. In 1981 formuleerde de Afdeling het zó: 'Uit de geschiedenis van de totstandkoming van de WSW blijkt dat de mogelijkheid van plaatsing in het kader van de sociale werkvoorziening niet uitsluitend is bedoeld voor medisch geïndiceerde personen, die potentiële geschiktheid hebben tot het verrichten van arbeid, maar vanwege bij henzelf gelegen factoren niet of moeilijk plaatsbaar zijn in een normale dienstbetrekking'.

Noch de stelling dat ex-gedetineerden als zodanig tot de personenkring van de WSW behoren, noch de stelling dat zij daartoe niet behoren, kan in zijn algemeenheid als juist worden aangemerkt.

De nadruk die in de tekst van artikel 7 WSW en in de geschiedenis van haar totstandkoming is gelegd op de bij de betrokken personen zelf aanwezige factoren brengt mede, dat in elk individueel geval de medische en de sociale omstandigheden van betrokkene in het onderzoek dienen te worden betrokken, welke omstandigheden mede bepaald worden door het feit dat betrokkene wegens misdrijf tot straf is veroordeeld'.

\subsection{De arbeidsverhouding in de WSW}

Als de wettelijk vereiste sollicitatieprocedure met goed gevolg is doorlopen kan men krachtens artikel 16 WSW door een gemeentebestuur als WSW-werknemer in dienst worden genomen. De desbetreffende persoon wordt op die manier echter géén ambtenaar of werknemer in civielrechtelijke zin. De rechtsverhouding tussen partijen wordt in artikel 19 WSW zó beschreven: 'Door de indienstneming ontstaat tussen de gemeente en de betrokken persoon een dienstbetrekking, welke met uitsluiting van de bepalingen van de Ambtenarenwet 1929, de tweede en zevende titel A van het vierde boek van het Burgerlijk Wetboek en het Buitengewoon Besluit Arbeidsverhoudingen 1945 beheerst wordt door de bepalingen van dit hoofdstuk'.

Op deze manier is er een sui generis arbeidsverhouding gecreëerd. Volgens het commentaar op de WSW van Riegen en Toet werd de omstandigheid, dat de verhouding tussen de WSW-werknemer en het gemeentebestuur primair wordt bepaald door de sociale taak van de overheid, een afdoende reden geacht om hier een publiekrechtelijke dienstbetrekking van eigen aard te introduceren: 'Wat betreft de mogelijkheid om de door de wet ontstane verhouding tussen de gehandicapte en de overheid te construeren als een verhouding, voortvloeiende uit cen privatrechtelijke overeenkomst, kan worden gesteld dat bij een zodanige constructie te zeer de nadruk zou vallen op de wilsovereenstemming tussen partijen, terwijl het in wezen echter gaat om de uitvoering van een taak van de overheid jegens een gehandicapte $(\ldots)^{\prime} .^{8}$

Daarmee vertoont de WSW-arbeidverhouding opvallende gelijkenis met die welke tussen Justitie en onveroordeelde gedetineerden bestaat. ${ }^{9}$ 
De WSW wordt onder toezicht van het ministerie van Sociale Zaken en Werkgelegenheid door de gemeentebesturen in verplicht medebewind ${ }^{11}$ uitgevoerd. De (eventueel in regional verband opererende sociale werkwoorzieningsschappen samenwerkende) gemeentebesturen wijzen krachtens art. 10 WSW op publiek- of privaatrechtelijke leest geschoeide 'werkverbanden' aan die als organisatorische eenheden er voor zorgen dat de WSW-werknemers door de gemeentebesturen aangewezen 'werkobjecten' uitvoeren. De werkverbanden worden onderscheiden in industriële, cultuur- en civieltechnische en administratieve.

De verbinding tussen gemeentebesturen en centrale overheid ligt in de persoon van een per provincie aangestelde rijksconsulent.

De minister van Sociale Zaken en Werkgelegenheid laat zich door de Adviescommissie Werkloosheidsvoorziening van de Sociaal Economische Raad (SER) over de toepassing van de WSW adviseren. In deze commissie van de SER zijn de werknemerscentrales, werkgeversorganisaties en de Vereniging van Nederlandse Gemeenten vertegenwoordigd.

De gemeentebesturen laten zich raden door sociale werkvoorzieningscommissies (WSW-commissies) waarin, naast de gemeentebesturen zelf, de werknemersen werkgeversorganisaties, de rijksconsulent, het Gewestelijk Arbeidsbureau en eventuele andere geïnteresseerden zijn vertegenwoordigd.

De WSW wordt vrijwel ${ }^{12}$ volledig door het ministerie van Sociale Zaken en Werkgelegenheid gefinancierd (art. 40 WSW). de ongeveer 80.000 WSW-ers kostten het Rijk in 1992 3,3, miljard gulden. ${ }^{13} \mathrm{De}$ aanvankelijke 'open eind' financiering van deze wet is sinds 1989 vervangen door een experimentele budgetfinanciering ${ }^{14}$ die een onbeperkte toestroom naar de WSW in de weg staat en de gemeenten noopt zuinig met de bevorderingsplicht uit artikel 7 WSW om te gaan.

\subsection{De arbeidsvoorwaarden van de WSW}

Het werk dat in WSW-verband wordt verricht en de daarbij geldende arbeidsvoorwaarden moeten zoveel mogelijk lijken op wat er in het vrije bedrijf gangbaar is. Cazemier-Kleij zegt dat er in dit verband wel wordt gesproken van de parallelliteitsgedachte. Deze impliceert volgens het proefschrift van Limborgh dat de arbeidssituatie voor de WSW-werknemers niet al te zeer zou mogen afwijken van het normale arbeidsmilieu. Dit zou volgens hem ook de mogelijke doorstroming naar het vrije bedrijfsleven ten goede komen. ${ }^{15}$ Limborgh wijdde de volgende stelling aan deze kwestie: "In de zogenaamde "Parallelliteitsgedachte" is het particuliere bedrijfsleven een voorbeeld voor de Sociale Werkvoorziening; in het aanpassen van de werksituatie aan de mogelijkheden van de mensen die daarin moeten functioneren, in plaats van het omgekeerde, is de Sociale Werkvoorziening een voorbeeld voor het bedrijfsleven'. 
Deze parallelliteitsgedachte treft men ook aan in het penitentiaire arbeidsrecht. Het 'vrije bedrijf' wordt in de artikelen 33 lid 2 en 37 van de Beginselenwet Gevangeniswezen en in de artikelen 50 en 55 lid 2 van de Gevangenismaatregel als referentiekader gebruikt voor de berekening van door derden te betalen loonkosten, voor de arbeidsciuur en voor de arbeidsprestaties van gedetineerden.

De uitwerking van de voomaamste arbeidsvoorwaarden in de sociale werkvoorziening, zoals het loon, de werktijden, de vakantie en de disciplinaire regels, geschiedt op grond van artikel 30 lid 1 WSW bij of krachtens algemene maatregel van bestuur. Volgens het derde lid van dit artikel dienen deze nadere regels '(...) zoveel mogelijk afgestemd te zijn op hetgeen met betrekking tot arbeid onder normale omstandigheden rechtens geldt of gebruikelijk is, voorzover de lichamelijke of geestelijke gesteldheid van de werknemers geen afwijking daarvan rechtvaardigt'. Maar voorop staat dat het werk aan de WSW-er moet worden aangepast en niet andersom (zie artikel 30 lid 4 WSW).

De WSW-werknemers worden op grond van een onderzoek naar hun capaciteiten bij indienstneming ingedeeld in een $\mathrm{A}$ of $\mathrm{B}$ categorie. In art. 1 van het Besluit dienstbetrekking sociale werkvoorziening ${ }^{16}$ worden deze categorieën als volgt inhoudelijk gedefinieerd:

'categorie A: de categorie waarin de werknemer wordt ingedeeld, van wie redelijkerwijs verondersteld mag worden dat hij in staat is in aan hem aangepaste omstandigheden, zonder verstoring van de arbeidssfeer, regelmatig arbeid te verrichten en daarmede een kwantitatieve arbeidsprestatie te leveren van tenminste een derde van een redelijke minimumprestatie in het normale arbeidsproces in dezelfde of soortgelijke arbeid;

categorie B: de categorie waarin de werknemer wordt ingedeeld, van wie de gegevens een indeling in categorie A niet rechtvaardigen, doch van wie is vastgesteld dat hij in staat is in aan hem aangepaste omstandigheden, zonder verstoring van de arbeidssfeer, regelmatig arbeid te verrichten en het verschaffen van zodanige arbeid voor zijn. welzijn wenselijk is'.

Dit besluit bevat verder onder meer bepalingen over de in acht te nemen proeftijd bij indienstneming ( 2 maanden, conform artikel 5a) en over de wijze waarop de dienstbetrekking kan worden beëindigd (artt. 9 en 10).

De indeling in één van deze beide categorieën is bepalend voor het loon dat men kan verdienen. In het Besluit Arbeidsvoorwaarden ${ }^{17}$ is vastgelegd dat de WSW-werknemer aanspraak heeft op een loon ter hoogte van tenminste het minimum(jeugd)loon, een en ander naar evenredigheid van de voor hem geldende werktijd.

De werknemers die tot categorie $A$ behoren worden ingedeeld in één van de tien loongroepen die artikel 3 van dit Besluit kent. Deze groepen zijn gerangeerd naar oplopende moeilijkheidsgraad van de te verrichten werkzaamheden. Groep I betreft 'Zeer eenvoudige werkzaamheden, welke na korte aanwijzingen en enige 
oefening kunnen worden uitgevoerd'. Groep X slaat op 'Moeilijke, ingewikkelde, wisselende, zelfstandig uit te voeren werkzaamheden welke, naast een ruime algemene ontwikkeling, een door opleiding en/of langdurige ervaring verkregen gedegen vakkennis alsmede in aanzienlijke mate het vermogen tot zelfstandig oordelen vereisen'.

Het Besluit Arbeidsvoorwaarden kent voorts bepalingen over doorbetaling van loon tijdens erkende feest- en vrije dagen, gedurende de tijd die aan bevordering van de arbeidsgeschiktheid, vorming en scholing wordt besteed en gedurende perioden van werkloosheid die voor risico van de werkgever komen. Het Besluit voorziet tevens in tegemoetkoming in de kosten van ziektekostenverzekering, vakantietoeslagen en in (aanvullende) pensioenrechten. Het opent de mogelijkheid om in deeltijd te werken, regelt verlofaanspraken en voorziet in de mogelijkheid om 'in de tijd van de baas' aan vakbondswerk te doen. Het Besluit bevat tenslotte bepalingen over disciplinaire maatregelen die het gemeentebestuur een WSW-werknemer kan opleggen wanneer die zich in verband met zijn dienstbetrekking misdraagt.

Artikel 24 WSW is de basis van een medezeggenschapsregeling die vergelijkbaar is met die welke in het burgerlijk arbeidsrecht en ambtenarenrecht bestaan. $\mathrm{Zij}$ is uitgewerkt in het 'Besluit organen van overleg sociale werkvoorziening'. ${ }^{15}$

Kortom: de WSW-dienstberrekking kan rechtspositioneel een volwaardige genoemd worden.

\subsection{Rechtsmiddelen voor de WSW-er}

Meningsverschillen tussen de werkgever (het gemeentebestuur) en WSWwerknemers kunnen via een administratiefrechtelijke rechtsgang worden uitgeprocedeerd.

Krachtens artikel 31 WSW kan de WSW-werknemer tegen besluiten, handelingen of (fictieve) weigeringen om te handelen of te besluiten een bezwaarschrift bij het gemeentebestuur indienen. In bepaalde (in artikel 34 WSW aangegeven) gevallen kan de werknemer tegen een beslissing op een bezwaarschrift bij de Sector Bestuursrecht van de Arrondissementsrechtbank in beroep gaan. Van een beslissing van de sector Bestuursrecht kan overeenkonstig de bepalingen van de Beroepswet hoger beroep worden ingesteld bij de Centrale Raad van Beroep in Utrecht.

Deze rechtsmiddelen staan in beginsel alleen open voor WSW-zerknemers. De wet maakt echter een uitzondering voor afgewezen sollicitanten. Krachtens artikel 31 lid 3 WSW kan ook degene die zijn verzoek om in dienst genomen te worden zag afgewezen bij het desbetreffende gemeentebestuur een bezwaarschrift indienen.

De afgewezen sollicitant zal op basis van de Algemene Wet Bestuursrecht en de Beroepswet van een afwijzing van het bezwaarschrift eveneens bij de Sector Bestuursrecht van de rechtbank in beroep en zonodig bij de Centrale Raad van Beroep in hoger beroep kunnen komen. ${ }^{19}$ 
Voor de toepassing van het bij of krachtens deze wet bepaalde wordt verstaan onder:

a. Onze Minister: de minister van fustitie;

b. De directeur: de (geneesheer-) directeur van een huis van bewaring, gevangenis of justitiële rijksinsichting voor verpleging van terbeschikking-gestelden; de directeur treedt ingevolge deze wet namens de Staat der Nederlanden op als werkgever;

c. de commissie: de werkvoorzieningscommissie uit de commissie van toezicht;

d. gedetineerde: persoon, ingesloten in een huis van bewaring, gevangenis of justitiele rijksinrichting voor verpleging van terbeschikking-gestelden;

e. werknemer: de gedetineerde die ingevolge deze wet in een dienstbetrekking tot de Staat der Nederlanden staat.

\section{Toelichting}

Het ligt voor de hand dat de minister van Justitie, als degene die verantwoordelijk is voor alles wat er in de inrichtingen van het gevangeniswezen gebeurt, de eerst-aangewezene is een WPW uit te voeren. Omdat een WPW tot het stelsel van de sociale zekerheidswetgeving zou behoren, ligt het eveneens voor de hand dat de minister van Justitie bij de uitvoering ervan nauw zou samenwerken met zijn ambtgenoot van Sociale Zaken en Werkgelegenheid, die - zoals hieronder nog zal worden aangegeven - zou dienen te zorgen voor de financiering van die wet.

De definitie van gedetineerde is ontleend aan artikel I van de Beginselenwet Gevangeniswezen. Dat artikel noemt nog de rijkswerkinrichtingen. De bijkomende straf van plaatsing in een rijkswerkinrichting is echter al geruime tijd niet meer opgelegd. De beperking van de definitie tot personen die in een justitiële rijksinrichting voor terbeschikking-gestelden zijn ingesloten laat onverlet dat door aanpassing van desbetreffende subsidievoorwaarden ook personen, die in de particuliere tbs-inrichtingen zijn ingesloten onder de werking van een WPW kunnen worden gebracht.

Nieuw is hier de introductie van het begrip werknemer voor de in het kader van de WPW werkende gedetineerde. Bij de toelichting op artikel 19 WPW zal op de daarmee bedoelde rechtsverhouding worden ingegaan.

\section{Art. 7 WSW}

1. Het gemeentebestuur bevordert dat ten behoeve van personen die tot arbeid in staat zijn, doch voor wie, in belangrijke mate ten gevolge van bij hen gelegen factoren, gelegenheid om onder normale omstandigheden arbeid te verrichten niet of voorshands niet aanwezig is, gelegenheid bestaat tot het verrichten van arbeid onder aangepaste omstandigheden, welke zoveel mogelijk gericht is op het behoud, het herstel of de bevordering van hun arbeidsgeschiktheid. 
2. Het gemeentebestuur bevordert dat personen als bedoeld in het eerste lid die daarom verzoeken krachtens deze wet in dienst worden genomen om tegen loon arbeid als bedoeld in dat lid te verrichten, voorzover zodanige arbeid beschikbaar is.

3. Het eerste en tweede lid zijn slechts van toepassing ten aanzien van personen, die de 65-jarige leeftijd nog niet hebben bereikt en die in de betrokken gemeente in het bevolkingsregister staan ingeschreven.

\section{Equivalent voor een concept-WPW}

De directeur bevordert dat voor de de in zijn inrichting verblijvende gedetineerden, die kunnen en willen werken, gelegenheid bestaat tot het verrichten van arbeid onder aangepaste omstandigheden, welke arbeid is gericht op behoud, herstel of bevordering van hun arbeidsmogelijkheden. Het voorgaande geldt slechts ten aanzien van personen die nog geen 65 jaar zijn.

\section{Toelichting}

De 'bevorderingsplicht' die op de directeur wordt gelegd houdt in dat iedereen die zijn inrichting binnenkomt in de gelegenheid wordt gesteld om te werken en zo een loon te verdienen. Er bestaat geen verplichting om op dat aanbod in te gaan. Personen, die een (arbeidsongeschiktheids)uitkering hebben welke tijdens detentie doorloopt of die over eigen inkomsten beschikken, kunnen zo'n aanbod naast zich neerleggen. ${ }^{22}$

Personen die wèl willen werken worden binnen veertien dagen nadat zij daartoe de wens te kennen hebben gegeven op hun arbeidsgeschiktheid getest. Dat gebeurt niet, zoals thans op basis van artikel 45 Gevangenismaatregel het geval is, door de inrichtingsarts die in de eerste plaats de vertrouwensfunctie van 'huisarts' behoort te hebben en daamaast verantwoordelijk is voor de controle op de hygiëne in de inrichting. De keuring geschiedt door een arts van de Gemeenschappelijke Medische Dienst die, zonodig met behulp van een arbeidsdeskundige, de arbeidscapaciteit van de desbetreffende gedetineerde inschat.

De bevorderingsplicht van de directeur stoelt in de eerste plaats op het grondrecht van vrije arbeidskeuze dat in artikel 19 lid 1 van de Grondwet is neergelegd. De gedetineerde is immers binnen de muren beperkt in die keuze-vrijheid. De bevorderingsplicht is mede gebaseerd op artikel 1 van het Europees Sociaal Handvest en artikel 6 van het Internationaal Verdrag inzake Economische, Sociale en Culturele rechten in samenhang met de artikelen 26 en 26 bis BWG. De directeuren dienen ter zake een actief beleid te voeren.

Ook 'spijtoptanten', daarmee zijn hier bedoeld gedetineerden, die in eerste instantie niet wilden werken maar op dat standpunt zijn teruggekomen, worden in de gelegenheid gesteld in het kader van de WPW te werk te worden gesteld. Dat betekent niet dat gedetineerden volstrekt willekeurig nu eens wel en dan weer niet kunnen werken. Er dient de directeuren een zekere ruimte te worden gelaten om 


\section{Equivalent voor een concept-WPW}

Voor de toepassing van het bij of krachtens deze wet bepaalde wordt verstaan onder:

a. Onze Minister: de minister van fustitie;

b. De directeur: de (geneesheer-) directeur van een huis van bewaring, gevangenis of justitiele rijksinrichting voor verpleging van terbeschikking-gestelden; de directeur treedt ingevolge deze wet namens de Siaat der Nederlanden op als werkgever;

c. de commissie: de werkvoorzieningscommissie uit de commissie van toczicht;

d. gedetineerde: persoon, ingesloten in een huis van bewaring, gevangenis of justitielle rijksinrichting voor verpleging van terbeschikking-gestelden;

e. werknemer: de gedetineerde die ingevolge deze wet in een dienstbetrekking tot de Staat der Nederlanden staat.

Toelichting

Het ligt voor de hand dat de minister van Justitie, als degene die verantwoordelijk is voor alles wat er in de inrichtingen van het gevangeniswezen gebeurt, de eerst-aangewezene is een WPW uit te voeren. Omdat een WPW tot het stelsel van de sociale zekerheidswetgeving zou behoren, ligt het eveneens voor de hand dat de minister van Justitie bij de uitvoering ervan nauw zou samenwerken mer zijn ambtgenoot van Sociale Zaken en Werkgelegenheid, die - zoals hieronder nog zal worden aangegeven - zou dienen te zorgen voor de financiering van die wet.

De definitie van gedetineerde is ontleend aan artikel 1 van de Beginselenwet Gevangeniswezen. Dat artikel noemt nog de rijkswerkinrichtingen. De bijkomende straf van plaatsing in een rijkswerkinrichting is echter al geruime tijd niet meer opgelegd. De beperking van de definitie tot personen die in een justitiële rijksinrichting voor terbeschikking-gestelden zijn ingesloten laat onverlet dat door aanpassing van desbetreffende subsidievoorwaarden ook personen, die in de particuliere rbs-inrichtingen zijn ingesloten onder de werking van een WPW kunnen worden gebracht.

Nieuw is hier de introductie van het begrip werknemer voor de in het kader van de WPW werkende gedetineerde. Bij de toelichting op artikel 19 WPW zal op de daarmee bedoelde rechtsverhouding worden ingegaan.

(..)

\section{Art. 7 WSW}

1. Het gemeentebestuur bevordert dat ten behoeve van personen die tot arbeid in staat zijn, doch voor wie, in belangrijke mate ten gevolge van bij hen gelegen factoren, gelegenheid om onder normale omstandigheden arbeid te verrichten niet of voorshands niet aanwezig is, gelegenheid bestaat tot het verrichten van arbeid onder aangepaste omstandigheden, welke zoveel mogelijk gericht is op het behoud, het herstel of de bevordering van hun arbeidsgeschiktheid. 
2. Het gemeentebestuur bevordert dat personen als bedoeld in het eerste lid die daarom verzoeken krachtens deze wet in dienst worden genomen om tegen loon arbeid als bedoeld in dat lid te verrichten, voorzover zodanige arbeid beschikbaar is.

3. Het eerste en tweede lid zijn slechts van toepassing ten aanzien van personen, die de 65 -jarige leeftijd nog niet hebben bereikt en die in de betrokken gemeente in het bevolkingsregister staan ingeschreven.

\section{Equivalent voor een concept-WPW}

De directeur bevordert dat voor de de in zijn inrichting verblijvende gedetineerden, die kunnen en willen werken, gelegenheid bestaat tot het verrichten van arbeid onder aangepaste omstandigheden, welke arbeid is gericht op behoud, herstel of bevordering van hun arbeidsmogelijkheden. Het voorgaande geldt slechts ten aanzien van personen die nog geen 65 jaar zijn.

Toelichting

De 'bevorderingsplicht' die op de directeur wordt gelegd houdt in dat iedereen die zijn inrichting binnenkomt in de gelegenheid wordt gesteld om te werken en zo een loon te verdienen. Er bestaat geen verplichting om op dat aanbod in te gaan. Personen, die een (arbeidsongeschiktheids) uitkering hebben welke tijdens detentie doorloopt of die over eigen inkomsten beschikken, kunnen zo'n aanbod naast zich neerleggen. ${ }^{22}$

Personen die wèl willen werken worden binnen veertien dagen nadat zij daartoe de wens te kennen hebben gegeven op hun arbeidsgeschiktheid getest. Dat gebeurt niet, zoals thans op basis van artikel 45 Gevangenismaatregel het geval is, door de inrichtingsarts die in de eerste plaats de vertrouwensfunctie van 'huisarts' behoort te hebben en daamaast verantwoordelijk is voor de controle op de hygiëne in de inrichting. De keuring geschiedt door een arts van de Gemeenschappelijke Medische Dienst die, zonodig met behulp van een arbeidsdeskundige, de arbeidscapaciteit van de desbetreffende gedetineerde inschat.

De bevorderingsplicht van de directeur stoelt in de eerste plaats op her grondrecht van vrije arbeidskeuze dat in artikel 19 lid 1 van de Grondwet is neergelegd. De gedetineerde is immers binnen de muren beperkt in die keuze-vrijheid. De bevorderingsplicht is mede gebaseerd op artikel 1 van het Europees Sociaal Handvest en artikel 6 van het Internationaal Verdrag inzake Economische, Sociale en Culturele rechten in samenhang met de artikelen 26 en 26 bis BWG. De directeuren dienen ter zake een actief beleid te voeren.

Ook 'spijtoptanten', daarmee zijn hier bedoeld gedetineerden, die in eerste instantie niet wilden werken maar op dat standpunt zijn teruggekomen, worden in de gelegenheid gesteld in het kader van de WPW te werk te worden gesteld. Dat betekent niet dat gedetineerden volstrekt willekeurig nu eens wel en dan weer niet kunnen werken. Er dient de directeuren een zekere ruimte te worden gelaten om 
(hernieuwde) sollicitaties af te wijzen.23 Deze beleidsruimte dient door de administratieve rechter (zie hiema onder 'Rechtsmiddelen voor de werknemer') te worden genormeerd.

De begrenzing van de personenkring naar leeftijd hangt samen met de desbetreffende bepalingen in de AOW. ${ }^{24}$ Personen, die gebruik maken van een mogelijkheid om vóór hun 65 -ste jaar met pensioen te gaan vallen buiten de personenkring van de WPW.

Als - en dat is wel de bedoeling - over een WPW-uitkering loonbelasting wordt betaald, is volgens artikel 6 , lid 1 onder b AOW degene die nog niet de leeftijd van 65 jaar heeft bereikt verzekerd volgens deze wet en heeft hij bij het bereiken van de 65-jarige leeftijd recht op ouderdomspensioen.

Buitenlandse gedetineerden (een niet te verwaarlozen categorie onder de gevangenisbevolking) hoeven niet per se 'ingezerene ${ }^{25}$ te zijn om krachtens de AOW verzekerd te zijn. Voldoende is dat zij 'terzake van in Nederland in dienstbetrekking verrichte arbeid' loonbelasting betalen. Als de arbeidsverhouding tussen gedetineerden en staat als een dienstbetrekking wordt gedefinieerd zijn ook illegale gedetineerde buitenlanders verzekerd krachtens de AOW.

( ...)

\section{Art. 10 WSW}

1. Voor zover de vervulling van zijn in artikel 7 omschreven taak zulks vereist, wijst het gemeentebestuur een of meer organisatorische eenheden, welke in hoofdzaak gericht zijn op het doen uitvoeren van ingevolge artikel 13 aangewezen werkobjecten als werkverband aan.

2. Het gemeentebestuur kan als werkverband slechts een organisatorische eenheid aanwijzen, welke beoogt werkobjecten op het grondgebied van de gemeente uit te voeren, dan wel een organisatorische eenheid, welke beoogt werkobjecten op het grondgebied van een andere gemeente uit te voeren, mits het bestuur van deze gemeente daarin toestemt.

3. Indien het gemeentebestuur een organisatorische eenheid als werkverband aanwijst, die onder beheer staat van een privaatrechtelijke rechtspersoon, regelt het gemeentebestuur in het aanwijzingsbesluit de inhoud van de rechtsbetrekking tussen het gemeentebestuur en de privaatrechtelijke rechtspersoon.

\section{Equivalent voor een concept-WPW}

1. Elke inrichting kent een werkverband, Afdeling Arbeid genaamd, die beoogt op het terrein van de inrichting werkobjecten uit te voeren.

2. Met toestemming van Onze Minister kunnen de werknemers in de gelegenheid worden gesteld om buiten het terrein van de inrichting gelegen werkobjecten uit te voeren. 
De Afdeling Arbeid binnen elke strafinrichting is het penitentiaire equivalent van een werkverband zoals bedoeld in de WSW. Het hoofd van de Afdeling Arbeid, die de ambtelijke status van adjunct-directeur heeft, is verantwoordelijk voor het creëren en instandhouden van werkobjecten.

Het stelsel van open inrichtingen maakt het nodig om vast te leggen dat met toestemming van de minister ook buiten de inrichting kan worden gewerkt.

De Afdeling Arbeid opereert in de context van de inrichting feitelijk en financieel zo zelfstandig als maar enigszins mogelijk is. Daarbij is het niet de bedoeling dat het hoofd van de Afdeling Arbeid qua belangrijkheid gaat concurreren met de directeur. Het verschil zit voor alles in de aard van de functies. Het hoofd van de Afdeling Arbeid dient een economisch gekwalificeerd bedrijfsleider te zijn. De directeur is vooral justitiefunctionaris, belast met de tenuitvoerlegging van de vrijheidsbeneming zoals bevolen door de rechter.

(..)

\section{Art. 13 WSW}

1. Het gemeentebestuur wijst, voorzover de vervulling van zijn in arikel $7 \mathrm{om}$ schreven taak zulks vereist, ter uitwoering in elk door hem aangewezen werkverband werkobjecten aan.

2. Werkobjecten als bedoeld in het eerste lid omvatten werkzaamheden waarvoor het werkwerband een geldelijke opbrengst ontvangt dan wel, met inachtneming van het bepaalde in het derde en vierde lid, werkzaamheden die geen geldelijke opbrengst opleveren.

3. Het gemeentebestuur kan een werkobject dat geen geldelijke opbrengst oplevert aanwijzen indien wordt voldaan aan de voorwaarden:

a. Voor de betrokken werknemers of de personen die voor een dienstbetrekking in aanmerking komen is geen andere mogelijkheid tot arbeid in de zin van artikel 7, eerste lid, aanwezig dan het aan te wijzen werkobject, en

b. het werkobject omvat werkzaamheden ten behoeve van een publiekrechtelijk rechtspersoon of van een privaatrechtelijk rechtspersoon zonder winstoogmerk, welke zonder die aanwijzing niet tot uitwoering zouden komen, en

c. de werkzaamheden behoren niet tot de taken, die de onder $\mathrm{b}$ behorende rechtspersoon in elk geval behoort te verrichten.

4. (...).

5. Een werkobject mag door de bedongen prijs en de leverings- en betalingsvoorwaarden geen onverantwoorde concurrentie aandoen en voorts niet worden uitgevoerd onder omstandigheden die aanleiding kunnen geven tot ongewenste commerciele beinvloeding door een persoon of organisatie, die een bedrijf uitoefent.

6. Het gemeentebestuur kan afwijken van het in het derde lid bepaalde indien het werkobject werkzaamheden omvat, gedurende korte tijd te verrichten door een 
werknemer ten behoeve van een natuurlijk of een rechtspersoan, die de gemeente heeft toegezegd de betrokken werknemer bij gebleken geschiktheid in dienst te zullen nemen.

7. (...).

\section{Equivalent voor een concept-WPW}

1. De directeur wijst in overleg met het hoofd van Afdeling Arbeid werkobjecten aan die bij voorkeur een geldelijke opbrengst opleveren.

2. De directeur kan echter ook werkobjecten aanwijzen die geen geldelijke opbrengst opleveren indien wordt volitaan aan de volgende voorwaarden:

a. voor de betrokken (aspirant) werknemers bestaat er geen andere mogelijkheid tot arbeid bij een werkobject dat wel geld oplevert, en

b. het werkobject omvat werkzaamheden ten behoeve van een publiekrechtelijk rechtspersoon of van een privaatrechtelijk rechtspersoon zonder winstoogmerk, die zonder die aanwijzing niet tot uitvoering zouden komen, en

c. de werkzaamheden behoren niet tot de taken die de onder b bedoelde rechtspersonen in elk geval behoren te verrichten.

Deze voorwaarden gelden niet als vaststaat dat de werknemer na afloop van zijn detentie bij de afnemer van het produkt in dienst kan treden.

3. De Afdeling Arbeid dient de geproduceerde goederen of diensten zo veel mogelijk tegen de geldende marktprijzen aan de afnemers aan te bieden. De manier waarop die prïzen worden berekend wordt vastgesteld bij algemene maatregel van bestuur.

\section{Toelichting}

De ook in de penitentiaire setting geldende parallelliteitsgedachte brengt met zich mee dat er zo veel mogelijk op commerciële basis wordt geproduceerd.

Sommige werkobjecten zullen geen externe geldstromen (opdrachten van particuliere ondernemers) aantrekken. Bijvoorbeeld de 'huisdienst', waarin gedetineerden onderhouds- en schoonmaak- en keukendiensten verrichten. Deze werkzaamheden leveren weliswaar niet direct geld op maar resulteren wel in aanzienlijke besparingen op ambtelijk personeel.

Net zoals men ervan uitgaat dat WSW-arbeid nooit economisch rendabel zal kunnen zijn, dient men zich te realiseren dat penitentiaire arbeid nooit winstgevend of zelfs maar kostendekkend zal zijn. Daarvoor is de gedetineerdenbevolking nu eenmaal te verschillend van achtergrond, te vlottend en is het werkaanbod te onregelmatig en te divers.

Orn bezwaren van werknemers- en werkgeversorganisaties tegen een veronderstelde oneerlijke loon-, resp. -prijsconcurrentie te ondervangen, dient het formele streven wel op een commerciële produktie te zijn gericht. Overigens dient te worden bedacht dat het om een betrekkelijk kleine groep personen gaat en om een beperkt produktie-volume waarvan nauwelijks concurrentievervalsende effeoten uit zullen kunnen gaan. 
Uit resocialisatie-oogpunt is het aantrekkelijk om bij de opdrachtgever geen of weinig kosten in rekening te brengen wanneer verwacht kan worden dat de betrokken gedetineerde na afloop van zijn detentie bij die opdrachtgever in dienst kan komen. Het werken tijdens detentie fungeert dan als een soort proeftujd. Tegen eventueel misbruik van werkgeverszijde dient vanzelfsprekend te worden gewaakt.

\section{( $\ldots)$.}

\section{Art. 16 WSW}

Indienstneming, als bedoeld in artikel 7, geschiedt door het gemeentebestuur, dat het werkverband, waar de betrokkene wordt geplaatst, heeft aangewezen.

\section{Equivalent voor een concept-WPW}

Indienstneming, als bedoeld in arrikel 7, geschiedt door de directeur van de inrichting die het werkobject, waarvoor de arbeid zal worden verricht, leidt.

\section{Toelichting}

Hiermee wordt de directeur tevens werkgever van 'zijn' gedetineerden (zie het equivalent van art. 1 WSW voor een concept-WPW hierboven). Het betreft hier een door de Staat (de minister van Justitie) aan de directeur te delegeren bevoegdheid. De directeur oefent die an hem overgedragen bevoegdheid dus uit als een eigen bevoegdheid.

\section{(...).}

\section{Art.19 WSW}

Door de indienstneming ontstaat tussen de gemeente en de betrokken persoon een dienstbetrekking, welke met uitsluiting van de bepalingen van de Ambtenarenwet 1929, de tweede en zevende titel A van het vierde boek van het Burgerlijk Werboek en het Buitengewoon Besluit Arbeidsverhoudingen 1945 beheerst wordt door de bepalingen van dit hoofdstuk.

\section{Equivalent voor een concept-WPW}

Door de indienstneming ontstaat tussen de Staat der Nederlanden en de gedetineerde een dienstbetrekking die met uitsluiting van de bepalingen van de Ambtenarenwet 1929, de tweede en zevende titel $A$ van het vierde boek van het Burgerlijk Wetboek en het Buitengewoon Besluit Arbeidsverhoudingen 1945, beheerst wordt door de bepalingen van deze. wet. 
Hiermee is de vraag naar het rechtskarakter van de arbeidsverhouding tussen gedetineerde en staat opgelost. De gedetineerde is geen werknemer in civielrechtelijke zin, maar ook geen ambtenaar. De arbeidsverhouding is een sui generis relatie waarvan de juridische aard - naar het voorbeeld van de WSW - bepaald wordt door de WPW en de daarop gebaseerde uitvoeringsregelingen. Omdat het een sui generis rechtsverhouding is, staat niet bij voorbaat vast dat de daaraan onderworpen gedetineerden kunnen profiteren van de grondrechten van werknemers als bedoeld in diverse internationale verklaringen en overeenkomsten, zoals bijvoorbeeld het Europees Sociaal Handvest. De wetgever kan alle twijfel daarover wegnemen door in een Memorie van Toelichting vast te leggen dat alle nationale en intemationale grondrechten, die met betrekking tot arbeid en inkomen zijn geformuleerd, óók van toepassing zijn op degenen die een dienstverband krachtens een WPW hebben.

\title{
Art. 20 WSW
}

De dienstbetrekking vangt aan op het tijdstip, dat voor de aanvang van de werkzaamheden van de betrokkene is vastgesteld.

\section{Equivalent voor een concept-WPW}

\author{
De dienstbetrekking vangl aan uiterlijk veertien dagen nadat de betrokken persoon ar- \\ beidsgeschikt in het kader van deze wet is verklaard.
}

Toelichting

Het is belangrijk dat de werkzaamheden zo snel mogelijk na binnenkomst in een strafinrichting c.q. na opgave als werkwillige kunnen worden begonnen. De keuring op arbeidsgeschiktheid is in beginsel éénmalig. Bij overplaatsing behoeft niet opnieuw gekeurd te worden, tenzij de werkzaamheden in de nieuwe inrichting aanzienlijk afwijken van die in de inrichting van herkomst. Als veertien dagen na goedkeuring nog geen werk voor de betrokken gedetineerde is gevonden heeft die vanaf dat moment wel recht op loon.

\section{Art. 21 WSW}

De werknemer is verplicht:

a. de hem opgedragen werkzaambeden onder leiding van de daartoe aangewezen personen naar beste vermogen te verrichten;

b. gedurende zijn werktijd mede te werken aan het behouden, herstellen of berorderen van zijn arbeidsgeschiktheid; 
c. zonodig mede te werken aan een onderzoek naar zijn arbeidsgeschiktheid;

d. mede te werken aan het verkrijgen van passende arbeid onder normale omstandigheden.

\section{Equivalent voor een concept-WPW}

De werknemer is verplicht de hem opgedragen werkzaamheden onder leiding van de daantoe door de directeur aangewezen personen naar beste vermogen te verrichten.

\section{Toelichting}

Alleen het onder artikel 21 onder a. WSW gestelde behoeft in een WPW-tekst te worden vertaald. De verplichtingen, genoemd in de leden b tot en met $d$ van dat artikel zijn overbodig omdat de penitentiaire regelgeving voorziet in scholings- en vormingsmogelijkheden onder werktijd. Een verplichting om mede te werken aan het verkrijgen van passende arbeid na ommekomst van de detentie lijkt ook overbodig. In voorkomende gevallen biedt het (penitentiaire) reclasseringswerk mogelijkheden om de gedetineerde op de vrije arbeidsmarkt te herintroduceren.

\section{Art. 22 WSW}

1. Vervreemding, verpanding of belening van het aan de werknemer verschuldigde loon is slechts geldig voorzover beslag op zijn loon geldig zou zijn bij ontbreken van andere inkomsten.

2. Volmacht tot invordering van het loon, onder welke vorm of benaming dan ook door de werknemer verleend, is steeds herroepelijk.

3. Elk beding, strijdig met enige bepaling van dit artikel is nietig.

\section{Equivalent concept-WPW}

1. Het loon is het eigendom van de werknemer. Hij kan het. geheel naar eigen inzicht aanwenden;

2. (iekst gelijk aan die van art. 22 lid 2 WSW);

3. (tekst gelijk aan die van art. 22 lid 3 WSW).

Toelichting

De gedetineerde dient, wat de besteding van zijn loon betreft, als volwaardig staatsburger te worden beschouwd. Hij kan er mee doen en laten wat hij wil. Zou hij eventuele onderhoudsplichten verzaken, dan kan de onderhoudsgerechtigde zijn vordering langs de gebruikelijke gerechtelijke wegen geldend maken en desnoods onder de directeur/werkgever beslag op het WPW-loon laten leggen.

Een volledige bestedingsvrijheid bij de gedetineerde sluit niet uit dat die zich voor hulp bij budgettering van het inkomen kan wenden tot het bureau sociale 
dienstverlening (BSD) in zijn inrichting of tot zijn reclasserings-maatschappelijk werker. Hij kan die diensten eventueel volmachten geven om namens hem van zijn loon bepaalde (periodieke) betalingen te doen.

Het uitdrukkelijk vermelden van de bevoegdheid om eenmaal verleende volmachten (onmiddellijk) te kunnen intrekken is, hoewel niet strikt noodzakelijk, belangrijk omdat door de inrichtingen nogal eens een vast bedrag per week of per maand wordt gevraagd voor het bekostigen van extra faciliteiten op het gebied van de persoonlijke verzorging en de recreatie. Het moet voor de gedetineerde duidelijk zijn dat hij niet tot aan zijn vrijlating aan een dergelijke volmacht vastzit.

\section{Art. 23 WSW}

1. Verrekening met het loon van de werknemers is behalve bij de beeindiging van de dienstbetrekking uitsluitend toegelaten wegens de volgende schulden:

a. de door de werknemer in verband met zijn dienstbetrekking aan de gemeente verschuldigde schadevergoeding;

b. de voorschotten, die op het loon van de werknemer zijn verstrekt;

c. het bedrag, dat op het loon van de werknemer te veel is betaald.

\section{Equivalent concept-WPW}

De directeur kan bij de periodieke loonberaling of bij het einde van de diensabetrekking uirslutend de colgende sclulden op het loon inhouden:

a. de door de gedetineerde tïdens zijn detentie aan het Rijk toegebrachte schade, mits de aansprakelijkheid daarvoor rechtens bij hem berust;

b. op het loon, verstrekte voorschotten;

c. te veel betaald loon.

\section{Toelichting}

Deze tekst is vooral belangrijk on wat er niét in staat. Met deze formulering is namelijk uitgesloten dat de directeur kosten van levensonderhoud, detentiekosten of kosten van welke andere aard dan ook: op het loon kan inhouden. Indien en voorzover de overheid de invoering van een genormaliseerd loon afhankelijk sielt van een bijdrage aan de kosten van het levensonderhoud dient deze 'aftrekpost' aan dit artikel te worden toegevoegd. De hoogte van een dergelijke eigen bijdrage kan het beste bij algemene maatregel van bestuur worden vastgesteld. Daarbij zou de wetgever zich kunnen richten naar de bedragen die dienstplichrge militairen aan levensonderhoud moeten betalen.

Om willekeur te voorkomen is, in afwijking van de regeling in artikel $61 \mathrm{GM}$, de mogelijkheid van parate executie op het loon van aan het Rijk toegebrachte schade beperkt. Als de gedetineerde werknemer de aansprakelijkheid berwist, zal er eerst of een overeenkomst tussen partijen betreffende de aansprakelijkheid en 
het schadebedrag moeten zijn, òf een rechterlijk gewijsde waaruit de aansprakelijkheid van de gedetineerde/werknemer blijkt.

\section{Art. 23a WSW}

Indien een werknemer ingevolge het bepaalde bij of krachtens artikel 6, tweede lid, 11 en 12 van de Algemene Wet Bijzondere Ziektekosten een. bijdrage verschuldigd is in de kosten van een verstrekking als bedoeld in de artikelen 6 en 11 van die wet of een vergoeding als bedoeld in de artikelen. 11 en 12 van die wet, is het gemeentebestuur bevoegd het loon tot ten hoogste het bedrag van die bijdrage in plaats van aan de werknemer zonder diens machtiging uit te betalen aan de Ziekenfondsraad.

\section{Equivalent concept-WPW}

Tekst gelijk aan die van artikel. 23a: WSW, behoudens vervanging van het woord gemeentebestuur door her woord directeur.

\section{Toelichting}

In de penitentiaire wereld is inhouding van een eigen bijdrage in het kader van de AWBZ geen ongebruikelijke figuur: de WAO en AAW kennen ook dergelijke bepalingen. Ze vindt toepassing bij personen die over een WAO of AAW-uitkering beschikken en in een inrichting voor terbeschikkinggestelden worden verpleegd. ${ }^{26}$

\section{Art. 24 WSW}

Het gemeentebestuur bevordert de oprichting en instandhouding van organen van overleg tussen de leiding van het werkverband en de werknemers.

\section{Equivalent concept-WPW}

De directeur bevardert de oprichting en instandhouding van organen van overleg tussen het hoofd van de Afdeling Arbeid en de werknemers.

\section{Toelichting}

De medezeggenschap van WSW-werknemers krijgt in het kader van de WSW vorm en inhoud in organen van overleg, te vergelijken met de medezeggenschapscommissies in het ambtenarenrecht en met ondernemingsraden in het burgerlijk arbeidsrecht. Voor de WSW is dit gedetailleerd uitgewerkt in het hierboven genoemde, vijftig artikelen tellende, 'Besluit organen van overleg sociale werkvoorziening'. 
De gemeentebesturen dienen er volgens art. 2 van dit besluit voor te zorgen, dat er in elk werkverband een zogenaamd orgaan van overleg (ovo) ingesteld en in stand gehouden wordt. Deze ovo's bestaan uit leden die door de tot het werkverband behorende werknemers rechtstreeks uit hun midden worden verkozen. Het aantal leden van een ovo is gerelateerd aan het aantal werknemers dat een werkverband telt en varieert tussen een minimum van 3 en een maximum van 15 leden. Stemgerechtigd zijn de personen die gedurende tenminste drie maanden in het werkverband werknemer zijn. Om verkiesbaar te zijn dient men tenminste een half jaar in het werkverband werknemer te zijn.

Elk ovo kiest uit zijn midden een voorzitter en één of meer plaatsvervangende voorzitters. De verkiezing van leden van een ovo geschiedt bij geheime schriftelijke stemming en aan de hand van een of meer kandidatenlijsten, die zowel door een vakorganisatie als door één derde gedeelte of meer ( 30 handtekeningen zijn genoeg) van de tot het werkverband behorende stemgerechtigden kunnen worden ingediend. Bij reglement worden de details van de verkiezingen geregeld.

De leden van een ovo treden om de twee jaar tegelijk af maar zijn terstond herkiesbaar. De werkwijze van het orgaan wordt bij reglement vastgesteld. Een ovo kan commissies instellen ter advisering over dan wel ter voorbereiding van de behandeling van bepaalde aangelegenheden en kan desgewenst een of meer deskundigen bij zijn vergaderingen uitnodigen.

Het gemeentebestuur moet voldoende vergaderfaciliteiten bieden. De vergaderingen van de ovo's en commissies daaruit vinden zoveel mogelijk tijdens de normale arbeidstijd plaats, waarbij de leden hun loon doorbetaald krijgen. De ovo-leden mogen (met behoud van loon) onder werktijd met elkaar overleggen en krijgen een aantal werkdagen per jaar de gelegenheid voor, door het werkverband betaalde, scholing en vorming, voorzover die bijdraagt tot de vervulling van hun taak als lid van het ovo.

De kosten van elke ovo en commissies daaruit komen ten laste van de exploitatierekening van het desbetreffende werkverband. De kosten van externe deskundigen kunnen ook voor rekening van het werkverband komen, voorzover het gemeentebestuur met de vergoeding daarvan akkoord is gegaan.

Het hoofd van het werkwerband of diens plaatsvervanger en het ovo komen tenminste zes maal per kalenderjaar in vergadering bijeen. Deze vergaderingen worden beurtelings door het hoofd van het werkverband of zijn plaatsvervanger en de voorzitter of plaatsvervangend voorzitter van het ovo geleid.

In de overlegvergaderingen worden angelegenheden, het werkverband betreffende, aan de orde gesteld ten aanzien waarvan hetzij het hoofd van het werkverband, hetzij het orgaan van overleg beraad wenselijk acht of waarover, ingevolge het bij of krachtens dit besluit bepaalde, overleg tussen het hoofd van het werkverband en het orgaan moet plaatsvinden.

Het gemeentebestuur zorgt er voor dat het ovo in de gelegenheid wordt gesteld om advies uit te brengen over te nemen besluiten met betrekking tot:

a. overdracht van de bestuurlijke zeggenschap over het werkverband of een onderdeel daarvan; 
b. belangrijke inkrimping, uitbreiding, verplaatsing of andere wijziging van de werkzaamheden van het werkverband;

c. beëindiging van de werkzaamheden van het werkverband of een belangrijk onderdeel daarvan;

d. belangrijke wijziging in de organisatie van het werkverband, dan wel in de verdeling van de bevoegdheden binnen het werkverband;

e. het doen van een belangrijke investering ten behoeve van het werkverband;

f. het verstrekken en het formuleren van een advies-opdracht aan een deskundige buiten het werkverband betreffende een der hiervoor bedoelde aangelegenheden.

Het gemeentebestuur behoeft de instemming van het ovo voor elk door hem te nemen besluit tot vaststelling, wijziging of intrekking van:

a. een reglement waarin de huishoudelijke regels van het werkverband zijn opgenomen;

b. een werktijd- en vakantieregeling;

c. een regeling op het gebied van de veiligheid, de gezondheid of welzijn in verband met de arbeid;

d. het deelnemen aan een spaarregeling als bedoeld in het Besluit premiespaarregeling sociale werkvoorziening;

e. een regeling met betrekking tot de toepassing van artikel 25 en 26 van de wet (betreffende voorlichtings- en scholingsactiviteiten, vakonderwijs en vormingswerk);

f. een regeling op het gebied van het aanstellings-, ontslag- of bevorderingsbeleid;

g. een regeling op het gebied van de personeclsbeoordeling;

h. een regeling op het gebied van het bedrijfsmaatschappelijk werk;

i. een regeling op het gebied van het werkoverleg.

In ariikel 31 van het Besluit organen van overleg wordt een algemene richriijn met betrekking tot het functioneren van een orgaan van overleg gegeven: '1. Het orgaan draagt zoveel als in zijn vermogen ligt bij tot de naleving van de voor het werkverband geldende voorschriften op het gebied van de arbeidsvoorwaarden voor zover deze van toepassing zijn op de werknemers, alsmede van de voorschriften ter bescherming van de veiligheid, de gezondheid en het welzijn in verband met de arbeid van de in het werkwerband werkzame personen'.

Als een gemeentebestuur een besluit neemt dat niet in overeenstemming is met een krachtens artikel 29 door een ovo gegeven advies kan dat orgaan daartegen bij de minister van Sociale Zaken en Werkgelegenheid beroep instellen (art. 37 e.v.). Andere geschillen tussen gemeentebestuur en ovo kunnen ter bemiddeling aan een zogenaamde commissie organen van overleg worden voorgelegd (artikelen 41, 43 e.v.). 
Het is duidelijk dat voorstellen tot invoering van vergelijkbare medezeggenschapsorganen in strafinrichtingen door de directies als even revolutionair zullen worden ervaren als destijds de invoering van het inmiddels ingeburgerde beklagrecht. Het verplicht instellen en instandhouden van een medezeggenschapsorgaan is immers wel heel iets anders dan het gedogen van een gedetineerdencommissie die, bij gebrek aan wettelijke basis, slechts een efemeer bestaan leidt. Directies hebben er blijk van gegeven niets te voelen voor verplicht overleg met 'hun' gedetineerden. De communicatie is binnen de muren traditioneel een verticale.

Het gelijkheidsbeginsel brengt met zich mee dat, bij invoering van een WPW waarbij de gedetineerde als werknemer wordt erkend, deze een recht op medezeggenschap verwerft dat vergelijkbaar is met dat van de 'vrije' arbeider en de ambtenaar. De in artikel 9 van het Arbeidsomstandighedenbesluit Justitiële Rijksinrichtingen bedoelde samenwerking tussen de directeur en de gedetineerden kan meteen in een nieuwe penitentiaire medezeggenschapsregeling vorm krijgen.

Klakkeloos kopiëren van de inspraakregeling zoals die in het kader van de WSW is geconstrueerd lijkt niet zinvol. Daarvoor is er -dank zij het relatief korte voorarrest, de relatief korte vrijheidsstraffen en het overplaatsingsbeleid te weinig continuïteit bij de bevolking van een penitentiaire inrichting. Dat noopt er toe om in ieder geval in de huizen van bewaring de medezeggenschap 'lichter' te organiseren dan in de gevangenissen. Zonder hier een uitgewerkt voorstel daarvoor te willen geven (een aparte studie is daarvoor zeker vereist) kan alvast wel worden opgemerkt dat medezeggenschapsorganen in huizen van bewaring slechts dán kunnen functioneren als hun voortbestaan van buitenaf wordt gewaarborgd. Daarbij valt te denken aan secretariële ondersteuning door de vakorganisaties die middels een zogenaamde buitensecretaris voor duurzaamheid zouden kunnen zorgen.

Ten aanzien van leden van de medezeggenschapsorganen in huizen van bewaring zouden sterke restricties met betrekking tot hun overplaatsing moeten gelden. Immers: de huidige penitentiaire wetgeving biedt geen effectieve rechtsmiddelen tegen gedwongen overplaatsing van het ene naar het andere huis van bewaring. Maar ook voor leden van overlegorganen in gevangenissen zou een speciale bescherming tegen gedwongen overplaatsing dienen te worden ingebouwd. Het zou anders voor de directies bij arbeidsconflicten te verleidelijk zijn om in hun ogen te actieve werknemers te neutraliseren door middel van overplaatsing.

Bij het concipiëren van een advies- en instemmingsrecht van WPW-werknemers zal het vrijwel onmogelijk zijn om arbeidskwesties strikt te scheiden van regiemsaangelegenheden. Competentieproblemen kunnen worden voorkomen door inspraak en medezeggenschap met betrekking tot de arbeid te integreren in een inspraak- en medezeggenschapsbeleid dat alle aspecten van de detentie omvat. Daarbij zou een nieuwe inhoud kunnen worden gegeven aan het bestaande artikel 16 van de Gevangenismaatregel dat luidt: 'De directeur bevordert het overleg en de onderlinge gedachtenwisseling in het gesticht. (...)'. 
Deze handelen over de bevordering van voorlichting, scholing, vakonderwijs en vormingswerk. Deze bepalingen behoeven geen vertaling in een WPW omdat de geldende penitentiaire regelingen ter zake het mogelijk maken dat deze activiteiten met behoud van loon onder werktijd kunnen geschieden.

(...)

\section{Art. $28 \mathrm{WSW}^{27}$}

1. Het gemeentebestuur beëindigt met inachmeming van het in artikel 29 bepaalde de dienstbetrekking, indien:

a. de werknemer gedurende twaalf maanden achtereen wegens arbeidsongeschiktheid zijn werk heeft verzuimd;

b. de werknemer passende arbeid onder normale omstandigheden kan gaan verrichten;

c. de werknemer de leeftijd van 65 jaar bereikt;

d. de werknemer of, ingeval deze minderjarig is dan wel onder curatele staat, hetzij de werknemer, hetzij zijn wettelijk vertegenwoordiger te kennen geeft de dienstbetrekking niet langer te willen laten voortbestaan;

e. blijkt, dat de werknemer zijn woonplaats buiten Nederland heeft gevestigd, tenzij artikel 47 ten aanzien van hem toepassing vindt;

f. aan de werknemer, geen Nederlander zijnde, verder verblijf in Nederland is geweigerd, behoudens indien hij, hangende de beslissing op een door hem op grond van de Vreemdelingenwet ingesteld beroep, niet wordt uitgezer.

2. Het gemeentebestuur kan de dienstbetrekking beëindigen, indien

a. de werknemer zich bij de vervulling van zijn dienstbetrekking emstig misdraagt;

b. de werknemer in ernstige mate de hem bij of krachtens deze wet opgelegde verplichtingen verwaarloost;

c. arbeid in de zin van deze wet nier langer beschikbaar is noch op korte termijn beschikbaar komt;

d. de werknemer niet langer in staat is tot arbeid in de zin van deze wet.

3. Behoudens in de in het eerste lid onder $c$, $d$, e en $f$ genoemde gevallen, hoort het gemeentebestuur de commissie en stelt het de werknemer in de gelegenheid zijn gevoelens kenbaar te maken, alvorens het de dienstbetrekking beëindigt.

\section{Equivalent concept-WPW}

1. De directeur beëindigt, met inachtneming van de in het volgende artikel genoemde termijnen, de dienstbetrekking indien:

a. de werknemer gedurende twaalf maanden achtereen wegens arbeidsongeschiktheid zijn werk heeft verzuimd; 
b. de werknemer nog gedurende zïn detentie passende arbeid onder normale omstandigheden kan gaan verichten;

c. de werknemer de leeftijd van 65 jaar bereikt;

d. de werknemer of diens wettelijk vertegenwoordiger te kennen heeft gegeven de dienstbetrekking niet langer te willen laten voortbestaan;

e. de werknemer wordt ontslagen uit detentie.

2. De directeur kan de dienstbetrekking schorsen en vervolgens eventueel beëindigen indien:

a. de werknemer zich bij de vervulling van zijn diensibetrehking ernstig misdraagt;

b. de werknemer in ernstige mate de hem bij of krachtens deze wet opgelegde verplichtingen verusaarloost.

c. de werknemer niet langer in staat is tot arbeid in de zin van deze wet.

3. De directeur kan de dienstbetrekking beëindigen indien arbeid in de zin van deze wet niet langer beschikbaar is noch op korte termijn beschikbaar komt.

4. Behoudens in de in het eerste lid onder $c$, $d$ en e genoemde gevallen hoort de directeur de commissie en stelt hij de werknemer in de gelegenheid zijn gevoelens kenbaar te maken alvorens hij de dienstbetrekking beëindigt.

\section{Toelichting}

De parallelliteitsgedachte brengt met zich mee dat - net zoals in het vrije bedrijf mogelijk is - een WPW-dienstverband ook opgezegd kan worden. Daarbij moet echter wel worden bedacht dat de gedetineerde/werknemer na een opzegging geen kant meer op kan: binnen de muren is de directeur nu eenmaal een monopolistisch werkgever. Daarom dient de directeur zijn opzeggingsbevoegdheid met grote terughoudendheid te gebruiken. Als er wordt ontslagen, dan dient de gedetineerde in beginsel de mogelijkheid te hebben om - desnoods na een bij a.m.v.b. te bepalen wachttijd -opnieuw te solliciteren. Datzelfde geldt voor 'spijtoptanten': gedetineerden, die hebben gewerkt, hebben opgezegd, maar toch weer aan de slāg willen. Bij een eventuele her-indienstneming wordt men niet automatisch in zijn oude baan herplaatst en komt men niet automatisch op zijn oude loonniveau terecht.

Om niet meteen naar het zware wapen van ontslag te hoeven grijpen, is in de concept-tekst de mogelijkheid van een schorsing van het dienstverband ingebouwd. Voorafgaande aan een voorgenomen schorsing of gedwongen ontslag wordt door de directeur (of namens hem door het hoofd van de afdeling arbeid) een rapport opgemaakt en door hem met de betrokken werknemer besproken. Daarna gaan de stukken voor advies naar de uit leden van de commissie van toezicht samengestelde werkvoorzieningscommissie. Deze dient de directeur van advies over de jegens de werknemer te ondernemen stappen. Vanzelfsprekend kan de voorzitter van die commissie een bemiddelende rol spelen.

Ad la (concept WPW): na de daar genoemde ziekteperiode, gedurende welke de werknemer een Ziektewet-uitkering ontvangt, zal hij dienen te worden ge- 
keurd voor de WAO. Bij volledige (80-100\%) arbeidsongeschiktheid in de zin dier wet wordt de dienstbetrekking beẻindigd. Wellicht dient er ruimte te zijn voor een gedeeltelijk ontslag als de arbeidsongeschiktheid op een lager percentage wordt vastgesteld en aanstelling in deeltijd mogelijk is.

Ad lb (concept WPW): hier kan men denken aan situaties waarin arbeidsbureaus gedetineerden vanuit penitentiaire open inrichtingen bij particuliere werkgevers kunnen plaatsen of vanuit die inrichtingen aan door derden gefinancierde bij- of herscholingen kunnen laten deelnemen. In centra voor dagdetentie zouden dergelijke -door of vanwege de arbeidswoorzieningsorganisatie betaalde - scholingscursussen kunnen plaatsvinden, zodat de daar geplaatste gedetineerden niet (langer) in WPW-dienstverband werken.

Ad lc (concept WPW): daarbij dient op grond van het gelijkheidsbeginsel (in uitvoeringsregelingen) wel een financiële voorziening te worden getroffen voor hen (bijvoorbeeld illegale vreemdelingen) die bij het bereiken van de 65 -jarige leeftijd geen ouderdomspensioen ontvangen en dus blijvend op arbeid als bron van inkomsten zouden zijn aangewezen.

Ad 1d (concept WPW): de parallelliteitsgedachte brengt vanzelfsprekend met zich mee dat ook de werknemer het dienstverband kan beëindigen. In verband met de planning van de arbeid in het werkobject lijkt het redelijk om ook de opzegging door de werknemer aan termijnen te binden, tenzij voortzetting van het dienstverband in alle redelijkheid en billijkheid niet van hem kan worden gevergd.

Ad le (concept WPW): het dienstverband eindigt van rechtswege door beëindiging van de detentie. Bij illegale afwezigheid (bij ontvluchting of niet tijdig terugkeren van verlof bijvoorbeeld) blijft het dienstverband bestaan. Echter: geen werk geen loon en de directeur kan besluiten het dienstverband te beëindigen omdat de werknemer door zijn absentie de verplichtingen die uit het dienstverband voortvloeien in ernstige mate verwaarloost.

Ad le en $1 \mathrm{f}$ van art. 28 WSW: er is geen equivalent in de concepttekst voor de WPW opgenomen omdat het gelijkheidsbeginsel met zich meebrengt dat ook gedetineerde buitenlanders (al of niet in het bezit van een geldige verblijfstitel) conform de normen van de WPW een dienstverband met de directic kunnen aangaan. $^{2 \mathrm{~s}}$

Ad 2 (concept WPW): de hier geintroduceerde schorsingsbevoegdheid vult de leemte op tussen niets doen, nader te noemen disciplinaire maatregelen en ontslag. In hoeverre een schorsing gevolgen voor de uitbetaling van het loon heeft dient in uitvoeringsregelingen te worden vastgelegd.

Ad $2 a$ en $2 b$ (concept WPW): over wat in de penitentiaire arbeids-context als ernstige misdraging of verwaarlozing van de werknemersverplichtingen moet worden begrepen zal jurisprudentie moeten worden ontwikkeld. Het laat zich denken dat de vele spanningen waaraan een gedetineerde blootgesteld is zich ook in zijn werkhouding en arbeidsprestaties zullen vertalen. Dat betekent dat bij berechting van arbeidsconflicten in volle omvang rekening moet worden gehouden met de detentie-omstandigheden van de werknemer. 
Ad 3 (concept WPW): bij onvrijwillige werkloosheid dient de ex-werknemer als verzekerde op de normale wijze in het genot van een werkloosheidsuitkering te worden gesteld. De desbetreffende wetgeving dient daaromtrent bijzondere bepalingen te bevatten. Zo kan een gedetineerde nu eenmaal niet beschikbaar zijn voor de vrije arbeidsmarkt, hetgeen één van eisen is waaraan men moet voldoen om voor een WW-uitkering in aanmerking te komen. Zij die bij onvrijwillige werkloosheid niet onder de werking van de WW vallen dienen in beginsel in aanmerking te komen voor een RWW-uitkering.

Het moge vanzelf spreken dat de uitkerende instanties nagaan of de directie wel genoeg moeite doet om voldoende werk voor de gedetineerden aan te trekken en niet te gemakkelijk de loonkosten op de bedrijfsverenigingen en gemeentes afwentelt.

Ad 4 (concept WPW): tenzij zich uiterst dringende redenen voordoen, die in het burgerlijk arbeidsrecht en het ambtenarenrecht ontslag op staande voet rechtvaardigen, zal de directeur nimmer eenzijdig het dienstverband mogen beëindigen als niet eerst een duidelijk signaal aan de werknemer is gegeven dat hij niet voldoet. Men kan daarbij denken aan periodiek te houden functioneringsgesprekken of beoordelingsgesprekken, naar ambtelijk model. In ieder geval dient, voorafgaand aan een ingrijpende beslissing als ontslag, een overleg- en adviesronde plaats te vinden. De werknemer wordt 'rapport aangezegd', vergelijkbaar met de procedure die aan de oplegging van een disciplinaire straf voorafgaat (artikel $100 \mathrm{GM}$ ). Een belangrijke, bij voorkeur bemiddelende, rol is hier weggelegd voor de werkvoorzieningscommissie uit de commissie van toezicht die, na kennisneming van het rapport en eventuele gesprekken met directeur en werknemer, de directie over de eventuele beëindiging van het dienstverband adviseert.

\section{Art. $29 \mathrm{WSW}^{29}$}

1. Indien artikel 28 , eerste lid, onder $a$, van toepassing is, wordt de dienstbetrekking beëindigd, zodra het daar genoemde tijdvak is verstreken.

2. Indien artikel 28 , eerste lid, onder b, van toepassing is, wordt de dienstbetrekking zo spoedig mogelijk beêindigd;

3. Indien artikel 28, eerste lid, onder c, van toepassing is, wordt de dienstberrekking beëindigd aan het einde van de maand waarin de leeftijd van 65 jaar wordt bereikt.

4. Indien artikel 28 , eerste lid onder $\mathrm{d}$, van toepassing is, wordt de dienstbetrekking op het door de werknemer onderscheidenlijk zijn wettelijke vertegenwoordiger gewenste tijdstip beëindigd.

5. (...).

6. Indien artikel 28 , tweede lid, onder a of b, van toepassing is, kan de dienstbetrekking worden beëindigd zonder dat daarbij een opzeggingstermijn in acht behoeft te worden genomen.

7. Indien artikel 28 , tweede lid, onder $c$, van toepassing is, wordt bij het beëindigen van een dienstbetrekking een opzeggingstermijn in acht genomen van zo- 
veel weken als de dienstbetrekking jaren heeft geduurd, met dien verstande dat de opzeggingstermijn ten minste twee en ten hoogste dertien weken bedraagt.

8. Indien artikel 28 , tweede lid onder $d$ van toepassing is, wordt de dienstbetrekking binnen een redelijke termijn beëindigd.

\section{Equivalent concept-WPW}

1. Als artikel 28 , eerste lid, onder a van ioepassing is, wordt de dienstbetrekking beëindigd zodra her daar genoemde iijdvak is verstreken.

2. Als artikel 28 , eerste lid onder $b$, van toepassing is, wordt de dienstbetrekking zo spoedig mogelijk beëindigd;

3. Als artikel 28 , eerste lid onder $c$, van toepassing is, wordt de dienstbetrekking beëindigd aan het eind van de maand waarn de leeftijd van 65 jaar wordt berikt.

4. Als artikel 28 , eerste lid onder $d$, van toepassing is, wordt de dienstbetrekking zo spoedig mogelijk, maar in ieder geval binnen 14 dagen na ontvangst van de desbetreffende kennisgeving, beëindigd.

5. Als artikel 28, eerste lid onder $e$, van toepassing is, eindigt de dienstbetrekking op de dag van het ontslag uit detentie.

6. Een schorsing als bedoeld in artikel 28, tweede lid, wordt in uren of dagen bepaald en kan maximaal 14 dagen duren. Het dienstverband kan terstond na afloop van de schorsing worden beëindigd.

7. Als artikel 28 , derde lid, van toepassing is, wordt bij het beëindigen van een dienstbetrekking een opzeggingstermijn in acht genomen van zoveel weken als de dienstbetrekking halve jaren heefi geduurd, met dien verstande, dat de opzeggingstermijn tenminste twee en ten hoogste derrien weken bedraagt.

\section{Toelichting}

De termijnen in het WPW-equivalent zijn aan de detentiesituatie aangepast. Daarbij kan elke termijn worden verkort door ontslag uit detentie: dan eindigt het dienstverband altijd.

De schorsingstermijnen kunnen worden gehanteerd als disciplinaire maatregelen. Daarbij dient er tegen te worden gewaakt dat die worden gebruikt als tuchtrechtelijke sancties als bedoeld in artikel $44 \mathrm{BWG}$, die voor heel andere dan arbeidsrechtelijke conflicten zijn geschreven.

Lid 2 van concept artikel 29 doelt op de situatie waarin een gedetineerde vanuit een penitentiaire open inrichting of een dagdetentie-centrum door derden betaalde arbeid of scholing ontvangt.

\section{Art. 30 WSW}

1. Ten aanzien van de werknemers worden bij of krachtens algemene maatregel van bestuur regelen of nadere regelen gesteld betreffende:

a. het loon en andere financiële aanspraken; 

b. de werktijden;
c. de aanspraken op vakantie en verzuim wegens bijzondere omstandigheden;
d. het opleggen van disciplinaire maatregelen.

2. Bij of krachtens algemene maatregel van bestuur kunnen regelen of nadere regelen worden gesteld betreffende de overige rechten en verplichtingen van de werknemers of de gewezen werknemers.

3. De regelen, bedoeld in het eerste en tweede lid, dienen zoveel mogelijk afgestemd te zijn op hetgeen met betrekking tot de arbeid onder normale omstandigheden rechtens geldt of gebruikelijk is, voor zover de lichamelijke of geestelijke gesteldheid van de werknemers geen afwijzing daarvan rechtvaardigt.

4. Bij of krachtens het eerste lid te stellen regelen kan met betrekking tot de werktijden worden afgeweken van het derde lid. In verband daarmee kan voorts zo nodig worden afgeweken van de overige krachtens het eerste en tweede lid gestelde regelen.

\section{Equivalent concept-WPW}

De tekst is, op het weglaten van lid 1d na, gelijk aan die van art. 30 WSW.

\section{Toelichting}

De belangrijkste uitvoeringsregelingen in het kader van de WSW zijn hierboven al ter sprake gekomen: het Besluit arbeidsvoorwaarden sociale werkvoorziening en het Besluit dienstbetrekking sociale werkvoorziening. ${ }^{30}$

Het Besluit dienstbetrekking sociale werkvoorziening bevat de bovengenoemde indeling van WSW-werknemers in een A- en een B-categorie, hetgeen bepalend is voor de loonschaal volgens welke men wordt betaald.

Het lijkt voor de penitentiaire praktijk het verstandigst om in de huizen van bewaring vanwege de grote 'omloopsnelheid' van de bewoners maar met én categorie, vergelijkbaar met de B-categorie, te werken. De werkzaamheden die daar worden verricht zullen door de relatief korte aanwezigheid van de gedetineerden telkens door iemand anders moeten worden verricht, zodat een goede afstemming van vraag en aanbod daar structureel onmogelijk is. Dat betekent, dat een aantal gekwalificeerde werkers onder hun niveau zal zijn ingeschaald. Enige differentiatie lijkt pas mogelijk in gevangenissen, waar door het langere tijdsperspectief planmatiger kan worden gewerkt. Voor gevangenissen zou men, als men ook wat dat betreft de vergelijking met de WSW regeling zou willen doortrekken, een A-categorie kunnen instellen, zij het dat men vanwege de geringere arbeidsmogelijkheden die gevangeniswezen, vergeleken bij de veel omvangrijkere sociale werkvoorziening, kan bieden, zou kunnen volstaan met een eenvoudigere indeling in groepen dan voor WSW-ers is voorzien in artikel 3 van het Besluit arbeidsvoorwaarden sociale werkvoorziening. Zo'n tweedeling lijkt enigszins op het onderscheid dat thans wordt gemaakt tussen inrichtingen waar de (in het tweede en derde hoofdstuk vermelde) zogenaamde experimentele loonregeling langgestraf- 
ten geldt en inrichtingen waar die niet geldt. Een belangrijk verschil tussen WPW en de experimentele loonregeling is dat in het kader van een WPW de door de werknemer verkregen rechten, zolang hij in enige gevangenis verblijft, behouden blijven. Bij overplaatsingen neemt de nieuwe directie de bestaande rechtspositie over, zij het dat een ander soort werk kan worden opgedragen dan werd verricht in de inrichting van herkomst. Als de dienstbetrekking niet is beëindigd om een van de in de WPW genoemde redenen, kan zelfs een tijdelijk verblijf als passant in een huis van bewaring daar niets aan afdoen. De rechtspositie 'kleeft' aan de persoon, niet aan een inrichting.

Een en ander brengt met zich mee, dat het onderzoek naar de arbeidsgeschiktheid en de arbeidscapaciteit bij nieuwe 'inkomsten' in huizen van bewaring niet zo diepgaand hoeft te zijn. Bij plaatsing in een gevangenis zal dat nauwkeuriger kunnen zijn omdat daar meer tijd en gelegenheid is om vraag en aanbod op elkaar af te stemmen. ${ }^{31}$ De desbetreffende selectie-adviescommissie (SAC) beschikt dan onder meer over de arbeidsgegevens, voorzover die althans in het penitentiair en/of inrichtingsdossier zijn geadministreerd.

Het zal echter nooit zo mogen zijn dat de vraag van een bepaalde inrichting naar arbeidskrachten met een bepaalde kwalifikatie doorslaggevend is voor de plaats waar men gedetineerd wordt. ${ }^{32}$ De aard van het gehele regiem en de nabijheid van familie-relaties zullen bij beslissingen omtrent plaatsing en overplaatsing groter gewicht in de schaal moeten leggen.

Het zal onvermijdelijk zijn om in de uitvoeringsregelingen bijzondere bepalingen op te nemen voor gevangenissen waar het werkaanbod noodzakelijkerwijs weinig gevarieerd is. Men denke aan de extra beveiligde inrichtingen waar maar weinig personen in opgenomen kunnen worden en waar men de gedetineerden uit veiligheidsoverwegingen nauwelijks gereedschappen ter beschikking wil stellen.

Voorts dient er een aparte regeling te komen voor penitentiaire open inrichtingen, van waaruit in beginsel bij een externe werkgever (mogelijk zelfs in een WSW-werkverband) wordt gewerkt.

Het 'Besluit dienstbetrekking sociale werkvoorziening' stelt een proeftijd van 2 maanden verplicht. Er is geen reden om ook zo'n proeftijd in cen WPW op te nemen: beide partijen zijn min of meer tot elkaar veroordeeld. Mislukt de arbeidsrelatie, dan zijn er altijd nog de wertelijke beëindigingsmogelijkheden.

Het 'Besluit arbeidswoorwaarden' bevat bepalingen over de loonaanspraken. Een vergelijkbaar op een WPW gebaseerd besluit zal die bepalingen niet onverkort kunnen overnemen.

Men zou bijvoorbeeld wèl als basis kunnen nemen dat de loonschaal van de B-categorie (werknemers die in de huizen van bewaring verblijven) begint met het wettelijk minimum(jeugd)loon dat voor het eerst na 6 maanden en vervolgens jaarlijks kan worden verhoogd. Dat laatste is rechtvaardig jegens hen die door het benutten van rechtsmiddelen relatief lang in voorlopige hechtenis verblijven en 
jegens bijzondere categorieēn zoais zij die lange tijd in vreemdelingenbewaring of gijzeling worden gehouden en daardoor geen kans hebben 'carrière' in de beter betalende gevangenis te maken.

De schalen, behorende bij de loongroepen van hen die in een gevangenis werken, beginnen met verschillende bedragen die per 'dienstjaar' kunnen worden herzien. Aan het einde van een loonschaal gekomen kan men eventueel in een hogere loongroep worden geplaatst.

Het 'Besluit arbeidsvoorwaarden sociale werkvoorziening' kent bepalingen omtrent doorbetaling van loon tijdens bepaalde algemeen erkende vrije dagen, bepaalde vormen van verlof en nog een aantal in artikel 8 van dat besluit genoemde gevallen. Het lijkt zinvol om in het kader van een WPW een aan de bestaande circulaires angepaste versie te ontwerpen. Wat in het penitentiare arbeidsrecht zeker een plaats moet vinden is een bepaling, vergelijkbaar met artikel 16a van laatstgenoemd Besluit, waarin - kort gezegd - het verrichten van vakbondswerk in de tijd van de werkgever met behoud van loon mogelijk is. Dat kan variëren van het bijwonen van bepaalde vergaderingen van de vakorganisatie ${ }^{33}$, vakbondsactiviteiten binnen de inrichting tot en met het - op uitnodiging van de vakorganisatie - volgen van bepaalde cursussen.

In navolging van het 'Besluit arbeidswoorwaarden sociale werkvoorziening' kan het penitentiaire equivalent een bepaling bevatten over pensioenrechten die door de werknemer kunnen worden opgebouwd.

Artikel 30 lid 1 onder d WSW behoeft geen WPW-equivalent nu die disciplinaire maatregelen volgens art. 17 van het Besluit arbeidsvoorwaarden uitsluitend verkorting van het verlof tot maximaal twee weken en schorsing voor diezelfde termijn inhouden. Verkorting van verlof lijkt in penitentiaire termen minder opportuun omdat dit meteen reclasseringskansen raakt. Ten aanzien van de schorsing is in het bovenstaande voorgesteld om deze sanctiemogelijkheid meteen in het artikel betreffende de beëindiging van het dienstverband op te nemen. Daarbij lijkt het niet verstandig om, naast de tuchtrechtelijke sancties en maatregelen die de BWG c.a. kennen, nog sancties op basis van de penitentiaire arbeidswetgeving te introduceren.

\section{Rechtsmiddelen voor de werknemer}

Het lijkt niet verstandig om de bezwaar-en beroepsprocedure, zoals die in de huidige WSW is neergelegd geheel of gedeeltelijk over te nemen in een WPW. Daarmee zouden twee verschillende rechters verregaande bemoeienis krijgen met belangrijke aspecten van het gevangenisleven: de Beklagcommissies en Beroepscommissie als bedoeld in de Beginselenwet Gevangeniswezen en de Sector Bestuursrecht, c.q. de Centrale Raad van Beroep. Ook al omdat de arbeid in de strafinrichtingen een integrerend onderdeel van het regime is en conflicten in de arbeidssfeer niet zelden zullen samenhangen met andere, niet specifiek arbeidsrechtelijke, interne kwesties, lijkt het terwille van de innerlijke samenhang van de 
uitspraken goed om één rechter met alle interne klachtzaken te belasten: de beklag- en beroepsrechter als bedoeld in de Beginselenwet Gevangeniswezen. Deze wet behoeft daartoe niet eens aangepast te worden. Immers een WPW zou een in het gesticht geldend voorschrift zijn als bedoeld in artikel 51, lid 1, sub c BWG. Zoals vooral in het tweede hoofdstuk duidelijk is geworden is de rol van arbeidsrechter voor de Beklagcommissies en de Beroepscommissie geen nieuwe: ook thans worden met grote regelmaat uitspraken over arbeidsrechtelijke aangelegenheden gedaan.

Als ooit een bijzondere regeling als een WPW tot stand zou komen, dan ware het overigens wel te overwegen om in 'WPW-zaken' de Beklagcommissies en de Beroepscommissies te laten voorzitten door een uit de Sector Bestuursrecht van de rechtbank afkomstige rechter.

Vergoeding van het Rijk aan de gemeente

\section{Art. 40 WSW}

1. Het Rijk kent jaarlijks aan de gemeente een vooraf door Onze Minisrer vastgestelde vergoeding toe voor door de gemeente te maken kosten ter zake van uitvoering van deze wet.

2 (...).

\section{Equivalent concept-WSW}

Het Rijk kent jaarlijks aan de directeur een vooraf door de Minister van Sociale Zaken en Werkgelegenheid in overleg met Onze Minister vastgestelde vergoeding toe voor door de directie te maken kosten ter zake van uitvoering van deze wer.

\section{Toelichting}

Overwogen moet worden de WPW als penitentiair equivalent van de WSW direct door SZW te laten financieren.

\section{Slotopmerkingen}

Inpassing van een bijzondere penitentiaire werkvoorziening in het stelsel van de sociale zekerheid heeft enige deregulerende effecten op het bestaande penitentiaire recht.

Opheffing van de arbeidsplicht maakt de artikelen 14 en 20 van het wetboek van strafrecht overbodig. Uit artikel $22 \mathrm{Sr}$ kan de zinsnede 'de arbeid, de bestemming van de opbrengsten van de verplichte arbeid' verdwijnen.

De Beginselenwet Gevangeniswezen kan worden ontdaan van titel VI waarin thans bepalingen omtrent arbeid en arbeidsloon zijn opgenomen. Uit de Gevan- 
genismaatregel kan Afdeling 4 worden geschrapt, die eveneens over arbeid en arbeidslonen handelt. De talrijke circulaires met betrekking tot arbeid en beloning kunnen aan de hand van de WPW en uitvoeringsbepalingen daarvan worden herzien, evenals de huishoudelijke reglementen van alle penitentiaire inrichtingen.

Invoering van een werkvoorziening als bedoeld in de hierboven geschetste WPW vergt voorts aanpassing van de Gevangenismaatregel in een aantal andere opzichten.

De bij elke inrichting aan te stellen adjunct-directeur, die hoofd van de afdeling arbeid is, zou als zodanig dienen te worden vermeld in de eerste afdeling van titel II van de Gevangenismaatregel.

Als, zoals hierboven voorgesteld in de toelichting op het WPW-equivalent van artikel 7 WSW, de gestichtsarts ontheven dient te worden van de plicht om gedetineerden op hun arbeidsgeschiktheid te controleren, dient de tweede zin van het eerste lid van artikel $45 \mathrm{Gevangenismaatregel} \mathrm{te} \mathrm{vervallen.} \mathrm{Op} \mathrm{basis} \mathrm{van} \mathrm{artikel} 46$ Gevangenismaatregel ("Volgens door Onze Minister te stellen regelen kunnen niet aan het gesticht verbonden geneeskundigen in consult worden geroepen (...)' kan bij circulaire worden uitgewerkt hoe de arbeidsgeschiktheid en arbeidscapaciteit in voorkomende gevallen door externe deskundigen (GMD) kunnen worden vastgesteld en gecontroleerd. De gestichtsarts blijft dan vóór alles huisarts van de gedetineerden.

Het lijkt noodzakelijk de commissies van toezicht te bemannen met personen die deskundig zijn op het terrein van de sociale werkvoorziening en die ook ervaring hebben met de behandeling van bezwaarschriften op dat gebied. Te denken ware aan leden van gemeentelijke werkvoorzieningscommissies. Zij zouden deel dienen uit de maken van de beklagcommissie ex art. 51 BWG bij de behandeling van zaken die uit de WPW voortvloeien. Een en ander maakt aanpassing van artikel 9 lid 2 GM noodzakelijk.

Daaraan zou een nieuw lid e kunnen worden toegevoegd, dat luidt: 'een deskundige uit de kring van de sociale werkvoorziening'. ${ }^{34}$

In een periode waarin het streven naar afslanking van de verzorgingsstaat het politieke debat kleurt lijkt het op zijn zachtst gezegd weinig opportuun om aan te dringen op de totstandkoming van een nieuw, althans aanvullend, stuk sociale zekerheid. De voomaamste reden om dat toch te doen ligt in de enorme rechtspositionele kloof die tussen de vrije en gedetineerde arbeider is gegroeid en die niet als inherent aan de vrijheidsstraf kan worden beschouwd.

De ruwe schets van zo'n nieuwe voorziening die hier gegeven is moge een bijdrage leveren aan de hernieuwde discussie over de gevangenis-arbeid, zoals die door de nota 'Werkzame detentie ${ }^{35}$ is geëntameerd. In zo'n debat zal het wenselijke door het mogelijke worden begrensd. De vrees is daarbij gerechtvaardigd dat de kosten-factor de arbeidsrechtelijke emancipatie van gedetineerden zal remmen. Op het eerste gezicht lijkt het creëren van een WSW-achtige regeling voor het gevangeniswezen bij de huidige stand van de overheidsfinanciën een illusie. 
Bij nadere beschouwing zou het met de betaalbaarheid van zo'n stelsel mee kunnen vallen. Tot nu toe ontbreekt bijvoorbeeld een overicht van de besparingen die optreden doordat afhankelijke familieleden geen beroep op de Bijstand hoeven te doen, doordat van een WPW loon belastingen en premies worden ingehouden en doordat normalisering van het loon in een hogere produktie zal resulteren. Een onafhankelijk onderzoek naar de financiële effecten van normalisering van het gedetineerdenloon lijkt dan ook een noodzakelijke voorwaarde orm tot een verantwoorde oordeelsvorming over een voorstel als het hier gepresenteerde te kunnen komen. Daamaast zou onderzocht moeten worden welke gevolgen invoering van een voorziening als de hier voorgestelde WPW op de arbeidsmarkt zou hebben, met name op de aansluiting van detentie-arbeid op reguliere arbeid. Het is mogelijk dat ook een verbeterde aansluiting besparingen voor de overheid oplevert.

Een andere vraag is, in hoeverre een orientatie op de WSW nog opportuun is nu deze sociale werkvoorziening ter discussie staat. De FNV heeft deze wet in 1992 tegen het licht gehouden in de nota 'Naar een geïntegreerde werkvoorziening ${ }^{36}$ Daarin wordt gesteld dat de sociale werkvoorziening in een isolement verkeert omdat de afstand tot de reguliere arbeidsmarkt te groot is en er amper een relatie is tussen WSW en de rest van het arbeidsvoorzieningenbeleid. De FNV stelt vast dat van de WSW-werkers maar $1 \%$ naar de reguliere arbeid doorstroomt. Intussen is in het kader van de zogenaamde sociale vernieuwing het arbeidsparticipatiebeleid van de overheid uitgebreid met nieuwe onderdelen als de 'Banenpool' en het Jeugdwerkgarantieplan. In het kader van de banenpool moeten langdurig werklozen aan zinvolle arbeid in de collectieve en non-profit sector worden geholpen. Het Jeugdwerkgarantieplan biedt werkloze jongeren tot 21 jaar en schoolverlaters tot 27 jaar na 6 maanden werkloosheid een werkgarantie van 32 uur per week, eveneens in de collectieve en non-profit sector. ${ }^{37}$ In tegenstelling tot bij de banenpool is doorstroming naar arbeid in de 'profit'-sector een wezenlijke doelstelling van het Jeugdwerkgarantieplan.

Het met betrekking tot de WAO gevoerde volumebeleid zal - aldus nog steeds het genoemde FNV-rapport - betekenen dat de WSW 'meer in beeld komt als reintegratie-instrument voor (gedeeltelijk)arbeidsongeschikten'. De FNV ziet als probleem dat de WSW, met cen wachtlijst van meer dan 10.000 personen 'min of meer op slot zit' en dat de doorstroming vrijwel nihil is. De relatie met de reguliere arbeidsmarkt dient groter te worden, maar in dat streven ondervindt de WSW concurrentie van de genoemde banenpool en het Jeugdwerkgarantieplan.

Het Nationaal Overleg Orgaan Sociale Werkvoorziening (NOSW) heeft als reactie op de beleidsnota 'Werkzame detentie' de Vaste Tweede Kamercommissie van Justitie laten weten bevreesd te zijn voor prijsvervalsing door de, wat het noemt, penitentiaire ondernemingen. Het NOSW formuleerde dit als volgt: 'De financieel geprivilegieerde positie van de penitentiaire onderneming zal bij een onvoorwaardelijke uitvoering van de beleidsdoelstelling leiden tot ongekend lage tariefstellingen die de marktprijs aanzienlijk zullen bederven. Dit marktbederf zal ook de bedrijven in de sociale werkwoorziening treffen. Juist op het moment dat 
deze bedrijven bij verdere beperking van het rijksbudget meer arbeidsplaatsen moeten genereren èn uit eigen inkomsten moeten financieren. Ongeclausuleerde uitvoering van de arbeids-aanpak in penitentiaire inrichtingen leidt dus tot geweldige sub-optimalisatie van financiering van rijkswege uit collectieve middelen: het effect van sociale werkvoorziening wordt door dit overheidsbeleid en deze financiering in belangrijke mate weg-geconcurreerd en teniet gedaan. ${ }^{33}$

In de bovengenoemde FNV-nota wordt gepleit voor een werkvoorziening nieuwe stijl. Daarvoor is volgens het FNV harmonisering van de regels bij JWG en banenpool nodig, met name ten aanzien van de prijsstelling voor de werkgevers. ${ }^{39}$ Daarnaast zouden WSW, JWG en Banenpool onder één uitvoeringsregime gebracht moeten worden en op lange termijn moeten worden geïntegreerd. Het lijkt dat de 'penitentiaire ondernemingen' aan dit lijstje kunnen worden toegevoegd.

Heeft het zin om met zo'n perspectief nog een op de WSW georiënteerde voorziening als de WPW te introduceren? Het antwoord kan bevestigend zijn, mits van meet af aan wordt gestreefd naar een maximale integratie daarvan in het bestaande arbeidsvoorzieningenbeleid en een categoriale voorziening voor gedetineerden bij de verdere ontwikkeling van zo'n beleid wordt 'meegenomen'. Daarbij kan een belangrijke rol zijn weggelegd voor een intermediaire organisatie als de reclassering. Door middel van een actieve arbeidsbemiddeling kan die bijdragen tor een betere arbeidsmarktpositie van haar cliënten. Dat arbeidsbemiddeling tot de hulpverleningstaak van de reclassering behoort is een standpunt dat door Zaad is verdedigd. ${ }^{10} \mathrm{Al}$ eerder was uit onderzoek gebleken dat arbeid en inkomen tot de belangrijkste terreinen behoren waarop reclassenten hulp en bemiddeling verwachten. ${ }^{41}$

Realiteitszin gebiedt te erkennen dat verbetering van de rechtspositie van gedetineerden nooit een populair onderwerp is geweest en dat ook wel nooit zal worden. Belangrijke wijzigingen in de bejegening van gedetineerden zijn niet zozeer de directe resultaten van een rationeel beleid geweest als wel de onbedoelde gevolgen van grote sociaal-economische veranderingen. Twee wereldoorlogen waren ervoor nodig om bij ons het mensonterende cellulaire stelsel afgeschaft te krijgen: de eerste zorgde voor een zodanige overbevolking dat het principe van '24 uur alleen op cel" niet meer overeind kon blijven; de tweede confronteerde zoveel mensen persocnlijk met de narigheid van het gevangeniswezen dat de hervormingsvoorstellen van de commissie-Fick mede daardoor in vruchtbare maatschappelijke aarde vielen.

Zeker, de rechtspositie van gedetineerden is in veel opzichten mee-geëvoilueerd met die van de vrije burger, maar altijd op afstand. Op allerlei, maar zeker op arbeidsrechtelijk, terrein lijkt de rechtspositionele kloof tussen de gedetineerde en zijn niet van zijn vrijheid beroofde medemens structureel. Straffen is kennelijk afstand nemen en afstand bewaren. Straffen is maar voor een deel een rationeel proces. Punitieve reacties op ongewenst gedrag lijken au fond vooral psy- 
chologisch en cultureel bepaald. Dat maakt elk debat over strafrechtelijke onderwerpen zo ongelofelijk lastig. Ook over schijnbaar puur technische kwesties als arbeid en beloning.

Een moeilijk te beantwoorden vraag is hoe de afschaffing van de arbeidsplicht en normalisering van de beloning van werkende gedetineerden op de politieke agenda kan komen en hoe vervolgens op dit terrein voor (en wellicht door) gedetineerden vooruitgang kan worden geboekt. Die vragen komen in het volgende en laatste hoofdstuk aan de orde. 
1. Wet van 23 november 1967, Stb. 687 (zoals sindsdien gewijzigd).

2. M. Cazemier-Kleij, Samenhang rondom de sociale werkvoorziening; een inventarisatie van knelpunten rond de sociale werkvoorziening, Sociaal en Cultureel Planbureau, Rijswijk maart 1985, bl. 11-13.

3. J.Z. Heijink en J.B. Terpstra, De sociale werkvoorziening in werking, Ministerie van Sociale Zaken en Werkgelegenheid, 1983, bl. 11.

4. M. Cazemier-Kleij, a.w., bl. 2:1-25.

5. M. Cazemier-Kleij, a.w., bl. 25-29.

6. Circulaire vain 26 april 1979 , nr. 280/379, P.I. 1980 , nr. 58.

7. H.A.J. Riegen en M.J. Toet, Wet Sociale Werkvoorziening, deel 7 van de losbladige serie Sociale Voorzieningen, Deventer juni 1991 (t/m supplement 21), commentaar bij art. 7 WSW, bl. 22, 24-40 en 61. RvS, Afdeling rechtspraak 15 mei 1981, JWWV/NSW $1981 / 53,4$ januari 1983, JWWV/WSW $1983 / 31$ en 8 november 1985 (WSW) R03.84.0674, JWWV/WSW 1986/21.

8. H.A.J. Riegen en M.J. Toet, a.w., bl. 24-41. Volgens deze commentatoren moet dit stuk sociaal recht: worden gezien tegen de achtergrond van enerzijds het recht op arbeid en anderzijds het recht op gezondheid.

9. Zie paragraaf 1.1 van Hoofdstuk II.

10. Ontleend aan M. Cazemier-Kleij, a. w., bl. 16-18.

11. H.A.J. Riegen en M.J. Toet, a.vi., bl. 23. Medebewind, het medewerking verlenen aan de uitvoering van wetten, algemene maatregelen van bestuur en provinciale verordeningen, wanneer deze dit vorderen, staat tegenover autonomic, dat regeling èn bestuur van eigen zaken betekent. Zie hierover C.W. van der Pot, Handboek van her Nederlandse Staatsrecht bewerkt door A.M. Donner, $8 \mathrm{e}$ druk, Zwolle: 1968, bl. 513-519.

12. De gemeenten zijn financieel siechts verantwoordelijk voor $20 \%$ van de tekorten op de exploitatierekeningen van de werkverbanden (zie art. 42 a WSW c.a.).
13. Rijksbegroting 1992, Hoofdstuk XV, Sociale Zaken en Werkgelegenheid, Tweede Kamer, 1991-1992, 22 300, nr. 1, bl. 3.

14. Ministerie van Sociale Zaken en Werkgelegenheid, Beleidsoperatie experiment budgetfinanciering decentralisatie en deregulering sociale werkvoorziening. Elindrapportage tussentijds evaluatieonderzoek, 's-Gravenhage 1991, blz. 5. Volgens de begroting van SZW voor 1992 loopr het experiment met de budget-financiering van 1989-1992, mer een mogelijke uitJoop tot de jaren 1993 en 1994 (a.w., MvT, bl. 48).

15. E.H. Limborgh, Problemen voor het management van een gemeentelijke dienst sociale werkvoorziening, proefschrift Technische Universiteit Twente, geen plaats van uitgifte vermeld, 1982 , bl. 16.

16. Besluit van 30 september 1968, Stb. 1968,519 , houdende regelen betreffende de dienstbetrekking ingevolge de Wet Sociale W'erkvoorziening (zoals sindsdien gewijzigd). 17. Besluit van 30 september 1968, Stb. 518 , houdende regelingen betreffende de arbeidsvoorwaarden van werknemers in een dienstbetrekking krachtens de Wet Sociale Werkwoorziening, laatstelijk gewijzigd bij Besluit van 18 juni 1990 , Stb. 343 .

18. Besluit van 24 december $1986, S t b$. 724 , houdende regelen inzake de oprichting en de instandhouding van organen van overleg ingevolge de Wer Sociale Werkvoorziening.

19. A.W.M. Bijloos, 'De Algemene wer bestuursrecht en het bijzondere sociale zekerheidsrecht', Nederlands; Juristenblad 7 januari 1994, afl. 1, bl. 41-44. Voorts: A.Q.C. Tak, De algemene wet bestuursnecht; het nieuwe bestuursprocesrecht, Zwolle 1993, bl. 47-49 en. 174-176.

20. E. Goffinan, Stigma: Notes on the Management of spoiled Identity, Englewood Clifts, New Jersey 1963.

21. J.Z. Heijink en J.B. Terpstra, a.w., bl. 79.-80. 
22. Net zoals bij de WSW is geschied dient er een regeling te komen voor cle eventuele samenloop van cen WPW-Ioon mer andere uitkeringen .

23. De afgewezenen zullen dan in beginsel aanspraak op een RWW-uitkering hebben, zij het dat daarop wegens het onvrijwillige van de werkloosheid een surafkorting kan worden toegepast.

24. Merkwaardigerwijs kent de thans voor gedetineerden geldende arbeidsplicht geen leeftijdsgrens.

25. Volgens artikel $2 \mathrm{AOW}$ is 'ingezerene' in de zin van die wet 'degene die in Nederland woont'. Waar iemand woont wordt volgens artikel 3 lid 1 AOW naar de omstandigheden beoordeeld. Als de plck waar iemand gedetineerd is door een ruime interpretatie van dit artikel als woonplaats in de zin van de AOW wordt beschouwd is men al als 'ingezetene', zoals bedoeld in artikel 6 lid 1 onder a van de AOW van ouderdomspensioen verzekerd.

26. Zie R. Verpalen en G. de Jonge (red.), Bajesboek; handboek woor voor gedetineerden en ter beschikking gestelden, Breda 1992, bl. 154155.

27. Zoals gewijzigd bij Wet van 2 december 1993, Stb. 1993, 649.

28. De Wet Arbeid Buitenlandse Werknemers (WABW) zou in die zin moeten worden aangepast dat illegale gedetineerde vreemdelingen voor het verrichten van penitentiaire arbeid in het kader van de WPWW geen tewerkstellingsvergunning nodig hebben.

29. Zoals gewijzigd bij Wet van 2 december 1993, Stb. 1993, 649.

30. Beide van 30 september 1968 , Stb. 1968,518 , resp. 519.

31. Er dient een uitvoeringsregeling te komen waarbij de functies van gestichts- en keuringsarts uit elkaar worden gehaald. De gestichtsarts dient voor alles 'huisarts' van de gedetineerde te zijn. Bij ziekmelding wendt hij zich tot de gestichtsarts. De controle op de ziekmeldingen geschiedt op basis van het bij en krachtens de Ziektewet bepaalde.

32. In $N R C-H B$ van'14 februari 1994. Hct liefst zou gevangenisdirecteur B. Molenkamp alleen nog gedetineerden verwelkomen dic op grond van hun werkervaring naar De Bosch- poort (strafinrichting te Breda-gdj) worden gestuurd, niet wegens hun criminele achtergrond, hun sekse of omdat ze toevallig in het arrondissement in hun kraag zijn gevat. 'Het gevangeniswezen moet zich specialiseren om straks hoogwaardige produkten te kunnen maken ', zegt hij.

33. Dat is mogelijk als verlof wordt verkregen de inrichting daartoe te verlaten.

34. De nummering is hier die van het equivalent van het WSW-artikel.

35. Werkzame detentic; beleidsnota voor het gevangeniswezen, Tweede Kamer, 1993-1994, 22 999, nrs. 10-11.

36. FNV, Naar een geintegreerde werkvoorziening - samenspel in het doelgebied -; de FNV. visie op de tockomstige ontwikkeling van de sociale werkwoorziening, (Amsterdam) 28 januari $1992,19 \mathrm{bl}$.

37. Het wordt druk in die sectoren, ook al omdat die in het kader van dienstverleningsprojecten voor strafrechtelijk meer- en minderjarigen wordt overstroomd met alternatief gestraften. Het gevaar is niet denkbeeldig dat die sectoren afhankelijk worden van die goedkope, zo niet gratis arbeid.

38. Brief van 14 maart 1994 van het Nationaal Overlegorgaan Sociale Werkvoorziening aan de vaste Tweede Kamercommissie van Justitie.

39. Volgens de FNV-nota kost personeel uit het Jeugdwerkgarantieplan een werkgever niets, iemand uit de Banenpool kost hem $f 2500$ per jaar en als hij cen WSW-er voor zich laat werken wordt hem daarvoor $f 15.000$ 's jaars in rekening gebracht (a.w. , bl. 10).

40. A. Zaad, 'Ik ga er werk van maken', ongepubliceerde scriptie, vermeld in het artikel 'Werk maken van werk zoeken' door S.

Schutte in het reclasseringsblad Vrijspraak, nr. 2, maart 1992, bl. 9.

41. J.L.P. Spickenheuer, Het reclasseringswerk: visies van cliënten en maatschappelijk werkers op het hulpverleningsproces, 's-Gravenhage 1984, bl. 38 . 


\section{Hoofdstuk VI}

\section{De penitentiaire arbeidsverhouding in abolitionistisch perspectief}

In dit afshitende hoofdstuk wordt de vraag behandeld of een streven naar normale arbeidsverhoudingen binnen de strafinrichtingen niet eerder bijdraagt tot bestendiging van het gevangeniswezen dan tot de uiteindelijke afschaffing ervan.

Na vastgesteld te hebben, dat eventuele penitentiaire beschavingsoffensieven, niet het gewenste resultaat kunnen sorteren en een streven naar normale arbeidsverhoudingen ook niet bijster goed lijkt te passen in een reductionistische aanpak, wordt met behulp van een door Lesting ontwikkelde normaliseringstheorie geconstateerd, dat de strijd tegen dwangarbeid en voor redelijke arbeidsvoorwaarden juist heel goed in een abolitionistische strategie lijkt te passen.

Blijft de vraag hoe zo'n strategie dan vorm zou moeten krijgen. Ervaringen uit het recente verleden wijzen erop dat de gedetineerden als groep nauwelijks invloed kunnen uitoefenen omdat ze enerzijds van buiten af niet langdurig te organiseren zijn en anderzijds intern geen positie als formele gesprekspartner hebben kunnen verwerven. Elk streven tot verandering op dit vlak zal moeten worden geïnitieerd door 'entrepreneurs', wier hoofddoel is het komen tot nieuwe regelgeving.

Op basis van een door d'Anjou ontwikkeld wetgevingsmodel wordt bezien welke problemen er dienen te worden overwonnen om te kunnen komen tot de realisering van een wet als waarvan in dit boek de omtrekken zijn geschetst. 
De gevangenis is in allerlei opzichten een mislukking, concludeert Mathiesen op grond van zijn onderzoek naar de mogelijke rechtvaardigingen voor dit instituut. Een gevangenis reclasseert niet, schrikt anderen niet af en kan de maatschappij niet voor strafbaar gedrag behoeden. Dat komt uit alle onderzoek op dit terrein naar voren.' Binnen de muren wordt mensen onrecht aangedaan. ${ }^{2}$ Dat het gevangeniswezen niettemin staad houdt komt volgens Mathiesen doordat het een antal functies wèl goed vervult, al wordt dat door de overheid nooit met zoveel woorden gezegd. Het gevangeniswezen kan namelijk onproduktieve elementen uit de maatschappij verwijderen, politiek verzet smoren en de aandacht van echt gevaarlijke gedragingen van de machthebbers afleiden. De gevangenis heeft vooral een symbool-functie: de eigen deugdzaamheid valt beter op tegen een achtergrond van erkende slechterikken: gederineerden. ${ }^{3}$

Een aantal mensen dat het met Mathiesen eens is, dat de gevangenis de burger als slachtoffer en als dader niets positiefs te bieden heeft en vooral machtspolitieke doeleinden dient, zoekt al decennia naar een strategie om dit nefaste instituut helemaal af te schaffen. Zo'n abolitionistische stellingname, hoe goed die ook valt te motiveren, is zó radicaal dat zij in ons gematigde politieke klimaat moeilijk 'verkoopbaar' is. Toch is zo'n keuze onontkoombaar voor hen (waaronder schrijver dezes), die op grond van eigen ervaring en van hun bekende onderzoeksresultaten inzien dat handhaving van de status quo dag in dag uit bij duizenden gedetineerden schade aanricht en bij tallozen een vals idee van veiligheid in stand houdt. De vraag is dan gerechtvaardigd of een streven naar een volwaardig arbeidsstatuut voor gedetineerden wel met een abolitionistische stellingname rijmen valt. Bestaat daarbij immers niet het gevaar dat eventuele verbeteringen juist leiden tot bevestiging en bestendiging van het bestreden systeem? Past de arbeidsrechtelijke emancipatie niet beter in een, wat Franke een 'penitentiair beschavingsoffensief noemt? Kan een dergelijke hervorming wellicht ook worden 'meegenomen' in de veel minder radicale reductionistische benadering van het gevangeniswezen?

In het onderstaande worden de laatste twee opties afgewezen en wordt aangegeven waarom een een strijd voor afschafling van de arbeidsplicht en voor een betere beloning juist wel in een abolitionistische strategie lijkt te passen.

De vraag is, in welke hervormingsstrategie een streven naar een volwaardig arbeidsstatuut voor gedetineerden het best tot zijn recht komt. brengen.

Een nadere beschouwing van genoemde denkrichtingen kan hier opheldering

\subsection{Het civilisatieproces als emanciperende factor}

In zijn letterlijk en figuurlijk monumentale studie over de geschiedenis van het gevangeniswezen in Nederland vanaf het einde van de achttiende eeuw beschrijft 
de criminoloog Franke in extenso welke veranderingen de materiële detentie-omstandigheden en de rechtspositie van gedetineerden in de loop der tijd hebben ondergaan. ${ }^{4} \mathrm{Hij}$ beschrijft de door hem waargenomen ontwikkelingen als een succesvol verlopen emancipatieproces, dat er zijns inziens de oorzaak van is dat de machtsbalans tussen gevangenen en hun bestraffers in de loop van twee eeuwen ten gunste van de gevangenen is verschoven.

Franke gebruikt het woord emancipatie overigens in verschillende betekenissen. Soms doelt hij daarmee op het bevrijd worden van onderdrukkende krachten, soms op wettelijke gelijkstelling en toekenning van gelijke rechten, soms op erkenning van specifieke behoeften, maar altijd op veranderingen die gevangenen meer kansen geven het gedrag van hun bestraffers te beheersen en te beïnvloeden en hun eigen gedrag te bepalen. Volgens deze auteur is het emancipatieproces van gevangenen het grotendeels onbedoelde gevolg van relatief autonome veranderingen in het penitentiaire stelsel en sociale ontwikkelingen. De verbetering van de positie van gevangenen vloeit volgens Franke voort uit het civilisatieproces, zoals dat door de socioloog Elias is beschreven en waarvan volgens Franke het kenmerkende is dat door een toenemende onderlinge afhankelijkheid de mensen op steeds meer terreinen van het sociale leven dwong rekening met elkaar te houden. 'Dit stelde telkens opnieuw hogere eisen aan hun zelfbeheersing en inlevingsvermogen. (...) Alleen vanuit de vanzelfsprekendheid die "beschaafd" gedrag voor mensen uit de maatschappelijke bovenlaag kreeg, zijn de pogingen te begrijpen, die zij vanaf het einde van de achttiende eeuw ondernamen om ook het gewone, in hun ogen losbandige volk via maatschappelijke dwang tot zulk gedrag te brengen'. 5

Als het door Elias beschreven civilisatieproces, in negatieve of positieve zin, een van de belangrijkste factoren is die bepalen hoe een maatschappij zijn gedetineerden behandelt, dan lijken hervormingspogingen - door Franke 'penitentiaire beschavingsoffensieven' - genoemd ${ }^{6}$ alleen kans van slagen te hebben in tijden waarin de afstand tussen de (im)materiële levensomstandigheden binnen en buiten de muren naar ieders gevoel te groot zijn geworden. Als het inderdaad zo werkt, blijven gedetineerden materieel en rechtspositioneel altijd 'trendvolgers'. De relatieve afstand tussen buiten en binnen blijft bestaan. Gedetineerden zijn veroordeeld tot een parallel burgerschap.

Is het algemene beschavingsniveau inderdaad maatgevend is voor de kwaliteit van het gevangenisregiem, dan zal volgens de uit deze theorie voortvloeiende 'wet van behoud van relatieve achterstand' de hier besproken arbeidsrechtelijke positie van gedetineerden nooit op gelijk niveau kunnen komen met die van de vrije arbeider. Voor abolitionisten is het voortbestaan van een dergelijk tweederangs burgerschap niet aanvaardbaar omdat zij de vrijheidsstraf niet als noodzakelijk kwaad, maar als onnodig leed beschouwen en haar daarom uit het sanctiepakket willen zien verdwijnen.

Hoewel Frankes - op Elias' civilisatietheorie gebaseerde - verklaring van de betere behandeling, die de Nederlandse gevangene in de loop der tijd ontegen- 
zeglijk ten deel is gevallen, niet zonder kritiek gebleven is ${ }^{7}$, verrijkt zij het debat over de hervorming c.q. afschaffing van de vrijheidsstraf. Vooral de door Franke in het penitentiair debat geïntroduceerde term 'emancipatie' lijkt heel bruikbaar, maar dan misschien eerder in zijn klassieke Romeins-rechtelijke betekenis van de beëindiging van een machtsrelatie, de emancipatio. Dat was een rechtshandeling waarmee een vader de absolute zeggenschap over zijn zoon prijs gaf en waardoor deze een persoon sui iuris werd, wat onder meer betekende dat die een eigen vermogen kon hebben. ${ }^{8}$ In abolitionistische termen vertaald zou dit betekenen dat een gedetineerde pas dan gemancipeerd is wanneer hij niet meer in de macht van de totale inrichting verkeert. De ultieme emancipatie van de gedetineerde is zijn onvoorwaardelijke invrijheidstelling.

\subsection{Hoe minder hoe beter: het reductionisme}

Er is een hervormingsstroming die het niet wil laten bij incidentele inhaalmanoevres (Frankes' penitentiaire beschavingsoffensieven) maar actief wil streven naar afslanking van het strafrechtelijk systeem. Haar aanhangers oefenen zware kritiek uit op de irrationele kanten van dat stelsel en wijzen daarbij vooral op het disfunctioneren van het gevangeniswezen. Het zijn geen die-hards die per se het strafrechtelijk systeem willen afschaffen. Wel willen zij dat er vanwege de talloze schadelijke neven-effecten een minimaal gebruik van wordt gemaakt. Dit zijn de reductionisten.

Een belangrijke woordvoerder van deze denkrichting is de Brit Rutherford die als voorzitter van de Engelse Howard League for Penal Reform zijn theorieën neerlegde in het boek 'Prisons and the Process of Justice'. Daarin betoogt hij dat de reductionistische benadering van het strafrechtelijk systeem gebaseerd is op het uitgangspunt dat het gevangeniswezen aanzienlijk in omvang kan afnemen door het alleen te bestemmen voor personen die van ernstige criminaliteit worden verdacht of daarvoor zijn veroordeeld. In het kader van een reductionistisch alternatief wordt naar strategieën gezocht waarmee de lichtere gevallen buiten het gevangenis-systeem kunnen worden gehouden en waarmee ze, als ze toch gedetineerd zijn geraakt, daar snel weer uit kunnen worden geloodst.

Een van de kenmerkende eisen van de reductionisten is dat het aantal gedetineerden niet mag worden bepaald door autonome bureaucratische factoren die zorgen voor fluctuaties in de 'instroom' in de strafinrichtingen, maar dat het justitiële apparaat moet worden gedwongen de influx af te stemmen op een gebouwelijk beperkte, politiek gefixeerde, celcapaciteit. Tot het gedachtengoed van de reductionisten behoort ook de notie dat de clientèle van Justitie kan worden beperkt door decriminalisering (het schrappen van overbodige strafbepalingen) en door depenalisering (het verlagen van de strafmaat voor gedragingen die wel strafbaar blijven). Rutherford citeert met instemming Hulsmans pleidooien voor een zoveel mogelijk civielrechtelijke afdoening van conflicten, die nu aan het strafrechtelijk handhavingsapparaat worden toebedeeld. ${ }^{9}$ Daarmee geeft hij impliciet eigenlijk an dat reductionistische opties zeer wel met abolitionistische kunnen 
worden verbonden. Een dergelijke opstelling kan men bijvoorbeeld ook bij de strafrechthervormers van de Coornhert-Liga waarnemen. Tijdens een studiedag over de capaciteit van het Nederlandse gevangeniswezen op 3 juni 1988 (met Rutherford als gastspreker) stelde de Liga zich op het standpunt 'dat de ideale omvang van onze gevangeniscapaciteit de minimale is: toereikend om die mensen op te sluiten waarvoor een andere wijze van afdoening niet binnen het bereik ligt. Een fixatie van capaciteit is daarvoor een voorwaarde. En of het aantal cellen nu gesteld dient te worden op 3000, 3500 of 4000 is van ondergeschikt belang. Het gaat er om de belangrijkste groeisector van ons strafrechtelijk systeem in te dammen opdat echte alternatieven voor de gevangenisstraf tot ontwikkeling kunnen komen. Het ontwikkelen van alternatieven gaat niet vooraf aan het terugdringen van de vrijheidsstraf. Eerst zal oplegging van de vrijheidsstraf bemoeilijkt moeten worden voordat een anders gerichte ontwikkeling kan doorzetten. Onder wat dwang en drang komen de alternatieven vanzelf.${ }^{10}$ Hier nam de Coornhert-Liga een reductionistisch standpunt in terwille van een verder reikend, abolitionistisch, doel: het vervangen van de strafrechtspleging door andere reactie-systemen.

Ook de Nijmeegse criminoloog Fiselier (lid van de Centrale Raad voor Strafrechtstoepassing) heeft gepleit voor het fixeren van de beschikbare gevangenisruimte. Deze 'reductionist' wil het aan een te creëren Raad voor de Straftoemeting overlaten 'te bepalen hoe deze - gegeven het criminaliteitsaanbod - zou moeten worden benut. Dat dwingt tot het stellen van prioriteiten en het maken van keuzen in plaats van het bouwen van nog meer gevangenissen'."

Deze 'minimalisten' gebruiken wel, daar waar het speelt, het probleem van de overbevolking van cellen om hun standpunt kracht bij te zetten, maar houden zich niet per se met de kwaliteit van de detentie-omstandigheden of met de rechtspositie van gedetineerden bezig. Zij concentreren zich op de vraag hoe zo min mogelijk personen naar het strafrechtelijk systeem gesluisd kunnen komen en hoe mensen die daar tóch in verzeild zijn geraakt zo snel mogelijk en met zo min mogelijk schade daar weer uit weg kunnen komen. Een streven naar hervorming van het arbeidsrechtelijk statuut van gedetineerden, zoals hier wordt bepleit, lijkt dan ook nauwelijks op de reductionistische agenda te passen.

\subsection{Het abolitionisme als leidend beginsel}

De strijd van gedetineerden tegen arbeidsdwang en voor een ècht loon lijkt wel een factor van betekenis te kunnen zijn binnen een abolitionistische strategie. Alvorens daar nader op in te gaan lijkt het zinnig om eerst de term abolitionisme te preciseren. De term werd oorspronkelijk gebruikt voor het streven naar de afschaffing van de slavernij aan het begin van de $19 \mathrm{e}$ eeuw in Engeland en Ameri$\mathrm{ka}$. In het actuele debat over criminele politiek moet volgens Van Swaaningen abolitionisme worden verstaan als een streven naar afschaffing van strafrechtelijke dwangmiddelen. De abolitionistische benadering van het strafrechtelijk systeem is van betrekkelijk recente datum. Zij spruit volgens Van Swaaningen voort uit een beweging onder de Amerikaanse Quakers, die aan het begin van de tach- 
tiger jaren van déze eeuw zich voor de afschaffing van de gevangenisstraf begonnen in te zetten, en uit de theorieën van twee Noren: Christie en Mathiesen. Deze laatsten begonnen zich ongeveer tezelfdertijd tegen het hele strafrechtelijk systeem en met name tegen de kern daarvan, de gevangenis, te keren en inspireerden daarmee een aantal Europese academici, waaronder de Nederlandse hoogleraren Hulsman en Bianchi. ${ }^{12}$

$\mathrm{Na}$ het emeritaat van de twee Nederlandse protagonisten van het abolitionisme lijkt het, vanwege zijn radicaliteit vaak misverstane ${ }^{13}$, abolitionisme voorlopig van het academische toneel te zijn verdwenen. Het abolitionisme is hier nooit 'salonfähig' geworden. Aan geen enkele universiteit wordt nog stelselmatig gewerkt aan de verdere ontwikkeling van die theorie. Het aantal onderzoekers en praktijkmensen die het streven naar afschaffing van het strafrecht als Leitmotiv voor hun handelen zien is uiterst gering. Hoezeer een enkele hooggeleerde, mèt Hulsman, afscheid zou willen nemen van het strafrecht toch durft men zoals in dit geval Tulkens, die finale stap te zetten vanuit de overtuiging, dat de bevestiging en handhaving van normen een zichtbaar en gezaghebbend instrument vereisen. ${ }^{14}$

Maar, ook al kan het abolitionisme geen nationale of internationale beweging of stroming worden genoemd, dat doet weinig af aan de kracht van de onder die noemer ontwikkelde kritiek op het strafrechtelijk systeem. ${ }^{15}$

Wat is nu de essentie van de kritiek van de abolitionisten op het strafrecht zoals dat in Nederland functioneert?

Een van de kernpunten van Bianchi's kritiek betreft de 'artificiële consensus' die, in zijn visie, in het strafrecht de specifieke posities van de betrokken partijen toedekt. Hij wil die schijn-eensgezindheid vervangen door conflicten te behandelen volgens een, wat hij noemt, assensus-model, waarin ervan wordt uitgegaan dat er nooit overeenstemming zal bestaan over de interpretatie van normen en waarden, maar partijen het wel eens kunnen worden over een oplossing of een voor beiden acceptabele regeling. 'Assensus hoeft niet per se te leiden tot een onderhandeling tussen duidelijk individualiseerbare daders en benadeelden, maar kan ook worden gezien als een gesprek tussen groepen verwanten dic partijen bijstaan of tussen belangenbehartigers als vakbonden, vrouwenbeweging, overheid et cetera. Het is een accusatoir proces, waarin het probleem in bredere zin dan de juridische wordt besproken, zonder dat een bemiddelaar een oplossing forceert'. ${ }^{16}$

Hulsman, die als strafrechtjurist met praktijkervaring de feilen van het strafrechtelijk systeem scherper kon analyseren dan de wellicht ietwat te romantisch ingestelde criminoloog Bianchi, vergeleek al in 1968 de opvarting, dat strafrechtelijke leedtoevoeging 'vereffenend' zou kunnen werken, met het heksengeloof uit vroeger eeuwen. De vrijheidsstraf noemde hij toen nog heel voorzichtig 'een van de minst gelukkige sancties'. ${ }^{17}$ Daarmee presenteerde hij zichzelf nog niet als abolitionist. In eerste instantie verweet hij de wetgever en strafrechtsplegers vooral een gebrek aan rationaliteit en meende dat, bij een verstandig gebruik van de beleids- en straftoemetingsvrijheid die de diverse strafrechtelijke diensten binnen ons systeem bezitten, het strafrecht zinvol kon worden gehanteerd..$^{18}$ Die hoop 
verdampte in de loop der tijd. Hij kwam tot de overtuiging, dat het strafrechtelijk systeem zó irrationeel was dat het niet meer te redden viel en beter helemaal kon verdwijnen. "Ik ben in de loop van de tijd na een langdurige omgang met strafrechtelijke systemen (...) tot de conclusie gekomen dat belangrijke aspecten van die strafrechtelijke werkelijkheid verwerpelijk zijn, in het bijzonder ook de strafrechtelijke ideologie, dat wil zeggen de denkbeelden over die strafrechtelijke werkelijkheid die aan vrijwel elk officieel discours en de meeste niet-officiële discours ten grondslag liggen. Daaruit trek ik de conclusie dat het wenselijk is te streven naar afschaffing van strafrechtelijke systemen. Hoe dat kan worden bevorderd is een kwestie van veranderingsstrategie, en als zodanig een apart vraagstuk (...)'.19

In misschien wel de belangrijkste publikatie van zijn gedachtengoed, het boek Peines perdues, liet hij zijn ontwikkeling in de richting van het abolitionisme door Jacqueline Bernat de Celis als volgt optekenen: 'Het boek van Thomas Mathiesen "Politics of Abolition"20 heeft op dat punt een grote rol in mijn denken gespeeld. Ik was er helemaal rijp voor. Er staan zoveel onthutsende dingen in dat boek. Het is ook zo persoonlijk geschreven... Een beetje als de Bijbel. Het is ook niet àf en dat vind ik zo belangrijk'. ${ }^{21}$ Hulsman werd nooit moe erop te wijzen dat uit gedragswetenschappelijk onderzoek is gebleken dat met name de vrijheidsstraf niemand vooruit helpt en dat gevangenen van hun persoonlijkheid worden beroofd en worden gedesocialiseerd. Zijn boodschap is duidelijk: het strafrechtelijk systeem is een maatschappelijk kwaad en moet worden afgeschaft. ${ }^{22}$

Blad, Van Mastrigt en Uildriks onderscheiden in de theorieën van hun leermeester Hulsman vier hoofdmotieven voor een dergelijke radicale stellingname. In de eerste plaats brengt het strafrechtelijke systeem leed toe aan personen die voor het merendeel toch al een marginaal bestaan leiden. Ten tweede beantwoordt het strafrechtelijk systeem niet aan zijn eigen doeleinden: het draagt niet bij tot preventie of oplossing van als criminaliteit gedefinieerde problemen. Een derde punt van Hulsmaniaanse kritiek betreft de fundamentele onbeheersbaarheid van het strafrechtelijk systeem: verdachte noch slachtoffer hebben enige invloed op het resultaat van de strafrechtelijke bemoeienis: het conflict wordt partijen ontstolen door volstrekt los van elkaar opererende strafrechtelijke diensten. Het vierde en meest fundamentele punt van kritiek is dat de hele strafrechtelijke benadering niet deugt, dat begrippen als 'misdaad' en 'misdadig' alleen maar geschikt zijn om inhoudelijk volstrekt niet op elkaar lijkende gebeurtenissen te criminaliseren, terwijl een standaard-antwoord in de vorm van een straf niet a prio$r i$ als de meest effectieve reactie daarop kan worden beschouwd. ${ }^{23}$

Hervorming van het strafrechtelijk stelsel is volgens Hulsman onmogelijk. Ook niet van het gevangeniswezen, waarin het gewelddadige karakter van het strafrecht is geconcretiseerd en gesymboliseerd. Het was hem opgevallen hoe weinig vooruitgang hervormingsbewegingen boeken die, vanuit een gevoel van solidariteit met gedetineerden, de gevangenis willen humaniseren.

'Ik heb echt hervormingsgezinde mensen zich verschrikkelijk zien inspannen voor futiele resultaten, bijvoorbeeld dat na een jaar strijd gedetineerden een kwar- 
tier televisie mochten kijken'. Een strategie die zich richt op veranderingen binnen de laatste fase van het strafrechtelijk proces acht hij niet effectief. Men moet zich volgens hem richten op de voorkant van het systeem, daar waar wordt uitgemaakt wie uiteindelijk gedetineerd zullen worden. Het gaat hem dus bepaald niet alleen om de afschaffing van het gevangeniswezen of de afschaffing van de vrijheidsstraf: 'wat mij betreft moet het hele strafrechtelijke systeem verdwijnen'. En: 'We hebben een nieuwe taal nodig, waarmee mensen en leefsituaties niet worden gestigmatiseerd. Zo kan men bijvoorbeeld spreken van "betreurenswaardige daden", "ongewenst gedrag", "betrokken personen" en "probleemsituaties" om een nieuwe mentaliteit te creëren. Daarbij moet men overigens geen nieuwe termen op oude begrippen plakken: heel wat gedragingen kunnen worden gedecriminaliseerd en het civiele recht zou ook een bepaalde rol kunnen spelen'. ${ }^{24}$ Daarmee deelt Hulsman Foucaults pessimisme over de strategische waarde van pogingen om het penitentiaire stelsel te hervormen. Foucault heeft erop gewezen dat al zolang er gevangenissen zijn men heeft geprobeerd die te hervormen. Men probeert voortdurend iets aan het gevangeniswezen te vertimmeren. Dat streven is een onderdeel van het systeem zelf geworden. ${ }^{25}$

De stelling, dat het zinloos is om te proberen het gevangeniswezen te hervormen is echter betwistbaar. Hulsmans' abolitionistische inspirator Mathiesen heeft zijn 'Politics of Abolition' juist voor een belangrijk deel ontwikkeld op basis van de strijd van de Noorse hervormingsbeweging KROM tegen het gevangeniswezen. Mathiesen heeft dat bepaald niet een zinloos gevecht genoemd. Integendeel. Hij heeft die ervaringen proberen in te passen in een strategie waarin een streven naar korte-termijn hervormingen niet tot versterking en legitimering van het bestaande systeem leidt, maar bijdraagt aan de afschaffing van dat systeem op lange termijn. Daartoe maakte hij een onderscheid tussen positieve en negatieve hervormingen.

Positieve hervormingen definieerde hij als veranderingen die het bestaande systeem verbeteren of uitbouwen, met als gevolg, dat het effectiever werkt, beter wordt gelegitimeerd en dus moeilijker af te schaffen wordt. Negatieve hervormingen beschreef hij als veranderingen die min of meer essentiële onderdelen van het systeem aantasten en doen verdwijnen.

Mathiesen meende dat men - als men een bepaald systeem op de lange duur wil afschaffen - zeer wel óók aan korte-termijn negatieve hervormingen kan werken. Alleen wanneer dat consistent gebeurt kan men aan het dilemma tussen korte- en lange-termijn doelen ontkomen. Abolitionistische actie op een beperkt terrein als het gevangeniswezen, is volgens deze auteur echter alleen realistisch wanneer die gekoppeld is aan een bredere abolitionistische strijd, anders wordt elk 'bevrijd' gebied onmiddelliik weer door het bestaande stelsel ingepalmd. ${ }^{26}$

Mathiesen vindt dat hervormers zich door de gevestigde instanties niet tot het formuleren van sluitende alternatieven moeten laten verleiden. Hij ziet in het idee van 'the unfinished' een belangrijke inspiratiebron voor abolitionisten.

Deze opvatting en verschillen van mening over de vraag welk soort van voorgestane hervormingen als negatief (systeembedreigend) en welk soort als positief 
(systeembevestigend) moest worden beschouwd maakten het hervormers bijzonder lastig om een praktisch hanteerbare abolitionistische strategie te formuleren.

De criminoloog Lesting heeft aangegeven hoe deze impasse voor wat betreft de strijd tegen het gevangeniswezen zou kunnen worden doorbroken.

\subsection{Lestings normaliserings-concept}

De Bremer hoogleraar strafrecht en criminologie en specialist op het terrein van het penitentiaire recht Johannes Feest meent dat een 'strategie van normalisering' een instrument van negatieve hervorming van het gevangeniswezen zou kunnen zijn. In plaats van het opstellen van minimumregels voor de bejegening van gedetineerden (zoals bijvoorbeeld de Europese Gevangenisregels) dient er volgens hem gestreefd te worden naar maximale normalisering van het leven in de gevangenis.

'Hoewel dit nooit en nergens helemaal kan slagen in totalitaire instellingen, zal het wel een gezonde spanning veroorzaken, een gezond gevoel voor "the unifnished"; het model voor het open alternatief, zoals Mathiesen heeft ontwikkeld, aldus Feest. ${ }^{27} \mathrm{Hij}$ refereerde daarbij aan het boek van zijn medewerker Lesting,Normalisierung im Strafvollzug, waarin deze de relatie tussen 'normalisering' en abolitionisme heeft uitgewerkt. ${ }^{28}$

Lestings betoog over normalisering is gebaseerd op een abolitionistische interpretatie van het tweede lid van artikel 3 van het Duitse equivalent van onze Beginselenwet Gevangeniswezen, het Strafvollzugsgesetz (StVollzG.). Daarin is bepaald dat het leven tijdens de tenuitvoerlegging van de vrijheidsstraf zoveel mogelijk moet lijken op dat buiten de muren. ${ }^{29}$ Daarmee doelt het StVollzG. niet zozeer op de rechtspositie als wel op de materiële omstandigheden van gedetineerden. Lesting gebruikt voor dit formeel vastgelegde streven naar gelijkschakeling van het leven binnen en buiten de muren de term normalisering. Onder normalisering als strategie verstaat hij het streven naar gelijkschakeling van de juridische en maatschappelijke positie van gedetineerden aan die van de vrije burger. Wat hij daar niet onder verstaat is her ijveren voor maatregelen die de negatieve kanten van de vrijheidsbeneming moeten verzachten. Lesting gebruikt 'normalisering' ook niet in de zin van gedwongen aanpassing of als het resultaat van disciplinering in Foucauldiaanse zin.

Lesting wil onderzoeken of het streven naar normalisering van het gevangenenbestaan een bruikbare strategie voor gevangenishervorming is. Eén van de argumenten pro normalisering is dat door het verminderen van de verschillen tussen het leven in de gevangenis en dat in de vrije maatschappij de vrijheidsstraf aan belang inboet, hetgeen de afschaffing van gevangenissen dichterbij zou kunnen brengen. Daartegen wordt wel ingebracht dat elk normaliseringsstreven zal afstuiten op het in 1843 door Jeremy Bentham geformuleerde less eligibility-begin- 
sel, dat inhoudt dat, wil de gevangenis zijn afschrikwekkende werking behouden, de levensomstandigheden daar altijd net iets slechter dienen te zijn dan die van de laagst geklasseerde vrije burger. ${ }^{30}$

Dit uitgangspunt acht Lesting in het huidige tijdsgewricht niet langer houdbaar. Volgens hem zit het afschrikwekkende van de vrijheidsstraf niet langer in de detentie-omstandigheden. Door de enorme opwaardering van de vrije tijd ligt de afschrikwekkende werking (als daar al van kan worden gesproken) besloten in de vrijheidsbeneming zèlf: het niet meer zelf kunnen bepalen hoe en waaraan men zijn tijd besteedt. ${ }^{31}$

Lesting wijst erop dat normalisering overigens ook in omgekeerde richting kan plaatsvinden, bijvoorbeeld doordat door bepaalde ontwikkelingen buiten de muren 'buiten' steeds meer op 'binnen' gaat lijken. Deze waarschuwing heeft bepaald niet louter theoretische waarde. Zo is er in Nederland in 1991 op basis van de vrijwel geheel uit justitieambtenaren bestaande Overleg- en Adviescommissie Alternatieve Sancties (OCAS) een debat op gang gekomen over de uitbreiding van het sanctie-arsenaal met een nieuwe straf die 'vrijheidsbeperking' wordt genoemd. Invoering daarvan geeft de rechter de mogelijkheid om met allerlei ge- en verboden de gedragsalternatieven van niet-gedetineerde veroordeelden zodanig te beperken dat het verschil van hun positie met die van gedetineerden alleen ligt in het ontbreken van gevangenismuren rond hun verblijfplaats. Daarbij hoeft een in zijn vrijheid 'beperkt' individu maar één rechterlijk ge- of verbod te overtreden of hij wordt door de hem controlerende gedragsdeskundigen aangegeven bij het openbaar ministerie, dat vervolgens de andragogische tralies door ijzeren vervangt. Uit het OCAS-rapport blijkt een streven om de strafsanctie zowel binnen als buiten de muren tot een inspanningsverplichting om te vormen. Rustig je tijd uit zitten of een girootje overmaken is niet meer genoeg. De bestraffer wil als het ware de ziel van de veroordeelde hebben. Laatstgenoemde zal de autoriteiten zijn gehoorzaamheid moeten tonen door zich gedurende een bepaalde periode op een voorgeschreven wijze te gedragen en te uiten. Aan beide kanten van de muur zal dat hetzelfde zijn. ${ }^{32}$ Buiten gaat het om een activiteitenprogramma, binnen om een regiems-activiteitenprogramma, zoals blijkt uit het wetsontwerp 'Herziening differentiatiestelsel gevangeniswezen' ${ }^{33}$ Koren op de molen van de conservatieve strafrechtsgeleerde Th.W. van Veen, die tijdens het op 26 september 1991 aan deze ideeën gewijde symposium 'Sanctietoepassing: een nieuwe ordening' de zaal de retorische vraag stelde: 'Zou het vruchtbaar zijn uit te gaan van de gedachte dat bij een veroordeling tot een vrijheidsbenemende sanctie het regime de hoofdzaak is en de fysieke vrijheidsbeneming een voorwaarde is die niet altijd vervuld hoeft te worden? (...) Zouden er mengvormen denkbaar zijn van vrijheidsbenemende en vrijetijdsbenemende straffen?'. ${ }^{34}$

Mochten deze plannen worden verwezenlijkt, dan zou de intramurale vrijheidsstraf voor een deel zijn genormaliseerd, maar dan wel op een geheel andere manier dan gevangenishervormers zich zouden wensen.

Als Lesting de door hen voorgestane normalisering toetst aan de door Mathiesen ontwikkelde voorwaarden voor een abolitionistische strategie, moet hij 
vaststellen dat er in de litteratuur grote onenigheid bestaat over het antwoord op de vraag, wat als een negatieve en wat als een positieve hervorming kan worden beschouwd. Hij is niet van plan zich in zo'n debat te verliezen en verwijst met instemming naar wat de Nederlandse criminoloog De Haan over dat probleem heeft gezegd. Die heeft namelijk gepleit voor een pragmatische aanpak, maar dan wel verbonden aan een radicaal theoretisch perspectief. De Haan meent dat het abolitionisme, zelfs als dat alleen maar een sensitizing theory zou zijn, een belangrijke rol kan spelen bij het onderbouwen van praktische voorstellen zoals bijvoorbeeld het anders afdoen van conflicten dan door het strafrecht. Een van de sterke kanten van het abolitionisme is volgens hem dat het de aandacht vraagt voor andere, meer rationele reacties op maatschappelijk problematisch gedrag. In een noot suggereert hij overigens dat het uit tactische overwegingen misschien verstandig is om de term 'abolitionisme' maar helemaal niet meer te gebruiken en voortaan te praten over cen 'reflexieve benadering' van het probleem van misdaad en straf. Op die manier zouden misverstanden kunnen worden voorkomen en duidelijk worden gemaakt dat men niet alleen maar negatieve hervormingen nastreeft. ${ }^{35}$

$\mathrm{Zij}$ die het gevangeniswezen willen afschaffen kunnen volgens Lesting ook beter volgens die tactiek gaan opereren. Om niet van het debat te worden uitgesloten doen zij er verstandig aan heel concrete normaliseringseisen te stellen. Daarin moeten ze anderzijds ook weer niet blijven steken. Het uiteindelijke doel moet afschaffing van de vrijheidsberoving blijven. Men moet telkens een stapje verder gaan, de normaliseringseisen langzamerhand radicaliseren, maar altijd in gedachten houden dat zelfs een volledig 'genormaliseerde' gevangenis een gevangenis blijft. De, wat Lesting noemt, 'kwalitatieve breuk met het beginsel van vrijheidsbeneming' kan pas tot stand komen door het normaliseringsstreven met het abolitionistisch perspectief te verbinden.

Kortom, Lesting meent dat eisen met betrekking tot normalisering van detentieomstandigheden zeer wel passen in een pragmatisch abolitionistische strategie.

\subsection{Arbeid als object van nomalisering}

Blijft de vraag of het zinvol is om normalisering van de arbeid en de beloning van die arbeid in de strafinrichtingen tot voorwerp van een abolitionistische strategie te maken. Sommige schrijvers achten strijd op deze punten ook los van dergelijke overwegingen cruciaal. Martineau en Carasso bijvoorbeeld zijn er in hun onderzoek naar de positie van de Franse gedetineerden in hun rol van arbeider kort over: als gedetineerden in verzet komen, uit zich dat allereerst op de werkvloer. De arbeid kan volgens hen daarom worden beschouwd als de kern van de penitentiaire onderdrukking en vormt het terrein bij uitstek voor de strijd daartegen. ${ }^{36}$

Ook Ortner en Wetter menen dat bij analyse van de gevangenisproblematick de arbeid daarin een essentiële rol blijkt te spelen. Zij zien de gemiddelde gedetineerde vóór alles als iemand die zijn arbeidskracht niet meer op de vrije arbeids- 
markt kan verkopen en op die manier is uitgesloten van het produktie- en consumptieproces. Als dat inderdaad het belangrijkste effect van de vrijheidsbeneming is, dan - zo menen zij - kan hervorming van de gevangenisarbeid tot veranderingen in het hele strafstelsel leiden. ${ }^{37}$

Dergelijke optimistische veronderstellingen blijken echter niet eenvoudig waargemaakt te kunnen worden. Dat blijkt uit de beschrijving en interpretatie van een tweetal acties die in de '60er en '70er jaren juist op de terreinen van (dwang)arbeid en beloning in Noorwegen en de Bondsrepubliek Duitsland zijn gevoerd en die hieronder kort worden weergegeven.

Mathiesen heeft in zijn 'Politics of abolition' de succesvolle strijd beschreven die de Noorse organisatie voor strafrechthervorming KROM tegen de dwangarbeid, die aan dronkaards en zwervers kon worden opgelegd, heeft gevoerd. ${ }^{38} \mathrm{Op}$ grond van een Landloperswet uit 1900 konden zwervers, bedelaars en dronkaards in de werkinrichting Oppstad aan dwangarbeid worden onderworpen. KROM greep in het voorjaar van 1969 de behandeling van een voorgenomen wijziging van de Landloperswet aan om te ijveren voor de volledige afschaffing van die wet en daarmee voor afschaffing van het werkkamp te Oppstad. Deze actie tegen dwangarbeid was tevens een actie tegen het criminaliseren van alcoholisme, want het waren vooral alcoholici die in Oppstad terecht kwamen. Het bijzondere was dat, ondanks druk in die richting van overheidswege, KROM zich niet liet verleiden tot het voorstellen van alternatieven voor dwangarbeid voor alcoholisten. KROM bleef aandringen op afschaffing daarvan zonder meer. Wat daarbij enorm hielp was dat de publieke opinie óók voor afschaffing van die dwangarbeid was en de kwestie in de media voortdurend aandacht kreeg. Toen ook de sociaal-democratische fractie unaniem de noodzaak van afschaffing van dwangarbeid en van decriminalisering van alcoholisme inzag, was her pleit beslecht. Op 1 juli 1970 werd de Landloperswet ingetrokken. Mathiesen zag hierin een voorbeeld van een geslaagde negatieve hervorming.

Wat in Noorwegen in abolitionistisch opzicht zo fraai gelukt was ging mis in Duitsland. Ook dáár was verandering van wergeving het aangrijpingspunt voor actie, zij het dat het om een ander onderwerp ging: om een betere beloning van de gedetinecrden-arbeid.

Schumann heeft beschreven ${ }^{39}$ hoe het in 1975 te Bielefeld opgerichte Informationszentrum für Gefangenengruppen (IFG) campagne voerde voor het betalen van een $\mathrm{CAO}-$ loon en het toekennen van sociale zekerheidsrechten aan gedetineerden. In die tijd vond juist de parlementaire behandeling plaats van het ñieuwe Strafvollzugsgesetz dat het gevangenen-loon in fasen wilde verhogen: in 1977 zou $5 \%$, in $198010 \%$ en in 1986 zou $40 \%$ van het in de vrije maatschappij gemiddeld uitbetaalde netto-loon worden uitgekeerd. De campagne mislukte.

De wetgever wilde geen normaal CAO-loon uitbetalen, verre van dat. $\mathrm{Zij}$ zag uiteindelijk zelfs af van de voorgenomen verhogingen van 10 , resp. $40 \%$ en liet het bij de genoemde $5 \%$. De actie was volgens Schumann niet alleen overhaast en 
slecht georganiseerd maar ook rampzalig op het niveau van de public-relations. Vóór alles ontbeerde zij echter een theorerische basis. En dat zou volgens hem nog duidelijker gebleken zij̣n als de campagne haar doel wèl bereikt had. Dan zou er namelijk aan het wezen van de gedetineerdenarbeid niets veranderd zijn. Als er wel een CAO-loon uitbetaald zou zijn, zou het grootste deel daar namelijk metéén weer van zijn. ingehouden om benadeelden schadeloos te stellen, detentiekosten te betalen en te reserveren voor een uitgaanskas. En zo zou slechts in schijn een normale arbeidsverhouding gecreëerd zijn. De arbeidsplicht zou onverminderd zijn blijven bestaan evenals de dienstbaarheid van gedetineerden ten aanzien van de inrichting die nog altijd zou bepalen wie welke arbeid moest verrichten. Dat alles zou alleen hebben kunnen veranderen als de arbeidsverhoudingen in de strafinrichtingen waren gelijkgeschakeld met die welke voor de vrije arbeiders gelden. Het eisen van uitbetaling van een CAO-loon was volgens Schumann een goed voorbeeld van het nastreven van een positieve, systeembevestigende hervorming, die als geïsoleerde verandering het gevangenis-systeem een rationeler aanzien zou hebben gegeven. Daarmee bedoelde Schumann geenszins te zeggen, dat arbeid en beloning géén geschikte punten zouden zijn om vanuit abolitionistisch perspectief actie op te voeren. Hij wilde ermee aantonen hoe frustrerend theoretisch en praktisch onvoldoende voorbereide hervormingspogingen kunnen aflopen.

Mathiesens strenge indeling in negatieve en positieve hervormingen heeft lang het debat onder abolitionisten beheerst. Ryan en Ward concluderen, terugkijkend op de res gestae van de Britse radicale hervormingsbeweging RAP (Radical Alternatives to Prison), dat dit onderscheid helemaal niet zo bruikbaar is als het aanvankelijk leek te zijn. In de eerste plaats, zeggen ze, kunnen aan elke hervorming positieve en negatieve kanten onderscheiden worden. In de tweede plaats is het moeilijk te voorspellen welk effect een hervorming op den duur zal blijken te hebben. Daarom kan men nooit a priori zeggen of een hervorming positief of negatief is. ${ }^{40}$

\subsection{Een veronderstelling}

Het Nederlandse gevangeniswezen mag het dan al sinds 1596 als instituut volhouden, het is niet onaantastbaar. Het is qua aard en omvang in de loop van zijn geschiedenis aan grote veranderingen onderhevig geweest.

Van Ruller is op zoek geweest naar de dieper liggende oorzaken van wat hij noemt het terugwijken van de vrijheidsstraf van halverwege de $19 \mathrm{e}$ eeuw tot omstreeks 1975. Hij schreef daarover: 'Het zijn processen die generaties lang aanhouden, allerminst gepland verlopen of het resultaat van een beleid zijn. Het is zelfs heel waarschijnlijk dat degenen die het justitie-apparaat laten werken en beslissingen nemen die deel uitmaken van generaties omspannende processen zich niet eens bewust zijn van het grotere geheel waarvan zij deel uitmaken. De diepere oorzaken van de lange termijn tendensen zijn heel wat moeilijker aan te wijzen dan de mechanismen via welke zij verlopen'. ${ }^{4 i}$ 
Zoals het gevangeniswezen een keer is ontstaan kan het - als de maatschappelijke voorwaarden daarvoor aanwezig zijn - ook weer verdwijnen of door andere strafsoorten worden verdrongen. Men kan dat overlaten aan de onzichtbare hand van de geschiedenis en hopen op zodanige sociaal-culturele veranderingen dat instituties als het strafrecht en gevangeniswezen overbodig worden. Men kan ook proberen die geschiedenis een handje te helpen. Het abolitionisme kan daarbij heel goed perspectief geven aan het concrete handelen. Maar wat moet dat concrete handelen inhouden? Op welke punten is het penitentiaire stelsel aantastbaar, vatbaar voor verandering? Die vraag, houdt hervormers - abolitionistisch of niet - al sinds het bestaan van dit in hun ogen verderfelijke stelsel bezig. Reden tot optimisme is er niet, tot pessimisme echter evenmin. Lang niet alle actiemogelijkheden zijn adequaat uitgeprobeerd en van in het verleden gemaakte fouten kan men leren.

Dat momenteel in tal van landen het gevangeniswezen groeit en bloeit mag geen reden zijn tot defaitisme, betoogde een geenszins uit het veld geslagen $\mathrm{Ma}-$ thiesen in 1990. Evenmin als protest en verzet tegen het fascisme en tegen de dreiging van een atoomoorlog zinloos waren is oppositie tegen gevangenissen dat. Hoe groter het probleem des te meer reden daar wat aan te doen, aldus deze 'afschaffer' van het eerste uur, die in tijden van crimineel-politieke tegenwind een pragmatisch/defensieve opstelling van abolitionisten wel degelijk blijkt te kunnen billijken. In zulke tijden is zijns inziens het gaande houden van een kritisch debat over de criminele politiek op zichzelf al van groot belang. ${ }^{42}$

Alles bij elkaar genomen lijkt het de moeite waard om, uitgaand van een pragmatisch abolitionisme zoals door de zoeven genoemde De Haan bepleit, het door Lesting beschreven normaliseringsconcept in een concreet handelingsproject te. vertalen. Mogelijk kan normalisering van de arbeidsrechtelijke positie van gedetineerden een bijdrage leveren tot hun werkelijke emancipatie.

De gewenste veranderingen kunnen uiteindelijk slechts via verandering in wetgeving worden bereikt. Of die weg begaanbaar is staat lang niet vast. In het volgende wordt geschetst. wat er zoal aan voetangels en klemmen op die route te vinden zịn.

\section{Loon naar werken: van wens tot wet}

Gezien hun tot nu toe uiterst afhoudende opstelling hoeft men niet te verwachten dat overheid of politiek initiatieven zullen nemen tot normalisering van de arbeidsrechtelijke positie van gedetineerden, bijvoorbeeld in de vorm van een Wet op de Penitentiaire Werkvoorziening (WPW) waarvan de omtrekken in het vorige hoofdstuk zijn gescherst. Er zijn ook geen redenen die de overheid zouden nopen tot initiatieven op dit vlak. Er zijn geen internationale minimum standaards die de overheid tot zulk een radicale verandering van wetgeving zouden nopen. Ook van de vakbeweging kan niet worden verwacht dat zij uit zichzelf dit 
soort vernieuwingen op haar agenda zet: haar achterban is nu eenmaal niet zonder meer solidair met werkende gedetineerden. Kortom, om beweging aan dit front te krijgen, zal het initiatief van dié organisaties en personen moeten komen, die zich traditioneel het lot van gedetineerden hebben aangetrokken. Op nationaal niveau kan men denken aan de Bond van Wetsovertreders (BWO), Coomhert-Liga, het Nederlands Juristen Comité voor de Mensenrechten (NJCM), de reclassering en dat cleel van de academische wereld en de advocatuur dat zich met penitentiair recht bezig houdt.

Op international niveau - en dat is van belang als wordt angestuurd op amendering van de anti-dwangarbeidsverdragen van de ILO - valt wellicht de steun te verwerven van organisaties als Amnesty International (AI) en Penal Reform International (PRI) en de internationale organisaties van de vakbeweging. Vanzelfsprekend dienen de belanghebbenden zelf, de (ex-)gedetineerden, een belangrijke stem in het kapittel te hebben, maar om later te specificeren redenen is het een misvatting om te veel op de eigen kracht en activiteiten van (ex-)gedetineerden te vertrouwen.

Mensen en organisaties genoeg om een actie te starten, dat zal het punt niet zijn. Het grootste probleem is de manier waarop zij de overheid kunnen brengen tot een wetswijziging die een aanzienlijke verbetering van de rechtspositie van gedetineerden zou inhouden. De kans is immers klein dat de overheid de ideeën, die in de voorgaande hoofdstukken zijn ontwikkeld, spontaan overneemt en in wetgeving omzet. Het wetgevingsproces is gecompliceerder dan dat. Een onwillige overheid kan rustig afwachten tot de roep om een betere arbeidsrechtelijke positie weer verstomd is. Een overheid blifft bestaan waar hervormingsbewegingen vervluchtigen. ${ }^{43}$

Om de kans op realisering van iets als een WPW te kunnen inschatten lijkt het zinvol om de zandbanken waarop zo'n streven kan stranden zo goed mogelijk in kaart te brengen. Of, positiever geformuleerd, na te gaan onder welke voorwarden zo'n wens tot hervorming kans heeft om als wet in het Staatsblad te belanden.

\subsection{Het wetgevingsmodel van d'Anjou}

Het proefschrift van L.J.M. d'Anjou biedt de entrepreneur (door hem de initiator van problematiseringsinspanningen genoemd) een theoretisch model waarin is aangegeven. welke voorwaarden een belangrijke rol spelen bij het omzetten van bepaalde in de maatschappij levende verlangens in wetgeving."

D'Anjou beschrijft wetgeving als een proces van agendavorming, in het kader waarvan vage behoeften en verlangens uiteindelijk in een wettelijke vorm worden gegoten. Voor structurele underdogs als gedetineerden is zijn vaststelling van belang dat aan het Nederlandse wetgevingsproces een zekere mate van openheid eigen is. Wetgeving vormt volgens hem voorwerp van strijd van allerlei matschappelijke actoren, waarbij de belangen van groepen die relaties onderhouden met de politieke besluitwormers een grotere kans hebben door te dringen tot het 
wetgevingsproces dan de belangen van groepen zonder dergelijke relaties. Dat deze laatsten toch tot dit proces doordringen, bijvoorbeeld door middel van acties, acht hij overigens niet onmogelijk.

Het wetgevingsproces begint met een fase waarin nog diffuse en abstracte behoeften door actoren (entrepeneurs, belangengroepen, zaakwaamemers, kunstenaars, bedrijven vakbonden enz.) worden gearticuleerd in wensen en verlangens. 'Deze actoren zijn voor hun optreden afhankelijk van zaken als invloedsbronnen, toegang tot de media en andere gegevenheden van maatschappelijke cultuur en structuur'.

De gearticuleerde wensen en verlangens dienen vervolgens als strijdpunten te worden geformuleerd, door politieke besluitvormers op de politieke agenda te worden gezet en door het politieke systeem te worden verwerkt. Zo moeten ze uiteindelijk op de wetgevingsagenda terecht komen. Die, wat d'Anjou politieke verwerking noemt, is afhankelijk van de toegang die men tot politieke besluitvormers heeft, de invloed waarover die beschikken en de vorm waarin de strijdpunten zijn gegoten. Genoemde auteur stelt vast dat het verkrijgen van toegang tot deze besluitvormers, dat wil zeggen hen er van overtuigen dat aan een bepaalde als strijdpunt geformuleerde wens aandacht moet worden besteed, daarbij de centrale variabele is. "Voor het verkrijgen van toegang is het nodig om over invloed te beschikken. Een belangrijke taak voor de entrepreneurs bestaat dan ook uit het bij elkaar brengen van invloedsmiddelen'.

Willen strijdpunten een zo groot mogelijke kans hebben om tot het wetgevingsproces door te dringen, dan dienen zij zo concreet mogelijk te zijn. Legislatief succes is verder afhankelijk van de grootte van de groep belanghebbenden (hoe groter hoe beter), de termijn waarbinnen het probleem kan worden opgelost (hoe korter hoe beter) en de complexiteit van het probleem (hoe eenvoudiger hoe beter). Het gaat volgens d'Anjou allemaal gemakkelijker als de wetgever kan aansluiten bij bestaande oplossingen, desnoods door het probleem te herdefiniëren tot een minder complex probleem waarvoor al een technische oplossing bestaat.

Belangrijk is ook de omvang van de maatschappelijke steun voor een strijdpunt. Die wordt bepaald door het aantal, de invloed, status en legitimiteit van degenen die wetgeving wensen. Actoren hebben meer kans van slagen als zij invloed genereren door coalitievorming of mobilisatie, waarvoor het kunnen beschikken over media heel belangrijk is. Men kan toegang tor her politieke systeem verkrijgen door het creëren van vaste verbindingen met de besluitvormers en door het uitoefenen van druk bijvoorbeeld in de vorm van demonstraties, stakingen, bezettingen e.d. waardoor de toegang als het ware wordt geforceerd.

Als de strijdpunten eenmaal tot de politieke besluitvormers zijn doorgedrongen is hun succes verder afhankelijk van de invloed die zij kunnen uitoefenen.

Gegeven de aanzienlijk mate van vervlechting tussen overheid en maatschappij maken wensen van aan die overheid gelieerde actoren een grotere kans in een wet terecht te komen dan die van actoren die niet over dergelijke verbindingen beschikken.

Een laatste vaststelling van d'Anjou, waarop hier ten behoeve van entrepreneurs wordt gewezen, is dat wensen die binnen de doelen van het bestaande overheids- 
beleid (zijn te) passen meer kans maken in een wettelijke regeling te worden opgenomen dan wensen die daar niet zo gemakkelijk in passen of daar zelfs tegengesteld aan zijn.

Als de omvang van het maatschappelijk draagvlak bepalend is voor het welslagen van wetgevingsoperaties zullen de meeste wensen van gedetineerden weinig kans hebben ooit het Staatsblad te halen. Zeker zijn (ex-)gedetineerden en hun belangenorganisaties in staat om hun wensen en verlangens, al of niet in de vorm van strijdpunten, te articuleren. Zij beschikken over eigen tijdschriften en publiceren nota's en memoranda die in de pers, voor radio en TV meestal voldoende aandacht kunnen krijgen. De media blijken altijd gretige afnemers van alles wat met criminaliteit en strafrechtspleging te maken heeft. Die toegang tot de media houdt weliswaar het bewustzijn levend dat achter de tralies veel wordt geleden, maar betekent nog niet dat de op die manier publiek gemaakte strijdpunten op een groot maatschappelijk draagvlak kunnen rekenen. Het is zelfs niet denkbeeldig dat zich een tegengesteld effect voordoet, namelijk dat klagende gedetineerden (al of niet valse) stereotiepe voorstellingen van het leven in de gevangenis versterken en op die manier juist systeembevestigend werken.

Gedetineerden hebben qualitate qua verbazend weinig machtsmiddelen waarmee ze zich met hun eisen een plaats op de politieke agenda kunnen verwerven. In het recente verleden is wel geprobeerd zulke machtsmiddelen te ontwikkelen, deels door te werken aan zelf-organisatie, deels door de hulp in te roepen van de rechter. Hoe beide wegen bij de Hoge Raad dood liepen, wordt hieronder beschreven.

\subsection{Machtsmiddelen van gedetineerden}

In de Nederlandse situatie is het opvallend hoe sterk het vertrouwen van gedetineerden en hun (rechts) hulpverleners in het machtswoord van de rechter is. Van echt lobbyen voor verandering in regelgeving volgens een 'model-d'Anjou' is nauwelijks sprake. Hervormers willen wel eens brieven naar de minister en staatssecretaris van Justitie sturen en persberichten zijn ook zó gemaakt, maar daar blijft het meestal bij. Als regelingen als onjuist worden ervaren of naar het idee van gederineerden een ruimere uitleg verdienen pleegt men naar de rechter te stappen. Die voorliefde voor procederen is geen toevallige. De infrastructuur is daar bij ons ook naar. Twee factoren spelen daarbij een rol. Ten eerste is er de ontwikkeling die de rechtshulp de laatste twee decennia heeft doorgemaakt. Het startpunt daarvan wordt gewoonlijk gelegd bij het in 1970 verschijnen van het 'zwarte' nummer van Ars Aequi 'De Balie, een leemte in de rechtshulp', waarin het ontbreken van een adequate rechtshulpvoorziening voor de sociaal zwakkeren aan de kaak werd gesteld. Sinds die tijd is er een door de overheid gefinancierde infrastructuur voor het verlenen van wat wel wordt genoemd sociale rechtshulp. Daarmee hebben bepaalde groepen kosteloos of relatief goedkoop toegang tot de rechter gekregen, hetgeen ze voordien niet hadden. De tweede factor is dat onge- 
veer in diezelfde tijd de gedetineerden, door de introductie van een (semi-)administratiefrechtelijke beklag- en beroepsprocedure in de Beginselenwet gevangeniswezen, de mogelijkheid hebben gekregen geschillen over hun rechtspositie in rechte uit te vechten.

Dat heeft vooral onder medewerkers van bureaus voor rechtshulp en bij een klein deel van de sociale advocatuur tot een specialisatie in het penitentiaire recht geleid. Als gevolg daarvan worden problemen rond detentie-omstandigheden vooral in de rechtszaal uitgevochten en niet of nauwelijks nog via maatschappelijke/politieke actie. Hervormingsgezinde juristen grijpen vrijwel automatisch naar hun procedurele bevoegdheden om diegenen te dienen die bij uitstek tot hun doelgroep lijken te behoren: gedetineerden, maximaal ontrecht, maximaal onmondig als zij zijn. Daarnaast wordt vanuit diezelfde sociale rechtshulp-beweging wel getracht de zelfredzaamheid van die groep te stimuleren, maar ook vooral weer door haar te wijzen op de mogelijkheid om in rechte voor haar belangen op te komen. ${ }^{45}$

In individuele gevallen wil procederen bij de in de Beginselenwet Gevangeniswezen bedoelde beklag- en beroepsrechter wel eens soelaas brengen. Ook de burgerlijke rechter kan in sommige gevallen te hulp worden geroepen. Het Kort Geding is onder penitentiair-rechtelijk actieve advocaten een zekere populariteit gaan genieten. Men verwacht kennelijk met procederen de gewenste veranderingen op penitentiair terrein sneller te bereiken dan via een moeizaam proces van lobbyen voor regelgeving, waarvoor het politieke enthousiasme immers maar gering is. Er lijkt sprake te zijn van eenzelfde vertrouwen in de rechter dat ook bij Amerikaanse rechtshulpverleners waar te nemen is geweest. ${ }^{46}$

Voor het bereiken van wezenlijke veranderingen in de rechtspositie lijkt de weg naar de rechter echter niet adequaat en kan hij zelfs zeer riskant zijn. Afwijzing van eisen van gedetineerden door de rechter kan door de overheid worden angegrepen om het probleem waarover werd geprocedeerd voor als opgelost te beschouwen. Toewijzende vonnissen kunnen van hun effect worden beroofd door ze, zoals in beklagzaken het geval is, precedentwerking te ontzeggen of ze te pareren met 'counterende' regelgeving. ${ }^{47}$

Prakken is van mening dat zo'n vertrouwen in het nut van procederen getuigt van een naïef instrumentalistische kijk op het recht. ${ }^{48} \mathrm{Zij}$ waarschuwt tegen een te groot optimisme: '(...) gewonnen procedures tegen de staat op het gebied van het (...) en detentierecht leiden op den duur nogal eens tot veranderde richtlijnen of wetswijzigingen die voor de betrokken categorieën mensen ongunstig zijn. Tegenover juridiese winst van dergelijke procedures staat vaak het juridiese verlies van de tegenmaatregelen. Tegenover de moeilijke organiseerbaarheid van deze kwetsbare groepen staat meestal een snel toenemende juridiese mondigheid van de machtige tegenpartij: het leereffect van de rechtshulp geldt in deze gevallen meestal vooral de tegenstander. Het twijfelachtige van de juridiese winst maakt het des te noodzakelijker op deze terreinen juridiese en politieke aktie te kombineren'. ${ }^{49}$ 
Dat procederen een buitengewoon remmende invloed op de penitentiaire ontwikkelingen kan hebben demonstreert Falkoff aan de hand van de zaak Jones v. North Carolina Prisoners' Labor Union (433 US 119; 1977). Daarin stelde het Supreme Court van de Verenigde Staten vast dat het geenszins in strijd met de Constitution was als de diverse staten het de vakbonden van gedetineerden wettelijk onmogelijk maakten om onder gedetineerden leden te werven of binnen de inrichtingen vergaderingen te beleggen. Falkoff verweet deze hoogste Amerikaanse rechter een blinde knieval te maken voor de gevangenisadministratie die, met een simpel beroep op gevaar voor orde en veiligheid, in de inrichtingen het (in het eerste amendement op de Constitution gegarandeerde) recht op vrije meningsuiting en vereniging kon inperken. ${ }^{50}$

Aan Amerikaanse rechtshulp-litteratuur ontleent Prakken de notie dat als rechtshulp überhaupt al tot sociale veranderingen kan leiden, dat alleen mogelijk is als de 'doelgroep' te organiseren is. ${ }^{51}$

Dat alleen onder laatstgenoemde voorwaarde een test-case-strategie succesvol kan zijn wordt betwist door Fox Piven en Cloward in hun analyse van het succes en falen van poor peoples movements. Zij verwijten leiders van dergelijke bewegingen juist een overmaat aan aandacht voor het organiseren van deze groepen, alsof dat dè voorwaarde zou zijn om de machtselite tot concessies te dwingen. Nee, veel belangrijker is het volgens hen om gebruik te maken van die zeldzame momenten, waarop deze kansarme groepen zó verontwaardigd zijn dat ze zich niet zoals gewoonlijk schikken in hun lot maar tegen het gezag in opstand durven komen: 'Organisers and leaders cannot prevent the ebbing of protest, nor the erosion of whatever influence protest yielded the lower class. They can only try to win whatever can be won while it can be won'. ${ }^{52}$

Het kan voor het ontwikkelen van een strategie die op normalisering van arbeid en beloning mikt leerzaam zijn te onderzoeken in hoeverre een 'naïef' instrumentalistische kijk op het recht en de mate van organiseerbaarheid van de doelgroep een rol heeft gespeeld in een tweetal aantal processen die in de 80-er: jaren met betrekking tot de rechtspositie van gedetineerden zijn gevoerd. Het waren beide lang lopende zaken waarin veel juridische energie is geïnvesteerd en die op rechterlijke onwelwillendheid en 'counterende regelgeving' zijn gestrand. Twee case histories mogen dit hieronder illustreren.

\subsection{Opkomst en ondergang van gedetineerdenverenigingen}

Voor de ontwikkeling van een strategie, die zich richt op een wezenlijke verandering, van het arbeidsrechtelijk statuut van gedetineerden, is het van belang een inschatting te maken van de invloed die gedetineerden zelf als directe belanghebbenden op het proces 'van wens tot wetgeving' zouden kunnen uitoefenen. Anders gezegd: een vraag, die beantwoord moet worden, is of de "entrepreneurs' tijd en energie dienen te besteden an het organiseren van de doelgroep, zodat die zelfstandig aan het beoogde hervormingsproces kan deelnemen. 
Het zij hier meteen gezegd: ervaringen die zijn opgedaan met het organiseren van gevangenen in gedetineerdenverenigingen wijzen erop dat daarvan niet te veel verwacht mag worden. Her organiseren van de gevangenisbevolking is weliswaar niet onmogelijk, maar continuïteits- en communicatieproblemen, veroorzaakt door niet-meewerkende directies en daarin gesteund door de Hoge Raad, maken daarvan een zó moeizame aangelegenheid dat de resultaten nier tegen de inspanningen lijken op te wegen. Dat moet worden geconcludeerd uit acties die eind zeventiger, begin tachtiger jaren zijn gevoerd om gedetineerden als belangengroep een eigen plaats te geven in het overleg binnen de strafgestichten. Daarmee werd, enigszins verlaat, gepoogd vorm te geven aan een inspraakmodel waarvoor de destijds aan het Strafrechtelijk en Criminologisch Instituut te Nijmegen verbonden psycholoog Denkers al in 1971 gepleit had. Hij was van mening dat bij uitstek in een gevangenis nog veel gedemocratiseerd kon worden. Hij zag daarin een antal voordelen voor bewakers en bewaakten. Het zou de resocialisatie kunnen bevorderen en de recidive doen verminderen. Er zou een groepsverantwoordelijkheid worden gekweekt. De gevangenis zou daardoor soepeler en efficiënter kunnen functioneren. Overlegstructuren zouden kunnen worden aangewend om 'spanningen te laten ventileren en stoom af te laten blazen'. Het toekennen van medebeslissingsrecht aan gedetineerden ging hem te ver daar dan de groepssolidariteit wel eens boven de redelijkheid zou kunnen gaan prevaleren. ${ }^{53}$ Gevangeniswezen heeft weinig oren naar dat advies gehad. Dat bleek wel uit de verkrampte reacties van de directies van gevangenissen en huizen van bewaring op een in 1979 door de Bond van Wetsovertreders en een aantal rechtshulpverleners gestarte campagne ten behoeve van gedetineerden. Daarin ging het aanvankelijk alleen om invoering van het minimumloon en uitbreiding van de mogelijkheid om bezoek zonder toezicht te mogen ontvangen (onder het motto 'Meer poen en een zoen'). In een later stadium kwam daar een eis bij: daar waar met behulp van de actievoerders gedetineerdenverenigingen waren opgericht wilde men door de directies als volwaardig gesprekspartner worden erkend en van de nodige faciliteiten worden voorzien.

De acties raakten in de zomer van 1979 in een stroomversnelling toen de VPRO de BWO in de gelegenheid stelde zijn eisen wekelijks in de rubriek 'Bajesberichten' van het door Paul Aalbers geproduceerde programma 'Oorkussen' te herhalen. ${ }^{54}$ De kracht van het medium radio bleek enorm. Het programma werd binnen de muren druk beluisterd en uit tal van inrichtingen kwamen verzoeken om ondersteuning bij het oprichten van gedetineerdenverenigingen. Zonder veel plan of overleg werd -voorzover mogelijk - elke belangstellende gedetineerde bezocht en van model-statuten en verdere instructies voorzien. De BWO miste echter het kader om de verenigingen, waarvan er steeds meer bijkwamen, de broodnodige centrale sturing te geven, zodat die voor hun juridisch en praktisch 'overleven' waren aangewezen op toevallig in hun buurt bij de actie betrokken advocaten. Het medium radio was eigenlijk tè krachtig voor de activisten, die de campagne tot een letterlijk en figuurlijk hoogtepunt voerden toen zij vanuit een door de VPRO gehuurde hoogwerker, die boven een luchtplaats van de 'Bijlmer- 
bajes' zweefde live on the air juichende gedetineerden toespraken en Bajesboe$k \mathrm{n}^{55}$ over hun hoofden uitstortten.

Begin maart 1980 kregen in vier strafinrichtingen de directies te horen dat hun bajes een gedetineerdenvereniging rijk was, schreef Verhart in het later aan zijn kritische inslag tenondergegane reclasseringdblad KRI. ${ }^{56}$

Met spektakel alleen kwam men er echter niet. Het oprichten van verenigingen was één ding, het laten functioneren ervan heel iets anders. Zoals te verwachten viel moesten de directies niets van deze Fremdkörper in hun inrichtingen hebben. Zij werden dan ook nergens als gesprekspartner aanvaard. Een snelle erkenning had de BWO overigens niet verwacht. Tegen KRI's reporter Verhart had de bond al gezegd erop te rekenen dat men voor erkenning naar de rechter zou moeten stappen.

De eerste die naar de rechtshulp greep om uit de impasse te geraken was de gedetineerdenvereniging in het huis van bewaring te Rotterdam, wier voorzitter bij de directeur geen erkenning voor zijn club kon krijgen. In een kort geding, dat op 11 april 1980 bij de President van de Rotterdamse rechtbank diende, eiste de vereniging van de directie:

a. haar een vergaderruimte beschikbaar te stellen, waar zij op een vast tijdstip in de week bijeen kon komen, desgewenst in de aanwezigheid van de 'toegevoegd' secretaris (iemand buiten de inrichting, die met name voor de continuïteit zorg moest dragen);

b. haar toe te staan om regelmatig enquêtes te houden onder de leden van de vereniging;

c. overleg met haar bestuur te voeren, zo vaak als dat of de directie daar behoefte aan hadden en

d. het bestuur toe te staan gedetineerden, die daarom vroegen op hun cel te bezoeken.

De Landsadvocaat had van het ministerie van Justitie de opdracht gekregen deze boot zover mogelijk af te houden en schilderde de eisen van de vereniging af als een komplot van de BWO om de macht binnen de muren over te nemen: (D)e BWO wil deze vereniging in de hand houden. Zij levert het enige permanente bestuurslid (hij doelde hier op de buitensecretaris; gdj), dat de andere bestuursleden (co)opteert; een bijzonder centrale machtspositie'. Het ging volgens hem om een door de BWO gedomineerde vereniging, die niet de belangen van de gedetineerden maar die van haarzelf nastreefde. Hij ontkende nergens het recht van gedetineerden op vereniging en vergadering, maar vond dat de eisen moesten worden afgewezen omdat gedetineerden hun wensen en verlangens via een gedetineerdencommissie aan de directie kenbaar konden maken. Wanneer een directeur niet zo'n commissie in het leven wilde roepen, kon daarover volgens de in de Beginselenwet Gevangeniswezen opgenomen procedure worden geklaagd. ${ }^{57} \mathrm{De}$ Rotterdamse president slaagde erin de partijen aan de onderhandelingstafel te 
krijgen, met als resultaat dat de vereniging voortaan op een vaste avond in de week een ruimte ter beschikking kreeg waar zonder toezicht vergaderd mocht worden door een bestuur waarin elk van de zes 'ringen' van het huis van bewaring een lid mocht afvaardigen. Maar, op twee essentiële punten had de Staat niet toegegeven: de 'buitensecretaris' mocht de vergaderingen niet bijwonen en een enquête-recht werd niet verleend. ${ }^{5 \mathrm{~s}}$

Het verlenen van deze concessies werd als een doorbraak gezien. Deze vonden hun juridische bevestiging in een vonnis van de president van de Amsterdamse rechtbank die op 2 oktober 1980 de, door de gedetineerdenvereniging in het Amsterdamse huis van bewaring 'De Schans' gevorderde, vergaderfaciliteiten toewees. Penitentiair deskundige Van de Pol was enthousiast: directeuren moesten gedetineerdenverenigingen voortaan optimaal in de gelegenheid stellen om hun voorgenomen activiteiten te ontplooien, meent hij. 'De strijd welke althans op papier in het voordeel van de onafhankelijke, vrije belangenvereniging is beslist roept bij mij associaties op met de staking van de Poolse arbeiders voor de vrije vakbonden. Polen leert ons echter dat de weg naar de verwezenlijking nog lang en moeilijk is', noteert hij in $1980 .^{59}$

Het ministerie van Justitie was knap verveeld mer de nier aflatende onrust in de diverse strafinrichtingen en de verliezen die in de rechtszaal keer op keer werden geleden. Op 3 februari 1981 had namelijk ook de Haarlemse president in kort geding de verlangde vergaderfaciliteiten aan de gedetineerdenvereniging in het huis van bewaring II in die stad toegewezen. De staatssecretaris van Justitie meende de op gang komende beweging in haar vaart te kunnen remmen door op 1 april 1980 bij de deken van de Rotterdamse balie een klacht in te dienen tegen een van de advocaten die de inrichtingen in- en uitliep met model-statuten, ledenlijsten en al wat een vereniging zoal nodig heeft en wiens gangen en correspondentie (!) nauwkeurig bleken te zijn bijgehouden. De directeur van de gevangenis Norgerhaven stuurde een kopie van hem 'toevallig' in handen gekomen advocatenpost naar Den Haag. De staatssecretaris schreef daarop aan de Rotterdamse deken: 'Ik ben van oordeel dat het hem als raadsman van zijn cliënt toekomend recht op vrije correspondentie, vrije toegang en vrij bezoek door mr. (...) met voeten is getreden. Behalve dat hij zich als raadsman van zijn cliënten heeft voorgedaan ofschoon hij zich in feite in de kwaliteit van BWO-lid tot hen heeft gewend, heeft hij verder zijn brief geschreven en zijn bezoeken gebracht tot een ander doel dan waartoe de regeling omtrent de vrije correspondentie en het vrije bezoek is gegeven. Te vrezen valt dat deze correspondentie en bezoeken niet beperkt zullen blijven tot de beschreven gevallen nu het hier gaat om een landelijke. actie van de BWO om te komen tot oprichting van gedetineerdenverenigingen in meerdere penitentiaire inrichtingen; $\mathrm{mr}(\ldots)$ is een van de daarbij op de voorgrond tredende initiatiefnemers' ${ }^{60}$ De Rotterdamse Raad van Toezicht sauveerde haar betichte lid en verklaarde de klacht ongegrond: de advocaat was met zijn normale taakuitoefening bezig geweest en had geen ongepast gebruik van zijn bevoegdheden gemaakt. Klager kon niet in beroep maar haalde de Landelijk. Deken 
over om 'ambtshalve' een zogenaamd deken-appèl in te stellen, hetgeen deze motiveerde door te stellen dat de zaak van principieel belang was en een uitspraak van het. Hof van Discipline aan de op dit gebied wenselijke duidelijkheid kon bijdragen. $^{6 !}$ Op 23 september 1981 verwierp het Hof van Discipline het beroep: 'Het Hof is (...) van oordeel dat een gedetineerde die wenst te komen tot de oprichting van een vereniging van gedetineerden in de inrichting waarin hij verblijft, daarbij een belang heeft dat hem zo rechtstreeks en individueel aangaat, dat de behartiging van dat belang door een daartoe door hem aangezochte advocaat gerekend moet worden tot het verlenen van rechtsbijstand'. ${ }^{62}$ Dank zij deze uitspraak konden de advocaten die de verbindingen tussen de verenigingen en de buitenwereld onderhielden daarmee doorgaan.

De staat kreeg echter hulp van machtige zijde. Op 25 juni 1982 maakte de Hoge Raad door het verwerpen van de cassatieberoepen, die namens de Amsterdamse en Haarlemse gedetineerdenverenigingen waren ingesteld, het functioneren van zulk soort belangenverenigingen praktisch geheel afhankelijk van de welwillendheid van de betrokken inrichtingsdirecteuren. ${ }^{63}$ De Amsterdamse en Haarlemse kort geding vonnissen waren intussen namelijk vrijwel geheel teruggedraaid door arresten van het gerechtshof te Amsterdam waartegen de staat had geappelleerd. ${ }^{64}$

Leyten, die als advocaat-generaal in beide cassatieberoepen concludeerde, vond overigens dat de verenigingen de faciliteiten waarom ze vroegen in beginsel wèl moesten krijgen. Hij vond dat de overheid geen beleidsvrijheid tockwam waar het inmenging in grondrechten of fundamentele vrijheden betrof. De Hoge Raad was echter van mening dat een besluit van een directeur om aan een vereniging de door haar gevraagde faciliteiten niet toe te staan niet met het tweede lid van artikel 11 EVRM, noch met het tweede lid van art. 22 IVBPR op gespannen voet stond. Het Hof had terecht slechts onderzocht of de directeur bij zijn afweging van de in aanmerking komende belangen in redelijkheid tot afwijzing van de verzochte faciliteiten had kunnen komen. 'Voornoemde verdragsbepalingen laten (...) toe dat rekening wordt gehouden met de normale en redelijke eisen die de gevangenhouding stelt; die eisen worden mede bepaald door de mate van beschikbaarheid van ruimte en personeel in het betrokken gesticht'. ${ }^{65}$ Net als het Amerikaanse Supreme Court in de hierboven genoemde zaak van Jones tegen de North Carolina Prisoners' Labor Union in 1977, liet de Nederlandse rechter de effectuering van grondrechten van gedetineerden over aan het ambtelijk inzicht van het gevangeniswezen. Daarmee laat een rechter zijn eigen cliëntèle in de kou staan vonden Biesheuvel en Peters, die stelden dat juist met het oog op de politieke gelijkwaardigheid in het besluitvormingsproces de rechter een beschermende rol diende te spelen ten aanzien van die groepen die per definitie niet uitsluitend hun heil mogen verwachten van de politieke besluitvormers die de belangen van hun eigen cliëntèle in het oog moeten houden om politiek te kunnen overleven: 'De rechter heeft zijn eigen cliëntèle: minderheidsgroepen die in het democratisch meerderheidssyteem verwaarloosd dreigen te worden. Tot die cliëntèle behoren in ieder geval de gedetineerden'. ${ }^{66}$ 
Alkema, die de genoemde arresten in de Nederlandse Jusrisprudentie annoteerde, moest weliswaar vaststellen dat ze overeenstemden met de toenmalige Straatsburgse jurisprudentie over de 'inherente beperkingen' van grondrechten van gedetineerden, maar was door de uitkomst toch niet bevredigd. Zijns inziens had de rechter een oordeel dienen te geven over het peil van de voorzieningen in de desbetreffende strafinrichtingen en zijn cordeel mede daardoor moeten laten bepalen. ${ }^{67}$ Sinds de uitspraak van het Europese Hof in de zaak Plattform Ärzte für das Leben tegen Oostenrijk (1988), waarin wordt overwogen dat de verwezenlijking van artikel 11 EVRM wel eens positieve stappen van de Staat kan vergen ${ }^{68}$, zou onze nationale rechter nu misschien wat kritischer naar de argumenten van Justitie mogen kijken. Er zijn echter geen aanwijzingen dat deze vragen spoedig opnieuw in cassatie zullen worden aangekaart. De teleurstellende uitspraken van de Hoge Raad hebben namelijk, in combinatie met continuïteitsproblemen en gebrek aan kader bij de BWO, tot een langzaam verval van de verenigingen geleid. Hetgeen een aantal directeuren de gelegenheid gaf om, waar zij dat opportuun vonden, gedetineerden een uitlaatklep te geven in door hen gecontroleerde gedetineerdencommissies. Die controle bestaat onder meer uit het recht van veto bij de benoeming van commissieleden en toezicht op de vergaderingen. In het 'Reglement voor de gedetineerden-commissie in het huis van bewaring te Roermond' was dat anno 1987 zó verwoord: (hoofdstuk III, artikel 8) 'De directie van de inrichting heeft het recht van veto over de samenstelling van de gedetineerdencommissie en kan bepaalde, gekozen leden weigeren zitting te laten nemen in de commissie' en (hoofdstuk IV, art. 2) 'De vergaderingen van de gedetineerdencommissie vinden plaats onder toezicht van directie-wege' en (hoofdstuk IV, art. 6.) 'Opgemaakte notulen worden pas vermenigvuldigd en verspreid ná goedkeuring door de directie.'

De Boer waarschuwde voor het 'fopspeeneffect' van zulke commissies, 'dat wil zegen dat de directie de inspraak door gedetineerden misbruikt ter legitimering van haar eigen handelen'. ${ }^{69}$

De gedetineerdenvereniging die zich nog het langst geweerd heeft was lusta Causa in de Haagse strafinrichtingen, waar zich destijds de strengste afdeling van het land bevond, de B1-vleugel ofwel 'De Bunker', die in het navolgende een centrale rol speelt.

\subsection{Zeven jaar procederen tegen arbeid op cel}

Langgestrafte gevangenen, die vlucht- of anderszins gevaarlijk werden geacht, werden in de zeventiger en tachtiger jaren opgeborgen in de 'Bunker', zoals de. B1-vleugel van de Haagse strafgevangenis door gedetineerden werd genoemd. In de Bunker heerste destijds het strengst denkbare regiem. Gevangeniswezen was continu beducht voor uitbraakpogingen, gijzelingen en opstanden. Om samenzweringen onder de daar opgesloten desperados te voorkomen werden die zoveel mogelijk van elkaar gescheiden gehouden, hetgeen culmineerde in een regiem van isolatie dat de facto weinig meer met het daar wettelijk geldende regiem van 'be- 
perkte gemeenschap' van doen had. Het protest, dat onder de bewoners van de Bunker tegen de daar heersende, uiterst restrictieve, detentie-omstandigheden rees, kreeg juridisch gestalte in de vorm van een beklagprocedure die eind 1980 werd aangespannen tegen een 'huisregel', die inhield, dat gedetineerden in de Bunker in hun eentje op cel moesten werken. De Haagse beklagcommissie $(\mathrm{BkC})$, die òf niet voor haar taak berekend was òf het protest door tijdsverloop wilde dempen, stuurde haar - negatieve - beslissing in plaats van binnen de wettelijke termijn van 3 weken pas maanden na de behandeling aan klager toe. Dat kwam naar voren in de beschikking die de Beroepscommissie (BrC) op 24 februari 1981 in dezelfde zaak nam. ${ }^{70}$ Klager kreeg in beroep wèl gelijk. De $\mathrm{BrC}$ achtte de in de Bunker geldende huisregels, met name voor wat betreft de arbeid, onverbindend, want in strijd met het huishoudelijk reglement van de gevangenis te 's-Gravenhage, dat van een hogere juridische orde werd geacht. ${ }^{71}$

Toen bleek dat deze uitspraak niets aan de praktijk van arbeid op cel in de Bvleugel veranderde spanden negen gedetineerden en de Vereniging van Gedetineerden in de Haagse gevangenis 'Iusta Causa' een kort geding tegen de Staat aan, waarin zij eisten dat de arbeid in de Bunker gemeenschappelijk verricht kon worden. Ook de Haagse President vond de desbetreffende huisregel strijdig met het huishoudelijk reglement en op 29 april 1981 verbood hij de Staat der Nederlanden de arbeid op de B-vleugel in de cel te doen verrichten.

De vreugde bij eisers en hun raadslieden werd echter nogal getemperd door de Landsadvocaat, die ter zitting had aangekondigd dat het bewuste huishoudelijk reglement op 3 april 1981 intussen zó was gewijzigd dat de arbeid in de Bunker toch op cel moest worden verricht. Dat de Haagse President de vordering toch toewees lag aan een procedurefoutje van de Staat. De wijziging van het huishoudelijk reglement was, toen het kort geding diende, nog niet door de Centrale Raad van Advies voor Gevangeniswezen gefiatteerd. Toen de Centrale Raad dat alsnog gedaan had werd de nieuwe regel van kracht: 'De gedetineerde die is geplaatst op de B-afdeling neemt deel aan de arbeid individueel in woon- of werkcellen'. ${ }^{72}$

Met een simpele wijziging van een huishoudelijk reglement werden alle juridische inspanningen van de gedetineerden en hun - destijds alle tot de sociale advocatuur behorende - rechtshulpverleners teniet gedaan. Men was weer terug bij af en de successen bij de Beroepscommissie en de Haagse President bleken door de effectieve defensie van de staatssecretaris tot Pyrhhus-overwinningen te zijn gereduceerd. Maar, de verdediging vond een lichtpunt in de noot die Vegter bij de in Penitentiaire Informatie gepubliceerde beschikking had geschreven. Daarin merkte hij op: 'Als nu in het systeem der wet zelfs in gevangenissen met een afzonderingsregiem gemeenschappelijke arbeid regel is, dan gaat het niet aan, dat de Minister in een inrichting met beperkte gemeenschap (zoals de Haagse strafgevangenis; gdj) arbeid in afzondering voorschrijft'. De wijziging van het huishoudelijk reglement was volgens hem in strijd met het systeem van de Beginselenwet Gevangeniswezen. De kracht van deze argumentatie werd met een expliciete verwijzing naar Vegters kritiek in eerste instantic in het kader van een 
nieuwe beklagprocedure over de arbeid op cel getest. De $\mathrm{BrC}$ verklaarde het desbetreffende beroep ongegrond met de overweging 'dat artikel 30 Beginselenwet Gevangeniswezen weliswaar voor de afzonderingsinrichtingen (bedoeld in de artikelen 19 en 20 van deze wet) bepaait dat de arbeid bij voorkeur in gemeenschap plaatsvindt, maar niets aangeeft ten aanzien van de arbeid in gemeenschapsinrichtingen (bedoeld in de artikelen 16,17 en 18 van deze wet) waar de gevangenis te Den Haag toe behoort' ${ }^{73}$ In zijn noot onder deze beschikking legt Vegter nog eens geduldig uit dat elke logica daaraan ontbreekt: 'Het gehanteerde argument is, dat artikel 30 Beginselenwet niets aangeeft ten aanzien van de arbeid in de gemeenschapsinrichtingen. Als constatering is dit niet onjuist, als argument is het zwak'. En: 'Het onderscheid tussen beperkte gemeenschapsgevangenissen en afzonderingsgevangenissen staat niet in de wet, ook niet in artikel $30 \mathrm{BG}$. Dat de eerstgenoemde gevangenis meer gemeenschap dient te kennen dan de als tweede genoemde lijkt me door niemand te ontkennen. Als de wet als een duidelijke intentieverklaring stelt, dat in afzonderingsinrichtingen (bedoeld in de artikelen 19 en $20 \mathrm{BG}$ ) met een heel bijzondere bevolking gemeenschappelijk wordt gewerkt, valt niet vol te houden, dat in beperkte gemeenschapsgevangenissen (bedoeld in de artikelen 17, $1819 \mathrm{BG}$ ) met in het wettelijk systeem een meer normale bevolking afzonderlijk gewerkt moet worden.

Een andere opvatting leidt er toe, dat de Minister een zeer verregaande vrijheid heeft. Hij kan dan een gevangenis voor langgestrafte volwassenen aanwijzen, deze conform artikel $30 \mathrm{BG}$ bestempelen tot gevangenis met beperkte gemeenschap en vervolgens deze beperkte gemeenschap volledig uithollen. Inhoudelijk maakt hij er dan een gevangenis met een afzonderingsregiem van. Deze tendens valt in de Haagse B-vleugel te bespeuren. Hoeveel uur per dag komen de aldaar verblijvenden buiten hun cel? Het zal niet veel meer zijn dan 1 à 2 uur gemiddeld per dag'.

Iusta Causa en haar raadslieden, nog immer in de overtuiging dat de rechter hun standpunt zou billijken, startten op basis van Vegters argumentatie een bodemprocedure waarin werd gevraagd het huishoudelijk regiement onverbindend te verklaren. De Haagse Rechtbank stelde hen op 7 december 1983, drie jaar: clus nadat de kwestie van de cel-arbeid voor het eerst juridisch werd aangevochten, in het gelijk. De Staat kreeg van de Rechtbank de volle laag: 'Naar het oordeel van de Rechtbank maakt (de) arbeidstijd een zeer omvangrijk gedeelte uit van de dag die een gedetineerde in de B-vleugel moet doorbrengen. Gelijk de Rechtbank de Beginselenwet Gevangeniswezen verstaat, dient naar het oordeel van de wetgever zelfs in een regiem van afzondering een zo tijdvullend, voor resocialisatie van de gedetineerde belangrijk, dagdeel in gemeenschap te worden doorgebracht. Waar zulks te gelden heeft voor een afzonderingsregiem, dat in Nederland feitelijk niet wordt toegepast, behoort zulks a fortiori te gelden voor een regiem van beperkte gemeenschap als heerst in de gevangenis te 's-Gravenhage'. De rechtbank achtte de regels van het Huishoudelijk Reglement en in de Huisregels van de gevangenis te 's-Gravenhage voor de B-vleugel, voor zover deze arbeid in gemeenschap uit- 
sloten, in strijd met de Beginselenwet Gevangeniswezen en de Gevangenismaatregel en verklaarde die in zoverre onverbindend ${ }^{74}$ Een overtuigend juridisch succes. Leek het. De. Staat sloeg echter op twee fronten terug.

De gevolgen van het vonnis van de Haagse rechtbank werden door Justitie ongedaan gemaakt, door de $\mathrm{C}$-vleugel als gevangenis met een afzonderingsregiem in de zin van artikel 20 Beginselenwet Gevangeniswezen aan te wijzen. Dáárheen gingen voortaan de vlucht- en beheersgevaarlijke gedetineerden.

Op het procedurele vlak profiteerde de Staat van de 'tijdbom' die zij in haar verweer in eerste aanleg had ingebouwd door daar te betogen dat de vereniging als eiseres niet ontvankelijk was omdat er een andere rechtsgang voor de beslechting van dit soort conflicten bestond, nl. die van 51 BWG. De Haagse Rechtbank: had in haar zoëven genoemde uitspraak dit verweer verworpen, zeggende dat de beroepsgang, neergelegd in de artikelen 51 e.v. Beginselenwet Gevangeniswezen alleen aan de individuele gedetineerde en dus niet aan eiseres, de vereniging Iusta Causa, toekwam. ${ }^{75}$ In hoger beroep scoorde de Staat echter wel op dit punt en ontkwam zij niet alleen aan een rechterlijke correctie op het regiem in de B-vleugel, maar slaagde zij er ook in om de kracht die een gedetineerdenvereniging in civiele procedures bleek te kunnen uitoefenen aanzienlijk in te perken. Op 25 april 1985 honoreerde het Haagse Gerechtshof het nu als 'grief' geformuleerde bezwaar van de Staat tegen de ontvankelijkheid van Iusta Causa: 'Het moet onaanvaardbaar worden geacht, dat geïntimeerde in het kader van de belangen-behartiging van haar leden een rechtsgang zou kunnen volgen, die haar leden individueel niet ter beschikking staat'. ${ }^{76}$ De uitspraak kreeg een kritische annotatie van Kelk, die vond dat het bewerkstelligen van een zo gemeenschappelijk mogelijk regiem een collectief belang was dat juist heel goed door een gedetineerdenvereniging kon worden behartigd. 'Het structurele karakter van deze regimaire aangelegenheid vraagt om een principieel andere, meer collectieve, benadering dan die van het zuiver-individuele en daarom wat kwetsbare beklag- en beroepsrecht, ook al heeft dit laatste meer dan eens tot algemene veranderingen geleid. De gedetineerde bevindt zich nu eenmaal in een tamelijk zwakke positie en men moet hem dan ook de mogelijkheid gunnen in verenigingsverband zijn belangen te verdedigen en zijn rechten te versterken.' Dat was - het is dan intussen 1987 gewordenook de mening van Advocaat-Generaal Asser die in het kader van het ingestelde cassatieberoep concludeerde dat het hof bij zijn niet-ontvankelijkverklaring ten onrechte had aangenomen dat de individuele leden van de vereniging in de beklagprocedure ex art. 51 BWG een vordering, als in deze kwestie door de vereniging was gedaan hadden kunnen instellen. Hij vond het veel te omslachtig dat een individuele gedetineerde eerst een voor beklag vatbare beslissing van de directeur moest uitlokken om in het kader daarvan zich op de onverbindendheid van cen algemene regeling te kunnen beroepen. De beroepsgang ex art. 51 kan immers niet rechtstreeks worden benut om een regeling of besluit van algemene strekking als zodanig rechtstreeks aan te tasten, zo memoreerde hij. Ook was Asser het niet eens met het oordeel van het Hof, dat het onaanvaardbaar was dat de vereniging in het kader van de belangenbehartiging van haar leden wèl naar de burgerlijke 
rechter zou kunnen stappen waar haar leden dat niet konden. Volgens hem kon de vereniging wel degelijk een eigen belang hebben dat door het toenmalige art. $1401 \mathrm{BW}$ werd beschermd en hij verweet het Hof op dat punt geen beslissing te hebben gegeven.

De Hoge Raad volgde Assers conclusie, dat 's. Hofs arrest vernietigd diende te worden echter niet en verwierp het beroep. ${ }^{77}$ Daarmee waren de juridische actiemogelijkheden van gedetineerdenverenigingen bij de burgerlijke rechter in één klap ingeperkt tot, wat de annotator van het arrest noemde, 'typische verenigingsbelangen, verband houdende met het recht van vereniging en vergadering'. En hoe beperkt de bescherming is die de HR die 'typische verenigingsbelangen' biedt is in de vorige paragraaf gebleken.

Niet alleen op juridisch vlak werd voor afschaffing van het isolerende regiem in de B-vleugel geijverd. De Bond van Wetsovertreders en de Amsterdamse stichting Vrij hadden een zwartboek, het 'Bunker Balen Boek'?7, samengesteld en verspreid om op die manier aandacht voor het lot van de gedetineerden op de Bvleugel te vragen. De bewoners van dat justitiële fort hadden het resultaat van al die pogingen maar niet meer afgewacht. Op 12 januari 1983 kwam er opstand. 'Er zit echt geen ruit meer in het hele pand. Heerlijk, de mooiste dag van mijn bajestijd. Die gehate bunker is bunker-af want hij ligt in puin', citeerde NRC-Handelsblad, dat verder berichtte: 'Aan de vooravond van de acties tegen bezuinigingsplannen van de staatssecretaris van justitie, mevrouw V. Korte-van Hemel, sloegen zeven van de vierentwintig gedetineerden in de "bunker" omstreeks tien uur bij afspraak hun wasbakken stuk en ramden met de resten daarvan in op het pantserglas dat hen scheidt van de buitenlucht. De actie, begeleid door keiharde muziek van Pink Floyd - "We don't need education" -duurde drie kwartier'. ${ }^{79}$

De animo voor het isoleren van (vlucht-)gevaarlijk geachte gedetineerden is er bij Justitie door acties tegen het B-vleugel-regiem niet minder op geworden. Integendeel. De Jong en Van Vliet beschrijven in het Crimineel Jaarboek 1991 van de: Coomhert-Liga ${ }^{80}$ hoe, op basis van een rapport dat in 1987 door de departementale werkgroep 'Opvang vlucht- en gemeengevaarlijke gedetineerden' is opgesteld, in 1990 bij eenvoudige circulaire de Extra Beveiligde Inrichting aan het ge-stichtenbestand is toegevoegd.

Het bleek uiteindelijk een misvatting dat alleen met rechtshulp een regiem van isolatie kon worden bestreden en de belangen van gedetineerden effectief konden worden behartigd.

\section{Lessen uit het verleden}

Uit de beschreven gevallen valt een tweetal dingen te leren.

Ten eerste: er moet geen energie verkwist worden met 'opbouwwerk' onder gedetineerden. Het is een te rooskleurig idee gebleken, dat gedetineerden, ook al 
zijn ze met veel moeite georganiseerd, zèlf veel aan hun lot zouden kunnen veranderen.

Ook waar gedetineerdenverenigingen aanvankelijk wel faciliteiten kregen bleek het voor de bestuursleden moeilijk om ledenlijsten bij te houden, vergaderingen te agenderen, te notuleren en er voor te zorgen dat besluiten werden uitgevoerd. Wat achteraf bezien te verwachten viel: onder de gedetineerden waren niet veel personen die in dit soort werk geschoold waren. Het verenigingswerk dreef daarom op enkele personen die in staat waren zich dit soort vaardigheden snel aan te leren en op, eigenlijk niet tor de gemiddelde gevangenispopulatie behorende, lieden als totaalweigeraars die qua opleiding en motivatie in die tijd een aparte, zeer kritische categorie onder de gedetineerden vormden. ${ }^{81}$

Een ander probleem was de relatief korte detentietijd waardoor telkens weer continuïteitsproblemen ontstonden. Daarnaast verstoorde de regelmatige overplaatsing van bestuursleden de voortgang van het bestuurswerk: mèr het bestuurslid verdween niet zelden de hele administratie en kon weer opnieuw begonnen worden. Ook moest niet uitgesloten worden geacht dat sommige bestuursleden alleen verenigingswerk deden ten bate van hun eigen machtspositie in de inrichting.

Al dit soort factoren, samen met een gebrekkige leiding en begeleiding van buitenaf konden niet anders dan tot het verdwijnen van het fenomeen gedetineerdenvereniging leiden. De directies hoefden er alleen maar op te wachten.

De les uit deze ervaringen is duidelijk en bevestigt wat Fox Piven en Cloward beweerden: besteed niet te veel energie aan de zelf-organisatie van de hele doelgroep. Bij kortdurende acties weten gedetineerden elkaar zelf wel te vinden en is men ook zonder hulp van buiten wel in staat acties, zoals korte stakingen, te organiseren of petities op te stellen en onder de publieke aandacht te brengen.

Gaat het om acties die mikken op lange-termijn hervormingen, dan lijkt het pas interessant om gedetineerden alleen te mobiliseren en te organiseren op die momenten waarop de entrepreneurs een drukmiddel nodig hebben om het hervormingsproces verder op weg te helpen, bijvoorbeeld op de politieke aganda te krijgen. Daarbij moet zorgvuldig worden bekeken welke categorieën gedetineerden worden benaderd. Inrichtingen met een groot verloop, zoals huizen van bewaring, zelfmeldinrichtingen en inrichtingen voor kortgestraften lijken dan de minst aangewezen plaatsen om de bevolking ervan te engageren. Men kan zich beter richten op inrichtingen met een relatief stabiele bevolking. Van die laatste categorie komen vervolgens alleen die in aanmerking, waar ombeen een professioneel opererende begeleidingsgroep gevormd kan worden, welker continüteit gewaarborgd is en die een vlekkeloos contact onderhoudt met degenen die de actie centraal sturen.

De consequentie van dit alles is dat niet weer geprobeerd moet worden om gedetineerden in eigen (vak)verenigingen te organiseren. Voorzover zij zich willen organiseren kunnen zij beter lid zien te worden van bestaande vakorganisaties en hervormingsbewegingen die zich op de strafrechtspleging richten. 
Ten tweede: Proefprocessen kunnen acties ondersteunen, maar bepalen niet het succes ervan. Het is onjuist gebleken te veel te vertrouwen op een actieve rol van de rechterlijke macht bij pogingen om de rechtspositie van gedetineerden te versterken. In beide beschreven casus heeft de Hoge Raad resoluut op de rem getrapt en sindsdien zijn er nauwelijks nog procedures aan te wijzen die zijn geëntameerd om het penitentiaire beleid in bredere zin omgebogen te krijgen in het voordeel van gedetineerden. Als er bij de civiele (kort geding) rechter wordt geprocedeerd is dat vooral om het eigen belang veilig te stellen, desnoods ten koste van dat van lotgenoten. ${ }^{82} \mathrm{Bij}$ de beklag- en beroepsrechter vinden geen gemeenschappelijk aangepakte acties plaats, ten eerste omdat het klachtrecht een individueel klachtrecht is, ten tweede omdat er niet rechtstreeks over regelingen van algemene strekking kan worden geklaagd en ten derde omdat Justitie er afkerig van is om aan uitspraken van beklag- en beroepscommissie precedentwerking toe te kennen.

De waarde van het procederen is in beide hier beschreven gevallen zeer beperkt geweest. Incidentele successen bij lagere rechters werden telkens in appèl en/of cassatie weer teniet gedaan. En anders had de overheid altijd nog de mogelijkheid de regels van het spel zo te wijzigen dat de overwinnaars weer van voren af aan konden beginnen. Daarmee wil niet gezegd zijn dat procederen zinloos is. In individuele gevallen kan het de gedetineerde cliënt helpen. In het kader van een streven naar fundamentele veranderingen in de toepassing van de vrijheidsstraf en in de bejegening van gedetineerden kan men procederen echter beter als pressiemiddel zien. De mogelijkheid om in openbare processen eisen te articuleren biedt een over weinig andere hulpmiddelen beschikkende minderheidsgroep als gedetineerden de kans om met hun problemen in de politieke arena door te dringen en zo te proberen regelgeving in hun voordeel te beünvloeden, aldus Milleman.$^{83}$ Entrepreneurs-rechtshulpverleners dienen er zich voortdurend van bewust te zijn dat ten processe de reële problemen van gedetineerden tot juridische problemen worden gereduceerd. Daarmee wordt de suggestie gewekt dat daar ook juridische oplossingen voor bestaan in de vorm van rechterlijke uitspraken. Dat doet af aan de veelkantige penitentiaire werkelijkheid. Telkens wanneer men in het kader van dergelijke procedures de openbaarheid zoekt, dient dan ook duidelijk te worden aangegeven met welk verder weg liggend doel die worden gevoerd.

Het is volgens Fry zeker de taak van advocaten om misstanden bij het gevangeniswezen aan de kaak te stellen. De Amerikaanse civil rights movement heeft ervaren dat een processtrategie, die mikt op het verbieden van een bepaalde handelwijze lang niet zo goed werkt als één die rechterlijke steun voor bepaalde, positief geformuleerde eisen probeert te verkrijgen ${ }^{84}$

Vertaald in Nederlandse verhoudingen zou een en ander kunnen betekenen dat, als het om rechten van gedetineerden gaat, er minder plompverloren naar het procedure-wapen moet word gegrepen om in de rechtszaal rechtstreeks de confrontatie met de Staat aan te gaan. Mede door de - gezochte - openbaarheid is 
het de Staat daar vrijwel onmogelijk om tot een genuanceerde opstelling te komen. Het lijkt strategisch interessanter om bepaalde onderwerpen die bij de Staat gevoelig liggen, zoals de arbeids- en beloningskwestie, via intermediaire instanties naar het ambtelijk-politiek niveau te loodsen, waar nuttig en nodig ondersteund door feitelijke en juridische acties van gedetineerden.

Om in termen van d'Anjou te spreken: het in dit onderzoek gearticuleerde probleem moet eerst op de maatschappelijke agenda terecht komen. Dat wil zeggen dat een of meer maatschappelijke organisaties of instellingen, die zich toch al met de arbeidsproblematiek en gedetineerden bezig houden en die vaste contacten onderhouden met politieke beleidsmakers, zodanig in het onderwerp moeten worden geïnteresseerd dat ze bereid zijn om - samen met de entrepreneurs - te overleggen over realisering van de hier gedane voorstellen. Het ligt voor de hand om hier te denken aan de vakbonden en Nederlandse Federatie van Reclasseringsinstellingen, die qua doelstellingen in het onderwerp zouden moeten zijn geïnteresseerd en die toegang hebben tot het ambtelijke en politieke apparaat en dus tot de politieke agenda. Een (zonder twijfel lange) tocht langs die route lijkt de kans op wezenlijke verbetering van het arbeidsstatuut van gedetineerden te vergroten. 
1. Zie over de ineffectiviteit van de vrijheidsstraf het op de internationale onderzoekslitteratuur gebaseerde rapport van: L.J.M. d'Anjou, G. de Jonge en J.J. van der Kaaden, 'Effectiviteit van sancties', Ministerie van Justitie (WODC), 1975 (Opgenomen in de door J. Fiselier e.a. geredigeerde bundel Tegen de Regels; 'een inleiding in de criminologie', Nijmegen 1977, bl. 441-465.

2. Th. Mathiesen, Gefängnislogik; über alte und neue Rechifertigungsversuche, Bielefeld 1989, bl. 156.

3. Mathiesen, a.w., bl. 157-158.

4. H. Franke, Twee eeuwen gevangen; misdaad en straf in Nederland, Utrecht 1990, 919 bl. Voor het aan Franke gewijde stuk is vooral geput uit bl. 7-13 en 764-766 van zijn boek.

5. H. Franke, a.w., bl. 766 .

6. H. Franke, a.w., bl. 767.

7. Zo zegt J.A.E. Vervaele in zijn bespreking van Franke's boek, dat daarin Elias zonder verdere uitleg te veel wordt geponeerd als hét theoretisch kader en vindt hij overigens dat de auteur zijn sociologische verklaringen niet waarmaakt (een stelling, die Vervaele daar overigens niet motiveert). In Recht en Kritiek 18 (1992) 1, bl. 86-90.

8. M. Kaser, Römisches Privarrech, München und Berlin 1964, bl. 239-240. Voor dochters gold een iets cenvoudiger procedure.

9. A. Rutherford, Prisons and the Frocess of Fustice, (1984), Oxford 1986, bl. 171-187, waar hij de 'reductionist agenda' beschrijft.

10. W. de Haan en R. Verpalen (red.), Bezeten van de bajes; strafrechtelijh klimaat en gevangeniswezen in een zorgzame samenleving, Breda 1989, bl. 182-183.

11. J.P.S. 'Fiselicr, Twee vliegen in één klap?", Sancties, afl. 4, 1992, bl. 209.

12. R. van Swaaningen, "What is abolitionism? An introduction', in H. Bianchi/ R. van Swaaningen (ed.), Abolition; toward a non-repressive approach to crime, Amsterdam 1986, bl. 9-10.
13. Zoals bijpoorbeeld door Lodewijk Brunt in zijn artikel 'Abolitionisten - Het leven een kerstboom', in Vrij Nederland van 29 juni 1985, bl. 22. Hij citeert daarin met instemming de Amerikaanse antropoloog E. Adamson Hoebel, die het streven naar afschaffing van het strafrecht als 'propagandistische fraude' betitelde. Brunt zelf: 'Wat wil de heer Bianchi eigenlijk? De gevangenissen afschaffen soms? Ja, inderdaad, dat is precies waar hij naar streeft. Samen met onder anderen zijn Rotterdamse collega Louk Hulsman behoort hij tot de zogenaamde "abolitionisten", een internationale beweging die gericht is tegen het strafrecht-systeem. De aanhangers vinden dat de misdaad een kuns rmatig in het leven geroepen produkt is van dit systeem. Als het laatste uit de wercld geholpen wordt, zal er van criminaliteit ook geen sprake meer zijn. Sommigen zijn van mening dat je niet eens woorden als misdaad mag gebruiken, omdat dit het strafrechtelijke stelsel alleen maar bevestigt en rechtvaardigt. Uitdrukkingen als 'onprettig gedrag' worden dan voorgesteld. Als ik dat hoor is mijn eerste aanvechting om in lachen uit te barsten, maar die lach besterft. in mijn mond als ik me realiseer, dat het in feite kan gaan om doodslag, moord, verkrachting of mishandeling'. 14. J.J.J. Tulkens, Graden van vrijheid, Arnhem 1988 , bi. 16 .

15. De twee-jaarlijkse congressen van de, International Conference on Penal Abolition (ICOPA) zịn eerder staalkaarten van hoogst individuele strafrechtkritiek dan demonstraties van consistente abolitionistische theorievorming. Zie daarover bijvoorbeeld $\mathrm{R}$, van Swaaningen, $M$. McMahon en G. de Jonge, 'The laborious conspiracy against the penal system: comments on the third abolitionist conference Montreal', June 1987, in Canadian Law Fonum Le form Canadien de criminologie, Vol. 10, 1989, bl. 67-75.

16. R. van Swaaningen in zijn bijdrage 'Ik ben geen zoon der lauwe westerstranden, in R. van Swaaningen, B. Snel, S. Faber en E. Blankenburg (red.), a Tort et à. Travers; liber amicorum Herman Bianchi, bl. 16. 
17. L.H.C. Hulsman, 'De strafrechtelijke sanctie en zijn maat', Wijsgerig Perspectief, $8 \mathrm{e}$ jaargang, nr. 4, maart 1968, bl. 219 en 227.

18. Dit geloof in rationalisering van de strafrechtspleging spreekt sterk uit het interim- en het eindrapport Vermogensstraffen (Den Haag 1969, resp 1972), waarin deze lijn van Hulsman duidelijk te herkennen valt. 19. L.H.C. Hulsman, Een abolitionistisch. perspectief op het strafrechtelijk systeem, bijlage bij 'Problematiek van de strafrechtspraak', uitgave van het Nederlands Gesprek Centrum, (plaats?) 1979, bl. 55-56.

20. Th. Mathiesen, The Politics of Abolition, Oslo 1974.

21. Louk Hulsman en Jacqueline Bernat de Celis, Peines perdues; le système pénal en question, Parijs 1982, bl. 23-24. Verder te citeren als 'Peines perdues'.

22. Peines perdues, bl. 66, 104-105.

23. J.R. Blad, H. van Mastrigt en N. Uildriks, 'The criminal justice system as a social problem: an abolitionist perspective'. Liber amicorum Louk Hulsman, Part one, Rotterdam 1987, bl. 8-12.

24. Peines perdues, bl. 106-108, 110.

25. M. Foucault, Surveiller et Punir; naissance de la prison, Parijs 1975, bl. 236-238.

26. Mathiesen, $a$. w., hoofdstuk VII 'On the Negative'.

27. J. Feest, Normalisering als een strategie tot hervorming en afschaffing van de gevangenisstraf, Proces 1990, nr. 9, bl. 264265.

28. W. Lesting, Normalisierung im Strafvollzug; Potential und Grenzen des $\$ 3$ Abs. 1 StVollzG, Pfafienweiler 1988.

29. Een vergelijkbaar normaliseringsbeginsel vindt men bij ons terug in art. 37 Beginselenwet Gevangeniswezen en de artikelen 50 en 55 lid 2 Gevangenismaatregel, waarin het 'vrije bedrijp de maatstaf is voor arbeidsduur en -prestaties en tevens voor de kosten van. de arbeid die aan opdrachtgevers in rekening worden gebracht.

30. Geciteerd door A. Rutherford, a.w., bl. 92. In de Groene Amsterdammer van 2 februari 1994 verwoordde Jesse Jackson in een kritiek. op Clintons antimisdaadcampagne dat beginsel aldus: 'Strengere straffen en meer gevangenissen zijn geen oplossing.
Voor veel bewoners van de zwarte getto's zijn de levensomstandigheden in de gevangenissen beter dan thuis; ze zijn. er dus niet bang voor. Gevangenissen zijn warm in de winter, koel in de zomer, er is georganiseerde ontspanning, scholing, medische verzorging gettobewoners hebben dat niet in hun eigen buurt'.

31. Binnen de Nederlandse strafinrichtingen uit zich dat in een voortdurend gekibbel tussen gedetineerden en directie over omvang en aard van het kantine-assortiment.

32. Overleg- en adviescommissie alternatieve sancties (OCAS), Advies 'Alternatieve sancties met het oog op de toekomst', (Den Haag) 1991 en de brief van de stantssecretaris van Justitie aan de Tweede Kamer van 5 maart 1992, Alternatieve sancties, Tweede Kamer, 1991-1992, 22 536, nr.1.

33. Tweede Kamer, 199(PM)-199(PM), 21 634, nr. (PM), bl. (PM).

34. Th. W. van Veen in zijn bijdrage 'Het toepassen van sancties' aan de door hem en $G$. van Essen geredigeerde congres-bunde! Sanctietoepassing: een nieuwe ordening, Arnhem 1991, bl. 7 .

35. W. de Haan, The Politics of Redress; Crime, Punishment and Penal Abolition, Londen 1990, hoofstuk 4, 'Explaining contraction: The politics of "bad conscience"', bl. 79 , welk hoofdstuk een uitwerking is van zijn "Die Politik met dem "schlechten Gewissen". Die Diskussion über den Abolitionismus in den Niederlanden', Kriminologisches fournal, 17. Jg. 4/1985, bl. 246-266.

36. C. Martineau en J-P. Carasso, Le travail dans les prisons, Parijs 1972, bl. 9 .

37. H. Ortner en R. Wetter, Gefängnis und Familie, Berlijn 1975, bl. 25.

38. Th. Mathiesen, Politics of Abolition, Oslo 1974, bl. 90-97.

39. K.F. Schumann, 'Politische Randgruppenarbeit nach Mathiesen und Foucault eine Einführung', in Th. Mathiesen, Öberwinder die Mauern! Die skandinavische Gefangenenbewegung als Modell politischer Randgruppenarbeit, Neuwied und Darmstadt 1979, bl. 18-20.

40. M. Ryan en T. Ward, The penal lobby in Britain, 1950-1990 - From positivism to poststructuralism -an autocritique, paper voor .. Conferentie te Haarlem, 1990. 
41. S. van Ruller, 'Honderd jaar vrijheidsbeneming in cijfers', in de bundel De Vrijheidsstraf, onder redactie van D.H. de Jong, J.L. van der Neut en J.J.J. Tulkens, Arnhem 1986, bl. 69 .

42. T. Mathiesen, KROM - Norwegian Association for Penal Reform, paper, Conferentie (...), Haarlem 1990.

43. H. Treiber, Widerstand gegen Reformpolitik; institutioneller Opposition im Politikfeld Strafvollzug, Düsseldorf 1973, bl. 101.

44. L.J.M. d'Anjou, Actoren en factoren in het wetgevingsproces; een empirische theorie over de torstandkoming van wetgeving, Deventer 1986, Hier is vooral gebruik gemaakt van hoofdstuk 10, 'Naar een theorie van wetgeving', bl. 273-306.

45. Dat is de strekking van het door $R$. Verpalen en $\mathrm{G}$. de Jonge samengestelde Bajesboek; handboek voor gederineerden en ter beschikking gestelden, 4e druk, Breda 1992.

46. Ph. J. Cooper, Hard Judicial Choices; Federal District Court Judges and State Local Officials, New YorkfOxford 1988, bl. 14.

47. Voor een aantal voorbeelden op het gebied van het beklagrecht zie G. de Jonge, 'Gedetineerden mogen wel klagen, maar geen gelijk hebben; enkele opmerkingen over de grenzen van het beklagrecht', Proces, $62 \mathrm{e}$ jrg. nr. 6, juni 1983, bl. 177-181.

48. T. Prakken, Rechrshulp en juridies aktivisme. Een vergelijkend onderzoek naar recente antwikkelingen in het gebruik van recht, Nijmegen 1985, bl. 284.

49. T. Prakken, a.w., bl. 279-280.

50. B.B. Falkoff, 'Prisoner representative organisations, prison reform, and Jones $v$. North Carolina prisoners' labor Union: an argument for increased court intervention in prison administration', The fournal of Criminal Law \&s Criminology, Vol. 70, nr. 1, september 1979 , bl. 42-56.

51. T. Prakken, a.w., bl. 278.

52. F. Fox Piven en R.A. Cloward, Poor peoples movements; why they succeed, how they fail, (plaats?) (1977), 1979, bl. 37.

53. F.A.C.M. Denkers, 'Democratisering in het gevangeniswezen', Nederlands Tïjschrift voor Griminologie 1971, bl. 156 en 165. 54. Algemeen Dagblad 15 augustus 1979, 'Actie voor gevangenen'.
55. R. Verpalen en $\mathbf{G}$. de Jonge (red.), Bajesboek, Handboek voor gedetineerden en ter beschikking gestelden, (thans $4 \mathrm{e}$ druk), Breda 1992, 286 bl. Dit was voor de Amsterdamse hoofdofficier van justitie aanleiding om tegen de VPRO een gerechtelijk vooronderzoek te openen ter beantwoording van de vraag of via die hoogwerker gedetineerden hadden kunnen ontsnappen. Het is nooit tot een vervolging gekomen.

56. Max Verhart, 'BWO wil reche van vereniging binnen bajes', $K R I$, Maandblad Reklassering, jrg. 10, nr. 3/4, april 1980, bl. 22. 57. Uit de pleitnotities van de Landsadvocaat; archief auteur.

58. M. Verhart, 'Kort Geding BWO; gedetineerdenvereniging kreeg toch erkenning', $K R I$, Maandblad Reklassering, jrg. $10, \mathrm{nr}$. $5 / 6$, juni 1980 , bl. 8 .

59. U. van de Pol, Van beperkte gemeenschap naar vereniging', Ars Aequi 29 (1980) 11, bl. 771, 773.

60. Brief van de staatssecretaris van Justitie aan de Deken van de Orde van Advocaten te Ronerdam, kenmerk. Dir. Gevangeniswezen nr. GD 10/Mo, dd I april 1980; archief auteur.

61. Appèl-schriftuur Landelijk Deken van 22 april 1981; archief auteur.

62. Hof van Discipline nr. 614,14 september 1981 , Advocatenblad 62-5, 5 maart 1982 . 63. HR 25 juni $1982, \mathrm{NJ} 1983,295 \mathrm{cn}$ 296, met noot E.A.(Alkema).

64. Zie over het verloop van de procedure de in de vorige noot genoemde arresten.

65. HR 25 juni 1982, Nf 1983, 296, bl. 920.

66. M.B.W. Biesheuvel en J.A. Peters, 'Rechten van gedetineerden: heeft de rechter een eigen clientète?' Nederlands furisten Blad 7 november 1981, afl. 39, bl. 1054.

67. Zijn opvatting werd gedeeld door A.E. Schilder in diens boek. Het recht tot vergadering en betoging. Een vergelijkende studie naar het Nederlands en West-Duitse recht, Amhem 1989, bl. 43-44.

68. EHRM, 21 juni 1988, series A, vol. 139, par. 32, op dit punt met instemming geciteerd door C.J. Forder, 'Positieve verplichtingen in het kader van het Europees verdrag tot Bescherming van de Rechten van Mens 
en de Fundamentele Vrijheden', NJCM-Bulletin 17-6 (1992), bi. 615 .

69. M. de Boer, De gedetineerdenvereniging in het Huis van Bewaring; een onderzoek naar de rechtspositie van de gedetineerdenvereniging in het Huis van Bewaring, Utrecht 1988, bl. 33. 70. BrC 24 februari 1981, A $153 / 80$, PI $1981, \mathrm{nr} .46$.

71. Op 8 oktober 1982 zette de Beroepscommissie (A 82/82 I, PI 1982, nr. 91) deze lijn voort, door te beslissen, dat het regiem in het Haagse huis van bewaring in strijd was mer het aldaar geldende huishoudelijk reglement, voorzover dat regiem inhield, dat op de D 2-vleugel van die inrichting alleen cellulaire arbeid kon worden verricht.

72. Wijziging huishoudelijk reglement gevangenis 's-Gravenhage, beschikking van de staatssecretaris van Justitie van 3 april 1981, nr. $369 / 381$, PI 1981, nr. 45.

73. BrC 7 juni 1982, A 5/1982; PI 1982, nr. 67.

74. Rechtbank 's-Gravenhage, 7 december 1983, PI 1984, nr. 16.

75. Hetzelfde standpunt werd ingenomen door de enkelvoudige kamer van de Haagse rechtbank in haar vonnis van 28 maart 1984 in een zaak met twee individuele eisers en de Vereniging van gedetineerden in het huis van bewaring te 's-Gravenhage over de cellulaire arbeid op de D-2 en F-vleugel van die inrichting. De individuele eisers werden niet ontvankelijk verklaard omdat hun de rechtsgang ex art. $51 \mathrm{BWG}$ ter beschikking stond. De vereniging werd - ondanks protest van de Staat - wel ontvankelijk geacht op grond van de volgende redenering: 'Volgens de art. 51 $\mathrm{t} / \mathrm{m} 58$ van de Beginselenwet Gevangeniswezen komen de daar omschreven rechtsmiddelen uitsluitend aan de gedetineerde in persoon toe, en niet aan een rechtspersoon, zoals de Vereniging. De Vereniging is derhalve aangewezen op de burgerlijke rechter'.

76. Gerechtshof 's-Gravenhage, 25 april 1985, PI 1985, nr. 73, met noot van C. Kelk. 77. HR 3 april 1987, NJ 1987, 744, met noot WHH.

78. Stichting Vrij en BWO, Bunker Balen Boek, Amsterdam (1983), 24 bl.
79. NRC-Hb, 3 februari 1983, 'Langgestraften in verzet tegen regime in bunker; directie erkent gegrondheid van klachten van advocaten'. Zie ook Nieutve Revu, nr. 5, 4 februari 1983, 'Scheveningen is pas het begin; oproer in de Nederlandse gevangenissen'. 80. H. de Jong en A. van Vliet, 'Penitentiajre Perikelen', in A. van Vliet e.a. (red.), Crimineel faarboek, uitgave 1991, Breda 1991, bl. 84-86. Zie ook hun bijdrage over de EBI's in het Crimineel faarboek, uitgave 1992.

81. Vergelijkbaar met de draft evaders, die in de zestiger jaren de federale gevangenissen in de Verenigde Staten gingen bevolken. Juist deze, vooral uit de 'middle class' afkomstige, gedetineerden hadden de middelen om zich tegen bepaalde detentieomstandigheden te weer te stellen, aldus R. Berkman, Opening the gates: the rise of the prison movement, Lexington, Massachussets \& Toronto 1979, bl. 41 . Voor een beeld van het debat onder Nederlandse totaalweigeraars over gevangenen en gevangenis zie S. Kraan, De muesli bloeit; uit het dagboek van een totaalweigeraar, Amsterdam 1982.

82. Zo is er in kort geding regelmatig geprocedeerd ten behoeve van TB(R)S-passanten, veroordeelden, die op een wachtlijst voor. een tbs-inrichting stonden en door te procederen in feite eerder dan de andere - niet procederende - wachtenden opgenomen probeerden te worden.

83. M.A. Milleman, 'An agenda for prisoners rights litigation', in J.P. Robbins (ed.), Prisoners' Rights Sourcebook; theory-litigationpractice, Volume II, New York 1980, bl. 157. 84. W.R. Fry, 'Prisons and lawyers' (1971), in: S. Krantz (ed.), Cases and materials on the law of corrections and prisoners' rights, St. Paul, Minn. 1986, bl. 15-18. 


\section{Samenvatting}

\section{Historie}

Waarschijnlijk onder invloed van Coomherts 'Boeventucht' ontstond - met het Amsterdamse Rasphuis als voorbeeld - in Noordwest-Europa eind 16e, begin $17 \mathrm{e}$ eeuw het gebruik om delinquenten op te sluiten in werk- annex tuchthuizen. Daarmee ontstond er naast de steeds minder frequent toegepaste dood- en lijistraffen een nieuwe sanctie: de vrijheidsstraf. Over de doelstellingen daarvan bestond bepaald geen communis opinio. Bij sommigen overheerste het mededogen met de opgepakte armoedzaaiers, anderen beoogden cen strikte controle op het gedrag van de opgesloten criminelen. Hoewel men alom meende dat de nieuwe strafinrichtingen zichzelf economisch moesten kunnen bedruipen is dat nooit ergens gerealiseerd. Menen sommigen (Sellin) dat de cerste strafgestichten staatsfabrieken waren, die pasten in een mercantilistische economie, anderen (Spierenburg) verwerpen die veronderstelling en zien in de werkhuizen net zulke zichtbare symbolen van onderdrukking als openbare terechtstellingen dat waren geweest. Dat de vrijheidsstraf in de Republiek binnen korte tijd tot een der belangrijkste strafsancties uitgroeide, kan deels worden toegeschreven aan een gebrek aan 'grote' alternatieven, zoals de galei- en transportstraffen, die de mediterrane staten en Engeland van een groot deel van hun criminele onderklasse afhielp.

Gedurende de $17 \mathrm{e}$ en $18 \mathrm{e}$ ecuw werden de werk- annex tuchthuizen geheel naar het eigen inzicht van de diverse stedelijke overheden beheerd en werden de regimes ervan gekenmerkt door eenvoudige, laag gehonoreerde, handenarbeid (Howard). Pas na het ontstaan van het Koninkrijk Holland wordt het stelsel van strafinrichtingen gesaneerd, culminerend in het Organisatiebesluit van 1821, waarin gedwongen, karig betaalde, arbeid een prominente plaats innam. De overheid zag in de beginjaren van het moderne gevangeniswezen de arbeid waartoe veroordeelden verplicht waren niet als straf, maar als middel om de orde in de gestichten te handhaven, ter bevordering van de verbetering van de veroordeelden en ter bestrijding van de kosten van hun levensonderhoud. De economische betekenis van de gedwongen arbeid bleef echter gering, niet in het minst door de overgang in 1850 naar het cellulaire systeem waarin alleen eenvoudige cel-arbeid mogelijk was en fabrieksmatige productie uitgesloten.

De gevangenisarbeid krijgt haar eerste wettelijke basis in de Beginselenwet Gevangeniswezen van 1886. Daarin werd - tegemoet komend aan kritiek op mogelijke valse concurrentie met het vrije bedrijf - uitdrukkelijk bepaald dat de ar- 
beid vooral de huisdienst en de productie voor 's Rijksdienst moest betreffen. De wet bepaalde ook dat het arbeidsloon eigendom werd van de gedetineerde, dat deze één rustdag per week kreeg, maar dat hij wel minstens 10 uur per dag moest werken.

Begin 20e eeuw werd onder invloed van de Nieuwe Richting aan de gevangenisarbeid primair een reclasserende functie toegedacht (Von Liszt, Van der Aa), hetgeen zijn weerslag vond in de Gevangenismaatregel van 1932, waarin stond dat de arbeid dienstbaar moest zijn aan de lichamelijke, zedelijke en geestelijke ontwikkeling van de gevangenen. De economische crisis van die tijd verhinderde echter dat deze bedoeling kon worden gerealiseerd.

$\mathrm{Na}$ de Tweede Wereldoorlog meende de Commissie Fick dat de gevangenisarbeid een rol kon spelen bij de wederopbouw van Nederland. Die arbeid moest zoveel mogelijk naar het model van het bedriffsleven worden georganiseerd en worden beheerst door 'het economisch motief'. Dat zou ook beter dan voorheen kunnen omdat in de Beginselenwet van 1951 (in werking getreden in 1953) van het cellulaire stelsel werd afgestapt. Het ontbreken van een geschikte outillage verhinderde echter dat de economische doelstelling werd gerealiseerd, waama in de 60-er jaren die doelstelling (weer) werd verruild voor een reclasseringsideaal (Nota-Scholten). Waar de Commissie Fick nog had gepleit voor een redelijke beloning nam minister Scholten afstand van dat idee: het (geringe) loon was hooguit bedoeld als spaarpotje voor de eerste tijd na ontslag uit detentie. Eind 70-er jaren verliest de arbeid veel van haar belang doordat zij wordt gezien als een van de vele regiemsactiviteiten (Nota Beleidsvraagstukken, 1976). In het rapport van de Commissie Van Hattum (1977) wordt nog gepleit voor de afschaffing van de verplichte arbeid van veroordeelden die zich in een huis van bewaring bevinden en voor invoering van het minimumloon. De overheid slaagt er echter niet in om de arbeid naar het model van het bedrijfsleven te organiseren en te belonen. Het gevangeniswezen raakt steeds meer gepreoccupeerd door een 'cellentekort'. Alle energie wordt in uitbreiding van het aantal inrichtingen gestoken. De arbeid wordt in de nota 'Werkzame Detentie' (1993) primair gezien als middel tot aanpassing van de gedetineerden aan het gevangenisregime. Wie beter wil worden bejegend dan volgens een voor allen geldend 'sober' standaard-regime zal gehoorzaam moeten werken. De beoogde Penitentiaire Beginselenwet zal de gewenste disciplinering door arbeid een legale basis moeten verschaffen.

\section{Het arbeidsrecht van de gedetineerde}

Er bestaat een eigensoortig penitentiair arbeidsrecht. De arbeidsvoorwaarden worden eenzijdig door de minister van Justitie vastgesteld. Toetsing van de arbeidspraktijk aan de daarvoor geldende rechtsregels (niet zelden circulaires) geschiedt vooral in het kader van het penitentiaire beklagrecht. Gedetineerden worden niet erkend als werknemers in de zin van het civiele arbeidsrecht. Hun actuele arbeidsrechtelijke rechtspositie wordt in hoofdzaak bepaald door de vraag of zij al dan niet veroordeeld zijn en - voorzover zij dat zijn - of zij zich bevinden in 
een inrichting voor kort- of langgestraften. Onveroordeelden en veroordeelden die zich in een huis van bewaring bevinden behoeven niet te werken, maar mogen dat wel. Veroordeelden die in een gevangenis verblijven zijn tot arbeid verplicht. In huizen van bewaring kan per week maximaal $f 27,25$ (incl. toeslagen) worden verdiend. In gevangenissen voor langgestraften kan per week maximaal $f 85,-$ (incl. toeslagen) worden verdiend. Gedetineerden die vanuit een penitentiaire open inrichting bij een particuliere werkgever werken ontvangen $40 \%$ van het door die werkgever aan de staat betaalde loon. Als een gedetineerde buiten eigen toedoen werkloos is ontvangt hij een grondloon. Is hij wegens ziekte arbeidsangeschikt dan ontvangt hij 'ziekengeld'. Het arbeidsongeschiktheidsbegrip heeft binnen de muren niet dezelfde inhoud als daarbuiten. Het oordeel van de gestichtsarts is hiervoor bepalend. Onterechte ziekmeldingen worden opgevat als werkweigering en kunnen disciplinair worden bestraft. De voor arbeid besternde uren kunnen - met toestemming van de directeur- ook worden benut voor zelfstudie. men ontvangt dan een uitkering ter hoogte van het grondloon. Binnen de muren bestaat zelfs een recht op vakantiedagen. Volgens de 'Regeling arbeidsvrije dagen' kan een langgestrafte gedetineerde én dag per twee maanden van de inrichtingsarbeid worden vrijgesteld. Deelname aan een werkstaking wordt als regel beschouwd al werkweigering en kan disciplinair worden bestraft. Van medezeggenschap is geen sprake. Deelname aan zogenaamde gedetineerdencommissies is volstrekt afhankelijk van de goedkeuring van de directies. De bestaande vakbonden hebben vrijwel geen aandacht besteed aan de gedetineerde als werknemer, terwijl de gedetineerden zelf (met name de Bond van Wetsovertreders - BWO) niet in staat zijn gebleken een eigen, levensvatbare, vakbond in stand te houden.

De arbeidsomstandigheden in de strafgestichten vallen in beginsel onder der werking van de Arbeidsomstandighedenwet 1980. De beoogde Arbeidstijdenwet zal ondanks protesten van 'Justitie' zeer waarschijnlijk ook betrekking hebben op gedetineerden.

\section{De arbeidsplicht}

Waar het internationale recht dwangarbeid verbiedt makt het tegelijk een uitzondering voor gedetineerden. De reden daarvoor moet worden gezocht in de geschiedenis van de totstandkoming van het eerste verdrag dat zich tegen dwangarbeid keerde, het in 1930 onder auspiciën van de Internationale Arbeidsorganisatie tot stand gekomen Verdrag betreffende de gedwongen of verplichte arbeid ofwel Arbeidsconventie nr. 29. Dat verdrag zondert in artikel 2 gevangenen (en een aantal andere categorieën) uit van het verbod op dwangarbeid. Het valt op dat bij de voorbereiding van Arbeidsconventie nr. 29 geen der daarbij betrokken partijen de vraag heeft gesteld naar de rechtsgrond voor de toelating van een arbeidsplicht voor gevangenen. Kennelijk was men het er stilzwijgend over eens dat de arbeidsplicht inherent was aan de gevangenisstraf. Ook het in 1957 tot stand gekomen Verdrag betreffende de afschaffing van de gedwongen arbeid (Arbeidsconventie nr. 105) liet de uizzondering met betrekking tot gevangenen onverlet. 
Dát verdrag keerde zich (als product van de toenmalige Koude Oorlog) vooral tegen politiek gebruik van dwangarbeid.

Ook het Europees Verdrag tot Bescherming van de Rechten van de Mens (art. 4) en het Internationaal Verdrag inzake Burgerrechten en Politieke rechten (art.

8) bevatten een verbod van dwangarbeid en maken tegelijkertijd een uitzondering voor gedetineerden. Laatstgenoemde verdragen verschillen in zoverre mer Arbeidsconventie nr. 29, dat waar die het slechts toelaatbaar acht veroordeelden tot arbeid te dwingen, het EVRM en het IVBPR de verdragsluitende partijden vrij laten ook onveroordeelden gedwongen te werk te stellen. De Europese Gevangenisregels - die slechts de status van aanbevelingen hebben - zeggen echter weer dat slechts van veroordeelde gedetineerdenmag worden verlangd dat zij arbeid verrichten.

De artikelen 14, 20 jo. 22 van het Wetboek van Strafrecht die, in samenhang met artikel 32 Beginselenwet Gevangeniswezen veroordeelden verplichten de hun opgedragen arbeid te verrichten vallen volledig binnen de termen van de genoemde internationale regelingen. Onze nationale wetgeving biedt ruimte om over te schakelen naar een stelsel van overeengekomen arbeid, zoals dat in feite al het geval is met betrekking tot veroordeelden die in huizen van bewaring verblijven.

De arbeidsplicht dient uit de nationale strafwetgeving te worden geschrapt, nu deze niet als een aan de vrijheidsbeneming inherente beperking kan worden beschouwd.

\section{Het arbeidsloon}

Nergens staat geschreven dat (al dan niet gedwongen) werkende gedetineerden slechts een symbolisch bedrag voor de door hen verrichte arbeid dienen te ontvangen. Er bestaat echter geen regelgeving die de Nederlandse overheid verplicht gedetineerden een normaal loon te betalen. Omdat zij niet de rechtsbescherming genieten waarover werknemers in civielrechtelijke zin en ambtenaren beschikken zijn gedetineerden niet in staat om door middel van gerechtelijke procedures de uitbetaling van een normaal (althans minimum-) loon af te dwingen. Acties van gedetineerden en hun belangenbehartigers hebben op dit terrein geen enkel resultaat gehad. De Commissie Van Hattum, die in 1977 pleitte voor de invoering van cen volwaardig loon bleek een roepende in de woestijn. De verantwoordelijke bewindslieden hebben op dit terrein nimmer enig initiatief genomen en looneisen zijn immer afgewezen op pragmatische (niet op juridische) gronden. En dit terwijl vlak over de grens in artikel 43 van het Duitse Strafvollzugsgesetz sinds 1977 een principieel recht op een normaal gedetineerdenloon is neergelegd, zij het dat dit artikel toe nu toe nog niet is geïmplementeerd. Experimenten in Zweedse strafinrichtigen met de uitbetaling van een normaal loon wijzen erop dat zulks wel gedegelijk uitvoerbaar is. Aanbevelingen van de Raad van Europa ten aanzien van normalisering van het gedetineerdenloon hebben in Nederland nog niet tot resultaat geleid. 


\section{De strafrechtelijke arbeidsdwang als onderdeel van de sociale zekerheid}

Volgens Rusche zou de manier waarop gedetineerden worden bejegend, meer in het bijzonder de wijze waarop hun arbeidskracht wordt benut of juist wordt vernietigd, worden bepaald door de stand van de arbeidsmarkt. De waarde van zijn in 1933 geformuleerde arbeidsmarkttheorie wordt tot op de dag van vanclaag onderzocht. Dit heeft tot nog toe echter niet geleid tot algemeen geldende conclusies met betrekking tot eventuele relaties tussen economische stelsels, conjunctuurschommelingen, de omvang van gedetineerdenpopulaties en de mate waarin van het arbeidspotentieel daarvan wordt benut.

De economische benadering van Rusche (en Kirchheimer) is als te eenzijdig, bekritiseerd. Anderen (Steinert, Treiber) kenden aan begrippen als 'disclipinering' en 'arbeidsethos' meer verklarende kracht toe. Het was Foucault die aan de gevangenisarbeid vóór alles een disciplinerende functie toekende. Als de gevangenisarbeid enig effect had, dan was dat daarin gelegen dat zij individuen afleverde die afgestemd waren op de normen van een industriële samenleving. Melossi meende dat 'disciplinering' een concept was van de bourgeoisie, die daarmee het arbeidsproces op kapitalistische wijze kon organiseren. Samen met Pavarini heeft hij de gevangenis beschreven als een fabriek die proletariërs voortbrengt.

Zonder de historisch/materialistische en foucauldiaanse benaderingen geheel te verwerpen heeft Garland de vrijheidsstraf (inclusief de daaraan klevende arbeidsdwang) een plaats toegekend in de strategie waarmee 'de sociale kwestie' wordt aangepakt. Ook het Nederlandse strafstelsel, en daarvan met name het gevangeniswezen, kan een plaats worden gegeven in het stelsel van sociale zekerheid, dat eens reeks arbeidsmarkten creëert. De gedetineerde kan dan worden beschouwd als iemand die zijn werkkracht aanbiedt op, via intermediaire systemen met de reguliere of 'eerste' arbeidsmarkt samenhangende 'vijfde' arbeidsmarkt, waarop Justitie als monopolistisch werkgever opereert.

\section{Naar een Wet op de Penitentiaire Werkvoorziening (WPW)}

Uitgaande van het gevangeniswezen als onderdeel van het gehele stelsel van sociale zekerheid kan - bij verwerping van de arbeidsdwang en aanvaarding van het beginsel van betaling van een normaal loon-de arbeid op de 'vijfde' arbeidsmarkt heel goed worden georganiseerd naar het model van de Wet op de Werkloosheidsvoorziening (WSW). In een WPW kan een sui generis arbeidsverhouding, een publiekrechtelijke arbeidsverhouding van eigen aard, worden gecreěerd die recht doet aan de bijzondere relatie die door de vrijheidsbeneming tussen gedetineerden en de overheid is ontstaan. De werkgever (de Staat der Nederlanden, ten dezen vertegenwoordigd door de directeuren van de strafinrichtingen) heeft de plicht te bevorderen dat alle daarvoor in aanmerking komende gedetineerden. 
de gelegenheid krijgen in het kader van zo'n WPW normaal gehonoreerd werk te vinden. Een sollicitatieplicht hoeft er niet te komen. De in het kader van een WPW geldende arbeidsvoorwaarden zijn vergelijkbaar met die welke in het kader van de WSW van kracht zijn. Dat wil onder meer zeggen, dat de gedetineerde werknemer wordt in geschaald naar werksoort en bekwaamheid. Ook al kan de (monopolistische) werkgever sollicitanten in beginsel niet afwijzen, hij heeft wel degelijk mogelijkheden om de arbeidsverhouding te beëindigen of te schorsen. Een bijzonder punt van de voorgestelde WPW is, dat daarin - net zoals de in WSW - aan de werknemers een vorm van medezeggenschap met betrekking tot de uitvoering van die wet wordt toegekend.

$\mathrm{Na}$ inpassing van een WPW in de sociale zekerheidswetgeving zullen alle strafrechtelijke en penitentiairrechtelijke bepalingen met betrekking tot de arbeid van gedetineerden kunnen vervallen.

\section{Normalisering van gedetineerden-arbeid en afschaffing van de vrijheidsstraf}

Afschaffing van gedwongen arbeid en normalisering van het loon kunnen bijdragen tot een (verdere) legitimering van het gevangeniswezen, hoezeer dat naar rationele maatstaven gemeten ook faalt. Wat dat betreft lijkt een voorstel tot invoering van een WPW haaks te staan op elk streven naar afschaffing van de vrijheidsstraf. Volgens de Bremer criminoloog Lesting kan normalisering van het gevangenen-bestaan echter wel degelijk passen in een abolitionistische strategie. Met name door een vermindering van de verschillen tussen het leven in de gevangenis en dat daarbuiten kan de vrijheidsstraf aan betekenis gaan inboeten.

In ieder geval lijken de thema's arbeid en beloning zeer geschikt om gedetineerden op te mobiliseren, als actie-punten ten behoeve van hun verdere emancipatie (Elias, Franke). De ervaring heeft geleerd dat gedetineerden niet bij machte zijn zichzelf langdurig te organiseren, zodat initiatieven vooral van buitenstaanders (vooral van rechtshulpverleners) zullen moeten komen. Het voeren van (proef)procedures heeft echter een beperkte waarde. Het kunnen ware juridische uitputtingsslagen worden waarvan de afloop ongewis is en waarbij de Staat meestel over de langste adem blijkt te beschikken. Overwinningen in de rechtszaal kunnen meestal zonder veel moeite door nieuwe regelgeving teniet worden gedaan. Daarom kan rechtshulp niet meer dan een middel zijn om de arbeids- en beloningskwestie op de agenda van de wetgever te krijgen. 


\section{Summary}

\section{History}

The practice of incarcerating delinquents in prison workhouses can be traced back to the Amsterdam Rasphuis which (presumably under the influence of Coornhert's book "Boeventucht") opened its doors in 1596. This signalled the birth of a new sanction, imprisonment, which over time came to replace the death penalty and corporal punishment. At that time, there was no general agreement as to the purposes of the new sanction. In the minds of some, compassion with the fate of the poor wretches who were arrested was dominant; others saw it as a means of strict control over criminals. Although the new institutions were supposed to be economically self-sufficient, this aim was never realized anywhere. Some scholars (Sellin) view the first prisons as state-run factories, integrated into a mercantilist economy. Others (Spierenburg) reject such presuppositions and attribute the same symbolic value to imprisonment as to the former practice of public executions. The fact that deprivation of liberty developed into the main penal sanction in the Dutch Republic can be partly explained by the lack of any "grand" alternatives, such as sending convicted criminals to the galleys (the practice in Mediterranean countries) or transporting them to overseas colonies (England).

During the 17th and 18th centuries, the prisons/workhouses were managed according to the particular insights of the various local administrators. The regimes were characterised by simple, poorly paid manual labour (Howard). Only after the emergence of the Kingdom of the Netherlands was the prison system reorganised, culminating in the "Organisatiebesluit" of 1821, which contained the first paragraphs pertaining to compulsory and poorly paid prison labour. In those times, prison labour was not viewed by the government as a punishment, but as a means of maintaining order in the institutions, of improving the prisoners and of alleviating the costs of their maintenance. However, the economic profit from compulsory labour proved to be minimal, due in no small measure to the transition to a cellular system in 1850 , which meant that only very simple work could be performed in individual small cells and which precluded any industrial production.

The legal basis of prison labour was established only in 1886 with the introduction of the "Beginselenwet Gevangeniswezen" (Prison Act). To avoid false competition, this Act stipulated that prisoners should work primarily for the upkeep of the institutions themselves and produce goods only for government use. It also stated that any remuneration paid for prison labour belonged to the prisoners themselves, that prisoners were to be allowed one day of rest every week, and 
that they were supposed to work at least 10 hours a day.

At the beginning of the 20th century, a new, rehabilitating function was attributed to (still compulsory) prison labour (Von List, Van der Aa), a view which became concretised after some time in the "Gevangenismaatregei" of 1932, which stated that prison labour should serve the physical, moral and mental development of the prisoners. The economic crisis at that time prevented the implementation of that aim.

After the end of World War II, the Fick Committee proposed that prison labour be used to help reconstruct the Dutch economy. The idea was that prison labour should, in so far as possible, be modelled on labour in the free enterprise system and be controlled by an "economic imperative". Chances for success seemed better than ever when the new Prison Act of 1951 (implemented in 1953) abandoned the cellular system and made industrial labour possible. Due to chronic shortages of necessary equipment, this project failed and the economic imperative was to be replaced by the rehabilitation ideal during the Sixties (Scholten green paper). While the Fick Committee had found reasons to plead for reasonable pay for working prisoners, Minister Scholten distanced himself from this idea: the (symbolic) payments were only meant to be a small reserve for use after release. At the end of the Seventies, prison labour was marginalised and seen as only one of the many activities under the prison regime (green paper on prison policy matters, 1976). The report of the Van Hattum Committee (1977) recommended the abolition of compulsory labour for sentenced prisoners still detained in remand centres as well as the introduction of standard minimum wages. The government was far from successful in organizing and remunerating prison labour along the lines of the free enterprise system. It became more and more preoccupied by the shortage of prison space and concentrated on building more and more prisons. Nowadays, prison labour is seen primarily as a means of adapting the prisoners to the regime (green paper "Diligent Detention", 1993). The better one obeys the labour rules, the better the regime one is entitled to. In the near future, a new Prison Act will provide a legal basis for the desired disciplining of prisoners through compulsory labour.

\section{Labour law and detention}

There is a separate penitentiary labour law in which the terms of employment are dictated unilaterally by the Minister of Justice. The juridical boundaries which the government has to respect in this field are primarily indicated by independent prisoner complaints committees (and an independent Appeal Board). Prisoners are not acknowledged as employees in the sense of civil labour legislation. Their actual juridical status as workers is primarily defined in terms of whether or not they are sentenced and in what type of prison they are detained. No prisoners in remand centres are compelled to work. Work is obligatory only in prisons. The weekly pay varies between Dfl. 27.25 and Dfl. 85. Prisoners 
(from open institutions only) who work for private enterprises receive $40 \%$ of the wages paid by their employers to the government. Any prisoner who is without a job through no fault of his own receives a percentage of the normal pay: sick pay when he is ill (depending on the judgement of the prison doctor) and compensation when there is no job available. Prisoners who falsely report themselves as ill are subject to disciplinary sanctions. With the permission of the warden, a prisoner can be allowed to pursue a course of study instead of working while receiving a percentage of the normal pay for work. Long-term prisoners are entitled to one day off from work (not to be spent outside the institution) every two months. Taking part in strikes is viewed as a simple refusal to work and can be punished with disciplinary measures. No form of employee participation exists. Participation in so-called prisoner committees is entirely dependent on the consent of the warden. So far, labour unions have paid no serious attention to prisoners as workers, while the prisoners themselves have not been able to maintain unions of their own.

\section{The obligation to work}

Wherever international law forbids compulsory labour, it simultaneously makes reservations in respect of prison labour. The rationale for this must be sought in the travaux préparatoires of the first convention ever to oppose forced labour, Labour Convention no. 29 of the International Labour Organisation. The second paragraph of this convention excludes sentenced prisoners from the ban on forced labour. Remarkably enough, none of the parties involved in the preparation of this convention ever questioned the legal basis for exacting obligatory work from sentenced prisoners. Everybody seems to have tacitly agreed that labour is inherent to imprisonment. The 1957 ILO (anti-forced labour) Convention no. 105 did nothing to alter the position of sentenced prisoners. It only opposed the political use of forced (prison) labour.

The European Treaty on Human Rights (par. 4) and the International Treaty on Civil and Political Rights (par. 8) also forbid forced labour while providing, reservations as to prison labour. They even allow forced labour for non-sentenced prisoners, in this respect differing from ILO Convention no. 29. The Europear Prison Rules, however, permit forced labour to be exacted only from sentenced prisoners. These Rules lack binding power, being only recommendations to the Member States of the Council of Europe. Dutch national penal and penitentiary legislations operate well within the legal framework of the international regulations by compelling only sentenced prisoners to work.

Dutch national law, however, offers plenty of room to change policy from compulsory to contractual labour. Still, the obligation for prisoners to work should be formally removed from Dutch penal law, since iabour is not "naturaliy" inherent to imprisonment. 
No law states that prison labour (compulsory or not) should be remunerated only symbolically, as is the case today. Nor does any law state that prisoners should be paid normal wages. Lacking the legal protection of free workers, prisoners have no access to the legal procedures which their free counterparts can follow to obtain their (minimum) wages. No action undertaken by prisoners has ever resulted in major changes on the wage front. The officials responsible for this policy always fended off any wage demands by pointing to what they considered to be major practical (never legal) problems preventing the payment of normal wages. In doing so they ignored the fact that, just over the border, the German Prison Act of 1977 contains a paragraph stating that, in principle, prisoners should be remunerated normally for their work (even though this paragraph has so far not been fully implemented). The prison administrators also close their eyes to experiments with normal wages (in Swedish prisons, for instance) which demonstrate the feasibility of this kind of project. Up until now, recommendations by the Council of Europe pertaining to the payment of minimum wages have had no effect on Dutch government policy.

\section{Prison labour in the social security system}

Rusche put forward the idea that the way prisoners are treated, especially as regards the use of their labour, should be determined by the dynamics of the labour market. Formulated in 1933, his labour market theory is still being investigated at the present time. This has not led to general conclusions about possible relations between economic systems, variations in the economic cycle, the size of prison populations and the way the labour force of these populations is used.

The economic approach of Rusche (and Kirchheimer) was criticised as being too one-sided. Others (Steinert, Treiber) emphasised concepts such as "discipline" and "work ethic" as having more explanatory value. It was Foucault who attributed to prison labour primarily a disciplinary function. The main effect of imprisonment (if any) was to produce individuals adjusted to the norms of an industrial society. Melossi considered "discipline" to be a bourgeois concept of great use in organising the labour process along capitalist lines. With Pavarini, he described prison as a factory for the production of proletarians.

Without denying the relative importance of the Marxist and Foucauldian approach, Garland saw the sanction of imprisonment (including prison labour) as part of a strategy aimed at the management of social problems in the modern welfare state. Following his theory, it is possible to give the Dutch penal and penitentiary system a place in the social security system which creates various labour markets. The prisoner offers his labour on a "fifth" labour market in which the Minister of Justice operates as a monopolist employer. This "fifth" labour market is connected with the regular or "first" labour market via intermediate systems. 


\section{Towards a Penitentiary Labour Act}

Starting from the viewpoint that the prison system is part of the general social security system, rejecting obligatory prison labour and promoting the idea of paying normal wages for work performed, prison labour could very well be organised along the lines of the Dutch "Wet op de Werkloosheidsvoorziening". It is proposed to create a sui generis labour relation between the State and its prisoners. under a new Penitentiary Labour Act. In such a new Act, the State as employer will stimulate prisoners to apply for normally paid jobs within the prison system. While the State as a monopolistic employer may have virtually no reason to refuse any applicant, it will be possible (on well-defined grounds) to dismiss employees or suspend their contracts. A point of special interest in the proposed Act are the paragraphs concerning employee participation.

The adoption of such an Act will make all penal and penitentiary rules and regulations regarding prison labour redundant.

\section{Normalisation of prison labour and abolitionism}

The abolition of compulsory prison labour and normalisation of prisoners' wages could easily contribute to a (further) legitimisation of the prison system, however much this system must be seen as a failure when measured against rational standards. Seen in this light, a proposal for a Penitentiary Labour Act seems to run counter to the abolitionist aim of doing away with prisons entirely. According to the German criminologist Lesting, however, normalisation of prison life could fit very well into an abolitionist strategy. By minimising the differences between life inside and outside prison, the significance of imprisonment as a sentence could be diminished.

In any case, labour and remuneration seem to be quite suitable themes on which to mobilise prisoners and appropriate vehicles for the further emancipation of this group. Experience has shown that it is extremely difficult for prisoners to organise themselves into a powerful lobby. Initiatives must come from outside, especially from interested professional lawyers. There is no reason to rely on the eventual results of test-cases fought out in court. These should be used only as vehicles to introduce the topic of prison labour into the political agenda. 


\section{Geraadpleegde litteratuur}

Aa, J.S. van der, De arbeid als element van de vrijheidsstraf, Groningen 1906.

AbvaKabo-CFO, Om de kwaliteit van het criminaliteitsbeleid, Zoetermeer/Den Haag 1985.

Adamson, Chr., 'Towards a Marxian Penology: Captive criminal Populations as economic Threats and Resources', Social Problems April 1984, Vol. 31, nr. 4, bl. 435-458.

Adang, $M$., Gevangenisbouw in Nederland, de zin van de straf en de hoogte van de kosten, Wonen-TA/BK, nr. 15 (1981), bl. 6-26.

Advies commissie dienstplicht, Naar dienstplicht nieuwe stijl, Den Haag 1993.

Alcock, A., History of the International Labour Organisation, Londen en Basingstoke 1971.

Alstorphius Grevelink, P.W., Bedenkingen tegen het ontwerp van wet ter vernieuwde uitbreiding der celstraf,'s-Gravenhage 1874.

Amnesty International, Indonesien; ein Bericht von Amnesty International, BadenBaden 1977.

Anjou, L.J.M. d', Actoren en factoren in het wetgevingsproces; een empirische theorie over de totstandkoming van wetgeving, Deventer 1986.

Anjou, L.J.M. d', G. de Jonge en J.J. van der Kaaden, Effectiviteit van sancties, Den Haag, 1975. Opgenomen in de door J. Fiselier e.a. geredigeerde bundel Tegen de Regels; 'een inleiding in de criminologie', Nijmegen 1977.

Anoniem, Aus den Sibirischen Bleibergwerken; unedierte Briefe des zu lebenslänglicher Zwangsarbeit verurtheilten russischen Professors Vaszilii Jaszakov; mit den Zeichnungen und dem Autogramm des Verurtheilten, Berlijn 1893. 
Anoniem, Nieuwe berigten omtrent het Pennsylvanische gevangenisstelsel en gedachten over lïfstraffen, deportatie en gevangenisstraffen, Groningen 1844.

Arboraad, Advies over het ontwerp-arbeidsomstandighedenbesluit jeugdbescherming en delinkwentenzorg, Zoetermeer 1988.

Aschrott, P.F., Strafensystem und. Gefängniswesen in England, Berlïn en Leipzig, 1887, facsimile-druk, Frankfurt/M. 1978.

Baardemans, W., 'Veel allochtonen moeten na detentic toch het land verlaten'; openbaar debat gevangeniswezen, Vrijspraak oktober 1993, 7e jrg., bl. 10-12.

Bakels, H.L., Schets van het Nederlandse arbeidsrecht, Deventer 1992.

Bakker, C., 'Detentie en sociale zekerheid', Proces (69) 1990, 3, b1. 63-69.

Beer, P. de, 'De eigenwijsheid van Coomhert', Tịdschrift voor Criminologie 1988, nr. 3, bl. 223-235.

Bemmelen, J.M. van, Gedenkt der gevangenen, 's-Gravenhage 1954.

Berends, R., A.H. Huussen jr., R. Mens en R. de Windr, Arbeid ter disciplinering en bestraffing; Veenhuizen als onorije kolonie van de Maatschappij van Weldadigheid 1823-1859, Zutphen 1984.

Berg, G.P. van den, 'Arbeidsovereenkomstenuecht van de Soviet: Unie', Sociaal Maandblad Arbeid 1982, nr.11, bl. 703-716.

Berkman, R., Opening the gates: the rise of the prison movement, Lexington, Massachussets \& Toronto 1979.

Betten, L., Intemational labour law; selected issues, Deventer-Boston 1993.

Beurskens, W.J.J., 'Medezeggenschap in het onderwijs', in: P.F. van der Heijden (red.), Schets van hot medezeggenschapsrecht, Deventer 1992, bl. 141-195.

Beyerink, J.F., Ontstaun en ontwikkeling van den arbeid in Nederl. Strafgestichten (zonder plaats, zonder jaartal maar vermoedelijk 1939).

Bianchi, H. (boekbespreking) D.V. Coornhert, 'Boeventucht', uitgegegeven en toegelicht door een werkgroep van Utrechtse neerlandici. Instituuut De Vooys, Utrecht 1980, De Nieure Taalgids 1981, bl. 452-457. 
Biesheuvel, M.B.W, en J.A. Peters, 'Rechten van gedetineerden: heeft de rechter een eigen cliëntèle?' Nederlands furistenblad 7 november 1981, afl. 39, bl. 1045-1054.

Bijloos, A.W.M., 'De Algemene wet bestuursrecht en het bijzondere sociale zekerheidsrecht', Nederlands furistenblad 7 januari 1994, afl. 1, bl. 41-44.

Binsbergen, W.C. van, Poenaal panorama, Zwolle 1986.

Blad, J.R., H. van Mastrigt en N. Uildriks, 'The criminal justice system as a social problem: an abolitionist perspective'. Liber amicorum Louk Hulsman, Part one, Rotterdam 1987.

Blumstein, A., en J. Cohen, 'A Theory of the Stability of Punishment, The fournal of Criminal Law and Criminology 1973, Vol. 64, nr. 2, bl. 198-207.

Boer, M. de, De gedetineerdenvereniging in het Huis van Bewaring; een onderzoek naar de rechtspositie van de gedetineerdenvereniging in het Huis van Bewaring, Utrecht 1988.

Bonger, H. 'Coomhert en Bianchi', De Nieuwe Taalgids 1982, bl. 230-233.

Bonger, W.A., Criminalité et conditions économiques, Amsterdam 1905.

Bonvoust Beeckman, M.H. de, Arbeid van gevangenen en vrije arbeid, Amsterdam 1892.

Box, S., Recession, Crime and Punishment, Basingstoke 1987.

Breman, J., Koelies, planters en koloniale politiek, Dordrecht/Providence 1987.

Brucken Fock, E.P. von, e.a., De rechtspositie van de gedetineerde in Nederland en België, Zwolle 1975.

Bruijn, W. de, 'Bijstand en dagdetentie; een per abuis verzonden circulaire?' In Sociaal Bestek, nr. 10-1991, bl. 9-10.

Bruinink-Darlang, A.M.C., Het penitentiair stelsel in Nederlands-Indië van 1905 tot 1940, Alblasserdam 1986.

Brunner, R.J., 'Het Gevangeniswezen te Batavia tijdens de Oost-Indische Compagnie', Tijdschrift voor Strafrecht (XIII) 1932, vooral bl. 40-79.

Brunt, L(odewijk), in zijn artikel 'Abolitionisten - Het leven een kerstboom', in Vrij Nederland van 29 juni 1985, bl. 22. 
Buitelaar, W.L. en R.J. Sierksma, Gevangen in de gevangenis, Meppel 1972.

Cain, M., en A. Hunt, Marx and Engels on law, Londen/New York/San Francisco 1979.

Cazemier-Kleij, M., Samenhang rondom de sociale werkvoorziening; een inventarisatie van knelpunten rond de sociale werkvoorziening, Sociaal en Cultureel Planbureau, Rijswijk maart 1985.

Centrale Raad van Advies voor het Gevangeniswezen, de Psychopatenzorg en de Reclassering, Rapport van de Commissie Arbeidsbeloning van Gedetineerden, ('s-Gravenhage) januari 1966.

Chiricos, Th. G., en W. D. Bales, 'Unemployment and Punishment: An empirical Assessment', Criminology 1991, Vol. 29, nr. 4, bl. 701-724.

Clerck, D. de, 'Deconcentratiebeleid is vallen en opstaan; gebrekkig overleg in gevangenissen;' Aanéén 18 december 1989, bl. 8-10.

Conseil de l'Europe, Comité Européen pour les problèmes criminels, Les régimes des institutions pénitentiaires, Strasbourg 1986.

Cooper, Ph.J., Hard Fudicial Choices; Federal District Court Fudges and State Local Officials, New York/Oxford 1988.

Coomhert, D.V., Boeventucht, naar de druk van 1587 uitgegeven en van commentaar voorzien door A-J Gelderblom, M. Meijer Drees en een werkgroep van Utrechtse neerlandici, (Utrecht 1980) Muiderberg 1985.

Coomhert-Liga, Altematieve justitiebegroting, Deventer 1971.

Coornhert-Liga, Notities over het Gevangeniswezen; een aanwulling op de TegenNota Beleidsvraagstukken Gevangeniswezen, Utrecht 1978.

Corrections in Swcclen, Kriminalvårdsstyrelsen, Norrköping 1990.

Council of Europe, Work in Penal Institutions, Straatsburg 1976.

Council of Europe, Prison management, Straatsburg 1983.

Council of Europe, European Prison Rules, Recommendation nr. R. (87) 3, Straatsburg 1987.

Council of Europe, Digest of Strasbourg Case-Law relating to the European Convention on Human Rights; Update to Volume 1 (Articles 1-5), Keulen (etc.), 1988. 
Council of Europe, European Committee for the prevention of torture and inhuman or degrading treatment or punishment (CPT), 1st General Report on the $C P T$ 's activities, covering the period November 1989 to December 1990, Straatsburg 20 februari 1991.

De Nederlandse gevangenissen en haar noodzakelijke verbeteringen; een rapport van de commissie bouwkundige voorzieningen van het gevangeniswezen (Rapport 's Jacob genoemd), 's-Gravenhage 1958.

Deinse, A.J. van, De algemene beginselen van strafregt, ontwikkeld en in verband beschouwd met de algemeene bepalingen der Nederlandsche strafwetgeving, Middelburg 1860.

Dekkers, F., Eindhoven 1933-1945. Kroniek van Nederlands Lichtstad in de schaduw van het Derde Rijk, Haarlem 1982.

Denkers, F.A.C.M., 'Democratisering in het gevangeniswezen', Nederlands Tijdschrift voor Criminologie 1971, bl. 154-168.

Depenbrock, J., Erwachsenen-Strafvollzug; die rechtlichten Grundlagen des Erwachsenen-Strafvollzuges und ihre Auswirkungen auf die Arbeit, das Wahlrecht und den Rechtsschutz des Strafgefangenen, Bonn 1960.

Diederiks, H.A., S. Faber en A.H. Huussen jr., Strafrecht en criminaliteit (Cahiers voor lokale en regionale geschiedenis), Zutphen 1988.

Dijk, P. van, en G.J.H. van Hoof, De Europese Conventie in theorie en praktijk, derde druk, Nijmegen 1990.

Duffy, P.J., 'Article 3 of the European Convention on Human Rights', in The International and Comparative Law Quarterly 1983, Vol. 32, bl. 316-346.

Duyne, P.C. van, 'Landlopers in het nieuwe Wetboek van Strafrecht', Tijdschrift voor Criminologie 1987, nummer 4, bl. 79-91.

Eggink, J.W., De geschiedenis van het Nederlandse gevangeniswezen, Assen 1958.

Fahsel, J., Das Recht des Gefangenen auf Arbeit und Entlohnung, Saarbrücken 1971.

Falkoff, B.B., 'Prisoner representative organisations, prison reform, and Jones v. North Carolina prisoners' labor Union: an argument for increased court intervention in prison administration', The Journal of Criminal Law \& Criminology, Vol. 70, nr. 1, september 1979, bl. 42-56. 
Fase, W.J.P.M., Wederzijds begrip; over de aansluiting tussen het arbeids- en sociale verzekeringsrecht, Deventer 1993.

Fawcett, J., 'Application of the European Convention on Human Rights', in M. Maguire e.a. (eds.), Accountability and prisons; opening up a closed world, Londen en New York 1985.

Feest, J., 'Normalisering als een strategie tot hervorming en afschaffing van de gevangenisstraf', Proces 1990, nr. 9, bl. 264-265.

Fijnaut, C., Verleden, heden en toekomst van de geintegreerde strafrechtswetenschap, Arnhem/Antwerpen 1986.

Fiselier, J.P.S., 'De hypothese van het stabiele strafniveau', in G.J.M. Corstens (red.), Straffen in gerechtigheid, Arnhem 1987.

Fiselier, J.P.S., Twee vliegen in één klap?', Sancties, afl. 4, 1992, bl. 205-209.

FNV, Naar een geintegreerde werkvoorziening - samenspel in het doelgebied -; de FNVvisie op de toekomstige ontwikkeling van de sociale werkvoorziening, (Amsterdam) 28 januari 1992.

Forder, C.J., 'Positieve verplichtingen in het kader van het Europees verdrag tot Bescherming van de Rechten van Mens en de Fundamentele Vrijheden', NFCMBulletin 17-6 (1992), bl. 611-637.

Foucault, M., Surveiller et punir; naissance de la prison, Parijs 1975.

Fox Piven, F., en R.A. Cloward, Poor peoples movements; why they succeed, how they fail, (geen plaats vermeld) (1977) 1979.

Franke, H., Twee eeuwen gevangen; misdaad en straf in Nederland, Utrecht 1990.

Fry, W.R., 'Prisons and lawyers' (1971), in: S. Krantz (ed.), Cases and materials on the law of corrections and prisoners' rights, St. Paul, Minn. 1986.

Ganter, H.G., Die Spruchpraxis der Europäischen Kommission für Menschenrechte auf dem Gebiet des Strafvollzuges, Bonn 1974.

Garland, D., Punishment and Welfare; A History of Penal Strategies, Aldershot 1985.

Geers, A.J.C.M., Recht en humanisering van de arbeid, Deventer 1988. 
Geers, A.J.C.M., 'Op de grenzen van arbeidsmarktbeleid, grondrechten, arbeidsrecht en het sociale-zekerheidsrecht: de banenpool.' In: W.H.C.M. Bouwens (e.a.), Sociaalrecht: de grenzen verkend, Zwolle 1994.

Geers, A.J.C.M., en G.J.J. Heerma van Voss, 'De overheid treedt terug: de nieuwe Arbeidstijdenwet', Sociaal Recht, 1994-5, bl. 136-144.

Geers. A.J.C.M., e.a. (red.), Arbeidsomstandigheden; recht en praktijk, (losbladig), Deventer.

Geremek, B., Het Kainsteken; het beeld van de armen en vagebonden in de Europese literatuur van de 15e tot de 17e eeuw, (Warschau 1980), Baarn 1992.

Goffman, E., Asylums; Essays on the Social Situation of mental patients and other inmates, Chicago 1962.

Goffman, E., Stigma: Notes on the Management of spoiled Identity, Englewood Cliffs, New Jersey 1963.

Grapendaal, M., In dynamisch evenwicht; een verkennend onderzoek naar de gedetineerdensubcultuur in drie Nederlandse gevangenissen, 's-Gravenhage 1987.

Greenberg, D.F., 'Imprisonment and Unemployment: A Comment', foumal of Quantitative Criminology 1989, Vol. 5, nr. 2, bl. 187-191.

Haan, W. de, 'Die Politik met dem "schlechten Gewissen". Die Diskussion über den Abolitionismus in den Niederlanden', Kriminologisches fournal, 17. Jg. 4/1985, bl. 246-266.

Haan, W. de, The Politics of Redress. Crime Punishment and penal Abolition, Londen 1990.

Haan, W. de, en R. Verpalen (red.), Bezeten van de bajes; strafrechtelijk klimaat en gevangeniswezen in een zorgzame samenleving, Breda 1989.

Hale, Chr., 'Unemployment, Imprisonment, and the Stability of Punishment Hypothesis: some results using cointegration and error correction models', foumal of Quantitative Criminology 1989, Vol. 5, nr. 2, bl. 169-186.

Hallema, A., 'Het gevangeniswezen in het vereenigd Koninkrijk der Nederlanden tijdens de regeering van Koning Willem I (1813-1830)', Tijdschrift voor Strafrecht (XL) 1930, bl. 259-280.

Hallema, A. 'De gevangenisarbeid in concurrentie met het particuliere bedrijfsleven en de strijd om het Amsterdamse tuchthuismonopolie ten tijde van de Republiek', Economisch Historisch faarboek, deel 19, 1935, bl. 114-201. 
Hallema, A., 'Toepassing van de galeistraf in de Nederlanden gedurende de $15 \mathrm{e}$ en 16e eeuw', Tijdschrift voor Strafrecht (LX) 1951, bl. 125-150.

Hallema, A., 'Vlaardingen en Dordrecht als oudste Nederlandse galeiendepôts', Tijdschrift voor Geschiedenis 1953, nr. 66, bl. 75-91.

Hallema, A., Geschiedenis van het gevangeniswezen, hoofdzakelijk in Nederland, 's-Gravenhage 1958.

Hanesch, W., 'Armutspolitik und neue Beschäftigungsformen; Perspektiven jenseits des Arbeitszwangs', in S. Leibfrid und F. Tennstedt (red.), Politik der Armut und dic Spaltung des Sozialstaats, Franfurt am Main, 1985.

Harmonisatieraad Welzijnsbeleid, Advies nr. 49: Op eigen kracht; een bodcmpakket als bestaanszekerheidsvoorziening, 's-Gravenhage 1987.

Heierli, U., Gefangenenarbeit, Entlohnung und Sozialisation; Fakten und Möglichkeitcn, Zürich 1973.

Heijink, J.Z., en J.B. Terpstra, De sociale werkvoorziening in werking, Ministerie van Sociale Zaken en Werkgelegenheid, 1983.

Heising, M., Die Entlohnung der Gefangenenarbeit, Basel und Stuttgart 1968.

Heringa, A.W. en T. Zwart, De Nederlandse Grondwet, Zwolle 1991.

Hermann, M.G. en M.G. Haft, Prisoners' rights sourcebook; theory - litigation practice, New York 1973.

Herziening differentiatiestelsel gevangeniswezen. Brief van de staatssecretaris van Justitie, 's-Gravenhage 4 juli 1990, Tweede Kamer, 1989 - 1990, 21 634, nr. 1.

Het Nederlandse gevangeniswezen; nota over het Nederlandse gevangeniswezen aangeboden door de minister van Justitie aan de Tweede Kanier der StatenGeneraal, (Nota-Scholten), Tweede Kamer, 1963-1964, 7709, nr. 2.

Het Nederlandse gevangeniswezen in de jaren 1945 tot en met 1953, 's-Gravenhage 1954.

Hongda Harry Wu, Laogai; the Chinese Gulag, Boulder/San Francisco/Oxford 1992.

Hoppensack, H-Ch., en G. Wenzel, 'Hilfe zur Arbcit und Arbcitszwang; Sozialhilfe und administrative "Normalisicrung" von Lohnarbeit", in S. Leibfried, und 
F. Tennstedt (red.), Politik der Armut und die Spaltung des Sozialstaats, Frankfurt am Main 1985.

Howard, J., The state of the prisons (1777, 1780 en 1784), heruitgave, Londen/New York 1929.

Hughes, R., The fatal shore; the epic of Australia's founding, New York 1987.

Hulsman, L.H.C., 'De strafrechtelijke sanctie en zijn maat', Wijsgerig Perspectief, 8 e jaargang, nr. 4, maart 1968, bl. 207-232.

Hulsman, L.H.C., Een abolitionistisch perspectief op het strafrechtelijk systeem, bijlage bij 'Problematiek van de strafrechtspraak', uitgave van het Nederlands Gesprek Centrum, (geen plaats vermeld) 1979.

Hulsman, L(ouk), en Jacqueline Bernat de Celis, Peines perdues; le système pénal en question, Parijs 1982.

Hulst, H. van, en J. Bos, Pan i rèspèt; criminaliteit van gemmigreerde Curaçaose jongeren, Utrecht 1993.

Ignatieff, M., $A$ just measure of pain; the penitentiary in the industrial revolution, 1750-1850, Londen en Basingstoke New York 1978.

Interim-en Eindrapport Vermogensstraffen, Den Haag 1969, resp. 1972.

International Labour Office, Prison I,abour: I, International Labour Review maart 1932, Vol. XXV, nr. 3, bl. 311-331 en Prison Labour: II, zelfde tijdschrift april 1932, Vol. XXV, nr. 4, bl. 499-524.

Inverarity, J., en R. Grattet, 'Institutional Responses to Unemployment: A Comparison of U.S. Trends, 1948-1985', Contemporary Crises, 13 (1989), bl. 351 370.

Isaïa, H., La Yustice en Chine, Parijs 1978.

Jankovic, I., 'Labor Market and Imprisonment', in T. Platt and P. Tagaki (red.), Punishment and penal Discipline; essays on the prisoners' movement, San Francisco (1980) 1982.

feugdwerkgarantieplan, Tweede Kamer, 1987-1988, 20 278, nr. 4.

Jong, A. de, Domela Nieuwenhuis, Den Haag 1972. 
Jong, H. de, en A. van Vliet, 'Penitentiaire Perikelen', in A. van Vliet e.a. (red.), Crimineel faarboek, uitgave 1991, Breda 1991.

Jong, L. de, Het Koninkrijk der Nederlanden in de Tweede Wereldoorlog, deel 8, 'Gevangenen en gedeporteerden', eerste helft, 's-Gravenhage 1978.

Jonge, G. de, 'Gedetineerden mogen wel klagen, maar geen gelijk hebben; enkele opmerkingen over de grenzen van het beklagrecht', Proces, 62e jrg. nr. 6, juni 1983, bl. 177-181.

Jonge, Gr. de, 'Harmonisatie van gedetineerdenrecht', in de onder redactie van G.P.M.F. Mols uitgegeven bundel Dissonanten bij het akkoord van Schengen, Deventer 1990.

Jonge, G. de, H. van de Velde en R. Verpalen, BWO - Bajesboek, Rotterdam 1982.

Jonge, G. de, en R. Verpalen, Bajesboek, Breda 1988.

Jongh, J.J. de, Verzameling van wetten, decreten, besluiten, reglementen, instructiën en bepalingen, betrekkelijk het gevangeniswezen in de Nederlanden, deel I (1791-1844), Leeuwarden 1846, deel II (1845-1859), Leeuwarden 1860, deel III (1860-1874) en deel IV (1875-1889) (geen plaats en jaar van uitgave vermeld).

Jongman, R. (W.), F. Weerman en L. Kroes, 'Maatschappelijke tweedeling en criminaliteit', in R.W. Jongman (red.), De armen van Vrouwe Fustitia; sociale pasitie, criminaliteit en justitiële reacties, Nijmegen 1993.

Kam, F. de, 'Het einde van de werkloosheid?', Intermediair 2 oktober 1987, 23e jrg., nr. 40, bl. 11 en 13.

Kamermans, C., 'Gezondheidszorg en de gedetineerde', in B.A.J. Cohen en H.J. Leliefeld (red.), Inleiding tot de forensische geneeskunde, Zeist 1990.

Kannegieter, G., 'Een passende straf: over verschillen in straftoemeting aan wer'kende en werkloze verdachten', in R. (W.) Jongman (red.), De armen van Vrouwe fustitia; sociale positie, criminaliteit en justitiele reacties, Nijmegen, 1993.

Kaser, M., Römisches Privatrecht, München und Berlin 1964

Kelk, C., Recht voor gedetineerden, Alphen aan den Rijn 1978.

Kelk, C., 'De beperkte betekenis van grondrechten in de strafexecutie', Delikt en Delinkwent 6/1989, bl. 573-588. 
Kelk, C., 'Nieuwe Europese Gevangenisregels', N7CM-Bulletin 14-1, Jan/Feb. 1989, bl. 20-35.

Kelk, C., Kort begrip van het detentierecht, Nijmegen 1993.

Kelk, C., 'Hoe werkzaam is de nota 'Werkzame detentie'?', Trema 1994, no. 8, bl. 303-306.

Klinkhamer, L., Arbeid in penitentiaire inrichtingen; onderzoek naar de functie van door gedetineerden verrichte arbeid, Utrecht 1991.

Kneepkens, M., Tegen-Nota Beleidsvraagstukken Gevangeniswezen van de Coornhert-Liga, Utrecht 1976.

Knight, B., and S.T. Early Jr., Prisoners' rights in America, Chicago 1986.

Koch, P., Gefangenenarbeit und Resozialisierung, Stuttgart 1969.

Kraan, S., De muesli bloeit; uit het dagboek van een totaalweigeraar, Amsterdam 1982.

Krantz, S. The law of corrections and prisoners' rights cases and materials, St. Paul, Minn. 1986.

Kruissink, M. en C. Verwers, Halt: een alternatieve aanpak van vandalisme; Eindrapport van een evaluatie-onderzoek naar HALT-projecten, Arnhem 1989.

Laffargue, B., en Th. Godefroy, 'Economic Cycles and Punishment: Unemployment and Imprisonment; A Time-series Study: France, 1920-1985', Contemporary Crises December 1989, Vol. 13, nr. 4, bl. 371-404.

Laffargue, B., en Th. Godefroy, 'La prison républicaine et son environment économique; population en prison et marché du travail', Déviance et Société 1990, Vol. 14, nr. 1, bl. 39-58.

Laingui, A., 'Aspects historique de la procédure pénale', Revue Internationale de droit pénal, 6le jrg., 3e/4e kwartaal 1990, bl. 373-389.

Leder, C., Arbeitsentgelt im Strafvollzug der Bundesrepublik Deutschland. Paradigma für fehlende soziologische Problemsicht. Rheinstetten-Neu 1978.

Lessan, G.T., 'Macro-economic determinants of penal policy: Estimating the unemployment and inflation influences on imprisonment rate changes in the United States, 1948-1985', Crime, Law and Social Change 1991 nr. 16, bl. 177-198. 
Lesting, W. Normalisierung im Strafvollzug; Potential und Grenzen des $\int 3$ Abs. 1 StVollzG, Pfaffenweiler 1988.

Lichtenberger, G., Dic Arbeitsentlohnung im Strafvollzug als Mittel der Resozialisation, München 1971.

Liebknecht, K., 'Tegen de vrijheidsstraf, 1918, opgenomen in Karl Liebknecht en Rosa Luxembourg over misdaad en straf, uitgegeven op verzoek van het 'Comité van actie tegen de bestaande opvattingen omtrent misdaad en straf, Amsterdam 1922 (met een inleiding van Clara Meijer Wichmann).

Limborgh, E.H., Problemen voor het management van een gemeentelijke dienst sociale werǩvoorziening, proefschrift Technische Universiteit Twente, geen plaats van uitgifte vermeld, 1982.

Liszt, F. von, Die Gefüngnisarbeit, Berlijn 1900.

Livrozer, S., De la prison à la révolte, (geen plaats vermeld) 1975.

Market adjusted wages to prison inmates; summary of the report from the MAIK-committee, Stockholm 1985.

Martineau, C., en J-P. Carasso, Le travail dans les prisons, Parijs 1972.

Marx, K., Kritick op het Program van Gotha (1875), Amsterdam 1975.

Marx, K., Critique of the Gotha Programme, Moskou 1976.

Marx-Engels, Ausgewauhlte Schriften, Kritik des Gothaer Programs, Berlijn 1983, Band II.

Marx-Engels Werke, Berlijn 1969, Band 8.

Mathiesen, Th. The Politics of Abolition, Oslo 1974.

Mathiesen, Th., Gefängnislogik; über alte und neue Rechtfertigungsversuche, Bielefeld 1989.

Mathiesen, Th., KROM - Norwegian Association for Penal Reform, paper, Coornhert - Liga, Haarlem 1990.

Melossi, D., 'Punishment and social Structure', in T. Platt en P. Tagaki (red.), Punishment and penal Discipline; essays on the prison and the prisoners' movement, San Francisco (1980) 1982. 
Melossi, D., Punishment and social Action: changing Vocabularies of punitive Motive within a political Business Cycle', Current Perspectives in social Theory 1985, Vol. 6, bl. 169-197.

Melossi, D., 'An Introduction: fifty Years later, Punishment and Social Structure in comparative Analysis', Contemporary Crises, 13 (1989), bl. 311-326.

Melossi, D., 'Gazette of Morality and Social Whip: Punishment, Hegemony and the Case of the USA, 1970-92', Social \& Legal Studies, London etc., Vol. 2 (1993), bl. 259-279.

Melossi, D., en M. Pavarini, The Prison and the Factory; Origins of the penitentiary System (oorspronkelijk gepubliceerd als Carcere e Fabrica, Bologna 1977), Londen en Basingstoke 1981.

Middendorp, W., Twee achterlijke arbeidssystemen voor inboorlingen in Nederlandsch Oost-Indië (heerendiensten en poenale sanctie), Haarlem, zonder jaartal.

Mikhlin, A.S., en R.D. King, The Russian prison system: yesterday, today and tomorrow, paper presented at 'Prisons 2000', an international conference on the present state and future of the prison system, Leicester 8-10 april 1994.

Milleman, M.A., 'An agenda for prisoners rights litigation', in J.P. Robbins (ed.), Prisoners' Rights Sourcebook; theory-litigation-practice, Volume II, New York 1980

Ministerie van Sociale Zaken en Werkgelegenheid, Beleidsoperatie experiment budgetfinanciering decentralisatie en deregulering sociale werkvoorziening. Eindrapportage tussentijds evaluatieonderzoek, 's-Gravenhage 1991.

Modderman, A.E.J., Siraf-geen kwaad, Amsterdam 1864.

Moerings, M., Gevangen en Werk: een problematische combinatie', BWONieuzs, 1991, 14e jaargang, nr. 5, bl. 4 .

More, Thomas, Utopia (1516), translated with an introduction by Paul Turner, Harmondsworth 1965.

Nota beleidsvraagstukken gevangeniswezen, Tweede kamer, 1976-1977, 14 102, nrs. 1-2

Noyon, T.J., G.E. Langemeijer en J. Remmelink, Het wetboek van strafrecht, losbladig, 7e druk, commentaar op art. $32 \mathrm{Sr}$., suppl. 64 , onder punt 8. 
Ohle, C.D., Arbeitsbelohnung und Arbeitsentlohnung im Gefangenenarbeitswesen, Hamburg 1972.

Ormer. H., en R. Wetter, Gefängnis und Familie, Berlijn 1975.

Overleg- en adviescommissie alternatieve sancties (OCAS), Advies 'Alternatieve sancties met het oog op de toekomst', (Den Haag) 1991.

Phillips, P., Marx and Engels on law and laws, Oxford 1980.

Pierre, M., 'La transportation (1848-1938)', in J.G. Petit e.a., Histoire des galères, bagnes et prisons; XIIIe-XXe siècles, Toulouse, 1991.

Pieters, F., 'Zweden: strafstelsel en penitentiair systeem', Panopticon (1990), bl. 236-242.

Pike, R., Penal servitude in early modern Spain, Wisconsin 1983.

Platschorre, J., 'De gevolgen van detentie in sociale zekerheidsregelingen'. In de bundel Buiten de muren; relaties van gedetineerden, o.r.v. M. Moerings en G. ter Haar, Arnhem 1990.

Pol, U. van de, 'Van beperkte gemeenschap naar vereniging', Ars Aequi 29 (1980)11, bl. 771-774.

Pompe, W.P.J., 'Comment faut-il organiser le travail pénitentiaire pour en obtenir à la fois un bénéfice moralisateur et un rendement économique et social utile?', Proceedings (of the) Twelfth International and Penitentiary Congress (The Hague 14-19 August 1950), Volume IV, General and national reports of section II, bl. 359-365, Bern 1951.

Pot, C.W. van der, Handboek van het Nederlandse Staatsrecht bewerkt door A.M. Donner, 8e druk, Zwolle 1968.

Prakken, T., Rechtshulp en juridies aktivisme. Een vergelijkend onderzoek naar recente ontwikkelingen in het gebruik van recht, Nijmegen 1985.

Prowse, R., H-M. Weber en Ch. Wilson, Rights \& Prisons in Germany: blueprint for Britain?, Paper presented to the British Criminology Society, Annual Conference at the University of York, 24-27 juli 1991.

Rapport commissie doelstelling en functie huis van bewaring (commissie-Van Hattum), 's-Gravenhage 1977. 
bundel Scherp toezicht; van 'Boeventucht' tot 'Samenleving en Criminaliteit', onder redactie van C. Fijnaut en P. Spierenburg, Arnhem 1990.

Spierenburg, P., The prison experience; disciplinary institutions and their inmates in early modern Europe, New Brunswick en Londen 1991.

Steinert, H., 'Die Geschichte der sozialen Kontrolle als Geschichte von Kapitalstrategien, Arbeitsmoral und moralische Empörung', Kriminologisches foumal 1986, 1. Beiheft, bl. 77-96.

Steinert, H., en H. Treiber, 'Versuch, die These von der strafrechtlichen Ausrottungspolitik im Spätmittelalter 'auszurotten'. Eine Kritik an Rusche/Kirchheimer und dem Ökonomismus in der Theorie der Strafrechtsentwicklung', Kriminologisches fournal 1978, 10. Jg., bl. 81-106.

Sternheim, A., 'Gedwongen arbeid en Nederlands Indië', De Vakbeweging, januari 1929.

Stichting Vrij en BWO, Bunker Balen Boek, Amsterdam 1983.

Sutherland, E.H., en D.R. Cressey, Principles of criminology, 6e druk, Chicago/ Philadelphia/New York 1960.

Swaaningen, R., 'What is abolitionism? An introduction', in H. Bianchi/ R. van Swaaningen (ed.), Abolition; toward a non-repressive approach to crime, Amsterdam 1986.

Swaaningen, R. van, ' $\mathrm{Ik}$ ben geen zoon der lauwe westerstranden, in R. van Swaaningen, B. Snel, S. Faber en E. Blankenburg (red.), à Tort et à Travers; liber amicorum Herman Bianchi, Amsterdam 1988.

Swaaningen, R. van, M. McMahon en G. de Jonge, 'The laborious conspiracy against the penal system: comments on the third abolitionist conference Montreal', June 1987, in Canadian Law Forum/ Le forum Canadien de criminologie, Vol. 10,1989 , bl. $67-75$.

Taak en Toekomst van het Nederlandse gevangeniswezen, nota op 2 september 1982 door de staatssecretaris van Justitie (Scheltema) aangeboden aan de Tweede Kamer der Staten-Generaal, Tweede Kamer, 1981-1982, 17 539, nrs. 1-2.

Tak, A.Q.C., De algernene wet bestuursrecht; het nieuwe bestuursprocesrecht, Zwolle 1993.

Teulings, A., Philips; geschiedenis en praktijk van een wereldconcern, Amsterdam 1977. 
Treiber, H., Widerstand gegen Reformpolitik; institutioneller Opposition im Politikfeld Strafvollzug, Düsseldorf 1973.

Tulkens, J.J.J., Graden van vrijheid, Arnhem 1988.

Tulkens, J.J.J., 'Vanuit het oogpunt van de gevangene', in: 'Th.W. van Veen en G. van Essen, Sanctietoepassing: een nieuwe ordening; opstellen aangeboden aan Dr. G.H. Veringa, Arnhem 1991.

United Nations - International Labour Office, Report of the Ad Hoc Committee on Forced Labour, Geneva 1953.

United Nations, Department of economic and social affairs, Prison Labour, New York 1955.

Vandekerckhove, L., Over het ontstaan van de gevangenisstraf; een kijk op het oude Rome, Leuven/Amersfoort 1989.

Veen, Th. W. van, in zijn bijdrage 'Het toepassen van sancties' aan de door hem en G. van Essen geredigeerde congres-bundel Sanctictoepassing: een nicucve ordening, Arnhem 1991.

Verhart, $M$., 'BWO wil recht van vereniging binnen bajes', $K R I$, Maandblad Reklassering, jrg. 10, nr. 3/4, april 1980, bl. 22.

Verhart, M. 'Kort Geding BWO; gedetineerdenvereniging kreeg toch erkenning', KRI, Maandblad Reklassering, jrg. 10, nr. 5/6, juni 1980, bl. 8.

Veringa, H.H., 'Beloning van gedetineerden', Maandschrift voor het gevangeniswezen, 9e irg. 1957-1958, bl. 13-17, 35-43 en 59-67.

Verpalen, R. en G. de Jonge (red.), Bajesboek; handboek voor gedetineerden en ter beschikking gestelden, Breda 1992.

Verschoor, E.C., 'Over gevangenisarbeid en reclassering', Tijdschrift voor Sirafrecht (XXVI) I 1916, bl. 252-275.

Verschueren, F., 'Ontwerp-Protocol bij het E.V.R.M. dat bijkomende rechten waarborgt voor personen die van hun vrijheid beroofd zijn', Nieuwsbrief van de Liga voor Mensenrechten, jrg. 12, nrs. 9-10, 1993, bl. 10-12.

Verslag van de commissie van onderzoek inzake de afbreuk, door den arbeid in gevangenissen, rijkswerkinrichtingen en rijksopvoedingsgestichten aan den arbeid in de vrije maatschappij gedaan, Den Haag 1897. 
Verslag van de commissie van onderzoek naar den gevangenisarbeid, 's-Gravenhage 1931.

Vervaele, J.A.E., bespreking van H. Franke, 'Twee eeuwen gevangen. Misdaad en straf in nederland, Utrecht, 1990, Recht en Kritiek 18 (1992) 1, bl. 86-90.

Voorontwerp Penitentiaire Beginselenwet. Voorontwerp van wet tot vaststelling van een Penitentiaire Beginselenwet en daarmee verband houdende intrekking van de Beginselenwet gevangeniswezen en wijziging van het Wetboek van Strafrecht en het Wetboek van Strafvordering. Wettekst en Memorie van Toelichting, Den Haag 1993.

Vries, Th(eun) de, 'Dirck Volkertszoon Coornhert; Wellevenskunstenaar', Vitrine 1990, nr. 3, bl. 18-20.

Waal, R. de, 'Arbeidsomstandighedenbesluit Justitiële Rijksinrichtingen', PS, 21, 19 september 1990, bl. 1386-1388.

Werff, J. van der, 'Jeugdwerkgarantieplan; uitvallers verdwijnen vaak in crimineel circuit', Aanéén 19 december 1992, bl. 7.

Werkzame detentie; beleidsnota voor her gevangeniswezen, Tweede Kamer, 19931994, 22 999, nrs. 10-11.

Yaeger, M.G., 'Unemployment and imprisonment; research note', The fournal of Criminal Law \& Criminology 1979, Vol. 70, nr. 4, bl. 586-588.

Zayas, A. de, J. Th. Möller en T. Opsahl, 'Toepassing van het Internationale verdrag inzake burgerlijke en politieke rechten door het Comité voor de rechten van. de mens op grond van het Facultatief Protocol', in P. van Dijk (e.a.), Het internationale verdrag inzake burgerlijke rechten en zijn betekenis voor Nederland, Nijmegen. 1987 ,

Zimring, F.E., en G. Hawkins, The Scale of Imprisonment, Chicago en Londen 1991.

Zysberg, A., 'Les galères de France de 1660 à 1748: une institution pénitentiaire sous l'Ancien Régime", in J.G. Petit La prison, le bagne et l'histoire, Genève 1984.

Zysberg, A., 'Le temps de galères (1481-1748)', in J.G. Petit e.a., Histoire des galères, bagnes et prisons; XIIIe-XXe siècles, Toulouse 1991. 


\section{Curriculum vitae}

De auteur is op 9 april 1945 te Rotterdam geboren. Hij volgde daar het Erasmiaans gymnasium (alpha) en studeerde Nederlands recht aan de juridische faculteit van de toenmalige Nederlandse Economische Hogeschool. Zijn werkzaam leven begon hij als secretaris van de Reclasseringsraad te Middelburg. Na korte tijd als litteratuuronderzoeker aan het Wetenschappelijk Onderzoek en Documentatie Centrum van het ministerie van Jusritie verbonden te zijn geweest werd hij coördinator van het Bureau voor Rechtshulp te Rotterdam. Vervolgens werd hij advocaat bij het Advokatenkollektief Noordsingel in die stad. Na een kort intermezzo als onderzoeker bij de Nationale ombudsman werd hij in 1986 universitair docent bij de vakgroep strafrecht en crininologie van de Erasmus Universiteit. In 1989 stapte hij over naar de vakgroep strafrecht en criminologie van de Rijksuniversiteit Limburg te Maastricht, waar hij tevens de advocatuur praktiseert. 


\section{Sinds de opening van het Amsterdamse}

Rasphuis in 1596 worden gedetineerden in Nederland dagelijks gedwongen tot het verrichten van vaak afstompende, nauwelijks beloonde arbeid. Deze studie wil de vanzelfsprekendheid doorbreken waarmee de overheid meent naar believen over de arbeidskracht van gevangenen te kunnen beschikken. Bij nadere beschouwing bljkt geen rechtvaardiging voor de toegepaste arbeidsdwang en onderbetaling te bestaan.

De auteur stelt voor gedetineerden als normale werknemers tegemoet te treden en presenteert een wettelijk kader waarbinnen dat zou kunnen worden gerealiseerd. Strijd tègen arbeidsdwang en voór een betere beloning kan het zelfbewustzijn van gedetineerden verhogen en de buitenwereld duidelijk maken dat het wegstoppen van veroordeelden achter tralies geen oplossing biedt voor de onderliggende maatschappelijke problematiek.

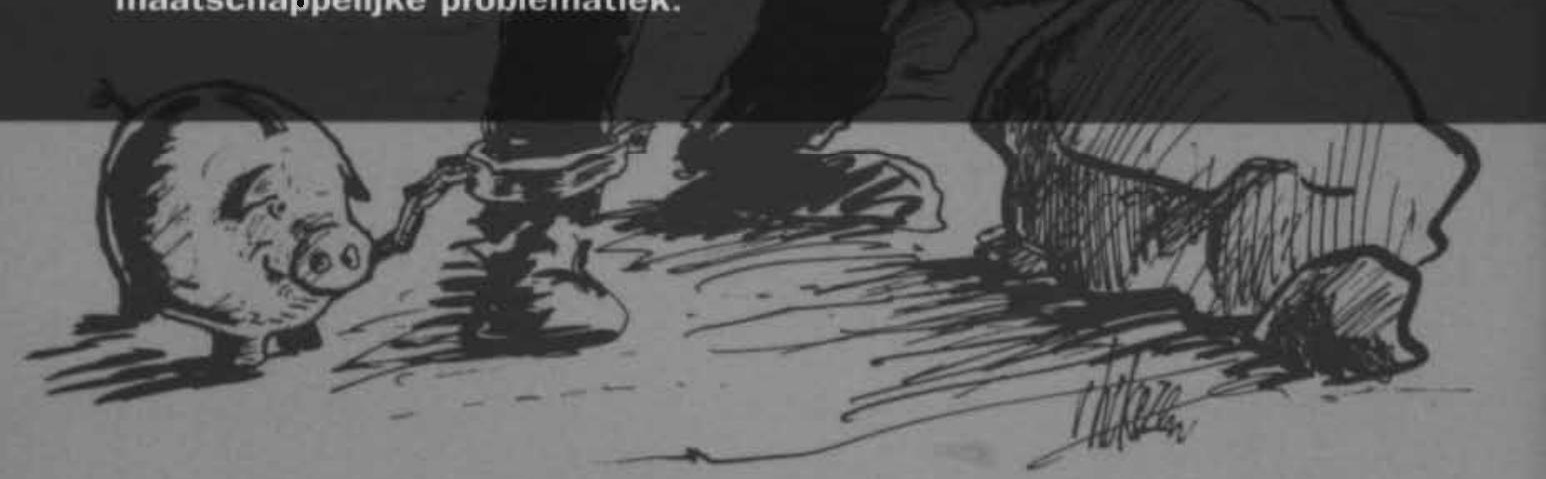

